

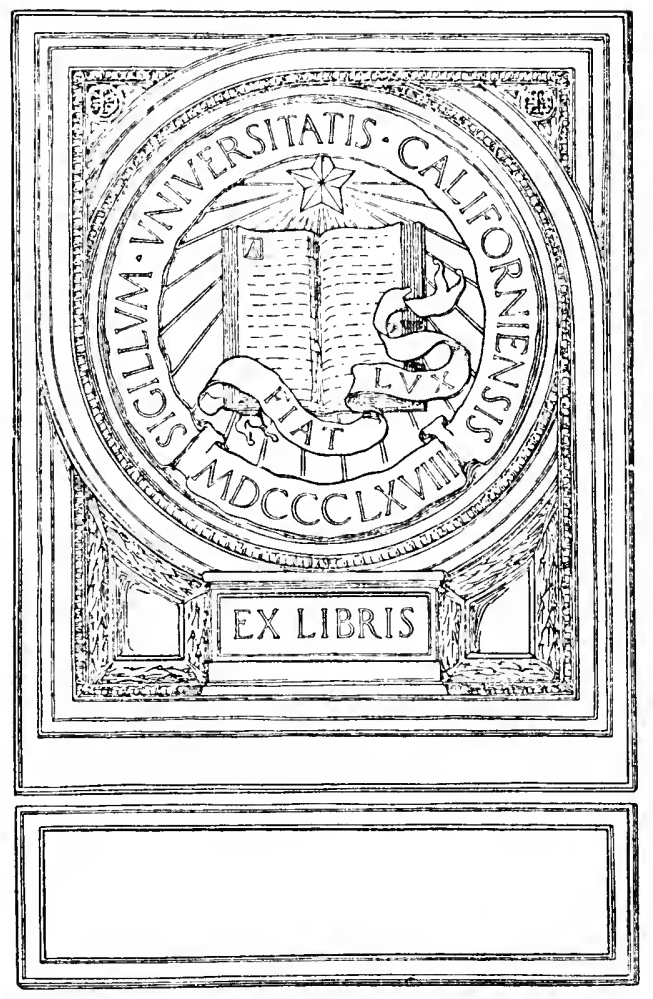





THE LIFE AND

CORRESPONDENCE OF

JAMES MCHENRY 




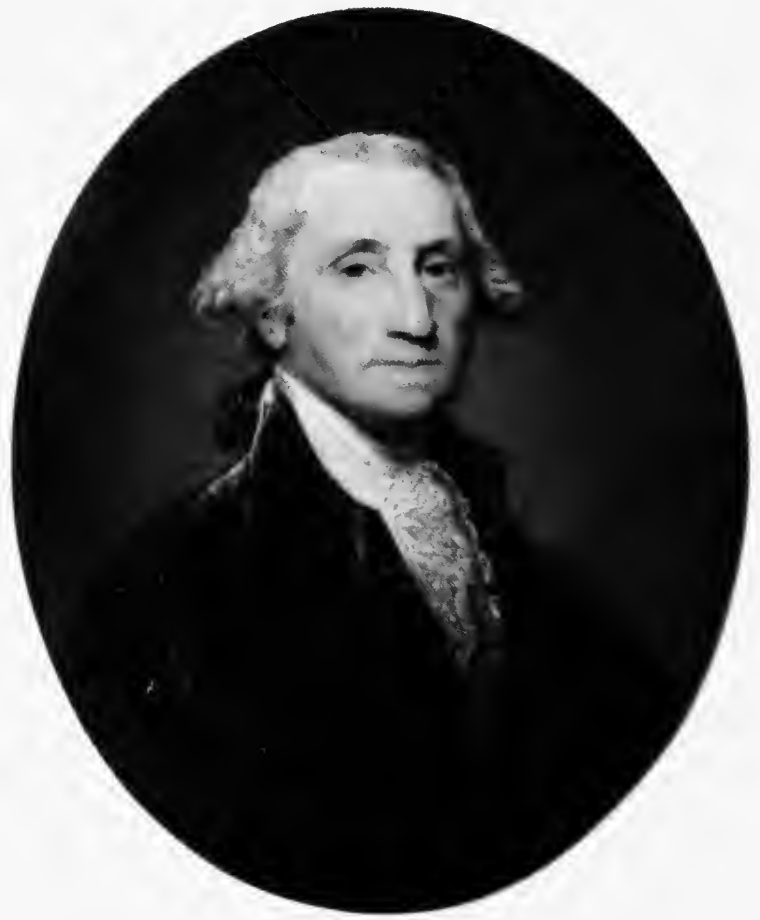

GEORGE WASHINGTON

Reproduced in original size from miniature owned by the heirs of Dr. James McHenry

(Copyright, 1907, The Burrows Brolhers Compony) 


\title{
THE LIFE AND
}

\section{CORRESPONDENCE OF}

\section{JAMES McHENRY}

SECRETARY OF WAR UNDER WASHINGTON AND ADAMS

\author{
BY \\ BERNARD C. STEINER
}

THE BURROWS BROTHERS COMPANY 1907 
का

COPYRIGHT, 9907

THE BURROWS BROTHERS COMPANY 
Preface . . . . . . . ix

I. Early Years and Medical Study, 1753-1775 1

II. Surgeon and Prisoner, 1775-1778 . . 6

III. Washington's Secretary, 1778-1780 . $\quad$. $\quad 19$

IV. Lafayette's Aid, 1780-1781 . . . $\quad 29$

$V$. The Maryland Senate and the Confederation Congress, until Washington's Resignation of his Commission in December, 1783 . . 41

VI. Marriage and Retirement from Public Life, 1784-1786

VII. Member of the Federal Constitutional Convention, $1757-1788$. $\quad . \quad . \quad . \quad . \quad 97$

VIII. Nember of the House of Delegates, 1788-1790 114

IX. A Year of Retirement, 1790-1791 . 128

X. Second Term in the Senate, 1791-1796 . 132

XI. Washington's Secretary of War, 1796-1797 . 163

XII. A Year in the War Department under Adams, 1797-1798 . . . . . . 208

XIII. The Provisional Army and the Strife over the Generals, 1798-1799 . . . . . 309

XIV. Events after the Nomination of the French Envoys, $1799-1800$. $\quad . \quad$. . . 370

XV. Fries's Rebellion and the West in 1798-1800 432

XVI. The Federalists in the Presidential Campaign

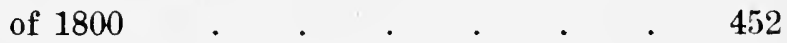

XVII. Retirement and Defense of his Administration of the War Office, 1801-1803 . . . . 497

XVIII. The Federalists in Opposition, 1803-1812 . 520

XIX. MeHenry's Last Days, 1812-1816 . . 580

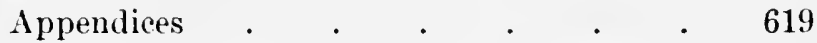

Index $\quad . \quad \cdot \quad \cdot \quad . \quad . \quad . \quad 625$ 



\title{
ILLUSTRATIONS
}

\author{
Iiniature Portrait of Washington, by William Russell \\ Birch \\ Frontispiece
}

While Dr. James McHenry was Washington's secretary of war, he purchased a miniature portrait of Washington, painted by the artist named above.

William Russell Birch was born in Warwick, England, April 9, 1755, and died in Philadelphia August 7, 1834. He studied enamel painting in London, and in 1784 was awarded the silver palette by the Society of Arts, for the production of a new enamel color-the red-brown that he ever afterwards used in his backgrounds. He came to America in 1794, when he ceased to use his middle name. In regard to his miniatures of Washington he says in his MS, autobiography :

"When he [Washington] was sitting for Stuart [1795] he [Washington] told hlm he had heard there was another artist of merit from London, naming myseif; that he would sit for me if I chose. I thanked Mr. Stuart that as he had painted his picture it would he a mark of the highest imposition to trouble the General to sit for me, but that when I had copied his [Stuart's] picture of him in enamel, which was my forte, that I would show it to the General and thank $\mathrm{h} / \mathrm{m}$ for his kind offer, which when I had done, I waited upon the General with a note that an artist waited the howor of showing personally to the General a specimen of his talents. When I saw the General I put the picture Into his hands; he looked at it steadfastly, but, from a pecullarity of solid (stolid?) habit of manner, left me to look at hlm as solld (stolid?) till feeling myself awkward I began the history of enamel painting which by the tIme I had got through he complimented me upon the beauty of my work. I then told him how much he was beholden to Mr. Stuart for the correctness of his likeness. I copied one enamel from it which was purchased by Mr. McHenry. From this portrait I made a correct drawing, the copying of which in enamel supplied me in work for a considerable time. I painted about sixty portraits of it from $\$ 30$ tc $\$ 100$ each."

The above information was supplfed by Mr. Charies Henry Hart the recognized authority on historical portraiture in America, and supplements very completely such information as had previousiy bcen possessed by the family and Dr. Bernard C. Steiner, our editor.

Mr. Hart further states that Birch brought with him from England but one letter of introduction and that was from Benjamin West, the Pennsylvania president of the Royal Academy of Arts in London to William Bingham of Phlladelphia. It was for Bingham that Stuart painted his first portrait of washington which is now in the collection of Marsden J. Perry, Esq., of Providence, R. I. This is the one that Birch copied in enamel.

Harper's Magazine for August, 1896 , in an article on Stuart's I ansdowne portrait of Washington, says: "When William Birch desired to make an enamel portrait of Washington, Stuart gave him his first head to copy and Washington stamped it with his approval."

This portrait is at present owned by the heirs of Dr. James McHenry.

\section{Miniature Portrait of Margaret Caldwell McHenry} (Mrs. elames MeHenry) . . . . facing 76 At present owned by the helrs of Dr. James McHenry of Baltimore. 
Miniature Portrait of Dr. James McHenry

facing 160 Military secretary to Washington during part of the Revolutionary war. Secretary of war 1796-1800. In his honor Fort McHenry, Baitimore, was named.

Owned at present by the heirs of Dr. James McHenry.

Portrait of George Washington . . . facing 420 Reproduction, reduced in size, of the Birch miniature of Washington which appears in colors as frontispiece.

Profile Portrait of Dr. James MeHenry

facing 580

Reproduction much reduced in size. The artist is supposed to have been St. Memin. Owned by the heirs of Dr. James McHenry. 


\section{PREFACE}

THE heirs of Dr. James MeHenry have placed in my hands a trunk containing the correspondence and other manuscripts of their ancestor, with the request that I nse these papers in the preparation of his biography. An examination of the collection showed its richness in unpublished letter's written by the greatest men of the period of the American revolution and revealed the affection felt for McHenry by his many friends. The varied relation to public affairs which McHenry held during his life also made the papers of extraordinary interest. He came to the British North American colonies from the north of Ireland and had just completed a course of study in medicine under Dr. Benjamin Rush of Philadelphia, when the war of independence broke out. As a surgeon, a prisoner of war, a member of Washington's military family, and an aid to Lafayette, McHenry saw service throughont that great conflict and, at its elose, became a legislator, being a member at the same time of the Maryland Senate, and of the Confederation Congress. In partnership with his father and brother in a successful mercantile business in Baltimore, he early accumulated a competence. In 1787, he served in the Constitutional Convention at Philadelphia and, in suceeeding years, was a Federalist member of the Maryland legislature, serving in both IIouse of Delegates and Senate. Washington called him to become Secretary of War in January 1796, and, in that position, MeIlenry continued during most of Adams's administration. He retired to private life in May, 1800, and spent the sixteen years which still remained of his life as a private eitizen, keeping a keen interest in politics and maintaining an active correspondence with Federalist leaders in Congress. Throughout his whole life, he showed himself a pure minded, high spirited, courteous, Christian gentleman. He was a man of rare charm and attractiveness, who gained and kept the love of the best men of his time. A mere list of names of his intimate friends, scores of whose letters are here published for the first time, proves the nobleness and loveliness of his character. Wash- 
ington loved him, as he loved few men. The men with whom MeIIenry was associated in the Revolutionary army, such as Iramilton, Lafayette and Tallmadge, never lost the esteem they there learned to feel for him. Among the men he met in later public life, he gained the warm friendship of persons of such diverse characteristies as Pickering, William Vans Murray, and Uriah Tracy. The correspondence of men who played so prominent a part in affairs reveals much of importance upon the history of the times. I have been fortunate enough to be able to consult the papers of Washington and Hamilton, while these papers were in the eustody of the Department of State in Washington, and the papers of Pickering in the library of the Massachusetts Historieal Society and, so to have seen both sides of the noteworthy correspondence of MeHenry with those men. It is a privilege to have studied the life of so attraetive and upright a man as McHenry - one who eompelled friendship and was faithful in the performance of every duty committed to his eare.

Bernard C. Steiner. 


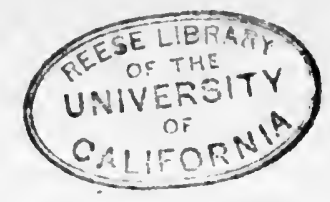

\section{CHAPTER I}

EARLY YEARS AND MEDICAL STUDY

\section{$1753-1775$}

A

MONG the Scotch Irish Presbyterian settlers who came to America in the eighteenth century were a father and two sons from Ballymena, near Belfast, county Antrim, Ireland. The elder of the sons, James MeHenry, came first in 1771 , sent out on a voyage to the colonies, because his health had become impaired by too close application to studies at a classical academy in Dublin. He was a youth of less than twenty years and was placed under the care of Captain William Allison, of Philadelphia, whose stepdaughter, Margaret Caldwell, he subsequently married. The date of James McHenry's birth is uncertain. It is usually given as November 16, 1753, but the family records give the year as 1752 , and in a letter to Timothy Pickering in June, 1813, McHenry gave it as November 25,1751 . The first is probably the correct date, as his only sister, Anna, who died in 1771, was born in 1751 . The parents of James McHenry were named Daniel and Agnes and the family traditions state that Daniel had been a merchant in Ireland and that the McHenrys had been settled at Ballymeni for many generations. Daniel McHenry was born in 1725, and, in 1772, was induced to emigrate to America through the representations of his son James. With him, came his wife and his younger son, John, the only remaining members of his family. In the autumn of 1773, Daniel McHenry established himself in business in Baltimore, together with his son John, under the firm name of Daniel McHenry \& Son. In the newspapers of the day, they announce that they have just laid in a large and various assortment of merchandise suitable to the season in the last vessels from London, Liverpool, Ireland, etc., consisting of Dry Goods, Cloths, Hardware, Groceries, Spiceries, Wines, Teas, and Brandies. The store was on the east side of Calvert street, south of Market now 
Baltimore street, within two doors of the corner. Mrs. Agnes McHenry died, aged forty-six years, on August 16, 1774.

Daniel McHenry continued in business with his son with considerable financial success and died November 3, 1782, aged fifty-seven years. The newspapers describe him as "a gentleman of respectable character." He does not seem to have purchased any real estate in Baltimore Town but had a country seat, probably in Anne Arundel county, as, in May, 1779, he advertised in the "Maryland Journal" $\$ 100$ reward for a horse stolen from his plantation, eight miles from Dorsey's Ferry. John McHenry, who was born in 1755 , and was only eighteen when the business was founded, continued it with success until his death on May 7, 1790, when the mercantile house ceased. In 1780, he began buying town property in connection with his brother and in 1785 , he acquired the block upon which the postoffice now stands. As he never married, his property passed to his brother James.

James McHenry, ${ }^{1}$ with whom we are chiefly concerned, is found in 1772, at Newark, Delaware, in connection with the academy there, probably as a student. The Reverend Patrick Allison and the Reverend Francis Allison, both connections of Captain William Allison, were among the incorporators of this academy, which fact, doubtless, explains McHenry's presence there. Verses are still preserved which he wrote during his residence at Newark. His earlier biographer speaks of these verses as "attributable perhaps rather to youth and rural surroundings than to any decided inspiration." This taste for versification continued throughout his life and, though he is not known to have printed any of his verses, he left a portfolio filled with them, some of which we shall quote.

The Newark verses were sent to the "Pennsylvania Packet," on October 12, 1772, and are an imitation of Milton's L'Allegro, a quotation from which was prefixed to them.

Fled's the philosophic train,

Now's the blithe vacation's reign;

To yon owl I give my thesis,

Whilst I wheel these chance-cut mases.

1 Much of this family history was kindly given by Mr. Wilson Miles Cary. A sketch of Dr. McHenry by Frederick J. Brown in the Md. Hist. Soc. Fund Pub. has also proved of value. McHenry speaks of being twenty when his wife was twelve. If this is correot he was born in 1753, as she was born in 1762. A sketch of McHenry, which speaks of him as "of wide information and of respectable talents but not of great ablities," is found in Ingersoll's 'History of the War Department, 422, and is based on Brown. Portraits of McHenry with brief sketches of his life are to be found in Carson's History of the Celebration of the Hundredth Anniversary of the Constitution in Mag. Am. Hist., xiii, 104, and ibid., vil, 104. 
I have read of Cam's fair rill,

Shady Windsor, Cooper's hill,

And of London, where is seen, (and of London where I ween)

Stars, and garters, and the queen; (ali antiquity is seen)

And can speli of every stream

That to music owes its name.

Let the curious visit those,

With, thee, New-Ark, I'il repose,

Shun a city's circling life,

Study nature, but not strife.

Friendly Flaccus me excuse,

'Tili I round these speaking views.

Dull is Piato, dry his morals,

To the forest's floating carois,

To the woodman's weighty stroke

Lev'ling low the distant oak,

To the nymphs with rustic tresses,

Dancing round the apple presses,

To the plowman's healthfui toil,

Curiing o'er the fallow soil;

Now his lusty meal appears,

Now unyoked his sweating steers:

Bounteous heav'n twice he blesses,

Twice bestows the bearer kisses.

Some are climbing chestnut trees,

Others, busy as the bees,

Culling from the roguish vine

Subject for their winter's wine. -

Boys with berry-tingéd cheeks,

Boats a rustling thro' the creeks,

Flails resounding to the beaches,

Maids with aprons full of peaches, -

Grant me oft these scenes to view

Distant from the artful crew ;

Near my Whiteclay's virgin stream.

To enjoy the mid-day dream:

And with New-Ark will I live

Whilst her plains these pleasures give.

McHenry's best work is seen in brief lyrics and epigrams, like the following:

of love, let fair Delia beware:

'Tis a charm that's destructive to ease,

That heaps on the heart but despair.

While it seems to do nothing but please.

Tho' it comes in a form th' most mild,

'Tis a quest that is sure to betray:

Tho' rob'd like an innocent child

It has wings that soon waft it away.

But if it can pleasure impart

To know that your passion is known

Then know you have pierc'd Damon's heart

With a flame that does equal your own.

What beauty could do Amarillis would try,

Would know by her absence how many must die:

So ordered her band-box, and footman and chair,

Determined to pass through a town in despair. -

But Venus, who sometimes to mortals is kind

The scheme to defeat kept her sister behind. 
When Cloe shone forth, what a Syren said I. She'll murder a score at a stroke;

She opened her lips, I was ready to die, But love flew away when she spoke.

The radiance of beauty Corinna could boast But managed the thing without art:

To be lov'd by a crowd, or to be the first toast

she gave, tlll she lost every heart.

From Newark, he returned to Philadelphia and took up the study of medicine under the famous Dr. Benjamin Rush. Between the teacher and pupil a warm attachment sprang up, as is shown by the letters which were exchanged in later years. There is no evidence that McHenry ever practiced medicine, save during his service as surgeon in the army. His letters show no trace of a love for the profession, while his easy financial circumstances did not force him to earn a livelihood from his medical knowledge. Dr. Rush was a friend of George Washington and it has been thought that, through the former's influence, McHenry first formed that acquaintance with the latter which was destined to exercise so great an influence over the life of the subject of this work.

The patriotic fever of the times seized the young physician and, shortly after Washington went to Cambridge, MeHenry prepared to follow him ${ }^{1}$ and drew up an informal will. The paper shows clearly the devoutness of McHenry's religious faith and the depth of his affection for his family.

"Being about to set off for the head Quarters in New England, to serve as a volunteer, or Surgeon, in the American Army, raised by order of the Continental Congress and Provincial Conventions, to defend the liberties of Americans and mankind, against the enemies of both - I therefore, resign the disposal of myself and soul, in ail sincerety and lowly reverence to their first giver. And should the events of war number me with the dead, in the name of the disposer of these and all other events, I will and bequeath by this writing, all my portion of earthly possessions in the manner following.

"In the first place I hereby will, order, and devise that the one third of the Principal, and the one third of the proffits arising from my partnership with my Father Daniel McHenry and John McHenry my Brother, both of Baltimore Town, Maryland, be equally and impartially divided between the said Daniel McHenry my Father, and John McHenry my Brother. I moreover bequeath, to my dear and well beloved 1774."

I There is a poem of McHenry's "To Mrs. M. on leaving Philadelphia 
Brother, John McHenry aforesaid - all my wearing apparel - military habiliments - books - and physical materials, to be disposed of as he may think proper. Preserving only out of this bequest 'Beattie on the nature and immutability of truth' for my good and worthy patron and friend Capt. William Allison of Philadelphia as a slender memorial of my gratitude and friendship Also to my much esteemed and bosom friend James Dunlap, now apothecary to the Pennsylvania Hospital, the eighteen volumes of 'Van Sweeten's Commentaries on the Aphorisms of Boerhaave.'

"As to the manuscript poetry and other rude sketches in my chest \&c I earnestly desire and request that they may be all burnt.

"I enter not into the formalities of a will, because the tender affections, and strong affinities of Father, Son, and Brother, render it unnecessary. May every form of success attend the struggles of liberty, and every possible felicity my dear Father and Brother. Amen.

"Philadelphia 29 July 1775

"Witness present

"JAMes McHenry

"Will Blair" 


\section{CH A P T E R II}

\section{SURGEON AND PRISONER}

$1775-1778$

$M$ CHENRY'S first service seems to have been without a regular commission and we know little of his activities, save that he was in attendance in the hospitals in Cambridge in January, 1776, whence he thus wrote his brother:

"My very dear Brother

"Am I to conclude by my not hearing from you since the 30th. Decr. Ulto. that your desire of serving America in a military eapacity has subsided for the present. Had I known some time ago that your thought turned this way, I could have procured you a captaincy here. But I imagined you were of opinion with myself that one out of our little family was its full share. I must confess that I had much rather see you pursuing the less hazardous business you have been accustomed to than engaged in the army. I do not suppose that the cause stands peculiarly in need of your assistance. You must consider yourself as the head of a family. Your conduct, ought, therefore be such as may be productive of the best and most advantageous consequences. These $I$ apprehend cannot be obtained by adopting the military plan. Do but reflect on the relation in which you stand and how much some people depend on your management and prudence. During the remainder of the suspension of our trade, our capital cannot be much diminished. Trade must soon be again opened, with other powers if not with European. A declaration of Independency may not be far off. And France - Holland \&c \&c will hardly abstain from a commerce which must show a very large balance in their favour.

"As to your scheme of going home, I also confess that as yet I have not been able to enter into its propriety. We can bardly suppose a reconciliation between England and America. Both are too far engaged to recede. Our terms of accommoda- 
tion would be too humiliating to the false dignity of Britain, and their's too ignominious for the sons of freedom. Strength must decide the present dispute. I have few fears of the scales turning against us. We have within ourselves materials for carrying on a war of any duration: We have many more natural resources than the ministry will confess. And may, if wanted, have foreign assistance. Under such circumstances, it would be foolishness in the extreme to accept of less than absolute independency. For in short we are only to be subjugated by pusillanimity and disunion. I would ask you if it is not advisable to stay where you are, and content vourself in doing a little till a change of times put it in your power to do more, or go home with a greater certainty of answering the purposes of trade. If for the present you can keep the old stock together we may be fully content. In all probability the merchant will soon find his usual employment. New manufactures - and trades will rise out of our confusions, and the calamities of war, in a short time be more than counterbalanced by a long train of blessings and advantages.

"But I would not have you think from what I have said, that I mean to damp your military ardor. I am willing as soon as the cause demands it to give up my fraternal feelings. If you suppose this to be the period, when engaged in the service, do your duty faithfully and when called into action let not the justice of our glorious cause, or the spirit of a freeman forsake you. But I am sure these will not. And if you have joined the army I doubt not but that you have put our affairs in proper order and proper hands, as you must be uncertain when or where you'may be called.

"If on the other hand you determine to cross the Atlantic I also expect you to make such arrangement and disposition of things as I mentioned in my last letter to you, thro' the medium of Capt. Allison. But as I said there, take the opinion of people who have more leisure to consider the step and a more extensive knowledge of the subject or consequences than I have.

"I must beg that in your future letters you will be more particular and less desultory. This will lead to a just habit of writing as well as thinking. You might ere now have told me a variety of things which I want to know. You have mentioned my father's family. Pray have I any sisters or brothers in it? But how many or can you find time to give me some idea of them? I thank my father for his compli- 
ments and beg you to return him mine, with the inclosed letter. You tell me that he lives happily. I am heartily glad of it. He has met with some heartaches in his time, so that I am pleased to think he is likely to finish his last act in peace and serenity.

"I cannot conclude this long letter, without telling you how much I am chagrined and disappointed at your writing so seldom. At your not discharging what some may imagine a duty which you owe in a peculiar manner, your ** and tenderly affectionate brother.

"JAMes MCHenry

"I wish that you would see about getting, making and forwarding the shirts, if my father cannot. I could buy linen but it is a most extravagant price * * that which you sold when last with you at ${ }^{* * *}$ is above a dollar per yd."

He evidently continued with the army after the close of the siege of Boston, for, on July 26, 1776, Washington gave written consent to his application for a week's leave of absence before going to Canada. The trip to Canada was probably given up and McHenry continued as a volunteer with the army. On August 27, his preceptor, Dr. Rush, sent him the following letter, transmitting a very commendatory resolution of the continental congress:

"Congress Aug 261776

"Resolved that Congress have a proper sense of the merit and services of Doctor McHenry and recommend it to the Directors of the different hospitals belonging to the United States to appoint Doctor McHenry to the first vacancy that shall happen of a surgeon's birth in any of the said hospitals.

"Extract from the minutes

"Chas Thomson Sec'y."

\section{"Dear Sir}

"The above resolution of Congress does you as much honor as if they had made you a director of a hospital. I need not hint to you after this how unjust it will be in you to desert their Service especially at the present juncture. You will please to furnish Dr. Morgan, Dr. Stringer, and the other Directors of the hospitals of the States with a copy of the above resolution. If there is at present a vacancy in any of 
these departments, you are authorised to demand a warrant for it. Wishing you my dear McHenry much health, honor and happiness I am with great regard your most Affectionate humble

Servant

"B. Rush"

On August 10, McHenry had been appointed surgeon of the Fifth Pennsylvania Battalion, commanded by Colonel Robert McGaw, and stationed at Fort Washington. McHenry remained with the command until the fort was taken by Sir William Howe on November 16, 1776. He was one of five surgeons taken prisoners among the 2000 Americans who were included in the capitulation. Shortly after his captivity began he wrote Dr. Rush:

"My very dear Sir

"In my last from F. Washington I vainly amused myself with a prospect of seeing you in a short time. But the events of war are uncontrolable and have taught me of how little avail the wisdom and hardihood of a few are against the councils and courage of the many.

"I have not as yet reflected so deeply on the fate of a prisoner as to make me unhappy. And perhaps I shall not. For I am no admirer of that philosophy which is constantly in tears or beating itself to pieces against the impassable bars of its prison. Methinks I feel something within me like that kindly resignation which when duly attended to never fails to befriend the unfortunate. But

" Altho' I am resigned with regard to my own fate, yet it were to be wished that an exchange of prisoners could be brought about as soon as possible. The officers thro' the goodness of his Excellency General Howe - have the liberty of the City - but the privates are crouded into Churches and the like. Prodire tenus, si non datur ultra.

"Col Magaw is ill of a fever, tho' in my opinion not dangerous. I am at private lodgings with him, Col. Miles, Atley, Swoope \&c. Their evening and morning devotions begin and end with Horace's $O$ rus, quando ego te aspiciam.

"I am Sir yours most respectfully sincerely and affectionately

"New York 21st Novr 1776"

James McHenry.

On this letter, McHenry endorsed the following reason why it was not sent: 
"The commissary of prisoners $\mathrm{Mr}$. Loring rejected this letter It would not pass"

Of his experience in eaptivity, we learn from a letter he wrote in Philadelphia to Washington on June 22, 1777:

"Observing it asserted in Gen. Howe's letter to your Exey of the 21st April Ult. that 'one half of the siek prisoners were rec'd into the British Hospitals - that the remainder were attended in their different places of confinement by their own Surgeons and lastly that these Surgeons, without restriction were supplied with medicines for this purpose until it was discovered that they disposed of large quantities by private sale ;' I conceive it incumbent on me to give your Excellency what information I can on this subject, the better to ascertain its eredibility, and that it may have its proper influence in the settlement of the proportion of prisoners to be accounted for.

"In the first place I would observe to your Excelly that Gen Howe seems to have fallen into a mistake in using the term B. H. in the sense in which he would have it understood. If it be not appropriated to amuse, his information must have come from persons whose interest it is that he himself should be deceived. For your Excellency is by no means to suppose that any of our sick prisoners were, at any one time whilst I was in N. Y received into the B. H., or treated in the same manner as their own sick and wounded.

"That great numbers of our sick and wounded were seperated from the rest, and put into houses provided for their reception is not to be doubted. But here they wanted, the necessary attendance, comforts, and conveniencies which eonstitute a hospital : either 'through design, or neglect of reasonable and practicable eare,' Whilst. On the other hand no patients could be better taken care of, or better provided, than those in B. Hospitals. Had ours received a similar treatment no cause of complaint could possibly have arisen on this head. But a detail [of] some of their sufferings, and what was attempted for their relief in comparison to our Enemies will better shew the discrimination. I enter upo it with pain and reluctance.

"The condition of the prisoners in gen. the want of such assistance as G. H. had it in his power to supply, \& wch was compatible with yr situation was at several times represented to Gen: Howe by letterg from our field officers. No answer was received. In December, Seir distresses became more 
peculiarly interesting. Heretofore the sick were under the care of Dr Antil a refugee from - But from this per:iod to their leaving $\mathrm{N}$. Y. they were principally under the direction of a person who called himself Dr Louis Debute a man of a most infamous and abandoned character.

"And It was now tho't advisable to acquaint Doctor Mallet (Surg. Gen. and providor to the B. H.) with their singular distresses. Accordingly in the presence of Col. Miles, I laid before him, and the commissary for Prisoners (Mr. Jos. Loring) their present condition. Mentioned their want of Hospital bed-bunks, bedding, and coverings - the almost total want of fire, in consequence of which several of their limbs had mortified - but more particularly their want of nurses and tenders to give cleanliness to the place and prepare and give them their drinks and nourishment at proper times. In short that they in a manner wanted every thing that could contribute to their comfort or recovery.

“'Dr. Mallet reply'd the account was affecting, and he was very sorry to hear it. He would look into the matter. But in the mean while could assure me that they were allowed the same as the patients in the B. H. And because it was thought, that it would please our officers better, they were under the eare of one of our own Doctors. If things were peculated or misapplied - it was not his fault. This complaint, I answered was made to him, and $\mathrm{Mr}$ Loring because it was imagined, it came more immediately under their cognizance. My state of their cruel sufferings was a true one. The evidence was no further off than the Quaker meeting house where they lay. That Louis Debute who seemed to be chiefly intrusted with their treatment did not belong to us, nor had ever been in our service, as I could learn. That he was notorious for crimes, and had been pillored some time before we evacuated N. York. Moreover That Dr. Oliver who had the management of our wounded had lately dismissed him upon its being discovered that he disposed of their medicines and necessaries. To this Dr. Mallet replied - that he was found amongst our people; and he supposed him one of ourselves.

"Dr Mallet then requested me to take the direction of the house upon myself, and said that if I could procure nurses (which I had remarked they wanted more than medicines) he would willingly pay them. To this I answered, that he must be sensible my situation in N. York was by no means calculated to procure nurses. But if nurses or even proper 
tenders were provided, and Debute turned off, I would immediately undertake the business. But altho' bound as well by profession as duty to render the sick service in my power, yet the superior regard which I owed my character, must determine me from the undertaking so long as he was continued.

"Mr Loring said Debute should not be suffered to prescribe, but as he was a useful fellow, might still be employed as an understrapper. I could not engage in the affair, I replied, until he was totally dismissed.

"Notwithstand[ing] this he was continued; tho' a Dr Hawkins, mate in the Gen. Hospital, came now and then to prescribe. But of his attendance or care they were little the better. And Debute was suffered to carry on his inhumanities and deceptions as usual 'till a more glaring act of cruelty rendered his dismission unavoidable.

"An officer, prisoner on Long Island, came to our lodgings to inform Cols McGaw \& Miles that the Doctor who had charge of our sick, had that morning in his presence given one of them a blow with his stick, in consequence of which the man died 15 minutes after.

"Upon this I renewed my complaints to Dr Mallet with this additional circumstance of Debute's barbarity: and begged, as the officer was willing to swear to the fact, that he might be tryed for the murder. The Doctor expressed much concern, and accompanied me to Debute. The fellow after some little hesitation confessed that he had that morning struck one of his patients; but argued that it was the man who lay next to him who died. The first detatchment of our officers, in the mean while was ordered over to Long Island, and unfortunately amongst them the person who was to evidence this fact. And the murdered man was already buried with a number of others, so that no testimony could be had from inspection.

"Now Debute was dismissed from his office and commanded never more to be seen near the sick. This comprehends a period of six week time their crowded situation the effects of severe cold on their limbs - the strong symptoms of a long deprivation of water expressed in many of their countenances - Exclamations for drink and food, from such as had strength left to speak - the groans of the dying - the looks of the dead that lay mixed with the living - and the insufferable impurity of the house, made up altogether a scene more affecting and horrid than the carnage of a field of battle wherein no quarter is given. 
"These things made impressions too strong to be forgotten. And I question whether the resentment of the few who survived can end, but with their feelings.

"But from this description which includes a period of 6 weeks I would in some manner discriminate the wounded, who were lodged in a different part of the Town; in houses provided with fire places, and under the direction of Dr Oliver, a refugee from Boston. I also make some distinction between the usage of the sick under Dr. Antil who had charge of them before Debute. But even under these gentlemen their state was often grievous and distressing to contemplate.

"Debute left the sick in such a condition that nothing save their immediate removal from $\mathrm{N}$. York afforded the smallest prospect of a single patients recovery. Wherefore all I could do, was to procure that application to Gen. Howe which got them out on parole; a copy of which I inclosed to your Excellency the latter end of Jany last dated from Hyde's Town Jersey.

"I come now to Gen. Howe's allegation against our Surgeons. I imagine that upon proper enquiry it will be found unsupported by admissible evidence: or to depend upon an equivoque of the same nature as that on which the assertion of our sick being recd into the B. H. is grounded. How far the following facts may serve to clear up the matter may not be difficult to ascertain.

"Doctor Hugh Hodge and myself made several applications for medicine for our sick officers, but were always refused. We were obliged to buy them for their use. An ounce or two of salts and a few nitre powders from Drs Oliver and Antil were all we ever recd. And these we had in consideration of our profession, not because they had orders to deliver any. For the latter Gent. told Dr. Hodge that Dr. Mallet had positively forbidden medicines to be given for patients out of his own care. Moreover when Debute had charge of our sick I bought from Dr. Brownjohn, and destributed amongst them medicines in his presence from time to time. I except here the dressings \&c - which Dr. Oliver from time to time furnished the wounded officers, who were attended at their own lodgings. Besides Dr. Hodge and myself there were 4 or 5 Surgeons prisoners belonging to Pennsylvania and the New England States. It is natural to suppose that those were also refused. But as I was not acquainted with them, do not affirm it. 
"But had medicines been allowed without restriction for the use of our sick remaining in their prisons - wherefore prevented from visiting them? Between the 20 November and middle of January, I attempted it several times but never obtained admission except in one instance, when $I$ had reason to believe that the guard had mistaken me for a British Surgn

"But further med. to men circumstanced as they were, could answer no one salutary purpose. It is even illiberal to suppose that any rational person would have prescribed them to men so totally unfurnished with those conveniencies and necessaries, without which, they are useless, if not hurtful. This would have been carrying eruelty to its utmost limits. And it ought really to be considered as a mark of G. $H$. humanity, that such a thing was not ordered to be done.

"This may serve as a commentary to G. Howe's third fact. I cannot be mistaken in a single assertion. In every part of the testimony I am clear, however it may stand contrasted with Sir William Howes. You will therefore use it as may best answer the course of justice. For 'Tis well I am G. Howes prisoner But this cannot prevent me from discharging the obligations $I$ am under to truth. With all due respect I have the honor to remain your Exl most obt and very humble servt",

\section{On January 27, 1777, Surgeon McHenry was paroled, ${ }^{1}$}

1.A rough drafi of the report made by McHenry to Loring, the commissary of prisoners in New York, is among the McHenry papers. Two of the letters sent Howe with reference to the prisoners here follow:

"To his Excy. Sir Wm. Howe commander in chief of his majesty's forces in $\mathbf{N}$. America may it please your Excelly.

"We being informed by several persons that the severity of the contagion in the prisoners' hospital is such as to encrease every disease and leave little or no probability of the unfortunate patient's recovery while confined in that place. And notwithstanding the severity of the season we are assured by some of the physicians that their removal wili be attended with less danger than their continuance there. We therefore take the liberty of requesting that your Excy. wili be pleased to give orders for these to be sent away as soon as convenient under the care of some of their Doctors, as it appears the only thing that can be done in their favor.

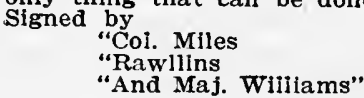

"And Maj. Williams"

"To his Excellency General Howe commander in chief of his magesties forces in North America.

"We should not have presumed one moment on your Excellency's time were we not called upon by the most powerful of motives. The state of the sick and wounded prisoners is of too melancholy a kind for recital and the consequences of a general contagion to be dreaded. We as witnesses of their situation feel every principle within us interested in thelr favour, and would beg leave to recommend them, in particular, as objects not unworthy of your Excellency's clemency. This winter will 
as we learn from a letter writen by him to Washington four days later from Hydestown:

"In consequence of the inclosed application to Gen: Howe the sick privates and those who remained of the well were ordered off on parole under my care as Doctor, and the conduct of a british officer \&c. But as the officer leaves them here, he gets no receipt. Six have died since our leaving NewYork; But I flatter myself, should the weather moderate a little that most of the remainder will recover. There is now Twenty five.

"May I hope that your Excellency will free me, as soon as convenient from the restrictions of a parole. I have the honour to be your Excellency's most obedient and most humble servant."

Over a year passed, however, before he was released from parole. During this time he probably resided in Baltimore. Then McHenry received a letter, written by his friend Hamilton on March 5, 1778:

"It gave me pleasure to inform you that Mr. Boudinotte has been able to effect your exchange for a Doctor Mentzes. Allow me to congratulate you on the event.

"We are again on the business of a general cartel with Mr. Howe. He seems inclined to meet us on fair ground. "Commissioners from us meet on equal numbers from him the 10th. instant. One great and preliminary point to be settled is the proportion of prisoners that we ought to account for. To assist our judgment in this point - we shall be much obliged to you by the return of this express, and without a moments loss of time to send us your deposition, to the best of your knowledge, on the actual state of the prisoners sent out at the time of the delivery; and whatever else may serve to throw light upon the subject,

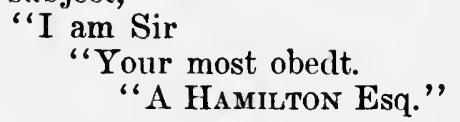

On the same day, Dr. James Hutchinson, who was a Philadelphia surgeon, wrote MeHenry from "Moorhall near headquarters, Valley Forge :"

assuredly place them beyond reach of human charity. We would therefore,
whilst a parole can be of any service entreat that a proper place may be
agreed to by your Excy, and Gen. W-n where the sick and wounded may
be conveyed they pledgting their falth to contlnue unactlve untill regulariy
exchanged or laid under such restrictlons and limitations as may be tho't
necessary by your Excellency and Gen. Washington. We beg that we
may be heard and are your Excellency's most obedient - humble servts." 
"I would have wrote you long since, but was uncertain where you were to be found, and now I only think it probable that you may be at Baltimore; therefore dispatch an Express thither, after you to carry this letter, and one which his Excellency has desired me to send you, on matters of importance. I sincerely congratulate you on your exchange, Mr. Boudinot has your parole in his possession, and you are once more at liberty to serve your Country, in such manner as your qualifications render you eminently capable; however I will say more to you on this subject when I have the pleasure of seeing you, at which time I shall have an opportunity of talking over the variety of scenes, which have passed since I saw you in Philadelphia, and since I have entered the army.

"I beg you to repair hither as soon as you possibly can, the Express who carries this has orders to ride night and day till he meets you, if you should be at Baltimore, his Excellency has Business with you of the greatest importance, and it is of the utmost consequence that you should be in Camp in four days from this date; I have fifty things to say to you, but am desired not to delay the Express, I have therefore no time to write half I wish to or to look over what I have already wrote."

McHenry now took up duties in the hospital and on May 17, Dr. Rush addressed a letter to him as "Senior Surgeon of the Flying Hospital, Valley Forge," in which letter he says: "It gives me pleasure to see one whom I had any hand in educating filling an honorable and useful post in the line of his profession in the army. May you continue to merit the esteem of your friends and the approbation of your country." On May 15, he was appointed secretary to the commander-in-chief. McHenry hesitated somewhat before he accepted the position and wrote his father to ask his prefelence in the matter:

"I find myself much embarrassed to know how to inform you of a matter in which my inclinations are deeply concerned; but in which I am not at liberty to proceed without your concurrence. Circumstances of some delicacy put it out of my power at present to be as explicit as I wish with a father - however, I hope to make it in some measure understood, so far as may be nécessary to obtain your opinion and consent.

"I do not forget the tenderness of our parting, your last 
injunctions, nor my promise to avoid all places of danger not strictly connected with the duties of my profession. It is the observation of those which prevents me from entering into a post of some danger till I can obtain your approbation. The post in contemplation is one not only of the most hon. ourable but the most flattering to a young man of any military views; or who wishes to be distinguished by the first in the military line. The idea of my being of use in my present station I trust will not be a reason with you why I should not change it for one more agreeable to my wishes. But I must not influence you in a matter which your own feelings must determine. I would only just beg to observe that those who believe in a superintending God can have little to fear from a change of situation. We are all under his eye, and under his particular providence, whether in the walks of private employment, or amidst the hurry and confusion of war and battle. We cannot die without his knowledge, nor live without his protection.

"It now rests upon you to say what I shall do. Whether accept of a post of danger honourable beyond my deservingness - or continue in a physical station wherein $I$ think I can be very useful to the army.

"Be good enough to write me by return of this express and believe me to be - with all due regard and affection your dutiful child."

Daniel McHenry's answer has not been preserved, but must have been favorable to McHenry's acceptance of the new post offered him. As secretary, he took an oath of allegiance to the United States and renunciation of the English king before General Nathaniel Greene on June 9 . With the appointment as secretary, McHenry gave up medical practice for the rest of his life. Save for an interesting prescription given Hamilton on the following 21st of September, we hear of no more medical work by McHenry. His advice to Hamilton was as follows:

"In order to get rid of your present accumulations you will be pleased to take the pills agreeable to the directions; and to prevent future accumulations observe the following table of diet.

"This will have a tendency also to correct your wit.

"I would advise for your breakfast two cups of tea sweetened with brown sugar, and coloured with about a teaspoon- 
ful of milk. I prefer brown sugar to loaf because it is more laxative. And I forbid the free use of milk until your stomach recovers its natural powers. At present you would feel less uneasiness in digesting a pound of beef than a pint of milk.

"You will not drink your tea just as it comes out of the pot; let it have time to cool. The astringuency of the tea is more than counterbalanced by the relaxing quality of hotwater.

"For your dinner let me recommend about six ounces of beef or mutton, either boiled or roasted, with eight or ten ounces of bread. Cut the meat from the tenderest part with little or no fat. Use the natural juice, but no rancid oily gravy whatsoever. For some time I would prefer the beef, because it contains more of a natural animal stimulus than mutton. Once or twice a week you may indulge in a thin slice of ham. Your best condiment will be salt.

"You must not eat as many vegitables as you please - a load of vegitables is as hurtful as a load of any other food. Besides the absurdity of crouding in a heap of discordant vegitables with a large quantity of meat too much of itself for the digestive powers. You may eat a few potatoes every day.

"Water is the most general solvent the kindliest and the best assistance in the process of digestion. I would therefore advise it for your table drink. When you indulge in wine let it be sparingly. Never go beyond three glasses - but by no means every day.

"I strictly forbid all eatables which I do not mention principally because a formula of diet for your case should be simple and short.

"Should this table be strictly observed, it will soon become of little use, because you will have recovered that degree of health which is compatable with the nature of your constitution. You will then be your own councellor in diet for the man who has had ten years experience in eating and its consequences is a fool if he does not know how to choose his dishes better than his Doctor.

"But in ease you should fall into a debauch - you must next day have recourse to the pills. I hope however that you will not have recourse to them often. The great Paracelsus trusted to his pills to destroy the effects of intemperance but he died if I forget not about the age of 30 notwithstanding his pills. Lewis Cornaro the Italian was wiser - he trusted to an egg, and I think lived to about ninety." 


\section{H A P T E R III}

\section{WASHINGTON'S SECRETARY}

1778-1780

$M^{\circ}$ CHENRY now took up a position he was to fill for two years and which determined his future life. He was a member of Washington's "military family," in close association with such men as Hamilton, Lafayette, and. Benjamin Talmadge, all of whom became his friends for life, and in such relations to "the General," as McHenry always called Washington, that McHenry grew to be one of the few with whom that austere man could unbend. McHenry's sincerity and purity of soul and his "easy and cheerful temper" attracted the great man and, though Washington ever remained a hero to his secretary, yet the intimacy showed itself in the easy and often playful style in their letters. McHenry ${ }^{1}$ was at the battle of Monmouth on June 28, 1778, and was then sent to the rear to look after the baggage, in case the result of the battle should be unfavorable to the American forces. Before the battle, he met Lee on the march towards the enemy and asked him if he had any information to send back to General Washington. Lee said the enemy did not appear well to understand the roads and that he expected to fall in with the rear of the enemy, with great certainty of cutting them off. McHenry started with this message, when Lee called him back and added, "with fixed and firm tone of voice and countenance," that General Wayne and Colonel Butler are amusing them with a few loose cannon shot, that the enemy are constantly changing their front, which is a usual thing with those who retreat. After the conflict, McHenry, was present, when Washington asked Lee the cause of the retreat and noticed his confusion. A third time, he saw Lee at Englishtown later in the day, when Lee was observing to a number of gentlemen that it was mere folly

1 Tower's Lafayette in the Revolution, 391, Lee Papers, N. Y. Hist. Soc., III, 77, 191. 
to make attempts against the enemy wherc they possessed so great a superiority in cavalry. ${ }^{1}$

While the army was in winter quarters, on December 10, Samuel Smith of Baltimore wrote MeHenry from that town:

"I arrived here Safe on Thursday last, my Stay in Philada. was but 7 days. I was astonish'd with the Luxuries \& extravagances of that once Federal City. it is true the Attention they pay to officers, flatters \& pleases us. but Such prodigality of our Money depreciates it \& in the end bids fair to destroy it. they talk of thousands as we do of Dollars in Camp. I lamented our Situation, \& to enforce it, assur'd as an instance of the Impossibility of our staying longer in the Service, that my half years pay was spent on my Journey home. I was laughed at for my parsimony. I was mistaken it cost me 50 Dr. more. - I hope Balto was not so bad. here it is true their living is not luxurious, but the Money is of as little value, what think you of J. M' Lure betting $200 \mathrm{D}$. on the throw of a Die. one thousand Dolls. to lose or win in a Night is peddling. - The consequence of this will be very soon felt by the Army. Pennsylvania says it can supply no flour. on this place a very chief dependance is plac'd by the Commisary General. his deputy has made frequent attempts to purchase, but to very little purpose, So Soon as he gives a price the Speculators give a higher until at length it has got to

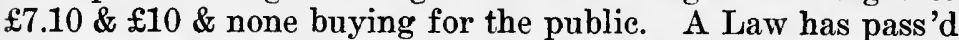
this State but it will have very little Effect. it prevents Monop-

\footnotetext{
1 After Hamilton's death, McHenry defended his reputation while in the Revolutionary army in the following communication to "Yundt \& Brown's Gazette":

"In the Aurora of the twenty ninth ulto. the following was inserted as an anecdote.

"When Colonel Hamilton aid de Camp to General Washington forced General Charles Lee to the field, for ridiculing that General's abllities Lee, recelved his fire; but refused elther to retract what he had said or to return a shot.

"." You may fire at me all day Sir, (sald Lee) If it will amuse you: what I have said I am not disposed to recall; - but I should conceive you do your patron no great honour by thus assuming his cause; and as for returning your fire, I beg to be excused. Gen. Lee can acquire no honour by the death of Colonel Hamilton."

"We have the authority of a gentleman whose situation in the army, during the revolutionary war, and intimacy with the deceased Gen. Hamilton, gave him an opportunity of knowing whether the fact related in the above anecdote took place, to state, that General Hamilton never did call General Charles Lee or any other officer of the revolutionary army to the field for any cause. It is possible our informant thinks that the mistake may have originated in the following circumstance. Col. John Laurens and Colonel Hamilton, were at the same time alds to General Washington, The latter Col. Laurens did call General Lee to the field. This gentleman was a son of Henry Laurens, the well remembered President of Congress, and was surpassed by few men in genlus, ability and gallantry. He fell in a skirmish in South Carolina fighting for his native country."
} 
olizers but does not prevent Millers from forestalling nor farmers from keeping up their grain. Good Men with a part of the Army had been Cantoon'd in Maryland. I fear it will again want flour, its Distance from the flour Country is very great

"The Situation of the Officers is truly distressing they not only have the Mortification to See every thing live except themselves, but, they see their private fortune wasting away to make fat those very Miscreants. they See their Country altho yet wanting their Assistance refuse to make any future provision for them, or even to give them the Necessary Supplies, which their Small pittance of pay will not purchase. Congress feels not for us, our Countrymen will soon avoid us, that they may not be troubled with our Complaint \& lest we should want to borrow their Money from them. I cannot bear to resign \& yet what Can I do. my Fathers opulent fortune is reduced to Nothing, it was chiefly in cash. exclusive of my Love for my Country \& the Service, my attachment to his Excelly. makes me wish to remain \& nothing but dire necessity Shall make me resign."'

After Washington and his military family reached Haverstraw, McHenry wrote an account of the march which gives glimpses of the pleasant side of the campaign.

"In our route to Paramus, where part of the army had encamped in order to rest and refresh, we visited the falls of Pasaic [on July 10]. We crossed the river at an old bridge in very bad repair and in half a mile reached the falls.

"The rock to which they owe their birth is of considerabi" compass (covered in general with herbage, some trees and shrubbery). But besides the chasm into which the water throws itself there are several other fissures and deep dismemberments, formed as it would seem by nature in some of her violent operations. The falls tho' curious in themselves derive additional beauties from those objects with which they are connected.

"The Pasaic appears to be about 30 or 40 yards broad but the water does not cover at the falls near this extent. There a smooth and gentle sheet tumbles down into a deep aperture or cleft of the rock, which crosses the channel, while, at the same time, several lesser portions seem to steal thro' different openings, rudely encountering each other in their descent, till they arrive at the bottom where they all mix to- 
gether. This conflict and the dashing of the water against the asperities and contrasted sides of the rock produces a fine spray that issuing from the cleft appears at a distance like a thin body of smoke. Near the bottom of the falls it exhibits a beautiful rainbow in miniature. The aperture into which the water falls does not seem to be more than from 21 to 22 feet wide, and about 30 feet in depth, tho' further down and towards where the river takes a new turn the distance between the walls of rock is much greater and the perpendicular depth perhaps not less than 70 feet. Here the water composes itself as in a large basin of solid stone and then spreads into a pretty broad channel, continuing its course uninterrupted to New-York bay.

"A little above the falls the water glides over some ledges of rock of about 3 or 4 feet perpendicular in a very pretty manner.

"It is observable that all the clefts and dismemberments in the several parts of the rock run in the same direction. You may descend into some of them by means of earth and stones with which their entrance is made gradual and easy. On each side of these fissures is a perpendicular wall of rock, overgrown with moss. There one enjoys a delightful coolness under an intermixture of ruins and the branches of trees that form a fine shade.

"After viewing these falls we seated ourselves round the General under a large spreading oak within view of the spray and in hearing of the noise.

"A fine cool spring bubled out most charmingly from the bottom of the tree. The travelling canteens were immediately emptied and a modest repast spread before us, of cold ham, tongue and some biscuit. With the assistance of a little spirit we composed some excellent grog. Then we chatted away a very cheerful half hour - and then took our leave of the friendly oak - its refreshing spring - and the meek falls of Pasaic - less noisy and boisterous than those of Niagara, or the more gentle Cohoes or the waters of the Mohawk.

"From hence we passed thro a fertile country to a place called Paramus. We stopped at a Mrs. Watkins whose house was marked for head Quarters. But the General receiving a note of invitation from a Mrs. Provost to make her Hermitage, as it was called, the seat of his stay while at Paramus, we only dined with Mrs. Watkins and her two charming daughters, who sang us several pretty songs in a very agreo- 
able manner. At Mrs. Provost we found some fair refugees from New York who were on a visit to the lady of the Hermitage; with them we talked - and walked - and laughed and danced and gallanted away the leisure hours of four days and four nights and would have gallanted - and danced and laughed and talked and walked with them till now had not the General given orders for our departure. We left them however in the spirit of modern soldiership without much sighing in pursuit of the dangers of war and pleasures of variety.

"It was about 6 o'clock in the (15 July) morning when we bade adien to the Hermitage - coasting it thro' narrow $\&$ stony roads to a place called Haverstraw in Orange County the state of New York.

"Our quarters was engaged at a Col Hay's. The house stands about a mile from the North River on an eminence commanding a large extent of water and a view of a considerable compass of Chester County on the opposite shore, and some of the heights of Duchess.

"After dinner I took a ride to a pond or lake - about half a mile from the West side of the North River. The lake is greatly elevated above the level of the river and affords some excellent fish, sun fish, carp \&c. \&c.

"It is formed in a bason of very high and commanding ground - there are several farm houses along its banks which adds greatly to the view. To get to it you ride around the base of a large chain of rocks - which border on the North River. We began to ascend these very gradually after 3 miles riding - and in a little time came to a fine level and cultivated piece of country. bason."'

"On this elevated ground the lake forms a very pretty

The harder side of the campaign is revealed in McHenry's letter to his father written from headquarters on August 15.

"My very dear Father.

"I yesterday received your letter dated the 28 of last month. your writing me thus yourself I take very kindly and shall consider it as a great satisfaction if you will but write me oftener - and by post, as this conveyance is the most constant and certain.

"The questions you have proposed to me with so much cordiality of inquiry I shall answer with very great pleasure. 
"I cannot say that the fatigues of our late march has been of any disservice to my constitution - in sleeping in the open fields - under trees exposed to the night air and all changes of the weather I only followed the example of our General. Tho' long in the army I was but a hospital soldier. When I joined his Excellency's suite I gave up soft beds - undisturbed repose - and the habits of ease and indulgence which reign in some departments - for a single blanket - the hard floor - or the softer sod of the fields - early rising and almost perpetual duty. These habitudes however I prefer to those of idleness and inactivity - they are more consistent with the profession of a soldier and repetition has now made them agreeable.

"This however is a description of all in the General's family. You will certainly suppose that men under these circumstances have small demands for money. This is really the case: with few or no opportunities to spend it, a very little serves our turn. And this too is one capital reason why I have no occasion to make use of your kind offer - of a supply. I may however perhaps claim it some other time when I have nothing to do but invent the most agreeable and instructive ways of spending it.

"As you extended your charitable inquiries to my horses I can do no less than let you into their history. At present they lead a very lazy and indolent kind of life. Tom feeds them well and I ride them but little. Perhaps once in the two days a circuit of a few miles to the different places of parade or round the encampment: so that upon the whole you see the two animals have a very comfortable time of it and are much happier than their master if idleness and ease can make them so.

"I need not tell you what real and cordial satisfaction $\mathrm{I}$ would feel in a change of situation for a few weeks; but I fear I must go many miles further from Baltimore before I can see you. The English have not yet left the United States and if they had, still the war would be unfinished. We may therefore be separated much longer than present appearances indicate or than either of us wish. I hope however that we will end our days not far from each other, and that the society of your sons will serve to make your evening hours not the most unhappy of your life.

"My brother was kind enough to write me from Philada. 
but I have no reason to expect the pleasure of seeing him at camp.

"There has been no accounts from Rhode Island since the 10th inst. Should any arrive before the post sets out which will be to-morrow evening you will have it in another letter.

"I am dear father yours most dutifully and affectionately.

"P. S. You desire to know if I want shirts. I would wish to have half a dozen with stocks, sent by the first safe conveyance. There is a little lace somewhere in my trunk wrapped up I believe in a remnant of linen."

During the whole of the remainder of the year, McHenry remained with the army at Fishkill.

The contrast between life in Philadelphia and in the camp, shown by Smith's letter, is also brought before us by a letter sent McHenry at Middlebrook by Tench Tilghman from Philadelphia on January 25, 1779 :

"Dear Mac

" I believe I am two or three letters in your debt, which I think is no great deal, considering you love scribbling, and have time to indulge it. I have hunted in vain for Justamonds translation of Abbe Reynell. I have seen a copy in the hands of a private Gentleman, but am told there is not a set for sale in the city. I suppose you think we must be, by this time, so wedded to sweet Philada. that it will break our hearts to leave it. Far from it I assure you my Friend. 'I cau speak for myself, and I am pretty eertain I can answer for all, when I say, that we anxiously wait for the moment that gives us liberty to return to humble Middle Brook. Philada. may answer very well for a man with his pockets well lined, whose pursuit is idleness and dissipation. But to us who are not in the first predicament, and who are not upon the latter errand, it is intolerable. We seem to work hard, and yet we do nothing; in fact we have no time to do any thing and that is the true reason why a great assembly do so little. A morning visit, a dinner at 5 o'clock - Tea at 8 or 9 - supper and up all night is the round die in diem. Does not the Republic go on charmingly? By the Body of my father as honest Sancho used to swear, we have advanced as far in luxury in the third year of our Indepeny. as the old musty Republies of Greece and Rome did in twice as many hundreds: But we 
Americans are a sharp people. And we are in more senses than one; and if we do not keep a sharp look out we shall be little the better for the profusion of money and no small quantity of Blood that has been spent. All cry out that nothing but Oeconomy can save us, and yet no one allows that he or she is extravagant. I will not touch upon politics. They are too valuable to trust to paper and Wax. You shall hear much when we fill the sociable Bunks, where all is under the secure lock and key of Friendship. Now for domestic matters, for we begin to look towards home. Say to Major Gibbs that we have heard with infinite pleasure of good Mrs. Thompson's arrival at Camp and as His Excelley has her ease and convenience this Winter much at heart, he wishes she may have a warm comfortable apartment built for her sole use and behoof in such place as he the major shall upon due deliberation and consultation with the sage matron judge most proper. This will be absolutely necessary, as Mrs. Washington will want the Chamber, we at first occupied, for a drawing Room, and we remove to the small back Chamber which Gibbs lodged in.

"Make my compliments to all at home and in the neighborhood and believe me with sincerity Dear Mac

$$
\begin{gathered}
\text { "Affecty. Yours } \\
\text { "Tench Tilghman." }
\end{gathered}
$$

Life in the camp was, however, not all hardship. Of its pleasant side we catch a glimpse in a letter Lord Stirling, on December 24, 1778, wrote McHenry, that he will be glad to see Lieutenant Clive this afternoon, but "it is so cold that for his own sake I could wish he would delay the visit till tomorrow \& that both he \& you would come \& take Christmas dinner with me."

From headquarters at West Point, on August 20, 1779, McHenry wrote to his future brother-in-law, John Caldwell, showing he already was interested in Margaret Caldwell, now a girl of seventeen, whom McHenry married four years and a half later:

"My dear Jack

"Since I had the pleasure of seeing you till today, there have been no military occurrences worth mentioning. I did not therefore think it necessary to trouble you with a letter. Besides, Jack, we have no time to spare for letters of cere- 
mony, and very little even to those of friendship. You will not however I am persuaded, esteem mine the less, for not writing, nor determine the number of your letters by those from me.

"I mix my rejoicings with yours on our late accounts from Europe and the success of our ally in the West Indies, and let me add for the capture of above 160 of the garrison of Powles Hook, by major Lee, on the night of the 18th instant. This was an enterprise of great risque - conducted with great judgment, and completed with the most inconsiderable loss. But you will see the particulars from Congress.

"I take too much interest in your studies not to inquire into them. I suppose them agreeable, and that you are sensible your reputation and future figure in the world, will depend on the acquirements you now make, and the conduct you may observe for some years to come. Let nothing prevent you from prosecuting them.

"Should your sister come to reside in town, she will naturally claim some of your attention. The pleasure of giving a turn, or proper bent, to her studies and amusements, must be very agreeable to a mind like yours. I envy you the enjoyment. Suppose she cannot have every thing she deserves, yet with your care she may have enough to appear very amiable. I would not have you forget, on any occasion, that whatever. you want to obtain either in your or her favor - must be attempted with prudence and caution. Your father may be persuaded - but he will not be forced. On this scale every thing in reason will be granted, with a little chiding.

"You will remember me to the family - to your sister and believe me yours very affectionately

\section{"JaMes McHenry."}

We are ignorant of McHenry's life in 1779 , apart from this letter, except that he was busy drafting orders for Washington and carrying out his commands. ${ }^{1}$

Dr. Rush wrote McHenry on January 19, 1780, that he might have to come to attend the trial of Dr. Shippen and if he does "shall be happy in spending as much time as ean be spared from the Court in your company!"

1 On the manuscript of one of Washington's plans of campaign, McHenry wrote: "The General's usual mode of giving notes to his secretaries or aids for letters of business. Having made out a letter from such notes, it was submitted to the General for his approbation and correction - afterwards copled fair, when it was again copied and signed by him." 
From headquarters on March 18, 1780, McHenry wrote a jesting letter to Hamilton, then at Amboy as a commissioner for negotiating an exchange of prisoners:

"The family since your departure have given hourly proofs of a growing weakness. Example I verily believe is infectious. For such a predominance is beauty establishingr over their hearts, that should things continue to wear as sweet an aspect as they are now beheld in, I shall be the only person left, of the whole household, to support the dignity of human nature. But in good earnest God bless both you, and your weakness, and preserve me your sincere friend."

All this time, as McHenry wrote Washington on July 18, "I have acted without pay \& it is my intention to receive none in future, unless some alteration in my circumstances render it necessary," but now he desires other rank than secretary; thinks of going to Europe, and wishes to be a volunteer in one of the regiments. These plans he did not carry out, but the secretaryship was nearly over. ${ }^{1}$

1 A letter from McHenry to his friend Dr. Binney speaks of this thought of a European trip. 


\section{H A P T E R IV}

\section{LAFAYETTE'S AID}

\section{$1780-1781$}

$I^{N}$

N August, 1780, McHenry was transferred to Lafayette's staff where he remained, until his resignation from the army in the autumn of 1781 .

John McHenry, a nephew of Dr. McHenry, left record ${ }^{1}$ that he had been told by his uncle, later in life, that "Washington feared lest the youthful ardor of the Marquis, entrusted when not quite 23 years of age with an important command, might outrun his discretion \& that he, accordingly, took the precaution of placing near him, one whom he knew to be a prudent adviser." It seems that Washington's opinion of the young secretary must have been that of McHenry's grandson, Ramsay McHenry, who wrote a century later of his grandfather: " $H$ is sagacity was very great, his intellect very clear and of a considerable compass. He was vivacious, exact and active in business, benevolent, prudent, and wise.'

McHenry wrote to Otto Holland Williams from Orangetown on August 12. In September, Hamilton married General Philip Schuyler's daughter and McHenry went to Albany for the wedding and wrote the following verses to his friend on the morning after the ceremony:

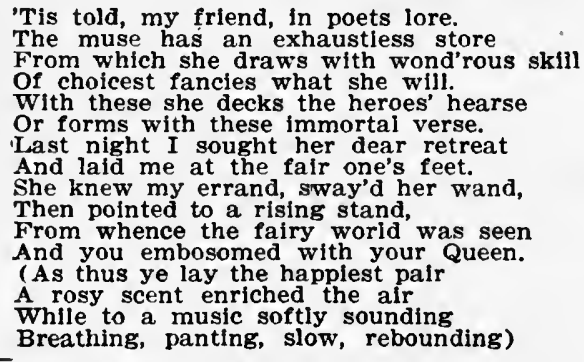

1 Brown's McHenry, 13. 
Love arose with pow'rful spell,

Hence, he cried, to dismal dell

Imps who haunt the gloomy breast

Ever jealous - never biest

This is ground for holy feet

Here the sports and pleasures meet.

Then in whispers caught the ear

What the gifted only hear.

"Chains of Priests or modes of art

"Weakly hold the human heart,

"Hence my Eloisa sald

"Give me those that love has made."

Now his fluttering wings out spread

Three times he bless'd the bridal bed,

While o'er it Faith her mantie threw

And said small care would keep it new.

Last Prudence came, in sober guise

With Pligrim's pace, and wisdom's eyes;

Forth from his stole a tablet took

Which you received with thankful look.

Genlus had deepiy mark'd the ground,

And Plutus finely edg'd it round.

This done, he bade you long improve

In all the sweets of mutual love.

And now would friendship's voice prevail

To point the moral of the tale.

Know then, dear Ham, a truth confest

Soon beauty fades, and love's a guest.

Love has no settled place on earth:

A very wan'rer from his birth:

And yet who happiness would prove,

Like you must build his hopes on love,

When love his choicest gifts has giv'n

He flies to make another heav'n;

But as he wheels his rapid flight

Calm joys succeed and pure delight.

Falth adds to all; for works we're told

Is love's alloy, and faith the gold.

Now genius plays the lovers part;

Now wakes to many a throb the heart:

With ev'ry sun brings something new,

And gally varles every view ;

Whilst Prudence all his sucoour lends

To mark the point where pleasure ends.

For, borne beyond a certain goal,

The sweetest joys disgust the soul.

He too instructs us how to use,

What's more a blessing than the muse [wealth];

For well he knows, deprived of this

That toil and care is human bliss.

All these attendants Ham are thine,

Be't yours to treat them as divine;

To cherish what keeps love alive:

What makes us young at sixty five.

What lends the eye its earliest fires;

What rightly managed still inspires.

To which Hamilton answered as follows:

"I thank you Dear Mac for your poetry and your confidence. The piece is a good one - your best. It has wit, which you know is a rare thing. I see by perseverance all ladies may be won. The Muses begin to be civil to you, in spite of Apollo and my prognosis. 
"You know I have often told you, you wrote prose well but had no genius for poetry. I retract. Adieu
"Sep. 12
[1780]
A Hamilton"

Shortly after this time, McHenry sought a more definite military rank and Hamilton wrote to General Schuyler in his behalf. Schuyler answered on September 16, asking McHenry to write to him directly. "Schuyler can obtain from the Governor of New York the appointment of Lieutenant Colonel in the State levies, which will give McHenry rank, when the militia is in the field. While the Governor is well disposed towards McHenry, he can not make him even a lieutenant in the regular forces, unless all the ensigns are provided for."'

On September 24, McHenry was with Lafayette as aid and, leaving Washington and Lafayette to go on and examine the redoubts about West Point, ${ }^{1}$ he rode with another aid up to Arnold's headquarters to make Washington's apologies to Mrs. Arnold for delaving breakfast. Before breakfast was over, came that fateful message to Arnold that his treason was discovered, which led him to take his horse and flee to the British lines.

A short time after this, Greene 2 was sent to the south to take command of the armies there and MeHenry was anxious to go with him. Greene, who had known McHenry for some time, "cherished an earnest wish to have him," but MeHenry insisted that, if he went, he must not lose rank. So Greene wrote to the president of congress, on November 2: "Nothing but a majority will engage him in the service," and, "if the indulgence can be consistently granted, it will lay me under particular obligations." It was not granted and so McHenry took no part in the southern campaign. Greene recurred to the matter, ${ }^{3}$ in a letter he wrote Washington, May 1, 1781, saying: "When I was appointed to the command of this army, I solicited Congress to give Dr. McHenry a majority, that he might serve me in the character of Aid. This they refused. I was persuaded, when I made the appli-

1 Brown's McHenry, 15. Chastellux Travels, i, 108, 112. On November 23. M. de Chastellux, traveling through America, net Lafayette at his camp near Haverstraw and thence was conducted by McHenry to Washington's headquarters about two miles to the north. Chastellux saw with McHenry, on his way, a great cataract, which much impressed him and remarked that he did not find his companion "much versed in natural history."

2 Greene's Greene, Iii, 44.

3 Brown's McHenry, 14. 
cation, of the necessity \& since have felt it most sensibly. Your Excellency can scarcely tell how happy you are in your family, \&, therefore, can hardly judge of my situation. I cannot make a second application to Congress on the subject, nor should I have hopes of succeeding if I did; but I shall esteem it a peculiar mark of your Excellency's friendship \& esteem, if you will interest yourself in the matter \& get him a majority. Your Excellency will judge of the propriety of my request.",

This time the effort was successful and, on May 30, 1781, MeHenry was granted a commission as major to date from October $30,1780$.

Meanwhile, McHenry was serving as the "confidential friend" in Lafayette's military family, of whom the ardent Frenchman had an "affecting recollection" over forty years later. ${ }^{1}$ In February, he was at home in Baltimore, whither Lafayette addressed him the following interesting letter, comparing French and English liberty.

"Dear Sir "New Windsor, February the 15th 1781.

"After a Debate on french and British Liberty, I was Collecting a few Comparisons in a Letter to a private friend, When Happening to See them you thought they Might Be Useful, And I Gave to You what I Had Already writen You are pleased to Request A Continuation, But Having No Copy of the part in your possession, And Many Months Being elapsed Since it came out of My Mind, I can only add, therefore, Broken ideas, and do not pretend to Be Answerable for Repetitions

"I Have Been, I think Speaking of French Parliaments, and (Correcting the Mistake Which is often Made from A Resemblance of Names) I Said that Parliamentary opposition was no where essential, And that in France it was More Collectively And More Freely Expressed - These French Courts of Justice Called Parliaments Must, in My opinion, Be Commended for two Advantages - the 1st. that they form Several Distinct Bodies, Most of whom Are Situated in removed Provinces where they Can See the Social Disadvantages of Measures they Mean to oppose, where they more immediately Can Collect the Sentiments of the people, where they keep More Distant from Court Influence And Corruption

"The $2 \mathrm{~d}$ is that Men in Parliament form a kind of Sepa-

1 Scharf's Chronicles of Baltimore, 411. 
rate Class the Greatest part of which Have independant fortunes, and Not Many Belong to Court Families - By their Station they Are excluded from Emploiements At Court, in the Navy, in the Army, From Almost every Appointment Which in England Becomes Means of Corruption - From the Duties of their profession they Renounce the Pleasures of Dissipation, their very dress imposes upon them A Sober Way of Living Which still Renders them More independent, While As a Body they Become Formidable And are Supported By Illustrious Families Which ever kept Some of their Branches in Parliamentary and Senatorial profession

"Many Great inconveniences are found in the French Mode of Rendering Justice, And Juries are Not Without Some - I far prefer the Later, And You Know theyr Advantages It might However Be Said that French Judges Must Be More Enlightened, More Used to Business and more strangers to Local Little Cabals, That if one of the parties think any form Has Been Neglected, these are revoked By a Superior And Different Board Called the Great Council - But upon the whole, the Mode By Juries Seems to Be Preferable - Let us now Consider A still more Important Point Viz - The Basis itself of Justice, The Law Upon which the fate of citizens Must Be Litteraly Decided in Both Countries

"In France Crimes Are Seldom Capital or imprisonments Permitted to what they are in the Laws of Great Britain These Seem to Have Rather Trifled with the life of Men and personal Liberty, While Both in the French Laws Have Bcen Most Deliberately treated - Next to Personal Laws comes Relligious Tolerance, and Here Also France Has the Advantage.

"Tolerance is Much Commended in English writings, and No where Less practiced than in that Country - and every other protestant Society are persecuted By the Church to which their King Presides - Catholics are still More particularly A prey to fanaticism And the Greater part of the inhabitants in Ireland are for Relligion Sake trampled Upon By the minority of their Country Men - The Last Riots in London Have Been A Wonder to All europe, and By their Violence and Indecency Equal Any thing that Disgraced the Barbarous Ages of Ignorance And Superstition

"In France there is also A predominant Relligion, But persecution Has long Since Vanished, and protestants are quiet in every part of the Kingdom-From an Ancient 
Institution the Military Order of St. Louis Requires a profession of Catholicism, But an other Ribband to Similar purposes with Similar Advantages Has Been Long Ago located for Protestant officers - Great places in the Kingdom are filled By them, And the Present Minister of France is a Calvinist - you know how it is in England with Regard to Catholics Many, Among their Generals and their troops are protestants, and few Catholics are to be found in the regiment of Deux Ponts now in Rhode Island-Jews are admitted to buy manors while they of course Appoint Catholic Clergymen to Churches Within theyr possession - And to Give You an instance of French Tolerance, there is now A Church in the Large City of Strasburg Which Belongs Both to a protestant and A Catholic Society, Where the Catholic service is performed Every Sunday, And when it is over the Protestants Congregation Come in to Worship the Same God in a Different Way

"An Additional Circumstance is that in England the popular ery and the popular maxims are pointed towards the Exclusion of Tolerance, While to France the Voice of the people and the omnipotent Influence of Society are Bent to its admission, and are Every Day Checking the Remaining privileges of A predominant Relligion, In Support of measures Which Are Conductive to the most perfect Relligious Liberty

"'Thus far My Dear Sir, I will go for the present, And if any other Matter Occurs to My Mind, An other Letter will soon Follow this to Baltimore - Good News Are Coming generally from the Sonth Ward And as you will know the disaster of the British Fleet, as Partout's affairs at Mauricinia must Have Reached the Banks of Chesapeake, My gazette of this Day will be very insipid. - Every Body Says You are Going to get into the Governor's Council - If Yon quit the House for the field, I shall Be Very Happy to obtain the preference in Your Military employment And Hoping You know my tender friendship and Affectionate Regard for You, Will not lengthen this letter with assurances from my Heart While the Heart itself must be known to You

"I intend to write to You Again in a few Days and with every Sentiment of Attachment and Esteem Have the Honor to be

"Yours

"LAFAYETTE

"I Have Been Happy to Hear of the Suceess Which our friend 
General Greene Has obtained - The first Letter I receiv'd from Him was intended to Give me his state of things and of Cource Discourage my coming - The second Has Been to announce the Affairs of Morgan, and to tell me that the Glory Reaching from it did not Blind Him on His true Situation",

At New Windsor, just about this time, came the rupture between Washington and Hamilton because of the stiff pride of the young aid de camp. On February 18, Hamilton wrote of it to his friend McHenry.

"I have, Dear Mac, several of your letters. I shall soon have time enough to write my friends as often as they please.

"The Great man and I have come to an open rupture. Proposals of accomodation have been made on his part, but rejected. I pledge my honor to you that he will find me inflexible. He shall for once at least repent his ill-humour. Without a shadow of reason and on the slightest grounds he charged me in the most affrontive manner with treating him with disrespect. I answered very decisively 'Sir, I am not conscious of it, but since you have thought it necessary to tell me, so we part!' I wait till more help arrives, at present there is besides my self only Tilghman, who is just recovering from a fit of illness, the consequence of too close application to business.

"We have often spoken freely our sentiments to each other. Except to a very few friends our difference will be a secret, therefore be silent.

"I shall continue to support a popularity that has been essential - is still useful.

"Adieu my friend. May the time come when characters may be Known in their true light.

"Madame sends her

friendship to you."

McHenry had not been wasting time in Baltimore. On his southward route to take command of the continental troops in Virginia, Lafayette wrote Washington from the head of Elk on March 7, "The State of Maryland have made me every offer in their power. Mr. McHenry has been very active in accelerating the measures of his State." The day before this, McHenry wrote the merchants of Baltimore, ${ }^{i}$ asking

1.Scharf's Maryland, ii, 437. See Sparks's Letters to Washington, 1i1, 255. McHenry himself gave $\$ 110.761 / 2$. 
them to form a committee to give effect and furtherance to the measures taken by the public for Lafayette's expedition. The general was greatly disappointed by the delays which had already occurred and, without general exertions, the expedition might be defeated in its commencement. "Such is the derangerl state of our treasury affairs that public officers find a thousand inconveniences \& obstacles in the execution of their duty. Scarce a wagon can be put in motion, without adding to the powers of government that of private assistance. In such a situation, it becomes the duty of individuals \& of particular societies of men to contribute a certain support, beyond what may be considered their proper proportion. This is looked for under all government, but expected more particularly in the republican. I need not select, as an instance, the Philadelphia merchants, who have so long kept the northern army supplied with provisions *** The Marquis cannot write you himself, in the first instance, nor before he knows your disposition or arrangements. If you do anything, I pray it may be instant, that we may have it to say to ourselves, the expedition has not failed for want of what support we could give it.

"As it is probable another detachment will follow this, we shall want more vessels. Your assistance may also become essential during the whole course of our operations."

The merchants called a public meeting in consequence of this letter and appointed a committee, composed of Robert Purviance, William Patterson, and Mathew Ridley to co-operate with Major McHenry in procuring supplies of clothing, money, etc. On the 9th, the committee answered: "We are authorized to assure you, in their [i. e. the merchants] names, that no exertions, within the compass of their abilities, shall be wanting to expedite the enterprise of Major General the Marquis de Lafayette \& the military subordinate to him, they being warmly disposed to aid \& give immediate energy to his operations against the common enemy."

The story is told that ${ }^{1}$ Lafayette stopped in Baltimore at this time and, at a ball given him, was sad, because so many of his soldiers were in want of clothes. Learning this fact, the ladies set to work to provide for this deficiency and Lafayette warmly thanked them in a letter he sent to Baltimore by McHenry some time later.

McHenry went to Annapolis during March, and labored to the same purpose, though impeded by illness. He kept in

1 Scharf's Chronicles of Baltimore, 194. 
close touch with the merchants, and it was doubtless partly due to his efforts ${ }^{1}$ that Governor Thomas Sim Lee wrote the merchants, on March 20, that the state will repay, with interest, the money advanced by them and said: "We very much applaud the zeal \& activity of the gentlemen of Baltimore \& think their readiness to assist the executive, at a time when they were destitute of the means of providing those things which were immediately necessary for the detachment under the command of the Marquis de la Fayette, justly entitle them to the thanks of the public."' 2 On April 14, McHenry wrote from Baltimore to Washington about the Virginia expedition. McHenry seems to have been with Lafayette during the whole of the campaign, but we know nothing of his services. In 1785, he furnished Dr. William Gordon, who was writing a history of the United States, with an account of the part taken by Lafayette in the Revolution, but the published history contains no mention of McHenry, though it gives some anecdotes which were probably taken from McHenry's sketch.

Greene's friendship and esteem for McHenry continued and letters passed between them from time to time, especially as Lafayette's command was nominally under Greene's orders, as chief of forces in the southern department.

Greene wrote McHenry from

\section{"Camp near Guilford \\ Court House March 221781}

" $\mathrm{My}$ dear friend

"Nothing could afford me greater pleasure than the arrival of the Marquis in this department, but $I$ am afraid his stay will be short. If we could form a junction of all our forces great things might be effected. I wish the Marquis may have a latitude equal to my wishes. A few Months may effect a great change in this quarter.

"I must beg leave to refer you to Col Morris for the particulars of the Southern operations. God bless you with health and make you as happy as I wish you to be

"Doctor McHenry

$$
\text { "Yours Aff }
$$

Aide de Camp to the

"N Greene

Marquis De la Lafayette."

On July 8, McHenry wrote Greene ${ }^{3}$ from Ambler's

1 Vide letter to him from J. B. Cutting of March 29, 1781.

2 Scharf's Maryiand, ii, 437.

3 McHenry's letter is printed in Mag. of Hist., il, 362 (Nov., 1905). 
Plantation (opposite James Island) telling of a brave attack by General Wayne's command on the British forces. This letter was answered by Greene from the

\section{"Dr Major}

"High Hills Santee July 241781

"Your letter by Mr Carlyle and those of the 12th giving an account of the Skirmish at James town all come safe to hand. Upon the whole I am not sorry for the late action, tho I confess if I have a proper Idea of the strength and constitution of the Marquis's Army the maneuver was hazardous. However in war you must always risque something and too much caution sometimes begets contempt and brings us into, the very evils we wish to avoid. I am persuaded the enemy from their movements, have a proper respect for you. But be careful, for you may be assured, his Lord ship is a modern Hannibal and is seeking for some capital advantage. I confess I am puzzled not a little by his movements on this side of the river. When he was returning on the other side I did not think it proceeded from fear; or from a desire to avoid an action, but from the operations going on against New York. But his latter movements seem to contradict that opinion. What are they about to the Northward; and what is your opinion of the plan, is it serious or only a diversion?

"I wish you with me exceedingly; but there is no inconvenience to which I will not subject my self to oblige the Marquis. I am persuaded you are useful to him, in moderating his military ardor, which no doubt is heated by the fire of the Modern hero, who by the by is an excellent officer; and had he been here lately would have done something glorious.

"Dont let your partiallity deceive you, there is no danger of my character rising so high as to be difficult to support. We have done nothing splendid and it is only the sensible that will give us eredit, and those are more steady and uniform in their Sentiments through all changes of fortune. -

"Yours Affectionately

"N. B. I shall pay

N. Greene

particular attention to

Mr Carlyle."

While with Lafayette at Malvern Hill on July 30, 1781, McHenry wrote Thomas Sim Lee, governor of Maryland, as 
follows: “The intelligence which remains after the General's letter is fit only to excite conjecture. On the 27th. 19 flat bottomed boats, with horse and foot, crossed from Portsmouth to Norfolk, the troops there marched towards King's landing. The day after, 2 companies of Hessians took the same rout. This, one would say, looks to the southward. We have nothing official from Gen. Greene, but it is reported that affairs are again in his favor. His fortune is a perfect resemblance of life, Gen. Wayne and Gen. Morgan are at Good's bridge on the South Side of James River Col. Moylan and one regiment of light infantry will cross to-day to take a post in front, the militia and the remainder of the infantry on this side." Lee forwarded McHenry's letter to the congress and wrote that body on August 4, "The State is making every exertion to collect such a force as with the regulars here, amounting to about 600 , under skilful and experienced officers, will enable us to confine them within very narrow limits. Our people are resolute and determined, they feel that animating spirit which diffused itself through all ranks at the commencement of this contest. The approach of the enemy apparently has banished every sordid, avaricious, and selfish view and we trust our people will act like men, sensible of the blessings they are struggling for and the miseries which, by an abject and dastardly conduct, they most deservedly will feel.", He requested help towards the arming of the militia and reminded congress that it had not often been troubled with applications from this state and "we flatter ourselves the exertions of our people upon all occasions merit every assistance that can be afforded."

MeHenry was present with the army at Yorktown. whence he wrote Otho Holland Williams.

\section{"Camp before York 7th Octtr. 1781.}

"My dear Williams. We cannot speak sufficiently of you, Howard and our brave troops. How happy I am at all that has happened; that you are safe; and that every one of your army deserves everything from our country.

"This seiging work is very serious business. We go on however very briskly. Last night we broke ground upon our 
first parallel and this morning we are under cover; but we shall not open our trenches for some days. When we do it, it will be with about eighty pieces of cannon and mortars.

"Col. Morris is setting out. He will tell you the rest. "Adieu

"JAMes McHenry"

At the surrender of Cornwallis he was also present and among his papers is a return of the number of those wh") capitulated. The service at this siege was the last of McHenry's military life. 


\section{H A P T E R V}

THE MARYLAND SENATE AND THE. CONFEDERATION CONGRESS, UNTIL WASHINGTON'S RESIGNATION OF HIS COMMISSION IN DECEMBER, 1783

$\mathrm{O}$ September 17, 1781, when he must have been still in the army before Yorktown, McHenry was elected to the senate of Maryland. The senate at that time consisted of fifteen members: nine from the western shore and six from the eastern shore of the Chesapeake Bay, and was elected for a term of five years, by a body of thirty-eight electors, chosen by the people in the counties of the state. MeHenry held his new post until he resigned early in 1786.

The acceptance of the senatorship, a noteworthy honor, considering how little McHenry had resided in the state, was followed by his resignation from the army on December 3. Washington wrote him $^{1}$ on December 11 , that his resignation was delivered to the secretary at war and added, "I am convinced your transition from the military to the civil line will be attended with good consequences, as you will be able to communicate that kind of information to the body of which you are now a member, which they often stand in need of, in times like the present." Washington promised to correspond with McHenry on public affairs and with "the highest opinion of the good will \& vigor' ${ }^{2}$ of the Maryland legislature, urged McHenry to impress upon them "that to make a good peace, you ought to be well prepared to carry on the war."

January, 1782, found McHenry at Annapolis in attendance upon the senate. On the 20th, as the session closed, 2 he wrote Washington that the "only novelty which it has given birth to, is a man called Intendant, whom we have vested with great powers \& who is to destroy that disorder

1 Ford, ix, 418.

2 On January 19 and 21, McHenry wrote to Hamilton and Major Edward Giles refusing to tell the name of Publius, but adding that he would send Publius, who is not an Inhabltant of the state, the proceedings of the house of delegates, in the case of Cadwalader against Chase, and will tell Publlus's name, only In case he is willing to retract. 
in our affairs, which has arisen ehiefly from a bad money \& a want of money. You, who know the confusion which reigns very generally through out the States, will suppose that Daniel of St. Thomas Jenifer, the Maryland Intendant, must have a very embarrassing time \& that he shall be uncommonly fortunate, should his administration be successful.", 1

This letter of McHenry's was sent by a lady and was answered by Washington on March 12 , from Philadelphia. ${ }^{2}$ He expresses the hope that "good laws, ample means, \& sufficient powers were given the intendant," and speaks of the "anxious state of suspense," in which all were with reference to affairs in the West Indies. "Never, since the commencement of the present Revolution, has there been, in my judgment, a period, when vigorous measures were more consonant to sound policy than the present." He thinks the British ministry "will obtain supplies for the current year, prepare vigorously for another campaign, \& then prosecute the war, or treat of peace, as circumstances \& fortuitous events may justify; \& that nothing will contribute more to the first, than a relaxation or apparent supineness on the part of these States." Men and money are much needed and it is idle now to "count merely on voluntary enlistment." There is no other "effectual method to get men suddenly, but that of classing the people \& compelling every class to furnish a recruit. Here every man is interested; every man becomes a recruiting officer."

On April 5, McHenry answered from Baltimore that he agreed with Washington that the prosecution of the war is intended, but feared that Maryland will not elass the people, in default of which recruiting goes on slowly. Matters were worse on July 14, when McHenry wrote Washington, regretting the French defeat in the West Indies and saying: "I do not calculate upon anything decisive on our coast from the operations, at least this season, $\&$ how we are to provide $\&$ carry on the war next year, if we receive no foreign money, is to me a great political mystery." Public affairs are in a most alarming situation for want of exertion on the part of the states. Congress asks Maryland, as her quota, to give nearly a million dollars and the state treasury has barely $£ 2000$.

1 See Sparks's Writings of Washington, viii, 254. He asks for news and speaks of the recruiting bill.

2 Ford, ix, 459 ; Sparks, vili, 254 
The particular request McHenry makes is of a more pleasing character. Mr. Lindsay, the manager of the Baltimore Theatre, bears the letter and asks that the band of music among the prisoners at Frederick be paroled to Baltimore, where Lindsay will employ them on a salary. This favor will increase the pleasures of Baltimore and satisfy the anxieties of the ladies.

Washington answered this letter ${ }^{1}$ on the 18th, stating that he referred the request to the secretary at war and had "no doubt of his acquiescence," adding: "If the ladies should derive as much additional pleasure from the allurement of this band, as I wish them, they will be soon at the summit of happiness." "At present we are enveloped in darkness," because of the naval engagement. "Providence has done much for us in this contest; but we must do something for ourselves, if we expect to go triumphantly through with it."

McHenry was subject to fever, probably of a malarial type, and had been ill this summer, but was now recovered. Washington suggests: "As your fever has been obstinate, may not change of air be of service to you? Whether for this or otler purposes, allow me to add that I should be very happy in your spending some time with us at head quarters."

McHenry seems to have been as yet uncertain as to his future, as is shown by a letter to Hamilton:

"Baltimore 11th. Aug. 1782.

"If you are not in the humor to read a long letter, do, prithee, give this to the child to play with and go on-with your amusement of rocking the cradle. To be serious, my dear Hamilton, I have been thinking of late upon my own situation \& this has led me as often to think of yours. Some men, I observe, are so born \& tempered, that it is not till after long bustling \& battling it in the world (and some scarcely then) that they come to learn a little prudence. Much I begin to suspect that you \& I want a great deal of this quality to bring us on a level with our neighbors and to carry us cheerfully through life. Have we not both of us continuerl long enough in the service of the public? Should not I exercise my profession or some profitable business \& should not you, putting off the politician, exert yourself only to acquire a profession? I find that to be dependent on a father is irksome, because I feel that it is in ny power to be indepen-

1 Ford, $x, 49$. 
dent by my own endeavours. I see that the good things of this world are all to be purchased with money and that the man who has money may be whatever he pleases.

"Hamilton, there are two lawyers in this Town, one of which has served the public in the General Assembly for three years with reputation and to the neglect of his practice. The other has done nothing but attend to his profession, by which he has acquired a handsome competency. Now the people have taken it into their heads to displace the lawyer which has served them till he is become poor, in order to put in his stead the lawyer who has served himself \& become rich. Let me add to this aneedote a bon mot of our friend Flenry's. Talking to me the other day. 'You are a Senator,' said he, 'pray what is your salary.' I told him it might perhaps defray about two thirds of our expenses while attending the Senate, and that we were only paid during our attendance, provided one was unmarried \& lived frugally. 'Then,' said he, 'I pity Maryland, for her Senate must be eomposed chiefly of rich fools.' What is the moral of all this, my dear friend, but that it is high time for you and I to set about in good earnest, doing something for ourselves.

"I hear you are chosen a delegate to Congress. Will you forgive me for saying that I would rather have heard that you had not been chosen. If you accept of the office, there is a stop to any further studying of the law, which I am desirous you should finish, because a few years practice at the bar would make you independent, and do you more substantial good than all the fugitive honors of Congress. This would put it in your power to obtain them and to hold them with more certainty should you still be inclined to risque in a troubled sea. The moment you cease to be a candidate for public places, the people will lament your loss and wait with impatience till they can persuade a man of your abilities to serve them. In the mean time, you will be doing justice to your family. Besides, you know that there is nothing at present to be had worthy your acceptance. The negotiators for peace have been long since appointed. The great departments of Government are all filled up. Our foreign ministers sit firm in their seats. It is not to be expected that any new ministers will be created before a peace. And when this comes, be assured, long residence and large possessions in this country will prelude superior merits.

"I wish, therefore, my dear friend that I could prevail 
upon you to avoid a disappointment \& a loss which I think I foresee. For, should you go to Congress, you will lose another year of time that is become more precious than ever and retire, perhaps in disgust, to renew your studies and to those domestic endearments which you will regret to have forsaken. How would it vex me to learn that you had exclaimed in the stile of an English Cardinal - If I had best served my family as faithfully as I have the public, my affairs would have been today in a very different order.

"It appears to me, Hamilton, to be no longer either necessary or a duty, for you and I to go on to sacrifice the small remnant of time that is left us. We have already immolated largely on the altar of liberty. At present, our country neither wants our services in the field or the cabinet, so that it is incumbent upon us to be useful in another line. By pushing your studies to a conclusion, you at once perfect your happiness. But I wonder, nor recollect, whilst my own life runs on in idleness and small follies that I stand in most need of the advice which I am presuming to offer. You have a wife and an increasing offspring to urge you forward, but I am without either - without your incitements to begin a reform or your perseverance to succeed. Write me then, what you are doing - What you have done and what you intend to do, that I may endeavour to follow your example. And be full, for I really intend to be wise and you shall be my Apollo.

"I have been a second time on the point of gaining immortality by a fever. It seized me a little after the arrival of the French troops here and has only permitted me to come abroad a few days since. Mrs. Carter \& Miss Peggy are with us and of course you will think I have been often with them. But I must tell you something of your relations. Mr. Carter is the mere man of business and I am informed has riches enough, with common management, to make the longest life very comfortable. Mrs. Carter is a fine woman. She charms in all companies. No one has seen her, of either sex, who has not been pleased with her and she pleased every one, chiefly, by means of those qualities which made you the husband of her sister. Peggy, though perhaps a finer woman, is not generally thought so. Her own sex are apprehensive that she considers them poor things, as Swift's Vanessa did, and they, in return, do not scruple to be displeased. In short, Peggy, to be admired as she ought, has only to please the 
men less and the ladies more. Tell her so. I am sure her good sense will soon place her in her proper station. ${ }^{1}$

"My dear Hamilton, adieu. Remember a man who lives in this world, without being satisfied with it. Who strives to seem happy among a people who cannot inspire happiness, but who thinks it unbecoming the dignity of man to leave his part, merely because it does not please him. I am melancholly you perceive. This plaguy fever has torn me to pieces and my mind yet shares in the weakness of my body. But I will recover spirits, as I recover strength. In the mean while do not fail to write me. Again my friend \& philosopher adieu.

JAMES MCHENRY

"I wrote you between $\mathrm{my}$ fevers on the affair of Chase, which letter I inclosed to Secretary Turnbull. Has it been received? It contains what you asked for."

Four days later, Washington addressed two letters to McHenry. One of these hitherto unpublished, in playful vein, chides him for not informing him as to matters.

"My dear McHenry, "Newburgh 15th Aug., 1782.

"Let me congratulate you, and I do it very sincerely, on your restoration to health. I was in pain for you. I was in some for myself - and wished for my $\mathrm{P} \mathrm{T}$ of $\mathrm{M}-$-; and both my $\mathrm{P}-\mathrm{e} \mathrm{L}-$ in $\mathrm{I} \longrightarrow$; resolving (like a man in the last agony) not to follow the trade \& occupation of a $\mathrm{G}-$ any more.

"I attributed all the delays, \& my disappointments in this business, to your sickness; for otherwise I should denominate you an unfeeling - teasing - Mortal. In proof of it, I would assert that in March last, I committed a matter to your eare of which you took no notice till July following - and then in such $a$ way, as to set afloat a thousand ideas; which resolved themselves into almost as many anxious questions. These again, you acknowledged the rect. of on the 26 th of July, - and on the 3d. of August promise an answer - when? three or four Weeks from that date; during this time my imagination is left on the rack. - I remain in the field of conjecture. - unable to acct. for causes of somethings, or to judge of their effect; - In a word, I cannot develop

$1 \mathrm{Mr}$. and Mrs. Carter are John Carter Church, an Englishman, and General Philip Schuyler's eldest daughter, Angelica, who eloped with Church, then known as Carter, in July, 1777. Lassing's Schuyler, ii, 206. 
some mistcries, the appcarance of which grave rise to those queries which were made the contents of a letter.

"Do not my Dear Doctor tease your Mistress in this manner - much less your wife, when you get one. The first will pout - \& the other may scold - a friend will bear with it, especially one who assures you, with as much truth as I do, that he is sincere.

$$
\text { "adieu "Go. Washington.", }
$$

In the other letter of the same date, Washington writes: 1 "My dear Doctr.

"If the Commanders of the Fleets and Armies of our late, most Gracious Sovereign, in America are not guilty of more duplicity than comports with candid minds, we are now advanced to that critical \& important crisis, when our hands are to be tried at the Arts of negotiation. -

"In a letter which I have received and forwarded to Congress, from Sir Guy Carlton and Admiral Digby, are these words 'We are acquainted, Sir, by authority, that negotiations for a Perm't Peace have already commenced at Paris, and that Mr. Greville is invested with full powers to treat with all Parties at war, and is now at Paris in the execution of his Commission. And we are likewise, Sir, further made acquainted, that his Majesty in order to remove all obstacles to that Peace which he so ardently wishes to restore, has commanded his Ministers to direct Mr. Greville that the Independency of the thirteen Provinces should be proposed by him in the first instance of making it a condition of a general Treaty; however, not without the highest confidence, that the loyalists Shall be restored to their possessions, or a full compensation made them for whatever confiscations may have been taken place.' ,'

Washington adds that this seems a "solid basis for our commissioners to raise their superstructure upon, \& things may \& probably soon will be brought to a speedy \& happy issue.", He urges that preparations be still pressed with vigor, for nothing will hasten peace more, and states that news of the probability of peace "spread universal consternation among all the tribes of refugees" in New York.

The same doctrine, that we must prepare for peace by

1 Partly printed, Ford, x, 52. 
preparing for war, ${ }^{1}$ was taught by Washington, in his letter of September 12, to McHenry, when the prospects of peace seemed less. The general wrote also:

"I am pained to find by your letter of the 30th. ulto. that you cannot get rid of your fever. Try change of air come to the Camp - anything to remove a disorder which seems to pursue you with unabating obstinacy, and may, it suffered to run on you any longer, become too powerful for medicine.

"The army has at length taken the Field, and is encamped at this place; awaiting a junction with the French Corps, which will, I expect, take effect in the course of this week."

McHenry was in wretched health all the summer and early antumn ${ }^{2}$ having five severe attacks of fever, but was keenly anxious for news from Washington and hopeful for peace. When his health was restored in October, he wrote to Washington, asking that the general aid him to obtain pay and depreciation certificate.

The Maryland law made no allowance to the general's secretaries and no new law of congress can affect the existing Maryland law. McHenry relied on getting this allowance and bought land on the Monocacy, for which he now must pay, and asks that Washington write Robert Morris, head of the treasury department, suggesting that McHenry be paid out of the federal treasury, for the time of secretaryship only, as this is all the pay McHenry will ever receive and he will, otherwise, get nothing for seven years' service. follows :

Washington wrote at once to the secretary at war as

"Dear sir

“Head Quarters 22d. Octr. 1782.

"Upon your return to Philadelphia, I beg leave to request your particular attention to the following matter, I look upon myself bound to procure the Gentleman interested, a full compensation for his services, while in my Family.

"Mr. McHenry, formerly one of my Secretaries, writes me, that upon application to the Auditor of the State of Maryland, of which he is a Citizen, to settle his arrearages of Pay and depreciation, he refused to do it upon a supposi-

1 Ford, $x, 77$; Sparks, viii, 344.

2 See McHenry's letter of S'ptember 30 and October 10. 
tion that the Resolve of Congress recommending to the Statie to make settlements of that kind, only extended to Officers properly belonging to their respective Lines. This has involved Mr. McHenry in the following difficulty, - Upon a presumption that the State would settle with and give him Certificates, as to their Officers, he purchased a quantity of Lands appropriated by the State to making good arrearages of Pay and depreciation, \& which were to be paid for in Certificates.

"- He now finds himself like to be excluded from this benefit, for want of the Certificates; - If he cannot procure them, he must give up his purchase. As there seems a doubt whether Mr. MeHenry, as one of my Secretaries, is included in the recommendatory Resolves already passed, I could wish, should it not be deemed improper, that you would apply to Congress to pass a short Resolve in his favor, recommending to the Secretary to make him the same allowance as to Officers of their Line."

But to McHenry he wrote ${ }^{1}$ : "I am pained because I cannot answer the expectations \& request of your letter ** to your satisfaction." He knew there was no hope in applying to the financier, for the United States had no money and he had been told that the only mode to help McHenry is to ask congress to recommend his case to the state of Maryland, which he has done. He goes on as follows:

"We have been at this place, Verplank's point, ever since the last days of August, and are upon the point of retiring into Winter Quarters. The French Army (except the Legion of Lauzon) have marched Eastward for theirs. We go Northward to the vicinity of West Point. We have long expected to hear of the evacuation of Charles Town, as the Enemy in New York do not scruple to say that it is a measure determined on - but how far a change of men may produce a change of measures, you can judge as well of as $I$. No man on this side of the water I believe (not even Sir Guy Carleton himself) knows the result of the British Councils. My opinion of the matter is that they are yet dependant upon the events of the Campaign. You will readily infer from hence that I have no idea of a speedy evacuation of New York.

"Mr. Greville has certainly left Paris but he is succeeded 
by a Mr. Fitzherbert and the negotiations are yet going on but limpingly.

"P. S.

"Since writing this

letter I have conversed

with the Secretary at War

on the Subject of it who assures me that there will be no difficulty at all in the way."

Before he had received MeHenry's letter, Washington had written him on the 17 th in answer to McHenry's letter of September 30, stating that there is no news and that we must not "be lulled by expectations of peace" which woulı "prove the ruin of our eause \& the disbanding of our army." The army is in hard straits and Washington writes that he must "stick very close to my flock this winter." 1

On November 26, 1782, MeHenry lost his father, who died in Baltimore. With the death of the father, James MeHenry seems to have decided to take his place in the mercantile business in partnership with his brother. The death of his father also made him financially independent.

On February 2, 1783, McHenry writes a bright note to Washington asking for the dismissal of Mrs. Nancy Dulany's negro Jacob, who 'nlisted in Bradford's company in Oetober', 1781.

"One of the best old ladies in the world, who has one of the eleverest ladies for ours for the recovery o. inclose you a note on the subject \& have to entreat youl Excelleney that you will order an inquiry \& have the negro restored. I recollect to have been told by Major Reed in Virginia something of that affair. At that time I could not take the necessary steps to have justiee done to the good old lady. I need not add, if Mrs. Dulany is known to your Excelleney, how much it will oblige me to see the negro restored, on account of her great virtues \& because it wil! be a great relief."

Over two months later, on April 15, MeHenry wrot? Washington again from Philadelphia:

"Beeause I have no reason to believe myself forgotten. notwithstanding you have not written me for a long time, I would not leave Philadelphia without congratulating with

1 Ford, $x, 94$. 
you upon an event the most glorious for my general. You have carried us through a long war; you have not sunk under the severest trials \& you live to see a country enjoy the blessings of peace \& the result of your struggles. I know that you will not have it in your power to return to your seat for some time; but, when you do, pray Stop over a day in Baltimore." McHenry adds that he wishes to go to Europe in the diplomatic service and requests Washington's help. 1 Washington wrote at once to $R$. R. Livingston and James Madison concerning the matter and told Hamilton ${ }^{2}$ that he spoke to them of McHenry "in warm terms and wish him success with all my heart." He then wrote to McHenry as follows :

"Dear Sir,

"Newburgh 24th April 1783.

"Immediately upon the receipt of your letter of the 15th. expressive of your wish to go to the Court of Versailles, or London, as Official Secretary to the Embassy:, I wrote to Messrs. Livingstone \& Madison on the subject \& mentioned you in warm terms to them - the Letters will go by this days Post.

"I thank you very sincerely for your kind congratulation on the approaching Peace; - none can enjoy it with more heart felt satisfaction than myself; but when I shall be able to leave this place is uncertain - there are many embarrassin: matters to settle first, and I am at this moment surroundel by more perplexing circumstances than you can have an idea of.

"As I shall have pleasure in spending a day at Baltimore on my return home, I can have no merit in complying with what you say is the wish of the Citizens of that place; from whom I have received many marks of polite attention

$$
\text { "I am with much truth }
$$

$$
\text { "Dr Sir }
$$

"Your most obedt. \& affet. Servt. "Go. WASHINGTON.

"P. S.

"The inclosed

is copy of a letter written to you agreeably to its date.

Colo. Vose is not now with the Army.'"

1 On March 23, 1783, Washington wrote Lafayette (Ford, $x, 196$ ): "McHenry has left the military \& embraced a civil walk of life. By which act he has disquallfied himself from answering your purposes," whatever they may have been.

2 Hamilton's Works, 1, 36 . 
To Washington's letter Madison answered as follows: "Philada April 29, 1783. "Sir

"I have been honored with your Excellencys favor of the 22d. inst. bearing testimony to the merits and talents of Mr. McHenry. the character which I had preconceived of this Gentleman was precisely that which your representation has confirmed - as congress has not yet fixed the peace establishment for their foreign affairs and will not probably fill up vacancies, unless there be some critical urgency - until such an establishment be made, it is uncertain when an opportunity will present itself of taking into consideration the wishes and merits of Mr. McHenry. should my stay here be protracted till that happens, which I do not at present expect, I shall feel an additional pleasure in promoting the public interest from my knowledge that I, at the same time, fulfill both your Excellencys public judgment and private inclination.

"I have the honor to be with perfect respect and sincere regard yr Excellencys Obedt \& Hble Sv "J. Madison Jr."

Livingston's reply soon followed from Philadelphia on the 2nd of May, 1783.

"I am so sensible of Mr. McHenrys merit, that even independant of the advantagious light in which your Excellency's recommendation places it, I should think my self happy to obtain his services in a line in which I am persuaded they will do honor to his country. Congress have it not in view at present to make an immediate appointment to London; and while Doctr. Franklin eontinues at paris it would be painful to him to have any other secretary than his grandson, who tho' not secretary to the embassy exercises the duties of one, and has lately been provided for as such by Congress.

"Should any opportunity offer of sending out $\mathrm{Mr}$ McHenry in such character as would be acceptable to him, during the short time of my continuance in office, you may be persuaded that your Excellency's recommendation will render me particularly attentive to avail my self of it."

These letters Washington transmitted to McHenry with the following note:

"Dear Sir,

“Newburgh 14th. May 1783.

"You will see by the inclosed Copies, which are answers 
to my letters to $\mathrm{Mr}$. Livingston and Mr. Madison, upon what footing the appointments to Foreign Courts stand.

"If these Gentlemen should leave Congress previous to the taking place of the event - Your friends in Congress should advise you thereof, \& of the time at which these elections may probably be made, - and I can facilitate your wishes by addressing any other Members (with whom I have an acquaintance) in your behalf you may freely lay your Commands on

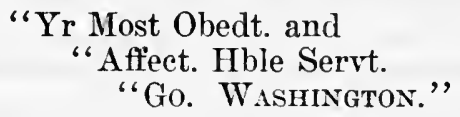

But McHenry's desires failed of fulfilment, and he endorsed on the letter just quoted : ${ }^{1}$

"N. B.

"The first foreign appt. made by Congress, was

to Mr. John Adams, then minister at the

Court of London.

"Having changed my plan of life, in other words about to be married, I declined being a candidate, in favour of $\mathrm{Wm}$. S. Smith, who was appointed and afterwards married one of the ministers daughters."

Towards the end of April, McHenry left Philadelphia, where the attractions of Miss Caldwell had made deep impression on him and of his journey to Baltimore he wrote on the first of May, 1783, to Major John Armstrong, the author of the Newburgh addresses to Washington:

"My dear Major

"Once on a time, I remember, in a pensive route to our modern Capua, a young lady descended from a flaming chariot, and entered the tavern at which I had stopped. Betsy, said she, with a look of blended gaiety and giddiness that bespoke a heart perfectly at rest, hasten to me with paper, for I would die were I not to write to my friend at every remove. Sweet insensible, said I to myself, as she tripped lightly along, followed by the girl whose face betrayed the sunshine of better days and the deep traces of some affecting disappointment - of what would you die - or of what would you write

1 Lafayette wrote Hamilton (Hamilton's Works, i, 327), asking to be made envoy extraordinary of the United States to Great Britain to ratify the treaty and added "send MoHenry to me." 
- you who never felt the uncertainties of love - or the pains of the wretched. But checking these reflexions - trifles, I perceive make you happy, and sensibility, perhaps, would render you otherwise. Go then - and write - and dress and talk - and throughout life think your heart interested but as now let it be always - by trifles. Having shook off the dust of my journey, of which bye and bye, and being somewhat in the humor of this fair itinerant, I called for my writing apparatus - that I might trifle with you half an hour, and that you might be able to find me when disposed either in seriousness or levity to do the same.

"To-morrow, then, I go to be very grave at Annapolis, and heaven knows, how much more I incline to be gay at Philadelphia. For, of those few things in this world which afford pleasure, I more than suspect - that solemnity and wisdom give the least. Vive la bagatelle, said Swift, oftener than he said his prayers - and what adds weight to this maxim, is, that he did not venture to pronounce it - before he had discovered by deep study and long intercourse with mankind - that no one could get fat upon wisdom - which between ourselves, I take to be the great cause of your leanness. Were other authorities necessary to support this maxim, besides the lady's I have quoted - Dean's - and my own invariable practice - I would mention the two celebrated Romans, spoken of by Cicero who would leave the business $\cap f$ government - to play marbles, and gather shells and periwinkles at Gaeta and Laurentium.

"Thinking in this manner I entered Phila. the capital, and without any material change of sentiment, I mounted the curricle that hurried me from it - satisfied that I had lost no flesh by the visit. In a moment we were out of sight of the ships - the buildings - the spires and the smoke. The sun shone benignly on the earth. On each side of the road was spring just beginning her frolicks - behind me lay the sleeping beauties of Philadelphia, and before me their sisters of Maryland - so that whichever way I looked - nothing presented me but objects of pleasure. We breakfasted at Chester, like hungry lions - passed through wilmington, like a squil - dined at New-port, like gluttons - ate supper at the Head of Elk like fools for we had no appetite - and here we took up our lodgings for the night. About eight o'clock the next morning, fresh and cheerful as young bridegrooms, we crossed the Susquehannah - more lovely than your Schuylkil - in 
its banks - its islands - and its windings - and by evening arrived at a place renowned for - its dirt - its dust - and its dulness.

"And, now, Sir, will you do me the favor, while I drink tea with some ladies, to hasten to the circle in which I lately found you. There single out the fair who possessed you for that evening - but do not press her hand so much - nor sit so long near her - for, believe me, you are no anchorite thus cautioned - assume the attitude of persuasion - awake her feelings by some well chosen story - take care at the same time of your own - then pause - and while, as she is wont, she casts her eyes thoughtfully, languishing on the ground tell her - that although the edges of her little silky present, are much fretted by the attention paid to it - and here and there a thread actually destroyed - yet what is left - which I intend to wear round my neck as an amulet - still retains the power which she gave it entire and undiminished. Oh my soul I am heartily glad that her sister is at home with her fine eyes and her penetrating wit - because the shrewd girl is forever suspecting insincerity under a compliment - and here I would not have my veracity even called into question. But my good Sir, it is time to leave this lady - as the nymph of the fête has remarked the length of your conversation. But - alas - my half hour is spent - and I have only time left me - to wish you a favorable wind to clear of her spells, and carry you round the rest of this dangerous circle - for at this instant - one of the whitest and prettiest hands in all Baltimore - is going to pour me ont a dish of imperial tea - and if I stay another moment, I shall undoubtedly - lose the pleasure of drinking it. Adieu therefore - and believe me yours very sincerely"

On April 24, 1783, the Maryland legislature was called together, but MeHenry did not appear at Annapolis until May 6, and Governor Paca's message was received on the following day. Five days later James MeHenry and Thomas Johnson were chosen to fill vacancies in Maryland's representation in the continental congress. ${ }^{1}$ In those days, the two positions were not deemed incompatible and so McHenry sat in both the confederation congress and the Maryland senate. The news of the treaty of peace had just come and General

1 Jas, Lloyd, Nathaniel Ramsay, and Thos. Wright, were also voted for. MeHenry accepts on June 1, the last day of the session. 
Greene had written him as follows from Charleston on April 28 :

"My dear friend

"I have only a moment to salute you with congratulations upon the joyful issue of the war; and to assure you that however fortune may dispose of me in future I shall always feel a lively friendship for you. Major Swan is just on the wing and will not allow me time to say more. I expect to be to the Northward this Summer and to have the pleasure of taking you by the hand as well as all my other Maryland friends."

As a representative of the commercial classes, we are not surprised to find that McHenry introduced in the senate tonnage and port warden's bills. Education, communication with the west, and readjustment of relations with loyalists receive attention at this session and Annapolis is offered the confederation as the seat of the general government.

During the summer, McHenry joined the continental congress at "Princetown," where he served on the committee on foreign affairs. Congress had been driven to Princeton by the mutiny of the Pennsylvania troops at Philadelphia.

On July 3, he wrote to Washington, as chairman of a committee appointed to consider a letter of Washington's which complained of his disagreeable situation, saying that congress wished Washington to come before it. Originally it had been planned to ask Washington about a peace establishment. Rhode Island wished to have none, so the clause was left out, but McHenry asks Washington to give his opinion on the matter, in any case. Evidently the letter was delayed, for Washington wrote to him on August 6,1 asking why congress had sent for him, as follows :

"After a tour of at least 750 miles (performed in nineteen days) I returned to this place yesterday afternoon when I found your favour of the 31st ulto. intimating a resolution to Congress for calling me to Princeton, partly as it would seem, on my own account, and partly for the purpose of giving aid to Congress; but the President not having sent on the Resolution.

"I wish you therefore, my dear Sir, to transmit to me by the earliest opportunity, a copy of the Resolutions with an explanation of the particular reasons \& motives which have

1 Ford, x, 291; Sparks, vili, 469. 
influenced Congress to pass it, that I may be enabled to regulate my conduct accordingly.

"With the greatest esteem \& much

"Affectionate regard

"I am Dr. Sir

"Yr. Obedt Serv.

"Go. Washington."

McHenry answered Washington's letter on the 11th stating that the first motive in asking him to come "was to get you out of a disagreeable situation to one less disagreeable." The second was "to get your assistance \& advice in the arrangements for peace. It may be necessary besides to consult you respecting promotions \& on a variety of military subjects." Washington came, occupied a house provided for him by congress at Rocky Hill, between three and four miles from Princeton, and remained there until November.

During the debate concerning the punishment of the Pennsylvania mutineers, McHenry spoke urging mercy:

"Before passing upon this proclamation I beg leave to say a few words.

"It is impossible that any set of men can be engaged in a business more serious or more solemn, than in deliberating upon an act that is to deprive a human being of his life or character. It will occur to the house that the operation of this act does not merely respect the life or character of Casberry \& Sullivan, but extends beyond them, to their relations and even to all those of the same name. If a soldier falls in battle - if an honest man is killed by a robber, or murdered by his enemy, this neither injures his fame, or reflects dishonor on his relations. But the case is far otherwise if he dies under the hands of the law or the executioner. His memory thenceforward is rendered infamous, and to be his relation or to bear his name, is to carry about one a mark of indelible disgrace.

"These observations are recalled to the recollection of the house, to shew us the importance of what we are about.

"Let us now for a moment consider the crime of these unfortunate exiles. They were both officers at an early period of the war, and uniformly and till its close, behaved with that fortitude and patience which have so distinguished our army. The situation and circumstances of the army before and at the time of the meeting need not be discredited. They displayed great virtues - they are pregnant with instruction to this country and full of excuse for the criminals. These

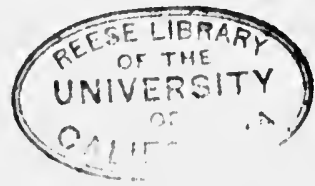


unfortunates worn down by poverty and grown desperate by necessity, that power which few persons can resist, formed a plan to relieve their wants.

"It is certainly an extenuation of their crime, that its object was founded in justice, and that violence was done to either life, person, or property. It is true the soldiers, whose motions they are said to have directed, had arms in their hands when they surrounded the state house - but it is also true that they did not use their arms.

"But other and more urgent reasons plead that their erime should be forgiven. Let the services and long sufferings of the army be remembered; and let the failings of these men be forgotten in their former merits and in the merits of the army. And let not the first fruits of their long and perilous contest, our peace, be watered with the blood of two of their companions.

"I hope it will not be urged that the measure is necessary for the support of our national character. Onr national character can never be supported by a sacrifice of national humanity. I have always thought, and the history of all nations teach me that I am right that acts of mercy serve more to dignify and raise the character of a goyernment than acts of blood. It is said that Draco's laws were written in blood — but no one has ever dared to praise them."

During the autumn, MeHenry wrote to Hamilton ${ }^{1}$ praising him and telling him that his "Congressional homilies" were still remembered with pleasure. Were he ten years older (Hamilton then was twenty-six) and $£ 20,000$ richer he might have the highest office in congress's gift. Cantious men "think you sometimes intemperate, but seldom visionary ***. Bold designs, measures calculated for their rapid execution - a wisdom that would convince from its own weight, a project that would surprise the people into greater happiness, without giving them an opportunity to view it \& reject it - are not adapted to a council composed of discordant materials or to a people which have 13 heads, each of which pays superstitious adorations to inferior divinities."

The Maryland Legislature began its autumn session on November 4, but MeHenry did not take his seat until the 19th, having been in Philadelphia in the meantime. On the 23rd he

1 J. C. Hamilton, iii, 8; Hamilton's Works, i, 411. Letter dated October 22 . 
was appointed with John Smith to ask the delegates to come and qualify the incoming governor and, on the 24 th, he was placed on the joint committee on the governor's message about a threatened disturbance in Annapolis. Two days later, he was nominated for congress ${ }^{1}$ and elected with Thomas Stone, Samuel Chase, and Edward Lloyd. The session of the legislature continued until December 23, and McHenry took quite an active part, bringing in a tonnage bill and one to regulate theatrical entertainments, and serving on the joint committee to provide proper accommodations for Washington. The delegates in congress were expected to report to the legislatures and we find that such reports were made in writing by McHenry and Daniel Carroll at this time. Congress met at Annapolis in November and on November 27, the senate invited that body to use its room, removing to the intendant's office and, a week later, voted to encourage congress to make their permanent seat at or near Georgetown.

From "Princetown" McHenry made a trip to Philadelphia to see Miss Caldwell whose declared lover he now was, and to her he wrote on the 15th of July:

"When I retired from the presence of my dear Peggy, the disquieting idea of not seeing her again for some time became more powerful than the pleasure I had just experienced. 'The hour you had given to my affection and endeared by your delicate sensibility served but to make me more conscious to the approaching separation. I was going it was true, only to Princetown, but the obstacles to a return far exceeded the distance, and that alone was sufficient to excite reflections inexpressibly painful. Well aware that you would not wish me to be accused of levity in business, or suffer me to be suspected of preferring even the gratification of my heart to the interests of my country, I said to myself, a public station is an enemy to peace, and there is no happiness but in the arms of my Peggy, I will, therefore, renounce its vain consequence to others; I will overcome my fears and speak to her parents tomorrow; she shall be mine, and the rest of the world may belong to the disciples of folly or the dupes of ambition. An instant however told me that to please you, I must not desert the station in which $I$ had been placed and incur a public censure, but relying on the promise you had made to sweeten absence with an intercourse of letters, forbear to be precipitate or to hurry you into a new condition of life,

1 He accepted the honor on December 2. 
before I could render it agreeable to the sole guardian of $\mathrm{my}$ fate. Thus my amiable and beloved charmer, I felt and I thought till the appearance of the punctual Davy informed me it was time to commence my journey. I stole softly to your room door, and gently kissed it, and prayed that your slumbers might be light, and your hours tranquil, till I again lost my speech in looking at my Peggy, and again felt from her head tenderly reclined on my arm, more substantial pleasure, than a monarch experiences when first seated on his throne, or a conqueror enjoys in the moment of his victories.

"Oh! my dear Peggy, till then, enliven the dull drudgery I must be engaged in by your cordial letters. You are to sensible, after my plighted faith, to think writing to me improper, and I am too much interested in whatever you do, to require, what if done, would diminish my regard. Will my Peggy, too, penetrate the disposition of her mother, respecting my passion and hasten to remove a suspense which she must know is insufferably distressing. Let me but reail your letters and have ease on this point, and I shall count the hours of absence as only interposed to heighten the happiness that awaits my return. Adieu my dear and beloved Peggy and believe me unchangeably yours

\section{"JAMES McHenRY}

"This is tuesday night, but as I cannot trust a letter to my Peggy to the common stage box I must keep it for a conveyance to which I can confide a name so very dear to my present and future felicity. As settled between us this will be delivered you by your brother."

It is amusing to see that McHenry's love for his Peggy did not deprive him of the ability to enjoy the society of other women, as may be seen from verses he wrote three days later.

"Extempore, on a young Quaquer lady

who very reluctantly shewed some poetry and wondered how it could be known that she wrote any. (Miss Horner.)

"Princetown Jersey 18 July 1783

\footnotetext{
"Bashful as a first-day bride,

With the muses at your slde,

Long you could not hide your art;

Soon you snatched them to your heart.

From such fondness I could tell

Without help of charm or spell,

Sweet companion of the nine,

That the laurel crown was thine."
} 
In spite of his official duties, McHenry found time to write frequently to his betrothed. From Annapolis on the night of the 19th of November, 1783, just after his arrival, he sent her a letter.

"What a change has one hundred and thirty miles wrought upon your friend. I sit down to write my dear Peggy under a gloom of sentiment that $I$ have never before experienced. The heaviness of absence has doubled with the distance. I dined today with the Governor and he would have it that I had met with some disappointment. In the evening I drank tea with your great rival, and she would have it that I was actually married - because I looked so grave. I endeavoured in vain to recover my spirits: I attempted some compliments to the lady: I failed however to please myself, and took leave of the company to try the effect of conversing with my Peggy. It is not easy, my amiable friend, all at once to assume a careless behavior, when the heart is wrought upon by the disquietudes of absence. I have involved myself in politics and high stations, while to preserve the latter I do violence to my heart. I followed a false light that never led any person to happiness. I have been more than once tempted to give up all public pursuits upon finding what appeared desirable while sought after, insipid or unsatisfying when attained. Since my affections have been interwoven with yours the nothingness of public honors have become more apparent, and the strongest conviction has arisen, that peace, pleasure \& content are peculiarly the inmates of a domestic circle. Still however I continue to seek after phantoms, or to work for what cannot increase ones happiness. How is it, my love, that not withstanding history is filled with precepts expressive of the delusory nature of ambitious pursuits, and the complainings of men who have been favoured to the extent of their projects that their successors should continue to tread in the same path which leads to the same disappointments. Why my Peggy have I left you - why do I remain here a day longer - Why do I not give up all public employments and return to the bosom of my beloved - Why do the deceitful sounds of love of country oppose the bent of my heart, and hold me from you even against the strong current of my inclinations. Is there not in the human constitution principles that draw contrary ways at the same time. I would go to Philada. and yet I do not go. Your heart would persuade you to be with me, and yet you feel the honest sensations at 
the thought of separating from those eonnections who have grown dear to you from habit and course of kind offices.

"You pereeive my charmer that I am illy at rest, and by no means in a humor to be satisfied with my present condition. Several circumstances besides my being forced to leave you have associated to encourage this temper. The arrival of $\mathrm{Mr}$. Carroll and myself do not make a senate - so that no business has been done, and we must wait here several days till our brethren think proper to come forward to their duty. This of course will make the session of Assembly longer than I expected. The reception I have met with from my friends in the house of delegates altho' very flattering does not counterbalance this circumstance. But I will not trouble my Peggy with more of my complaints, but wait for that conso!ation which her promised letter will bring with it.

"One thing however I cannot but mention. When I spoke to your mother on the subject of our marriage I suggested that you were desirous of delaying it till spring, but that I had my heart fixed upon an earlier period. I then spoke of January but at the same time told her what I told you that I wished to have a better house to bring you to than the one my brother lived in - but that this would be difficult to get in the winter. Your mother who is all goodness lessened this difficulty by proposing that I should come up as soon as I could leave Congress and that we might then be married after which I might return to Congress and in the mean time indulge her with your company until spring when it would be better traveling for you. I did not relish the idea of leaving you behind me, but since I have considered all the objections to your removal during the winter and that by spring I may have every thing arranged for your reception I must plead with my dear Peggy for her consent.

"Will you then consult with your own heart on this question and with your mother and write me the result. I anticipate a favorable answer to this proposal because it will be more agreeable than an immediate separation from your parents and because it will in a great measure lessen the distress I must experience should our marriage be delayed till spring or till every arrangement is complete for your reception. We shall also be eertain of your brother's presence and this is a circumstance which I know we both wish for. If my dear Peggy should approve of this plan I would hope to see her in January and would endeavour to be with her at 
least throughout that month. I shall bring no company but my brother and the marriage may be condueted with that privaey which I know is most pleasing to you."

To the above letter he added a postscript on the 21st.

"To day is to bring me your letter and to earry this to your hands. I ean safely pronounee that no one ean be a philosopher and in love. To be patient and acquieseent under every ehange of eireumstance is not within my power. I betray myself. I may however in a few days become more reeoneiled to my situation. When we make a senate I shall have full employment, and this will eall my attention from my own feelings to that of others. I find that it would be no easy matter for my enemies should I have any to leave me out of Congress. Almost every person seems pleased with my conduet and attendanee."

Early in December, MeHenry determined to go to Baltimore, to make preparations for his marriage and attend to other affairs and wrote on the 7th, Sunday morning, to Miss Caldwell :

"Every day, my eharming preacher, offers some lesson or other, whieh, to use your own words, may instruet us in our duty, and teach us to attend to it with sincerity and diligenee. He must indeed, one would suppose shut his eves on society who does not find its numerous follies, miseries, and misfortunes, produee improvement, exeite eharity or move compassion; who does not refleet on the provisionary steps requisite to meet that awful ehange of eondition, which repeated examples prove to be inevitable. And yet so it happens that these things though daily seen and talked of are unattended to and forgotten. We continue to live in the midst of them as it were without thinking of them: we swim earelessly down the insidious current of time, and are even observed to put forth fresh sail on the brink of the eataract into which we are just plunging. Henee it is, perhaps, my gentle moralist that earthquakes, voleanoes and inundations beeome necessary in the order of things to rouse men to a sense of their situation, and accomplish by a dreadful novelty what could not be affeeted by a succession of small examples.

"But, my beloved Peggy, you, and all those, who are endeavouring to do what is right need be ashamed of no inspection whatever, nor afraid of meeting the last eonvulsions of nature, whether in a ball room or a chureh at a wedding 
or a funeral; because, in all places you will be found in a temper of mind, and with a purity of heart which the deity himself cannot disapprove.

"And what is it my sweet friend, but this temper of mind and this purity of heart that keeps one always in good humor and without which no one can be happy.

"But I must put an end to my moralizing in ten minutes I shall be on horseback, and in five hours I expect to be in Baltimore. Adieu. Adieu.", evening:

After arriving at Baltimore, he wrote again, on the next

"I got to this place last night, later than I said, because I was detained some hours longer than I expected.

"To write to my Peggy from the place where I one day hope to see her and that not a very distant one, excites sensations of the most agreeable kind. Half of my business thither was to communicate to my brother my plan of being with you in January. He will be prepared to accompany me the moment I can withdraw myself from Congress. How I long, my friend for that moment - not that I want any new proof of the sincerity of your regard, but that I wish to be yours beyond the possibility of hazard of mischance. My Peggy will forward and complete all those little preparations she speaks of and if she is in sentiment with me she will also be desirous that the wedding should rather be private than otherwise. You know your father loves economy, so that we shall in this instance find our feelings gratified, by avoiding a very superfluous and fatiguing parade. But I am my love wholly under your direction."

His stay in Baltimore was short and from Annapolis on the 14th of December, Sunday, he wrote, urging an early date for the wedding :

"Let it suffice, says my charmer, that I have good reasons for requesting you will not think of coming the first of next month. I can assure you I did not think of doing anything that might contravene the wishes of my Peggy. I had just returned from disposing matters with my brother for our being in Philadelphia the first of January. I had flattered my self from some parts of former letters, unless some weighty reason opposed it - my friend would not. My fancy had done more; It had placed me by your side, as I received your 
letter, where I was enjoying in that imaginary situation all the waking certainties of human happiness. I made to your letter some answer in a tumult of opposition. But you would perceive this and forgive what sensations was hasty or improper. I now write in a moment of greater composure, and may I not also add of greater submission. I know what I. ought and I do struggle to conform to your interdiction. But my Peggy will consider, that should I leave Annapolis by the first of January and it will be almost impossible to leave it sooner, that I must be some days on the road, and some days in Baltimore, all of which conjoined must put off our marriage till within a few days of the period to which I am limited. May I hope that this arrangement, which is so near to that of my friends will comport with her ideas of propriety; and that it will not be defeated by any insurmountable obstacle. My beloved will observe that I have not taken into this calculation allowances for bad weather. But I fear I distress you - and I have promised you an entertainment at the Governor's.

"Well then - I got to this place of gaiety and business on Wednesday. Alass Peggy I am called unexpectedly from my promise - you will excuse me for delaying it's performance till next sunday - and believe that I regret being obliged for today - to bid my beloved adieu."

Later in the week, he wrote again:

"Friday morning.

"19 Decr.

"To day, my dear friend, I expect your letter, and with it a fresh source of agreeable sensations. Without being much pleased, I have been very busy since your last, and which increases my solicitude for a new conversation because this never failed to restore me to myself however wayward I may be or however disposed to be dissatisfied. I find, my Peggy, a consolation beyond expression in your visits - in hovering round you in the hall-room, in the attentions of your Spaniard, or waiting upon you to your own fire-side - in listening to the little Jane and hearing her sometimes please and sometimes alarm you. Such incidents as these bring with them a world of satisfactions, nor would I exchange them for all the gaieties and pleasures of Annapolis. There are routs - dinners and dances - but what are these when you are in Philadelphia. There is a variety of beauty - but none of it can satisfy. I flit through a round of company; I debate with 
politicians or I converse with philosophers: I feel interested for the moment but when I retire I do not find my charmer: and then Peggy I grow sullen and out of humor and sometimes desperate enough to resolve upon seeing you even against your consent.

"But my love I am getting into a serious mood and it is time to go to Congress. I shall take this with me and send John to his station earlier by two hours than he went last post day.

"Good morning my beloved."

“Annapolis, 21 Decr.

"To-morrow carries me from this place-but the day recalls to my mind a promise I made to my [friend] some weeks ago of an entertainment at the governors. When I got hither from Baltimore which was on Wednesday about noon I found every body preparing to go with the rest. It exhibited a strange mixture of men and characters. The lords of the old government, with some of the sovereigns and citizens of the new (if we may calculate on finding them together) seemed to have forgotten all former ideas of precedence and distinction. Sir Robert Eden would have persuaded one by being of the party, that he had lost all remembrance of his having been the owner of the house in which he danced, and late governor of Maryland - but the thing could not be, where every person he met, and every picture and piece of furniture he saw, served to remind him of the past, or brought up the recollection of pleasures he could no longer repeat. This state has taken away his property, and a libertine life his constitution. He finds himself a dependent on persons he despised, and insignificant on the spot where, but lately he was every thing. He sees his old parasites and companions enjoying places under the present government, and devoted to new interests. $\mathrm{He}$ is without a train of followers obedient to his pleasing will. He perceives, that even the hearts he is said to have subdued by his entertainments or warmed by his gallantries have altered by time or submitted to other seducers. If we loos for the cause of his return to this place in his pride - that would not suffer him to sue for favors, from men he so lately considered as rebels. If in his interest, he will be blamed for meanness. If in his poverty, he is certainly to be pitied. So situated and circumstanced I could neither believe him happy 
or at his ease, unless I had supposed, that, with his estate and constitution he had lost his sensibility.

"Mr. Harford is a young man, and excites more favorable ideas. He has no prejudices to encounter because this is his first visit to America. The natural son of the late lor Baltimore and heir to his estate which we have taken away, $\mathrm{He}$ is handsome, sensible and of polite manners, and withal seems to be governed by a discretion beyond his years. All this speaks in his behalf, and disposes one to wish, that amongst the virtues of the country $w$ ? could reckon magnanimity.

"Sir Robert danced with Mrs. Plater. Mr. Smith, his secretary, with her daughter. Mr. Clapham formerly receiver of rents, was at the card tables. Mr. Harford did not dance, but was seen sometimes chatting with the ladies and sometimes with himself.

"Such a blended assembly - men of so opposite principles and manners - those who had lost estates and those who had them, - those who were once the greatest, and who were now among the least- those who were once nothing, and who are now every thing -ladies who shone under the late constitution, and some few of both sexes, whose value and merits no revolutions could diminish - all conspired to excite reflections and to afford amusement. The scene did not cease to be interesting till near twelve o'clock - when I retired to my apartment took out a little amulet from my bosom - kissed it twice and went to sleep.

"But know my charmer, that the dear image the amulet presented did not leave me, but continued almost throughout the night to give birth to the tenderest and most agreeable dreams.

"This being the last engagement I had to discharge in Annapolis I hasten to join my amiable friend and interchange those solemn vows which are to make us one throughout time and eternity. Adieu, my beloved adieu, and may saturday bring your presence your truly affectionate

$$
\text { "McHenry" }
$$

When congress arrived, it found that it was necessary to make arrangements for Washington's resignation of his commission as general and Jefferson, Gerry, and McHenry were appointed a committee to attend to this. On December 10, 
Washington wrote ${ }^{1}$ McHenry from Philadelphia that, as New York had been evacuated by the British, he was on his way to Annapolis to "get translated into a private Citizen." Ten days later, he notified the president of congress that he had arrived in Annapolis and, on the 23rd, he read his address to congress in the senate chamber of the state house. The war was over and the commander, to whom the new country owed so much, felt he could now take his "leave of all the employments of public life." The original draft of the address was given to McHenry and has been preserved by his descendants to this day.

At this time McHenry was much distressed at not hearing from Miss Caldwell and wrote her on Monday, December 22:

"Could my love but know the uneasy hours I have spent since last post; and the fears that have been perpetually intrusive whenever I felt a moments serenity, I would become the object of her utmost compassion. At this instant I am on a rack of suspense. You may be sick and I must not know of it; nor have it in my power to be with you, or near you, or where I could in any manner be administering to your relief. Good God should this be the case, and Jack have neglected to write me out of a mistaken delicacy, I shall become mad. But I am nearly so at this instant. I was to have spent the evening with some ladies but I have sent an excuse. I wonder what they are to me. I was to assist in writing our answer to General Washington's resignation - but I am unfit for this purpose. If you are not sick I know the neglect did not lay with you. You certainly wrote me for I cannot suffer myself to think that I am all at once become so wretched as to be forgotten.

"Forgive me, forgive me, my love, my beloved - I am indeed, almost beside myself by this incident. Only see what a change it has produced in my situation. I had reconciled myself to the time you asked for in your last letter. I had supposed, my friend had good reasons which respected the preparations, why I should not see her till the middle of the next month; or perhaps, that she wished to keep me at my duty as long as it was possible. When I admitted the latter, I admired your Romanlike virtue: when the former I could not be otherwise than satisfied. If it is destined, I cried, that my Peggy should-always have the same commanding

1 Ford, x, 336. A photographic facsimile of Washington's manuscript address on the occasion of his resigning his commission was printed in Mag. Am. Hist., vii, 104. 
power over me that she now possesses I feel that I am destinel to be happy. And have I not a certainty of this, I continued, in her gentle spirit that subdues by yielding : her delicacy, that promises to be unchangeable in the arms of a husband: and her good sense that will always direct her behaviour so as to promote a constant exchange of tender and faithfully affectionate offices. I was lost in these delicious anticipations, and believed myself the happiest of mortals when the post arrived without one word from my Peggy.

"Oh Peggy Peggy - but my sufferings if you are sick will not comfort youl : and if well, as I hope and pray you are, I do not wish to make you melancholly by their recital. Adieu then, adien - nor think what I shall suffer till I hear from you."

McHenry's account of Washington's resignation, written to Miss Caldwell that very night, gives a vivid picture of the scene.

"Had I been obliged to count the sands as they fall from an hour glass, since last Friday, I could not have done it with more exactness than I have counted the minutes of each dar. It is, my dear Peggy, impossible for me to tell or you to feel the solicitudes and suspenses I have experienced. I am now become reasonable and do not think you are sick: but this does not relieve me. I do not think you have neglected me; but this does not place me at rest. I suppose that some sufficient cause must have intervened to prevent me getting your letter, as clouds intervene and prevent the sight of the sun. But I will say no more on this subject, for I do not wish to communicate any distress this incident has caused me to my affectionate Peggy.

"To day my love the General at a public audience made a deposit of his commission and in a very pathetic manner took leave of Congress. It was a solemn and affecting spectacle; such an one as history does not present. The spectators all wept, and there was hardly a member of Congress who did not drop tears. The General's hand which held the address shook as he read it. When he spoke of the officers who had composed his family, and recommended those who had continued in it to the present moment to the favorable notice of Congress he was obliged to support the paper with both hands. But when he commended the interests of his dearest country to almighty God, and those who had the superintendence of: 
them to his holy keeping, his voice faultered and sunk, and the whole house felt his agitations. After the pause which was necessary for him to recover himself, he proceeded to say in the most penetrating manner, 'Having now finished the work assigned me I retire from the great theatre of action, and bidding an affectionate farewell to this august body under whose orders I have so long acted I here offer my commission and take my leave of all the employments of public life.' So saying he drew out from his bosom his commission and delivered it up to the president of Congress. He then returned to his station, when the president read the reply that had been prepared - but I thought without any shew of feeling, tho' with much dignity.

"This is only a sketch of the scene. But, were I to write you a long letter I could not convey to you the whole. So many circumstances crowded into view and gave rise to so many affecting emotions. The events of the revolution just accomplished - the new situation into which it had thrown the affairs of the world - the great man who had borne so conspicuous a figure in it, in the act of relinquishing all public employments to return to private life - the past the present - the future - the manner - the oceasion - all conspired to render it a spectacle inexpressibly solemn and affecting.

"But I have written enough. Good night my love, my amiable friend good night."

"26 Decr.

“" 3 o'clock.

"Thank fortune my dearest friend that our session of assembly is at last finished; and that there is one reason less for my remaining much longer in this place. Having seen the laws signed \& sealed I made haste to the post office, but I did not find there the consolation I sought. It now snows most vehemently and this may detain the post rider perhaps till late in the evening. This my love is no little misfortune, for notwithstanding all I have written you, and argued with myself still I am far from being perfectly composed. Fears that you are sick or of some disagreeable mischance, will every now and then intrude - but let me also tell you, that I do not even suspect that you have been neglectful. You could not, I am sensible, torture me, even if you did not love.

"I go to dine at the president of Congress's. John is 
posted to bring your letter. Oh! may it soon arrive, and with it an evidence of your health and my happiness. Adieu - I take this in my pocket - adieu.

"It is 6 o'clock. I have your letter and am happy. You speak tender things to me in the tenderest manner, and have removed inquietudes which $I$ hope never again to experience. I will blot out nothing of what I have written. It is but reasonable that you should know what I have felt, and improper that I should conceal anything from you. You will extenuate where I have exceeded or forgive where I may have offended. I trust all to my friend.

"I have mentioned that the session is closed. I can only be detained now by the definitive treaty. I shall however leave this in the hands of my colleagues, and leave this the beginning of next week. I must stay a few days in Baltimore, where I expect to receive your next letter, or from which place I will write you the day I expect to be in Philadelphia.

"You will write me unless you hear from me.

"God almighty bless my dear Peggy, and make me to her what will make her happy.

"I go to write a few words to Jack. Adieu my beloved - Adieu.

$$
\text { “9 O'clock. }
$$

"I am in my chamber, and cannot go to sleep or close your letter without a few words in addition to what $I$ have pencilled. It is most likely my dear friend that the signing of this same definitive treaty will keep me here till the middle or last of next week. You will therefore write me. Should I be able to leave it sooner, you will hear from me, by a post that leaves this on tuesday evening or Wednesday morning, which gets to Philadelphia on Friday - If I should however be in Philadelphia the last of next week, my beloved, will not be surprised. I do not think however that the thing is practicable; altho' it may take place. The post sets off early in the morning."

On his return from Annapolis, McHenry wrote on Decem. ber 30, to Miss Caldwell, to tell her of his plans for the journey to Philadelphia:

"See my love the use that I make of your indulgence. I am here, but my expectations of being with you on Saturday are not so strong as when I left Annapolis. Jack is to accompany me, and he has yet many things to do. He was also to 
have done some business for me and that is still to be done. I do not mean however that he is in fault altho' somebody is. Notwithstanding this I shall endeavour exceedingly to get off on Friday. But if I cannot accomplish this, I shall on Monday, and on Tuesday be in Philadelphia should the roads admit of such traveling. It will be no crime I hope to set out on Sunday I know that in setting out even on Monday I encroach on your original plan, but my beloved friend will consider my solicitudes to be with her, and those countless anxieties and sufferings which I mușt continue to experience till they are lost in her arms.

"I shall hope that my Peggy will fix upon some day in next week for this event: for the performance of those nuptial rites that are to give us to each other by the tenderest and dearest of all names and affinities. I shall rest upon this delicious hope. It will cheer me on the road and do more to sweeten the hours which I must still be absent, than all the amusements and philosophy in the world. Even at this blessed instant it lights up in my bosom a flame of the purest and most perfect delight.

"But I would upon another account entreat the day being in next week. This would at once relieve my beloved from those busy set of inquirers and questioners, who heed not or feel not the pain they excite in a delicate mind by their injudicious euriosity.

"I expect to arrest your letter on its passage to Annapolis. If the return of the post does not bring you one on Monday it will be because I shall expect to see you on Tuesday.

"My friend my beloved adieu.

"Tuesday night.

"It has snowed all day, which has detained Armstrong" and given me time to write your parents. I have mentioned a private wedding which I know you have much at heart, and if it can be accomplished with propriety I know they will comply. However what they think right we must not think wrong.

"A thousand sweet and tender agitations oppress and delight me. I hope there ean be no reason why we should not be married next week. I rely upon your goodness. Do not oh do not disappoint your expecting hoping trembling ____" 
To Captain Allison, McHenry wrote:

"My dear Sir

"I have taken leave of Congress for some time and expect to see you the beginning of next week. As I wish for many reasons to have our marriage over as early as possible. In a letter I have written to Mrs. Allison on the subject of my marriage, but I want also to say a few words to yourself. I am as well as Peggy desirous to avoid as much as possible that parade of visits which you know is eommon on such occasions, but which has nothing to authorise them but eustom. For my own part I am of the opinion that a few friends and a supper is all that is necessary or proper; and that all that follows had much better be omitted. A private wedding would exclude all this foolish formality. But as I said to Mrs. Allison I must leave all these matters to be arranged by those who understand them much better than I do. I have only to bes of you, that if you think as I think and see no impropriety in a private wedding that you would add your reasons to mine, provided Mrs. Allison is of the same opinion.

"I know not whether I shall be fortunate enough in prevailing upon Peggy, that our marriage should be next week. I set out however under this impression and with the hope if ought depends upon you I will not be disappointed."

The letter to Mrs. Allison was in the same vein :

"My dear Madam.

"I have got this far on my way to Philadelphia, but will be detained in this place till the last of the week. I have intreated Peggy to fix some day in the next week for our marriage. Should my wishes meet your approbation, and prove agreeable to her it would add greatly to my happiness. I need not explain the reasons why the marriage should take place as soon as may be after my coming up, as they will occur to yourself. There is one thing however which I would beg leave to mention and which I am extremely anxious to have accomplished if it ean be done without too great a violation of established forms. If the cerimonial part of the business could end with the supper, at which I hope there will be only a few friends, I am sure it would be relieving us all from very idle and very useless visits. Might not these and the parade usual on such occasions be all avoided by considering the marriage as private? If private, visits would come only from those one would wish to see or that would be in. 
vited. But I know too little of these matters to direct, and if I knew ever so much I should not. You will therefore do what you please, and I will be pleased with whatever is done.

"I hope if there is no good reason against next week you will dispose the mind of my dear Peggy for the event and thus give me a new motive to love and esteem you.

"Sincerely and affectionately I am my dear Mrs. Allison." 
CHAP TER VI

\section{MARRIAGE AND RETIREMENT FROM PUBLIC LIFE}

$M$

cHENRY reached Philadelphia safely and married on January 8, Margaret, only surviving daughter of David Caldwell, merchant, of Philadelphia. She was born October 8, 1762, and died in Baltimore November 20, 1833. Her father, who died in Philadelphia, the year in which she was born, married in Ireland Miss Grace Allison. She married secondly, her cousin, Captain William Allison of Philadelphia, a near relative of the Rev. Patrick Allison, first pastor of the First Presbyterian Church of Baltimore, in which both James McHenry and his wife were communicant members, McHenry also serving in 1786 as one of the original trustees of the graveyard of that church. Mrs. McHenry's only brother, John Caldwell, to whom frequent reference is made in this book, was born in 1759 and died at Baltimore in 1820, leaving three sons. He married his cousin Margaret Caldwell of Philadelphia and settled in Baltimore as a lawyer.

James MeHenry and his wife had five children, who may well be named here: Grace, the eldest, was born on November 2, 1784, baptized on December 4, and died in infancy, March 24, 1789. Daniel William, the second child, was named for his grandfather, was born November 12, 1786, baptized on November 26, and died suddenly June 30, 1814. After his marriage, he removed to Allegany County where he possessed an estate. On June 23, 1812, he married Sophia Hall Ramsay who was born on October 23, 1794, and died on December 13, 1874. She was daughter of Colonel Nathaniel Ramsay, a distinguished officer in the American revolution. Daniel McHenry had one son, Ramsay, born January 15, 1814, baptized Febrinary 16, died August 13, 1878. He lived at Monmouth, Harford County, as a country gentleman and never married. He took great interest in agriculture and possessed fine herds of imported cattle. He served several terms in the Maryland legislature. The third child was Anna, born November 20. 
1788, baptized January 4, 1789, married James Pillar Boyd, an attorney of Baltimore, February 4, 1808. She died April 16, 1837, having had four children, viz: Mary, born March 2, 1810, and died October 7, 1811; James McHenry, born December 15, 1817, died December 4, 1847, married December 4, 1847 on his deathbed Annie Eliza Hall, a granddaughter of Colonel Nathaniel Ramsay (she is still alive, having married again Major-General John G. Barnard); Andrew, born November 9, 1811, died January 15, 1815; and John Pillar, born August 3, 1816, died March 21, 1826.

All the living descendants of James McHenry are descended from his second son and fourth child, John, who was born March 3, 1797, baptized May 7, and died at Mercersburg, Pa., of fever on October 6, 1822. He married ${ }^{1}$ on December 7, 1819, Juliana Elizabeth, a daughter of Colonel John Egger Howard. She was born on May 3, 1796 and died May 22, 1821. John McHenry was educated for the bar and left one son, James Howard, born November 11, 1820, died October 25, 1888. He married, June 25, 1855, Sarah Nicholas Cary, the daughter of Wilson Miles Cary of Baltimore, and had seven children : Juliana, who died in 1900; James and Charles Howard, who died in infancy; Wilson Cary, who married Edith L. Dove of Andover, Mass.; Ellen Carr, who married R. Brent Keyser of Baltimore; John, who married Priscilla Stewart of Baltimore County; and Sophia Howard, who married Charles Morton Stewart, Jr., of Baltimore County. James McHenry's youngest child was Margaretta, who was born March 7, 1794, baptized March 27, and died of consumption November 26, 1809.

McHenry's marriage was very happy. His wife returned his devotion and their love did not weaken with the passage of the years. The wedding was a surprise to his friends. He had written to his friend Cochran some time before:

"I had reasoned with myself a thousand times upon matrimony. You know I could not pass over this subject. That I had gone on to build houses and plant vineyards, and after

1 Mrs. McHenry wrote thus to a friend of this marriage:

"The only information I have to give you of a pleasant kind is that of the marriage of my son with Howard which took piace last Decr. This event did indeed produce feelings of joy \& gratification which my heart had long been a stranger to \& I hope of sincere thankfuiness that my only \& deservedly beloved son had been directed to so good a choice. She is the very person we would have chosen for him; her mind so well improved. She is discreet \& very amiabie. When I say that he is deserving of her, you will be pleased to know that he also is of an amiable character. This union was long in contemplation, \& much desired by the friends on both sides for they are worthy of each other." 


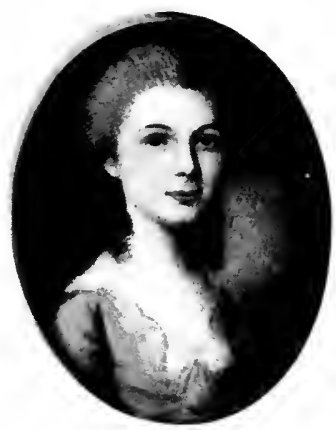

MARGARET CALDWELL McHENRY

(Mrs. James McHenry)

Reproduced in original size from miniature owned by the heirs of Dr. James McHenry

(Copyright, 1907, The Burrows Brothers Company) 

looking at them a little, either capriciously or wisely (I did not say which) determined not to enter into one of them. Then I went on to say that I was a poor philosopher, and that in a hovel, with only a cabbage garden annexed to it, could not be happy with a wife."

Mrs. McHenry was a woman of a deeply religious nature, a good mother and housewife, not greatly interested in public affairs. To her McHenry wrote from time to time brief poems like the following:

\section{BLOOM-HILL.}

To Mrs. McHenry.

Oh how I long my weary head to rest

on the soft plllow of my Peggy's breast:

To taste with you the warb'lings of the grove;

The shades of Bloom-hill and the sweets of love.

To lead through clover'd fields your dewy feet, At glimm'ring morn the opal clouds to greet; To help you o'er the fence and up the hill;

And hear you talk and praise your rural skill.

To see you playful sklm the banks that shelve As when that $I$ was twenty thou but twelve, Just seem to fall then rise with sudden grace, With eye averted and with blushing face!

At silent noon hard by the osier'd brook, To read with you some philosophlc book; To wring the heart with Shakespear's glowing page old Lear's madness or Othello's rage.

At eve to sip the dalry's nlcest cream

Or help our Grace to paddle thro' the stream;

Hear the hens cluck to roost their scatter'd brood

And distant cattle lowing o'er their food.

See the starr'd nlght lead forth her fairy train

And jocund hamlets smoke along the plaln:

Then, to retlre from ev'ry mortal vlew

And pass tlll morn the wedded hours with you.

When Uriah Forrest heard of the marriage, he wrote MeHenry thus:

"Although you do not merit it, I cannot forhear my congratulations on your success. MeHenry married! is it possible - myself \& several of our friends have been years in pursuit of that happiness without effect \& the man who upon all occasions reprobated the Idea - the first that has put it in practice.

"What are going about now you have got married? I do not mean to ask in what manner you mean to treat Mrs. McHenry; but do you mean to continue Politician, return to Physic, adopt the Law, or commence merchant. Salute Mrs. Me for me - Say to your brother I very much respect him - 
$\&$ to yourself I will say you have the most perfect wishes for every Happiness that you can desire \& be assured of the affection of me while you possess that worth that first commanded U. Forrest."

McHenry had known his wife from her tenth year and some time after her marriage wrote from Philadelphia to her:

"My dear Peggy. I am in the old house in which I first saw you and writing at the very desk on which I taught your fingers to form the first letter they ever made. My feelings correspond to my situation.'

He seems to have remained in Philadelphia until the latter part of March, when he left his wife with her mother and eame to Maryland to attend the sessions of the legislature and of congress, both of which were to meet in Annapolis. On the way, he stopped at Baltimore and wrote Mrs. MeHenry on March 25:

"When I left my dear Peggy, the great difficulty was got over, and I neither cared or thought about the badness of the roads; they were not however as bad as we were told, for we got that night to the Head of Elk, and yesterday morning to this place. You will naturally conceive my anxiety to hear from you, and will have written me before this can reach you. I shall receive your letter at Annapolis where I go tomorrow to consign myself to some weeks unavoidable drudgery and to wait with sullen impatience that moment when I may leave it to embrace what I hold most dear in this world."

After arriving at Annapolis, he wrote her constantly. Some of the letters are of interest, showing his character and the social side of the legislative duties.

\section{"Sunday 28th March 1784}

"I have said that the great difficulty was to leave you but I was mistaken, for I am hardly two days in Annapolis when I find that to keep from you, is yet more difficult. Ah Peggy, how was I softened and tried in the moment of our parting, by your tender embrace, your restrained emotions, and your melting tears. Even now they speak to my very heart, and almost persuade me to relinquish a service which has been gradually losing its charms ever since you gave me your love. In truth, I am no longer anxious to please my state, seeing it cannot be done without sacrificing too much of your company. It is time too that I should accommodate 
my leisure and industry to our prospects and circumstances. Neither of us can be happy under a long separation; nor can our interest be promoted by my sitting in Congress. My first object was to get you to Baltimore, to see you mistress of your house, and pleased in your new situation - but a strong hand restrains me where I am and delays that necessary event. I fear my beloved that I shall not have it in my power to move from this place sooner than the first of May. It is a tedious period - but unless I do what I have censured others for doing I cannot make it shorter."

"Tuesday evening. [March 30]

"Most of my visits are made, and I have received the usual compliments and answered the usual enquiries. Your health has been asked for by those who never saw you, and you cannot think how prodigiously happy it made them to hear that you were well. I often regret that so endearing a stile should have obtained a currency, without possessing any value. Adieu till post day.

"This is thursday night [April 1] and no post or letter from my Peggy. It has happened to me to dine at different houses every day this week, but I have not felt less solicitude on account of this variety. I have also been very busy in Congress, but even there I found moments to be anxious and uneasy. To-morrow I, hope will bring me an evidence of your health and console me as much as I can be consoled in your absence. It is late and I am not quite free from a headache good night my friend, my beloved good night.

"The seeond of April is arrived without bringing the post. It must however be here sometime to-day, so that I go to Congress in hopes that Patton, the doorkeeper, will bring me a letter while we are sitting. Be assured I shall not complain if it should interrupt me in the midst of a speech. - good morning."

\section{"Sunday morning 4th of April.}

"When I was about to despair of the post he arrived and brought me your letter. It was late before he came in last night, and he goes off at nine o'clock this morning. The new name under which you write excited a thousand new emotions. I no longer saw the name that I formerly kissed with rapture, but one still more dear and interesting. I would give a great deal to be assured that the mind of my Peggy was 
composed and at ease. But now the roads are better, we shall have two posts in the week, and this will give me an opportunity of being frequently informed of your health. Adieu, my beloved Peggy adieu - "

"Wednesday night 7 April 1784

"I snatched a few minutes on monday last to thank my dear Peggy for her letter of sunday, but I was so straitened for time that I could not thank her enough. Indeed I feel that I ought to be satisfied with so much tenderness and affection, notwithstanding this very tenderness and affection serves to embitter separation. But I am far from being unhappy, nor must you think me so, since it is true that the very agonies of parting and the distress of absence are accompanied with some cordial emotions. At this moment however mine are of the pensive kind, and I forbear to cast a longing look at Philadelphia. I believe you to be well and that you will be careful of your health; but this belief, though it may sometimes soothe, is rarely satisfactory. Whenever I count the days I have been gone from you, and the days that must elapse before my return to you, I sit down more dissatisfied than pleased. But I will write you no more to-night, lest you should catch my present disposition, and be discontented as I am. Good night then, and may you experience no tooth ache to rob you of your rest."

\section{“Thursday night. [April 8]}

"It is exactly three months this night since my dear and amiable Peggy relinquished the name she had from her infancy, for that she now bears, and I can safely say, that no three months of my life comprehended less pain more happiness. But you ought not to reckon me just, were I to stop here. It is a common opinion that lovers generally find an abatement of their passion soon after their marriage - but you are still to me the same charming Peggy you were before this event, nor has marriage deprived you of one of those maiden decencies so essential to the existence of love, and the permanence of affection. I owed to you this little tribute of acknowledgement, and I could not go to sleep without paying it. I left a large company of ladies at the president's that I might not neglect it, but there was no sacrifice in this for you were not of the party. Adieu Adieu." 
"Sunday morning 11 April.

"I removed from the tavern yesterday and am fixed in private lodgings. The room in which I write overlooks the Bay and discovers an agreeable corner of the country just beginning to shew the first operations of Spring. I am of course more at my ease and less subject to interruption : and were the post but to arrive I should have little to complain of to-day, except what is unavoidable, and to which it seems I must submit. There has been no mail since last sunday, nor is one expected before tomorrow, after which perhaps the post will arrive regularly and on stated days twice a week in this place, and as often in Philadelphia. I hope to hear that the tooth ache has been less troublesome. If it has not I think you had better try another ounce of the bark, taking a dose twice a day. It may do good, and it cannot do hurt. I would also when the fit is on, hold a bit of salt petre over the afflicted teeth, till it gradually dissolves, rincing the mouth afterwards with a little warm water.

"Doctor Allison [Dr. Patrick Allison of Baltimore] has been with us since thursday, and is to give us a sermon this morning in the state house. I am going to hear him. We dine together, and shall no doubt talk at least a little about my Peggy. Good morning my beloved; good morning."

“"Thursday morning. 13 April.-

"My Peggy who is every thing that is tender good and affectionate has this moment blessed me with her letter, and indeed I wanted it as much as I wished for it. If it is not among the impossible things it is surely among the most difficult, to be at peace or to be easy under my circumstances. My only consolation is that you are in the bosom of your friends, and that there is not one of them who does not love you, and who will not endeavour to make you happy. I feal that I shall love them the better for their endeavours. I hope also that the little preparations for your removal will afford some amusement, or employment, which as it engages the mind is often in the place of amusement. You ask me respecting some furniture - but I am told the post sets off immediately, so that I must answer you in my next letter, which I suppose will go by Friday's post. Adieu then my dearest Peggy adieu."

$$
\text { “Thursday } 15 \text { April. }
$$

"Do we not possess each others affections, and are we 
not inseperable though separated? In this thought there is a shew of solace and support, there is not however enough to satisfy the heart; for the heart that loves cannot be satisfied in absence. I am anxiously striving to hasten my departure from this place, that I may be with you by the beginning of May. In the mean while, my Peggy, do not suffer the mere apprehensions of fancy to alarm you. All is as it ought to be, and all will be well with you. Only take care of your health, and every thing must terminate happily. But, like you my beloved, I feel myself too tenderly interested to write more on this subject; and shall conclude with telling you, that I expect the post to arrive to-morrow but do not expect any letter from you, as you may not yet be acquainted with the days of his leaving Philadelphia; or if you were, may not have time to write me twice a week. In this perhaps I shall fail myself, because there are some hours that I cannot call my own.

"But I must tell you the news, adjournment of Congress has been tried and I believe will be carried; so that it is likely about the time we get settled in Baltimore the adjournment will take place to Trenton. After leaving this town, there will be a recess till perhaps the last of the year. A committee of the states will be appointed, I imagine, to sit in the recess of Congress. This is composed of a member from each state, whose powers are defined by Congress. I write by this opportunity to your father, lest he should think that I neglect him. Adieu my dear and beloved Peggy."

"Wednesday night 21st April 1784-

"Whenever the objects around me cease to interest. I have recourse to recollection. I was in this situation this morning when I brought into review, the letters you have sent me since I got to this place; the little impression that gave me so much pleasure at Princetown, which you have repeated; and the new signature under which you write; but I soon perceived, notwithstanding these precious circumstances, that I wanted what they could not give me, that I wanted yourself. I then said as you had instructed me, there remains only a little interval of absence, when we shall again be with each other: but although $I$ believed in what I said, I found it brought me no nearer to you. At this moment I became poetical, and seizing a pen wrote the following lines. 
You, only you, with wond'rous skill

Can make my hours just what you will;

Can soothe the troubled mind to rest.

or raise a heaven within my breast.

I'll strive against the stream no more,

That drives me to a happier shore:

Blow fresh ye gales, no wind alarms

That bears me back to Emma's arms.

"There is no doubt but the poetical wind would have carried me to Philadelphia, had I not been interrupted by the appearance of the minister of France, who convinced me that I was still in Annapolis. Adieu."

"Friday morning 23 April

"My ever amiable and beloved Peggy thus to soothe and delight your absent friend - but I have time at this moment to write little more than an acknowledgement of your sunday's and monday's letters. The post goes out in half an hour. I had planned to have left this to-day and felt lighter by many pounds in consequence of it - as Mr. Chase and Mr. Stone were both in town. But $\mathrm{I}$ am prevented most effectually by one of the delegation being taken suddenly ill, nor can I have the smallest expectation, from the nature of his complaint, of getting away till some time in the next week. It may perhaps be the last of it; and the last of the week following (it will be necessary to stop to stop a few days in Baltimore), I shall hope to be blessed with your presence in Philadelphia - On this plan then, the last day of April I shall leave this place and the last of the first week in May be with my beloved. In the mean while, you will continue to address your letters to Annapolis; because if I am not here, I shall take them out at Baltimore.-

"Farewell my beloved, I shall write you on this subject by" the next tuesday's post.-."

\section{"Sunday 25 April 1784}

I strive, my Emma, but in vain

To llghten absence, sweeten pain.

Since in whate'er I say or do

$I$ find I'm absent still from you.

Not e'en the precious pledge I bear

The dear resemblance of my fair,

Or warms my heart or makes it beat

For like the moon it gives no heat.

But I'll no more or say or do

But hasten back to love and you:

For you alone can warm my heart,

Can sweeten pain or peace impart.

Who would not quit the cares of state,

The subtle crew, the vain debate:

Who would not leave a wrangling life

For such a woman - such a wife? 
"I shall make no excuse to my love, for conveying my feelings to her in this manner. I know that a kind wife cannot be a severe critic; but what is of more consequence, I know you will not doubt my sincerety whether I speak to you in numbers or in prose. I shall only add, that if I can confirm the prophetic part by tuesday's post, I shall then be your happy as I am now your affectionate

"McHenry - "

"Monday morning 26th April -

"It was not till I read your letter of the 19th that I could flatter myself that you were tolerably at ease; for amidst all your endeavours to please me I could not find that you were content. On this account that letter has given me more pleasure, than any I have received from you since I left you. You now visit and the hours are less tedious and cumb'rous, and yourself more lively ; in consequence of which I am just what you wish me to be. I am not gloomy, I am not discontented - I am not like patience on a monument, but like one who sees happiness before him and expects soon to enjoy it. I am strongly flattered that I shall be able to leave town this week for Baltimore.

"As Hoffman does not leave his house before the 1st of May, which is next saturday, of course we cannot move into it or make any alterations till the monday following. I shall write you by the tuesday's mail our progress, and my time of leaving Baltimore, should no untoward accident keep me in this place - after friday - Good morning my beloved. I go to Congress, and expect a letter from you to-day - and yet I do not expect it, for I know of many things that may prevent you from writing by the second post to your

"McHeNRY -

"For some days past I have been troubled with a slight inflammation in the throat, but you will conclude by my going to Congress, without my telling you, that it is not very troublesome. Oh Peggy, how rejoiced I am that your tooth ache has remitted its severity. Mr. Smith - Sir Robt. Eden's secretary brought in from England a receipt for the toothache which I have got from him and inclose, from which he gets much relief. You will use it in the same manner that you would use the liquid landanum. Adieu again my love adien - I shall seal this last I should not have time in Congress should the post arrive while we are sitting." 
"Annapolis 28th April 1784

"Every new day brings me a day nearer to that town which alone can receive and return my affection: and yet my love, every day that is still to hold us separate must seem tedious; even the last one that gives me to your bosom. It is true however, that the days are not so irksome now as they were at first, and that the nearer they bring me to you, the more I am disposed to be pleased with them: but, perhaps this arises from my seeing, or thinking that $I$ see, in your letters, an air of satisfaction and resigned composure; which while it enhances your character secretly increases my happiness. It is certainly among my greatest blessings, that whether I am with you or absent from you, I find you constantly attentive to what is becoming and always agreeable so that the more perfectly I know you, the more interesting and amiable you appear in the eyes of your friend. But - It is the hour of business - adieu - "

\section{"Thursday 29.}

"Another day, and would I could say the last, but altho" it is not, the last is not far distant, since I expect to leave this place on saturday, and know of nothing to prevent me, my colleagues being able to attend Congress, and I in perfect health. The last then of next week (for I must spend some days in Baltimore) I shall hope to be blessed in the sight of my Peggy, and be restored to all the pleasures of her society. This letter will be the last you will receive from me, (unless I am obliged to stay longer in Baltimore than $I$ have reason to expect) altho' I shall perhaps get one from you tomorrow in this place, and another next tuesday in Baltimore, which will be the last I shall receive from you. Again to Congress, and I do assure my Peggy, that I go more light than I have for a whole month past. adieu - adieu. - "

\section{“30th - Friday morning 8 o'clock -}

"My love. I set out in less than half an hour from Annapolis, and shall leave this in the post-office for you, lest I should not be lucky enough to hit upon the post's hour of passing through Baltimore. I come nearer to my Peggy, and my heart beats with new sensations - but it will be one whole week before I see you - but I shall be employed during that week in hastening the preparations for your reception. God bless my Peggy, and may our meeting be propitious. I go to Baltimore - farewell my beloved farewell -, 
While at Annapolis, McHenry received a letter sent by his friend, Humphreys, and dated from

"New Haven April 2nd. 1784.

"Cannot the man who had so much agency in inducing Congress 'to charge themselves with the interests \&c' which to me appear to be words of no small import have an equal influence in persuading them to take effectual measures for carrying their Resolution into execution? Well do it then my dear friend! et eris mihi magnus Apollo. -

"It was extremely unfortunate for me that I had not the pleasure of seeing you on my return from Virginia; but you will perceive my inclination to be employed in the public service, by recurring to the files of Congress where you will find a letter from the late Commander in Chief \& another from myself on the subject: I have addresed a second by this conveyance to His Excellency the President in order to bring the matter to a speedy decision.

"Relying on your patronage and friendly assistance, I need say no more than that, I dare almost pledge myself to accept of any Appointment which in your judgment shall be deemed respectable \& proper. -

"You will be pleased to recollect that there was something in agitation respecting presenting miniature likenesses of General Washington to the Gentlemen who composed his family at the close of the War including the Adjutant General; I dare say this would be esteemed by those Gentlemen as the most grateful token of the sovereign approbation which could possibly be conferred on them.-

"With the greatest regard and esteem I have the honor to be

"My dear Sir

"Your most obedt. servt. "D. HuMPHREYS.

"P. S. It is probable, I presume, that Commissioners may be appointed to treat with the Indian Nations; or that a Person or Persons will be commissioned to negociate some public business in Canada or at the Western Posts, in case nothing should occur in which I could be more usefully employed, I should have no objection to either of these appointments."

McHenry was now to continue his mercantile business in Baltimore and his dual legislative office for several ${ }^{1}$ years.

1 In the confederation congress, McHenry seems to have been in 
In all these relations, he corresponded with his friend, Lafayette, who wrote him on December 26, 1783, from Paris :

"My dear McHenry

"Had you not Been employed in Quartering the Continental Congress, I would find it very ill in you not to Have writen $\mathrm{By}$ Colonel Gouvion - I wanted to Hear from you, about you, and then I wanted to know your opinion upon several matters - my letter to Congress will let you know what intelligences we Have in this Quarter-my letter to Mr Moris will acquaint them with some late measures I Have taken Respecting American Commerce - it contains one letter from M. de Vergennes, two from M. de Calonne, and a piece from me to Government which I also inclose to you, and which, for reasons obvious, I Request may not Be sprearl out of Congress - it is on that Account, and Also for a Good translation that I send it to you, and thirdly Because that entrusting temper which you know me to Be possessed of, Now and then is Altered By the selfishness of others - when I Hear, By way of example, that your plenipotentiary's letters, Ratler' Gave a Ground to think I Have not Been so Active as they in winning the last six millions, I Cannot Help Remembering that Jay and Adams never went to Versailles But twice, I think, when I pushed them to it, that M. Franklin did Repose Himself upon me who went so far as to say that I Had Rather delay the departure of 8000 men and nine ships waiting for me at boat than to go without an assurance of the six millions - in Consequence of which I went in my travelling dress to Count de Vergennes's and upon His table wrote a Billet to doctor Franklin insinuating He should Have the Money - But never mind that, and Be so kind only as to take care my Commercial efforts Be known in America, and Also that Congress had instructions Respecting trade, least the matter should Be dropped as Has Been my very. well Begun Spanish Negotiations

"The institution of the Cincinnati Has pretty well succeeded in France, the officers who Have Been in America set a great value $\mathrm{By}$ the Mark of the society - a few objections Have Been made By the public to some part of the institution which may Be either mended or improved - But it Has

regular attendance. He voted in the negative against Daniel Carroll on the question whether any but citizens of the United States could be consuls. On April 1 and 2, 1784, he moved in the unsuccessful affirmative on the report on commercial treaties; on May 5 , he was appointed on a committee to determine what civil offices may be discontinued, and on Juno 1 and 2 , he voted on questlons concerning foreign relations. 
Been found very interesting, and even some what affecting, and people in General Have Been pleased with that Brotherly Association

[One half page missing here.]

"whereas I Have well served America in the field and Cabinet they expect my assistance in settling their Commercial affairs with some European Nations - my station in life, Knowledge of Courts, and facility of accompanying those Sovereigns Both in their Camps of peace, and in their private parties would enable me to introduce to Advantage an American Consul - it ought to Be immediately settled, and orders sent by the Washington

"the second point is that I do not choose to quit the American service - it is the only way I Have to make a kind of official Representation in favour of America - independant of that Affectionate love for Her which makes me proud of Being Among Her Citizens and

[One half page missing here.]

"My — letters Have acquainted you of the measures * * * taken with respect to Madame le Vacher - there is very little to Be got - But I am in pursuit of the affair with the same eagerness, as if it concerned my own sister - as to MI. Chace a memorial Has Been Required from Him By the Naval Minister

"As an ardent lover of America I am glad to Hear of the influence you are said to Have in Congress - as your most affectionate friend I shall Be glad whenever you Have an opportunity to display your abilities - if Congress do not send me any Commands, I shall most certainly embark in the spring - if they Have Commands for me, I would Be twice Happy to Receive you along with them, and to make with yon French and European travels. You ought to make them charge you with some political commission to Courts in Europe and I would like going as a volunteer with you.

"family and friends - Most affectionately I am for

"LAFAYETTE

"the Washington will probably arrive at the end of january - Your answers may Be Here at the end of March - for, if $I$ am to go, I would like embarking for America in April - You may as soon as you Receive this write me By several opportunities in such a way as I will easily understand, altho' post offices will not understand it - By the way when I think of it, you ought to advise Congress voting for the general's 
statue which Has not yet Been ordered - should Mr. Greene $\mathrm{Be}$ entitled to some Honour of the kind? adieu my dear friend."

The Maryland legislature met on November 1, 1784, and on December 2nd, elected McHenry as delegate to congress and granted the delegates a per diem allowance of $£ 3$ currency, while in congress and on the way to or from that body. McHenry did not come to Annapolis until December 8, and was absent from the 18th to the 21st. The early part of the session was largely occupied with consideration of Samuel Chase's conduct, as agent in connection with the Maryland Stock in the Bank of England. McHenry went to congress about January, and does not seem to have returned to Annapolis during the session. 1

The condition of federal affairs steadily grew more critical and the point of view of the Federalists may be gained from a letter sent McHenry by Jenifer at Annapolis on February $17,1785$.

"Dear Sir.

"I shall be very much obliged to you to forward the enclosed letters by the March Packet - In consequence of a late information from Congress to our Executive, it seems to be the opinion of some members that the Assembly should be called immediately. I am fearful that such a measure if adopted would not be productive of the expected consequence, i. e., the raising an immediate supply of money, whether this measure be adopted or not, I shall hasten the remittance of every shilling that comes into the Treasury from the funds appropriated to Congress which may soon amount to 80,000 dollars, from arrearages, as to this year's appropriations they will not be paid into the Treasury till midsummer \& November, but when collected will be considerable as $3 / 4$ th of the duties of 2 p. ct. on commerce besides those on enumerated estates \& 7 p. ct. upon property are to be remitted to Congress.

"But my friend Requisitions will never do; Congress must have permanent funds the 5 p. ct. is the most elegible

1 In the confederation congress, he is recorded as having voted with the minority to let Franklin come home when a successor was appointed on January 21, 1785; to postpone fixing a term to the continuance of foreign ministers in office and, for the three years' term of foreign ministers proposed by Pinckney on February 17. He nominated W. S. Smith as secretary of legation to Great Britain on March, and reported on the ceremonial for the reception of Gardoqui, the Spanish minister, on June 17, and on the attempt to secure the free navigation of the Mississippi on August 25. On October 27, he voted for the ordinance of consuls. 
method in my opinion that can be adopted for the purpose of raising a revenue. Cannot Rhode Island be brought in the measure. Is that state to frustrate so salutary a measure, is her veto to be of equal force with that of a tribune of Anct. Rome. If this state should continue to be inflexible, I fear there must be a new convention especially appointed by all the states to encrease the powers of Congress, or it will be obliged from necessity to assume them, as Politicial bodies have heretofore generally done.

"Inform me how your friends stand, by my calculation if you received the money for my order on Mr Mclaughlin, you would have received an allowance to the 1st of April. I have wrote to Messers Willing Morris \& Swanwick to supply you from that time with $£ 90$ per month you possibly may be in want before that time if you should inform me and I shall remit money for this purpose immediately in haste.

"I am with great respect dear Sir

"Your obedt. servt.

"DANl. of St Thos. JeNifer"

On August 14, 1785, McHenry wrote Washington from New York, 1 on the proposed federal regulation of commerce and incidentally mentioned that Lafayette is writing by every packet and frequently tells congress news which they get from no other quarter. Congress is about to recommend that they be given power to regulate interstate and foreign trade by vote of nine states, that they may retaliate for heavy foreign duties. The eastern states, New York and Pennsylvania, seem anxious for this, but the southern states oppose and McHenry joins them, fearing that the eastern states wish to monopolize the carrying trade. Will not the southern states have fewer purchasers if only American vessels can transport exports, and will not the price of foreign goods be higher, if fewer of them are imported? When the Sonth is as well peopled as the eastern states, naval defense will be easily established, or will come of itself without restraint. Till then "it would seem to be good policy in the Southern States to encourage the number of buyers for what they have to sell \& the number of importers of those articles they must buy." Why do we want a navy or navigation acts? When Great Britain took them up, she was well peopled and had much shipping. For a compromise, McHenry suggests a nav-

1 Sparks, ix, 501. 
igation act framed so that its operation would, gradually and slowly, tend to augment the seamen and shipping of the States, without sensibly wounding in its progress the interests of any state. Then the States could see what they had to give and could repeal the law, if inconvenient.

Washington answers, on August 22, in a strong national letter: 1

"As I have ever been a friend to adequate powers in Congress, without which it is evident to me we never shall establish a national character or be considered on a respectable footing by the powers of Europe, I am sorry I cannot agree with you in sentiment not to enlarge them for the regulation of commerce * * * . Your argument against it, principally that some States may be more benefitted than others by a commercial regulation, applies to every matter of general utility * * * We. are either a United people under one head \& for federal purposes, or we are 13 independent sovereignties, eternally counteracting each other. It the former, whatever such a majority of the States as the Constitution requires conceives to be for the benefit of the whole, should in my humble opinion, be submitted to by the minority." If the southern states were always represented in congress and acted together, there would be no danger of the passage of measures prejudicial to their interest. "I can forsee no evil greater than disunion, than those unreasonable jealousies (I say unreasonable) because I would have a proper jealousy always awake \& the United States always upon the watch to prevent individual States from infracting the Constitution with impunity, which are continually poisoning our minds \& filling themselves with imaginary evils to the prevention of real ones." Great Britain needs our trade and will only do justice to us, when forced to do so by retaliatory measures. Probably the carrying business will not "devolve wholly upon" the eastern states, nor "remain long with them, if it should." "Either Great Britain wili depart from her present selfish system," or the southern states "will devise ways \& means to encourage seamen for the transportation of their own produce, or for the encouragement of manufactures, but, admitting the contrary, if the Union is considered as permanent \&, on this I presume all superstructures are

1 Ford, x, 490: Sparks, 1x, 121. Both print the letter carelessly. From a careful comparison of the original of the letters of washington to McHenry, there seems little reason for Ford to be praised over Sparks as an editor. He is little more careful and often merely builds on Sparks's foundation. 
built, had we not better encourage seamen among ourselves with less imports, than divide it with foreigners \&, by increasing them, ruin our merchants \& greatly injure the mass of our citizens." Without federal commercial power we stand "in a ridiculous point of view, in the eyes of the nations of the earth; with whom we are attempting to enter into commercial treaties, without the means of carrying them into effect, \& who must see \& feel that the Union, or the States individually, are sovereigns, as it best suits their purposes. In a word, that we are a nation to day \& 13 tomorrow - Who will treat with us on such terms?",

On November 17, 1785, the Maryland legislature met again, but McHenry does not seem to have been present at the session. He was ineligible for re-election to congress, in which body his term consequently ended in December.

On January 7, 1786, McHenry resigned his seat in the senate, pecause of "my long absence from my own affairs \& their absolutely demanding my presence." Of his life during this year we know almost nothing, save that he was elected a member of the American Philosophical Society on January 20, though we have two pleasant letters from Washington to him on private matters.

"My dear Sir,

"Mount Vernon.

"I met your favor of the 5th. in Alexandria yesterday. To day I dispatch one of my Overseers and two Servants for the Jack and Mules which are arrived at Baltimore. The Pheasants \& Partridge, I pray you to procure a passage for them by water, in the Packet. To bring them by land would be troublesome, \& might perhaps be dangerous for them.

"Be so good as to let me know the expence of these and the cost of their detention in Baltimore. It shall be immediately be paid, with many thanks to you, for your obliging attention to the business. -

"If you have any particular information from my good friend the Marquis de la Fayette, respecting the above things, I shall be obliged to you for it; his letter to me takes * * * * * two of them, altho I had for some time expected one Jack and two she asses through his medium - but by no means as a present. -

"One of the Servants, who accompany my Overseer, belongs to the Honble William Drayton of Charleston So Ca. This Gentm spent a day or two here on his return from New 
York, and at Dumfries (proceeding on) the above fellow ran away from him \& came here. He goes to Baltimore under the impression of assisting in bringing the Jack \& Mules home, but the real design of sending him there is to have him shipped for Charleston, if the Packet (which I am informed is regularly established between that place \& Baltimore) or any other vessel is on the point of Sailing for the former. -

"Mr. Drayton will readily pay the Captn. for his passage, and the other incidental expences, having intimated this in a letter to my Nephew; but if any doubt is entertained of it, I will see it done. -

tending *** I would beg of you, portunity presents) to have him shipped, \& previously secured. The fellow pretends a willingnes to return to his Master, but I think it would be unsafe to trust to this, especially as ho has discovered an inclination to get back to Philadelphia (with a view he says of taking passage from thence)

"Why will you not make a small excursion to see an old acquaintance. It is unnecessary I hope to assure you of the pleasure it would give.

\section{"Yr. Obedt \& affect \& Hble Serv.} "Go. WASHINGTON.

"P. S.

"Engage the Master of the

Packet Boat to drop the Birds at this place as he passes by - otherwise I shall have to send to Alexandria for them. - "

"Dear Sir,

"Mount Vernon 29th, Novr 1786.

"Your letter of the 18th. by the Packet, \& 19th. by the Post, are both at hand - The Birds were landed yesterday. A Partridge died on the passage.

"If Monsr. Campion's information is to be depended on, he had no letter from the Marquis de la Fayette or any other eharacters in France for me; nothing confidential therefore could have been disclosed by the loss of his pocket book, unless it was deposited in your letter. -

"His acct. is that he was ordered to repair to L'Orient with the Asses \& Birds, from whence he \& they were to be shipped by the messrs Baraud. That the Marquis told him, 
letters should follow, and he supposes they will arrive in the French Packet. -

"By Monsr. Campion 1 I send the guinea you paid for his board; if there are any charges yet behind, I wish to be informed of them that they may be immediately paid.

"My sincere thanks are due to you, My dear Sir, for your kind attention to this business. Having received no intimation at, or previous to the arrival of Monsr Campiou respecting the light in which he ought to be viewed, I thought it best to be on the safe side, and therefore took him to my table, where he has conducted himself with modesty \& propriety.

"Under full conviction that the Asses were never intended as a present, and that the Chinese Pheasants (instead of costing 16 Gus [?] a pair as the Baltimore paragraphist has anounced to the public) came from the Kings Aviary as a present to the Marquis for me (for so says Monsr. Campion) I am eoncerned that such information should have been exhibited in a public gazette as appeared in the B. Post, for it may be viewed as contrivance to bespeak, what I should industriously have endeavoured to avoid, had I supposed it was so meant - A present - Was this publication confined to Maryland, or over the United States, there would not be so much in it ; but as these paragraphs for want of other matter to fill a Paper, are handed from one to another, and ultimately get into the British \& French Gazettes; the Marquis will entertain a queer idea of it, if nothing more is meant Dear Sir,

Mount Vernon May 8th. 1788.

you.

To a letter which I wrote to you somedays ago, I beg leave to refer you. I congratulate with you on the happy decision of your Convention; having no doubt of 1 ts weight on those States which are to follow.

In a letter (just received) from Colo. Spaight of North Carolina he informs me of his having sent a small bag of peas to your care for me. Have you received them? If so be so good as to forward them by the stage (the cost of which I will pay; without dispatch they will come too late) to Alexandria.

A Monsr. Camplon who brought over my Asses, says he is in distress, and has written to me for money. Pray what is his character in Baltimore, and what has he been employed about this year and half, in that place? Though he had no demand upon me for the service he performed, yet I gave him a sum of money as an acknowledgment of my sense of the proper discharge of the trust reposed in him. He told me at that time (fall was twelve months) that he should spend the winter in Baltimore \& sail for France in the Spring. In the spring (as I was going to Phila) he told me he should sail in the Fall. In the fall, as I returned thence, he assured me he should sall in a fortnight. Slnce which $I$ have heard nothing from or of hlm till now, his application to me for money. Your answer (soon) to this part of my letter will be very acceptable to Dear Sir Yr. Most Obedt \& Affect Servt.

To James McHenry Go. Washinaton. 
than what was promised, \& expected - that is - to be the instrument through the medium of Adm. de Suffran (Govr. of the Island of Malta or head of the order) of procuring \& forwarding them from that place to me. That he should have paid all the expences which attended the getting, and shipping them is beyond a doubt - It could not well be otherwise, as their procuration was a doubtful essay. As I have not however received a single line respecting these animals, I do not undertake to contradict the report, but think the evidence of it - the cost \&c appears to have been too slight to hand it in such a dress to the public.

"With sincere esteem \& regard

"I am - Dear sir

"Yr most obedt \&

"affect Servant

"Go. WAShington."

MeHenry was keenly interested in the discussion as to whether the constitution of Maryland permitted the people to instruct the legislature. Chase held that it did; but MeHenry took the other side, in an article written February 20, 1787, and published in the American Museum ${ }^{1}$ over a year later. He maintained that sovereignty is lodged in the law enacting power, that is, for Maryland, in the General Assembly. The constitutional compact does not allow all to participate in the government and those who may participate by frequent elections have an opportunity to change the "trustees of the sovereignty." "This organization fixes the deliberative power with the sovereignty and the elective with the people." To prevent "the abuse of this deliberative power are the constitutional provisions and the right to amend the constitution and to revolt. One of the privileges of the people is that to petition" and no one ever stipulates for an inferior privilege and expects to enjoy a superior, one "which the right to instruct would be. If the relation of representative to eonstituent is that of principal and deputy, the former would be subject to recall by the people, which he is not." The right to instruct the sovereignty places the deliberative power in the people and brings everything back to that chaos which existed before the compact. Even if the right of instruction is admitted, who shall exercise the power, shall nonvoters, or even voters who are not qualified for seats in the assembly? If so, "then are men, whom the compact disquali-

1 Am. Museum, iv, 332. 
fies from exercising the sovereignty, greater than the sovereignty." Further, "a government by instruction is a government never ending still beginning, in which everything fluctuates, in which nothing is stable." Much to be preferred to the right to instruct is the existing right to discontinue, which gives the people efficient control over the deliberative power.

About this time, MeHenry obtained the greatest privilege of his life, by being elected a member from Maryland of the convention which met at Philadelphia in the summer of $\mathbf{1 7 8 7}$ and drafted the United States constitution. 


\section{H A P T E R VII}

\section{MEMBER OF THE FEDERAL CONSTITUTIONAL CONVENTION}

M CHENRY was the only one of those first elected as delegates from Maryland to the Philadelphia convention who accepted the position. John B. Cutting ${ }^{1}$ wrote Jefferson, in July, 1788, that Charles Carroll and Thomas Johnson, the first choice, "declined quitting Maryland, even upon the important business of new framing the National government, Mr. Chase having just before menaced the senate for rejecting an emission of paper money and appealed to the people against them. They had joined in that general issue and could not venture to relinquish, to a violent and headstrong party, their active influence in the senate, as well as in the lower house, at the very moment when it was so essentially needed to stem the torrent of the populace and for the paper. Those gentlemen, therefore, remained at home, convinced their fellow citizens of their superior rectitude and wisdom, and defeated that favorite measure of Mr. Chase." By later elections ${ }^{2}$ there were associated with McHenry, Daniel Carroll and Daniel of .St. Thomas Jenifer, who were.nationalist in their tendencies, and John Francis Mercer and Luther Martin, who were so opposed to a strong federal government that they refused to sign the constitution and strove to prevent Maryland's ratification of the document. Between these two extremes, McHenry took a middle ground, though his own views were not strongly in favor of much centralization of power. In the convention he was seldom heard ${ }^{3}$ and an absence of two months, on account of his brother's ill health, deprived him of the opportunity of being present dur-

1 Mass. Hist. Soc. Proc. (2nd Series), xvii, 503 ; Doc. Hist. Const., iv,

770. MeHenry's journal is printed in Am. Hist. Rev., xi, 595.

2 May 22, 1787, after the date of the convention's call.

3 Pierce's Notes, Am. Hist. Rev., iil, 330. "Mr. McHenry was bred a physician, but he afterwards turned Soidier and acted as Aid to Genl. Washington and the Marquis de la Fayette. He is a man of Specious talents with nothing of genious to improve them. As a politician there is nothing remarkable in him, nor has he any of the graces of the Orator. $\mathrm{He}$ is however, a very respectable young Gentleman, and deserves the honor which his country has bestowed on him. Mr. McHenry is about 32 years of age," 
ing a large part of the sessions. ${ }^{1}$ Yet several portions of the constitution owe their present form to McHenry's efforts and he may well be taken as a type of the average member of the convention - one of those useful men who made it possible by their action to have a "more perfect union." While at Philadelphia he kept a diary for the only time in his life, so far as I know, and its pages show his influence in forming some of the clauses regarding commerce and also give a clearer picture than is elsewhere found of the conferences between members from the same state which must have taken place almost daily between the sessions of the convention.

Mr. MeHenry's correspondence with his wife during the sessions of the convention is disappointing, in that it gives no information, except as to personal and family affairs. On his way to Philadelphia he wrote her:

"When there is a handsome woman and opium to be had, says a Turkish maxim, one never thinks of one's wife. There are at this instant two very handsome girls chattering about sweet hearts in the next room, and wine before me, which you know is as good as opium, and yet I could not be at rest till I got the materials that enable me to contradict the Turk. That people, I find, ought not, my Peggy, be considered as judges of what constitutes happiness - or they have no good wives in their country. But why am I at Bush town? I will tell you. A poor devil of a traveller who had his sulky dashed to pieces against a stump, happened to want assistance which I forsooth most courteously giving did not arrive at this place till the evening was shut in, and some rain had begun to fall - so that I was fain to take up my lodging for the night twelve miles short of the Ferry.

"This is my little history and now I have one question to ask you. Why is it, that I who love you should wish. that I could have got twelve miles further from you?

"Good night and God bless you, prays your

$$
\text { "James McHenry" }
$$

Shortly after the opening of the convention he wrote again :

“Philadelphia Sunday 27 May 1787.

"I would not for ten thousand pounds be the wretched husband who can leave home without regret and return to it

$1 \mathrm{He}$ seems to have been paid for seventy-two days attendance at the rate of thirty-five shililings per day by the state, which record would show that he was paid whether present or not. The assembly had voted to pay the delegates as delegates in congress were paid. 
without pleasure. My impatience for the arrival of your letters, and the delight they brought with them will be a new proof that you still retain over my heart the most interesting influence a woman can possess. What shall we do to perpetuate this influence?

"If we take a survey of the marriage state we shall find this influence strongest in the first years, after which, if not guarded with great care, it gradually diminishes and at length disappears, leaving in its room indifference or disgust. When the novelty of love ceases and the cares of a family succeed, it is full time for the parties to attend minutely to every thing which can render home a place of tranquility. They may have studied each others character before marriage, but, generally speaking, it is now only that they begin to know each other and, if they do not make a proper use of this knowledge, they have no just cause to complain of their mutual unhappiness. Many precepts have been administered as necessary at this crisis, but they may be all comprehended in one. What the husband does not like to hear or see he should hear or see, only when he can interfere with propriety and to advantage; and what his circumstances will not permit him to alter or amend is to be endured without murmuring, unless it is of such a nature as to affect the source of felicity, when sympathy may abate its force or participation render it less oppressive. The same rule applies to the husband who will avoid complaints which can only distress, unless where they are required by the laws of love and conjugal confidence. As yet we are in the first stage of marriage and may think we do not stand in need of these precepts: but while we are dear to each other it may not be improfitable to contemplate the rocks upon which so much human happiness has been shipwrecked."

Two days later he wrote her again:

"We are beginning to enter seriously upon the business of the convention, so that I shall have but little leisure to give to my Peggy, except to the reading of your letters. You are all well, and here we are all well. Adien affectionately",

His notes indicate that he was in Philadelphia as early as the 14th of May, but he did not appear in the convention until May 28, probably awaiting for some of his Maryland colleagues. The first of these, Jenifer, did not arrive until June 2.

On the 25th of May, the convention had organized by the election on the part of the seven states then represented, 
as president of the man whom McHenry always knew as "the General." In addition to Washington, McHenry found his intimate friend Hamilton among the members. MeHenry recorded fully Edmund Randolph's speech and the resolutions introduced by him, but before the work of preparing the constitution had more than begun, an "express from home," with the news that his "brother lay dangerously sick," caused him to set "out immediately" for Baltimore.

As John McHenry grew better, it was possible for James McHenry to leave Baltimore on August 2. Arriving at Philadelphia two days later, he found the committee which was drafting the constitution ready to report and Dunlop, the printer, striking off copies of the report for the members. On the 6 th, the report was brought in by Rutledge and the convention adjourned, "to give the members an opportunity for consideration." McHenry at once proposed to the Maryland delegates that they hold a conference and prepare to "act in unison:" At Carroll's lodgings that afternoon, McHenry "repeated the object of our meeting" and proposed that "we should take the report up by paragraphs and give our opinions thereon." All five of the delegates were present and Mercer at once asked McHenry whether he thought Maryland would embrace such a system. "I do not know," was the answer, but "I presume the people would not object to a wise system." Mercer then asked the others their opinion. Martin said the people would not accept it. "That he was against the system, that a compromise only had enabled its abettors to bring it in its present stage, that had Mr. Jenifer voted with him, things would have taken a different turn. Mr. Jenifer said he voted with him, till he saw it was in vain to oppose its progress." Fearing the members would indulge in personal controversy, McHenry "begged the gentlemen to observe some order to enable us to do the business we had convened upon. I wished that we could be unanimous and would make a proposition to effect it. I would join the deputation, in bringing in a motion to postpone the report, to try the affections of the house to an amendment of the confederation, without altering the sovereignty of suffrage, which failing, we should then agree to render the system reported as perfect as we could. In the mean while, to consider our motion to fail and proceed to confer upon the report, agreeably to the intention of our meeting, i. e. That we should now and, at our future meetings, alter the report 
to our own judgement, to be able to appear unanimous, in case our motion failed.",

Carroll could not agree to this proposition, because he did not think "the confederation could be amended to answer its intentions." McHenry said he "thought it was susceptible of a revision, which would sufficiently invigorate it for the exigencies of the times." Mercer and Jenifer thought otherwise and so McHenry's conciliatory resolution was rejected. Martin now stated that he was against having two branches of the congress, against popular elections of representatives, and that "he wished to see the States' Governments rendered capable of the most vigorous exertions, and so knit together by a confederation as to act together on national emergencies."

MeHenry found that they could come to no conclusions and recommended that a second meeting of the delegation be held on the morrow, stating, "unless we could appear in the convention with some degree of unanimity, it would be unnecessary to remain in it, sacrificing time \& money, without being able to render any service." All agreed to this, except Martin, who said he was going to New York for a few days.

Feeling it of "importance to know \& to fix the opinions of my colleagues, on the most consequential articles of the new system," McHenry prepared four queries as follows: (1) Art iv. Sec. 5. "Will you use your best endeavours to obtain for the Senate an equal authority over money bills with the House of Representatives?" (2) Art xii. Sec. 6. "Will you use your best endeavours to have it made a part of the system that no navigation act shall be passed without the assent of two thirds of the representation from each State?" (3) "In case these alterations cannot be obtained will you give your assent to the 5 section of the iv. article and 6 section of the xii. article as they stand in the report? (In other words will you accept a greater authority over money bills in the House of Representatives and allow a majority of the members of Congress to pass a navigation act?)" (4) "Will you also (in case these alterations are not obtained) agree that the ratification of the conventions of nine States shall be sufficient for organizing the new constitution?"

During the interview, McHenry noticed Mercer make out a list of the members of the convention and mark for and against, opposite most of the names. This led McHenry to ask, carelessly, "what question occasioned your being so particular?" At this, Mercer said laughingly, "that it was 
no question, but that those marked with a for were for a king." 1 McHenry then asked, "how he knew that," to which he said: "No matter, the thing is so," and permitted McHenry to copy the list. Martin saw this list and asked what it was and learning Mercer's account, induced McHenry to let him copy it also.

The next morning, McHenry showed his propositions to Carroll, Jenifer and Mercer in the convention and "they said, in general terms, that they believed they should accord" with them. At five o'clock that afternoon, McHenry went to Carroll's lodgings and, finding him alone, began to discuss the four queries. Carroll agreed with McHenry that "the deputation should oppose a resolute face" to the provision, lodging in the House of Representatives the "sole right of raising and appropriating money upon which the Senate had only a negative," as it "gave the former branch an inordinate power in the constitution, which must end in its destruction. The article should be rejected and its tendency was clear. Without equal powers, the houses were not an equal check upon each other." Carroll also agreed, that the Maryland delegates should, in no event, consent to the passage of navigation laws by a mere quorum of the houses, as that would place the "dearest interest of trade" under the control of four states, or of seventeen members in one branch and eight in the other. The powers to regulate commerce and lay taxes were so great that McHenry recorded that "we almost shuddered at the fate of the commerce of Maryland, should we be unable to make any change in this extraordinary power. We agreed that our deputation ought never to assent to this article in its present form, or without obtaining such a provision as I proposed." As to the ratification of the constitution by nine states, MeHenry said: "We had taken an oath to support our State constitution and frame of government. We had been empowered by a legislature, legally constituted, to revise the confederation and fit it for the exigencies of government and preservation of the union. Conld we do this business in a manner contrary to our constitution? I feared we could not; if we relinquished any of the rights or powers of our government to the United States of America, we could no otherwise agree to that relinquishment, than in the mode our constitution prescribed for making changes or alterations in it." Carroll answered that he doubted the propriety of the article on

\footnotetext{
1 Carroll's name was on this list.
} 
ratifications, "as it respected Maryland, but he hoped we should be able to get over this difficulty.' Jenifer now came in and "agreed to act in unison" with the others, though McHenry thought he "seemed to have rather vague ideas of the mischief of the system, as it stood in the report."

Wishing to impress Jenifer with the necessity of supporting "them, McHenry touched upon some popular points," suggesting "the unfavourable impression" the new government "would make upon the people on account of its expense An army and navy was to be raised and supported, expensive courts of judicature to be maintained and a princely president to be provided for. That it was plain that the revenue for these purposes was to be chiefly drawn from commerce. That Maryland would have this resource taken from her without the expenses of her own government being lessened. That what would be raised from her commerce and by indirect taxation would far exceed the proportion she would be called upon to pay under the present confederation. An increase of taxes, and a decrease in the objects of taxation, as they respected a revenue for the State, would not prove very palatable to our people, who might think that the whole objects of taxation were hardly sufficient to discharge the State's obligations."'

While McHenry was speaking, Mercer "came in and said he would go with the deputation on the points in question. He would wish to be understood, that he did not like the system, that it was weak. That he would produce a better one, since the convention had undertaken to go radically to. work, that perhaps he would not be supported by any one, but, if he was not, he would go with the stream."

It is curious to see McHenry's objections, and the fact that he was closely connected with a mercantile establishment makes his objections more interesting. That so good a lover of the Union as he should oppose so strongly the grant of extensive powers to the central government shows clearly that the constitution was "wrung from the grinding necessities of a reluctant people."

On August 8, the provision giving the sole power of raising and appropriating money to the house of representatives was expunged and, on a reconsideration of the question on the 13th, McHenry joined Carroll, in stating that the most ingenious men in Maryland are puzzled to define money bills and added an instance of extraordinary subterfuge, from his. 
experience in the state senate, to get rid of the apparent force of the constitution. 1

We next hear of McHenry, as a member of the committeeon the assumption of state debts, ${ }^{2}$ appointed on August 18. Three days later, ${ }^{3}$ he showed his fear of granting too much taxing power to the federal government, by seconding Martin's motion that no direct tax be laid until a requisition on the state has been made and failed. On the same day, he stated that he conceived an embargo might be laid under the war power. ${ }^{4}$

The next day, ${ }^{5}$ he joined with Gerry in proposing that congress be forbidden to pass a bill of attainder or any ex post facto law. The Maryland delegation, on the same day, agreed to bring forward some restrictive clauses drawn by Martin on the federal power to regulate commerce. These amendments ${ }^{6}$ were brought in by the delegation on August 25 , and provided that no preference should be given to any state in duties, nor should vessels in the coasting trade be obliged to enter or clear, and that congress could establish no new ports of entry unless the states failed to do so after application made by congress.

On the $23 \mathrm{~d}$ of August McHenry wrote his wife: "My dear Peggy

"It is altogether uncertain when the convention will rise; but it is likely to be about three weeks hence. As soon as this happens, it will be necessary for me to go to New Ark in Jersey to settle an account with a Mr. Mackay which may take up eight days more, so that it may be five weeks before my return. This, you may be assured, excites no one comfortable sensation; yet when I cast my eyes homeward; when I venture to anticipate our future prospects; my heart tells me that my dear Peggy will condense in one week as much happiness as to countervail the pains of two months absence."

On the 27th, he joined with Madison to try to prevent an increase ${ }^{7}$ as well as a diminution in the salaries of judges. On the 30th, McHenry tried in vain to have the commercial questions considered 8 " "before the system is got through." On the following day, the convention finally voted to have the

1 Doc. Hist. Const., IIi, 522, Madison's Notes.

2 Doc. Hist. Const., ili, 558.

3 Doc. Hist. Const., ili, 578. Jenifer and Carroll voted No. Mercer was absent.

4 Doc. Hist. Const., iii, 581.

5 Doc. Hist. Const., ili, 592 .

6 Doc. Hist. Const., iii, 619.

7 Doc. Hist. Const., lii, 625 .

8 Doc. Hist. Const., III, 656 . 
constitution go into effect, when ratified. by nine states. Washington was in favor of as small a number as seven and Maryland was alone in striving for thirteen. In the debate, McHenry advanced his point that the officers of government in Maryland were under oath to follow "the mode of alteration prescribed by" the state constitution. ${ }^{1}$

The same day, however, the Maryland men were gratified by the adoption of part of their commercial clauses, which prevented preference of any state and freed the coasting trade. In the debate, McHenry remarked that the clause would not "screen a vessel from being obliged to take an officer on board as security for due entry,' and so avoid smuggling of goods into states below the point of entry, as in the case of vessels bound for Philadelphia. We hear no more from McHenry on the floor of the convention until September 12, when he voted, vainly, to require three-fourths of the houses to override the president's veto.

During this time, however, he was not idle but employed himself, especially in trying to amend the commercial clauses. On September 4, he wrote in his note book: "Upon looking over the constitution it does not appear that the national legislature can erect lighthouses or clean out or preserve the navigation of harbours. This expense ought to be borne by commerce, of course, by the general treasury, into which all the revenue of commerce must come.

"Is it proper to declare all the navigable waters or rivers \&c. within the U. S. common highways? Perhaps a power to restrain any State from demanding tribute from citizens of another State in such cases is comprehended in the power to regulate trade between State and State.

"This is be further considered and a motion to be made on the light house \&c. tomorrow." The morrow was consumed by discussion of the election of president, but, on the 6th, McHenry spoke to Gouveneur Morris, Fitzsimmons, and Gorham, about the insertion of a "power in the confederation enabling the legislature to erect piers for protection of shipping in winter \& to preserve the navigation of harbours." Gorham opposed, the others favored this and Morris thought it might be done under the power to "provide for the common defence and general welfare." Whereupon McHenry remarked, "If this comprehends such a power, it goes to authorize the legislature to grant exclusive privileges to trading companies,

1 Doc. Hist. Const., ill, 661. 
etc." The commercial question still disturbed the Maryland men and on Saturday, September 8, they gave notice that they had a proposition of much importance to bring forward. This was brought forward on the 15th ; but, meantime, the committee on style had reported the constitution and McHenry, making a careful study of the draft on the 13th, found the Maryland propositions as to preference of one state over another had been overlooked and secured their insertion in the proper place.

Maryland's new proposition, ${ }^{1}$ introduced by McHenry and seconded by Carroll, was that "no State shall be prohibited from laying such duties of tonnage, as may be sufficient for improving their harbours \& keeping up lights, but all acts laying such duties shall be subject to the approbation or repeal of Congress." Mason joined the Marylanders in advoeating their proposition, because the "situation of the Chesapeake peculiarly required expenses of this sort," and the proposition was carried with but slight amendment, by a vote of six states to four, with Connecticut divided.

Although the two-thirds majority for the passage of navigation acts was defeated on the same day, Maryland had gained so much of her desires, that Jenifer felt sure the state would accept the constitution. When Martin said to him, "I'll be hanged if ever the people of Maryland agree to it," Jenifer quickly replied: "Then I advise you to stay in Philadelphia, lest you be hanged."

On Sunday, September 9, 1787, McHenry looked forward to the close of the convention in a letter to his wife:

"After all the researches of ambition and curiosity, it is only, my dear Peggy, in the bosom of one's family where man is born to find real enjoyment. Whenever we suffer ourselves to be allured from this spot, the mind is dissatisfied, till we return again to it. We may indeed flatter ourselves that every thing ought to be sacrificed to certain popular objects ; but we may also distrust a philosophy which is daily contradicted by lessons of disgrace or disappointment. Home then possesses a power over the human heart that is nearly irresistable when aided by the endearments of an affectionate wife and the prattle of a tender ofspring. Still however it is true, that a home having these attractions may be left: but it will be left with regret, and soon rejoined with increased delight. I shall soon I hope rejoin this home as it is likely the convention will

1 Doc. Hist. Const., iii, 751. 
finish their business in about eight days. In the meanwhile, I pray God to bless my dear Peggy and our little ones. Adieu affectionately"

The next Sunday on the eve of the convention's final adjournment he wrote her:

"My dear Peggy.

"Yesterday evening the plan of government passed by an unanimous vote, and to-morrow we shall determine the mode to promulge it and then put an end to the existence of the convention. This done, I shall have nothing to detain me in this place, but the repartition of the effects of the Estate which I hope may be accomplished in time to permit me to make use of the friday's stage. I must add, however, that I do not expect to leave this sooner than friday, and scarcely then; but I will write you by Wednesday's mail, when, perhaps, I may be able to speak with more certainty."

On Monday, September 17, the engrossed constitution was read and slightly amended. "Doctor Franklin put a paper into Mr. Wilson's hand to read, containing his reasons for assenting to the constitution. It was plain, insinuating, persuasive," wrote McHenry, "and in any event of the system guarded the Doctor's fame."

Then MeHenry signed the constitution with Jenifer and Carroll; Mercer and Martin refusing to do so.

The injunction of secrecy was taken off, the convention adjourned sine die, and the members dined together at the City Tavern. McHenry had hesitated about signing and wrote a justification of his course in so doing in his note book, as follows: "Being opposed to many parts of the system I make a remark why I signed it and mean to support it. 1stly. I distrust my own judgement, especially as it is opposite to the opinion of a majority of gentlemen whose abilities and patriotism are of the first cast; and as I have already frequent occasions to be convinced that I have not always judged right. $2 \mathrm{dly}$. alterations may be obtained, it being provided that the concurrence of 2-3 of the congress may at any time introduce them. 3dly. Comparing the inconveniences and the evils which we labor under and may experience from the present confederation, and the little good we can expect from it, with the possible evils and probable benefits and advantages promised us by the new system, I am clear that I ought to give it all the support in my power.

"Philada. 17, Sept. 1787. James McHenry." 
On his return, McHenry was nominated as one of Baltimore Town's two delegates to the state ratifying convention and was summoned, with the other delegates to Philadelphia, to appear at Annapolis before the house of deleyates on November 29 and report on their work. Mercer did not come, but the other four did and all but Martin supported the new document, though the speeches of the three Federalists have not been preserved. ${ }^{2}$ It is not known whether McHenry participated in the fierce war of newspaper articles which followed, but Daniel Carroll, Jenifer, and A. C. Hanson seem to have led the Federalists and McHenry appears to have taken rather a minor part in the campaign.

At the election, early in April, 1788, MeHenry and John Coulter, the Federal candidates from Baltimore Town were elected, by votes of 962 and 958 respectively, to 385 and 380 for Samuel Sterrett and Daniel McMechen, the Anti-Federalists. Cries of fraud were raised by the defeated party, but no contest was made in the convention.

Just before the state convention met, Charles Thomson, secretary of congress, wrote McHenry:

"Dear Sir.

"New York April 19. 1788.

"I am sorry I have not been able sooner to answer your

1 See Steiner's Md.'s Adoption of the Federal Const., Am. Hist. Rev., v, 228-207. Tench Coxe (Doc. Hist. Const, Iv, 523) wrote Madison February 25,1783 , that he has forwarded Contee a large packet of pamphlets sent him by Judge Hanson who writes "there is no doubt in Maryland."

2 Doc. Hist. Const., Iv, 378, Samuel Powell wrote Washington from Phlladelphia on November 13, "In Maryland there is a secret opposition from a member of the assembly but it is belleved that his politics will not succeed." Doc. Hist. Const., Iv, 396, Madison wrote Jefferson on December 9, that Maryland "has copled" Virginla's example in "opening a door for amendments, if the Convention there should chuse to propose them. . A more formidable opposition is llkely to be made in Maryland than was at first conjectured. Mr. Mercer, it seems, who was a member of the convention, though his attendance was but for a short time, is become an auxiliary to Chase. Johnson, the Carrolls, Govr. Lee and most of the other characters of welght are on the other side. Mr. T. Stone died a little before the Government was promulged." Doc. Hist. Const. iv, 408, Jefferson wrote Carmichael on December 15, "Maryland is thought favorable to it; yet it is supposed Chase, \& Paca will oppose it." Doc. Hist. Const.. Iv, 436, Washington on January 10, 1788, wrote Knox. "Maryland must unquestionably, will adopt it:" and on the 18th wrote Samuel Powell (Doc. Hist. Const., Iv, 449) "Of Maryland there can be little doubt." Mass. Hist. Soc. Proc. (2nd Series), xvil, 484. Daniel Carroll wrote on October 28, 1787, that Maryland wlll probably ratlfy the constitution and Johnson has told him he is in favor of so doing. J. Lee and Potts were chosen delegates in congress, with a view principally, of preventing mischief and forwarding this great object. Chase's article, signed "Caution," showed an adverse disposition; but he has bound himself to propose a state convention and, if chosen as a member of this body, will be bound to ratify the proposed plan, "the impression in Baltimore being so strong for it." 
letter of the 19 of last month. I happened to be in Philadelphia, when it reached New York. It was transmitted to me and, when I received it, I was in hopes I should have finished my business \& returned in a few days. Therefore $\mathrm{I}$ immediately sent back the letter which was enclosed therein to be forwarded by the packet and deferred writing to you until I returned. My stay was longer than I expected, and after my return here I rec'd your second letter of the 12 of this month and, at the same time, an account of your election. I hope, notwithstanding the choice made by the counties of Anne Arundel, Baltimore and Harford, that the elections *** are such as will ensure the adoption of the new constitution, for, unless that take place, I confess to you my fears for the safety, tranquility and happiness of my country are greater than at any period of the late war. The present federal government is at the point of expiring. It cannot, I think, survive the present year and if it could, experience must have convinced every man of reflection that it is altogether inadequate to the end designed. What remedy then have we prepared for the train of disastrons events which must necessarily ensue from a dissolution of the union, what security for our independence, peace \& happiness as a nation?

"You ask me what is the amount of the foreign and domestic debt. With regard to the foreign debt, I beg leave to refer youn to the enclosed schedule of the French and Dutch loans, shewing the periods of their redemption, the annual interest payable thereon, \& the instalments stipulated for discharging the principal. To this, you must add about 150,000 dollars due to Spain, 186,427 dollars due to foreign officers also a million of florins which, from the failure of the states, congress were under the necessity of borrowing last year to defray the interest of the dutch loans \& other demands in Europe. As to the domestic debt, I have to inform you that, by the last estimate which the board of treasury laid before congress, the amount thereof, as then liquidated, is $28,340,018$ dollars. How much of this has been actually extinguished by the sale of western territory, I cannot certainly say. The tract which the Ohio company have in view to purchase is supposed to be between $5 \& 6$ millions of acres, but I believe they have only paid 500,000 dollars. The residue of the purchase money is to be paid by yearly instalments and the company by their agreement are at liberty to confine their purchase within the compass of their abilities \& to take no more land than they are able 
to pay for. The tract which Symmes has agreed for is said to be 2 million acres \& Flint Parker \& Co. have applied for the purchase of 3 million acres; but I believe neither of these have yet paid any money. The quantity of land purchased \& laid out into townships, agreeably to the land ordinance, is upwards of 700,000 acres but of this there is only about 100,000 sold. As to the land unsurveyed, the quantity is immense and, in my opinion, adequate to the extinquishment of the whole debt of the Union, provided we can have a firm, stable federal government; but without this I am apprehensive the Union will derive little benefit from it. As to the amount of the duties on a 5 per cent import \& the expense of the civil list under the new government, it is altogether conjectural, but of this I am confident that the new government, if established, will from prudential motives encrease the former and lessen the latter, as much as possible, and however proper it may have been judged to vest it with the power of direct taxation, it will not proceed to the exercise of that power except in the last necessity.

"Enclosed I send you the first volume of the federalist the second volume is in the press \& will, it is expected be out in the course of a week or two. As soon as it is published I will forward it to you."

On April 21, the convention met at Annapolis with a decided Federal majority ${ }^{1}$ and, in spite of the protests of Samuel Chase and William Paca, who led the minority, resolved to adopt the constitution. Amendments to the constitution were referred to a committee of thirteen, on which McHenry served, and after considering them, the committee voted eight to five, McHenry being in the majority, that there be no amendments reported to the convention, but that the constitution be ratified unconditionally without amendment. This advice was accepted and there was no danger that the cause of federalism in Virginia should be injured by the recommendation of such amendments, as McHenry wrote to Washington he had feared. ${ }^{2}$

McHenry's letter, dated April 20, stated that while present appearances in Maryland are flattering, he thinks that the - 1 McHenry came on April 22. See JeJnlfer to Washington April 15, Doc. Hist. Const., iv, 580. Shippen to Jefferson April 22, Doc. Hist. Const., iv, 586 . Washington to Jenifer, Doc. Hist. Const., iv. 596 . Smailwood to President of Congress, Dóc. Hist. Const., iv, 604. Griffin to Madison, Doc. Hist. Const., iv, 609.

2 Bancroft Hist. of Const., 1i, 282. See Nicholas's letter of April 5 to Madison, Doc. Hist. Const., iv, 551 , and of May 9. Doc. Hist. Const., iv, 670. 
adjournment without ratifying the constitution would be equivalent to rejection, both there and in Virginia, and asked Washington how matters were in Virginia and that he give his sentiments, which may be useful. Washington replied as follows :

“Dear Sir,

"Not having sent to the Post Office for several days, your favor of the 20th. Inst. did not get to my hand till last night. I mention this circumstanee as an apology for my not giving it an earlier acknowledgment.

"As you are pleased to ask my opinion of the consequences of an adjournment of your Convention until the meeting of ours, I shall, tho' I have meddled very little in this political controversy - (less perhaps than a man so thoroughly persuaded as I am of the evils \& confusions which will result from the rejection of the proposed Constitution ought to have done) - give it as my sincere and decided opinion, that, a postponement of the question would be Tantamount to the final rejection of it - that the adversaries to the plan consider it in this light, - and for this purpose are using every endeavour to effect it. To advance arguments in support of this opinion is as unnecessary as they would be prolix. They are obvious - and will occur to you upon a moment's reflection.

"Though the period to which the adjournment in New Hampshire was fixed, had no respect to the meeting of the Convention in this State, but was the effect, solely, of its own local circumstances, yet, the opposition here ascribe it wholly to complaisanee towards Virginia - make great use of it - and undertake to pronounce that all the succeeding determinations, preceeding hers, will be similar thereto; - of course that those which are to follow will take the tone from it. Should Maryland fulfil this prognostic, So. Carolina may indeed be stargered, and the prediction with respect to the rejection of the Constitution, be realized; for the assertion, so far as it applies to No. Carolina, I believe is well founded; and it is well known that the opposition in New York would catch at straws, if they would subserve their purpose by it.

"The sentiments of the Western (or Kentucky) districts of this State are not yet brought to my view.

"Independently thereof the majority, so far as the opinions of the delegates are known, or presumed, is in favor of 
the adoption, and this spirit, according to my information, is increasing, - but as the parties, by report, are pretty equally poized, a small matter cast into either scale, may give it the preponderancy. Decision, or indecision then, with you, in my opinion, will determine the fate of the Constitution, and with it, whether peace \& happiness, or discord \& confusion, is to be our lott. The federalists here see \& deprecate the consequences of indecision with you - their opposers, seeing that it is the dernier resort, are using all their endeavours to effect it. Thus stands the matter in my eye. With very great esteem \& regard

\section{"I am Dear Sir \\ "Yr. Most Obedt \& Affect Servt. "Go. WASHINGTON"}

On this letter is endorsed in McHenry's handwriting: "The Maryland convention should not postpone its action on the qu. of Adoption of the new Constitu. until learning the decision of Virginia." 1

Again on May 8, Washington wrote, "I congratulate you on the happy decision of your convention; having no doubt of its weight on those States which are to follow." Ten days later, McHenry answered," "You will have concluded from the address of our minority that the convention was a little embarrassed on the subject of amendments. A very good friend of yours, for whom I have the greatest respect (i. e. Thomas Johnson,) brought us into the difficulty \& we were obliged to leave him to get out. The amendments were intended to injure the cause of federalism in your State \&, had we agreed to them, they were well calculated to effect it." McHenry wrote Madison ${ }^{3}$ on June 17 that he sends "authentic information respecting the present state of the opposition to the Constitution in Pennsylvania," in the shape of a letter from the chief justice and a certificate from the clerk of the general assembly. "I find the same misrepresentations have been played upon the uninformed with you which was practised with us." He hoped soon to hear the "desirable news" that Virginia had adopted the constitution. On July 27, McHenry wrote Washington again: "It is whispered here that some leading characters among you have by no means, dropped

1 Printed in Doc. Hisf. Const., iv, 594. See also Washington to Lincoln May 2, Doc. Hist. Const., iv, 606, and to Madison of same date, Doc. Hist. Const, iv, 607, and to Morris of same date, Doc. Hist. Const., iv, 605 . 2 Doc. Hist. Const., iv, 618.

3 Doc. Hist. Const., iv, 707. 
their resentment to the new constitution, but have determined on some secret plan to suspend the proper organization of the government, or to defeat it altogether. Have you heard of this?" Anti-federalists must be kept out of the legislature. ${ }^{1}$ Four days later, Washington answered ${ }^{2}$ that he feels deeply the great importance of selecting proper members for the first congress and hopes the "Omnipotent Being" will not yield the United States a "prey to anarchy or despotism." Going little from home, he has no news, but fears the Anti-federalists may make combinations to change the constitution. By this time, nine states had ratified and it was certain that the constitution would go into effect. In this connection, it is interesting to note that J. B. Cutting wrote to Jefferson " on July 11, "a superficial examination of the liberal and patriotic convention of Maryland would lead to the thought that the objections of the minority were treated with too much levity and even disdain, but minute scrutiny disproves this. The opposition to a thorough reform of the federal government began in Maryland, even before the Philadelphia convention. So far did Luther Martin proceed in his avowed hostility as even to detail, in the face of decency, before the assembled legislature of Maryland, the petty dialogues and paltry anecdotes of every description that came to his knowledge in conventional committees and private conversations with the respective members of the convention in Philadelphia. So when the convention at Annapolis met, whatever proposition came from Messrs. Chase, Paca, Martin, or Mercer was received with jealousy or disgust and generally rejected by a great majority." 4

1 Doc. Hist. Const., iv, $\$ 21$.

2 Doc. Hist. Const., iv, 827 .

3 Doc. Hist. Const., iv, 770.

4 On October 10,1789 , Thomas Johnson wrote Washington of his own position in the Annapolis convention, that he does not "recollect any' conduct of mine which can be called active to bring about amendments. I was not well pleased at the manner of our breaking up. I thought it to our discredit and should be better pleased with the constitution with some alterations, but I am very far from wishing all that were proposed to take place." As a faithful friend of Washington, he says the United States need his further services. "We cannot, sir, do without you and $I$ and one thousand more can explain to everybody but yourself, why we cannot do without you." On the Maryland ratifying convention, see also Jefferson's letter to Dumas of May 15, Doc. Hist. Const., iv, 614. Carroll to Madison, May 28, Doc. Hist. Const., iv, 636. Brooke to Stuart, Juiy 10. Doc. Hist. Const., iv, 769 . 


\section{H A P T E R VIII}

\section{MEMBER OF THE HOUSE OF DELEGATES}

$\mathrm{N}$ the autumn of $1788, \mathrm{McHenry}$ was nominated with John Coulter by the Federalists of Baltimore town for membership in the house of delegates and was elected, after an exciting campaign. The opposition candidates were Samuel Chase and David McMechen, who issued a broadside on October 3, attacking McHenry for refusing to permit the state eonvention to submit amendments to the federal constitution and for refusing with Coulter to make proper arrangements for voting in the election. 1 The Federalists, on the other hand, scattered handbills, threatening to publish the names of those who voted in the opposition, as enemies to the new federal government. The election occurred from October 6 to 10 and resulted in the election of MeHenry and Coulter, who received 635 and 622 votes respectively, while Chase's vote was only 505 and McMechen's 494 . On the first day of the election, the Federalists paraded through the town, carrying a ship and a pilot boat, with drums beating, fifes playing and colors flying. The "respectable characters," aided by some non-voters, took possession of the polls and all access to the hustings depended upon their pleasure. On the second day, the Anti-Federalists did the same, but were forced from their position by violence.

When the assembly met on November 4 , a petition was presented, praying that the election be declared void for acts of violence committed and threats used by the Federalists to elect their candidates. The Anti-Federalists also complained of a large sum of money subseribed, by one of the successful candidates, to the Federal campaign fund. On November 6, the house voted ${ }^{2}$ to read the petition for a second time on the 14th, and gave notice that the parties should call witnesses. A vote was also passed that the contestants need not

1 Scharf's Baltimore Clty and County, 116.

2 The vote was 31 to 24 . The house voted 35 to 20 (McHenry and Coulter did not vote) that the contestees should not vote on any question concerning the contest. 
specify with certainty and under specific heads the particular facts they meant to prove in support of their petition. ${ }^{1}$ On the 14th, MeHenry and Coulter agreed to bear the expenses of the contest and the hearing began. It continued until the 21st and was then postponed until the $25 \mathrm{th}$, when it seems to have been dropped. ${ }^{2}$ On the 20th, the house voted that Charles Myers was a competent witness, though he had bet a beaver hat that Chase would defeat McHenry and another that McMechen would defeat Coulter. ${ }^{3}$

McHenry seems to have been particularly active during this session. He was chairman of a committee to consider an application for a patent, and served also on committees on divorce and corporations. ${ }^{4}$

The new relations of the state to the federal government demanded attention, and when the assembly had elected John Eager Howard governor, after Thomas Johnson had declined to return to that office, they took up the method of electing congressmen. The committee, to which the matter was referred, recommended that the state be divided into two districts: the Western Shore to elect four members and the Eastern Shore two, but the final decision was to divide the state into six districts, each to choose one member, while the presidential electors were apportioned, five to the Western Shore and three to the Eastern. On December 3, the house resolved to take the oath to support the federal constitution and, on the 8th, they ballotted for United States senators. John Henry, George Gale, Uriah Forrest, and Charles Carroll of Carrollton were nominated and all received forty-one votes, save Carroll who received forty. The house of delegates refused to accept the proposition of the senate and elect one from each shore. On the second ballot, Henry received one more vote and was chosen. On the 10 th, Carroll was elected as the second senator, receiving forty-two votes to thirty-nine for Forrest. On the 19th, the assembly voted to petition congress for amendments to the constitution and, on the 22nd, came the final adjournment.

After Washington's election to the presidency, McHenry

1 The rote on this was 29 to 26 .

2 On December 20,1789 , the house of delegates voted that the costs of this contest, $£ 61.9$, should be paid by the parties.

3 McHenry's opponents published a boardside, claiming that the subscribers to a purse to defend his election, whom they named, were men who had been Tories or who had come from the British Isles and been naturalized since the Revolution, and that some of them had been naturalized during the election.

$4 \mathrm{He}$ has leave of absence on November 7 and 21 . 
wrote him on March 29, inviting him to visit him on his way to New York and saying: "Though I may be among the last in congratulating my dear general, upon his elevation to a rank which few men are born to enjoy and still fewer deserve, yet I am persuaded you will believe that I feel as much sincere joy on the occasion, as those who may have been earlier in their demonstrations. You are now a King under a different name and I am well satisfied that sovereign prerogatives have in no age or country been more honorably obtained, or that at any time will they be more prudently and wisely exercised. This expectation excites in every bosom the finest sensations and I am sure had a secret and powerful influence in disposing the minds of the people to embrace the new constitution. That you may reign long and happy over us and never for a moment cease to be the public favorite is a wish that I can truly say is congenial to my heart. Please visit me enroute to New York." Washington answered as follows:

"Dear Sir,

“Mount Vernon April 1st. 1789.

"With a heart duly impressed with'a sense of the kind invitation you have been pleased to give me to your House, I received your favor of the 29 th. ult, and pray you to accept my thanks for this further testimony of your polite attention to me; but at the same time I offer you this tribute of my gratitude, I must beg your excuse for not complying with the request. For, however pleasing it might be to me, on any other occasion, to render this proof of my; regard for you, I cannot consistently with my ideas of propriety (under the existing circumstances) consent to give so much trouble to a private family. The party that may possibly attend methe crowd that always gathers on novel occasions - and the compliment of visiting (which some may incline to pay a new character) all contribute to render a public house the fittest place for scenes of bustle \& trouble.

"Mrs Washington joins me in compliments \& best wishes, and with sentiments of very great esteem \& regard I remain

"Dear Sir

"Yr. Most Obedient and

Affect Hble Servt.

"Go. Washington."

Quite fittingly we find McHenry at the head of the com- 
mittee which prepared an address to Washington ${ }^{1}$ on April 17. On the 8th, his brother-in-law, John Caldwell, had written him from Philadelphia, asking that McHenry recommend him for a position under the new government, and saying :

"The stage has this moment passed my window from New York. I run to hear the news - am told that Secretary Thomson is on his way to escort his most serene Highness (a title our Ch. judge has fixed on for the President General) but who will always be better known by the name of General Washington - an endearing name - which always recalls the remembrance of his services and is generally received as tantamount to Saviour of his Country. Mr. Thomson comes in the state coach - which crossed the ferry from New York on Monday afternoon - and for the sake of dispatch - will be drawn on by post horses supplied at the different stages - for which arrangements are made. So that in all probability he may be here at this moment - and will no doubt be moved immediately forward - this I hope he will honour with his conveyance - and a moment may lose the opportunity.

"On monday (a passenger in the stage from whom my information comes) tells me - the returns were opened. The votes were for General Washington unanimous - and for John Adams a large majority. I understood a kind of declaration had taken place of the former as President the latter as V. President."

McHenry was ill in June and writing of his recovery to Washington, on the 28th, urged him to keep old Dr. Craik near him, as McHenry has been alarmed by accounts of Washington's illness, and stated that he expects soon to lcave Baltimore for the Sweet Springs with his brother, who engrosses much of his time. Washington answered on July 3, describing his illness, praising Dr. Bard, who had attended him, and expressing hopes that McHenry's trip to the Sweet Springs might be the means of restoring his brother to health. ${ }^{2}$ These hopes were vain, but the excursion to the Sweet Springs gives us some interesting letters to Mrs. McHenry, who remained in Baltimore with an infant daughter, while her hus-

1 Scharf's Chron. of Baltimore, 273.

2 Ford, xi, 401; Sparks, $x, 12$. He wrote also on June 12, probably just before his lilness, asking Washington to visit him and enclosing an address to the president. 
band took with him the son Daniel, who had been ailing. From Staunton, McHenry wrote her on July 17:

"My dear Peggy.

"I am now at Staunton where we arrived yesterday evening. It is about 200 miles from Baltimore and 95 from the Sweet Springs. We shall rest here two days. Here is some company from Virginia on their way to the waters. My brother continues near as he was when I left home, I am in good health and Daniel much better.

"We came from Winchester hither in three days. The first night we slept in Millerstown, at Crookshank's tavern, where we had good beds and tolerable coffee: the second night, at a kind of private house, one David Harned's where we had indifferent beds and bad coffee: but the horses had fine hay and good oats. The road in some places is rocky, mountainous, and dreadfully rugged; but in general very good. The second day we drove 40 miles and could have easily driven fifty. When you get within a few miles of Staunton the country rises into high mountains. Staunton is placed in the midst of a body of them.

"This town which contains about 120 houses (all framed except a few of stone) is remarkable for two things. 1st, a tavern, kept by one Hiershell, equal in many respects to $\mathrm{Mr}$. Grant's, where we lodge. It is chiefly of stone, two story high, and 85 feet front. 2dly. Every house has more or less of a garden, and every garden a small stream of water running through it, which has its course in one of the neighbouring mountains. The air, in addition to this charming circumstance, seems fine and highly salubrious; not notwithstanding all this, I would not choose it for my residence. I am in love with other scenes, and other prospects: and that I suppose is enough to prejudice me against, the mountains, groves, vallies, and waters of Staunton, though they frolic in abundance of bewitching forms.

"I thought you would be glad to learn thus much of our progress, and Mrs. Shield's, who is on her return from Kentucke to Philadelphia, affords me an opportunity to Winchester: whence this will be forwarded to Alexandria and thence by the regular mail to Baltimore.

"Adieu my dear Peggy, the keeper and dispenser of all my affections" 
Six days later another letter was sent on Thursday, July 23, 1789, from "Warm Springs - Lewis's house" :

"My dear Peggy.

"My last to you was from Staunton which I put into the hands of Col. Knox who was on his way to Baltimore. The day after we recommenced our journey to this place. The roads very bad: the entertainment tolerable. Venison very common and very good. the last four miles of the road thither is over the highest mountain we have yet crossed. Long before we gained the most elevated part of it where the road runs, which is a considerable distance from its summit, we had a very interesting view of the subjacent world. Far below us, for an immense extent, lay an infinity of mountains, each of them an Alp; with corresponding, deep, and irriguous vallies; the whole forming a prospect astonishingly great and sublime. The sun shone upon the rocks, mountains, and trees, which affords a variety of intermingled shades and rendered the scenery more picturesque and animated. The descent in some places is rather rapid, and somewhat dangerous, owing to the badness of the road, which is much cut, shelving, and only wide enough for one carriage.

"Notwithstanding it was hardly possible to deviate from the right road, yet from the length of time it took us to travel the last six miles, we were almost certain we had some how or other got out of our course. About six miles from the springs we had an opportunity of inquiring the distance which we were informed of, and also that the road was very good. By our calculation we had travelled nine miles, \& most of it over bad road. At length, however, late in the evening, we reached the bottom of the mountain, and were agreeably surprised to find ourselves at the warm springs.

"These springs are a great curiosity. The water is about blood hot (96 degrees) and bathing is a very great luxury. It is said to contain sulphur. A large quantity of air is continually rising from the bottom in bubbles and the vapor has a sulphurous smell. The bath is an octagonal inclosure of stone, about eight or ten feet high, open at top, and 132 feet in circumference. Its depth between three and four feet. The body of water it discharges forms a stream capable of turning the largest mill. Trees flourish round the spring, the cattle drink of its water, and it fertilizes some excellent medow ground through which it runs.

"We bath in it twice a day. The first time Daniel went 
into it very reluctantly; and now he leaves it with as much reluctance, and goes to it with pleasure. I think it has been serviceable to his complaint; but my brother has received no seeming benefit from it. We propose two days longer stay, and then try the Sweet Springs, which is forty three miles from this place.

"The company here is a Mrs. Dunbar of this state, with her daughter a Mrs. Banister, a young handsome wealthy widow, and a Mr. Skipwith, a suitor I imagine of the latter.

"My brother has not been so well yesterday and to-day as heretofore. He presents his respects to you and Miss Caldwell. Adieu my dear Peggy.

"Yours affectionately "JAMES McHenry"

From the Warm Springs the party went on to the Sweet Springs, where they remained several weeks and whence McHenry wrote his wife on September 7, 1789 :

"My dear Peggy.

"Mrs. Perry died on sunday morning, and was intered yesterday afternoon. She was thonght to be somewhat better on her arrival; but a few days shewed the fallacy of hopes founded on a strong expectation of the benefit from the waters. Perhaps the experiment was too long delayed; or perhaps it would not at any time have proved successful. Why are we so anxious for life? In one point of view it hardly seems to be worth the trouble we take to preserve it. Give to man the most extensive acquaintance and exalted virtues, yet how seldom does he leave behind him a friend to lament his loss or remember him when he is forgotten by the rest of the world.

"The burying ground is at a little distance from the springs, on the summit of a hill which is covered with large and shady oaks. I counted eleven graves, some inclosed with a kind of pailing, and the rest with large logs of timber, said to be intended as a security against wolves. I could not contemplate the remains of the dead quietly resting in these rude impalements withont a few mournful emotions, arising from the reflection that all of them must have closed the last hours of life, far from any domestic comforts, and, most of them, perhaps, without the last kind offices of kindred attention. There is neither stone or monumental inscription to be seen to tell any thing respecting the dead. 
"When you leave this melancholly ground and get about half way down the hill you have rather an agreeable prospect, made up of intermingled huts and trees, The Sweet Springs, a mess house, a dwelling house, and a corn field lay below you, while the mountains rise amphitheatre like in a pleasing manner, chiefly covered with trees, but without either house, cultivated spot or plantation to relieve the eye.

"To-morrow we propose setting out, notwithstanding my brother's state of health is but little different from what it was when I last wrote you. The fear of being locked up in this place during the winter is one motive which puts him in motion: and the convenience of the stage waggon Mr. Perry came in another. Mr. Perry is to ride with me, and Jack can lay at full length in the waggon. We may not however set out to-morrow as there are strong symptoms of bad weather. Should it rain we shall remain here till it settles. It will be a long and tedious journey in all probability.

"Adieu my dear Peggy; and may God grant us a happy meeting."

During the return journey McHenry wrote from Staunton on the 26th of September, 1789.

"My dear Peggy.

"Mrs. Pratt is to leave this town to-morrow, which reminds me of my promise to give you some account of the Falling Springs.

"I went from Mr. Morris's on the 12 Sept. to visit this remarkable curiosity. It is in Augusta county about six miles south of Morris's. After riding about four miles we entered the Falling Spring valley where we were entertained with innumerable little water falls till we came in view of the object of our visit.

"I cannot give you an adequate idea of this great work of nature. To describe it correctly one must see it more than once, and be provided with an apparatus to ascertain heights and distances. Mr. Jefferson ${ }^{1}$ estimates the altitude of the rock from which the water falls at two hundred feet. It did not strike me as so high by fifty feet. He speaks also as if the water fell only from one part of the rock, whereas it precipitates from five different places, each fall being distinct from, and at a considerable distance from the other.

"We took our stand between the first and second cat-

1 See Jefferson's Notes on Virginla, Query 5 (ed. 1801, p. 30). 
aract. The former hurried over the lowest part of the rock, and dashed down an irregular and shelving surface with considerable noise and impetuosity : but though composed of the largest sheet of water it was by no means the most striking. The second certainly engaged more of our attention. It precipitated itself in the air about one hundred and fifty feet above us from the loftiest part of an almost perpendicular rock, in five or six spouts, which suddenly uniting formed a thin broad sheet of water that descended in a beautiful manner, till it reached half way down, when it dashed against the smooth surface of the rock, and separated into millions of drops that fell to the bottom in a kind of close heavy rain. This is a most lively an interesting spectacle. We contemplated it with admiration and thought nature had finished her work, when moving on a little further round a bend of the rock, we discovered three other cascades, the most remote of which was just visible through the intervening rocks and trees.

"This exhibition far exceeded the first in variety and grandieur of expression. I do not think either of these falls discharged more water than any of those we had just turned from: but their different sheets were so disposed as to shew each other to more advantage; this part of the mountain too was more diversified, and the shrouded cataract almost concealed by huge pieces of rock and fallen trees accumulated and congregated in a kind of horrid wildness; whilst the two mountains which formed the valley approaching each other seemed to close the scene by forbidding further investigation.

"There we remained for some time, alternately contemplating the stupendous descent of the water, \& its various appearances, from its first shewing itself over the mountain till lost among the fragments of rocks beneath. The whole, with the face of the valley, formed a most animated and interesting scene; and yet the father of our guide, Mr. Morris, has resided twenty five years within six miles of the falls, has been above a hundred times within half a mile of them, without having seen them. I asked him on my return how he would like to see this circumstance mentioned in a book. I should be indifferent about it, he replied, as it could only mean that I was a person of litle curiosity.

"The spring that supplies these eataracts rises about 3/4 of a mile from the summit of the mountain. The land through which it runs belongs to a Major Massie whom I since met at 
the warm springs. This gentleman told me that twenty years ago Dr. Bland had forced a kind of promise from him to throw the several branches of the stream into one, for the purpose of increasing the cataract. In my opinion it is more interesting as it is; and Major Massie being of the same opinion has thought proper to defer the execution of his promise, which he says was only given to get rid of the Doctor's importunity.

"My brother is better. We shall leave this in all probability on Wednesday next. We have new wheels to get to our carriage and my brother wants a little more strength to enable him to make the next hundred miles. Daniel is well, and your affectionate

\section{"JAMES McHenry"}

In the autumn, McHenry was re-elected to the house of delegates, Samuel Sterrett being associated with him. Shortly after the election, McHenry wrote Hamilton, ${ }^{1}$ stating that he feared the majority of the house would be Anti-Federalist. He rejoiced in everything that could add to Hamilton's fame or fortune and congratulated him on his appointment as secretary of the treasury: "Your office is vastly important and you are worthy of it and, what is more, equal to its duties, but, at the same time, it is extremely hazardous." McHenry still had thoughts of a diplomatic career and added: "I asked appointments for some honest but poor federals of this place and the President has been very attentive to my recommendations. I asked nothing for myself; because, in fact, I am very easy in my circumstances. Still, however, I am not wholly lost to ambition and would have no objections to a situation, where I might indulge and improve, at the same time, my literary propensities, with perhaps some advantages to the public. Will you, therefore, be good enough to feel (if a resident or even chargé des affaires is to be appointed to London or France) whether the President has thought of me or would, in such a case, nominate me. I wish you to do this for me, as a thing springing wholly from yourself and to write me freely on the subject at some convenient moment."

On November 14, McHenry wrote Washington from Annapolis: "You have created a new fountain of blessings. In your nominations and appointments, you have had respect to want and wretchedness, where united with worth and capacity, and have thereby drawn upon you more prayers and

1 October 27, letter partly printed in Hamilton's Works, v, 444. 
gratitude than has ever fallen to the lot of any dead or living sovereign, prince, or first magistrate whatever." Washington had asked McHenry to secure an acceptance of office from Judge R. H. Harrison. Harrison returned the commission, because he could not keep it longer, but wished more time to consider the offer and would probably accept, if his brotherin-law should die. The value of Harrison, "his goodness of heart, and unalterable attachment" to Washington are praised by McHenry.

On November 30 , Washington answered the letter and returned the commission, hoping that Harrison would accept. ${ }^{1}$ Thomas Johnson had declined the appointment of district judge for Maryland and Washington does not wish to receive another declination. He thinks of appointing Alexander Contee Hanson and asks MeHenry to ascertain whether he would accept. Hanson was chancellor at the time and Washington was in doubt whether he might prefer his present position. If Hanson will not accept, William Paca's name has been thought of, "althongh his sentiments have not been altogether in favor of the General Government and a little adverse on the score of Paper Emissions." Gustavus Scott and Robert Smith have also been mentioned. The latter seemed to Washington to be too young.

On December 10, MeHenry replied that he found Hanson preferred the chancellorship to the judgeship, but that Paca would accept the place. He will "carry much respectability and legal dignity into the office." "He will make every exertion in his power to execute the trust in the most unexceptionable manner. I believe also that the appointment will be highly gratifying to him and, I think, it may have good political consequences."' 2

Washington took McHenry's advice, appointed Paca and thus the services of one of the state's most distinguished sons were secured for the federal government.

McHenry was then kept very busy at Annapolis and longed "exceedingly to get back to my little garden and little wife." " 3 The house of delegates was "not very federal" but he thought a joint address would be sent to the president. Among the many committees on which McHenry served at this session was one to consider amendments to the United States constitution and another to prepare an address of congratu-

1 Ford, xi, 447 ; Sparks, x, 55.

2 Ford, xi, 449 .

$3 \mathrm{He}$ was absent for a few days from November 30. 
lation to the president. The address was adopted on December 20. It is interesting to note that he voted for bills to provide for the gradual manumission of slaves and for the admission of Quakers to office, by permitting affirmation to be substituted for oath.

On May 7, 1790, MeHenry's brother John died, “after a long and painful illness, which he bore," according to the Maryland Journal, "with uneommon patience and fortitude, deeply mourned and regretted by his relatives, friends and fellow citizens." He left an only son, an illegitimate child, named John, ${ }^{1}$ who was brought up in James MeHenry's family, at the request of his brother and became a distinguished lawyer. He edited, with Harris, the first series of Maryland Law Reports, wrote a text book on ejeetments and was secretary of legation at the Hague in 1800 . He married Miss Martha Hall of Harford eounty in 1813 and later removed to Allegany county, where he died without issue in 1856.

The death of his brother saddened McHenry and its effect is to be seen in a letter he wrote Washington on August 30 . "My own dear Sir.

"I am much to blame. I have neither congratulated you on your reeovery from a dangerous illness nor yet sympathised with you in those many and perplexed labors in which you have been involved during the late important session of Congress. I will tell you the truth. Every sorrow and eonsideration whatever has been swallowed up, or diminished, in the depth of affliction I have felt on the loss of my brother. You perhaps have heard that our friendship for each other was uncommon and that I am still far from reeoneiled to this sad shipwreck of my tenderest affeetions. I thought however that I ought to venture, before seeing you, to apologise for not mingling my congratulations with the many you must have received, and request your forgiveness notwithstanding my seeming negleet. I wanted besides an opportunity to inform you of a revolution in my sentiments that in all probability will govern the remainder of my days.

"Some years since I entertained an aversion to public life, and was only an humble actor in it these two years from the persuasions of the deceased. This ehange has been induced by several causes. I had met with some applause in a

$1 \mathrm{McH}$ enry left him a house in Baltimore in lieu of a payment of $\mathbf{1 0 0 0}$ currency which his brother had asked him to pay. 
few instances, but never found it compensated for the sacrifices I submitted to in the discharge of my duty. I grew disgusted too at perceiving, as I thought, many of those men, who called themselves servants of the people, secretly devoted to the promotion of their own purposes and yet continued in the public service by the people.

"I thought also that I beheld him who profaned the name of patriotism and country gain by the profanation and him, who was directed by the most laudable motives, the frequent subject of abuse on suspicion. These discoveries or supposed discoveries were so repulsive as not to be counteracted by the conduct of the few whom I believe act from most pure and honorable principles, and whom I saw boldly risking their all for the bencfit of others. I hence and henceforth conceived a settled disgust to every thing out of the line of private life, and cherished a concealed contempt for almost every thing save friendship. Such was the situation of my opinions for some years before my brothers death, an event which has still further confirmed my disrelish of public life and the vanity of human enjoyments. I have now no longer a brother to gratify.

"I have estimated the value of public applause, and well know that neither talents nor merits insure it with posterity. The one I do not want, the other I have not talents to attain. I am independent in my circumstances. I have retired to the vicinity of the Town a little spot from which $\mathrm{I}$ can see its smoke and hear its noise without being offended with either. I resist all solicitations to venture upon the ocean of politics, and intend to devote the remainder of my time to my own ease, to devotion, the recollections of a dear brother, the happiness of a little family and literary amusements. In this retirement, I feel one misfortune only; but that I am satisfied will always accompany me, I feel too sensibly my loss. Will you, after this explanation of $\mathrm{my} \sin$ of omission, condescend to give a sanction to my sorrow and my retreat, and visit a man whose professions have ever fallen short of his love and affection; a man who regards and respects you, not for your high station but your true patriotism and rare virtues. Mrs. Washington has lodged a promise with Mrs. McHenry with which I am often reminded. My house is only a mile from Grant's Tavern and in your route. So far it can be productive of no delay. I engage, moreover, that you shall not be troubled with company. The prophet Elisha deigned to favor a Shun- 
amitish stranger with his company, as often as he had occasion to pass by her house, and will not my ever respected general find it convenient to stay one night on his way to Mount Vernon with his sincere and devoted humble friend

"JAMES MCHENRY.

"To the President of the

United States."

McHenry's benevolence led him to give his countenance to the negro mathematician, Benjamin Banneker, and to write a commendatory letter, on August 20, 1791, to the publishers of the Almanac for 1792, which Banneker prepared. This letter was printed in the Almanac; gave a brief sketch of Banneker with especial reference to his mathematical powers, and concluded with the following sentences, noteworthy as showing McHenry's wide sympathies: ${ }^{1}$ " I consider this negro as a fresh proof that the powers of the mind are disconnected with the color of the skin, or, in other words, a striking contradiction to Mr. Hume's doctrine, that 'the negroes are naturally inferior to the whites, and unsusceptible of attainments in arts and sciences.' In every civilized country, we shall find thousands of whites liberally educated and who have enjoyed greater opportunities for instruction than this negro, his inferiors in those intellectual acquirements and capacities that form the most characteristic features in the human race.

"But the system that would assign to these degraded blacks an origin different from the whites, if it is not ready to be deserted by philosophers, must be relinquished as similar instances multiply; and that such must frequently happen, cannot well be doubted, should no check impede the progress of humanity, which, meliorating the conditions of slavery, necessarily leads to its final extinction. Let, however, the issue be what it will, I cannot but wish on this occasion to see the public patronage keep pace with my black friend's merit."

1 The letter is reprinted in Carey's American Museum, xii, 186, and in Tyson's Banneker, 48. 


\section{CHA P T E R IX}

\section{A YEAR OF RETIREMENT}

$M^{\mathrm{c}}$

CHENRY'S retirement from office lasted only a year after which he was chosen again as a member of the state senate. During this year of withdrawal from public life, McHenry was actively engaged in mercantile business, as is shown by the following letters from Jefferson to him.

\section{"Dear Sir}

“Philadelphia Feb. 5. 1791.

"An extraordinary press of business, ever since the meeting of Congress, has obliged me to suspend all my correspondences, so that it is not till now that I am able to take them up, \& among the first your favor of Dec. 14. on the subject of that I am obliged to ask you to name some person at Paris who may, as your agent, attend to all the details of sollicitation, as it would be impossible for MIr Short to do that, and indeed contrary to a fixed rule which has been established of necessity to prevent his being used as the factor of individuals which would be more than he could do, \& lead him often to that would be improper. I will write to him to support your interposition at proper occasions, as far as shall be right, and in this he will move in concert with M. de la Fayette. as soon as you shall advise me to whom to address your papers, I will forward them through Mr Short \& with a letter to him in the mean time they remain in my hands. I have the honor to be with great esteem Dr Sir

"Your most obedt. humble servt

"TH: JEFFERSON

"P. S. no time is lost as yet

he being at Amsterdam."

"Philadelphia Mar. 28. 1791.

"Dear Sir

"Having sent your letters to Mr Short with a desire that he will, as far as is right, patronize the application which shall 
be made to the minister on your demand, instead of destroying your first letter to Messrs Le Couteulx, I have thought it better to return it to you, in proof that your desires have been complied with. a murder of some friendly Indians a little beyond Fort Pitt is likely to defeat our efforts to make a general peace \& to render the combination in war against us more extensive. this was done by a party of Virginians within the limits of Pennsylvania, the only news from Europe interesting to us is that the Brit. Parl. is about to give free storage to American wheat carried to Engld. in British bottoms for re-exportation - in this case we must make British bottoms lading with wheat, pay that storage here, in the form of a duty, \& give it to American bottoms lading with the same article, in order not only to keep our vessels on a par as to transportation of our own produce, but to shift the meditated advantage into their scale, at least so say $I$.

"I am with very great esteem Dear Sir "Your most obedt. humble servt.

"THо : JeFFERSON."

On private matters, McHenry writes on January 3, 1791, to Hamilton ${ }^{1}$ of whose wife he hears that she "has as much merit as your treasurer, as you have as treasurer of the wealth of the United States." McHenry states that he approves of the plan for the United States Bank and adds: "You may think I have neglected you, from my long silence, but I can assure you $I$ have never forgot you. Having withdrawn myself from everything of a public nature; this has led me to endeavor to reduce my pleasures as much as possible to a small compass and thus to neglect many correspondents, for whom I entertain the liveliest affection.

"That I love and esteem you, I know you will believe, without my repeating it. Your career as yet has been glorious. I wish sincerely that nothing adverse may interrupt it."

On April 26, Hamilton wrote McHenry asking him to ascertain whether General Otho Holland Williams ${ }^{2}$ would accept the position of collector of the port of Baltimore.

MeHenry answered on May 3, that he has seen General Williams.

1 Hamilton's Works, edited by J. C. Hamilton, v, 462

2 March 5, 1792, Williams wrote Hamilton on an Indian war and the Seneca chiefs and said he had long been fll. Williams finally accepted the collectorship. 
"You know his ambitious cast and that he thinks he could be more serviceable at the head of a great department than collector of a district. I mentioned the death of the comptroller and the probability, in my opinion, that the President, from the knowledge he had of the present auditor's habits, experienee, and capacities for business, would fix upon him for a successor, in which case the auditorship, which was a very important office, would become vacant. I observed on the advantages of a residence at the seat of Congress, if he still inclined to mount higher, that he knew your power and disposition, and said, I would take upon myself to make the necessary suggestions. The idea of the auditor's office being a step to a still more desirable one had its weight, but he, finally, declined, alledging his ill state of health and the recent death of a brother in law, Col. Stull, which has devolved upon him the eare of his children and estate. In short, he was not to be induced to be auditor, though I thought, could I have said comptroller, he might, notwithstanding his present state of health would unfit him for discharging the duties of the other. I then called on Mr. Wm. Smith, who with his show of talents will make a much better auditor. He will have as little to learn as the General, is as systematie, a more correct and perfect accountant, of great respectability and longer standing in society. I found also here that the comptrollership was a more darling object. My first conversation was yesterday and it was not till about one half an hour ago $\mathrm{I}$ got him to consent to use my discretion, so you may use yours. I was obliged to intimate that, from the opinion you had of him, I could entertain no doubt but his appointment would be certain, unless the President got entangled to the Southward. You judged right. Nay, should even what I once thought of take place and my present temper of mind continue, I would remain where $\mathrm{I}$ am. My mind in the loss of a brother has received a severe shock. My wife, like yours, is every thing that is kind, good, and excellent and was there only one man more in the world I should be the happiest man in it. Adieu and believe me yours most sincerely and most affectionately."

In the autumn, McHenry wrote Hamilton again. The letter is dated on October 15 , and states that

"The electors of the Senate of Maryland have ehosen me one of the Senate of our State legislature and many of my friends are urgent that I should aceept, as yet I have given 
no answer. If you still entertain the project you mentioned to me, when in Philadelphia, it may somewhat influence my determination. Perhaps the complexion of several European powers, as it respects France and the claims for succours she may bring forward under the 11th. article of the treaty of alliance in case of being attacked, may render the presence of a ministerial character necessary at the Hague, as a spot which can afford a tolerable view of the parties likely to be concerned. Perhaps too, it is an eligible situation to forward our commerce with the Northern nations, as well as England, at least it would seem a position which might enable a qualified person to watch the course of trade and improve favorable conjunctions. But if the chicf object would be your loans or financial operations, I think I could give you entire satisfaction. I have been led thus far into a change of sentiment since we spoke together on this subject by an alteration in my health, which I flatter myself would be benefited by the voyage and the new materials which the employment would furnish my mind. Should things take the turn you wish, you will readily conceive that I ought to be allowed sometime for preparations, as I must take my family with me. But whether here or elsewhere, in sickness or health, I shall always, my dear Hamilton, be your sincere friend."

To this letter Hamilton answered on November 2, as follows :

"My Dr. Sir

"Your letter of the 15. of October came duly to hand and an answer has only been delayed through extreme hurry. My views on the point you mentioned cannot have changed and I am glad to know how you stand. All that confidence or Attachment on my part could dictate will be employed. But nothing is certain And nothing ought to be suspended on the event.

"Indeed I cannot perceive how the one thing ought to interfere with the other. A change of position upon an unforseen circumstance is as common in politics as in war.

"Yrs Affect. \& sincerely

"A. Hamilton."

The diplomatic project having failed, McHenry accepted the senatorship to which he had been elected. The session of assembly began on the 7th of November and he appeared and qualified on the 15 th. 

second appearance in the Maryland senate. ${ }^{1}$ The attorney general had instituted proceedings against him, as survivor of the firm of John and James McHenry, on account of a contract made by them with the late intendant, Jenifer, for the purchase of final settlements of revolutionary pay. The McHenrys sold the certificates and there was some deficiency in their returns, for which suit was brought. On December 29, the assembly directed the attorney general to suspend proceedings until the end of the next session. In 1792, on November 26, MeHenry's petition for relief was finally refused.

Shortly after taking his seat, McHenry wrote Hamilton, on November 19:

"Since taking my seat in the Senate, which I have done more in conformity with your opinion than my own, I have used the opportunity it affords of conversing with Mr. Wm. Perry, the gentleman I mentioned to you when in Philadelphia as a person well qualified for auditor and have discovered that, had he been appointed, he would not have refused. I have two reasons for telling you this now. That you may keep him in mind, should such a vacancy occur, as one that may be fully relied on. That you may also know that, besides his being independent or wealthy, he exerted his whole influence to establish our government, continues to exert it for its daily preservation, and possesses a large share of public confidence, especially on the Eastern Shore where he resides and for which he is senator, circumstances which might render him peculiarly proper for an office in the excise, in case of a new arrangement of the system. An opinion prevails in our House of Delegates that our constitution wants mending and Mercer, Pinkney, and Craik are to lead in the business. They

$1 \mathrm{He}$ was absent from November 29 to December 10, 1791. 
do not venture, I mean the two first, for the last is rather federal to expose their true reason, though they have not been able to conceal it. I cannot tell how the project may terminate, but I like our constitution as it stands and trust the people, having heretofore found it a good one, will not easily be brought to any radical alterations."

At the session of $1791,{ }^{1}$ McHenry pushed an unsuccessful projeet that Maryland should buy a house for Lafayette in Washington City. It is impossible to trace his activity, however, at this session, or at a short one from April 2 to 6, 1792 .

On July 17, MeHenry wrote Washington asking him to stop in Baltimore and aecept a dinner from the citizens. The president replied on August 13.

"Dear Sir,

"Your letter of the 17th. of July came duly to hand. I could, with pleasure spend a day in Baltimore on my return to Philadelphia, if time \& circumstanees would permit; but it is not for me at this moment to say whether either would suit me; besides I shall confess to you candidly, I have no relish for formal \& ceremonious engagements, and only give into them when they cannot be avoided - among other reasons because it oftentimes - if not always - proves inconvenient to some of the party bestowing, if it is not to the party receiving the compliment of a public dinner - and is a tax which I am as unwilling to impose as many are to pay, if false delicacy would allow them to express their real sentiments.

"If it should so happen that I can, conveniently, spend a day in Baltimore, as I return, it would give me pleasure to dine with yourself \& a few other friends in a social way; - \& on this footing let the matter rest, as no previous notice of my coming is necessary in that case.

"Having begun a letter to you, I will add something to it of a public nature

"Mr. Potts, the District Attorney of Maryland has resigned that office. Who, in general estimation, is best qualified to fill it?

"Mr. Robert Smith has been spoken of - Mr. Hollingsworth has been mentioned - and Mr. Tilghman and Mr. Ham-

1 He favored in principle the publication of the proceedings of the senate though he voted against a bill to that effect sent from the house of delegates. 
mond have also been thought of, but the two last living on the Eastern shore, and Baltimore being the theatre for the Courts, it might be inconvenient to both those Gentlemen to attend them; and the appointment no inducement to their removal.

"Which then of the other two would be most eligable? Would Mr. Smith, if the preference is given to him, accept? - or is there any other person more prominently qualified than either of the Gentlemen I have mentioned?

"Your sentiments freely given, on these enquiries will much oblige

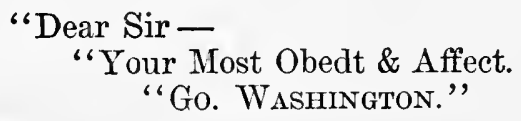

MeHenry's reply was sent on the 16th. Hollingshead, he thought, was more of a wit and not less of a lawyer than Smith. Marriage has corrected some of his levities and study will make him more able than Smith; but the latter is more steady, cautious, industrious, and painstaking, and has a character of perhaps greater probity in the profession. McHenry wished Craik would settle in Baltimore. Tilghman and Hammond are both good. The former will sooner yield to transient circumstances than the latter. Luther Martin is the best qualified man in the state; but, through his polities, is the last person who merits the appointment. If Washington sees Paca or Colonel Lloyd, who possesses "vast property," McHenry wishes he would speak of the necessity of the leading men removing misapprehensions eoncerning the laws. This "may lead Paca from Mercer, who is, if possible, more desperately mischievous, than when the open, decided, and declared enemy of the constitution."

Washington answered this letter as follows:

"Dear Sir,

"Mount Vernon Augt. 31st. 1792

"The characters given of Messrs. Smith \& Hollingsworth by you, comports very much with those I have received from others, and therefore of the two, the preference is given to the former. But as neither stand upon such high ground as $\mathrm{Mr}$. Tilghman or Mr. Hammond, and as it is my duty as well as inclination to fill offices with the most suitable characters, I 
pray you to make all the indirect enquiry you can whether either of the last named Gentlemen would accept; and, as the nature of the case seems to require, would make Baltimore the place of Residence.

"If the result is unfavourable, be so good as to cause the enclosed to be delivered. This case requires a little deli. cacy in the management and $I$ am persuaded it will receive it from you

"I am with sincere esteem and regard -

"Your obed. \& affect

"G. WASHINGTON

"James MicHenry Esqr.

"Baltimore

"The Postmr at that place, will please to cause the delivery of this letter President U. S."

The matter was not then settled, however, and Washington wrote again on September 21:

"Dear Sir,

"Fearing some accident may have prevented my last (cnclosing a letter for Mr. Robt. Smith) from reaching your hands, I take the liberty of giving you the trouble to receive this, requesting to be informed if this be the fact - and if not, what has been the result of your enquiries in the business committed to you

"I have had many applications in favor of Mr. Hollingsworth as a fit character for the attorney, and lately, one from the District Judge in his behalf. No answer has been given to any of them awaiting to hear from you first.

"With sincere esteem \& regard

"I am - Dear Sir

"Yr. affect. \& obedt servt

"G. WASHINGTON"

On the 25th, McHenry wrote that he had been very ill, that Hammond had decided not to remove to Baltimore, and that the merchants of the city are still anxious to tender Washington a banquet.

Washington writes again on October 3 :

"Dear Sir

"If this letter shall have reached your hands before that which I addressed to Mr. Robt. Smith (under cover to you) 
has passed from them, I pray you to retain it until you see me, which will be, I expect, about the middle of next week on my return to Philadelphia (if I am not detained by the convalescent state of two of my servants) - or, if that should happen, till you hear further from,

$$
\begin{aligned}
& \text { "Dear Sir, } \\
& \text { "Your obedt. \& affect. } \\
& \text { "Go WASHINGTON" }
\end{aligned}
$$

The day after Washington's letter, McHenry writes him that Tilghman is considering whether he will settle in Baltimore. McHenry wishes more Federal lawyers would do so, as Hollingshead is neither one nor the other.

In the congressional election of 1792, McHenry took a warm interest. On the Eastern Shore, in the upper district, the Federalists of Talbot and Caroline favored William Perry ${ }^{1}$ of Niles River. He declined and William Hindman of Queen Anne's was nominated. Mercer was thought by the Federalists to be at the bottom of Tilghman's ${ }^{2}$ running in opposition, after he had said he would not run against Perry or Hindman. Perry wrote McHenry on August 4, that the Anti-Federalists were closely linked together and kept up regular correspondence throughout the state, asserting that they are friends of the federal constitution, but opposed to Hamilton. They thus wound the constitution through the secretary. Perry supports both constitution and the secretary and after much travel in Talbot and Caroline thinks Hindman's election secure.

On August 16, McHenry wrote Hamilton of state affairs in the approaching congressional election:

"I mentioned Mr. Carroll ${ }^{3}$ as proper to be brought forward to oppose a man whom I suspect the antifederal interest will unite in supporting, in case of an opportunity. I calculate that Mr. Carroll will not succeed, but it may produce more votes in this State for some man who ought. I mean also that it should operate to detach Mr. Carroll from Mr. Jefferson, whose polities have in some instances infected him. In all this, however, you will understand, should it be an

\footnotetext{
1 Perry was Hindman's brother-in-law and had all but one of the electoral votes in 1791 when chosen to the senate of Maryland. See George Gale's letter to Hamllton, December 20,1792 .

2 On November 18, McHenry wrote Hamilton that Tilghman was connected with good Federalists yet was a disciple of Mercer. The contest became a family affair and the heavlest welght fell on Perry. 3 Charies Carroll of Carrollton.
} 
eligible line of politics, that I do not mean to be an actor. 'The interest you feel in it, more than any other consideration, would induce me to take a little trouble. I still think Mercer will carry his election. I have been with Bishop Carroll, whose friendship and intimacy I enjoy. He has much greater control over the minds of the German Catholics than Charles and I believe that description of men will vote for Campbell. Col. Smith has entered for this district. Mr. Ridgely, you know, also stands. Ridgely, I am told, is a friend to a further assumption [i. e., of state debts]. Samuel Smith is not. He is however a good federalist. As a merchant, he will dislike any increase of duties on dry goods. He is, however, concerned in shipping in a sugar house and distillery and supplies Williams \& Co., contractors, with dry goods for the Indian trade. Besides it would give him great pleasure to get Col. Hall into office, Mr. Robert Snith his brother, a judge, and Robert's father in law, an office of $£ 1500$ a year. On the other hand, he is largely in the iron works, a man of great wealth, without skill in public affairs and from habits closely connected with Chase, whom he would wish to see noticed. Mr. Jefferson, I suspect, will say in reply to his having been against the constitution in France, that you were for monarchy in the convention and will take some of the features of your systems which correspond the nearest with the fiscal systems of England, as a commentary upon your principles. The exposition which has been given was wanted. God bless and preserve you.'"

McHenry wrote again on Sunday, September 30, stating that he should support Adams and resist the New York project to set him aside for another.

The campaign against Mercer ${ }^{1}$ was brisk and the elec-

1 Of Mercer's conduct William Bayly wrote Hamilton on November 4, that Mercer had said at Upper Marlborough that he went to Hamilton's office to get money due him and the clerks would not pay him. On his return he met Hamliton who said he would pay the money, if Mercer would vote for assumption of state debts. When asked whether Hamilton had offered him money he exclalmed, "Yes, by God, he had." Walter Bowle sald, "Hamilton was jocular," and Bayly put the question to Mercer, "Was Hamilton serious or jesting?" to which Mercer responded that he had a right to take it either way. About this time McHenry wrote Hamilton: "Knowing that I was apt to lose letters out of my pocket and recollecting that you were a little subject to lose them by not putting them into yours, I thought it best that we should burn them," therefore he can only say that, in his letter to Hamilton, he opposed Mercer for his political principles, but was not influenced thereto by Hamilton. McHenry has written an article in behalf of Adams for Goddard's paner, and has signed the article Consistent Federallst. It will appear next Tuesday. 
tion was to be held from Monday until Thursday. MeHenry had written letters for Goddard's paper, the Maryland Journal, signed Valerius, while he was "under a depression of spirits and great debility," and had employed Major Hopkins of Anne Arundel county, who was under obligations to him, to eirculate handbills with popular eharges against Mercer, "ffixing on him some falsehoods." Mereer's defeat was still possible. Ross, whose ability is not equal to his honesty and good intention, was in Baltimore to get a reply published for the polls, in answer to Mercer, who eireulated a report that the president wished him elected. Washington denied this and "the lie has lodged where it ought."

MeHenry had been ill and now only gets around in his garden. General Otho Holland Williams was also very ill. If he die, MeHenry asks that John Purviance, the naval officer of the port, may sueceed him, ${ }^{1}$ as Purviance is the "natural heir" of the position, is "one of the first merchants in this town, and is qualified to discharge its duties." He has "never shrunk from the right cause" and has a "very numerous and young family to maintain." If Purviance is promoted, MeHenry asks that Hamilton serve him by appointing George Salmon in Purviance's place. The federal government ean procure no man better qualified than Salmon. "He is popular, a man of honor, and a respected judge in our criminal and orphan's court." If neither appointment is made, MeHenry asks that he be informed, before any other person is chosen. The office "nets perhaps better than $£ 2000$ " a year, possesses "vast influence, and ought not to be given lightly." The letter eloses with "Farewell, God bless my dear Hamilton."

On October 4, MeHenry wrote Washington that Colonel Smith would probably defeat Ridgely in the Baltimore district, but that the vote was small. It was the last day of the eleetion and only one-half the town and not a fourth of the county had voted.

Later in the month, ${ }^{2}$ McHenry wrote Hamilton that he had been confined to his bed with fever for seventeen days, and had sat up for the first time the day before. "If I should

$1 \mathrm{On}$ August 27, 1793, Samuel Smith wrote Hamilton that Daniel Delozier was the best man for surveyor of the port of Baltimore and John Pnrviance secnnd best. The people of Baltimore would not like one from elsewhere in the state. On August 128, James Lloyd of Chestertown wrote Hamilton asking to be made surveyor.

2 October 20, Hamilton's Works, v, 536 . 
get to heaven before you, I shall remember you. I must go to bed. Yours affectionately," are the closing sentences. Hamilton's letter, missent to Fayetteville, N. C., had just reached him and he promised to show it to Bishop Carroll on his return to Baltimore. "Your project with regard to the President in a certain event, will I believe not have an opportunity of being executed. Happily for the public tranquility, the present incumbent, after a serious struggle, inclines, if I mistake not, to submit to another election. If it turns out otherwise, I say, unequivocally, I will cooperate in running the gentleman ${ }^{1}$ you mention, as one of the two who are to fill the two great offices. Which of the two may turn up first or second must be a matter of some casualty, as the constitution stands. Hy real respect and esteem for the character brought into, view will ensure him my best wishes in any event.". 2

The Maryland legislature met on November 5, 1792, but the senate did not have a quorum until the 12th. On the 13th, McHenry came and was present about half of the session. ${ }^{3}$ From Annapolis, he wrote Hamilton on November 18: "We have scattered in air the long string of amendments that has been proposed to be incorporated into our constitution, by those who were no friends"' to it, so "we remain a free people and a tolerably virtuous people." After the session ${ }^{4}$ McHenry expects to go to his "little farm with my little wife, where, if my health returns, I shall envy no man's happiness." He recommended for an office, Perry, who made uncommon exertions in the last election. Washington did not appoint Perry to the desired post, as Hamilton explained in a letter he sent McHenry.

1 Who was this man?

2 Two days later, Charles Carroll of Carrollton, wrote Hamilton that he could not find that the Anti-Federalists, who maintain communication throughout the United States, have whispered his (Jefferson's?) name. Carroll does not feel sure as to his character and noticed in him a "disposition to perplex and puzzle." "He seemed not to want talent but judgment and steadiness. I suspect he possesses much ambition." ICarroll hopes the "friends of stability and order, 1. e., the real friends of liberty and their country, will unite to counteract the schemes of men, who have uniformiy manifested hostile temper to the present government, the adoption of which has rescued these States from that debility and confusion and those horrors which unhappy France has experienced."

$3 \mathrm{He}$ was away on November 26 and until December 15. Session adjourned December 20. He was on the conference committee on the militia bill.

4 Rowland's Carroll, 11, 189, Charles Carroll of Carrollton resigned from the United States senate, December 3.1792, and wrote John Henry that Potts, McHenry and Stone are the three spoken of to succeed him. 


$$
\begin{aligned}
& \text { "Philadelphia } \\
& \text { “April 5, } 1793
\end{aligned}
$$

"It is a good while my Dear Mac since I have either written to or received a line from you. I embrace the first moment I have been really able to spare to say some things to you which have for some time "lain heavy on my mind'

"I have been conscious that I owed you an explanation concerning the issue of a certain Inspectorship and I have meditated it ever since that issue took place.

"In giving it now, I must rely on your discretion and delicacy; for you know I have no occasion to make enemies and I must confide to you what in truth are in the nature of official secrets

"The Supervisor named Perry, Richardson, and Cham. berlain; - laying most stress on Perry. I had a conversation with Mr. Coxe (a matter of course in reference to his office) and it was agreed to recommend Perry. The three names were given in to the President (he always chooses to have more than one) with a decided recommendation of Perry. I thought his appointment certain.

"Coxe spoke to Murray or Murray to Coxe about this appointment Murray recommended Richardson and Eccleston, preferring rather the latter. I believe, but I do not know it, that he rather spoke lightly of Perry. A gentleman from Maryland ( $\mathrm{I}$ think of the name of Hammersly) said to Coxe several things very disadvantageous to Perry. It seems he had opposed Mr. Tilghman's election \& through different channels, Tilghman's Friends had approached Coxe who, from his connection with the family, was not difficult to be impressed against him.

"Coxe came to me with his tone entirely altered on the subject of Perry. He was a man not respected by respectable men - an intriguing and rather crooked character \&c \&c. I perceived the influence of the election story \& no impression was made. My byass towards Perry continued \& Coxe perceived it.

"The next morning I received a letter from him of which the enclosed is a copy. This after the full conversations we had had was rather an officious proceeding. The design of it was not difficult to be understood.

"The same morning I had occasion to call on the Presi- 
dent - he had received a letter from Murray recommending strongly Richardson and Eccleston and I found he had through some channel been approached disadvantageously to Mr. Perry.

"He expressed a wish that I should make further Inquiry \& particularly of Mr. Henry.

"I called on Mr. Henry. He was strong in favour of Richardson \& Eccleston and unusually decided against Mr. Perry.

"Having then no clue to it and having been led from former communication to entertain a favourable opinion of Henry's Candor I was much struck with his decision against Perry \& I own a good deal shaken

"It was my duty to state facts to the President.

"The Argument with him stood thus 'Perry is strongly objected to by some; Richardson is recommended by every body - Ergo Richardson is the safest appointment'

"Much could not be said by way of direct opposition. My own mind had been put in doubt - I took the course of recommending delay for further Inquiry \& I understood that this idea would be pursued. I therefore wrote to you \& I believe to Mr. Gale - I received letters from both which threw light upon the subject - but to my surprise the nomination was put in before either letter came to hand.

"I flatter myself this detail will give you a correct idea of the business and that you will be satisfied that I have neither been wanting to you nor to Mr. Perry.

"But this explanation is sacredly for your own breast Mr. Henry's communications in particular were made under the most precise sanction of Confidence.

"Nothing but a desire to vindicate the propriety of my conduct towards a friend could induce me to disclose it at any rate

$$
\text { "Affecty \&c truly Yrs }
$$

"What say your folks as to Peace or War in reference to the U. states?"

On receiving this letter, McHenry wrote Perry as follows :

"I have had a communication upon a recent subject. Mr. Gale actually gave you the preference in his recommendation and the head of the treasury handed in your name to the 
President under circumstances which did"not seem to leave a doubt as to your appointment. The intrigues against you began then to appear. Delay was proposed till further information could be obtained and it was supposed was ac. quiesced in : but it so happened notwithstanding, that before my letter Mr. Gale's letter or any other letter arrived, the nomination was made to the senate. You see $I$ cannot be particular. One day I may be so. In the mean while rest assured that every thing was done by my little friend, and that his regret and disappointment was not less than mine. 'Patience and shuffle the cards.',

To Hamilton, McHenry wrote on April 14, that he was mortified and hurt, exceedingly, that Perry did not win, but did not blame Hamilton. The Tilghmans influenced Coxe and "you had greater things to attend to." Richardson, who had been treasurer of the Eastern Shore, is no more worthy and less active than Perry. McHenry invites Hamilton to visit him and says of our foreign relations that "our people wish to be able to carry our produce freely to all the parties at war who may want it, without having anything further to do with the war." 1

Baltimore was quite excited that summer; a number of French refugees arrived from the island of Santo Domingo and MeHenry served on the committee to solicit subseriptions for their relief. ${ }^{2}$ The sudden arrival of the refugees caused the governor to make a grant of the public arms to the Balti-

1 An interesting side light on our relation to France is found in a letter by William Vans Murray, the member of congress from the lower Eastern Shore district then living at Cambridge, written on May 8, 1793; A British prlze, taken by a French privateer, was brought past Cambridge, under command of a citizen of the district. There was not a man in Dorchester county who could lawfully enter on board the prize, till Colonel Banning, an excellent officer, came from Oxford, in Talbot county, across the Choptank, a river as wide as the Delaware at Wilmington. "So extremely naked is the body of the Federal government, so wanting, not only in clothing, but in limbs." Colonel Banning and Murray went aboard the prize and the captain showed a commission from the French republic authorizing Citizen Hooper to carry the prize to the nearest port. Colonel Banning seized the vessel, Murray, the only member of congress on the spot hazarding the step, and then writing Paca, the federal district judge. Murray adds that the public are satisfied, as they support the neutrality proclamation, though they are friendly to the French revolution. The prize was lawfully taken, but unlawfully sent to a neutral country and became subject to all the rights of dominion inherent in a neutral. Samuel Smith wrote Hamiltor on June 16, that a neutral should not permit the sale of prizes. Hooper is suspected to own a share in the privateer which he fitted out in Charleston and sold it to the French who may bring up other prizes. He is an ignorant young man and is much alarmed, saying that the great men and governor at Charleston misled him.

2 Scharf's Chron., 206. 
more volunteer companies, which action was ratified by the legislature in November. On November 29, the assembly voted that a committee be appointed in Baltimore, with power to draw on the treasurer of the Western Shore, weekly for $\$ 500$, from December 1 to February 2, "for the subsistence of the distressed French eitizens now in this State from St. Domingo," unless congress should make earlier provision. On the 30th, John Ganevain and William Du Bourg thanked the assembly for the relief, in the name of the refugees. On December 23, the house of delegates asked the senate to join in an address to Maryland's representatives in congress, to have the state reeompensed for relief given 1,200 persons from Santo Domingo who arrived in Baltimore, "destitute of every necessity of life, without money and unskilled in our language." Reference is made to the glory England received from reseuing such fugitives as the Huguenots and Palatines. On August 11, MeHenry wrote Washington that the French minister had made a requisition on the French merchant fleet in Baltimore harbor for 600 seamen to rendezvous at Philadelphia and had ordered the consul at Baltimore to furnish each volunteer with $\$ 5$. The greatest part had already 1 left town.

On Angust 20, Samuel Smith wrote Hamilton, supporting the president's action in the Genct matter, ${ }^{2}$ and saving that an Irishman, desirous of custom, hung out the tricolor on July 17, but, finding he did not attract French customers, pulled it in again. Robert Smith, Captain Strieker, and two magistrates went to Fell's Point and found that there was no foundation for the report that there was a Freneh rendezvous there. Only one privateer was in the harbor. Kilty seized her, but found she had on board only the arms which she had brought, and on sailing, her eaptain promised to take off the French that are a burden and one young Irishman.

Six days later, Colonel John Eager Howard wrote Hamilton that, while he approved Hamilton's instructions concerning privateers, there is so much money to be made from them,

1 On August 27, Samuel Smith wrote Hamilton that there was no truth in a report that an expedition against Providence in the Bahamas would set forth from Baltimore.

2 The governor, he writes, is sound in prlnciples, but Annapolis, the seat of government, is not the seat of trade and he is not well informed. The English at New York hurt their own cause. On the 27 th, he wrote that Governor Lee has been long opposed to French measures, the malicious say because the revolutionists seized the priests' property, Lee having become a Roman Catholic, "I believe, from principle." He refused to give Thornton, the British consul, an exequatur, when in Baltimore, as everything must be done in council at Annapolls. 
that some persons are discontented, and that the conduct of the English privateers makes us wish for peace. ${ }^{1}$

The general assembly met on November 4, but McHenry did not attend until the 30th. On that day, he introduced a bill for a health officer in Baltimore, a city then regarded as very unhealthy in summer and where "malignant contagious fever" had raged that year. On December 3, he was appointed one of a committee of five to bring in a bill to erect Baltimore into a city. ${ }^{2}$ This question of incorporation was a very live one in local polities and Fell's Point was anxious to be excluded from the eity limits. A charter was proposed and passed the senate on December 24, but was lost in the house, and, when the charter was finally passed in 1796 , it is said that the representatives from Baltimore had no small ado to reconcile the city to it. ${ }^{3}$

The militia bill was also discussed. McHenry voted with the majority to exempt minor apprentices, agricultural laborers, students under twenty-one, and teachers, and that volunteer companies be given up, save in Baltimore, where the "public interest requires that energy and activity of exertion which is best produced" by them. 'The assembly was quite strenuous on the desirability of the federal senate's sitting with open doors and of the enactment of the eleventh amendment to the constitution, preventing an individual from bringing suit against a state. The house of delegates made at this time an assault on the annual gift to the state colleges, but the senate refused to join in the repeal. It is interesting to note that McHenry voted in favor of the resolution to grant the federal government, with consent of the owner of the land, permission to build a fort or arsenal on Whetstone Point, to which fort McHenry's name was later given.

MeHenry wrote Washington on March 31, and April 3, 1794, asking that he be sent to France and Vienna to secure the release of Lafayette and his family. ${ }^{4}$ This would be like the friendship of Achilles for Patroclus and the autumnal fevers, from which McHenry had suffered in 1792 and 1793, caused him to wish for a change of air.

1 On November 29,1793 , the state senate unanimously passed resolves in favor of neutrality.

2 He was ill on the 10 th.

3 Scharf's Chron., 280.

4 Ford, xil, 412; Sparks, x, 397. McHenry complains of ill health. It is interesting to note that on April 8, Monroe wrote Washington protesting against the appointment of Hamilton as minister to Great Britain, which he heard was proposed. 
Washington answered on April 8, breaking through his usual rule of not replying to letters asking for appointments, "from motives of estcem and regard and our former connexion in public life," and said that there would be no advantage in sending McHenry, inasmuch as everything that could be done, "without committing my public character and involving this country in embarrassments," had already been done. McHenry answered on April 10, regretting that the president cannot appoint him and thanking Washington for news of that "unfortunate person," Lafayette.

On July 17, 1794, Richard Potts, one of the federal senators from Maryland, wrote Hamilton, stating that he intended to resign his position because of family losses and the death of a wife, who left him with a family of small children. He asked to be made collector of the port of Baltimore. To fill his place in the senate, Uriah Forrest urged McHenry to become a candidate as follows:

"I presume you know that Mr. Potts does not mean again to attend the Senate. I need not I am sure observe to you how important is the replacing of his appointment well I am a sanguine not a desponding man - and $I$ do in $m y$ heart believe the time has never been nor perhaps may never again happen, when the Choice for that House, from Maryland was of such consequence to the happiness of this Country. Presuming on Izard's successor being of Butler's sentiments, you will find in the Senate, exclusive of Maryland, an equal number of disorganizing with orderly Members. Then on Maryland does every thing Hang. Under these circumstances, fond as I know you are of retirement, I count with firm reliance on your agreeing to serve. Should opposition arise, You Shall be suported well from this quarter. I have not been much in the habit of Pressing men into servicebut in times of danger, I shall always be ready to act \& do for common good, \& in urging you by a regard for that Common good, by a regard to your own \& others safety, \& by that friendship which though for a long time not much professed I hope never slept, I think I am doing service, because I think it will have some influence in your determination."

As McHenry was not to be sent to Europe, he went to the Sweet Springs again this summer for his health. Some of his letters to his wife give interesting pictures of the life 
at that resort. Thus he wrote on the 8th of August, 1794 :

"My dear Peggy.

"My last letter to you was dated at the warm springs and sent by a traveller as far as Frederick where it was to be put into the post office.

"I arrived at this place the 4th instant in the forenoon, and have got into a good room, near the water and have no reason to complain of the table or general accommodations. There are about sixty boarders, of which twelve or fourteen are ladies. The gentlemen dine at a common table; the ladies in their huts or rooms.

"There are several consumptive patients at the springs; those in the early stages of that disorder seem to receive benefit, those far advanced according to an observation I made in 1789 , seem on the contrary to fall sooner than they would have done by the natural course of the disease under a proper regimen. Indeed the latter appears so well established as to admit of little or no doubt. There may however be exceptions to the rule arising from the species of consumption.

"The care of souls is not neglected in this quarter. I attended a methodist sermon yesterday and heard card playing and dancing condemned as damnable sins. The sermon was scarcely ended when some of the gentlemen returned to the card-table, and others joined the ladies to receive their approbation for an assembly. Whether the ladies were convinced by the arguments of the preacher or the beaux a little time will determine. The holy men I find propose to preach on sunday and no doubt will resume the subject should they hear of these attempts to mislead the fair, and perpetuate the practice of gaming.

"The amusements of this place are neither so numerous nor various as to draw off my attention from those affectionate attractions I have left at home. These often make my day dream and always my night. Fancy thus removes the distance and brings me near to those I love with the most tender affection. Shall I not soon receive news to realize my hopes and convince me of your health and that of our dear little ones? I shall then enjoy a real and solid satisfaction, next to that of seeing and embracing you and my children.

"Did I say amusements? Why there are none here unless card parties are considered of that class. I have heard of an assembly it is true, but dancing to no music or bad 
music can hardly be called an amusement. One may occupy themselves however in various ways. First in drinking the water, and next in riding or walking to get quit of it. Then comes breakfast about 8 o'clock after having kept the appetite on the rack for an hour or more before. About eleven o'clock you renew your potions of water; make little riding or walking excursions, visit Beaver dam, or sit on benches or chat till three o'clock when every one is anxious to hear a horn blow which is the summons to dinner. From six to eight o'clock there is a little more water drinking after which those who choose coffee, tea, bread and milk or rye-mush eat supper, and in a general way thus begins proceeds and closes the diurnal occupations of the Sweet Springs.

"Mr. Barton has been here a few days and sets out on his return tomorrow; so that I expect by sunday week you will have this letter in your possession. But when shall I get one from you? It will be ten days at least before our post comes from Staunton, for the arrangement fell somewhat short in point of expedition of what I have described it to you. Instead of being here once a week it will be once a fortnight only. Continue however to write me once a week, and let them be put into the post office the evening before the mail is closed for Winchester by the way of Alexandria, which I imagine to be the shortest route to Staunton.

"God bless my dear Peggy and our little one, with our dear Jane, to whom remember me.

$$
\begin{aligned}
& \text { "Your affectionate } \\
& \text { "JAMES McHenry" }
\end{aligned}
$$

“My dear Peggy.

$$
\text { “Sweet Springs 18th Augt. } 1794 .
$$

"My last letter mentioned to you my excursion to Botetourt, and a hurried account of the aspect of the country through which I passed. The town of Botetourt was erected about twenty years since; contains about one hundred and thirty houses; has a church without a clergyman; a court house and goal in good order; a tolerable tavern, and fourteen stores or shops. It and the neighbourhood furnishes a scanty practice for one Doctor, and sufficient employment for several lawyers.

"Two miles on this side of the town is a plantation late the property of one Carper, now Mr. Breckenridges, with whom I had some business that led me to Botetourt. What 
induces me to notice this plantation is a kind of circular mole or monticello which commands a fine view of the whole vale below, a meandring stream, and numerous surrounding mountains. Upon the summit of this hill, which attracts the attention from all other objects is Carper's house; but if this Dutchman has discovered taste in the choice of ground it stands on, it is to be regretted that he has left neither tree nor shrub visible from the road that might have afforded shade or shelter, or added by their ariangement to the natural charms of the place. The road from whence I contemplated this beautiful spot lays about one quarter of a mile from the house. To arrive here from the Sweet Springs you must ride twenty three miles over stupendously high and rugged mountains, where a horse never trots, by a pathway sometimes bordering on precipices and sometimes winding on the steep banks of rivers, with not more than three or four small pieces of cultivated ground to relieve the eye during the whole distance. It is more than likely that such a journey prepares the mind to reject none of the beauties of Carper's hill, nay, may do more, serve to enhance them

"Seated again at the springs I wish I could find wherewithal to amuse you. Here everything wears the same face as when I left them save some changes the company have undergone by departures and arrivals. The preachers have all withdrawn except one, and seemingly yielded to the ascendency of loo and whist. Much of the female youth and beauty which supported the hopes of future assemblies have also disappeared whilst in addition to this stroke the sudden conversion of the only fidler in these parts to methodism, has effectually destroyed all expectation of their renewal during the season.

"You will be surprised perhaps to hear that I have spent a part of this morning and yesterday in the examination of ancient and modern inscriptions, or to learn that so remote a quarter of the world should contain any food for the antiquarian. Here the stool you sit on, the table you eat off, the walls and door of the room or hut you sleep in present you with the names of persons who have visited these waters, and in many instances with the place of their abode and dates of their arrival and departure, carved, some in Roman and some in Italian characters with much apparent labour and pen-knife ingenuity. I find that I am acquainted with sev- 
eral of these candidates for distinction and immortality; but it is greatly to be apprehended that the whole group may be gradually lost to posterity in proportion as the materials they have made the vehicle of their fame shall moulder and decay. One thing is very remarkable in these records, that no lover should have carved the name of his mistress, nor any mistress that of her lovers or her own.

"To you my dear Peggy who loved me early and who loves me still I inscribe myself on paper your still fond and affectionate lover and husband JAMES MCHeNRY"

"My dear Peggy.

$$
\text { "Sunday - Sweet Springs } 24 \text { Augt. } 1794 .
$$

"I have been this morning to hear a very animated sermon delivered by Bishop Maddison upon the excellency of the christian worship; the superiority of the morality it prescribes, the hope it inspires, and the means it enjoins to attain its end. As the shortest route to persuasion seems to have been intended he was no ways sparing in rhetorica! figures allusions and similes, most of which appeared to be happily placed and some of the last perhaps new. On the whole I felt pleased as well with the sentiments and turn of expression as general texture of the discourse, and could have listened to another of the same kind without danger of falling asleep. I can further say, that of five sermons by different persons which I have heard since my arrival here, the Bishop's notwithstanding Pope's irony is decidedly the best.

A judge is just a chancellor juster still

a gownman learn'd, a Bishop what you will,

"But as Mr Maddison is a philosopher as well as Bishop we propose to renew our chemical experiments to-morrow on the Sweet Spring water.

"Your absent and affectionate

"JaMes McHenry"

“'Sweet Springs Sept. 7th 1794.

"MIy dear Peggy.

"The first of this month I used the bath for the first time and have repeated it every morning since, but make the experiment under circumstances which render its utility doubtful. I do not know as yet whether I shall continue to use it. One thing I can say, that I have as yet perceived no inconvenience from the experiment. I get up about 5 o'clock; wrap my cloak round me, and in that dress go down to the bath house 
which is within one hundred yards of my room: I stay in the bath about five minutes return and dress myself; ride three or four miles immediately after, drink about a quart of the red-spring water (a mile from the Sweet Springs) and return to breakfast which is generally on table between eight and nine. About eleven o'clock I ride six miles drink again of the red spring water, and dine about 3 o'clock. I ride no more during the day, and generally spend the afternoon in sauntering or making experiments on the waters.

"Adieu my dear Peggy adieu and God bless you and our dear little ones."

$$
\text { "Sweet Springs } 16 \text { Sept. } 1794 .
$$

“My dear Peggy.

" Yesterday I visited some thermal waters on the edge of Snake-run about five miles from this place and four miles nearer to Baltimore. As far as one can judge by the eye taste and sensible effects of these waters they possess at least in as great a degree the same operative principals as the Sweet and Red Spring waters; of course are no less valuable in a medicinal point of view. The one whose qualities are similar to the Red Spring water gushes out of a rock at the base of a mountain into a large natural bason with an aperture in it like the lip of a jug through which its contents pass into Snake-run colouring the stones and sides of the bason with an ochry matter such as the Red-spring exhibits.

"Close by this is another gaseus water from which fixed air rises abundantly in bubbles, and which tastes as acidulous as the water of the Sweet Spring; while a few yards further on there rises from the same mountain a stream of pure common spring water devoid of the medicinal qualities of either of the others. Thus has bountiful Providence in a small compass given to his ereature man two invaluable gifts, and at the same time placed them in a salubrious climate and fertile soil; for altho' the land in the vicinity of these waters is chiefly high and mountainous much of it is nevertheless capable of being converted into fine upland meadow and corn and wheat fields.

"Snake-run which is considerably increased by these ther. mal waters, meanders through a narrow vale formed by tyo opposite mountains whose sides and summits are covered with large trees. After it gets about a quarter of a mile from the 
springs the fixed air of the thermal waters which held in dissolution their saline and calcarious matters, having chiefly evaporated, these matters precipitate and adhere to whatever obstruction they find to cross the stream, and form by gradual and successive accumulations masses of a porous stoney substance ranged in order like the seats of a theatre, over which the water tumbles and murmurs and whitens into foam, giving an image in miniature of the roarings and dashings of gigantic Niagara.

"To this fine spectacle is subjoined another perhaps more beautiful, but more concealed from observation and difficult of access. Having clambered up about the third part of a very high rugged and rocky mountain adjoining the medicinal springs, you descend (taking with you lights) a kind of shaft about twenty feet in depth, when there opens to the right and left several suits of subterranian appartments, repeated and extended much further than I chose to penetrate. Some of these are very lofty and spacious and all of them adorned and incrusted, tho' with unequal elegance, with pillars and wainscotting composed of a depositum of a christalline appearance. This substance or depositum is in many of the compartments of a snowy whiteness and fleecy. Many of the pillars which it forms are ornamented with great fancy and exhibit, as well as the pitted vaults and sides of the rooms and passages various natural and fantastical figures. Over a horisontal projection seems to hang a young child not badly expressed, while at a small distance, a half-pillar, which stands as if it had been placed by design to assist you to descend from one appartment to another, represents the bald head of an old man. Some of these pillars and their plates which fall like eurtains from the walls are sonorous when struck, and gently echo the gurgling of a stream of water (supposed to be Snakerun) which takes its dark and devious way through these abodes of eternal dampness, darkness and solitude. You know my dear, that this subterranean creation so various and interesting is produced by means apparently the most simple. You know that the water which is continually filtering through the mountain above into the cave through the crevices of its rock brings with it matter that christallises into this assemblage of pillars, white roofs and fleecy wainscotting; and that each new addition of christalline fluid which distills from the incumbent rocks changes and varies the size and appearance 
of the pillars, the roof, the wainscotting and all the figures that adorn and embellish this beautiful assemblage.

"There is another cave in the vicinity of this one, but as it exhibits only inferior beauties you will not be displeased at me for omitting its description.

"Would you believe it that the medicinal waters of Snake-run and about two hundred and fifty acres of land containing all these interesting spectacles could be bought for about $£ 250$. Whereas I have no doubt considering the probable progress of population and wealth that at no very remote period the purchase will require two or three thousand.

"I have only one intimation to give you should curiosity ever lead you to view this cave: do not venture into it when heated by the exercise of ascending the mountain, but patiently saunter about till you acquire somewhat of the coolness of its atmosphere otherwise you may pay too dear for a view of its beauties.

"Thus my dear Peggy I have given you a faithful transcript of my yesterday's excursion and survey. To-morrow Mr. Richie who accompanied me from Frederick leaves me and will carry this letter; but as he talks of some delays on the road, it may not reach you in the usual time by some days. Adieu my dear Peggy far dearer than the medicinal waters of Snake-run, its caves and their christalline beauties to your affectionate

"My dear Peggy.

$$
\text { "McHenry" }
$$

\section{"Sweet Spring 28th Sept. 1794}

"Yesterday I received Mr. Jorri's letter of the 9th inst. which you may be certain gave me pleasure inasmuch as it assured me you and our children were well when he wrote; but had it been convenient for you to have said so yourself my pleasure would have been much more perfect.

"How embarrassed with sick servants, and overloaded with fatigue for want of assistants since I left you! Under such accounts I cannot stay longer here and be at rest in my mind; I shall therefore leave this place so as to arrive at Staunton Wednesday next which is the post day when I hope to find a letter from yourself of a later date than that from Mr. Jorri. Why did you not give ten dollars a month rather than be without servants? Why subject yourself to fatigues in hot weather, which might be injurious to your health? 
"The waters are at present in their best state and will continue so throughout October; and yet the company have almost all disappeared, even those who found most benefit from them, or rather stood most in want of their assistance. It would seem that the idea of solitude was more dreadful to some than the prospect of disease. The appearance of the place it is true is very different from what it was a few weeks ago. A village deserted by its inhabitants whose houses are falling into ruin gives a faint idea of the deserted and ruinous state of the huts at the Sweet Springs. You walk through them without seeing any of their late inhabitants and hear nothing to disturb the silence that universally reigns save the noise of the wood pecker, the falling of the leaves of trees or the murmuring of the hollow wind among the neighbouring mountains and everlasting forests.

"Can one find any amusement amid such scenes? Yes my Peggy, were I but certain, that you were well, at your ease, and our children so also, I should like to remain an inhabitant of these solitary places during the month of October. The wind should answer to my love murmurs, while echo would carry your name through the mountains, and the falling leaves speak to my soul most excellent morality. He is poor in ideas and barren in resources indeed who sees in solitude nothing but frightful chimeras, and in these mountains no amusement whatever.

"But whatever praise may be due to solitude, and whatever entertainment these places may contain, I yield all with pleasure for you and Fayetteville.

"God bless you my Peggy and make our meeting happy prays your affectionate

\section{"James McHenry"}

On November 2, the day before the assembly should meet at Annapolis, Chase wrote McHenry on the projected incorporation of Baltimore City as follows:

"Dear Sir,

"Balto. Sunday Noon.

"The place of the Clerk of the Senate will be solicited by several Gentlemen. Mr. Ninian Pinkney, brother of Mr. William Pinkney, my friend, will be one of the applicants, and I wish he may meet your Approbation. I have no doubt that he is every way qualified to execute the Duties of the 
Office, and therefore I earnestly recommend him to your patronage and friendship, - if you should be pleased to honour him with your Vote You will confer on Me a personal obligation.

"I only returned yesterday afternoon from Annapolis, and have no Information of any thing intended by the friends of the proposed Bill for the incorporation of Balto Town. I have seen the thing proposed by the united Committees, and your strictures on it. I imagine it would be proper to draw instructions to the Representatives of this place, directing them to ratify the Bill and altho I am inclined [?] to propose to the Senate certain amendments, to agree to such others as will effectuate the great object of the original Bill, the establishment of an energetic Government for Baltimore founded with principles of a Republican Government.

"It appears to Me from the Numbers (500) who last year petitioned for a law of Incorporation, a fourth Thing was proposed by the Senators, that all kinds of Citizens agree in the Necessity of incorporating the Town, but differ about the form of the Government. I return to Annapolis on tomorrow Week. I am

$$
\begin{aligned}
& \text { "With great respect } \\
& \text { "Yr. Hble. Obedt Servt. } \\
& \text { "SAM. ChaSe." }
\end{aligned}
$$

McHenry did not appear in the senate until the 17th, but this delay seems to have been a characterisic of most of the members; for, frequently, two weeks passed before a quorum was secured and the body organized at this time, on the day when McHenry came.

On December 3 , he introduced a bill to establish a bank in Baltimore and on the 16th, with Carroll of Carrollton, he voted in the minority against ratifying the eleventh amendment. 1

He had but one voting with him, while ten were against him, on the adoption of the following resolutions, which he offered on the 18th:

"Resolved that the situation and circumstances of the people of this State make it expedient to frame a system of county schools, as subsidiary to the colleges and the more expensive promulgating of learning.

$1 \mathrm{He}$ was absent on December 24. 
"Resolved that a committee from the Senate should be appointed to confer with a committee from the House of Delegates in order to obtain their sentiments on the subject and what taxes might be with propriety laid to support the said schools."

He stood with nine others against the two who voted to take the annual grant from St. John's College, voted with four others, against seven, to destroy the governor's council and brought in a bill to permit members of the legislature to affirm instead of taking an oath.

Washington had great trouble with his cabinet in his second administration. Hamilton and Knox resigned in the winter of 1794-95, and the feeling in Philadelphia about the secretaryship is clearly shown in two interesting letters William Vans Murray, a member of congress, sent McHenry at the time.

\section{"Philad. 16 Dee. 1794.}

\section{"Dear Sir,}

"There has nothing new come forward lately from England. It would appear as though the publication (by Mr. $\mathrm{R}$ [andolph]) of the two official notes from Mr. Jay \& Lord Grenville were an untimely gratification of public curiosity. It show'd the feebler part, the mere introduction of the business, of a scheme in which vigour appeared necessary, at least appeared so to the public mind here which was greatly excited by recent injuries. - \& a proper regard to silence on an uncertain event necessarily prevented a further publication of that part. The effect was not happy here as they did not see all, they ought perhaps to have seen nothing - and yet directions, or rules, might have been given by the Secretary of State for the guidance of the sufferers or claimants agreeably to Mr. J's ideas - but the murmur soon subsided The impression of the [whiskey] insurrection aided in smoothing down every asperity. It has been deep, \& effective, it is to be hoped. The roots of the eause however are perhaps to be looked for if any where existing in the remnant of the Democratic clubs. These will I am convinced still go on. They assume a ground so plausible in a free country that they will still flourish \& ocassionally produce convulsions, or rather prepare the public mind for them. The present time however is certainly propitions to a sober examination of their tendency, \& perhaps of their Objects. Every thing is to be 
hoped for from the good sense of the public when so lately roused into reflexion.

"That your old Military comes Col Hamilton should be about to retire from office must give you \& every friend to the country much regret. Knox too talks of resigning. In fact the government does not seem to grow better, as to its agents, In every part of it - instead of growing more mellow - it seems more crude \& green. The prospect of the new elections too for the next Congress presents no consolation - much I fear that the Majority in this house at least if not in the Senate will be wrong, to say no more. That is they will be composed of a majority who will be composed of two sorts of men. A few who were anti in 87 - and are so still and those also were Federal in 87 - and also think themselves to be so still - men who do not wish to overturn the government - but who by an undue infusion of new fangled disor. ganizing principles are outrageously wild in their theories \& practice, \& who wish to make the constitution the post on which they would hang up these new principles - These men would ruin this or any other energetic system by their mode of administering \& working it. They sail down a current and mean to stop at the cataract. They would unintentionally go down the cataract at last. For I can not believe that you can find twelve men in the government who would by one decisive blow destroy it. But the other description are \& will be too much guided by these.

"Between our selves, there is ground to expect that this late affair to the Westward will produce a sort of crisis in the parties of the ancient Dominion - where a respect for the personal private characters of some pretty eminent men has hitherto evaded an open \& marked line between the puzzlers \& disorganizing politicians \& the sober, good \& firm Federalists. I rejoice that my name has not been brought forward agt Mr. Henry or to the slightest interruption of his re-election $\&$ am much flattered by the kind manner in which you mention the circumstance",

\section{"Dear Sir,}

“Philad. 1. Jany 1795.

"The stream of time running on silently for ages would be a dutch canal, tame \& insipid were it not intersected by here $\&$ there a point of flowers and verdure to enliven its banks. 
Sundays - months \& years - even fasts as well as festivals aid the mind \& spirits like these resting points. I can easily conceive why the ladies \& fine gentlemen drop the ceremony of gratulation on the birth of the new year \& it is for the reason you have given - wrinkles - We love the new year perhaps because not to have reached it would have been a greater evil than to grow old. Like you I had rather enjoy it at home in the true Maryland feudal like style of the $E$. Shore. To make the Banjo (in lieu of the Hall's Harp, or the Bagpipe) drone away in the Kitchen - to give out brandy to the poor slaves \& see them eat blood puddings as a luxury. But Mrs. Murray is with me \& I am consoled. Though the beating of the drums near us \& the firing of guns \& ringing of bells at Twelve o'clock last night were not abso[lutely] necessary to that repose which is so necessary before a man starts on the long journey of a full year. But I am well today - \& what is better the President is in fine health \& seems to defy the ravages of time during life as much as his name certainly will after death. We all went to see him to day $\&$ he so little understands the taste of politicians as to have had a treat of sweet cake \& wine ready for his 'faithful commons.'

"The subject which engages the House is a Naturalization bill - we would lengthen the time of residence. The flood of men \& of their opinions is to be feared by all who can trace the fitness of the people to their governments, and of those to the People - most of this fitness perhaps arises more from the peculiar composition of the Society than from any exercise of the will of the people. So naturally \& essentially do the Theories belong to the opinions habits \& immemorial practice of the citizens of the U. S. that their General and particular modes of Government can hardly be said to have been Willed. What ever will materially affect or suddenly derange this composition perhaps ought to be guarded against. It is fair to expect probably one million of souls here in less than three years, let the contest end as it may in France. Ought we not to set a high price on a participation of citizenship where an easy acquisition of it, by those who must have very different ideas from those of our eitizens, might affect the political complexion of the mass \& of course be felt in the government.

"I am so much flattered by an agreement with you in former opinions, that you see I venture to go on in giving mine freely - indeed this is the line I have taken in the Debate. 
Giles has made a very frivolous motion relatively to the bill wh. you will see in the enclosed paper of Brown's. Wishing you \& Mrs MeHenry a happy new year in a continuance of all your own blessings I am with sincere esteem Dear Sir

\section{"respectfully yrs}

"W. V. Murray.

"Genl. Knox resigned yesterday - Pickering is talked of - a sober man \& accurate but not so known on the broad scale - we certainly are retrograding as to characters. Jefferson succeeded by R. - Knox by P. - Hamilton by - anybody no - I have no reason to believe that Mr. J. has been thought of seriously - once I heard his name out of Doors."

In consequence of Hamilton's retirement, McHenry wrote him on February 17, 1795, the first letter he had sent, since Perry failed to receive the desired appointment. 1 Though not writing "I have not ceased to love you, nor for a moment felt any abatement of my friendship." He had not written, for he thought thus to free Hamilton from embarrassment and that, if Hamilton wished his services, he would write for them.

"You see how well I have persevered in this determin. ation and that it is only now, when I ean have nothing to expect and you nothing to give, that I recall you to the rememberance of our early union and friendship. It is during this period, my dear Hamilton, that you will find unequivocal instances of the disinterested friendship I feel for you and which ought to convince you, how well I am entitled to a full return of yours. The tempest weathered and landed on the same shore, I may now congratulate you upon having established a system of credit and having conducted the affairs of our country upon principles and reasoning, which ought to insure its immortality, as it undoubtedly will your fame. Few public men have been so eminently fortunate, as voluntarily to leave so high a station with such a character and so well assured a reputation and still fewer have so well deserved the gratitude of their country and the eulogiums of history. Let this console you for past toils and pains and reconcile you to humble pleasures and a private life. What remains for you, having ensured fame, but to ensure felicity? Look for it in the moderate pursuit of your profession or, if public life still flatters, in that office most congenial to it and which will not

1 Hamilton, v, 623 ; J. C. Hamilton, Life of Hamilton, v, 194. 
withdraw you from those literary objects that require no violent waste of spirits and those little plans that involve gentler exercise and which you can drop or indulge in without injury to your family. I have built houses. I have cultivated fields. I have planned gardens. I have planted trees. I have written little essays. I have made poetry once a year to please my wife, at times got children and, at all times, thought myself happy. Why cannot you do the same? for, after all, if a man is only to acquire fame or distinction by continued privations and abuse, I would incline to prefer a life of privacy and little pleasures."

On June 14, McHenry wrote Washington ${ }^{1}$ expecting soon to start for the Sweet Springs and recommending Samuel Chase for a position on the federal bench, without his knowledge, saying, "Chase and I are on neither good nor bad terms, neither friends nor enemies. To profound knowledge, he adds a valuable stock of political science and information."

In that summer, which McHenry spent in Virginia, came the scandal about the French dispatches, followed by Randolph's resignation, which led Murray to write McHenry as follows :

\section{"Dear Sir,}

"Your letter I answered by Doctor Sulivan who went to the Berkley Springs as he had no opportunity of delivering it - he brought it back. Since that period you have I hope found your old friends the mountains and cascades true to their promises of health as well as pleasure \& now enjoy in the rosy cheeks of your little ones the best evidence the nature of such friendship will admit.

"You are - you must be very solicitous to know something of the mysteries of Fauchet's letter. I have seen it's copy in english. It is a most curious affair - \& highly disgraceful to certain men in this country. He declares that Randolph ${ }^{2}$ came to him during the critical appearances of the Insurrection and made him the offers - referring to No. 6 wh. I have not seen. This No. 6 must have contained something wh. he (F.) deemed infamous - for, after the reference to No. 6 - he bursts into an apostrophe. Thus the consciences of these pretended patriots have their price (tariff). Thus

$1 \mathrm{He}$ asks information about Lafayette.

2 On this episode see Conway's "Omitted Chapters of History." which is a defense of Randolph's acts. 
for a few thousand dollars the Republic wd., had she been disposed to pay men for doing their duty, have decided on peace or a Civil War - (by duty he means from the preceeding speculations on the degeneracy \& aristocracy of the Govt - to have supported the Insurrection). (What will be the old age of this country if its infancy is thus decrepid!). He says $R$. came to him (in another part of his long letter) and told him the Govt. was determined to push these people into open violence that a pretext might be obtained for force \& the establishment of despotic principles. He says the explosion was too soon. That the excise was the ostensible motion $\&$ the habits of the W. people gave a fitness for the workings of party. That they expected friends in the East \& South nay even in the bosom of the Govt itself!

"This letter is a valuable comment upon many appearances at that period \& since \& before - to preserve the alliance of the French Govt. wth. the antis $* * *$ here for the purpose of overturning the Govt. - he says to confine the actual crisis (of the Insurreetion) to the simple question of the excise is to reduce it much below its real scale. It is connected with a general explosion long since prepared in the public mind but wth. this local \& precipitate eruption rendered abortive or at least put back for a long time.

"If Mr R. is innocent he will clear himself at least I hope so - but he must have a power over the Science of Construction more than is conceivable to me if he can hold out even a shadow of vindication. His defence is not out. It will be an attack on the administration $-\&$ a slurring of the president." 1

1 On December 24, 1795, W. V. Murray wrote McHenry in reference to Chase and Randolph as follows:

"I have several times brought up Mr. Chace to view while the official wheel was in motion. I have taken pains to place his \& Martins politics in the true point of view - as yet no consequence has follow'd except perhaps a preparation. Yes - Rutledge was rejected. It is said openly that he is in an unhappy State of mind - \& often deranged - by gentlemen immediately from his own country.

"I have aiways been of your opinion with respect to forelgn ministers, \& have constantly avoided any intercourse more than formal visits \& even those I have not gone into more than two years past. Not having been visited by any British minister for two years nor by any French minister for two years - nor having seen the first at his own house or my own for three winters nor the second but once at his own house at dinner once Fauchet - nor having dined with the Spanish minister these three years though I shall next monday dine with him - in a gala style. Having not been of consequerce enough to be sought $-\&$ being too proud unsought to be won. I am but little known to them Genet \& Fauchet never returned my visit. Nor that of many others of my complexion \& last winter not having even paid the visit of ceremony to Hammond of course I had no visit from him. I have waited on Adet - but he has not 


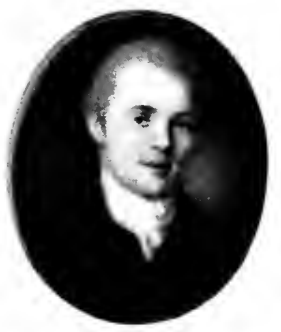

\section{DR. JAMES MCHENRY}

Reproduced in original size from miniature owned by the heirs of Dr. James McHenry

(Copuright, 1907, The Burrows Brothers Company). 

Washington offered the place left vacant to Thomas Johnson, who declined it in a letter of August 29, shortly after returning from a visit to the Old White Sulphur Springs: "I am far from being ont of humor with the world on my own account. It has done me more than justice, in estimating my abilities and more justice than common in conjecturing my motive. I feel nothing of fear, either, in hazarding again the little reputation I may have acquired; for I am not conscious of having sought or despised applause. But, without affectation, I do not think I could do credit to the office of Secretary, I cannot persuade myself that I possess the necessary qualities for it and I am sure I am too old to expect improvement. My strength declines and so too probably will my mental powers soon, my views in this world have been for sometime bounded chiefly to my children; they, yet for a little while, may have me to lean on, being constantly with them adds to their happiness and makes my chief comfort. Most sincerely wishing you less alloy in the Returns of this world and the fullness of joy in the next, I remain with truth your affectionate and most obedient servant." 1

While Washington was trying to fill the place, Hamilton wrote him, on November 5, making a number of suggestions. Among them, he said, not letting his friendship cause him to praise over much: "McHenry, you know. He would give no strength to the administration, but would not disgrace the

yet called on me-upon Le Freire I have called and he on me - upon Bond as charge des affaires I have called - he not yet on me. You will pardon this monstrous egotism, when I tell you that Forrest once told me this time two years that a man told him that a baker in this town said (to his Son who told F.) that the britlsh minister \& consul were night \& morning at my lodgings in 'Union Street. I told F. to tell the baker's Son that his Father Lied-from me if he saw him again - \& showing Forrest a note In which I stated the fact of his (Mr Forrest's report) \& that he was a liar. F. wd. not let me send it - as a thing perfectly beneath my notice. Nelther Bond nor Hammond having been once in my lodgings that winter \& spring. Such stories were industriously circulated I believe through the town where Madison's propositions had been a little in discussion.

'Pandolph's Vindication of his Resignation' is out \& much read. In vain I looked into F's explanation for an innocent meaning of terms so portentous of infamy - not that $I$ think $R$. received money but that the passages still impress the conviction of his duplicity \& of some sort of corruption.

"Do you remember anything of a letter on the Secret files of the old Congress - written by Marbois \& intercepted? a chaln of evidence rises gradually to view highly lllustrative of the old polley of the French Court \& connects their policy as one \& indivisible with that wh. I firmly belleve actuates the Republican court of Paris. In this the nation has little to do.

"I thank you for your good intentions towards Mr Robertson \& can only lament that circumstances deprived him of the benefit I intended him" 1 Hamilton, xi, 63 . 
office. His views are good. Perhaps his health \&c would prevent his accepting."

Three days later, McHenry wrote Washington that he was going shortly to Annapolis and would there favor the application to the state for a loan towards public buildings in the District of Columbia. He enclosed a prospectus of a new bank proposed to be established in Baltimore and had written an address which appeared in the Winchester (Va.) papers of October 15, on political matters. "Let me add," he continues, "my humble intreaty to that of the prayers of all good men that the publications pointed at yourself with the evident intention to induce you either to resign or withdraw from another election may not be permitted to have that effect. You know the force and danger of the present crisis and how indispensible your remaining at the helm is to subdue it and give permanence to our prosperity and government."

The assembly met at Annapolis on November 2, but Mcr Henry did not attend ${ }^{1}$ until the 16th. Shortly afterwards a declaration of confidence ${ }^{2}$ in Washington was introduced in the house of delegates by William Pinkney, "a man of real talents and genius and a fascinating speaker" and was supported "beautifully and irresistibly" by him, as McHenry wrote Washington on December 5. "His influence and conduct on the occasion overawed some restless spirits and reached even into the Senate," which body passed it with the same unanimity as the house.

$1 \mathrm{He}$ was absent on December 7,18 and 19 . He voted to enlarge the state's investment in the Potowmack company.

2 Ford, xi, 138, 140. Washington thanked Governor John H. Stone for this declaration of confidence. 


\title{
C H A P T E R XI
}

\author{
WASHINGTON'S SECRETARY OF WAR
}

$\mathrm{W}$

ASHINGTON'S difficulties as to his cabinet increased towards the end of his second administration. Pickering was finally transferred from the department of war to that of state, leaving the former department vacant, General Pinckney of South Carolina, Colonel Edward Carrington of Virginia, and Governor John Eager Howard of Maryland all declined it. Washington now thought of his old secretary, McHenry, and, on January 20, 1796, wrote him 1 " that it would now give me sincere pleasure if you will fill the office of Secretary of War."' 2 With frank candor and friendliness, the president tells of the three previous tenders of the office, but states: "Let this letter be received with the same friendship and frankness with which it is written;- nothing would add more to the satisfaction this would give me than your acceptance of the offer." He pressed McHenry for an "immediate reply" and, if the reply be favorable, for an immediate journey to the seat of government, even though Mrs. McHenry and the family be not brought along "in the present State of the roads."

Washington further asked McHenry to ascertain whether Samuel Chase will accept a seat on the "Supreme judicial bench of the United States."

McHenry's answer was dated 9 P. M., January 21, and said: "I have this moment received your favour of the 20th and am truly sensible of the sincerity of your wishes that I should accept of the war office department. On my part, I beg you to believe that nothing could give me more pleasure than to be near you for a few years, independent of public motives or considerations. I must, however, pray you to allow me till Monday to reflect on the offer and determine whether I can

1 Ford, xill, 113 ; Sparks, xi, 106.

2 Brown's McHenry, 21. MeHenry's nephew, John, wrote that he felt Washington's letter was "an injunction that he could not refuse and most reluctantly accepted the appointment, leaving his pleasant retirement to embark in the troubled sea of politics." 
with propriety and, as it respects my family, venture upon a change of position, which, by bringing me into public life, must necessarily bring with it much care and trouble and uneasiness. My inclination is to accept, but I shall be definite by next post. In the meantime, I shall obtain Mr. Chase's sentiments, which shall accompany my letter."

On Monday, January 24, McHenry wrote again, accepting the office that was for more than four years to bring him from his quiet home into the rush and glare of public life: "I resume the answer to your letter. I cannot say that I have ever experienced so much hesitation between giving way to inclination and attachment to you personally and my own interest and ease, as has taken place during the two past days. It is now, however, all over and it is right I should confess that the soothing idea of serving under you, more particularly at this erisis, has effectually and irresistibly silenced all opposition. Such then as I am and with a heart truly devoted to you and the public good, dispose of as you please.

"I shall commence tomorrow to prepare everything to facilitate my departure hence as soon as it is practicable after hearing from you and, in the meanwhile, have obtained Mrs. M's. consent to remain here, till I can get a house in Philadelphia and the necessary furniture for her reception and accommodation. Chase will accept too. Thus, sir, you see what you have done, you have made an old veteran very proud and happy and one not very young to approach the station you have assigned him with fear and trembling, for who, hereafter, may hope to escape without a wound, while there are men to be found who could aim poisoned arrows at yourself?"

On the receipt of McHenry's letter, his nomination was at once sent to the senate and promptly confirmed, as was Chase's which was sent in at the same time. Williamson and Murray wrote warm letters of congratulation as follows:

\section{"Dear Sir}

$$
\text { "Philada. 27th Jany } 1796 .
$$

"You will probably learn from another Hand by this days Post that you are nominated and appointed Secy at War. Your friends and many Persons who know you only by Character hope that you may serve in this Office although it is known that you have generally been averse from public Employment. Knox, as you know, was considered to be a Man who went on a most expensive Scale. The follies of a gamb- 
ling wife were passed to the Debit of her Husband, in Addition to his own - no great Stock of Talents. Pickering was considered to be a firm \& frugal Man and the Appointment I think gave much satisfaction. Since he had been advanced, Terror has siezed the public mind from the apprehension that we should be reduced to a State of insolvency by Genl. Wayne or Govr. Lee in the Character of Secy. of War. Both of them have bcen spoken of and both are supposed to have been seeking the Place. And within a few hours I have seen several countenances illuminated with the Idea of being again out of danger. Nothing is so fervently desired by Eastern men \& by Southern Men who take the trouble of thinking as that in our War Department, the Channel through [which] the greater Part of our Treasure goes, we may have a prudent, firm, frugal Officer who in private Life having shown that he knows the Value of money may be expected to be equally attentive to the National Property. When you cast an eye on the two Candidates here named and the ei-derant Secy. you will readily discover the former cause of apprehension, a present Cause of Satisfaction.

\section{"Dear Sir,}

"Believe me to be

"Dr. sir With great sincerity

"Your obedt Servt.

"Hu. Williamson."

"Philadelphia, “Thursday Evening January 281796.

"To day the Senate, I hear, unanimously, concurred in the Presidents nomination of you as Secretary at War. I know not whether the President had previously obtained your consent. This however I can assure you of that he is exceedingly solicitous that you should come into the administration. Many names pretty high in military rank, and some in that of Talent too, were in view, \& yours among them. You will, I know, not misconstrue me when I venture to urge you to accept. I do not think, upon my honour, that you will consult your own glory in accepting this tribute of confidence from the first of men, after an intimate knowledge of you for so many years, part of which time, the most trying too, was past in his own family. Till the present administration, $\mathrm{He}$ has always had some of his old family with him. I think he still wishes to have his old inmates with him. This is certainly a habit that grows out of time, that no sudden confidence, how- 
ever solid \& merited, comes up to, as it respects the affections. Since Hamilton's days he has not had one of his old set. The Two gentlemen, ${ }^{1}$ confidentially, though men of honour, and capacity and of clear judgement \& of very improvable minds, are without doubt your inferiors as Cabinet ministers - in That \& that only is the present admon. weaker than Hamilton's - a more various reading \& more general knowledge of mankind would make them strong in this point for each has strength \& vigor of mind.

"The more disagreeable part of official business in the War Department is infinitely lessened by the present \& prospective State of affairs - and yet such is the political ticklishness of it that a steady policy in the admon. will be essential for three or four years. Cabinet business is conducted by the Three conjointly - for instance Randolph was directed by the $P$. to address the $B$. minister in a memorial on the provision orders - \& was desired to lay it before the other heads of Departt \& the attorney Genl. — \& they thought it too fiery $\&$ hostile for that season of our negociation \& refused their consent.

"You have this consolation, \& it ought to be a great one to you, certain I am it will be so to your boys when they grow up \& Washington shall be gone, that your nomination was the Presidents own act - \& the original conception of it entirely his own. After he had determined, he sent for me, \& I found it was to know if I thought you would accept. I stated to him that though you found your own home extremely endeared to you, I firmly believed that your affectionate respect for him \& good wishes to the Fedl. Govt. would supersede every other consideration \& that you would. He then talked a great deal about you \&, on the whole, I am convinced has felt no common emotion in the nomination.

"Depend on this, that men long known to the public must accept these high offices or the Govt. dwindles into insignificance - and what public duty is there wh. to a certain degree does not demand some sacrifice of predetermined schemes of life \& personal quiet? Vanity \& ambition I know you will say will always supply candidates enough. I know that, \& that is the reason why such candidates shd. not be accepted.

"Education is here at your door. Mrs. McHenry would be happy in her native place - as to the Salary (though it will be increased, if not this, the next session) it will maintain

1 Timothy Pickering and Oliver Wolcott. 
you in that easy style of elegant but quiet accomodation wh. I think you love - at all events it does Wolcott \& Pickering. The first lives in Fourth South, at the corner of Spruce, in a neat house of two rooms, one small, on a floor and must I think live wh in his means. He is a very worthy man \& quite equal to his duty - his wife one of the mildest \& most amiable women in town - an excellent manager, kind but economical. Col. P., Sec. of State, you must have known - a plain, industrious, well informed man - with a wife \& four or five children. They see little company. I have never been at his house as a visitor - he lives plainly but quietly. Both these men are practicable men to deal with to work with - without humours or caprice \& perfectly agreeable, I think they wd. prove to you as associates in business.

"Another reason for your accepting. You are known as an officer connected wt. the Genl. during the war - as a member of our Senate - a member of the old Congress - a member of the convention - at present a Senator. These extrinsic circumstances become intrinsic fitnesses, \& do more; they enable a man to do what is right in his own opinion. This a character however intentionally great wh. has been but just built up ean not always do.

"Besides you will be gratify'd with that literary treasure Wh though certainly not full is here more copious than in Baltimore. You renew that intercourse of mind with Hamilton Wh. ever must have been a source of consolation. So large $\&$ changed is the city that a man may be retired if he please.

"In fact my dear Sir, if you review your life or look forward, you belong to that Federal Interest wh. you are called on in the most flattering way to support - \& you will obey the call.

"AT ALL EVENTS COME UP HERE! if it be only for three days.

"I have been confined to my room since Sunday by an inflamation in my jaw that obliges me Literally to hide my face. S. Smith's motion will be on next Monday. Strange work at such a time to make such a motion!

"If the President consulted you - you will laugh at all this - if he did not - be contented to be Secretary at War! of the most flourishing and free people on earth.

"Yours, Dear Sir, Sincerely

"WM. V. Murray." 
Washington repeated the urgency of his first letter, when the nomination had been confirmed.

"Dear Sir,

"Philadelphia 28th. Jan 1796

"Your letters of the 21st \& 24th. instant have been duly received. The last, in time on tuesday, to give in the nominations of yourself \& Mr. Chase for the offices contemplated. The day following they were advised \& consented to by the Senate, - and the commissions will be ready for the reception of you both on your arrival in this eity - of this be so good as to inform Mr. Chase; and, if he is still at Baltimore, to remind him, that monday next is the day appointed for the sitting of the Supreme Court, and without him, there is no certainty of a sufficient number of Judges to constitute it

"For" the reasons assigned in my last to you, and which press more \& more every day, I shall look anxiously for your arrival. Always \& affectly

$$
\text { "I am-Yours - "Go. Washington" }
$$

McHenry replied, on the 31st, that he expected to leave Baltimore on horseback on the following Wednesday and to be in I'hiladelphia by Friday or Saturday. He had a bad cold and so must take lodgings before sundown and start after sunrise each day. He perceived the incompatibility of public office and private business and told the president that, "having been connected in two mercantile partnerships, I have thought it fit to enter into my office totally free from any such connection. One of them I have settled yesterday at an actual loss of about $£ 3,000$. The other, which has netted me for five years past $£ 1,000$ annually, I expect will be finally adjusted tomorrow, after which I shall meet you with a disembarrassed mind and rich enough to require no increase of salary and, by no means, displeased at any sacrifice I have made that approached me at this moment to your labours and cares."

On the 8th of February, McHenry took the oath of office before Chase and entered upon his duties, which included the care of military and naval affairs and of Indian relations.

It is of Indian affairs that we first have information in the following letter from Washington.

"Dear Sir

- "Tuesday Morning - 28th Feb.

"Let me entreat you to attend early this morning to a fit 
character as a Comr. to attend the proposed Treaty with the Indians, by Mr. Morris - and, on this head, and on the message proper to accompany the nomination, I wish you would advise with Col. Pickering, who has had more to do in Indian affairs than any other officer now in the Government, and perhaps may more readily think of a proper person to be entrusted.

"As it is several days since the application was made, I wish to make the nomination without further delay. If a gentleman from New Jersey, Delaware, or Maryland could be obtained it wd. be desirable - or from Connecticut, and I believe Mr. Larned is in Town - so is Mr. Dexter both good characters. Something must also be done with the Military Bill, this day

\section{"Yours always "Go. WaShington"}

It may be convenient to survey McHenry's relations to Indian affairs under Washington, at this place. On March 10, Pickering wrote him to accept the accounts of Chapin, the Indian superintendent, without vouchers as the Indians can give none. A payment had been made to Captain Joseph Brant (Thayendanega) ${ }^{1}$ at the treaty of 1794 and was not certified to by Jasper Parish, the interpreter, as Brandt understood English pretty well and his character is too well known to Pickering to believe that he would "have received the present, but in absolute privacy." The supplies for the Iroquois should be gradually reduced to the fixed annuity of $\$ 4,500$, especially since the Western war is over, but we have made too many professions of uarm friendliness for the six nations, suddenly to abandon them and, particularly, to neglect the chiefs. A few days later, Pickering wrote again to Washington on the affairs ${ }^{2}$ of the Iroquois.

"The Secretary of State respectfully returns to the President his report on the claims of the Cohnawagos, or Seven Nations of Canada, with the draught of a letter which he thinks proper to go from the department of war, with the report to the Governor of New-York. The Secretary also transmits a press copy of the report, to be lodged in the waroffice, which will enable the Secretary of War to dispatch the original this day by post. The Governor may then be pre-

1 Konondaigua, Pickering calls him.

2 A second letter on this subject was sent on April 18. 
pared to give an answer to the deputation as soon as they reach New-York. And it is of consequence to the deputation not to be detained in that city; because the Commissioners of the State, at the treaty, told the Cohnawagos that they were not to reckon on the State to defray the expenses of any more of their deputations.

"The Secretary supposes it will be necessary to make a present of two hundred and fifty or three hundred dollars to Colo. Louis and the rest of the deputies, to enable them to return to Cohnawaga. And if this be given them to-day, they may certainly leave this eity to-morrow-morning. Mr. Francis, on notice, will have their passages engaged.

"March 21. 1796."

“Timothy Pickering.

On April 25, the Caughnawaga question was still unsettled and Pickering wrote McHenry :

"Finding no such paper as the Cohnawagos now call for, I returned from my house to examine once more at my office: but no such paper appears: and I am confident I never saw any paper purporting to be a power from the Chief to Colo. Louis and others; for when by their speeches they declared they were impowered to make a final agreement for their nation, I recollect that the idea was perfectly new to me.

"I think however, that the final settlement may be made in the way I suggested. I am disposed to believe the present deputation to have been empowered, as they declare. The negotiation then may be held with them, and the terms agreed on. They may then return to their nations, and the State of New-York suspend the payments stipulated, until agents duly empowered shall come to receive them. To make the transaction still more satisfactory, New-York might send an agent with the deed or treaty which the present deputies shall conclude, and obtain a formal ratification by the signatures of all the Chiefs of the Seven Nations.'"

It was with the Western Indians that McHenry was chiefly concerned however, especially in connection with the transfer of the Western military posts from Great Britain to the United States as a consequence of the Jay treaty. ${ }^{1}$ The

\footnotetext{
1 Sir.

"I have received from a highly respectable source the following observations.

"It certainly is desirable that the officers commanding the detach-
} 
frontiersmen were, of course, hostile to these Indians and, on May 22, Thomas Dillon wrote MeHenry from Nashville, urging him to invest in Western lands and saying that he had been at several forts, at each of which "are stationed about fifteen men, altho not under that regular discipline or subordination as might be expected, many of them being commonly absent, from which a body might be apt to infer, that supporting the Garrisons were useless and unnecessary; but the fact is otherwise; I think them highly necessary, and very proper barriers between the whites and Indians. These garrisons are very ill supplied with provisions owing in some measure to the economical ideas of Col. Henly, the agent for Indian affairs at Knoxville. The people murmur very much. These parsimonious ideas ought not to prevail, so as to injure the public credit. Many of the whites are disorderly and licentious and would be glad to seek an opportunity of kicking up a dust with the Indians, but these are of a class that have nothing to lose or that have lands within the Indian boundaries; the more respectable and thinking part, however, are highly averse to any proceedings that might have a tendency to involve the Country in a war. In Cumberland, I believe they are possessed of these sentiments to a man. Those on Holstein ${ }^{1}$ are less orderly" and have recently killed some Indians.

On Indian relations, we find a very interesting letter written to MeHenry by Bishop John Carroll, of the Roman Catholic church.

\section{"Dear Sir}

"Baltimore May 29th 1796.

"Your kind favour of April 23d. inclosing one from the Rev. Mr. Rivet, Missionary on the Ouabache and among the

ments who are to occupy tl.e posts, should be moderate and discreet men. I have heard that a Capt. Bruff is to be one of them - that he is violent \& preclpitate; and also warm in his resentments to the British. All this may not be accurate; but I mention it as worthy of attention \& enquiry ; not conceiving myself at liberty to mention whence I had these hints, I mention them in confidence, \& only as inducements to enquiry.'

"I am inclined to suspect the character of Capt. B. may warrant the above remark: but if he has been designated, as I suppose is the fact, for that service. I do not see how any change can be made: But a very serious caution may be given to him and to every other officer, to avoid every cause of irritation. and on the contrary, to study on all occasions to concillate, and establish a friendly intercourse, so far as any intercourse shall arise out of the service: a very famillar intercourse would be too expensive for the American officers.

$$
\text { "Sincerely yours }
$$

"T. PICKERING"

A letter from General Anthony Wayne to McHenry about the equipment of the Western posts, dated Philadelphia, February 24, 1796, was printed in 2 nd series Hist. Mag., ii.

1 Holston River.

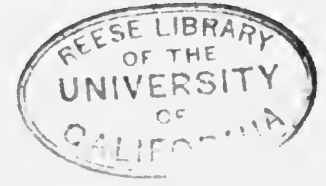


Illinois and neighbouring Indians, was received some time ago, and gave me new reason to regret my absence from Baltimore at the time, when you received your appointment; because I should have taken the liberty of making you acquainted with his merit, and sollicitude to render important services to the United States, by humanising \& moralising the Indians; and of interesting your sensibility for him and his companion who have undergone the greatest hardships, by an unfortunate delay of payment, and other disappointments. But that, which seems to affect him the most, is, that tho' he is engaged in a pursuit so useful and humane, he does not meet with that support and consideration from the officers of the United States, which, he thinks, it would be proper for them to afford to him, whilst he is acting under public authority, \& for a public purpose, as well as the benefit of those wild savages. He says: "je suis ici sans conseil, sans credit, sans moiens quelconques pour parvenir aux fins, que le gouvernement paroit s'être proposé. Ce n'est pas ainsi, que la France est parvenue à civiliser et reformer entierement plusieurs de ces tribus. Ausi ma commission est elle ici dans un discredit total. Le commandant du poste ne m'a appellé à aucun conseil des Savages tenus au fort, quoiqu'il me l'eut promis lors de mon arrivée, et que cela se fut toujours pratiqué sous les Francois. J'ai ecrit au General à Greensville pour les objects tres essentiels; je n'en ai eu aucune reponse; aussi je n'ose presque plus faire un pas, former une demande, ou off rir une reflexion \&c.' After citing thus his own words, allow me to submit to your prudence and discretion the propriety of recommending him to the countenance and regard of those, who may contribute to the good purposes of his mission: to which will greatly contribute some good regulations, faithfully executed, with respect to the furnishing of the Indians with spirituous liquors. Every person must be sensible of the difficulty of this measure; but, as it appears from your letter to have engaged your attention, it may be reasonably hoped that all will be effected, that is possible under our laws.

"Mr. Rivet requested, for the sake of greater security to letters for him, that they might be sent by the same conveyance if possible as those from your department; and with your recommendation of them. I adopt this method with diffidence, and shall not persist in it, if there be the least impropriety.

"'Receive, Dr. Sir, tho' late my cordial congratulation for the distinguished testimony of esteem and confidence bestowed 
on you by him by whom it is so honourable to be esteemed: and assure yourself, that I feel the more pleasure at your being raised to your present station, not merely because it is a public acknowledgement of your merit, but because I believe in my heart that you are, in every respect, worthy of it

"I am with great esteem and respect,

"Dr. Sir,

"Your most obedt. \& humble St.

"J. Bishop of Baltimore.

"P. S. I have been addressed to provide Clergymen attached to the United States, for the stations, which are now to be ceded by the British, and I have taken already some measures to that effect: and you may rest assured, that the persons appointed will make it their endeavour to rcconcile the inhabitants to our Government and interests. Amongst other places requiring such provision there is one, including, I believe, the rapids of the Miami, and called la riviere aux raisins. The parish priest residing there, under the British, is called Edmund Burke; and I am informed, that he was obnoxious to General Wayne \& our officers, from a persuasion, they were under, that he instigated the Indians to enmity with the United States. I have reason to think nevertheless that Mr. Burke wishes to become a citizen with us : and in a letter to me he denies in the most peremptory manner, the charge brought against him; which, he says, has no other foundation, than his having opposed, with success, the machinations of inflammatory emisaries from the faction of Genet, who has penetrated to Fort Detroit and its neighbourhood, to produce anarchy and insurrection. I take the liberty of mentioning this, that if there be, in your office, any certain documents of Burke's enmity to the United States, you may be pleased to advise me thereof. \& I may know, how to proceed with him."

On May 9, Washington wrote McHenry to facilitate the march of troops to Western posts, but to proceed with caution. 1 On June 28, McHenry wrote Washington, describing the reception in Quebec of Major Lewis with dispatches concerning the Western posts. " He "was treated with much civility by Lord Dorchester's family" and reported "that the people seemed everywhere pleased with the prospect of a friendly intercourse with our citizens." Dorchester was par-

1 Sparks, xi, 125. ernor of Canada. 
ticular in his inquiries as to Washington's health, and, at the dinners, which were so numerous that Major Lewis could have dined out for a month in Quebec, "the first toast was The King of Great Britain, the second, invariably, the President." Washington, in his answer on July 1, referred to these accounts as "very pleasing," as they point toward the realization of "that tranquility and peace with the Indians, which, in itself, is so desirable and has been so much wished and sought for." In the same letter, he directed McHenry, "by civil expressions, to stimulate the present Governor of Tennessee to an effectual repression of encroachments on Indian territory (secured to them by treaties)." If he will not act, "the honor of the government and the peace of the Union require" that the laws be "promptly and energetically (with temper and prudence) enforced."

On August 8, Washington informed McHenry ${ }^{1}$ of the occupation of Fort Ontario and discussed sending supplies to that post. The Federalists felt the transfer of the posts redounded much to their credit and Murray wrote on August 21:

"Would it not be a good thing to paragraph \& press a little the late events in the delivery of the posts. A manner pointedly conciliatory \& even handsome seems to have characterised all the several surrenders - as we hear-much might be made of this at least as fringe work to the Triumphs of the Treaty \& its friends. Events strike more powerfully than systems. Wayne! ah could we both have but seen W's Entre into Detroit! when he pranced over the Barbacon."

Troubles with the Creeks $^{2}$ and with the Cherokees,

1 Sparks, xi, 159.

Sir,

The Secretary of War.

Your letter of the 18 th instant with its enclosures, came to hand by the last Mall. Such of the latter, as are original, I herewith return to your Office.

It would appear from the extract of Mr. Habersham's letter, that the Treaty (or rather meeting) between the Georgians and Creek Indians, has terminated unfavourably, and will tend, it is to be feared, to hostilities. A favorable result could not have been predicted from the speech of the Georgia Commissioners, at their commencement of the business with the Iridian chlefs; and it having ended without a cession of Land, I shall be agreeably disappointed if there are not other means, soon used, to get possession of them.

By the letters from General Wilkinson and Captn. Briff, I expect the Western Posts wlll soon be in our possession; and I hope proper measures will be adopted to keep the-Garrisons well supplied with provisions and Milltary Stores.

Mount Vernon 22d July 1796

Go. WASHINGTON 
also occupied MeHenry's thoughts. ${ }^{1}$ As to the former tribe, McHenry wrote Washington on August 3, urging him to place regulars rather than militia in the Indian country. For the latter tribe, McHenry drafted a talk which he sent Washington ${ }^{2}$ on August 24, recommending instructions to Dinsmore, the agent, and adding, "I have consulted him upon the practicableness of teaching the women to spin and weave and he thinks it may be accomplished." Pickering, in a letter to Washington of September 2, criticised the talk as not dignified. Shortly afterwards McHenry wrote certain instructions to Hawkins, 3 which Washington returned with the following note:

"Private

$$
\text { "Wednesday Morning [September 7, 1796.] }
$$

"Dear Sir,

"The principles of the Enclosed Instructions I approve; and since they are drawn, I shall not object to the Phraseology ; tho' considering that it is addressed to our Agent, for his Government, part of them, I think is too much in the stile of a talk to the Indians. And I think too, as it is intended for the general superintendent his attentions seems to be too much confined to the Creek Nation

$$
\begin{gathered}
\text { "Yours always — \& sincerely , } \\
\text { "Go. WAshingtoN." }
\end{gathered}
$$

1 Pickering wrote MeFenry :

"Department of State July 8, 1796. "Dear Sir

"The President, in two letters I have received this week, mentions these points for consideration -

"1. 'How soon \& in what manner' the Cherokee boundary can and ought to be run \& marked, agreeably to the treaty of Holston.

"2. What can be done relative to the appointment of an Indian agent (superintendant) in the room of Governor Blount; and of the Agents for carrying on the Indian Trade."

2 Washington wrote McHenry on July 18 (Ford, xii, 246), regretting that the boundary of their reservation could not be marked before spring, as no commissioners to superintend it colid be appointed in the recess of the senate. He also stated that he hoped the visit of the Cherokee chiefs might be deferred until November. "Sir,

A short note from Washington about this time reads thus:

"The enclosed Conditions appear proper-but as there are certain principles I practice that govern in such cases - it would be too hazardous to Give an opinion with out consuiting them - and it is impossible for me to go into such detail.

"Philadelphla 4 th. Sep.

$$
\text { "1796 }
$$

"Go. Washington."

3 Benjamin Hawkins was born in North Carolina in 1754, graduated at Princeton, served in the Revolutionary War, was a delegate in the confederation congress, was United States senator from North Carolina during the years 1789-95, and then became agent for superintending all the Indians south of the Ohio River. 
On September 13 and on October 13, Pickering wrote McHenry about the Oneida and Stockbridge Indians and their annuities. Among those tribes, the Quakers had built a grist mill and a meeting house.

McHenry had much at heart the improvement of the Indians' condition, as is shown by a letter sent him by Murray in October.

"Of the policy which you are now organizing, the civilization of the Savages, great donbts may be entertained without an affront to the Czar who attempts so much glory. From what is known of the progress of nations from infancy to manhood may it not be ventured as a general proposition that the means which have drawn out the social character have been snch as were congenial to the State in wh. any nation was, to whom they were applyd.

"Every one of the European nations was martial. It is thus that of their Savage State we know nothing. We have testimonies of their barbarism or second state only, but from the data which these furnish, something may be learned of that scheme wh. might most probably draw them from the savage to the barbarous. One engine of incalculable powers is now possest by the civilizing hand that was not known in the early ages, the art of printing, yet this affords not a ready source of those habits which constitute Society as it stands any where. An individual may acqnire learning by it - but it would teach the indian scholar things applicable to refined Society not to his own - were it possible to digest a plan of Property for them in Land agreeably to the Feudal earlier ideas, the most congenial to their present State, it appears probable that it would not last long. The existence of nations behind this belt of eivilization which you would stretch along the Frontier would hold out a tempting asylum for original habits \& manners \& the belt would be gradually depopulated. Were there an ocean interior of a Mississippi a plan of coarse \& improving principles might possibly be formed - as it is, I confess, I almost despair - because I can find nothing like it elsewhere. I fear that the only way to civilize savages is to first enslave them - all nations have so advanced. It is dread. ful - but I fear true. Peter \& the following Czars, for some time, seemed inclined to consider the vast nation they owned as capable of any civil impressions they might choose to give. They found this not the case - that a half savage nation have 
habits as inveterate as a refined nation \& perhaps the habits of such a nation are more so - \& that to advance Such a nation it was necessary not to consider it as a blank paper upon wh. any thing might be written. but to ascertain the last step it had taken in its progress \& only invite the foot a little forward in what was the most natural attitude. I have all along imagined it a useless attempt to make the Indians like a white nation - my humble ( \& I own it may be a crude) plan is if any attempt is made, to make them as much as possible like the Barbarians of Germany - first, still infusing that milder tinge into their character that would follow the art of printing - one mistake in all the plans I have seen seems to me to be that the whole was predicated upon what could be done upon one or two individuals educated in a white country. Were it possible to bring a tribe of infants \& educate them in Philad. it would prove nothing that was not as well known before. The difficulty is in rearing a nation from old habits by attracting them to higher habits, analogous to those they are invited to forsake. But you are fatigued by objections without reasoning that points to any alteration - \& all must [be] jejune to you who have been turning the subject over and over for some time. I write for the mere pleasure of having conversation with you \& always in strict confidence - so it is like a fire side chat."

By the admission of the Southwest territory, on June 1, 1796 , as the state of Tennessee, the office of superintendent of Indian affairs there ceased. McHenry ${ }^{1}$ wished to appoint agents for carrying on commerce with the Indian tribes, in accordance with a recent act of congress, but Wolcott said he had no money for that purpose. In that case, said Washing. ton in his letter of July 18, we can have no agents, but a temporary regulation of the trade in the hands of some one man may be made. ${ }^{2}$

In his report to congress, ${ }^{3}$ MeHenry opposed a petition favored by Andrew Jackson, to pay a claim for militia called out in 1793 to act offensively, but said congress must decide

\footnotetext{
$1 \mathrm{He}$ estimated the six nations as 3580 in number. A drunken smith is complained of.

2 Ford, xili, 246.

3 State Papers, Indian Affairs, i, 585, 621. In November, 1796. John D. Chishoim (Am. Hist. Rev., 595) brought with him to Philadelphia about twenty-two Indians and a petition of about twentysive British residing in the territory of the Indian nations asking to be made United States citizens. He presented this petition to McHenry, who treated it with coldness and said he would refer it to Hawkins.
} 
how far the Indian aggressions constituted an imminent danger, or whether the expedition was a just and necessary measure.

In relation to appointments to office McHenry appears to have had but little trouble under Washington. Only two letters have been found on this subject and one of them is an answer to a tender of an office made by Washington through MeHenry. ${ }^{1}$

1 Pinkney was offered the position of commissioner under the Jay treaty to adjust claims between Great Britain and the United States.

Another letter respecting an appointment reads thus:

"New York 11th April 1798.

"Dear Sir

"A Letter recd. the 5 th inst. intimating that one of my little Boys was ill of a Fever occasioned my sudden Departure for the Place. The child is happily recovered and runs about as usual.

"It is high Time that my little Boys went to School and I wish if possible to have them under my own Eye but how to effect that Arrangement is the Question If I was to remove them to Carolina and either of them to sink under the Climate I should never forgive myself knowing the Climate there to be very unfavourable to Children. To settle in the Country might not be agreeable to a person accustomed to converse with Men of good Information and my finances on the present Scale of Prices are not quite equal to a City Establishment. 8 or 10 hundr. additional Dollars per Annum would answer my Purpose but I cannot submit to any subordinate Station and higher ones are generally objects of much Competition. There is a Bill now before the Senate for opening a land Office It contemplates a Surveyor Genl. I have not heard what Salary he is to have. I am informed that Ellicot will be appointed to run the Line betwecn Spain \& the U. S. viz the boundary of Florida. The Surveyor Genl. ought to be fully acquainted with Geometry. I think I should not greatly overrate my Abllities in supposing that on the meer Question of Capacity to execute the Office I should not have many Rivals. I should not refuse the Place if it was offered and presume you could with a safe Conscience before the President has fixed on any Person, intimate that I might be considered capable of executing such an office. I know that if the Salary is respectable Members from the several States will be pressing the Interest of some of their Constituents. The North Carolina Members are I believe without exception desirous to do any thing that in their Opinion would be profitable or acceptable to me, but as they are at present every one in Opposition to the Measures of Govt I know they would not willingly ask favours. Whereforc I have never intimated to any one of them that I would accept of any Employment. If the President, when the Object is simply presented to his View, does not make the appointmt. he ought not to be solicited, but as he probably may never have heard that Geometrical Calculations had formed part of my Study, you probably will have no Objection to mention to him what You take to be the generai Opinion on this Head.

"I find people here very anxious concerning the Determination of Congress on the Subject of Treaty appropriations.

"I have no pretentions to Prophecy but believing that things will happen as they usually have happened and having read from History to be informed how they have evented, I am under strong Impressions that if French Obstinacy or Pride of conquest produces another Campalgn the Republican Governmt. of that Country will be in great Danger. French Arms have uniformiy proved unfortunate across the Rhine.

"I am Dr sir with great Respect

"Your obedt. hble. Servt.

"Hu Williamson." 
"Susquehanah Ferry

"March 21st 1796.

"Dear Sir.

"Your friendly letter has found me at Mrs. Rodger's, at a distance from my Family, excessively fatigued and somewhat indisposed; and you will of course perceive that I ought not to determine conclusively on the subject of it until I reach Annapolis, for which place I am under the necessity of setting out Tomorrow.

"I will, however, state to you my private Impressions; and hope that a definite Answer may be dispensed with for a few Days.

"The Veneration and Attachment I have always felt for" the President of the United States can hardly admit of addition; but I confess to you that I have never experienced any gratification superior to that which results from this flattering Proof of his Confidence. Without Expectations of any Sort from the Federal Government I had not for a Moment turned my views to any appointment under it; but I have felt an uniform Anxiety to obtain the good opinion of the President as a valuable Testimony that $I$ have not lived in vain. Your Letter affords me this Testimony in a Way so honorable to myself that I cannot express to you the pleasure it affords me.

"My inclinations lead me to avail myself, immediately, of the Presidents favourable Intentions - and I believe it to be my Interest to do so. If I should decide finally, at this Time, I should undoubtedly declare my ready Acquiescence. But as the Acceptance of this Trust might, and certainly would, materially change my future Prospects, and, during a considerable period, suspend my professional pursuits, it will be prudent to reflect a little on its Consequences before I act definitely. I shall not require more than four or five days for this purpose and will communicate the Result by Express.

"I cannot avoid expressing the grateful sense I feel of the Interest you are good enough to take in my concerns.

"You may be assured that I shall not easily lose the Remembrance of it and that I shall seek opportunities of manifesting the Value I place upon your Friendship.

"I am, Dr Sir, with sincere Esteem

"V. Obedt Servt.

"WM. Pinkney." 
On the side of his naval duties, ${ }^{1}$ McHenry's chief care was the superintendence of the disgraceful task of building the frigate which the country gave the Dey of Algiers and which Pickering, on August 11, recommended to be built at Portsmouth, as it could be completed there in twelve months, while it would take sixteen montlis in New York. The "materials must be durable, or we shall, in a few years, have to build another frigate for the same use." McHenry was slightly uncertain at.first, whether he or Pickering should built it, though he thought it fell in his province and wrote Washington who was at Mt. Vernon on July 7 , asking ${ }^{2}$ about it. Twice, on July 8, Pickering wrote McHenry on the general plan of the ship :

"I have conversed with Mr. Wolcott: We are both of opinion that the first step towards building the frigate, is to send Mr. Fox to the different Navy Yards, to take an account of the timber, and to converse with the principal builders, to see on what terms \& within what time they will, any of them, undertake to have her completed. We think it ineligible and fruitless to advertise for a contract. The explanation which Mr. Fox ean give to the master builders, will enable them to state their terms, which he will bring back with him, \& then a choice may be made. I am convinced that it will be in vain to seek a substitute for Mr. Fox : \& I beg you to decide thereon that his instructions may be prepared to enable him to start, by farthest on Monday."

"In answer to your enquiries relative to the dimensions of the frigate for the Mediterranean service, I have to inform you, that she is to carry 36 guns, of which 24 are to be nine. pounders, and the other twelve six pounders. On these grounds, I desired Mr. Humphreys to calculate the proper dimensions of the hulk, and to make a draught of the same. The draught I presume Mr. Fox has completed, in which the dimensions must be accurately stated. Independently of which however, Mr. Humphreys made the inclosed statement: but if it varies from the dranght (for it was written you will see on the 29th of June, when the dranght was only begun) the latter must be the guide. Her masts, spars, sails and cordage may be calculated after Mr. Fox's return, as well as the

1 On February 21, 1797, he suggested to Hamilton the establishment of a permanent navy yard, and enclosed a draft of his departmental report in which he tried not to censure his predecessors.

2 Wolcott also wrote Washington on the 7 th, asking whether he, McHenry, or Pickering should superintend the building. Sparks, xi, 147 . 
anchors and all her other equipments. The guns, powder \& shot, you will perceive by the inclosed letter \& estimate of $\mathrm{Mr}$. Hodgdon, are on hand. The guns, however, ought to be criti. cally examined, and proved: they ought also, I think, to be uniform; and if those we have are not so, it may be best to cast a new set at Cecil furnace, and to have them turned (to take off the most considerable roughness at least) while they are boring." 1

Washington answered ${ }^{2}$ McHenry's note on the 13 th, expressing his surprise and displeasure that the frigate had not already been begun, but not answering McHenry's question and saying, "Let me, in a friendly way, impress the following maxims upon the Executive Officers. In all important matters, to deliberate maturely, but to execute promptly and vigorously, and not to put things off until the morrow which can be done and require to be done today. Without an adherence to these rules, business will never be well done, or done in an easy manner, but will always be in arrear; with one thing treading upon the heels of another." Five days later, ${ }^{3}$ he wrote again, stating that he approved McHenry's plans for the frigate and directing him to sell all timber and plank owned by the government and not needed for the building of the Algerine frigate or the three which were to be constructed for our own navy. 4

On July 12, McHenry ordered Josiah Fox to inspect the

1 Cecil furnace was probably that at Principio, in Cecil county, Maryland. Another letter of Pickering is as follows :

"Sir,

"Department of State July 14, 1796.

"The foliowing are the articles about the procuring of which it is desirable that Mr. Fox may make enquiry, as to the places where, and the terms on which they can be obtained.

"60 masts, 90 feet long, 32 Inches diameter; 110 spars, 80 feet long, 20 Inches diameter; 1500 pine planks)

1500 oak planks) 44 feet long, 6 inches thick, 200 pleces of pine scantling.

"I suppose pine planks should be hard pine. No breadth is mentioned In the stipulation for planks, nor any dimensions for the pine scantling. The oak planks should doubtless be of white oak. It may be practicable to procure some of the spars, plank and scantling without delay; and it is much to be desired that at least one ship load may be obtained to be sent to their destination the ensuing autumn. If some of the planks were shorter and some longer, so as to average 44 feet in length, I should Imagine the purpose would be answered.

2 Sparks, xi, 146.

"Your obt. servt.

3 Ford, xili, 246.

4 Three frigates formerly planned had been discontinued by a rocent act of congress. Six erigates were ordered to be built against the Algerines by act of March 27, 1794. 
navy yards and on September 13, the specifications for cannons for the frigates were issued. 1

When McHenry came to the department of war he found the army organized in a legion composed of the three branches of the service.

McHenry's first report was made to a senate committee on March 14. He advised against reducing the military force of the United States, placing the necessity of a military establishment on the following grounds: It enables us to repel insult and invasion and maintain our dignity, it counteracts the influence of the British and Spanish armies in exciting Indian hostilities, it serves as a model or school for an army and furnishes experienced officers to form one in case of war, and it supplements the inadequacy of the militia. The diffieulty is to avoid useless expense and yet secure these advan. tages. The British and Spanish forces in North America are probably greater than ours and are not likely to be contracted on the evacuation of the posts, for England will not wish to lessen her influence over the Indians and will try to preserve the influence and safety of Canada, where she finds a link in the great chain of her dependencies, especially important in respect to the West Indies, while Spain has even stronger reasons, for the new treaty will bring our eitizens near her possessions. He thought there was no need of a judge advocate at present and that, probably, there could be no saving in the quartermaster's department, for the expenses of transport to the Western posts will be great, whether by land or water.

On May 30, 1796, a law was passed changing the organization of the army into one of four regiments of infantry, a troop of dragoons, and a battery of artillery. This reorganization was clearly a result of MeHenry's suggestion, as Washington's letter of July 1st to him shows. ${ }^{2}$ The arsenal at Harper's Ferry had been begun. ${ }^{3}$

1 State Papers, Milit. Aff., i, 114. Naval Aff., 44, 54.

2 Sparks, xi, 132 ; Ford, xili, 222.

3 Dear Sir,

Your favour of the $2 d$ instant. came duly to hand. For the perusal of the enclosure I thank you. It is returned.

We heard with much concern, but long after the thing had happened, of the accident which befel your son. we hope he is perfectly recovered from the fall, and you from your bilious attack.

Having no news to enfertain you with, and could only fill a letter with the perplexitles I experienced daily from workmen, and other occurrences of little moment to any besides myself, I shall conclude this letter with best respects - in which Mrs. Washington and Nelly Custis nons for the frigates were issued. ${ }^{23}$ 
During the summer, charges were laid against General Wayne, the head of the army, by General James Wilkinson. Washington, in his letter of July 1, directed McHenry to obtain the opinion of the other heads of departments as to the proper course for him to pursue. He doubts whether a court martial can be called. In any case, he thinks Wayne should have a copy of all the charges made against him, and Wilkinson should be furloughed. For advice as to what should be done in reference to these charges, McHenry wrote to Hamilton, Chase, Murray, and Charles Lee, the attorney general, from all of whom he received replies. Hamilton, on July 15, answered that the president might order a general court martial, but it would be preferable for him to examine into the charges as commander in chief and displace Wayne, as holding his commission "during pleasure," if he found him guilty, Chase, in an extra judicial opinion, on July 22, held that Wayne might ask for a court of inquiry, or be tried by a court martial. Murray, on August 6, held that there could be no court martial of the commanding general and seemed to think there was no legal method of action. ${ }^{1}$ Lee, on November 22, not yet having seen the charges, wrote that either a court of inquiry or a court martial could be held. Before any steps could be taken, however, Wayne's death, on December 15, put an end to the controversy.

unite-to Mrs. McHenry and yourself - and with assurances of being Dear Sir

Your Affecte friend

Go. WASHINGTON.

P. S. My mind during the last days of my remaining in Philadelphia was so much occupied with public \& private concerns tilat I always forgot, when I was in your company, to enquire whether Mr. Lear had accounted to the War Office for the money he had received to purchase the site for the Arsenal on Potomac. As I was, in some measure the cause of his Agency in that business, I wish to know whether it is settled to your satisfaction.

Be so good as to send the letter for Mr. Dandridge to his lodgings if he has not salled, or left the City.

Private

Tuesday 11 th. Jan. 1797 .

Dear Sir,

I shall have occasion to write to Mr. Lear by tomorrow's Post, and would thank you to let me know (in a summary way) what money he has drawn on acct. of the Arsenal on the Potomack; and what report he has made to the War Office of his proceedings in that business; for I shall take an occasion (as from myself) to ask him what has been dono therein Yours always

McHenry answered this letter.

Go. WASHINGTON.

1 "Upon the point which you told me to write an opinion on (W's trial) I can collect nothing but from unaided reflexion for I have no books at command in which I could find Precedents - if I had you (know) I would search with - pleasure \& alacrity." See "Army and Navy Journal," xlii, 195. 
How well McHenry succeeded in smoothing over difficulties between officers and how tactful he was in so doing, may be seen from the letter he addressed Captain Decius Wadsworth, on July 1, in response to a letter from the captain asking that papers making charges against him be sent him.

"I well know, having often witnessed the struggles of high minded men in the course of that obedience which military subordination exacts, how difficult it is to bear with the neglects and sometimes rude ignorance of superior rank, or to suppress the idea of revenge for matters which torture the soul without their coming under the description of noticeable insult. These are among the incidental evils of a military life, which to support, requires magnanimity, joined to patience, which looks forward for better things; while it submits to what it cannot avoid. It is in the service, we expect to find an honor that shrinks from every thing mean and, at the same time, a respect to rank and strict conformity to the right principles of subordination, without which an army must soon become one huge mass of discontent and sedition. If men of sense, on such occasions, will not give up every consideration but their honor, if they will not make sacrifices of feelings for the sake of their country, I must relinquish the idea of being useful to the corps, but I trust, without fear of being disappointed, upon receiving assistance of men of your understanding to calm the spirits which have been excited, to restore the harmony which has been disturbed, and save the corps from dissolution. Relying on your cooperation in these particulars, you will at once perceive that it will be best that the request which you have made me for a copy of Col. Rochefontaine's defence should not be urged. It is a writing, composed when the Colonel's sensibilities were high, and if it includes any observation to which you could take exception, consider that it is not intended for publication, that it can not escape from my keeping, and, above all, that it contains nothing which has produced any change in the good opinion I had formed of your understanding and honor."

With Washington, the secretary's relations were pleasant and even in rebuke the chief was thoughtful and considerate. When Lafayette's son came to Philadelphia, Washington wrote McHenry on April 11, 1796.

"Dear Sir

"Young Fayette and his friend are with me. Come \& 
dine with them to day at 3 o'clock if you are not otherwise engaged

\author{
"Yours always \\ "Go. Washington."
}

When Washington ${ }^{1}$ wrote his official letter of July $\mathbf{1}$, previously referred to, he also wrote a personal letter which follows :

"By the Post, rather than by the Express, you will receive my Official letter, and its Enclosures. For the difference of a few hours, in a case that is not urgent, I would have you avoid sending an Express to me. The latter does not travel faster than the mail; of course there cannot (unless sunday intervenes) be more, in any case (supposing an occasion to arise in one hour after the mail was closed) than the difference of 48 hours in the receipt of the dispatches; as I send regularly, every Post day, to Alexandria for my letters. Your Express came in yesterday at 5 o'clock in the afternoon, and if you had sent the letters by the mail of Wednesday, they would have been here at 9 o'clock this afternoon, a difference of 28 hours only.

"The information brot. by Captn Lewis is very pleasing; and I hope the orders on both sides will go smoothly into effect: but the Aurora will have doubts, that all is not well, notwithstanding. This, however, is a matter of course ; for the Executive Acts must be arraigned.

"I hope you have got perfectly recovered, and that Mrs. McHenry and the rest of your family are well also.

"When I left Philadelphia, it was expected that MIr. \& Mrs. Liston (and from their own declaration') was to follow, on a visit to this place, in ten days; an interval of a few days - and then the Chevr. de Freire \& Lady were to follow them ; and altho' Mr. Adet gave me (tho' asked) no assurance that he would make me a visit, yet to Mr. Fayette he said he should set out in ten days - since which I have heard nothing from,

1 "Return the enclosed as soon as Mr Ross (under strong injunctions) has read it. Never put papers, improper to be sent, under a cover sealed with a wafer - at any time, but especially when wet, the contents may be seen and the cover closed again without suspicion, or appearance of being opened.

"G W $\mathrm{W}$ "

This note is thus docketed:

"This enclosed the information given by Mr Wolcott respecting [Collot Waren] \&c - which I communicated to Mr Ross "4 June 1796 "J MCH" 
or of any of them, which occasions suspence, that impede other arrangements.

"If you could, therefore, indirectly, or at least informally, ascertain whether and when, I am to receive these visits, I should be obliged to you; as it would enable me to regulate some other matters which depend thereon.

"With sincere esteem \& regard

"I am - Dear Sir

"Yr. Affectionate

"Go. WASHINGTON

“"Friday

" 7 oclock in the morng.

"Have you allotted any Infantry for the Posts of Oswego \& Niagara? How many, \& when will they be there?"

On July 5, McHenry writes that the Chevalier Le Freire and Liston will soon start to visit Washington at Mount Vernon, but that he has no news as to Adet. ${ }^{1}$ Two days later, he writes that Chevalier Freire will not come, as his wife thinks it is too hot for the journey. McHenry himself was somewhat unwell at the time and shortly afterwards writes that he has heard a rumor that Washington had been thrown from his phaeton, and is glad it is false. "I know not what new sacrifices we may yet have to require of you. The world grows older and republics occupy more and more of its surface but I do not find that it becomes better." Washington seems to have been quite offended at the rumor of his injury and replied on July 18.

"Private

“18th. July 96.

"Dear Sir,

"I have not sagacity enough to discover what end was to be answered by reporting - first, that I was to be in Philadelphia on the 4th July and secondly, when that report was contradicted by my non-appearance, then to account for it by a fall from my Phaeton.

"If any scheme could have originated, or been facilitated by these, or any other reports, however unfounded, I should not have been surprised at the propagation of them ; for evidence enough has been given that truth or falsehood is equally

1 On July 11, Washington wrote (Ford, xiii, 214) that he invited Adet, as cordially as he did the others, and trusts that McHenry will repeat to him the invitation. Liston was the British minister. 
used, and indifferent to that class of men, if their object can be obtained.

$$
\begin{gathered}
\text { “I wish you well \& am always your } \\
\text { "Affectionate } \\
\text { "Go. WAsHington.", I }
\end{gathered}
$$

As early as August, Washington began to consider the framing of his message to congress ${ }^{2}$ and wrote McHenry on the 8th.

"Dear Sir,

"Your private letter of the $3 \mathrm{~d}$. instant, accompanying the Official one of the same date, came to hand by the last Post. The draught of the letter to the Governor of Georgia is approved. I have added a word or two to the last paragraph but one - by way of hint, where we shall look for the cause, if Peace is not preserved an the frontier of that State.

"I request that you would begin to note the occurrences that have happened in the War Department (since the ad. journment of Congress) which will require to be communicated to that body in the Speech, or by messages, at the next Session. It is from the materials furnished by each Department, and the Memorandums taken by myself, that the first is framed; and it will be an omission, not to commit these to writing in the moment they occur; it being much easier to select, than to collect matter, for these purposes, when the hour arrives for digesting them into form. If other things (although they may be extraneous to your department) should occur let them be noted also. It is better to have them in all than to escape all the Memorandums I shall be furnished with.

"I am always \& sincerely

"Your Affectionate

"Go. Washington."

Relations with France were growing more strained. On

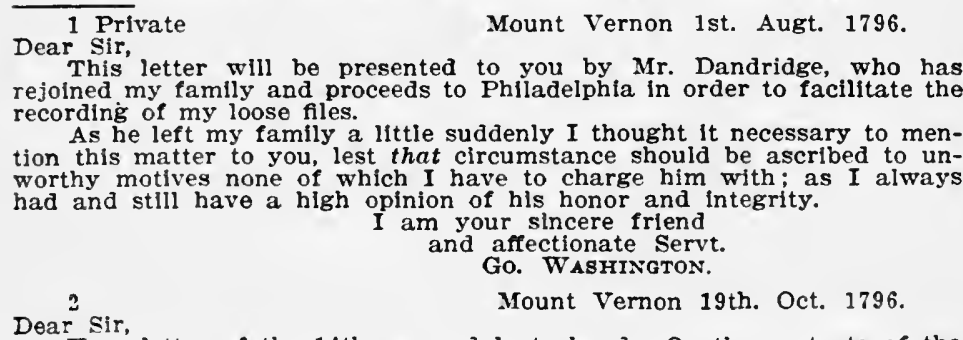

Your letter of the $14 \mathrm{th}$. came duly to hand. On the contents of the 
June 1, Hamilton wrote ${ }^{1}$ telling McHenry that he writes to him rather than Adams or Pickering, as his information is not official, but that he hears that the Directory complain of Parish, the American consul at Hamburg, and adds: "We must not quarrel with France for pins and needles. 'Tis a case for temporizing, reserving our firmness for great and necessary occasions." Monroe was not satisfactory as our minister at Paris and, on June 15, Hamilton wrote Wolcott: "After turning the thing over and over in my mind, I know of nothing better that you have in your power than to send McHenry. He is not yet obnoxious to the French, and has been understood, formerly, to have had some kindness towards them. His present office would give a sort of importance to the mission. If he should not incline to an absolute relinquishment, his mission might be temporary, and Col. Pickering could carry on his office in his absence. He is at hand and might depart immediately; and I believe he would explain very well and do no foolish thing." 2

On July 2, Pickering, Wolcott, and McHenry united in recommending to Washington Monroe's recall. Washington answered McHenry on the 8th:

"Dear Sir;

"Having written a great many letters for this day's Post, and being a good deal fatigued thereby and with the heat of the weather, I shall do no more at present, than to inform you that your letters of the $2 \mathrm{~d}$. and $3 \mathrm{~d}$. instant with the enclosures of the first came perfectly safe, and that my letter to the Secretary of State of this date, will inform you confidentially of my decision with respect to the recall of Colo. Monroe and the measures which I am pursuing to provide a Successor

"I am sorry to hear you have been [un]well, and glad to

enclosure I shall make no comments 'tlll I see you; - which, probably, will be on, or about, the first part of next month.

Let me remind you of what I have before requested - namely, - to have noted against my arrival, all those things which will be fit and proper subjects for my communication to Congress (in the Speech) at the opening of the session; that I may have time to consider and digest such of them as are proper for that occasion, before the meeting of it. $I_{i}$ am always and sincerely Your affectionate

GEORGE WASHINGTON

1 Hamilton, vi, 127. Lodge's Hamilton, x, 171.

2 Gibbs, i, 359. 
hear you are better. Keep so - one well day is worth a dozen sick ones

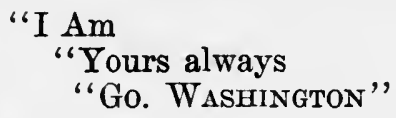

Hamilton wrote McHenry on July 15, "Have you devised any means of ensuring an explanation to the French Government? If it be not done and anything amiss happens, I don't know what will befall you all." On news of Monroe's recall, France at once suspended her embassy to the United States, summoning Adet to return. Monroe:

Murray wrote, on August 29, concerning the recall of

"The executive may be abused, as no doubt they will be by the Jacobins, on the Recall of Monroe, but the measure is perfectly proper. Surely unless there was perfect confidence in a co-operation from a foreign minister in the systems \& designs of his government well known \& openly manifested, that minister can be no longer a fit instrument of the country's affairs. Now, in this case, there can hardly be a doubt that there was no co-operation in the part of the system lately exhibited, the Treaty. A new minister will be able to conciliate this late event, with explanation, with the duties the U. S. owe as an ally to France. This, it may be suspected, has not been M. inclination \& conduct - yet considering the pains taken in this country by our precious fellows to misrepresent the temper of Govt. towards France \& stir up her indignation, it wd. appear as a measure of prime consequence to have a man who would counteract, not increase these impressions. I do rejoice at the measure - one of the Pinkneys is a man of eapital parts it is said. I only hope it may not be the anti Treaty spouter. I doubt not, however, it is the Mr. P. of whose genius \& learning I have heard much - \& who will be an ornament to the corps. You will be brilliant as well as strong in the foreign corps. I had hoped that Ames would have been the man, if a move took place \& was yet aware of the obstacle in his seat."

On November 22, 1796, Murray wrote again from Cambridge, Md. :

"To day I received yours of the 12 th. and, after some recollection, have been able to get the paper containing the 
address of the French Directory, (not embassador, as I believe I had it) to the Spanish nation \&c. This is better than I had imagined. Yes I have seen, \& twice or thrice read, the answer to Adet - and I \& others too believe it to be yours - \& I can assure you it gives pleasure - concise, clear - firm \& temperately retortive. It is the first opening of the present administration on great ground with foreign nations that has been published. I was very much pleased to hear from Shippen that it was supposed to be yours - as it proved my penetration. If all the Union were as we are here and for Fifty miles on each side, you might utter strong things to the citizen \& his treacherous directory. My fears are unaffected about the views of France upon us. Canada, Nova Scotia, Newfoundland, \& the Floridas Hers. a disorganised public mind within the union! where are we? Fisheries - posts \& a mighty influence more powerful than armies in the very bosom of the Union! Yet do I believe that, in a crisis, the PEOPLE so well understand her \& their own good that they would follow their Govt."

Hugh Williamson wrote on the same subject from Philadelphia on the 21st of November, after the publication of a letter from Adet attacking the administration.

"I have noted with Indignation, I had almost said with Surprise, the Manifesto of Mr. Adet published this Morning, for there are some Points of extravagance to which the wildest Citoyen francais could hardly be expected to attain. I am aware that Mr. Pickering cannot return an Answer to a dead or sleeping Minister and yet I have Reasons for thinking that a solid and speedy answer to this Manifesto would have most salutory Effect on the public Mind. Though an official answer cannot come out, any Citizen has a right, at this Hour, to publish his Remarks on that Insult on the rights of an independent nation, who ought not, it seems ever to make a Treaty with Pirates without consulting France. Clear solid and conclusive answers have been given by Jefferson and others to most of the acts complained of in this long address to the Passions of the People, but those answers are detached and in few hands. A-clear and general answer, conclusive to every mind, as was Mr. Pickering's last Note to the French Minister, is now wanted. Such a piece, if published, might 
soon be circulated with equal speed and universality to that with which the Manifesto is now propagated.

"I have strong and some very particular Reasons for saying that such a Publication as I have been describing is greatly needed \& cannot fail of having salutory Effects on the Minds of People in the southern \& Western Part of the Union. I confide that some of you who have every neeessary Information on the Subject will give dispatch to this, as I believe, necessary work.',

On January 25, 1797, Isaac McKim, a Baltimore merchant, wrote MeHenry from Philadelphia regarding the vexatious conduct of the French in the West Indies in seizing our merchantinen:

"Having lately arrived from the city of Cape Francois in Saint Domingo, I beg leave to inform you some intelligence of a private nature which I heard during my stay there, viz. that between the 6th \& 12th day of December last, being in company with a Mr Labigar, a merchant of the Cape, he informed me that he had heard the Commissary Sothonax declare that, if Mr. Jefferson was elected president of the United States, he would annul all those decrees lately passed, so injurious to the American Commerce, but if $\mathrm{Mr}$. Adams was elected President they should all be eontinued in torce, as also on the 23d day of Decr. last, I was informed by $\mathrm{Mr}$ Carriere that he had heard one of the offiecrs of Government say that the French minister Adet wrote ont to them that they could not possibly treat the Americans too bad, this in. telligenee I believe was received by a French gentleman who came passenger with Captain Decosta from this place, and brought dispatches from the French minister here to the Directory, Capt. Decosta left Philadelphia about the 20th November \& arrived in Cape Francois on the 8th of December. It was not believed in Cape Francois that the island Directory condemned our vessels \& property by orders received from France, but had done it from seeing the decree issued by the National Directory, respecting the treatment of neutral powers, and which decree they received by the schooner, General Green, who arrived from here about the 5th of November. Previous to this vessel's arrival, we had been assured by the Directory that all our vessels should be restored, provided we had no contraband articles on board, and a decree had been passed forbidding the privateers of the Republic to 
capture any more of our vessels, and their conduct in other respects to the Americans was friendly - the correspondence between the Secretary of State and the French Minister here, arriving shortly after the schooner Genl. Green by the Brig Abigail of New York, there was an immediate change took place in the conduct of the Directory towards the Captured vessels and those daily arriving from the Continent, by the cargos of those vessels arrived, being put in requisition for the Republic, and if the owner of them refused selling them to the Administration, the cargo was taken by force for the nse of the Republic. I left Cape Francois on the 24th of December, at which time their cruisers was daily sending in our vessels, either from or bound to English ports, and there had been no instance of any of the vessels under these circumstances being cleared."

On the same subject Pickering wrote McHenry on February 2,1797 :

"I showed you Mr. Swan's letter to Gen. Smith, in which the former would have it understood that the conduct of Santhonax and the other agents of the French Governments have not determined on their late depredations on American Commerce in consequence of any orders or letters from M. Adet, and that he has no communications from France that authorize the conduct now followed there, and that he (M. Adet) believes that it can never have entered into the 'Heads of power' (by which it must be presumed he means the Directory in france) to make such a regulation.

"Without enquiring whether Mr. Swan's statement is or is not correct, I will just remark, that the first captures made of American vessels by order of Victor Hugues for having Horses and other contraband articles on board, are expressly grounded, by that 'Special Agent' of the French Directory, on the advices he had received from $\boldsymbol{M}$. Adet, under the date of the Messidor or 2nd. of July last, and that twelve days after (July 14th.) M. Adet, in answer to a number of questions I had proposed to him relative to any new orders which might have been issued by the French Government, or any branch of it for capturing American Vessels, professed entire ignorance on the subject.

"I will further inform you that the capturing of American Vessels going to or from British ports is not confined (as 
M. Adet seems inclined to have us believe) to the West Indies; the same Game is playing in Europe: and not against Americans only: for the French Privateers, beside two of these, had captured three Swedes and two Danes and carried them into Spain, or the Spanish port of Ceuta on the Barbary Coast and the French Consul at Cadiz avowed his determination to condemn all neutral vessels going to or coming from ports of any of the enemies of France; adding that he had authority so to do. Such was the State of things agreeable to my latest information from Spain.

"'Thusmuch I thought it would be agreeable to you to know after Swan's letter to General Smith."

Meanwhile Charles Cotesworth Pinckney, who had been appointed to succeed Monroe, arrived in Paris on December 3 , and presented his credentials on the 12 th. He was soon notified that no minister could be received from the United States. Monroe was still in Paris, of which place he took public leave on December 30. Pinckney remained over a month longer, but, in February, was told to leave France. News of this insult did not come to the United States until after the close of Washington's presidency.

Washington had made up his mind to decline a third term and on this matter McHenry wrote him from Phila. delphia on September 25: "I thought best to wait till I could ascertain the full expression of the public sentiment, before I should comply with your request, to tell you all and conceal nothing from you. Your address, on the first day of its publication, drew from the friends of the government through every part of the city, the strongest expressions of sensibility. I am well assured that many tears were shed on the occasion and propositions made, in various companies, for soliciting your consent to serve another term, which were afterwards dropped, on reflecting that nothing short of a very solemn crisis could possibly lead to a change of your determination. The enemies of the government, upon their part, discovered a sullenness, silence, and uneasiness that marked a considerable portion of chagreen and alarm, at the impression which it was calculated to make on the public mind.

"Such have been the 1st. effects of an address which still continues to be a subject of melancholy conversation and regret, and I think I may safely add that, what has been exhibited here, will be found to be a transcript of the general 
expression of the people of the United States. I sincerely believe that no nation ever felt a more ardent attachment to its chief and 'tis certain that history cannot furnish an-example, such as you have given. The men who have relinquished sovereign power have done it under circumstances which tarnished more or less the glory of the act, but in the present case, there is no circumstance which does not serve to augment it."

There had been much interest in the question as to who would be president, if Washington should refuse a third term. The bitter opposition aroused to him by the Jay treaty had not shaken his position with the mass of the people. From Baltimore, James Winchester wrote ${ }^{1}$ McHenry on April 22, 1796. He had thought the treaty a "bad one," but has no doubt that "the Legislature possesses, neither expressly or incidentally, any authority to give effect to or oppose the operation of treaties." In the city, great alarm had been occasioned by the "disorganizing system" of the opposition and General Samuel Smith, who had opposed the treaty in the house of representatives and who represented the Baltimore district, was made conscious that his conduct opposed the sense of his constituents and that his popularity received a severe blow. Instructions to him to vote for the treaty were circulated, which instructions contained "strong indirect censure of his past conduct." He came to Baltimore and exerted himself to have them suppressed. Failing in this, he "set on foot a counter instruction (if I may so call it) expressing approbation of his conduct and reliance on his prudence, judgement, and integrity." It would not have done to have proposed an address against carrying the treaty into effect. Twenty signers could not have been obtained. "Washington and peace" was "the exclamation in every Circle and in every street of the Town." The prospect of defeating Smith, if he should stand for re-election, was a good one. Winchester or Howard was talked of for his opponent and, as Winchester found his professional engagements rendered it impossible to engage in any representative office, Howard would probably be chosen.

After congress had ratified the treaty, made the necessary appropriations, and adjourned on June 24, Murray wrote

1 In a second letter dated May 1, Winchester stated that public feeling ran stlll higher against Smith. 
from Cambridge that he longed for news, would retire from congress at the end of the term and found that the Eastern Shore of Maryland "had been more agitated on the late crisis than I expected." "Delaware was in a perfect ferment and are yet so at their member, Mr. Patton. Young Bayard, a fine young man of parts, and the right sort of parts well directed, will succeed him."

Three days later, Murray wrote again of his own prospects, of his wife's health, and of the capture of a merchantman by a French privateer.

"My dear" Sir,

‘27. June 96. Cambridge.

"My best friend is better and, to keep her so, I have indulged her not in a sea voyage, wh. she declines, but in bargaining for the most beautiful farm in this shore. It is about a mile from the village lower down \& upon the river - it stands with an elevation \& boldness \& variety of view worthy of a better country - \& will be, I am certain, healthy. It contains 150 acres -40 of wh. are woods - in these woods I shall soon give the raccoons \& squirrel 'notice to quit,' that I may burn brick to advantage on the spot for the foundation of a small neat house. The lady who owns it is at George Town \&, by the Packet of this morning, Col. Harrison, who is her friend here, writes that he has accepted my terms of purchase - which is $800 £$ at two equal payments by quarterly instalments. By next April, I shall be there - I should have been mortify'd, had you not missed me very much yet well do I know soon the water closes upon the oar-how soon in such a city so throng elegant and various a man's space is occupy'd. I have felt that myself in London \& without blame - for I was acted upon naturally by the genius of the place - \& when I left it the thought struck upon my heart, as if it had been new, that in that great place where I had never missed any one, in two weeks' time, I too should not be missed - but so it is. A large city is a bad scene to illustrate any state of Constancy in.

"We had heard of the capture - at first that it was a clear violation - that the captn went out of the city to take the ship, knowing her destination \& that she was genuine American property - but since we heard that the captors knew that she belonged to Mr Dunkinson, a british subject, - my remark to others is that it is to be expected that the 
French Jacobin faction in this country will, if possible, induce the french government to wink at such acts, as some indemnification for our having adopted our real independence in the Treaty - wh. is my real fear. This idea struck me too in hearing of this capture. The U. S. will not vindicate the rights of citizenship acquired by british subjects, since the peace by their acts of naturalizn-because the british say these persons are still british subjects. now if the French take the vessels or property of such trading firms residing in this eountry, \& we should complain of this as a wrong done to our citizens, they will say, no - we take the property of british subjects, not of American citizens - not regarding their rights as neutral burghers as is done by every nation, as last war those of ostend - St Thomas's \&c. What could you say in such a case? could you allow the british to treat these persons as subjects \& yet insist on the French treating them as American citizens? I should not be surprised, if our patriots were to adopt some mode of treating this ease like that wh. I have mentioned."

Several times during the summer, Murray wrote. On Augnist 8, he said, "My declaration is public that I decline to serve their majesties the people longer," and on the 21st he answered one of McHenry's letters:

"I was so fortunate as to receive yours of the 13th to day, inclosing a Minerva whom Jupiter serve in all her attributes. Except Fox's speech, the Minerva show'd herself to be as dull as wise; for She attended to little more than that lucrative walk of Literature vulgarly called advertisements.

"You know me too well not to give me credit for all due sensibility towards you \& Mr. Wolcott for your kind wishes respecting my future views \& opinions on my past life. If personal good falls on my shoulders I shall rejoice. If it do not, I am only in the situation of an hundred worthier men \& I know that there are a great many who expect - \& not an abundance from which to gratify. I will confess my weakness to you when I express a fear that, though I can not, with any convenience, continue in Congress, my habits may not have exactly fitted me to enjoy much in a very retired life, without mental enjoyment of a masculine \& energetic Kind. Of this, however, \& other things, we will hold a conversation in Decr., when you shall philosophise me into as 
real a love of Retirement as his worship Gil Blas felt when Liberated from the Tower of Segovia \& exiled from court. Pray remember me cordially to Mr. Wolcott.

"Some time since I sent down an address to their majesties the people of Somerset \& Worcester, on my declining to serve - no candidate has yet been mentioned. We shall have excellent \& trusty Electors of a Presdt., the worst come to the worst. It is said that the great Hindman has lately divided a regiment in Queen Anne's \& left his opponent in a small minority. $H$. addressed them - he is an excellent man.

"I need not say that the people here are right \& are deeply affected by the idea of the President's declining or even the chance of it. I wish he would terminate his great career by handing the government to its permanent seat - it would be a fine finish."

When the news of Washington's declination of re-election reached Murray, he wrote on September 9 :

"Of the President in future - It is in vain to lament that the President will not longer serve at least till the war is over. The timing of the exertions of the Fedd party seems to me very important. This will come from you \& Mr W. \& Col. P., for a party dispersed act without concert, unless a rallying point is understood among them. I know the delicacy of such a proceeding, but a hint might I suppose be confidentially dropt to fit persons. However you will be the best judge. I have mentioned $\mathrm{Mr} \mathrm{A}$ [dams] as the man. our electors from this shore, at least for three counties, will be good men. Done, Eccleston, \& Hemsley."

Later in the month, 1 he wrote again on the election, stating that the Maryland senate was Federal.

"My dear Sir.

“24. Sep 1796.

"The address of the President I have seen from Annapolis. Though this important event had been familiarized to my mind, Yet its actual happening affected me with a fear something like that produced by an unlooked for evil. It is an epocha in the affairs of America \& will be a point for future dates to be graduated by. Venerable man. The effect of his piece has been immense, considering the tranquility of Village understandings. The men, who can think at all, feel \&

1 September 24. 
acknowledge the force of his advice \& maxims. Could this effect be rendered general, his retiring might prove a new good to his country, as it has produced the public adoption of those important truths that are essential to the U. S. Truths which are felt with the strength of conviction of enthusiasm, because they are delivered by that man in the situation most affecting to his country \& which I hope will produce a death bed effect upon all. He may yet live to recall us all to their value, perhaps in some day of distraction. This is the only consolation the public mind can feel at such a loss.

"Forrest writes me that if this Shore is right, Mr. A. will lose not more than two, if those - an elector just from Annapolis however tells me that a great many talk of Mr. J. A man just from the Delaware says they talk of three there. Mr A. Mr Jeff \& Mr Jay. The first or last would do here. But I understood that Mr A. was the man, if they divide the friends of the Govt., the State of Virginia will again have a President."

In October, Murray writes twice, telling the good news of Hindman's election to congress by the Federalists from the upper district of the Eastern Shore, complaining of lack of news and speaking of Jefferson's weakness in Dorchester county.

\section{"2d day of Election}

"We just hear from Talbot that Hindman goes a head of Wright 3 to 1 . - fair speed the worthy member of the red rose.

"Jefferson will be pushed in this State on the W. S. particularly - but Mr. A. will, undoubtedly, have greatly the majority - but J. ought not to get more than two, or he will be elected. No Vice is yet mentioned here.

"Christie I hear certainly goes out \& Matthews comes in - a better member all hollow. Smith \& Young Sprigg are not opposed. T. S. declines \& Bear runs against Ringold Crabb resigned \& W. Dorsey a good man succeeds him. So F. writes me from the City."

"9. Oct. 96. Cambridge.

"Hindman is elected - considering the State of parties, this is an important thing. W. beat him 45. in Q. A. H. 
above him in Caroline 27. In Talbot 697 . so we beat him hollow. Christie I hear will be ousted too. This will be pleasant to you and $\mathrm{Mr}$ Wolcott I know. One gentleman \& only one in this county is for Mr Jeffin. I know not how the report got about, but the answer is common, when his name is mentioned, that he is in debt to the English largely. Of the State of parties Eastd. or Southwd. I hear nothing - no one hears of such things except at Philad. \&, as I have no correspondent there who ought to trust to a letter by post, I am in the dark - indeed light would be of no service to me nor to any one else if I had it - more than it could be to a man confined in a hogshead. - the hogshead, for a hogshead, might be light enough, but it could not extend its light far."

All the Federalists rejoiced that Gabriel Christie was defeated in Baltimore and succeeded by Matthews, "a better member all hollow." Hindman himself wrote McHenry after the election:

\section{"My dear McHenry}

"Bellfield Oct. 13th. 1796.

"That I have been remiss in not writing you before, I do admit, I have frequently determined it, \& have been as often prevented. I presume You have heard tne Issue of the Election between Mr. Wright and Myself, I had a Majority in the District of 672 , \& a Majority in Talbot \& Caroline. He was 45 Votes a Head in Queen Annes, where I am convinced He was fairly beaten, as one of his Men had the Effrontery to declare, that $\mathrm{He}$ had voted five times for $\mathrm{Mr}$. Wright under different Names. My Friend Mr. Edwd. Wright voted for $\mathrm{Me}$, the only One of that Name; this has increased my Sollicitude for his obtaining some satisfactory Office, \& I must beg You not to forget Him. I am afraid Messrs. Sedgwick \& Goodhue's Successors are not Sound men - \& I Find We are on the Point of loosing that best of Men, our amiable President, a Loss never to be repaired. I wish not to anticipate Evil, I cannot however help dreading the Consequence - God send us a Federal Successor. I sincerely pray that little Swanwick may be overthrown. I lament much that Murray declined; it is however said that almost every Man in his District is Federal, if so, We must have a good Man. Mr. Dennis, who was in the House of Delegates, I hear 
in his Successor. I have not heard whether Christie ${ }^{1}$ is reelected, I have been unwell for nearly four Weeks with the bilious \& Ague \& Fever."

Yet the result of the presidential election was far from certain and, practically, there was no unanimous decision as to whom the members of each party should support for vice president. Williamson wrote from New York on October 20:

"Yesterday I returned from the Eastern States, having been about 200 miles beyond Boston. Nothing was talked of six weeks ago, but the measures of placing federal Members in the Place of those who voted against supporting the Treaty. The New Englanders seem, on that head, to be nearly unanimous.

"Who is to be our next President? has been the universal Question, ever since the President's Resolution was published of not serving again. I have, uniformly, ventured to predict \& have been ready to support my Opinion, in the true English mode, by a bet - that John Adams will out poll Mr. Jefferson as 7 to 5 nearly and that he will be chosen by the Electors. Great Pleasure has been expressed by many People on hearing so clear \& positive a prediction, and they have given, as a Reason for the Pleasure they felt, that they conceived that my very extensive acquaintance through the Country gave me good means of forming a well founded Opinion. But there are People who think different from me on the head of Majorities. Col. Burr was in Boston when I left it \& his Informants, it seems, had induced him to conclude that the votes would be nearly equal - and yet we both converse with the World. How is it that, from the same Informant, we draw different Conclusions? I have just heard of a strange Dispute between Greenleaf and Nicholson, but what is doing in Philada., or in the Seat of American Govt., I have heard as little as concerning the Govt. of Persia. I have only heard of and seen the Presdts. Address."

Shortly afterwards, ${ }^{2}$ Murray wrote that a Federal elector would be chosen from his district. "In this county, I think I never knew an election so much of principles. General

1 Theodore Sedgwick of Connecticut and Benjamin Goodhue of Massachusetts were elected to the federal senate. From Pennsylvania John Swanwick was reelected. Gabriel Christie was representative from Maryland from 1793 to 1797 and 1799 to 1801 .

2 November 2. 
Eccleston (the Federal candidate) is obnoxious to about one half the county and is to be opposed next year by them in a sheriff's election, yet the language is, our choice is a party question, not a personal matter-this, for a Southern election, is a pleasing feature of the People's goodness." Murray feared French aggression on neutral trade and asked, "Who is thought of for a Vice President?"' again :

On the ninth, when the election was over, Murray wrote

"I inclose you a Herald - our election closed this evening The Jefferson candidate got one vote. The Adams candidate 582 - no riots - noise or seduction. The farmers came in without leaders to support government, they said, by voting for a Fedl. man as Presdt. I assure you I never saw an election before, in which real good sense appeared unmixed. We do not know how the polls go in the other countiesEccleston wt. out doubt is elected.

"A foolish report circulates that the F. minister is ordered by his govt. to leave U. S. instantly \& that they offer us the alternative of fighting them or the british. A wheat job I suppose. Adet's letter to Col. Pickering is a curious circumstance in diplomatic business I shd. think-pretty much the Spargere Voces inter vulgus, in Genet's way of appeal. I hope no answer will be given to it - public or private - whatever may be done on the subject of it. He wd. love a newspaper dispute - so wd. Dallas, his counsel.

"I dare say I am very very troublesome to you - but I ease myself - \& must say or write - \& I have more to say to \& you only to write to - \& this is the season of fires wherein my scrawl can be most conveniently deposited."

As late as the 15th, however, Murray was uncertain of the general result, and felt that no effort ought to be omitted. Winchester wrote, a day later, that he believed Jefferson would have but three electoral votes in Maryland and that he was anxious for news from outside of the state. He was too sanguine; on the 22nd, Murray wrote: "We shall be, to my mortification, half and half, a punster would say quite drunk, as we shall be 5 for A. and 5 for J."

Murray had been writing articles, signed Union, in the newspapers in Adams's behalf and, in answer to MeHenry's 
information in reference to the vice presidential candidate, wrote :

"If it is thought best, Smith \& others in Philad. ought to take care \& write to every seat of Govt. where the Electors meet, to run Pinckney as Vice, that we may have two strings. His christian name too would be necessary - though I could find it, yet I forget it.

"If you like unions \& get a Georgetown paper \& Edwards's of B. you will find them there. I sent several - one in E's ( $I$ think signed Union) particularly on Mr. A's Dutch Services \& a little upon his book - the first I had an opportunity in Holland of getting some ideas of that probably else had not reached us - \& I thought it important, in Speaking of the man, to associate him with Revolution Services as most unquestioned \& most splendid \& long past."

When the state legislature met at Annapolis, McHenry sent Philip Key letters "covering the communications made by Mr. Adet to our government" and Key answered from Annapolis on November 28th, 1796:

"I am obliged to you for your two letters covering the communications made by Mr. Adet to our Government. Violent men think them improper - and indeed all agree that they contain untruths - \& evidently shew a meddling - that ought to be frowned out of countenance. He has lost all character and irretrievably diminished that good will felt for his Government \& the people of France by most people here - fortunately, however, his appeal is made at a time when public opinion is too well matured for any injury to result from such conduct. The answer of our Senate \& the Honse of Delegates to Govr. Stone's address (which I inclose you) has. an indirect alusion to $\mathrm{Mr}$ Adet's communication. Our Legislature has been very much employed in local matters - Colo. IIoward is appointed a successor to Mr. Potts resigned - in the Senate of the U. States; it's probable his place in our State Senate will be filled by some character from Baltimore-\& McMechen is talked of."

Carroll of Carrollton on the 28th, still uncertain of the result of the presidential election, echoed the same sentiments from Annapolis :

"I need not therefore tell you that Adet's note, assign- 
ing the reasons for suspending his functions, is not at all relished with us. If Adet has recd. orders to resume his functions, why not notify the orders to our Government? does he wait for a reply to his last note, before he gives official notice of those orders? does our Govt mean to answer his last note, wh Includes an appeal from The Governt. to the People? We suspect that ye enemies of ye present administration have Stimulated Adet to this measure, to have an influence on the elections of electors of a Presdt. \& Vice Presdt. the timing of this note gives room for the conjecture.

"I hope the Legislature, in imitation of the Jersey As. sembly, will pass some resolves highly approving the Presdt's. address to the People, \& perhaps some occasion may be taken, besides the one already mentioned, of reprobating the interference of foreign Ministers with our Govt.

"I fear Jefferson will be elected Presdt. if left to himself he may act wisely: but, as he will be elected by a faction, it is apprehended he will consider him self rather as the head of that faction, than the first magistrate of the American People: may the good Genius of America avert from us so great an evil \& may ye event prove these conjectures groundless. If you have a little leisure, do answer the queries in this letter, if you are at liberty to answer them."

Chase, too, in a letter sent from Baltimore on December 4, warmly supported the administration against Adet.

"I thank you for the Aurora, but my absence prevents Me from any knowledge of the sentiments of the People here, respecting Mr. Adet's abuse of our whole Administration, and Appeal to the People. I think the Printer ought to be indicted for a false \& base Libel on our Government. A free Press is the Support of Liberty and a Republican Govt., but a licentious press is the bane of freedom, and the peril of Society, and will do more to destroy real liberty than any other Instrument in the Hands of knaves \& fools. I sce no Difference between Genet and Adet. For the opinion of our Legislature, I refer you to the Resolution of both Houses for perpetuating the presidents Address, but more particularly to the joint Answer of the Senate \& House of Delegates to the Governor's Address, which I enclose you. You may be assured there is but one opinion in Maryland out of this Town."

$\mathrm{He}$ added that there would be seven electors from the 
state who would vote for Adams and four for Jefferson, one of the electors voting for both men.

On December 2, Carroll wrote again:

"Notwithstanding the Pen'a ticket is gone in favor of Jefferson, those who pretend to have good information say that Adams will be elected by a majority of 6 votes. I rather think the probability is that no election of President will be made by the electors, as, probably, several of the electors may not be able to attend at the seats of Gov't, many of them being at a great distance from those seats, sickness and badness of the roads may prevent their attendance.

"We are anxious here to know what notice, if any, our Gov't will take of Adet's last note, assigning reasons for your suspension of his functions."

So strong a Federalist as Carroll was anxious that the legislature should not go too far in passing resolutions against Adet and wrote, on December 5, when he thought the chances for Adams's election were brighter:

"I recd, the 4th instant, your letter of the 2 d. I perfectly approve the determination of the executive not to deign to answer Adet's last note. I have not heard myself a single person speak of him with out expressing great disapprobation; yet I am told these are who excuse it, alleging he has Said nothing but the truth. You may readily guess what sort of men these are.

"Mr Key I believe means to move some resolutions respecting the President's address, expressive of the same Sentiments with those in our answer to the Governor's address.

"I do not see how the Legislature can with propriety go far there. The Individual States, as Such are not known to foreign powers; We have nothing to do with them, nor they with us. Should we pointedly notice \& disapprove of Adet's proceeding, might we not be accused of reaching in upon the boundary \& province of another Legislature Solely entrusted with the management of our external relations. 8th December Yesterday all the Electors met. Mr. Adams got 7 votes Mr. Jefferson 4, Mr. Pinkney 4, Mr. Burr 3 votes; \& Mr. Jno. Henry 2. Three eastern shore electors voted for Mr. Adams; one (Gilpin) for Jefferson; Deakins, Murdock, \& Lynn voted for Adams, Duvall; Archer for Jefferson; Plater 
for both. It is said, but upon what foundation I know not, how neither Adams or Jefferson will get any votes in S. Carolina. It is confidently asserted that Mr. Adams will be elected by a majority of at least 3 votes. I have my fears, Should Jefferson be elected, or, if no election takes place by the Electors, I suppose he will be elected by present house of Representatives. Great anxiety prevails, generally, respecting the future President, the friends of the Government, dread the election of Jefferson; they fear he will pursue a very different line of conduct from the present President. You intimate that the Secretary of State's communications to Mr. Pinckney relative to Adet's proceedings will be laid before Congress. the french party, it is probable, will not approve the Serretary's communications: however, I flatter myself the real friends of their country are the strongest party in Congress; You may be assured that, among the People, they are much the strongest: there are, no doubt, many in all the States wishing for a revolution \& war, but I am confident the great body of the people are attached to the Governt., approve its measures, \& wish to remain at peace with the nation.

" 9 th Decr. We have this day reelected Col. Howard into the Senate of the U. S. to serve 6 years from the 4 th of next March, he may be said to have been unanimously elected: there were 5 blanks \& 4 votes for Mr. Richd. Sprigg, altho' no other person was in nomination but Col. Howard. I am with much respect \& regard.'"

Resolutions, however, were adopted by the assembly and forwarded from Baltimore by Chase on December 10 . In the letter conveying them, Chase said:

"I believe the enclosed conveys the Real Sentiments of the People of Maryland. the Resolutions were adopted, moved and carried by Mr. Key of Annapolis. I expect the Senate will accede, with some few amendments which will improve them - when our assembly first met there were 8 or 10 Dele. gates who objected to that Part of the answer to the Governor's address which spoke of the Conduct of foreign agents - but even they are now convinced or Silent. the Charge of a fraudulent Neutrality, the indecent language to the Executive, and the appeal to the People agt. their whole Government is such a breach of truth \& good manners, and such an inter-meddling in our Government as wound the feelings \& ruins the Dignity of our People. I am greatly pleased with 
the answer of our National Senate. I wait with Impatience for that of our Representatives. I hope they will feel as their Constituents. I believe and expect the assemblies of a great majority of the States will concur with the President. I still think my old friend the Vice President will be elected president."

Even yet the election was uncertain, and on December 12, Carroll of Carrollton answered, as follows, McHenry's letter, in which was sent a copy of Washington's address at the opening of congress :

"I rec'd, by this day's post, yr letter of the 9th, covering the Presidents speech, with wh I am much pleased, particularly the part relating to Adet's conduct, it contains a due mixture of temper \& firmness. May I hope the Congress will be unanimous in expressing their disapprobation of the minister's proceedings? surely they must be offensive to every good American.

"The resolution you speak of was brought in by Mr. Robt. Smith, when in the house of delegates; it will make way for one drawn up by Mr. Key, \& which will be discussed tomorrow, \& I expect will pass unanimously - I think you will prefer it to the one brought in by Mr. Smith.

"Wednesday, the application of the commissioners for the loan 140,000 of 6 p. ct. stock will be taken up by the house of Delegates. Mr. Scott the attending commissioner says a majority of 10 will be in favor of the loan - you know I mix little with the members, \& am therefore less able to judge whether Scott's calculation is to be relied on. It is conjectured with us that Mr. Pinkney will be elected President; if the eastern electors have generally voted for him, the conjecture may be realized. Some think this event would be a fortunate one, as his administration would be less opposed than that of Mr. Adam's : however, not so much the man as measures occasioned opposition: It was not Washington, but his measures that were opposed; his great sin was the preventing his country from becoming a party in the war with France, and being involved in the same calamities which afflict that country. A man must be blind indeed not to see thro' the designs of the party. I hope, yet do not expect it, that peace will save us from serious discussions with the Directory. I am with respect" 
Key also acknowledged Washington's address thus:

"Dear Sir

"I thank you for your favor of the 9th. The President's speech is extremely satisfactory - and an additional evidence of his Paternal regard for the welfare \& prosperity of our Country - the enclosed Resolutions passed our House this day \& tomorrow will certainly pass the Senate unanimously. The House of Delegates - have voted 100,000 dollars 6 pct. for the use of the F [ederal] City - this aid could only be obtained in our House, by the Commissioners making themselves answerable, in their individual eapaeity, for the repay't - in case the funds pledged under the act of Congress should prove inadequate - so powerfully does Potomack \& this City eombine against Baltimore that I very mueh suspect no money will be invested in the New Bank." 1

1 This city is Annapolis. Potomac refers to the Potomac company whose plans for improving the navigation of that river were then much discussed. 


\title{
CH A P T E R XII
}

\section{A YEAR IN THE WAR DEPARTMENT UNDER ADAMS}

\begin{abstract}
DAMS kept in office all of his predecessor's secretaries: Pickering, Wolcott, McHenry and Lee. Almost at the opening of the administration, came news which made the difficulty with France acute. Shortly after the inauguration, there arrived a letter sent Pickering from London on February 6, by Rufus King, our minister to Great Britain :
\end{abstract}

"Dear Sir

"Mr Sands of New York has this morning shown me a letter that he had just received from Mr. Pitcairn, dated Paris, Jany. 28. which states, that General Pinckney has been ordered by the Directory to leave Paris, and that he would depart for Amsterdam on Tuesday the 31. ult.

"Knowing that it was the General's intention (in case he received such an order) to go to Amsterdam, and being apprehensive, that such an order might be issued in the moment of elevation that followed the news of Buonaparte's late victories, I entertain no doubt of the authenticity of this very unpleasant intelligence.

"With perfect respect and esteem "I have the honor to be, Dear Sir, "Yr. ob. sert. "Rufus King."

This news was soon confirmed and created a great excitement throughout the United States.

From Murray, McHenry heard by note sent from Cam. bridge on March 10:

"Our Packet just brought us the news, Norfolk news, that Pinckney is refused! I do not credit it. The people from one end to the other of this Shore Are right as to France. Some even think a war would do well."'

Hindman wrote McHenry twice from the Eastern Shore 
The first letter was written at Bellfield on March 21st, 1797, and is as follows:

"I reach'd Home on the Tuesday after I left Philadelphia, having had a very tempestuous and rather a cold Ride. Since my Return I have dispatched Burke's two Letters \& Mr : Pickering's to Mr: Pinckney, the last is most highly thought of by both parties \& will have a most excellent Effect as it must \& will open the Eyes of the People towards the French, from what I can hear it has already made a good Impression. I find that Burke's Letters are not approv'd, particularly by those who are tinged with Jacobinism, they say it is a low dirty Performance \& very unworthy of the Author, it will not be prudent to distribute Them here. As I fear'd, Phocion will not be read, being too lengthy, tho' of high \& acknowledged Merit.

"The last papers received here say, that Mr: Pinckney was denied an Audience by the French Directory \& was on his way back to this Country, if this should be true, Congress I suppose will be called hefore the Time to which They Stand adjourned. Surely We shall be unfrenchified \& as becomes Us, feel ourselves as Americans only."

The second letter written from Bellfield on April 1st, 1797 , stated that

"I see by the last Papers, that the President has decided Congress to meet on the 15th. May, so that my Suspicions are verified. What will the high toned Jacobins now Say of their good Friends the French, they will not surely have the Effrontery still to justify them. there is scarcely any Calamity so bad, but what some good may be drawn from it, I take it for granted, that the unwarrantable, shameless Conduct of the French towards Us, must \& will alienate the Regards which the Americans have heretofore had For that Nation. As far as I can hear the Sentiments of the People here, they say War must be the Consequence, \& some I find are extremely anxious for it, viewing Us in a worse Situation, than if We were actually at War, as, in that Event, We could afford some protection to our Commerce."

To Washington, on March 24, MeHenry wrote of the refusal to receive Pinckney. It was the first letter he had sent his former chief since Washington's return to Mount Vernon, 
and McHenry mentioned that: "You have witnessed on your route the great affection and attachment of the people and the sound part of the community, which is still visible in every company I go into and which, I am persuaded, will not diminish, though the external marks of it may, gradually, be less strongly expressed. This is the last reward you would have received, or the country could have given you. It is, nevertheless, a precious one." Turning to foreign affairs, he writes: "Every step on the part of the Directorial minister is insulting and the form of the rejection, passing through Mr. Munroe, not the least so."

"I presume Congress must be called and that immediately and that it may-also be expedient in the mean time to direct Mr. Pinclney to make another effort, such as may not commit the dignity of the United States and, if unsuccessful, retire to Hamburg, or some other place, to wait events, or a better disposition on the part of France."

Washington answered McHenry's letter on April 3,1 thanking him for the news and asking his former secretary: "to communicate to me, occasionally, such matters as are interesting and not contrary to the rules of your official duty to disclose. We get so many details in the Gazettes, and of such different complexions that it is impossible to know what credence to give to any of them." Washingtan has arrived home safely, avoiding all the "parades or escorts" he could, and is very busy, preparing a place for the security of his papers and making needed repairs. He has workmen of all kinds at Mount Vernon and has "scarcely a room to put a friend into, or to sit in myself, without the music of hammers, or the odoriferous smell of paint."

"The conduct of the French government" appeared to Washington "beyond calculation" and "unaccountable, upon

1 Sparks, xi, 196. Ford, xili, 381. The following paragraphs are omitted in both collections:

"I will make no apology for putting the enclosed under cover to you, If General Lee should have left Philadelphia, let me request the favor of you to open the letter to him and cause the one under that cover to be delivered to Messrs Reed \& Ford by a person you can inform me with certainty, has done so; that I may know to what cause to ascribe (should it happen) any delay in their answer; and add, if you please, whether there be any cause to suspect a fallure of the Gentlemen.

"You will readily perceive that what is said of them, and what I write to Genl. Lee is of a private nature, and not to be mentioned unless the reports respecting Reed \& Ford are facts of notoriety. . . . Dear Sir,

"Your sincere friend \& affectionate "Go. WASHINGTON." 
any principle of justice, or even of that sort of policy which is familiar to sound understanding."

On the 6th, McHenry replied that he found having nothing to do a great enemy to happiness. "I very well remem. ber that, before you brought me back into public life, I always experienced somewhat of restlessness in the interval between dropping one pursuit and finding out another."

Strong words came to McHenry from the Federalist leader, James Ross, at Pittsburg, in a letter written on April 3 :

"Not a word of news here, \& from the public papers it would seem that even at the seat of Government, you must be in Considerable uncertainty respecting our European power. Will an envoy extraordinary of the tribe of Virginia, satisfy the Jacobins of France \& this country! - or must the Directory have a negative upon our laws? I will agree to the first for peace Sake, but I cannot go further."

Samuel Smith, however, whose sympathies were always more with the French, wrote from Baltimore on April 5, still in doubt as to the truth of the refusal to receive Pinckney:

"Your Letter to Mr Oliver has tended to Increase the present Alarm. It says positively that Mr. Pinckney was Ordered from Paris by the Directory; Have you this from himself? or only from London. If the latter I shall still doubt, - because the Inclosed Extract from Mr Jas Calhoun's Letter seems fully to explain the report which had at first prevail'd.

"I am deeply interested \& might Solicit your Immediate Answer - that is - Are your Accts. from Mr. Pinckney, if not, from whom 1 \& what London Dates."

Adams summoned an extra session of congress to meet on May 15 and discuss the question on which subject Hamilton wrote $\mathrm{McHenry}{ }^{2}$ a-most important letter.

1 The enclosure in Smith's letter is as follows:

"Extract of a Letter from James Calhoun

dated Liverpool

16 Feby 1797

"Premiums of Insurance at Lloyds have been very fluctuating, a report was circulated that an Embargo was lald in France on all American Vessels, \& Insurance rose to ten Guineas from hence to America, on Goods by American Vescels, this being contradicted, they had fallen to six Guineas: when Mr. Pinckney, who had never yet been acknowledged by the Directory: finding the situation at Paris unpleasant, asked Passport to go to Amsterdam, \& set out on the 7 th Inst; his request for a Passport, was 1mm'y stated at Lloyds to have risen from an order of the Directory that he should quit Paris; \& the alarm threw every thing again Into confusion - the Underwriters for a day or two refused to write, they then asked ten Guineas \& within a few days some Policies have been done at six'" letter.

2 Lodge's Hamilton, $x, 241$, prints a different and briefer text of this 
"My dear friend,

"Take my ideas and weigh them, of a proper course of conduct for our administration on the present juncture. You have ealled Congress, 'tis well. When the Senate meets (which I should be glad to see anticipated) send a Commission extraordinary to France. Let it consist of Jefferson or Madison, Pinckney, and a third very safe man, say Cabot. Proclaim a Religious Solemnity, to take place at the meeting of Congress. When Congress meets, get them to lay an embargo, with liberty to the executive to grant license to depart to vessels armed and sailing with Convoys. Increase the Revenue vigorously and provide naval force for Convoys. Purchase a number of vessels now built, the most fit for sloops of war and cutters, and arm and commission them to serve as Convoys. Grant qualified letters of mark to your Merchantmen to arm, defend themselves, and capture those who attack, but not to cruise or attack. Form a provisional army of 25,000 men to be engaged eventually and have certain emoluments. Increase your cavalry and artillery in immediate service.

"Or do as much of all this as you can. Make a last effort for peace, but be prepared for the worst.

"The Emperor Paul is at best equivocal. A successor is apt to differ from a predecessor. He seems to be a Reformer too. Who can say into what scale his weight may be finally thrown? If things shall so turn that Austria is driven to make peace and England left to contend alone? Who can guarantee us that France may not sport in this country a proseliting army? Even to get rid of the troops if it fails, may be no bad thing to the Government of that Country. There is a possible course of things which may subject us even to an internal invasion by France. Our calculations, to be solid, should contemplate this possibility.

"I know, in your administration, there is a doubt about a Commission or Envoy Extraordinary. I am very sorry for it, because I am sure it is an expedient measure. But, perhaps, France has said she will receive no Minister, till her grievances shall be redressed. 'Tis hardly possible this can refer to any but a Minister who is to reside. A special extraordinary mission cannot be intended to be excluded, because it is at least necessary to know what measure of redress will satisfy, if any is due. But grant she will refuse to hear. Still the great advantage results of showing in the most glar- 
ing light to our people her unreasonableness, of disarming a party of the plea that all has not been done which might be done, of refuting completely the charge that the actual administration desires war with France.

"But the enemies of the Government desire the measure. 'Tis the strongest reason for adopting it. This will meet them on their own ground and shut their mouths.

"But to answer the end, a man who will have their con. fidence must be sent, Jefferson or Madison. To do this and to be safe others must be united, say Pinckney and Cabot. Thence the idea of a commission.

"I am, really, my friend, anxious that this should be your plan. Depend on it it will unite the double advantage of silencing enemies and satisfying friends.

"I write you this letter on your fidelity. No mortal must see it or know its contents. Yours A. Hamilton."

On April 14, Adams called together the heads of departments and asked them a series of questions on relations with France. ${ }^{1}$ McHenry sent the queries to Hamilton, asking his opinion upon them and received the following answer, written on April 29:

"I now send you a cursory answer to certain questions They are imperfect $\&$, probably, may come too late. But court avocations and distress in the family have prevented any thing better - General Schuyler has been critically ill, though now, as I hope, out of danger. My brother in law, Mr. Rensselaer, has just lost a favourite Daughter, one and the eldest of two children, without a prospect of more. The whole has thrown a gloom upon the family \& my health is not the stoutest. I shall answer your last by the next post

"Ade

$$
\text { "A H" }
$$

"Dr Sir

"Situated as I am at this moment I am obliged to confine myself to very general hints respecting the paper of the 15 of April.

"As to the first head - I think it will be adviseable that the speech should be confined to the foreign affairs of the Country, giving the primary \& prominent place to those with

1 J. Adams, vlil, 540. 
France. This will make the main business the more striking. Domestic matters may follow in messages \&c

"As to the second head-Announcing his intention to have recourse to the measure of an extraordinary mission - to endeavour, by an earnest and amicable appeal to the justice, candour, and friendship of the French government, to rectify misapprehensions, to satisfy them of the good faith and iriendly sentiments which have always directed the U. States, to endeavour, by a revision and readjustment of the Treaties between the two Nations, as far as shall consist with the engagements of the U. States towards other nations and the duties which their neutral position enjoins, to obviate causes of discontent and restore and confirm cordial harmony, to dismiss and settle amicably the topies of the mutual complaints and thereby to obtain a revocation of those acts on the part of France and of her Agents in her colonies which have oppressed our Trade and injured our Citizens and with it retribution for the losses which they have suffered from depredations, contrary alike to the laws of Nations and the faith of Treaties.

"The speech should proceed to say that inasmuch as depredations by the cruisers of France continue to go on, of a nature to destroy the mercantile eapital, ruin the commerce of the country and depress its agricalture \& industry generally, and, inasmuch, as it is impossible to foresee the issue of the attempt, by negotiation, to avert the consequences of the serious inisunderstandings which exist - it is matter of necessity, with regard to the interest, honor, present and future security of the U. States, to adopt and carry into execution, without delay, vigorous measures of defensive precaution.

"These measures to consist of the prompt equipment of a Iaval force, sufficient to serve as convoys to our Trade and protect it against the spoliations of petty eruisers.

"Permission to our vessels to arm for their own defence under proper guard and restrictions to prevent their cruising and acting offensively.

"The intermediate passing of an embargo till these measures can be matured - with a discretion vested somewhere to grant licenses to sail to such ports \& under such circumstances as may be deemed safe.

"Arrangements which, in case of emergency, will give the Government the prompt command of an efficacious force 
with a particular view to Artillery and Cavalry; corps which require considerable time for forming them and which in case of need will be of the most peculiar and essential utility

"The more complete \& effectual fortification of our seaports, especially the principal ones.

"The increase of our Revenue, as far as shall be practicable without overburthening our Citizens, to an extent which shall be equal to the additional expense of these provisions, avoid an increase of the National debt, and prepare the Country for the exigencies which may arise.

"Whether it will be expedient for the President to go into detail, or deal with energy in generals embracing the great points, is a serious question. The inclination of my opinion is towards the fence, dealing in generals in Speeches \& having reports from departments either to be communicated afterwards, or to be transmitted with the Speech by a general reference.

"As to Instructions to the extraordinary Minister or Ministers, they should embrace the following objects -

"I. Explanation of the real views \& intentions of the Government of the U. States during the present war, so as to satisfy France that they have aimed at a sincere neutrality and have been influenced by no spirit partial to her enemies or inimical to her.

"II. The Discussion, if necessary, of the constructions of the Treaties between the two countries in the points which have been litigated, insisting upon our own, but not refusing to agree to any measures consistent with our constitution, for avoiding an inconvenient or abusive application of them.

"III. The remodification of the Guarantee in our Treaty of alliance into a stipulation of specific succours having reference to future wars and defining the casus foederis to be, that where the war has begun by the commission upon the ally of some actual military hostility, by sea or land. The succour on our part may, in the next fifteen years, be five sail of the line to be furnished once for all, or an equivalent sum of money to be defined (with option to pay in provision or military stores) - after the fifteen years, ten sail of the line, or an equivalent sum of money - The remaining vessels to return at the conclusion of the war.

"IV The remodification of our Treaty of Commerce, so as to accommodate it to that with G. Britain, having regard to duration as well as other things 
" $V$ Reparation for spoliations \& payment of sum due by Contract and other damages. A Commission or Commissions may be agreed to but carefully restricted to compensation to Individuals on either side. For

"VI There should in no event be admitted the idea of compensation or contribution from the Government of the U. States to that of France, Nor

"VII. Any admission, secretly or indirectly, that they are Aggressors with regard to France

"VIII To avoid every stipulation in any shape inconsistent with our other Treaties, or that may compromit our neutrality in the present war

"IX To steer clear of particular or exclusive privileges or preferences in Trade which are always precarious, \& embarrassing; occasioning dissatisfaction at home \& jealousy abroad

" $\mathrm{X}$ To consent, if desired by France, to the annulling of the Treaties between the two Countries - altogether

"This last idea is a delicate one \& it is only, if at all, to be so suggested as that our Minister may, in no case, appear to contend for the continuance of these Treaties as a favour to the U. States - as France may consider her guarantee of our sovereignty and independence as a thing of importance to us.

"Yrs truly

"A H"

Hamilton later elaborated his views in a second paper, which he sent McHenry:

"Answer to questions proposed by the Prest of the U. States.

"To the first. It is difficult to fix the precise point at which indignity or affront from one State to another ceases to be negotiable without absolute humiliation and disgrace. It is for the most part a relative question - relative to the comparative strength of the parties - the motives for peace or war - the antecedent relations - the circumstances of the moment, as well with regard to the nations as to those between whom the question arises. The conduct of France, exclusive of the refusal of Mr. Pinckney, is no doubt very violent, insulting, and injurious. The treatment of Mr. Pinckney, if it does not pass, certainly touches upon the utmost 
limit of what is tolerable. Yet it is conceived that, under all the singular and very extraordinary circumstances of the case, further negotiation may be admitted, without that absolute humiliation and disgrace which ought perhaps never to be incurred - to avoid which it is, probably, always wise to put even the political existence of a Nation upon the hazard of the die.

"The triumphs of France have been'such as to confound and astonish mankind. Several of the principal powers of Europe, even England herself, have found it necessary, or expedient, in greater or less degrees, to submit to some humiliation from France. At the present juncture, the course of her affairs and the Situation of her enemies, more than ever, admonishes those who are in danger of becoming so and who are not able to oppose barriers to her progress, to temporise. The mind of mankind, tired with the suffering, or spectacle, of a war, fatal beyond example, is prepared to see more than usual forbearance in powers not yet parties to it, who may be in danger of being involved. It is prepared to view, as only prudent, what, in other circumstances, would be deemed dishonorable submission.

"The U. States have the strongest motives to avoid war. They may lose a great deal; they can gain nothing. They may be annoyed much and can annoy comparatively little. Tis even a possible event that they may be left alone to contend with the Conquerors of Europe. When interests so great invite and dangers so great menace, delicacy is called upon to yield a great deal to prudence. And a considerable degree of humiliation may, without ignominy, be encountered to avoid the possibility of much greater and a train of incalculable evils.

"The former relations of the U. States to France - the agency of that power in promoting our revolution - are reasons, in the nature of things, for not lightly running into a quarrel with - even for bearing and forbearing to a consid: erable extent. There is perhaps in such a case peculiar dignity in moderation.

"France, in declining to receive Mr Pinckney, has not gone to the ne plus ultra. She has declined to receive a minister till grievances, of which she complains, are redressed. She has not absolutely ordered away a minister as the prelim- 
inary to war. She has mingled some qualifications. It is not even clear that she means to say she will not receive an extraordinary minister. This leaves some vacant ground between her act and rupture. The U. States may occupy it by a further attempt at negotiation. This further attempt seems to be that which must carry us to the point beyond which we cannot go.

"Besides the object of explanation to satisfy France, we have the most serious grievanees to complain of and of which to seek redress. This last will be a principal object of an extraordinary mission. It will not be to make submissions but to explain and to demand reparation. This double object contains a great salvo for the national honor.

"We have just seen, in the case of Sweden, the negotiation, in some way or other, of a similar insult. Though the refusal of our minister, as being mere pretext, is more offensive - Yet the forbearance of Sweden is a precedent of some force for us.

"As to our own Country - There is a general and strong desire for peace - and, with a considerable party, still a particular repugnance to war with France. The state of public opinion is not likely to consider a further attempt at negotiation as too humiliating. It may be safely taken for granted that it will approve such an attempt as prudent - \& that at home it will have no other effect than to lay the foundation for greater Union, and Constancy in case of failure.

"But to preserve character abroad - and esteem for the Government at home, it is essential that the idea of further negotiation be accompanied by measures that shall demonstrate a spirit of resistance in case of failure - that shall yield present protection - and promote future security.

"With this adjunct, it is believed that the Government, in pursuing the plan of further negotiation, will raise rather than depress the character of the Nation \& will preserve the dignity of the American mind \& the esteem of the American people.

"The enunciation of one measure by the Executive ought, therefore, to be accompanied with a decisive recommendation of the other course. In doing this, however, it will be wise 
to avoid all expressions that may look like menacing France with what we intend to do. The attempt to negotiate must be put upon the foot of an appeal to her justice and friendship. The recommendation of preparatory \& defensive precautions be put on the foot of present necessity \&* the possibility of future dangers which it may not be in our power to avert

" *in reference

to the actual

$\&$ ruinous depre-

dations

of our Trade.

"* The desiring

of some of the stipulations, according to our practice upon them, would be desirable if obtainable, but it is better to leave them as they are, than desire the other way. And the probability is that the definition would end in the last way which might compromit us with other powers
"To the second - It will be expedient to declare to France that if there be any thing in the Treaty with G. Britain which France is desirous of incorporating in the Treaty with her - The U. States are ready to do so - having no wish to give any other power privileges which France may not equally enjoy on the same terms. This general offer seems the most unexceptionable \& will stop as well the mouths of France as of her partisans among ourselves. The duration of privileges should also be in both cases the same.

"To the third It does not occur that it will be expedient to propose the abolition of any of the articles of our Treaties with France further than may be implied in the above general offer. To propose the abolition of things inconvenient to us would confirm the suspicion that we were disposed to narrow the privileges of France and would do harm there and here* The only thing that can be done with advantage is to propose to liquidate the meaning and effect of the mutual guarantee in the Treaty of Alliance.

"That Guarantee is now general. The obligation it impresses on France towards us is essentially nominal in future, because our sovereignty and independence can hardly again come in question. That which it lays upon us would expose us to a general war 
with the enemy of France, as often as, in a purely defensive war, her West India possessions should be attacked. This is a great evil. The alternative, in such a case, is to chicane our en. gagements and risk war with France for not performing them - or to per-

"“*A definite succour is not a cause of war, if previously stipulated. form them, if called upon, and encounter war with her enemies. It would be a great point gained to reduce this general guarantee to a treaty of mutual, Specific, definite, Succour,* excluding the present war and defining the casus foederis to be that case, in which the first act of actual hostility by Sea or land is committed against the ally - without reference to antecedent motives and causes, which are ever vague \& complicated.

"To the fourth - If an amicable course of negotiation should take place, modifications in the Convention may be proposed. Not having it by me, the desireable alterations do not occur further than the restraining the mutual right of jurisdiction in questions between the citizens of either power to cases between the Officers \& Crews of Vessels. Beyond this it works ill - establishes an imperium in imperio - ex. tends foreign influence \&, indirectly, injures our own Citizens \& preventing efficacious justice between French Citizens who are often their Debtors \&c. Particularly, it is ill to insert foreign jurisdiction in our Country.

"To the fifth - It does not appear expedient to propose or agree to such new articles. In general it is wisest neither to give nor take peculiar privileges - but equalize our commercial system with all nations. Indeed, it will be very difficult to adjust new articles without interference with other Treaties. The only method of favouring France is to stipulate that certain articles of her production or manufacture, not common to Great Britain, which enter largely into our possessions should be admited without duty, or on light duties to be specified. This applies principally to her brandies and wines; but even there they must be on the same footing, if coming through G. Britain, as if coming directly from France. Yet the essential \& utimate benefit would accrue to France, as 
favouring the vent \& consumption in our Country of her peculiar commodities. But all this is far better avoided. The diminution of our Revenue and jealousies in other powers will be certain evils, for which France will \& can give no real equivalent.

"To the 6th. What was done in the case of Great Britain will be a good precedent for this case.

"To the seventh. The terms of the remonstrances against spoliations should be mild and calm without offensive epithets, but serious and depicting strongly the extent of the evil. They should suppose the West India constructions to be abuses of the Orders of the directory; but they should notice that these were so vague and indefinite in themselves as to be naturally liable to abuse. They should urge a revo. cation of these orders and compensation for the injuries they have produced, as due from good will, Justice, and Friendship of France to the violated rights of the U. States and their Citizens - and to restoration of cordial harmony between the two nations, which might otherwise suffer a deep and perhaps incurable wound.

"To the 8th. This is answered in the answer to the seventh. To the 9th. This claim of our Citizens ought to be noticed and urged as a great and serious one, having, from the motives of the individuals in the greatest number of cases, a title to peculiar attention. Yet the whole ought to be so managed, as not to compromise the Government for the ultimate vindication of the claim. It is very questionable whether it be not such a one (as far as credit was voluntary) as that those who gave it ought finally to be left to the honor of the Government to which they trusted.

"To the 10th. This is answered in the Affirmative in the answer to the seventh question. There is no solid distinction between captures and seizures by private vessels or public vessels. The Government which gave the Commission to cruise is liable in both cases. This observation has reference to those depredations which result from vague orders of the Government, or the abusive constructions of its Agents entrusted with local jurisdiction, as Governors, Commissioners \&c.

"To the 11th. A Commission, like that with England, ought to be agreed to, as a very happy issue out of the embarrassment.

"To the 12th. This is answered in the answer to the second question. The equivalent privileges in the French 
East India Trade will be the analogous compensation, though not of equal extent. But situated as we are with France, it seems proper to be content with less. If privileges on her West India Trade could be obtained, it would be desireable But this ought not to be a sine qua non. A limitation of the duration of a new Treaty, if made is a great desideratum. ${ }^{1}$

"To the 13th. It scarcely seems adviseable to offer the project of such a new Treaty. It opens at once all the cards. It is better to deal in generals. This will leave less in the power of France or her partisans.

"To the 14. It is conceived most adviseable to follow former precedent in this respect, which may avoid much delay and embarrassment. In the exercise of this branch of Executive Power, it will be found the best course to reduce the Cooperation of the Senate to the appointment of the Negotiator and the ultimate fiat or negative. Much has been done to this end \& it will not be expedient to relinquish the ground which has been gained."

McHenry's opinion, filed with the president, is interesting to compare with the preceding letter, as showing the measure of the secretary's reliance upon Hamilton. McHenry decidedly favored further negotiations and proposed that we offer to modify every commercial inequality between France and England. He was averse to changes in old treaties with France, save the mutual guarantees, and opposed saying anything concerning a consular convention. He proposed the same course with reference to evidences of insult and injuries against American commerce by France, as was pursued in case of Great Britain; a remonstrance against French outrages to be made in mild and calm terms. Payment of claims for property purchased by the French government in Europe, East or West Indies should be urged but not demanded. France should be asked to pay for vessels and eargoes eaptured and seized by ships of war or private ships and a commission of inquiry, like that with England, should be agreed to. No project of a new treaty, abolishing the old one, should be proposed to France nor laid before the senate. In many sentences McHenry quoted Hamilton's exact words.

The perturbed condition of the public mind, when the extra session was called, is clearly shown by the letter John Henry, one of the senators from Maryland, wrote:

1 "Bridge for both," in McHenry's handwriting, is written on the letter here. 
"My dear Sir,

“3 Apr. 1797

"Can you inform me what is the immediate object of the meeting of Congress. Is it probable that the session will be long. The attendance of the southern gentlemen, who are engaged in agricultural pursuits is very inconvenient, at this season of the year; and if the session is to be of any continuance, it will be oppressive.

"As you are in possession of the grounds of issuing the proclamation, you will oblige me by giving such information as you are at liberty to state.

"Is the object an embargo, or does the state of our foreign concerns, call for other measures, more injurious to our tranquility. Will the folly and madness of France force us into offensive acts. Altho' in my apprehension their vessels in some instance, have been hardly treated, and detained on grounds not satisfactory to my understanding of the treaty, yet these trifles will never be seriously stated as the eause of war; nor I trust will the treaty with Britain, be urged in the face of the world, as grounds of offensive operations against this country.

"If your leisure will permit, do drop me a line, my solicitude is great \& in the present state of imperfect health, not a little injurious to me.

"In the warmth of ancient friendship, I am sincerely "Yrs. Jno. Henry."

On May 14, McHenry wrote Hamilton that he had added to, but changed naught of the latter's draft. The president's speech, to be read to congress at the special session, 1 " extenuates nothing, recommends proper measures, promises a fresh attempt at negotiation and declares the principles by which administration mean to be governed, in other words that the President will follow the principles of the late administration. It is not, perhaps, precisely such a speech as you would have written - a little too plain. It may, however, be better fitted on that account for the occasion." On the next day he wrote again ${ }^{2}$ that a quorum was expected on the morrow. The emperor has not made peace, had he done so, "it ought to have augmented our endeavours to meet hostility. As it is, probably a new character will be given Pinckney with a secretary."

On the 14th, McHenry had written Washington of the

1 Hamilton, vi, 250.

2 Hamilton, vi, 250 . 
speech and added: "Mr. Craik says you look well, God send that you may long look well and enjoy good health and that nothing that is to happen may be of such a nature as to disturb your consoling privacy and retirement. France, however, is playing a great game and has views perhaps little less extensive than those which opened upon the Roman Republic and deluged so great a portion of the world with blood. She does not appoint consuls over the countries she conquers, but she does what is as effectual, permits them to erect themselves into republics and governs them by their own passions, or she annexes them to her own territory and governs them in Paris."

Washington answered on the 29th, describing the daily routine of his life at Mount Vernon and apologizing for not answering several of McHenry's letters. ${ }^{1}$

Adams now called together the cabinet and suggested sending a mission of three ambassadors to France, adding to Pinckney, Marshall of Virginia, and Gerry of Massachusetts. Fifteen years later, McHenry thus recalled the occasion in a letter to Pickering: "I well remember the meeting, for I have often thought of it since. It was composed of Mr. Wolcott, yourself [Pickering], Mr. Lee, and myself. Mr. Adams, in a familiar way, said 'Gentlemen, what think you of Mr. Gerry for the mission?' None of the gentlemen offering to speak, I observed: 'I have served in the old Congress with Mr. Gerry. If, sir, it was a desirable thing to distract the mission, a fitter person could not perhaps, be found. It is ten to one against his agreeing with his colleagues.' Mr. Wolcott made some remark. Mr. Lee and you were silent. Mr. Adams replied: 'Mr. Gerry was an honest and firm man on whom French acts could have no effect. He had known him long and knew him well.' Nothing more was said on the letter to Pickering: "I well remember the meeting, for I was next to incurring his enmity."

A fortnight ${ }^{3}$ after the letters to Hamilton and Washington, McHenry wrote Pickering, after failing to find him at home when he ealled: "The more I weigh the measure of adding to the mission, instead of clothing Mr. Pinckney with a new character, the more I am inclined to distrust its policy and utility.

1 Sparks, xi, 203. Ford, xiii, 391.

2 February 23, 1811. Lodge's Cabot, 204.

3 May 28, 1797 . 
"The mere addition, in the first place, will convey an idea to Mr. Pinckney's friends that the President does not (for some reason or other) like to trust him alone; or that he thinks him incompetent to so important a transaction. This suspicion will operate mischievously on the relations of Mr. Pinckney: on the whole of the Rutleges and generally to the Southward, where they have great influence. In this point of view, it will certainly do no good. In the second place, the addition will serve to conciliate no person, or description of men in the United States. The friends of the government have full confidence in Mr. Pinckney; and the enemies of it have acknowledged in the House of Representatives their reliance upon his integrity and honour; and have not suggested an idea that they wish for any other. On what ground then, it will be asked, and for what purpose, are two negotiators added to his mission, when both parties are satisfied with the same man? It will be remembered also that the idea of a commission of three took its rise from the supposed policy of incorporating into it a man of the opposition. In the third place, both parties in the House of Representatives have conceded and expressed in their speeches, in my hearing, that should Mr. Pinckney be clothed with new and extraordinary powers and be refused, that it would be sufficient cause of war. Having no expectation of getting an envoy of their own cast, they appear to have given up all idea of any addition to the mission. Both parties, therefore, seem to have relinquished the project of a plurality of negotiators for the present occasion. In the fourth place, the mission will be considered defective, in as much as it will possess no merchantile character, being composed of lawyers only, neither of which have as yet acquired much continental reputation. Fifthly, it will be charged, as being expensive to the United States without apparent necessity, or advantage to countervail the expense. Sixth, it will be charged with being calculated to delay the negotiation, inasmuch as Mr. Pinckney must wait at Amsterdam, till the arrival of his coadjutors, by their refusal to serve, or by their requiring time, should they accept, to arrange themselves for the voyage. On the whole, I wish you to consider, whether it might not be expedient to have the nomination suspended till the President can review the subject. For my own part, I have not been able to discover any advantage attending a trio. It will please nobody, not even those that may be nominated and will not ensure the United 
States against a single possible evil, nor create to government one additional friend.'

This letter shows that McHenry did not always follow Hamilton as has been alleged, for Hamilton favored a commission, as we have seen.

Adams later charged ${ }^{1}$ that the secretaries, spurred on by Hamilton, showed inveterate prejudice against Gerry. This is clearly incorrect, as is shown by McHenry's letter. Lodge, in his life of Cabot, ${ }^{2}$ says McHenry's account of the trans. action is at least perfectly natural and does not require a strong effort of the imagination from the reader. Either McHenry, a perfectly honorable man, has wilfully and knowingly lied, or the inveterate prejudice against Gerry is greatly exaggerated by Adams.

One of McHenry's intimate friends and correspondents, Murray, was not allowed to remain long in retirement. His congressional term ended on March 4, and on April 10, Mc. Henry wrote Washington of his embarkation for Amsterdam. Later in the same month, Adams ${ }^{3}$ wrote to his son, John Quincy Adams, from Philadelphia: "Mr. Murray of Maryland, your old friend, with whom you formed your first acquaintance at the Hague is to succeed you," as minister to Holland, as Adams had been appointed minister to Portugal. "That gentleman [Murray] has been so long a member of Congress and has given such proofs of talents, amiable dispositions, and patriotic sentiments, as qualify him to do honor to the mission, as well as to his predecessor."

This sending of Murray to Holland was destined to be of considerable importance to the United States government and gave rise to a series of long news letters from him to McHenry, describing with great frankness the passing events, as they appeared to an observer at the Hague. The letters are of importance because they were written, not merely from one friend to another, but by the United States minister to a member of the president's cabinet. As soon as Murray landed he began writing and continued to send letters of great length with considerable frequency.

The first of these letters is written at Helder (Texel), on June 9, 1797:

1 J. Adams, i, 287. Adams also mistakenly speaks of five heads of departments; there were but four.

2 Pages 104, 204. McHenry to Plckering, February 23, 1811

3 J. Adams, vili, 537. March 31. 
"My dear Friend,

"After two months precisely it pleased god that we should land safely - \& we are this moment come on Shore Finding a ship to $N$. York that sails this night \& it is now seven - I seize the moment to drop a line to the Sec. of State - one to you \& one to my brother. a british officer, who boarded us about two hours, since told us that it was reported the Emperor had made peace - That G. B. was treating through Hammond - \& the King of Prussia dead - but as this is not authentic enough for Col. P's office I said nothing of it. Mrs. M. sends her love to Mrs. MeH. We were terribly sick all the way. $\mathrm{D}$ [andridge] is well. In real haste I pray god to bless you. always \&

"most affectionately yrs. "Wur. V. M."

A week later, in the first of his news letters, he thus expressed himself on our relations with France:

"The Hague

22d. June 1797.

"My dear Sir,

"I just informed you from the Helder on the 9th. that on that day we arrived. Fortunately Mr. Adams was not gone — \& I had the pleasure of meeting him at Amsterdam. This was lucky for me both because to meet so amiable and intelligent a man at all is desirable, \& that the conversations I have had with him are to prove the only chance \& resource of know [ledge] upon any of the foreign affairs connected with the U. S. that I am to enjoy \& draw from independent of my own apprenticeship \& experience - for the U. S. have never had a single book, paper - register or archive kept at this court that I can hear of and each successor is to take up business wh. may have been left unfinished - unless he has a copy of a memorial or two - either at the right or wrong end, or according to the light which doubtful intelligence on the spot may enable him.

"From all I can collect however the government here is as well disposed as they durst appear to be towards the U. S. - \& of course there will not be many occasions of great delicacy with them. They say nothing lately of a renewal of our treaty. Did I not hear that from the manner in which my appointment was taken up in the national assembly $I$ should suppose they meant to have their American ministers 
at the Hague with out business - for Mr. Adams has delivered his letter of Recall. I hear that the Delay of two days in my case arises from some papers that they have to make out - this is but report.

"The french still preserve their piratical practices agt. our trade and probably will continue to do so until a spirit of Union shall display itself against them in America. This, united with the growing disposition in France for Peace, \& a necessity of regenerating their navy, to wh. their West India colonies are essential, would produce an opportunity for reflexion that would be embraced by parties agt. the Direc. tory and by the more worthy men of the new delegations, many of whom, as Marbois \& Barthelemi \& others, are doubtless, not friends to America, but have sense enough to see the real policy of a good understanding with the U. S. But depend upon it their object, is not now to injure Great Britain by crippling her trade at present, than to dissolve the Union for the purpose of directing its affairs. They dread the growth of what they call the Anglo Americans. The temptation of immediate plunder - the policy of wounding mortally a future rival to their marine greatness and those two ideas, coupled with a third, perhaps more precious to them, the giving of a totally new direction to the commercial affairs of a country to whose commerce \& consumption they think G. Britain must principally look for resuscitation after the war, will \& must, to a set of beings inconceivably corrupt, prove a cause of war upon us, unless we remove the only founda. tion on wh. they can possibly expect success - internal dis. cord. They certainly govern Europe at present \& are planning immense schemes of grandeur. One of their means at present, \& for some time, in use is the getting possession of the Diplomatic corps of Europe - Sweden, Portugal (at this place), the U. S., \& the Batavian Republic have all felt the determination. Even from the republic, they have rejected a minister who belonged to the more worthy men \& party here, because they a M. . . . . . . already whom they approved - \& I shall not be at all surprised if they reject every british mission till a man who suits them shall appear.

"The british again endeavour to open negociation through Mr. Trevor (brother of Ld. Hamden) whom Gibbon, in his miscellanies, takss well of. my own speculation is that they will not make peace wt. G. B. till they shall have try'd an invasion - from France-\& This country. Here they 
have a larger collection of transports \& about 25,000 more ready - with 13 sail of the line besides 16 from 50 to 20 guns with in the Texel. They must know that England is more ripe than ever for a revolution - that an invasion, if even partially successful, would probably bring things to a crisis. France too, in peace with the contiuent, may concentrate that immense force \& those ardent spirits against Engd with a greater advantage of ground, having Batavia \& Belgium \& all France in her co-operation, than she ever had. Could she set in motion the revolutionary wheel in Engd. \& then, leaving her to her fate, turn all her attention to her marine \& manufactures, she would have accomplished every thing. Of the Fate of Venice, you have heard no doubt. The plan, it seems, is to give Friuli Bergamo \& some other districts of the Venetian territories to the Emperor - \& indemnify Venice out of the Papal territories wh. are to be divided with a ceremony as cold as the holiness used to exert over the division of kingdoms. The Idea of an Italian Republic will not be abandoned by France. it is necessary to break the actual \& family influence of the Emperor from the Southern side of his German dominions through all Italy. Genoa will probably go to or merge in the Sardinian Dominions. These are crude speculations, my dear friend - but I cd. not help the desire I had to converse mentally with you - \& as yet I have no arranged correspondence \& am not en train.

"I find that the idea that the P. \& V. P. are cordially united gives alarm to the enemies of our country \& stability to our prospects in the eyes of European politicians. I am excessively anxious to hear of the proceedings of Congress The Speech - the answers \& how far your military business has answered.

"Pray send me a list of your library (of the office) \& I will select what is not there, if you please, \& send what I get.

"I am hammering away upon French. Mrs. M. writes to Mrs. McHenry to whom remember me with respectful kindness - not forgetting my young friend Mr. John MeHenry.

"In writing to Col. Pickering, I have not thought myself at liberty to indulge much in Speculation-\& of facts of authority I could not be master of them. D'Estade, I observe, in his official letters reserves himself - \& as short simple, \& generally confined to what has been done-give 
me your opinion on this will you. God bless you \& yours, my dear friend \& believe me always

$$
\begin{gathered}
\text { "Affectionately , } \\
\text { "W. V. M." }
\end{gathered}
$$

President Adams wrote to Pickering from East Chester, October 26, 1797: "Mr. Murray ${ }^{1}$ arrived in season to renew his old friendship with his predecessor [J. Q. Adams]. They had spent some weeks together at the Hague, more than a dozen years ago. Mr. Adams had an opportunity to introduce Mr. Murray to his friends and to communicate to him the train of affairs; an advantage which Mr. Murray earnestly wished before he sailed from Philadelphia." 2

McHenry forwarded Murray Adams's speech to congress on May 23 and on July 14, the latter answered as follows :

\section{"My dear Sir,}

"Your favour of the 23d May was truly a cordial to me - as it evinced a friendship of which I never doubted \& consoled my jaded mind with the prospects of better opinions in my own country \& of a better State of public affairs. The Speech, we had seen through the kindness of the Bankers, who always get intelligence very early so propitious are the winds from America to the views of these exceedingly money loving politicians \& financiers of private wealth - \& so very unpropitious are they to the conveyance of ministers $\&$ dispatches to them. Genl Pinckney, who is here, immediately, with his accustomed vigilance sent a copy (manuscript) off to Paris that the Directory might be anticipated \& the public get an ungarbled edition of it, neat as imported - for they stick not at altering, omitting \& - if they get the first blow. immediately after, I sent off to Paris through Genl. P. - (as a friend of mine used to send to Fenno \& as I used to give to that manifest friend of brilliant paragraphs \& pointed hits) attempting to point out to the public a line of conduct which a profound policy would dictate to the Directory, - viz - a generous \& elevated course towards the U. S. ; - pointing out to them the egregious mistakes of G. B., both during the revolution \& since, in not seizing upon moments favourable to great impressions, by wh. the amity of the country might have been secured, that this was the critical moment, in wh.

1 J. Q. Adams was almost at once transferred to Berlin.

2 On August 7. 
France should defeat the views of G. B. upon our affections, by acting a handsome part; that in such a state of things the people \& Govt. U. S. would probably receive even common justice, as an act of grace \&c - that there was no ground of war; \& that being the case, the true policy of France was to show so handsome a conduct towards U. S. as would place her at least upon a footing with her rival in our opinions at the peace: that, if the peace found us in our present irritated State, G. B. wd. reap much more of our good opinion \& of our commerce, than she was entitled to - and that the present state of things, being friendly between U. S. \& G. B. she wd. have some ascendancy, upon that ground, in the negociation for Peace, if France continued to have a quarrel with a nation so vigorous \& unbroken by taxes as the U. S. are \& in the vicinity of the islands wh. wd. be in a very helpless State on the peace \& need american supplies \& friendly intercourse - this \& much more of similar sort of prosing went to be drest in French \& to a confidential person - but wt. out name known to any at Paris. I have not seen it since. My anxiety is exceedingly great, indeed, upon the present state of the question between France \& the U. S. Depend upon it that, from all I can hear of the public opinions at paris, they have not one single sound opinion upon our subjects - none of them. They all, in their heart, consider us as proper for ally'd dependants \& under eternal obligations to them and that the PEOPLE U. S. are with them, merely because the great mass of the people there dislike G. Britain \& have manifested some marks of esteem for the French revolution. I have seen a letter from a member of the council of ancients explicitly upon the various questions. He thought the Directory wrong in their rough treatment of Mr. Pinckney - but through his whole letter insisted upon vague undefined injuries wh. the U. S. had done France by the Treaty of 19. Nov. '94-That we must give satisfaction for these injuries - \& took it for granted that we owed our national existence to France \& a gratitude wh. rendered our late conduct monstrous - outwardly he is a violent party man agt. the Directory upon these points - writes against them \& speaks against them - but it is merely he hates the Directory. If any thing is to be done, it is through the passions of such men who would do right from spleen \& to inculpate their own executive. If, however, no language of concession is held by Congress - (\& there was in debate something like it, on or 
about the 3d. June on the word "indignation") \& you arm, provide a navy for the country \& hold up, I would risk my head that they would feel the importance of amity with the U. S., particularly as her force thus brought upon the parade, ought be most surely felt by the West Indies, if carry'd into use. Her vast maritime possessions in Europe add new im. portance to the West India Islands. She must be the rival of England in marine - to this the islands have been \& will again be considered as necessary - I see no hold upon France at present but our relationship to those islands.

"What can the new commission do except gain time? I speak entirely to you. The object of France is to make you break your treaty with G. B., or to dissolve the union, that we may be her dependents. Her efforts will be in America through this very negociation to bring the Govt. of our country \& the People too to this point - a war, or an abandonment of the british treaty. in a proposal of such a nature, the chances are not absolute evil to her - but merely that negative one of disappointment. It will be success if she breaks the Treaty, wh. I do not expect; for that wd. be Sovereignty over us. If she produced civil commotion (wh. I do not expect) She Succeeds amply in her diabolical scheme. This I do not expect - for the conduct of France to all the Italian States, but especially to Venice demonstrates, \& by this time it must be acknowledged in all America, that she revolutionises exclusively with a view to her own aggrandisement - \& that, after having destroy'd a Govt., to render the nation impotent, she parcels out, \& sells to a crowned Head! \& her bitter enemy \& the enemy of the State thus sold, just what parts and parcels of the revolutionised \& subverted States may suit her interests. Istria and all Venetian Dalmatia, and Friuli, on the Italian side - and some other small districts, were Sold to the Emperor, in lien of Belgium, at the peace of the Emperor \& Buonaparte. this is, by this time, known among you - it is not deny'd even in France that all the north of Italy has been plundered of immense value in silver \& gold \& jewels, part of which goes, \& it is but a drop for a good brother to give, from Buonaparte to his sister on her marriage to one of his Generals, viz 500,000 Liveres in silver. From the poor wretched Venetians, he has exacted Five hundd. thousand Ducats \& they are to maintain the French army till it leaves them! To pay in naval stores $3,000,000$ Six ships of the line - To say nothing of 40 of the best paint. 
ings - three bronze Lions \& Horses of St. Marc's \&c. This after having sent in an order, during a time of Neutrality, to the Senate to change the Govt. - and this order sent to a Govt., wh. though certainly wretched, was the favourite of the people, which is a Fact. In that awful moment, it will gratify you to know, that in such a Senatorial Herd as that which abandoned the Government upon a Vote - Five Senators were found to dissent - these are probably the descendants of the Five houses whom I have heard of still living - in a right line from the original Senate of 700 years since. This country also, as an instance, must be familiar to the just fears of our country. The French have literally plundered the pockets, though not the houses of Batavia. The maintenance of an army of 25,000 men now quartered \& shifted about from town to Town - in small bodies of 1000 - or 1500 men must be added. These are at the expence of Batavia. They are Fed, \& enormously fed; clothed, \& elegantly clad; paid \& generously \& excessively paid, in a thousand secret [ways] at the expence of this unhappy country. And the expence of these over expensive men, exceeds that of an army of 35,000 during the war, of national troops. Nine million Stirling is daily paying into the French pockets - agreeably to their treaty, as a sort of ransom. To raise this in a country, where taxation had reached almost every mode \& article of life, before their treaty wh. France, the people are literally prest to earth. A prodigious fever is visible even among all ranks but the muzzle is placed Upon their lips - partly by their own act - \& partly, it is true, by such a train of events as was not long since coming upon the U. S. - \& which scarcely anything short of the present rupture could have arrested. After these two terrible instances, america will never lend an ear to the wiles \& the hypocrisy of France - and while her just \& correctly national opinions are Set in open day against the influence of great Britain, she will be taught to guard that subtle Tyger which has ravaged the liberties \& wealth of every nation that has been fool enough to trust her causes, \& doctrines; \& wavering enough not to Arm \& be ready. Half measures ruined Venice - they will any nation with whom France, Monarchy or Republic, moderates or Jacobins shall come into unequal contact of friendship or confidence. The passions of the people in America must be set completely against the French or our independence will fall \& they ought to be excited not by Govt. as that is negociating - but by a 
display of every part that illustrates the terrible consequences of admitting them into confidence or permitting approval. To gain time is a great deal - \& I know nothing better that could have been done. indeed it was essential, as during this, we aim \& continually put them ever in the wrong - finding the negociation, I expect they will attempt to show to the people U. S. that it would be an easy thing to gain their friendship \& support, wh. they will hold out as valuable in some tempting shape or other;-- \& they will do it for the purpose of convulsion, if they can not drive the negociation from their rock of right, $-\&$ probably still keep the negociation open. If however we arm \& the people are united, as I am sure from your letter \& my recollection they are, \& the congress speak a united language of support to the issue of the negociation \& particularly of the President (whom they the French hate or late hated) their plans will fail; \& though we shall never get redress, we shall get out of this quarrel honourably, \& the national mind will become truly National. As to the negociation you are very strong both in men \& matter - for vindication \& for assertion. Genl. P. is a very clever man, shrewd \& vigilant - a good scholar \& a good lawyer. I dare say - of Judge Dana, I know nothing personally-but he of course is skillful in the use of argument, fact \&c - and as to Mr. Marshall, they have no mettal equal to him. In fact, they are able men \& good ones. But what ean they do? can they convince? Were the point, for reasoning \& for Justice, they could convince - but the dispute on their side will assume the air of wounded Sensibility - they will not reason, but expect a flood of Sentiment to heal this wound-\&, in that healing, no Sentiment short of an affection veryfied by concessions that thwart our true Sovereignty, \& that retrospectively disgraces every principle of Neutral Justice for four years back will satisfy them - as to reasoning, there could be no doubt, if your Corps of generals, Sanctify'd by the ermin of Justice, would once bring them into a pitched battle - but depend upon it they will be all nerve - all sensibility - \& unless your commistioners are prepared upon that tangled track, they will not be attentively heard. What are the 'concessions' which in one day's debate I saw alluded to by my excellent \& orthodox friend Mr. Sitgreaves, wh. he said all were agreed upon, I can not divine certain that the term can neither mean the sacrifice of our Domestic honour in points of Sovereignty, nor of our existing engagements, I can imagine but one thing 
which it may mean. A determination, in revising the Treaty of Feb. 1778, to place France on the same footing with G. Britain \& Spain - or to give up, in the new treaty, those provisions which at the time we considered as benefits to us when Neutral - \& which France may consider the surrender of, as a concession - as Free bottoms - the list of contraband - \& the provision article \&c - to give her such in the revised old, or the new 'Treaty or as in that of G. Britain - but else what can we have to concede, as we are the grossly injured \& insulted nation. But my dear friend, I know we think alike. We know that this noise about the British Treaty is but rank Pretence. I have assured Genl. P. that the note taken had not fully stated or had misrepresented the Debate - as Mr. Sitgreaves is undoubtedly as orthodox a man as is in the Union - \& we know him to be able \& sincere, and also Firm and dignify'd in his purposes. Dana also, a good man, seemed to take it for granted that some concessions were to be made - but the cursed note takers spoil every thing - yet I would not for a million of dollars, that the paper which we read here Should be read at Paris by the Directoire. Genl. Smith's statement of the few vessels captured by France astonished us.

"Genl. P., daily almost, received letters from consuls in France \& from Paris exhibiting lists of captures - \& this sort of grievance is of so old an origin, that it is impossible that the information shd. not have reached congress - even the American traitors in France whose privateers, fitted out under french commissioners from france \& in France, which weekly bring in vessels (American) from our ports, some bound to France other to Dutch ports \& some to Ostend, and plunder them \& get them condemned - on the most frivolous pretences - even these must laugh in their sleeves at the proposition that few are taken. It is notorious here. I have been apply'd to by the house of Salomons, Amsterdam, to whom our ship, the good friends, was consigned, to give my opinion whether it was safe to send her, agreeably to Mr. Girard's discretionary power to them, to Bourdeaux - on enquiry I answered they must judge \& stated these facts. "The Mineral Springs, Capt. Boylton, stopped at Estaples by the Commissary of the Navy. The Romulus of Charles Town S. C., coming to ostend (since released by orders of the minister of marine). The William of N. P., Rhode Island, Capt. Baker, going to Bourdeaux, Captured \& sent into L'Orient by the 
Privateer Eagle, said to belong to an American of Boston, now in Paris, the cargo of the Wm., coffee \& sugar. The Briseis of N. York bound to Rotterdam, coffee \& sugar all belonging to Messr. Seaman Rutgers \& Ogden of N. Yrk, taken - carry'd into Nantz. Catharina of Newbury port, owned by Messr. Anthony \& Moses Davenport from Dumfries with Tobacco shipped by Furguson, Henderson, \& Gilson bound for Rotterdam, taken \& earry'd in.' They take our ships, they say, because they have no Rôle D' Equipage \&, by bribing part of the crew, \& if bribing will not do, condemn without the slightest reason. The practice, it is true, varies in different ports but this variance, though sometimes productive of appearances of Justice, is treacherous, for it is part of a scheme to distract - to excite hope \& attachment in some \& general dread of this power in all. It rests on the assumed position of France, that she acts by her own rules, \& liberates herself from the tyranny of all nations, by disavowing the obligations of the law of Nations, or of adopting its rules, according to her convenience. Nothing can be said to such a nation, but that we wish cordially for Peace with you, but we can \& will injure you, if you will injure us - \& show the power to support this self-defensive language. Nothing else can stop that career towards general \& Rome-like Dominion, but a species of universal police and armed one too, among the nations, who shall for many years to come have an acquaintance and a connection with her. In fact the tendency of things flowing from this infernal war is certainly to form all nations who are not her dependents to introduce a greater degree of the military spirit than was formerly necessary; to force all independent governments to be more or less military in their character \& unhappily to render all her dependent friends, unmilitary. In every thing, she preserves Roman maxims; - \& the execrable corruption \& slavishness of Europe have, it seems to me, prepared them for a fate similar to that which overwhelmed Europe, Asia, \& Africa with the stagnating \& bitter waters of Roman alliance, conquest, \& subjugation - for instance, the Roman Republic took upon herself, generously, to defend \& protect her conquered or influenced allies. In every spot, when a French army, or her influence, has got or become from circumstances complete, She does the same - \& even, in her own country, the people were disarmed. Paris is at this moment disarmed. These consequences, instead of producing what the real philanthropists imagined, \& what till three years since, I believed 
would arise, a greater portion of civil liberty to Europe, will tend, more than even the Feudal System, to enslave mankind - for it must produce military Despotism, acting over people who have lost the elevated tone $\&$ taste of the Feudal times nothing but the fear of a greater influence has prevented Spain from calling in French troops to join in her meditated attack upon Portugal - this fear, however, will Save Portugal, as Spain is unequal to its conquest.

"It is a fact that almost the whole of the Diplomatic corps of Europe in its inferior orders, I mean as to rank, as Secretaries, Charge Des affaires \& men who are even higher, but who were lately in that grade, are Jacobinical Philosophers all clerks, servants, \& the efficient men employ'd to work the business of affairs are so - this is the case, whether they belong to Republics or to Monarchies. Every man of reflexion seems to be endeavouring to acquire an apathy against all possible contingences \& changes - \& a vague uncertain sort of fear has taken possession of all men that some vast change in human affairs is not far distant - they see that all the old sources of power are drying up - that authority is stripped of its weight by reasoning scepticism. That though ignorance \&. superstition seem removed by the complete diffusion of books which reaches all sorts of people, yet real \& wholesome knowledge is not increased, when it ought to be - \& that though superstition be extinguished in appearance, morals, instead of gaining, have lost ground by the convulsions \& habitual strokes of that violence which removed it - a general scepticism upon all things exists - and men of speculation are lost in the magnitude of that crisis which they think they deserve - almost all this depends upon France. If she got into order. If she restored the christian religion \& could possibly restore her morals, the tide of insubordination might stop. If she continue, as she has gone on, a great crisis must come upon Europe, in which nothing but military despotism will at all hold society in a tolerable state of combination. In that country, there is nothing like a settled opinion. They love, all of them, as they ought, France above anything imag. inable. But their love is connected with ten thousand various directions of self interest \& party views. From exceedingly good information, it is probable, that the majority of that nation are tired with their Theory of Republicanism, \& wish for a King - \& it would not be wonderful if the Prince de Conde or the Duke of Orleans, according to party force, were 
brought into administration. The Jacobins would support the last. Clubs are now getting head once more, though contrary to the constitution, \& are endeavouring to rouse the people of Paris, for the nation has little or nothing to do with politics, on the score of danger arising from the royalists. This charge is partly true, \& partly owing to party hatred, which affixes to its adversary all sorts of opprobrious names.

"The embarkation of 15,000 french \& Dutch on board the transports at the Texel \& the appearance of a movement of the dutch fleet, wh. has been kept within the Texel a long time by a very few british ships at anchor, have excited much speculation - 500,000 Guilders went to it the other day from this place for contingent service. The real object is a secret that I am not master of. Hoche was here some days very lately \& a few, Then, of the Dutch public men, were admitted into his councils at the French minister's - he has returned. Some say this armament is against the Elbe - to block that up - others agt. Hanover - but that can not be, as the King of Prussia would preserve its neutrality \& it has an army of 30,000 very fine troops. my own conjecture is that it is an alarm to G. Britain - probably intending also to try the Dutch sailors in an engagement with Duncan's squadron French troops are put on board the new man of war, also.

"Lord Malmsbury \& his suite and a splendid one it is, are at Lisle with the French commissioners - Belgium, which was a principal obstacle, is removed by its cession to the Emperor, in Bonaparte's Peace.

"Genl. Pinckney \& family - Maj. Rutledge who ought to be secretary of Legation, as he is a very fine young man \& has had the rough of the business - \& the Genl's. nephew Mr. Hory are in lodgings near us - this Mr. Mountflorance is a great acquisition - as he is alert \& intelligent. The Genl. is much pleased with his commissioners. I do as you tell me, try to please the Dutch - but I must tell you entrè nous (you see I progress in french \& I read nothing else) that as yet I have, perhaps, received as little active politeness here from any one, as ever minister or traveller did. They (the committee) have, it is true, returned $m y$ visit wh. I made as is usual - but I saw none of them, as they either sent cards, or I was actually out when they called. They seem to me very distant.

"We are yet in lod̂gings at an hotel - one subject I wish to speak to you upon particularly. The American Hotel - 
as a minister $I$ am to live in it $-I$ so informed the Bankers who, Mr. Adams told me, had the care of it \& there were in it two or three poor families. I, at the same time, wrote to them to know, if they had a prospect of selling it to advantage. They answered they had never had orders to sell it - \& had not heard a sylable upon the subject. I had heard of some intention of selling. Mr Van Staphorst told me they meant to repair it, so as to preserve it from the weather, for the windows were rotten \& the roof excessively out of repair - that they had an original authority that extended to common repairs for the kceping up of the house \& to prevent its absolute decay \& they wished to put it into repair. I had previously told them that I intended to repair the rooms wh. I should use, at my own expence - \& that all wh. I could expect of them was such a repair as they wd. have given it merely to preserve the house. He said he would do as I wished but that they had been in the habit of giving it occasional repairs \& charged them to Govt. We got a workman \& I made him note down every repair \& its place or part of the house that I might divide the expence with the Govt. upon the principle, that I would pay for all repairs, except such as they considered essential to the preservation of the building these points are in this country particularly the windows, the out doors - painting of these - \& mending the outside - my part I considered to be painting in side, white washing \& papering - parts of the carpenters work inside wh. little I considered as the Bankers affair. They said they would charge the whole to Govt. \& if they did not authorise it, I should pay it. I agreed to this, so it stands - in fact, nothing will be done to it by this repair (for I intend to give it one myself when I get in \& have more time) which is not in a degree essential to the House, either as a tenement-or a subject of Sale. If the Govt. will sell it - It will sell best in other times - for now it would not sell for a 20th part of its value - as it is very large and has a garden back of it would sell, after - even this repair, probably, for twice as much as it would have done without it. All the ministers here have houses belonging to the Govt. wt. the Arms over the door as ours has. It will be more respectable to live in it than, in lodgings, or a hired small house in a bye part of the Town, for a marry'd man. I do not wish you to speak to the Secretary. of State, on it - but to give me your opinion upon my proceedings. If you think there will be the least emotion - 
pray tell me \& I will prevent the Bankers from making the charge and pay the bill which will be about $150 £$ Sterl, myself. If I am here two years, it will just be about the rent of a small house. Though the size of it will render it to one, in my small way, a much less comfortable residence than a small \& well finished house.

"As to Lisbon! ! - my dear friend, if it comes or not, I feel as I ought so as you know I do with a sincere sense of your constant kindness to me. It would be excellent - the climate fine \&c - but my humble merits have been already over valued. I am sincere - to know myself has been a pursuit of some standing with me. I am only astonished, sometimes, when I find myself forsooth here as I am - dear me! how this world is carry'd on!

"As to these commissioners - believe me, I have been relieved-from great terrors. I dreaded, lest the news of the mutiny in the british fleet \& the appearance of peace generally - the existing peace \& triumphant one of France wt. the Emperor all coming upon you might have damped that manly ardour that became us \& led to a concession in the appointment of at least the middle commissioner whom France has as far as she could do Dictated. I mean him who tells what the greatest philosophers have said upon all subjects. He could not have sustained that plan wt. out making a sacrifice of all he has said \& done for six years. His duty wd. have led him to justify our Govt. how could he have done that! I do rejoice-- \& I can see the administration all unite firmly against a pressure of party address or influence exceedingly powerful for his nomination.

"How ardently I wish to hear from you, you can not conceive, as you are not in a distant country - in a scene that every moment affords visible proof of the danger we run, if preparation, union, \& especially a firm appearance are not the result by this very day of our councils - god almighty direct them!

"To write with more freedom you need not sign your name. I also do not - you can put my name on the endorsement \&c. I wrote a few days after I got here. Tell me, in perfect confidence, if I go too much in to speculation \& opinion in my letters to Col. Pickering, my means yet are extremely small - not that I ever expect to equal the comprehensive digestion of my predecessor - who is really a very learned and able man \& was exceedingly cordial in his communica- 
tions to me - he was here but a very short time after my arrival. I got your letter just time to tell him, then wind: bound at Maas-Sluys (12 miles off) of his appointment - he sailed seven days since for London - in excellent health \& good spirits \& I hope by this time marry'd to his beautiful \& I hear very charming Miss Louisa Johnson. A young Baron de Bielfeld is here charge des affairs from Prussia, as soon as I saw the nomination mentioned in the paper wh. you sent me I wrote to him a note in confidence!! Stating it. He wishes to know if it be a steady \& permanent appointment. I told him I did not know, but it probably was. There my dear Sir - is not that political \& diplomatical intelligence! you see I have secrets \& tell them in confidence. Baron $B$. is a very clever youngish man - speaks english well - \& I wanted to give him with a proper air of mystery the opportunity of making the earliest dispatch upon this subject - as I wish much to gain his information \&c.

"I wrote to Col. Pickering on the 30 . June \& shall write to day, or rather to night, as this letter has cramped my fingers — it is egregiously long - but I can not now fall in \& greet \& be greeted by you \& Mrs MeHenry - set down to a hot supper \& preach up an austere abstinence - so I must write.

"Mr V. Polanan's memorial was not among the papers wh. you enclosed. Don or Chevalier Yonge's was literally a curious thing. Col. Pickering completely discomfited the Secretary of the council of State \& the member of the distinguished order of Carlos the 3d. \&c \&c \&c Genl. P. is much pleased with it. He laughs at 'the wheels of his carriage' which broke down \& which appear to travel throughout the U. S. as among the most interesting parts of the detail. I wish the wheels had been omitted in publication - unless it was intended to show the crippled situation of his equipage \& of course their brutality in driving from France a minister whose wheels were destroyd by their own roads.

"A few days after I received yours of the 23 May - I heard that a ship had run ashore at the Texel from Philad. got 3 feet water in her hold - \& that dispatches for Genl P. \& myself were lost - two days after I got a letter from $\mathrm{Mr}$. Wolcott which was open at the end, appeared to have been wet - but of the others I can hear nothing. I subscribed to Fenno \& paid him for one year. It would be a most pleasant thing if you would make him send them papered in strong paper in small bundles by ships going to any port in Holland. 
"The part of your letter respecting Genl. P. \& young Rutledge gave both Genl. P. \& his Secretary very great pleasure - as I took the liberty of reading that part to them.

"Pecquet \& some others you shall have with pleasure there is not one at this place but at Leyden I shall get one. I shall send you Mably's Droit Public de l' Europe with notes by Rousset - \& Callier. I can not hear of the letters pub. lished at Amsterdam on Neutrality but will still seek for them.

"The excessive moisture of this country has affected me a little but, thank god, I enjoy good health compared to anything I have tasted these two years.

"I am my dear friend with sincere and affectionate esteem yrs always

"Genl. P. comes in and knowing that I had just written requests his respects \& compl. to you \& that he will get the books you spoke to him about - \& will write in a fortnight to you.

"The inclosed letter to the president (Mr. Adams) I will thank you to have delivered to him - on the day when you receive it." ness :

On the wrapper of the letter Murray wrote urging firm-

"In sending this large wrapper, its white surface tempted me, as it is to go so very far to my friend, again to speak upon the wish nearest $m y$ heart \& to which all my reflexions tend from what I can hear \& know. That you shall put the peace of the country into a good attitude. Arm the Executive with means to sustain a certain port \& carriage with the Directoryrepress every thing in Congress that the French might mistake for two opinions upon their conduct - you actually raise an army \& put the keels down for the Large Frigates and for the small ones, and enable the negociators to agree as well as to explain - then my dear Sir we shall have peace with France - of Half measures, I mean as to preparation against * * * \& a certain decided \& well supported purpose sufficiently manifested, though accompany'd by a sincere disposition at the same time to settle \& adjust amicably - of half measures, my dear Sir, look at Venice! It will be said this will be useless expense and you will want an armed neutrality against that state of things which will take place after the peace. I sincerely hope that, if the old treaty of 1778 is to be revived - 
the Free ships free goods may be omitted. The internal code of France has always contravened it \& always will - \& no nation will observe it, unless the neutrality be armed. If we can arm \& enforce, it wd. be great for us - but that can not be expected. In 20 years, we shall be equal to its enforcement Were we to give to France a severe lesson for this break of that provision, we might hope to see it gratify'd in the next war she has - but that is not intended. She \& G. Britain must be at war in two or three years after this peace, shd. one take place - \& then we should only go through a course of similar usage and have fresh cause of complaint \& of complain. ing - again good night.

"Russia \& G. B. in the month of Feb. made a commercial Treaty, in may it was ratify'd - upon liberal terms - but nothing new in it."

McHenry had asked Murray to procure and forward him some text books on the art of war. On July 18, the minister writes, forwarding one of them. He also gives news as to France's position with reference to the United States.

"My dear Sir,

"Since I wrote the other day I have got you a second hand Pecquet - and enclose it with a paper or two from England wh. Mr Ross of Philad. brought over to this place.

"Nothing yet transpired as to the actual propositions of the Negociaters at Lisle. What is singularly severe is though this Republic has provisionally appointed them commissioners to treat in conjunction wh France, yet they wait for an invitation before they venture to send them! There is much s secret sensibility to this humiliating situation. I really do wish to see my friends the Dutch, happy, independant \& strong. Spain also has, it is said, been checked on her sending on another minister, Cabarrus, to join. Her ordinary minis. ter, Marquis del Campo, I believe is not yet admitted to the negociation. Probably France will make more money out of both. If she chuses, she san say to them, when the negociation has advanced, you are both to take care of your selves, unless you will do so and so for me $-\&$ force them, the Dutch particularly, into further sacrifices. The extent of the means of France is in her inventions - when once She has a people's affairs in her power. Since I wrote some days since we have the Philad. papers with the answer as carry'd - \& have been extremely exhilirated by both the answer \& the Speeches of 
our fine fellows - would you think it - but I panted to be in the midst of them \& to increase the dust of the race, if I could not run as fast \& well as they. Mr. Dennis's I did not see. I am rejoiced in my successor. I knew he would be found worthy of the District \& of public confidence.

"I am getting more and more into the circles here. Within these few days, means have been taken to impress me with the persuasion that the Directory mean to conciliate towards the U. States. A member of the national assembly visited me the other morning and assured me that as Batavia \& France were so connected that what ever affected the last also would be felt by the first, it became important to ascertain exactly the intentions of France respecting the U. States - that they had ascertained them decidedly to be not to have a rupture. I remarked that France had taken a singular way of manifesting such an intention - that the U. States would seek the means of continuing Peace \& amity with sincerety - but that she was also united \& prepared for the worst, if her means failed - \& then spoke of the high animation that united all men, in a band as strong in union, \& greater in means, than was seen in 76 . That parties lost their distinctions in what they considered as a second question of Independence \& that the Government was stronger than ever \&c. He said he was convinced that there would be no war. This gentleman is a warm but honest revolutionary - Is with the French - \& a confidential man with them. I wished this channel to carry an impression to the French minister, who is of a conciliatory disposition, agreeably to the principles of French conciliation $\&$ is considered as among the most moderate men among them. Since, I saw him - He exprest a wish that matters might be made up - \& his decided expectation that they would be; that he could say so, because he had the day before (this was yesterday) received dispatches from the Governt. to that effect. I assured him that, while the United States sought Justice, He would find that they did it in a spirit so perfectly conciliatory that it would not be their fault, if every sentiment of amity were not only revived, but very much encreased. God forbid that the very same sentiment of amity should even revive, much less be encreased! All this, however, on the part of the French or their friends here I consider, as you certainly will - as used for the purpose of abating our exertions - of diminishing, in our eyes, the appearances that lead to preparation on our side - all this flummery is meted out 
too at a moment when they go on, with encreased vivacity, in both taking and condemning our vessels - \& when they publish in the Redacteur (the official paper) the intelligence of the petition of the owners of privateers at Nantz, in support of the hostile proceedings of the Directory, as A Complete Answer to Pastorets arguments against the Directory on our relations. Were it not monstrous, it would be ridiculous, to hear this language of conciliation under such circumstances of extreme insult \& provocation. But they will come down in their language, because they see we rise in ours - they will do this, though they do not alter their conduct-\& if they find it politic to do justice, they will then say, we always held this language, since we heard of their new negociation that was intended \& wh. show'd that the U. S. meant to explain. The expense of preparation, though hard upon us all, will be a tax upon them, as it will be in the account of national sentiment against them \& will lead to that glorious iudependence of all European states which will make us a nation. If it save us honourably from a war - and nothing but that can, it will be a trifle. If it do not, it will have made us ready to meet it.

"I write in great haste. Doubts are entertained of the new constitution of this country. M. Noel, the French Minister, yesterday, wrote a note to the National assembly, informing them that the Directory of France felt the most earn. est wish that the new constitution may be adopted. This is Internal Sovereignty for the national assembly. I hear that, while they were upon the constitution, he used to send to them to hasten the work. This was \& is kind. But not essential to their exercise of Sovereignty.

"A westerly wind actually came up to save appearances - \& prevent the Fleet from getting out of the Texel. But they can not attempt it. I wish they were as independent \& as strong in marine as in the great days of Tromp!

"I shall write soon - very soon - if my dispatch for the Secretary of State wh I have kept open should not arrive, when this does, you need not say ought of this.

"Yours always my dear Sir

\& most affectionately"

Some weeks later, he writes again, urging that a firm position be taken by the United States, but saying that if America does not take a sufficiently strong position, he, never- 
theless, will try to explain a weaker attitude to his country's advantage.

“My dear Sir, "The Hague 7. Augt. 1797.

"At length, in an auction of old books, I picked up a Pecquet's Le Esprit de maxims for you \& now send it. I am looking out for Lempredi on the rights of neutral nations, wh., when I get, I will send also to you. I was so lucky as to get your No. 1. - but none since \& expect a line from Mr. Wolcott $\&$ two letters from Col. Pickering. I have not received any thing from America. If Fenno would seal up his Week's papers, for wh. I have paid him in advance \& send each packet to Mr. Girard, in whose ship I came - Mr. G., I am sure, would put them in a way to some port in Holland - \& I am so extremely anxious sometimes upon the State of things at Philad. that I would give their weight in gold for late papers.

"My dear Sir, I fear - much fear that nothing will be done by congress that will bear out your negociators with spirit. I am well aware of the folly \& wickedness of any rash step that would do mischief - but I am certain that Spirit guided by moderation in its display - \& PREPARATION alone can insure PEACE. A weak nation must arm as well as negociate - a powerful one need not always. A nation supposed to be divided must give a testimony of its union by those great preparatory measures, which never would be taken unless the country was united. Preparation must be the evidence that we are united \& that we are not French. Doubtless France has several objects. First, to destroy british commerce. Sec. ondly, to plunder, while she produces this end - thirdly, to produce eventually disunion, that she may erect any part into an independent government, as she has The Lombardy Republic, Genoa \& Batavia - part of the scheme she has accomplished, the plunder of our trade - this is among her means of forcing us to give up british commerce. If she finds us not united, she will urge the necessity of giving up the Treaty \& of making such a Treaty with her as the Dutch have done - \& in the party struggle upon her propositions, she will expect to see the completion of her grand scheme - a dissolution of the union \& a revolution in the U. S., in which she would occupy all the ground she could. A united \& most decided tone, attended by armed preparation, alone can lead her to listen to reason - our relation from situation to the colonies, \& especially to the dominions of her ally, Spain, 
would, if we arm \& treat, give us very high ground. Unless we have the virtue to encounter present evil in taxes $I$ am convinced we shall have to meet one much greater - War.

"There is little expectation of Peace between France \& G. B. Ceylon \& the Cape of good hope are among the obstacles. G. B. will not yield them to the Dutch - she probably might to Portugal as Free ports. I have not, as you may have perceived, calculated upon Peace this Summer. This is important to the U. S. The mutiny in the B. navy, I have feared, would tend to destroy the energy in Congress, as though no alliance was thought of, if we were forced into war, there w'd be a national co-operation between all the enemies of France. The british navy, however, is now more energetic than everDiscipline restored \& even mended, neither France, Spain nor this Republic venture their fleets out of the harbour. The moderates too in the councils of France daily confirm their influence over the public mind. They are rather more rational than the others - \&, of course, if we show union \& can convince them that they have no chance of Striking a great blow for their own country through our inviting weakness \& disunion, these men will, if any ever will in France, do us something like justice. Parties are again critically high in Paris. The army of the Sombre \& Meuse advance in detachments to the vicinity of the Capital, it is supposed to act with the Directory against the Cinque Cents. Depend upon it that devoted country is yet to unfold all the horrors which superstition has accorded as the punishment of impious opinions \& dissolute moral character. I wish our exclusive patriots could see \& hear the Republicanism of Frenchmen in Europe, not as they write it, but practice it - if they could recollect in the most gloomy periods of Roman despotism or invent a scheme of practices more oppressive \& at the same time more ambitious, more sickening to the soul of any man who can pity the miseries \& vices of the human species, I would agree to admit of the apology - and thank the apologist. I remember nothing worse. But this is like canting - yet so perfectly does the human nature appear trampled upon \& so withered all the opinions resulting from the civilized state, it is impossible to be here \& not be occasionally gloomy. The Batavians, to a certainty, will reject the constitution which has been in truth bastardized upon their bed by those French universal political cuckoos - but which it had been best for them to accept. If they reject, \& to-morrow is the day of trial, the French will 
force one down their throats - that they expect \& lamentable! Some of their best men wish it!! Such is their State - a nation without a political existence. By a Paris paper it is exultingly said Congress has rejected the propositions to arm except militia! Sorrowfully did I read this. Since I saw this, I have said - As France had not made any great naval preparation to act eventually agt. us, America, strong in herself conscious of her vast internal strength, waited the result of a conciliating negociation \& that we reply on the justice of France \& on reason.

"I am always most affectionately my dear "Yrs. faithfully"

Four days later Murray wrote again, still urging firmness and complaining of the conduct of the French towards Americans.

"The Hague 11. Augt. 1797.

"I wrote to you, my dear friend, on the 7 th. - and since have seen in a N. York paper that little is to be expected from this Session. Sincerely do I lament! Several here in public life have asked me about this. I say to them France does not arm against us - \& we can not. That if she had seamen \& officers she has not revenue, that we are conscious of immense internal strength \& that there is a perfect sincerity in the executive to treat amicably, that congress have gratify'd the views of the Executive which were but for a small beginning - for that eight or Ten Frigates and so far ships are considered as a trifle in a country whose tonnage bears near 40,000 seamen \& $66,000,000$ of exports - \& of course feeling the greatness \& immediate readiness of resources that can be put into array if the worst Should come, we lay upon our oars till the disposition of France manifests itself. This is true too. But alas, alas!

"France will urge us away the terms of returning grace and favour a loan of ten or more million of dollars. Paine industriously now circulates the idea that the clear unreturned expence of France, when she gave us our Independence! ! was $18,000,000$ dolls. - \& that it is as little as we can do to lend her as much at present - i. e. - give her as much.

"Daily almost, I have to give passports to our citizens with French cockades. Those who are of the true blue, or have a special passport from M. Adet - or a letter from a member of the Government of France can obtain the necessary 
indorsement of M. Noel, the French minister here - those who have not those mysterious recomendations are told by him, Sir, the arretè of the Directory renders these passports from all American ministers, nugatory - \& you can not go into France, except you have a vessel under trial. This is the policy of France to let our citizens see \& feel the importance of their own government - that as mere Americans they are nothing - \& something only if Gallo-Americans! Yet in the U. S. the treaty, which the french violate in all its provisions, is honourably maintained in all its rights!

"Sir, the day is past - \& the Constitution, from the best intelligence, is Rejected by a large majority. I really do pity these good people - to be asked to quit the desk - their dykes - their strait walks - their calculations about stocks \& their heavy taxes to study an abstruse volume of constitutional rights! It is impossible.

"About Four to one voted, of those few who would vote, against the acceptation. I went on that day to Rotterdam, passed awhile at Delft, \& returned next day to this place all was still \& apathic (if such a word be!) at Delft, out of 1500 votes, 1100 won against adoption. Several told me they would not vote, because they did not understand such things - others, because the preliminary Declaration of the rights of man excluded the Prince of Orange - \& others, because NI. Noel had recommended it. Pray remember me to Mr. V. Polanen. The French will now give them one in the stile of the Italian Caesar. I can perceive attempts are making to obtain M. Noel's recall. He is too good a man, I believe, for the dirty work expected of him who is to regenerate a people by deception \& gulling or fear \& peace - though he can do a little at all - pray send the inclosed to the President - the News papers. Yours always most affectionately my dear "friend

During this time McHenry had been very much occupied. He had been cheered by such tokens of popular approval of the administration, as Hindman sent him from Bellfield on May 7.

"I did not receive your Letter of the $22 \mathrm{~d}$ nito. until last Evening, it having gone to an Office with which I have little Intercourse .

"A considerable change of Sentiment has taken Place here towards the French, I wish it was universal throughout 
the United States, as I believe Them to be a perfidious and abominable Nation, whose Object appears to be to lord it over the rest of the World, I should be much gratified to hear of their being thoroughly drubbed, as it might possibly bring them to a Sense of Justice \& Humanity. Mr: Pickering's Letter \& Phocion, if generally circulated, would do immense Goed to this Country, as 'They are both excellent \& masterly perf()rmances "

A month after Congress met, McHenry was disturbed by a fear lest Canada should be yielded by England to France. In that case, he felt that "our situation would become extremely critical. She will not let us alone, even if she fails to receive Canada. Her internal practices upon our people go on as usual and it seems to be the determination of a part of Congress to do nothing." On the subject of our foreign relations, Carroll of Carrollton wrote McHenry from Doughoregan on June 26 :

"I am obliged to you for the communication in your letter of the 15th instant. Poor Spain, how art thou fallen! Is it possible for any Americans to wish to place their country in the same degraded situation \& miserable dependence on France? A war with that power should be avoided by every means which will not dishonour ourselves. I detest war, and look upon it as the greatest calamity, which can happen to a nation, except infamy \& the want of virtue: a too passive a conduct, even instead of averting, may court hostilities.

"Does not the tranquillity of this country depend on a decided superiority at sea of England? If on a general peace, France should establish a good government, her attention will be turned to commerce $\&$ the formation of a powerful marine; liberated from public debt (I consider her as bankrupt) she will, in this respect, have a great advantage over her rival; if hard conditions of peace be imposed on G. B., the ill humour of the nation, the heavy taxes, the irritation \& discontent of Ireland, the folly and profligacy of the heir apparent will probably occasion some great revolution in those isiands, an event which may be productive of the most serious consequences to our country, as France would then be without a rival on the seas: and I think it would be imprudent to rely on her moderation \& justice. I am anxiously conjecturing what measures she will adopt with respect to us on a peace with England : compensation for depredations I do not expect; 
this would be admitting she has acted unjustly, and she is now too proud to acknowledge this - should the war with England, her only remaining enemy, be continued, may we not expect every effort will be made by the Directory to cut off our commerce with that nation and its dependencies? is there not great danger of our being forced to become a party in the war, and will the most extreme passiveness and servility, if we can bare to be humbled so much, exempt us from declaring in favor of the one power or the other? Time, the great unfolder of events, will clear up all these conjectures, with which I will no longer tire you. I am with regard \& respect

"Dr-Sir

"Yl most hum. Servt.

"Ch. Carroll of Carrollton.",

Naval natters were still under McHenry's care. The frigate for the Dey was building and the casting of the guns and the purchase of colors for it demanded consideration. For our own navy, the Constitution and the Constellation were under construction, ${ }^{1}$ the work on the last vessel being supervised by Thomas 'Truxtun at Baltimore. As these were the first vessels of our permanent navy, Truxtun's letters to McHeury are of interest.

He wrote from Baltimore on the 3rd of March, 1797 :

"Agreeable to your desire, I have now the honor of transmitting you a list, of such officers \& men as I consider necessary to kecp employed for the care and preservation of the frigate now building near this city; that is to say, after she is launched, completed and the master carpenter and other artificers, \&c, are discharged and the ship laid up.

"If the chinese system is not to be adopted, in the United States, and the people of our towns continue their commercial habits of trading beyond the sea, it is evident that whenever two European powers are at war, we shall always be subject to insult and depredation from their Public and private ships of war, unless we have a Navy to defend our rights, and support the honor and dignity of our flag - but without officers what can be expected from a Navy : the ships cannot manuvre themselves: nor will the best of soldiers answer as substitutes for seamen, this every man must be convinced of, that reads the numerous accounts of British \& French engagements at

1 See McHenry's reports June 16 and December 26, in State Papers, Naval Affairs, pp. 28 and 32 . 
sea, in which we find the former always victorious, not because they are a braver people, but on account of their knowing their duty as seamen and tacticians, whereas the latter nation is but little acquainted with either art.

"Thus, sir, it is evident that, if we are to have a Navy, we must make officers to manage that Navy and this can only be done by employing a few ships of war, in cruising about in times of peace \& guarding the revenue \&c., for in a very few years more there will scarcely be an officer fit for service to be found, who acquired any practical knowledge, during our Revolution, and to introduce foreigners into our Navy would appear to me a very dangerous policy.

"For the above reasons, I should be glad to see active and respectable men appointed as lieutenants and midshipmen, in order that they might be brought on to learn the art of marine science and to supply the place of those, who in a few years will be incapable of this sort of service: But knowing the pusillanimity of Congress, and supposing the Executive will let the business in question remain in Statu quo, untill the next session, I have only made out a list of such officers, as are necessary to take care of the ship, stores, and other public property within the Yard.

"It is always considered that even small merchant ships, suffer more from being laid up in port, tho' under the eye of the owner, than when in actual service, and I am convinced the fact is so, since the necessity of having proper people to take care of these ships when afloat is very obvious.

"This frigate, while laying in ordinary, will be moored at the end of the wharf where she is now building (with two anchors out) near to which are all the magazines of stores, containing the articles of equipment, which are under care of the clerk, and should in my opinion continue so, as he appears to me a faithfull, honest, diligent, sober, and carefull young man. If the arrangement I here offer, meets with your approbation, I will, as soon as the frigate is launched, order the Clerk and Petty Officers and men to be employed to take up their abode, lodge, and keep watch on board, and, by that means, they can guard the store houses and all the other public property within the yard, as well as the ship. But while every thing that respects the frigate is now in motion, it will certainly be most economical to completely finish them, and provide every necessary article requisite for their equipment, 
except provisions, in order that they may be ready for any emergency.

"When the contract was made with Stodder for his grounds, that are now enclosed as a public yard, and on which are several buildings for the accommodation of the materials, it was agreed to pay him for the said lot now enclosed, a rent of four hundred dollars per annum, during the pleasure of the Government. I have, therefore, made a calculation of the probable expense, that will attend this ship, while laying in Ordinary, including the said rent.

"Rent of Navy Yard per aunum........... \$400

"One Captain 75 D per Mo. \& six rations per day. . 1338

"One clerk to attend the yard and ship........ 600

"One Boatswain per month to find himself.........\$30

"One carpenter ditto ditto... 30 is per annum 1680

"One cook ditto ditto...20

"Three seamen each at $\$ 20$ ditto 60 )

"Paints, oil, brushes, brooms, buckets, wind sails moorings, junk \& sundries

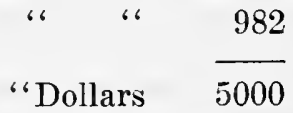

"Altho' I have contemplated that the persons employed to attend, watch and take care of the ship while in Ordinary shoula find themselves provisions \&c. a cook will be necessary to dress their victuals on board, and such a person may also be useful, in aiding the others in doing the various duties of the ship : otherwise four seamen would be necessary instead of three, which amounts to the same thing.

"The expense here stated will perhaps appear high to you, but unless proper people are employed, there will always be a waste and plunder of the public property, and I know of no way of lessening this expence, but by assembling the ships after they are built at one place, and then it might be curtailed very considerably from the aforegoing calculation, \& many other savings made to the United States.

"In my report to you in December last, I stated that, if the winter was not unfavourable to us, that this frigate would be launched in May ensuing, but, as two months has been lost, owing to the severity of the weather, she cannot well be put afloat before July, unless some extraordinary efforts are made, 
and the workmen augmented. Therefore, if you will be pleased to refer to my said report and add; that the bottom is now all planked except two Streaks : the upper works the same all but two Streaks; the orlop and lower deck beams all in and mostly knee'd \& the other deck beams ready. You will then be completely master of the true state of this frigate: Stodder, however, will send you a report by Monday's mail, agreeable to your request. I have the honor to be very respectfully your obedient \& humble servant

\section{"Thomas Truxtun"}

Truxtun wrote again from Baltimore on the 20th of May, 1798:

"Under a blank cover, but I presume forwarded by your order for my perusal, the last mail brought me your letter and documents, addressed to Mr Livingston, Chairman of the Committee appointed by the house of representatives to inquire into the expenditure of the Naval Appropriations, and published by order of that house. Altho' the cost of three frigates taken separately, was not ascertained when these papers were published, nor perhaps very accurately estimated, on account of the manner in which the business has been transacted by so many persons concerned in the arrangements \&c: I very long since anticipated, that the one built here, would cost an immense sum of money, previous to any step being taken, towards making preparations for laying the keel of the constitution, I stated to General Knox that it was my opinion, none of the ships contemplated by the Act of 1794 for providing an Naval Armament, ought to be built to the southward of Philadelphia, and, in giving that opinion, I considered the interest of the United States alone, without any local consideration whatever. The Secy. received my communication with politeness \& thanked me for my attention, observing at the same time that tho'he himself was not conversant in Marine affairs, he was under a belief that the ships built to the southward, would cost. 25 pret more than the others, but that the President was willing to make experiment, in order to ascertain where they could in fact be built and equipt on the most favourable terms, and that another object with him was, in point of policy, to harmonize and distribute the money to be spent in the opperation more generally through out the Union. On these observations, it was not for me to reply, but, in short time after I came here, I was more than ever confirmed in my 
opinion, of the ineligibility of this place, and regretted that it fell to my lot to be fixed here. I found no choice of artificers, labourers scarce and indolent, every article higher in point of price than in the other parts of the United States $N$. E. of this, where yards were preparing - that part of the city called Fells Point, in point of imposition a second Wapping. The master builder determined to make the most of the job, as he early declared he would never build another vessel, after completing the frigate. Thus circumstanced I became early disgusted with almost every one engaged in the business in this quarter, and wrote your predecessors and self with candor, from the eommencement of the business, up to this time stating every thing as it really was, and to Mr. Pickering. I proposed, at an early period, an alteration in the powers vested in the parties concerned in building this vessel, and have his answer now before me; he declined to acquiesce, on the prineiple of not altering the original arrangement of Genl. Knox, as I understood him afterwards; which perhaps, in the then state of things, he was prudent in adhereing to.

"It would be of no sort of use for me to dwell long on this subject, or to write a lengthy epistle. I will only say, I have by a deeided conduct, and independent spirit, saved thousands to the United States here, and I thank God I have never touched a shilling of the publick money or derived an: advantage from the building of this ship; but have made great sacrifices of my time \& have spent much money in attending four years now within a few weeks on her; not as a commander only, but as a direetor to the arrangements for the Carpenter, Rigger, Joiner, and every other tradesmen, for they were alike ignorant of such business; tho' otherwise good workmen.

"The agent, however, he or his brother, or others of their friends may suppose, I have often stept ont of my line or was unauthorised in giving my opinion in matters of aceounts, as decidedly as I have done: I have, notwithstanding, never hesitated to talk to him in plain terms, when I diseovered an indifference, as I thought, in checking, with promptness, the evident impositions of most or all of the tradesmen. Many charges exhibited I have often told him he ought not to admit, in some instances, he may have taken my adviee, in others, I believe he has not, for, as I do not see his books, I do not know, and, if he has not, I camnot help it: but however unqualified Sterett may be from his age, easy temper, and inexperience, I am under a firm belief that he is a very upright, honest 
young man - as I have constantly stated every thing of moment, respecting this frigate and her materials \& the expense of building and equipping her, I must beg leave once and for the last time in all probability to inform you - that the great quantity of materials in this yard I fear will be totally ruined, if left exposed to the sun \& if they are moved, the expense will be enormous, in fact, Sir, the salary of Mr. Cole, and the rent of Stodder's yard, with what will be stolen in the course of a year or two, will leave little for the United States to calculate on receiving thereafter, and again, if in the final settlement of Mr. Stodder's account with the agent, carc is not taken by proper precaution and advice to Mr. Sterett, charges will be admitted that ought not to be, and credits omitted that ought to be given, through the management of Stodder and the easy disposition of the other.

"Stodder owes the United States for iron, nails and he now demands $£ 50$ for the use of an old Smith's shop, which he told me at the time we first made use of it, in the presence of the clerk and others, that the United States was welcome to occupy it without any charge whatever. The salary of Stodder, I suppose, was only continued, one quarter after the first of Jany. last, as we have not employed him more than that time. I mention these circumstances merely for your information, and more particularly as the business to Stodder, has not been of that nature, that he ought to receive further compensation.

" Altho' this is a very improper place for building large vessels, the Chesapeake turns out the finest shaped and fastest small vessels built in America.

"Since my last I have sent down twenty men, and leave this tomorrow for the ship myself.

"I have the honor to be sir with great respect, "Your very obt. h. S. in haste.

\section{"Thomas T'ruxtun"}

On June 3 and 6, 1797, MeHenry recommended congress $^{1}$ to appropriate $\$ 2,000,000$ for fortifications and $\$ 23$,400 for repairs, etc. Forts were to be built at New York, Philadelphia, Norfolk, Savannah, and in North and South Carolina. MeHenry was discouraged at the outlook in French relations and wrote Washington on July 9: "It would seem

1 State Papers, Military Affairs, i, 118. 
as if nothing, short of a dismemberment of the Union and having a part of it under French protection, would satisfy the directory. After gaining this point, at which I am sure they aim, France will then play for the whole."

In answering the letter, Washington asked McHenry to have the articles left by him in l'hiladelphia packed for forwarding to him, except the three two bottle wine coolers, one of which he wished given to McHenry, one to Pickering, and one to Wolcott, "as a token of my friendship and as a rememberance of it." 1 McHenry's cooler is still possessed by his descendants. Yellow fever broke out at Philadelphia in the summer and, on August 19, McHenry wrote Wolcott, ${ }^{2}$ who had gone home to nurse his sick father, that he has sent to provide a retreat for his family forty miles away on the Lancaster Road, but hopes "there will be no occasion to use it." As the fever increased, he did remove to near Downingstown, whither Wolcott wrote him from Philadelphia on September 11:

\section{"My Dear Sir}

"I reed. your oblidging favour of Aug. 19th. which gave me the first information that a serious state of things existed in the city - it gives me pleasure to find that yourself and family have removed; I hope you have found a dry \& healthy situation; - here I imagine we are exposed to the fever \& ague. The yellow fever, or the Doctors, or both together, have killed poor Lewis, your messenger, and I am entreated by a worthy old man, Mr. Borrows, the messenger to the Comptroller's office to recommend a relation of his, William Markworth, who lives nine or ten miles from the City - Borrows is one of the most exemplary men of my acquaintance \& he speaks of Markworth in decided terms as an honest, sober, \& diligent man. I could not \& ought not to refuse conveying his wishes to you, though I have been careful not to raise his expectations.

"My friend, I have not been here a week, \& yet I have found out that living alone, in a small room in a tavern, with the prospect of a crooked river running through a marsh, \& occupied alternately with some dull job of business or conversation respecting the distresses of a great city, is far from 222 .

1 Ford, xili, 413, Lear's "Letters and Recollections of Washington," 2 Gibbs, i, 559 . 
being in a state of perfect happiness. The contrast between my present situation and that which I have lately left is most impressive. I have been lately too happy; - it is just that I should experience some reverse.

"Please to present my respects to Mrs. McHenry \& believe me your assured friend

\section{"Oliv. WolcotT"}

McHenry himself fell ill in September and, while convalescing, wrote Wolcott ${ }^{1}$ on September 22: "The bilious fever, with which I have been attacked ${ }^{2}$ has left me weak and subject to feverish returns that affect both my sleep and my spirits. I flatter myself, however, that a little care and time will enable me to enjoy the beauties of this part of the country; which are far more numerous and interesting than the dull, damp, sedgy, serpentine, sorrowful river, whose banks have become your residence."

From this country retreat, McHenry wrote ${ }^{3}$ Wolcott again on October 2, "I am kept too busy to get well," and on the 4th, Wolcott suggested that the president would do well to invite congress to consider the same measures as were introduced at the last session. McHenry agreed to this proposition ${ }^{4}$ and, on the 16 th, Wolcott wrote Adams that both McHenry and Lee had favored a continuance of the former recommendations and that he hoped the president and secretaries may all meet together before congress convenes.

Adams, meanwhile, had started towards Philadelphia, and wrote McHenry from East Chester, twenty miles from New York, on October 15:

\section{"Dear Sir}

"I arrived, with my Family at this Place four days ago and propose to remain here and at New York, till the Meeting of Congress. Letters addressed to me, to the Care of Charles Adams Esq., Counseller at Law in New York, will soon find me.

"I pray you to commit to writing Such Things as you judge necessary to be communicated or recommended to Con-

1 Gibbs, i, 563.

2 One of his sons fell and injured hlmself and Washington inquired after the health of both, in a letter sent McHenry on October 16, 1797. Lear's "Letters and Recollections of Washington," 242.

3 Gibbs, i, 565,566 .

4 Gibbs, i, 567 ; 568 . 
gress at the opening of the Session, and convey them to me, as early as possible - And to give me your Opinion, whether the Prevalent Sickness in Philadelphia, is so dangerous to the Lives or health of the Members as to make it necessary to convene them at any other Place.

"With great regard I am Dear Sir

"Your most obedient "John ADAMs.",

MeHenry promptly wrote Adams and received a reply dated from East Chester on October 27 :

"Dear Sir

"I last night received your favour of the 22nd and thank you for your Sentiments, with which in general I very well agree.

"At the Same time I recd your other Letter of the Same Date with its Inclosures, all of which I return to you with this. I thank you Sir for your indefatigable attention to all these subjects. The Letters and Instructions to the officers, especially to General Wilkinson, appear to me to be all well weighed, and judiciously decided.

"I shall observe to put my name, on my Letters in future, as you desire. Mr. Malcom omitted it by mistake, on one instance only, I believe.

"My Servants are returned to Philadelphia and found the House in Order, notwithstanding two unsuccessful attacks upon it.

\section{"I, Am, Dear Sir your humble servant "JoHN ADAms."}

The reference to Wilkinson carries us to the West, whose affairs had pressed themselves on McHenry's attention for some time.

As early as April 3, James Ross, the Federal leader in western Pennsylvania, had written from Pittsburg:

\section{"Dear Sir}

"Genl. Gibson is summoned to Attend the Federal Court as a Witness, probably you will be making Indian Arrangements this Spring. If so, you will find Genl. Gibson well informed and Useful in that department. It was always my opinion that Congress was Starving the business \& should the French set on foot any of their projects in our Western 
frontier, the Indians must infallibly Attach themselves to their old Allies, as we have neither force, presents, agents, government, nor any thing else to prevent it. If this gentleman should be invested with any Commission of the description which has heretofore been contemplated, I am persuaded you will find his industry, \& Fidelity equal to that of any of your officers \& much more than equal to any Compensation which you ean Allow him by law. I have told him, however, that it is questionable whether the business ean assume any shape or go into operation this summer \& that he ean only know from yourself how it will progress."

Thomas Pinekney had made a treaty with Spain in 1796 in order to ascertain the boundary between the United States, Florida and Louisiana and to accomplish Spain's relinquishment of her forts within our territory. There was ground to suspect that Carondelet and the Spanish administration were having secret communication with the Cherokees. A letter from Carondelet to one of the chiefs ${ }^{1}$ was sent MeHenry from Tennessee in June. On June 10, Pickering ${ }^{2}$ wrote McHenry

\section{New Orleans the 2nd April 1797. \\ My dear son \& friend,}

The warrior Broom delivered to me your esteemed letter of 26 th September of the last year, I took him by the hand, \& ordered to give him \& his young follower a little present, sending them by the Movila on account of the war we are carrying on with the English. The same reason prevents me to let your son go now; it is better for him to be acquainted with the Spanish \& French \& then he will be useful to your nation \& to us. We are to make our dispositions for running the boundary line between our territory \& that of the United States.

The love I profess to you induces me to give you the advice of following the example of those of your nation, who consulting their security put themselves under the protection of the Spanish nation between Arkansaw \& New Madrid.

I remain always with friendship and esteem for you \& your nation Your beloved father

The Baron of Carondelet.

2 Pickering's personal relations to McHenry are clearly seen from the following letter written this summer.

\footnotetext{
"Dr "Sir
}

“Trenton Sept. 12, 1797.

mentioning Mr. John Caldwell for the office of Treasurer of the mint; and altho' you referred to me to say what appeared proper concerning him, I chose to forward your letter to the President, to the contents of which I with pleasure subscribed. The only circumstance that would excite any hesitation as to the fitness of the appointment was his near connection with the Secretary of War, which might give rise to disagreeable remarks among the enemies of the Government, to excite the disapprobation of its friends. This circumstance a sense of duty led me to intimate for the President's consideration. But I had better give you all that I wrote concerning $\mathrm{Mr}$. Caldwell. It here follows.

"Altho' Mr. MeHenry, on account of his connection with Mr. John Caldwell (the brother of Mirs. McHenry) did not think it proper directly to me to say what appeared proper concerning him, I chose to forward to make known his wishes to you, yet all that he has written in his letter to me appears so correct, I thought it best to inclose it. Mr. Caldwell is by profession a lawyer: yet having some fortune he has very little engaged in practice. I have known him these ten years. He is a 
that D'Yrujo, the Spanish minister, complained that Ellicott, the United States commissioner, was unsatisfactory to Carondelet and Gayoso, and asks that he be confined to running the boundary and that a discreet, eool, and prudent officer be appointed to command the American troops who may find quarters at Natehez, even if Spain does not at once evacuate that post. The Spaniards do not intend to resist our claim to possession and Carondelet has written to Spain to Godoy, the prince of peace, as to the demolition of the forts.

The commissioners for running the line between the Cherokee country and that open to settlement by the whites were at Dividing Ridge, between the waters of Cumberland and Duck rivers on June 4, whence Silas Dinsmoor, who was in attendance on them, wrote McHenry, expressing his distrust of the frontiersmen and of Governor Sevier and telling of the relations with Indians:

"I was yesterday favored with your letter of the 20th of April enclosing a copy, of the same date, to Governor Sevier. The occasion of my being at Jellico, at the date of my letter, which you acknowledge, was not on account of the danger of being in a more interior position, for, however deceitful the Indians may be represented to be, allowing the representation to be true, I shall still consider myself more safe in the interior of the Indian country than on the frontier of our own in the time of disturbance. I was at that time making arrangements for effecting the President's plan of eivilization, notwithstanding the disagreeable aspect of af. fairs, by procuring looms, wheels, ploughs, \&c. \&c. a man \& woman to go into the country to shew the Indians how to use them. Thus far I have succeeded. I have sanguine hopes that the wishes of government will, eventually, be an-

sensible, well-informed man, a declded federalist and supporter of our government, with a fair morai character. He has an increasing family. But with entire fitness for the office, perhaps the expediency of appointing the brother-in-law of the Secretary of War may merit consideration.' "All this I hope will meet with your approbation, which the confidence and candour that ought to subsist between us have induced me frankly to lay before you.

"There are many other candidates, some of whom have revolutionary merit, for their service in the American war. I forward all their applications to the President, accompanied with remarks, where I have knowiedge of the characters.

"My family is comfortably situated in this place. We moved in good time to save ourselves from the risk of the Philadelphia fever.

"The President highly approves the letter to Yrujo. I ordered Mr. Fenno to send you 30 copies, agreeably to your request.

"Truly yours

"T. Pickering." 
swered, \& it shall be my care to deserve success. I see by your enclosure what you expect from Governor Sevier. I most sincerely pray, that your expectations may be realized \& that mine may be happily disappointed.

"The early arrival and firm conduct of the commissioners for running the Cherokee line have afforded a curious subject of speculation among the half wise politicians of this country, in which they have admitted the usual proportion of calumny."

Shortly afterwards charges ${ }^{1}$ were made against William Blount, United States senator from Tennessee, who was expelled from the senate as a result. IIe seems to have expected to induce the Cherokees and Creeks to make an invasion of Spanish territory under British auspices. The Spanish minister used these revelations to justify the delay in surrendering their posts, by the fear of British designs.

Of the charges against Blount, Washington wrote MeHenry $^{2}$ on July 7 . If the letter from Blount to James Carey, the Cherokee interpreter, which was intercepted, "is a genuine one" and Blount's "handwriting is not easily mistaken or counterfeited I hope that the author will receive all the punishment which the Constitution and Laws of this country can inflict and, thereafter, be held in detestation by all good men. To seek private emolument at the expense of public peace - perhaps at the expense of many innocent lives and to aim a stroke at the reputation of a virtuous character, hazarding his health - probably life - to promote tranquility between the Indians and our frontier inhabitants; by destroying his influence and well earned good name among the former, to render him incapable of serving his country and this, forsooth, because he may be a stumbling block in the way of a plan which he has in contemplation, is a crime of so deep a dye as no epithet can convey an adequate idea of to my mind." On August 14, Washington wrote again: "It will be to be regretted much if this business is not probed to the bottom." 3

All sorts of rumors flitted about, as is shown by reports made by William H. IIarrison, later to be president of the United States, but now a lieutenant in the first regiment. $\mathrm{He}$

$1 \mathrm{McH}$ enry wrote of them to Washington on July 3 and 9.

2 Ford, xiji, 400. See Report of the Committee of the House of Representatives appointed to prepare articles of impeachment against $\mathrm{Wm}$. Blount, and Am. Hist. Rev., $x, 595$.

3 Ford, xiii, 413. 
wrote from Fort Washington on May 22, 1797, reporting "that a certain person of the name of Hamilton, who is said to have a major's commission in the serviee of Spain, arrived in the town of Cineinnati some time in the month of January last, and has remained, (excepting a short absenee of a few weeks, ) ever since. His avowed objeet is to prevail on the eitizens of this territory to beeome settlers in the Spanish country west of the Mississippi, offering to adventurers donations of land and other inducements. Hamilton was born in New Jersey, and was some time a merchant in New York, from whenee, after being tried for a forgery, he emigrated to Dumfries, in Virginia, where he resided until about a year ago; for a few months previous to his arrival here, he was in Kentueky, where, I believe, he obtained authority to offer lands on the Mississippi to sueh persons as were inelinable to transfer their allegianee from the United States to His Catholic Majesty. Many families have emigrated, and many more are preparing to go the ensuing fall from this country, in consequence of the liberal offers made them by the Spanish agents. Hamilton has avowed himself a Spanish subjeet to several persons in this town, but I do not believe that he has any commission in their service; but is, I imagine, anthorized by the Spanish eonsul or some other agent in Kentueky to grant lands to persons who wish to emigrate to Lowisiana. I shall use every exertion to get information of the views of this man and every other suspicious eharacter who may come within my reach.",

On August 13th, 1797, Harrison wrote again :

"Sir

"I have the honor to acknowledge the recept of your letter of the 17th. Ultimo. Sinee my last report on the subject of suspieious persons passing through this country, I have until now met with nothing worthy of communieation. A few days ago, a Mr Manuel de Lesa, a merchant of New Orleans, arrived in company with $\mathrm{Mr} \mathrm{Knox}$, a person who is charged with dispatehes from the Department of State to our Commissioner, Mr Ellieot. Mr Knox informed me that de Lesa came with him from Philada. \& was to aceompany him to the falls of Ohio \& from there he intended to go to Post Vincennes where he has a store. De Lesa was here but one night \& I believe had no communieation with the Inhabitants. 
Hamilton, the person mentioned in my last Report, is still in the neighborhood \& follows the occupation of a Dentist. I do not find that he has of late done any thing to confirm the suspicions I had at first formed of him - he is a man of desperate fortune \&, I imagine, it would not be difficult to employ him in any villanous scheme which would tend to better his circumstances.

"Whilst I am on the subject of suspicious characters I shall take the liberty of mentioning to you some circumstances relating to Mr David Jones, late chaplain to the Army. this man I know to be as just a promoter of Sedition as the world can produce. He has lately made a tour through Kentucky \& passed this a few days ago. I endeavoured to discover from him the motive of his journey but all that I could get from him was that he descended the Ohio for the purpose of taking up with him a mare which he had bought when he was last in this country - it appeared to me strange that a man of his years should have taken such a journey in bad health for such an object - this, together with my knowledge of the man - his violent attachment to the French Government, \& dislike to our own; together with a declaration which he made to me, created a suspicion of his being engaged in some agency prejudicial to the interest of the United States - the declaration I allude to, was, "that if the French established a Republic west of the Missippi, he intended to emigrate to that country.' Having lived for a considerable time with Mr Jones in the family of the late Major Genl. Wayne, \& still being on good terms with him (for he was my guest when he was last here) I am extremely sorry to be the means of exciting the suspicions of Government against him, when I have no proof of his guilt - but the times are such, as, in my opinion, to make it the duty of every friend of his country to keep a true look out \&, if possible, discover $\&$ expose to the detestation of the world those traitors, who acting under foreign influence, are plotting schemes destructive to the interests of their country.

"This day arrived here, Mr Pike, a Cadet in the 3rd Regt, from Fort Massac. He informs me that Capt Guion, after having been joined by Dember's Artillery, left that post on the 11th July. Capt G-n had communicated with the Commdr. of New Madrid \& had informed him that he expected to descend the River to Natches, the Spaniards replied that, if he passed his post, he should treat him with polite- 
ness - but hinted that he had better stay where he was. They (the Spaniards) are building a large-Fort on the West side of the Missippi, sixty miles above the month of Ohio. I give you this information Sir - because I imagine you are desirous of having the earliest accounts of the Movements of Capt: Guion.

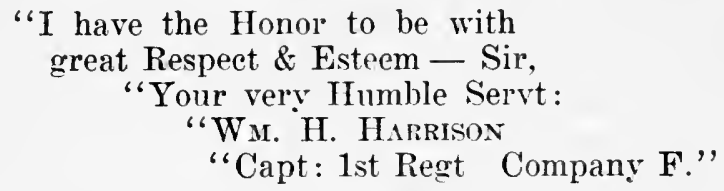

From Detroit on July 28. 1797, Major Rivardi wrote Pickering as to western matter's:

"The British merchants of this place seem exceedingly" opposed to every measure taken by the General, in order to remedy the evils which actually threatened our garrison, the greater part of which was always in a state of intoxication, on account of the small liquor shops held under the sanction of licenses issued by the Magistrates within the lines of our guards and sentries. The proclamation which forbids such intolerable abuse has occasioned many murmers and remonstrances from a set of people who have long before that declined being considered as American citizens, bought settlements on the British shore, and expressed, on every occasion, their contempt for our Government, although our money has enriched them since our taking possession of the Posts. The French here are very little better, and, in my opinion, not in the least to be trusted, happily they are indolent, cowardly, and (with prudence) little to be dreaded. The emissaries from their Mother Country alone are dangerous. Yesterday we drummed out an Imposter born in Canada, who made sereral false depositions respecting the intentions of the Spaniards and French to attack Mackinac and Fort Wayne. $\mathrm{He}$ pretended to have been a prisoner at the Illinois and gave a spurious account of the regular forces landed there, aiming, I suppose, to spread the alarm among the Canadians and to lead the General into some unnecessary and perhaps improper measures - fortunately we found that he never was, since two years, nearer of the Illinois than three hundred leagues.

"Another man (a British subject) was detected, attempting to seduce some of our soldiers from their duty, and was 
punished accordingly. It is so long since we received an Express that we know nothing of what passed in Congress these seven weeks past. The Indians are still very numerous here, owing to their receiving plenty of provisions on both shores; but I find that they all expect to see their Fathers, the French. The little Turtle, although peaceably inclined, cannot be persuaded that he received false information."

While McHenry thought ${ }^{1}$ his arrangements wou?d keep the Indians quiet, D'Yrujo had aroused further trouble by charging that Pickering had entered into a conspiracy with the British minister to have a joint expedition seize the Spanish forts in the West. ${ }^{2}$ Pickering answered this attack with acerbity and printed his reply through Fenno on August 8, sending copies to his friends. On August 19, Hamilton wrote McHenry: "Considering how insensibly precious the friendship of the United States is to Spain, I can only ascribe the late conduct of some of her officers to an influence which controuls their better judgment. War is not desired by the United States, they will shun it if possible and I am (sure) Spain ought carefully to avoid foreing them into it."

On September 4, Adams thanked Pickering and McHenry for their vigilant attention and judicious execution of all the business relative to D'Yrujo. The frontiersmen were also troublesome. One Zachariah Cox was organizing an expedition and other incursions were made into the Indian lands, concerning which letters came to the administration, either directly, or through General Davie of North Carolina. Among these letters was one written by William Polk from Charlotte, August 9, 1797, to General Davie and forwarded by him:

\section{"Dear Sir}

"Mr. Wallace has delivered me your favor of the $22 \mathrm{~d}$ July, and I now, by the first Post office after the receipt of your letter, transmit what information I have been able to collect on the subject of the Tennessee expedition from this country.

"Six or eight weeks ago, a Mr. John Johnson who lives near Jonesborough in the State of Tennessee came into this county where many of his \& his wife's relations live and 
where he moved from about 8 years ago, his business appeared to be of two kinds, the first to sell as much land as he could out of a body purchased by him from a certain Zack Coxe, said to be 30,000 acres, in payment of which he took horses, cattle, notes \& money if he could get it. The seeond, to encourage persons to make a settlement somewhere in the coast of the Tennessee on the lands of this Coxe, who by some written instrument promised to each settler 1000 acres of his Land, on eondition that they would make a settlement, cultivate five acres of ground in wheat or corn, live on the soil 12 months, support themselves, and defend themselves against the enemy; how far the word enemy was to extend I don't know, whether against the Indians only, or all who should attempt to molest them, in either going there or whilst there, was what nobody here, I believe, is in the knowledge of. Johnson. to some, said Coxe had extinguished the Indian claim \&, to them and others, that Congress had consented to the settlement. I am informed Genl. Sevier, at a eonsiderable meeting at his louse, harangued the people in favor of the plan \&, through his influence \& that of Col. Ezekiel Polk, most of 25 persons who accompanyed the latter were induced to proceed on this wild expedition. I am unwilling to believe that any one of these people had any hostile views towards the Spanish settlements or that they knew anything of Blount's plan; it is a mere land speculation without any expectation, at least by $E$. $P$., of seeing or experiencing any danger. I know his weak nerves too well to believe he would hazard himself, where there would be the most distant idea that blood would be spilt. Mr. Polk is a man charged with impatience, has no fortitude, fickle in the extreme, a lover of home, and never saw blood but from a lancet or his nose in his life, from such a leader I fear nothing - some of his party have, a few days ago, returned who left them about 50 miles above Knoxville on the Tennessee or Holston River, who say the party had become very impatient and uneasy, as at that place they were to meet Coxe, whom they had not seen or certainly heard of, some said he had gone down the River to hasten the finishing some boats he had making to transport stores to his settlement, by others that he had gone to Philadelphia. Johnson was taken here and brought before the Court, who then happened to be in Session, but through the influence of Genl. Sevier \& the ignorances of the Court they permitted him to depart." 
From the state of Tennessee, Hawkins county, on September 14th, 1797, William Cocke wrote John Adams, protesting against the removal of the settlers who had encroached upon the Indian lands:

"To inform you that a large number of respectable citizens of the State of Tennessee are found to be within the limits of the Indian Claims. Justice requires that I should speak to you in plain and decided language. When I last had the honour to converse with you and Secretary of War on the subject, I felt myself highly pleased at the assurance you then gave me that you would take the matter under your serious consideration and notify the commissioners the result of your deliberation, from the manner you then expressed yourself I had every reason to believe would have produced a decision favourable to the people. Impressed with this idea, I communicated to them what had passed between us, but to my great mortification and surprise, I have seen an order from Col. Butler, directing the people to prepare to remove from their farms by the 25th of October, it will not be improper to remark to the President that the people of the state of " Tennessee know that they are not entirely governed by military laws, that no citizen can be deprived of his property for public conveniency without full compensation and that the Courts Judicial are bound to decide all questions of right, according to the Constitutional Laws of our country. Sir, it is painful to me to make these remarks, but as the Constitution of my country warrant them and as my fellow citizens are likely to be injured, as I conceive contrary to law, as a number of them possess Legal Rights to the land in question, I submit to you whether such orders should not be countermanded, especially at a time when Congress hath had the subject before them and hath postponed it for further consideration, I am Sir with

$$
\text { "every sentiment of esteem \&c." }
$$

Meanwhile letters came from North Carolina 1 to Wolcott and were sent by him to McHenry on September 15, showing that Blount's influence in Tennessee was not dead. In answering Wolcott's letter on September 22, McHenry acknowledged the continuance of Blount's influence and re-

1 Gibbs, 1. 562. 
ferred to the troubles over the Spanish boundary ${ }^{1}$ and to the projects of Cox, against which he had taken measures which he trusts will succeed.

On September 19, Pickering wrote McHenry that he hears from Ellicott at Natchez that Carondelet confirmed Gayoso's agreement with the inhabitants. Two days later, Pickering wrote again, concerning the attempts of the Spaniards to entice Indians from our territory, with a view to future hostilities, and on the 25th he told McHenry that Carondelet and Gayoso disagreed, the latter, "as deficient in understanding as in honor," does not act "with the prudence and persistency" which the baron might desire. Pickering hears from Daniel Coxe that the grant to Great Britain by the United States of the free navigation of the Mississippi is the chief obstacle to Spain's giving up the posts. ${ }^{2}$ On the 7 th of October, Pickering transmits information from Daniel Coxe that the Spanish governors and D'Yrujo are acting without authority from their government, anticipating war between the United States and France.

Meantime McHenry wrote Wolcott, on October 2, that he thought he could settle Tennessee matters without the aid of General. Wilkinson ${ }^{3}$ and received a reply from Wolcott ${ }^{4}$ who thought there would be no war with Spain. "You will, however, by Hook or by Crook, get the Spanish posts and the Dons will be more anxious to keep what remains than to retake them." In his answer, McHenry states he was very busy with Blount, Cox, and the Mississippi, "the current of which latter river you know is not so easy to stem." 5 MicHenry sent copies of Pickering's letter to D'Yrujo, to different army posts, including one to Ross at Pittsburg, with the request that the letter be not published in the papers. Somehow the letter was published and though McHenry thought the publication did much good, Pickering was disturbed at it and wrote:

\section{"Dear Sir,}

“Trenton Oct. 19. 1797.

"You see by the Pittsburg paper of last week, that my letter of Augt. 8 to Yrujo, is prematurely publishing. I must charge some of your military friends with the communi-

1 Gibbs, 1, 563 .

2 On September 30, Pickering writes again of Zachariah Cox's scheme for unlawfui settlements in the Indian country.

3 Gibbs, i, 565 .

4 Gibbs, i, 566 .

5 Gibbs, i, 567 . 
eation; as I have sent no copy to that quarter; and wherever I have handed it to my friends, it has been with an explicit caution against such a publication. But I do not know that it is to be regretted: it is an anticipation of but a few weeks; for I doubt not that Congress would have directed its publication, as usual with documents before presented to them on the same subject. And (as one of my friends has lately written to me) 'Since the policy of France has dragged our Executive into the street, it is best to make the people who are there understand that we are wholly right, and our accusers altogether wrong.' This friend thus begins his letter. 'I am greatly obliged to you for the pamphlet (letter of Aug. 8 to Y.) you sent me, as I felt a strong desire to see the argument, which should prove conclusively that the Knight would be a Knave, if he were not by nature a Fool.'

"It is a good while since I heard from your or of you: how are you? is your health restored? I shall be glad to learn; being very truly yours,

\section{"Timothy Pickering."}

In his letter explaining the matter, on October 22, McHenry said that he was so much occupied with affairs in the Northwest and the South that he was tired of life and enclosed a packet for the president, which showed that the secretary had "not been idle and that it requires some hammering to make certain heads comprehend one object, when they have conceived another." Two days later, Pickering wrote him:

"What do you think of the Washington news, by the Mr. Purslie who arrived at Brownsville the $2 \mathrm{~d}$ of Oct. in 45 days from New-Orleans - That the Posts were given up, \& the boundary line running? You will recollect that such was Mr. Ellicott's expectation, when he conversed with D. W. Coxe, whose narrative I sent you."

On the following day Pickering wrote again:

“Trenton Oct. 25. 1797.

"Dr. Sir,

"Last evening I received your letter of the $22 \mathrm{~d}$. with an open packet for the President, which I have read, sealed, and shall this day forward. 
"Can the cautious restriction of Powers - the preposterous idea of taking the posts of St. Louis, Genevieve \& New-Madrid - be accounted for, except on the principle that they may cover sinister views, the consciousness of which prompts ....... to overact his part? But if hostilities were to commence on the Mississippi, why not collect the utmost force to that quarter? Why the zeal to attack - \& the contradictory measure of lessening the force he could command, by remanding a company where it was not needed?

"His construction of Rivet's letter is probably just. But if the poor missionary has two years salary in arrears, it would seem advisable to pay him at least one, immediately. What is become of the other priest? Jannin? I thought both had gone to the Spaniards. Will not the retaining of his par, furnisl an excuse for unfaithfulness \& desertion? and with the influence he has acquired over the Indians, may not his desertion hazard mischief? Doubtless it had been better that we had never seen either. By the overtures of R., it is clear that he belongs to the nation of spies \& intriguers

"I return Mr. Hindman's letter, \& thank you for the perusal. But how astonishing that, at this time, Jacobinism should increase! Surely the people want information.

"Adieu!

$$
\text { "T. Pickering." }
$$

On the 28th came still another letter on Western affairs from Pickering:

"Dr Sir,

"The enclosed letter from Kentuckey I received last evening, evering one from Walter Evans to James Farris, relative Z. Coxe's project of a forced settlement at the Muscle Shoals. The 1000 men mentioned as ready to proceed must be a monstrous exaggeration: such villains always exaggerate, to encourage \& fortify their deluded partisans, and with such decoys to lure others into their snares.

"I do not consider the letter much consequence: but it may afford some evidence against the writer this friend addressed, should the scheme be prosecuted.

"I am respectfully yours,

The enclosed letter, written from Russess Creek, Tennes- 
see, Grainger county, on August 10th, 1797, by one Walter Evans to James Farris, Jr., stated:

"By this you may be informed that We, the Tennessee Company, have not had access to the Musscle Shoals, and indeed, have but a faint Idea of being admitted by Congress to go to that Country.

"There are upwards of 1000 men who are now in readiness to prosecute the intended voyage to the musscle Shoal Country. We - have 70 pieces of Cannon and other suitable Equipage for war - at the head of which is Zacheriah Cox, a Citizen of Georgia, who will endeavour to force his way down to that Country, The Indian Tribes notwithstanding, with whom I expect to go, provided we can go next winter, otherwise not." 1

Vigilant in their endeavors to obtain information relative to any project of France to excite the Southwestern part of the Union and Georgia to a separation from the United States in the winter of 1797 and 1798 , McHenry and Pickering expended $\$ 2,560$, paid to one St. Hilaire. The account for this was one of the causes of accusation made against McHenry, after he left the war department and was not closed until 1810. ${ }^{2}$

Fort Massac 18 February 1798.

I find by this Mitchell that he is concerned with Cox \& his party, that finding it impracticable to pass the Military posts upon the Tennessee, they have altered their route, \& Marched thro' Kentucky, in part, where they are assembling at the falls of the Ohlo from whence they intend to embark for the Mouth of Cumberland River, where a Town was to be laid out for their temporary accommodation; Mitchell is to be, as he says the principal surveyor, \& that his business at this place was to know from Captain Pike, where the Indian line, particularly ran, that he wishes to know as they intended to move as near it as possible; however I am well assured that all this enquiry of $W$ Mitchell, is nothing more, than finesse; I think his real object was to discover what number of Troops the Garrison consisted of, \& to know the disposition of this detachment, particularly. Cox's Artillery consists as I am informed, of small pieces which he has packed on Horseback to Kentucky \& will embark them at the falls.

I have the honor to remain with great respect \& Esteem your mo.

Obt. Hble Servant

2

City of Washington Jany. 17. 1810.

Dear Sir,

I enclose an exact copy of your certificate \& receipt which I had filed as a voucher for my payment of that sum of $\$ 2560$. but which not being certified by the President is not admitted at the Treasury department. Mr. Gallatin, whom I have just conversed with, remarked that you were responsible for the money; but he thought you might be discharged in one of these two ways - Either by producing receipts or other written acknowledgements from the person or persons to whom you actu- 
After the Spaniards ceded the forts, ${ }^{1}$ Pickering wrote MeHenry on December 23, stating that the governor at Natchez must exercise liberal hospitality to visiting chiefs, giving them some presents, "to keep the Indians in an amicable temper and may have to call a council of the tribes. If the governor serve in the field, what rank shall he have? These matters should be attended to at once."

The greed for Western lands led all classes to purchase them and this complicated Indian relations, as may be clearly seen from a letter Chase wrote McHenry on December 10:

"There is another Matter in which I wish for your advise - You have heard of a Claim by Citizens of U. S. to two purchases from the Indians - called the Illinois and Wabash Purchase. I am entitled to a $22 \mathrm{~d}$ or whole share in both purchases, which cost me with interest about 1600 eury. The Case has been sometime before Congress, \& you will see

ally paid the money; or by furnishing to the existing President (Madison) evidence to satisfy him of the application of the money to the purpose specified in your certificate, so as to induce him to certify (what President Adams should have done) that the money had been applied to the service of the U States: conformably to the power vested in the President by the $2 d$ section of "the act providing the means of intercourse between the U. States \& foreign nations." Vol. IV. page 69-70 of the Acts of Congress. If you have no such receipts - or if they were burnt in the war-office, you will advise me. Do you suppose that Pres. Adams possesses such a knowledge or remembrance of the transaction as to enable him (on sight of your certificate and receipt to me) as would enable him now to give such a certificate as, if given during his presidency, would have been sufficient? Or can you make such a statement of facts, times and circumstances as must bring the affair so fully to his recollection? If this can be done, I think it not improbable that Mr. Madison may, on Mr. Adams' certificate, furnish the requisite voucher for the Treasury.

Please to favour me with an answer as speedily as possible. Very truly yours

James McHenry Esq.

$$
\text { T. Pickering }
$$
Baltimore

This may certify that there has been expended by the subscriber Two thousand five hundred and sixty dollars in obtaining from ................ $\ldots \ldots \ldots$ information relative to a project of France to excite the So Western part of the Union and Georgla to a separation from the United States.

Dollars 2560

JAMES MCHENRY Secy. of War

19 March $179 \mathrm{~S}-$

Received the above mentioned two thousand five hundred and sixty dollars this 25 th of April 1798 of T. Pickering Secy. of State.

JAMES MCHENRT

1 On January 5, 1798, (State Papers, i, Milit. Affairs, 62S, 632, 638) McHenry reported on the Cherokee boundary of 1791 , on April 6 , he opposed paying militia in $\mathbf{1 7 9 4}$ for an offensive expedition against the Cherokees and on January 16, 1799, he sent the senate papers concerning the Cherokee treaty of 1798 . 
the grounds of our claim as published by the Company, \& their proposal to Congress. without examining our Right, I wish to be quit of the Business. It is very clear that Congress must purchase of the Indians to extinguish their claims, if we have no Right and as we have done it, \& have their Title, at least so far as the Right of preemption, I would agree to relinquish all Claim for what I have paid with Interest, on $1600 £$, and I will take a Certificate payable with annual Interest when Congress thinks proper. I think Justice will say that my request is reasonable. I do not wish to injure the claims of my Partners, but I have no inclination to contest by suit, with Congress. Be so kind as to give me your candid opinion whether a memorial making such an offer would be successful. Read our Claim, which you can procure from Dr. Smith.

"I wish you Health, \& Happiness, adieu

"Your affectionate \& obedt. servt.

"Samuel Chase"

From Europe news came in the autumn. Pinckney wrote from Rotterdam on September 19, concerning military books which MeHenry desired:

"By this opportunity (the Adelaide, Capt Mann via Baltimore) I send you the Military regulations during the time of the French Republic; they were to have been sent above three months ago, but by some mistake were pestponed. Briquet's Military Code is out of print, I am informed a new edition is preparing which, when published, I will procure and transmit to you, and anything I may meet with new and of reputation in that line.

"Genl. Marshall and myself are now upon our progress to Paris; you will hear by my letters and enclosed papers to the Secretary of State, and Mr. Murray's communications to you, of the extraordinary transactions in Paris; these transactions and some intimations we have received that our presence at this juncture at Paris might be important, and the delay of our journey imputed to very false and improper motives, have induced Genl. Marshall and myself, to set ont to Paris, more particularly, as Mr. Prince, the Agent of the Union, the vessel in which Mr. Gerry is to sail from Boston, writes word to the Consul at Rotterdam that she is to call 
at Havre; I have therefore written to that port to request Mr. Gerry to proceed from thence to Paris, without coming round by Holland.

"We shall not commence any direct negociations, before we are joined by Mr. Gerry, without circumstances, should indicate great probable advantages.

"These I do not expect; for so much reliance is placed in France, on the individual divisions in America, and so large a party is thought to be more attached to French measures than to the interests of our Country, that, tho' I am convinced this opinion is erroneous, yet as it is entertained by men in power, I am apprehensive our negociations will be very difficult, and my hopes of suceess are not at all sanguine.

"I remain $\mathrm{My}$ dear Sir, with great regard and esteem -

"Your most obt.

"humble Servant

"Charles Cotesworth Pinckney."

Three days later a letter was sent McHenry by Murray, who had tried to ward off any danger of a war between $\mathrm{Hol}$ land and the United States:

"Mr Gerry arrived here last night. He will proceed on to Paris as soon as he can return from Amsterdam, whither he must first go. The other ministers went on the 18th. inst. The only chance it seems to me they have, is in the renewal of the war. This would give to us, all the advantages of ally'd force, without the odium. Still however to me our affairs do appear desperate in Paris. This dreadful convulsion which took place on the 4 th, in which all fell, upon whose sense of justice we could have any reliance, has been to me a most serious event. Pastoret Portalis - Boissy d' Anglois - Dumas, Voublanc - Barbe Marbois \& Pichigru these were men of superior cast - who wished to restore order to the whole social \& political state in France; to recall the public bodies to a recognition of foreign nations in the good faith of France; \& to check the Directoire, in those violations both of the constitution \& of the law of nations which had excited alarm at home \& fear \& hatred abroad. These men, confounded with the emigrants who had returned, \& many of whom had kept up a perpetual conspiracy agt. the Republican system, are swept off, \& by this are on their way to Madagascar. Since, the two councils, like the peasant when 
arguing with justice, agree to every proposition, \& anticipate every wish of the Directoire. They have broken up Pastorets committee which he had got appointed, after a most able speech on our affairs, in which he urged the right we had to enter with the Treaty of $94-\&$ held up the violence of the Directoire \& their Tribunals agt. our neutral rights in a variety of ways, as unjust, tyrannical \& impolite. The object of this committee was to report upon the existing relations between the U.S. \& France \& upon the injuries that had been inflicted upon our trade. The report was delay'd till the arrival of our minister, \& probably under the foresight of an intervening crisis, on which they counted upon success. They have declared the object of such committees (Zumolard had one also, upon the transactions in Genoa Venice \&c \&c) as inconsistent with the constitution \& Republicanism, \& have expressly affirmed the respective acts of the Directory upon our affairs. Mulin, too, the late minister of Justice, \& the official instrument of the numerous condemnations, is now a Director, in Carnot's place. Whether you consider the acts of the present Legislature or of the Directory \& the nature of the government, wh. is now a complete military despotism $\&$ the characters of the men who are in the Executive, we shall have little reason to expect justice. By a letter wh. I received a few days since from a very intelligent man at Paris, it appears, that the table talk in select \& official parties is, that we may have peace, but it must be upon their terms:that there is a party in the United States strong enough to controul, \&, if necessary, to overthrow the government; - \& that a six months war with France would dissolve the Union. M. Adet's Secretary was in this party \& confirmed their assertions. I fear that our ministers may think that delay, and the gaining of time, would be a good thing. my idea is that all the speed, consistent with candour \& gentleness in manner, is in every aspect of their \& our affairs important. To you, I can write with perfect freedom - I do not believe they will grant us a single object of our just demands, that they will wish to keep the negociation open, after they shall have had use of it, to throw into discussion in America, two or three proposals: as to give us a free West India, \& a guaranteed Mediterranean trade - if we will abandon the Treaty; probably with this, an assurance of indemnification, after the war. To dissolve the Union - to revolutionize the South \& West - to place those into a State, available to them 
against the British, both in arms \& especially commerce \& West India relations, will be the object of such offers, pending the negociation. This idea I have had for months, \& so exprest myself in one of my letters to you. The pamphlets which are published in the U. S. under French auspices of late, tending to familiarise the breach of the Treaty of 94 , $\&$ to conciliate this with the constitution \& the interests \& duties of America, I consider as mere collateral evidence, compared with those stronger inferences, which may be drawn from their past \& present spirit \& proceedings, \& the connexion of symptoms wh. have gradually developed themselves in America. Congress \& the State Legislatures will all be in Session at a period when they might, I should think, be brought to a fixed complexion; \& when some definite idea might be transmitted to you from Paris. In such a state of things the rigour of public spirit would have something certain to act upon. If it is assailed by discussions upon the alternatives with which France will endeavour to amuse it $\&$ if expectation be long kept on a stretch, \& raised \& deprest by an indefinite variety of news from Europe, \& conjectures. this spirit may tire, or cool, or divide into difficult points of doctrine \& policy. But surely, long before this, the mist has been withdrawn from the eyes of thousands of our countrymen who have been certainly in the most profound errors respecting the views of France towards us \& all other nations. Her object is aggrandisement. Her means the destruction of great Britain. Weak or infatuated neutral nations are her stepping stones to reach at her rival. As to Republicanism She has it not herself - She is ruled by the Directoire through the army. To preserve this despotism, this Directoire must \& will keep at war, as then the executive is all in all, \& have the armies more at their disposal, \& more temptations to offer them as the price of their obedience. When Buonaparte held out his olive branch to the arch Duke, clever \& great as he is, he was in the utmost danger - Both sides gained time. The Directoire had nothing to do with it. In this interval of a Peace, for which all France groans the two councils set about really organising the true principles of their constitution. They wished to produce that responsibility in the Executive which this expressly gave them as the source of the executive. they examined into the State of the Finances, saw confusion \& penury \& no system even attempted. They looked into the expenditures \& found a wider \& more devouring pro- 
fusion than had disgraced the ancient regime. They examined into the State of the Bureaus \& into the different departments of the Govt., and beheld a more disgusting parade, and a more intricate chain of patronage, $\&$ a more extensive arrangement of official \& subofficial machinery than the old court had ever been charged with by its enemies \& reformers. They then attempted to ameliorate the revenues \& to give them system; - to check this profusion, $-\&$ even dared to point out the propriety of looking into the expenditure of those vast treasures with whieh different generals in Italy had been debited. They sought into the State of the colonies $\&$ pointed ont the necessity of really regenerating their lost commercial \& regular habits, as a source of maritime strength $\&$ as generally connected with the poliey of internal strength, agriculture \& manufactures. Their object, in fact was to revive the internal happiness of France; to bring the people to cherish order, industry \& peaeeful habits \& to methodise that dreadful chaos into which the relaxation of laws, \& the great irregularity in the proceedings $\&$ the principles of the revolutionary governments, had thrown the people more than any external force had done. Then happened, in the election of a new Third, who were moderates (ie. Anti Jacobins,) and the preliminary articles of peace wth. the Empire, a coincidence favouring this great \& patriotic design. This election gave the men who entertained these enlightened views, the decided majority - as 3 to 1 . Their efforts \& objects were of a nature to excite alarm among all who lived in truth upon public eonfusion. The Directoire saw, in the line of conduet which they promised to pursue, that check which they were not willing to endure. The Bureaus - \& all the offices felt sore under this serutiny into their members, incapacity, \& profusion - the armies were stimulated by the generals in a hatred against the councils \&, in the same proportion, into a respect for the Directoire. Wth. whom it became politie then to make a common cause. From the moment that the Directory perceived that the Legislature resolved to act with firmness in the reform of publie abuses, \& undertook to exercise some pretence to their rights of Peace \& war, agreeably to the constitution, they excited sedition against those councils \& gradually took their measures under the pretence of guarding against Royalism, to overthrow the moderates \& to put all power under their own, absolute direction. Pichigru \& others foresaw this crisis - the mysterious march of 
the army towards Paris \& the daring language in the army addressed to the Directoire agt. the couneils, \& to each other, from Italy to the Sambre \& Meuse, led that great man to attempt those measures of safety wh. the constitution put wt.in the reach of the councils. He set about organizing the national guards or militia - France had been disarmed about a year since - Not a cannon nor a musket had been permitted to appear in Paris but those in the hands of the guards. The sections of Paris had been disarmed on the celebrated Vendemiere. 'The Directory saw that if this national guard were organised \& armed, the Legislature wd. be supported. They saw too that if Peace with the Emperor \& G. Britain follow'd such a Legislative preparation of strength, their schemes of ambition \& absolute power might be frustrated. They anticipated the Legislature by placing peace at a distance, and by the convulsion of the 4 . Sep. triumph. Never perhaps in the Roman Senate under Tiberius, when Senators could be nodded by the Tyrant to the Baths, was there a bolder stroke of despotism, under the eloak of Republicanism! Fifty odd of the most enlightened Revolutionists in France, seized as members of the Legislature, and ordered for Banishment, to one of the most distant \& savage scenes upon earth - without notice - hearing or a trial! for the order of Banishment preeeded even the frivolous \& unexamined seraps of inadmissible evidence which had been exhibited against one of them, \& that one Piehegru - undoubtedly there were emigrants in France who watehed \& always will watch for a crisis between the republican parties, that they may direet the crisis to their own ends; - but the members of the $500 \&$ of the ancients, exeept perhaps Camille Jourdan, who had lately returned from England, were as remarkable for their revolutionary characters, as Mr Rewbill, Mr. Barros \& Mr. Lepeaux. So also were Carnot \& Barthelemy. The real crimes of these men were attempts to put the constitution in force - to execute the Laws - \& to extricate the people out of revolutionary government, in favour of Peace, order \& justice. The charge agt Pichegru is derived from the papers of a count D' Entrigue, an emigrant, who states conversations with another emigrant, a count Montgaillard, near two years since. These were tricks which the tories used to play off upon the whigs with us - but america had too much goodness \& justice to eredit such trumpery. From this period, however, it is probable that very serious designs. 
will be taken up by the ablest revolutionists in France, to restore a share of monarchy to the government. My own idea is that the different parties \& generals will wait for an opportunity of placing a King upon the throne of France. That whatever party attempts, it will be opposed by an opposite party, because each will be jealous of the others; \& each would, if it be at all done, wish to have the advantages \& emoluments of such a decisive event. But a vast \& horrible involution of party rage \& personal rivalship will long continue to distract them, \& retard any government but a revolutionary \& military despotism.

"Lord Malmsbury has left Lisle - This is not from public authority, but I hear it through a channel upon which I completely rely. I do not regret this, as the war will recommence with vigour, \& as parties are distrusted in France, \& they have no means to fit out distant expeditions, they may be the more inclined to listen to our ministers. Still I am convinced that they rely upon a source of transatlantic means which they will organise in proportion as the negociation is lengthened \& spun out by their acts.

"There is a certainty that upon the Rhine at Bonn, Coblentz, \& Cologne, a revolutionary spirit has brought a revolution to bear upon the constituted authorities. The plan is to erect a Cis-Rhine Republic. The plan of France is not only to avail herself of the confusion \& weakness which her enemies will feel from revolutions in their towns, but also to surround her land - Frontier with a cordon of small republics, who will be her satellites, her out guards, \& whose existence, as republics, must depend upon subserviency to her \& on her protection. Her agents have produced this event. Her force is at hand-\& Though the great majority of the people there, as here, are agt. this plan, her partizans there will get possession of power \& call their ambition Republicanism. Dear God! a Republic in the wealthy \& corrupt parts of Europe! as a republican I shd. rejoice if I saw manners, morals, \& independence in these scenes. Formerly where luxury had totally debauched the morals of a nation they supply'd in energy of govt, what their vices \& habits rendered necessary, to hold the society at all together. At present the attempt at Liberty begins at the point of the social state when it used to end. An impatience under moral, religious, \& civil institutions, arising from a knowledge of only abstract doctrines, \& stimulated by ambition, love of plunder, 
idleness \& profligacy, is mistaken for love of Liberty. It is in fact the restlessness of Vice - a popular path which it takes to avoid the imputation of criminality \& to enjoy all its extravagances \& profits. A dreadful anarchy is the result - \& society is thrown back into its elements, without its simplicity \& morals, I can see no end, except that which one man enjoys in the charge \& possession of another's property.

"The revolution at Paris has affected this country but slightly. The violent men would like to see the present intermediary govt. here a little more revolutionary; but the great mass of virtuous phlegm, the fair \& honest views of the very great majority of the People \& the whole genius of the nation. incorporated as it is in a thousand circumstances \& arising out of the artificial existence of the whole Republic, are against sudden bursts of fanaticism. Dykes which repel the beseiging ocean are the bulwarks of the national character. Those who exist but by the tenure of a never ending vigilance to sensible objects, of such importance as the whole of their embanking system, you can readily believe, are preserving - of course, patient, thoughtful - slow to alter, \& fixed when once determined - a real overthrow of things in Holland, in the true revolutionary sense in wh. Europe work:s changes in Govt., would produce the catastrophe of which the Zuyder Zee, at this moment, is an awful momento. Where this South or Zud Zee now is, once was land! There are records in Overyssel \& Guilderland of this fact. The great exterior Dykes had been neglected - Storms had accumulated the Ocean upon that quarter - the bottoms of the Dykes were softened and sapped and were burst. The deluge in four \& twenty hours destroy'd, and in a great degree covered, \& soon obliterated many hundred Villages - (The people live in villages) I hear eight hundred! You have often hearc, but scarcely believed that the ocean is higher than the land in many of the finest parts of the Seven Provinees - The fact is so - The country rests upon a foot of soft mudThey must have banked out first in the flats of the sea \& then pumped out all the surrounded water. This is done daily, as to pumping; \& the maintenance of wind mills for this purpose, to keep the land dry which is below the surface of the sea, forms a part of something like ground rent, to each lot in the town districts. Thus it is near Leyden-\& between Rotterdam - the Hague. A people so placed are obliged to be grave and steady, or drown. A Fete indeed is to take 
place upon the event of the downfall of Royalism, as they eall the overthrow of the Legislature at Paris - a Speech from the President of the assembly \& from Mr Noel, the minister, is it is said, to manifest the sympathy of Batavia in the triumphs of Liberty. These Fetes are useful things to any party who use them triumphantly. they have an imposing effeet - They strike all, \& upon thousands who love brilliance, effect, \& suceess, but who have neither opportunity nor power to examine into the justice of the oceasion. These fetes are to extend from the mouth of the Rhine, to the ancient Kingdom of Ulysses in the mouth of the Adriatic, that 'Lewd whore' - where the tri-coloured flag now waves over the ruins of that wise king. These fetes are to pervade every scene where France has influence or possession. They will be attempted in america. I consider them as partly the triumphs over our friends \& those who might, if any in France eould, do us justice. It will be highly important to destroy the influence of these Fetes then. It is to celebrate the brutality of a strictly military Despotism, over a sineere \& cordial operation, through which the great experiment was to be fairly made, whether France could endure a real republican form of Govt. The experiment was a fair one - The people chose their members - these now were not Jacobins - the Jacobins formed the elub of Saline afterward Montmoreney. The Direetoire grew jealous of the two new thirds - the Jacobins united wt. it, \& with the armies agt. them - The Directoire turned out these men whom the people appointed and banished the ablest of them. The elections of all men of that deseription, exeept of those who from timidity have made terms with the Executive, are declared illegal, \& others put in before the intelligenee could have reached the communes \& Departments! This is the way the Directoire secures majorities! If a proper use be made of the late event in Paris I shonld suppose the eyes of many, eertainly not all, in America might be opened; \& that the Deception of the Govt. once manifested, our worthy eitizens would no longer be the dupes of the most graceful \& vicious nation under the sun.

"I have written to Mr. Smith, the minister Plenipotent'y at Lisbon, eongratulating him - He merited the distinetion - I went to house-keeping as soon as I heard of his appointment, \& could get ready. But my dear friend, I never hear from you - nor from a soul except Col. Pickering, in his 
public letters. When you write, you could omit your name as I do.

"I can not omit one piece of information of which I shall also inform Col. P. The publication of Mr. Adam's letter respecting this country does us mischief. It has exeited considerable heat $-\&$ is thonght an insult. They wd. certainly have demanded his reeall had he been here. Yet I will still suppose that to answer a great end, these steps must sometimes be taken - and, in this case, whatever incon. venience arises to the minister it is his duty to bear it as part of his official labours \& troubles. Certainty of good, however, ought always to be placed against certainty of evil. Unless the good is great and eertain from publication, I should hope the govt. would never publish. I know that it is to tell the truth, however unweleome, that a minister is sent abroad. I have not been spoken to nor written to formally; \& have, when I saw it would be convenient, attempted to soften the affair. The violence is pretty much against Mr. Adams - who is out of the reach of this anger. They say its hurts them with France \& is impolitic as it enables her to stimulate this country against us contrary to their wishes, by appealing to the pride of the Batavian People and national Govt. But I have no fears respecting their disposition to be at peace, unless, shd. a war unfortunately come on with France, they should be urged, under their Treaty offensive \& Defensive of 1795 , to join $\mathrm{F}$. in the war agt. us. 'To guard against this probability I have for months seized \& sought oecasions of supporting this proposition, when I thought it might work to the proposed end - That it is the interest of France to suffer the Dutch to be at Peace with America. This, I believe, is true. To support this proposition I am endeavouring to collect materials to show the importance of the American trade to the Dutch and the bearings of the Dutch trade and money'd operations upon the French resources \& affairs. The relations of the American trade with Bremen \& Hamburg \& the eonnection of these in this trade with Amsterdam and Rotterdam. The subserviency of the instalments \& interest to those sources of Duteh competency which are available to France at present. The relations of the Ameriean trade to France as diverted from English into a Dutch channel \& the importance of keeping up this diversion. The great importance of the American neutral bottoms to Holland \& France in the Surinam \& Batavia E. India 
trade - and a prodigious deal of this carrying is done now in American ships which have not been at home for three years - particularly those in the E. India freights. In fact, the great value to France of an extensive Dutch trade, till she can revive her own navigation - and the very little aid she could derive from a power whose fleets, are year after year blockaded in the Texel - together with the loss which the Dutch would sustain in the West Indies \& South America without benefit to the $\mathrm{U}$. S. but to the certain aggrandisement of the great rival of France, G. Britain. In these attempts, I shall not show, nor have I manifested, any the remotest apprehension of a failure of our pacific negociation which will open at Paris - but only urged them to lend them as far as friendly sympathy might act, to aid the force of our reasonings \& to prevent a rupture \& a good understanding with France \&c. \&c \&c.

"The mutiny in the British fleet is crushed, not only by the government, but by that union in all sorts of parties which was produced by so serious \& unmetaphysical a situation \& as to the British, they behave handsomely enough to our trade, from all I can learn - of course interest \& that alone produces this conduct \& of course they wish us to go to war. There is one thing very far from pleasant, in the prospect of the busi. ness of settlement of claims by the board of commissioners. No case falls wth. in the cognizance of that board, but such as can not be reached in the ordinary course of judicial proceedings there - cases have to travel through certain stages of process in the courts first - here is the approaching hardship. Either the courts are injustifiably slow, or their delays are designed to take many cases out of the remedy of the Treaty, for the commissioners, I believe, can not reccive cases longer than about the next April. In such a state of cases undecided, they might avail themselves of circumstances, and say, (though with chicanery) that the Treaty had been gratify'd. However we have debts as a pledge - but that again sets the old sores to running.

"Mrs M. has written I think twice to Mrs. McHenrypray remember us both with the most cordial respect \& kindness to her \& accept these from us both - my compliments to my friend Mr. John McHenry. I have written thrice to Genl. Washington. 1. under cover a blank cover to you, soon after my arrival. 2. inclosed by a gentleman to Baltimore to $\mathrm{Mr}$ Gilmor. 3d. lately by Cap. Izard, who returns an 
accomplished, refined right sort of young man. One letter from you, your first - \& one from my brother are all — all that I have seen from America! Mun's letters I have seen. I admire the way in which Col. P. has turned aside from him - god bless you, my dear friend, \& believe me to be always

"Sincerely \& Affectionately yrs."'

On October 13, another letter was sent by Murray, I telling of the events of the European war and saying:

"My dear Sir,

"The Hague 13. Oct. 1797.

"Were I in China I should not wonder at the total absence of letters from those who are such friends as I am possessed of. But so near, with such constant opportunities, I do wonder \& grieve. If you have not time, my young friend, Mr John MeHenry would write \& let me know how you do \& that I am not gone from all remembrance. Mrs. M. also grieves - for I have received but one letter from you - but one from my brother — \& a line from Harper since I became Dutch!

"The Dutch Fleet at length resolved to try its title to the ocean with the british. They went out on Saturday last. Duncan's Squadron being supposed to be in port. The Fleets met a little South of the Texel, where, you may easily suppose, from the map I send for your acceptance, an engagement took place. The Dutch Fleet under Admiral De Winter, formerly a Lieutenant of a ship, consisted of 17 of the line \& ten Frigates \& small ships. The British, it is said, of 15 . of the line \& some frigates (I do not hear how many). The Dutch, as might be expected from their inexperience \& want of old officers, \& especially of old Seasoned, between-deck subalterns, were defeated \& eight fine ships of the line, some say ten, taken. They behaved very handsomely \& with the greatest bravery. De Winter \& another Admiral Krayestein were among the prisoners!

"On the sailing of the Fleet, the greatest joy prevailed

1 On October 24, Pickering wrote McHenry as follows :

"Mr. Murray's last letter is dated July 21 . He mentions that last spring certain terms had been agreed between Delacroix \& the Portuguese minister at Paris, and the treaty prepared for signing - but just then arrived the news of Bonaparte's great successes - and the Directory had the perfidy and the insolence, not only to abandon the treaty agreed on, but to present a paper with very different terms to the Portuguese minister to sign: but he refused - and they ordered him to quit Paris Tho' not France. He chose to go to Holland. I suppose it was from him that Mr. M. received the account." 
among the men in public life - \&, on a false report of the british flying before the Batavian flag, the guns were fired at Rotterdam \& great demonstrations of triumph took place. The sudden reverse of fortune has affected all classes, as you may imagine, with a steady gloom. Dead bodies, \& the wreck of masts, sails, \&c \&e float up hourly upon the long line of sea coast \& present a mournful detail of the defeat.

"This, thongh I can not help grieving for my Sober \& honest friends the Dutch, who deserve to be a free \& independent nation, under present circumstances will help us; as that british squadron which was large \& expensive, will be no longer necessary on this coast. The French, the pivot of modern speculation, will find their rival enemy so very strong by this liberation of force from European attention in the West Indies, as to render the vessels \& supplies of the U. S. \& their neutrality, more \& more essential.

"Parties here are differently affected by this event. The mass of the people, who appear to be orangists, do not lament it - many of them are to day drinking \& rejoicing in private at this defeat, which they think will help their friend the Prince.

"I have not heard from any of our Negotiators at Paris since their arrival. I have written every post. I am almost certain they would write. Since the publication of $\mathrm{Mr}$ Adam's letter respecting this country \&e - I have reason to apprehend a great attention on the part of the French to all letters to a prime minister U. S. Indeed, I feel the effects of that publication in various ways, for it has produced an undisguised resentment in the members of the Govt. If you would have any minister ordered off - the way would be to publish his dispatches. I shall still do my duty, as I have told one of the members of the Commission des Relations Exterieures who, among others, spoke to me with rather a menace, or at best a warning, agt. such communications. So, my dear Sir, you will judge upon this affair. The minister must write the truth \& the whole of it - \& I shall do so - the Govt. must judge as to publication - always, however, under a Certainty that from that moment any minister becomes offensive at the place he is. As yet, from appearances, they seem to like me very well.

"They have a committee upon another constitution. I 
very lately wrote by Capt. Stiles of Baltimore to you \& to Genl. W. Fayette is liberated.

"\& believe me always affectionately Yrs"

These difficulties with France disturbed Lafayette, who was now released, and wrote McHenry at the end of the year:

"My Dear MIcHenry

"Lhemkull December 26th 1797

"I do not know Whether or Not My former Letters Have reached America. Should they have Miscarried I Hope the various Dangers now attending the Navigation Will Sufficiently Apologize for me. This prison Scrible of Mine I Risk at Random. Lieutenant Juimpi of the Artillery acquaints me, in a Letter Dated October the 24 th, that, in a fortnight, He will Sail for Baltimore. I Heard of it But Lately And Depend Upon Some Mistake in the Date or an Unforseen Delay that May Have Detained him. I am Much obliged to IIim for the Notice He Has given Me, nor was it His fault if it Comes too Late. To him also I owed on my passage through Germany the pleasing emotions I felt at the first Sight, after so long a time, of an American Uniform. How Many Dear Ideas it Recalls to My Mind and to My Heart! Among Which My Beloved MeHenry Comes in for a great Share.

"I am Sick, and, for the Whole Winter, intend to Remain in this Solitary Country Seat in Holstein, on Danish Territory. where my fellow prisoner Latour Maubourg and our two families are With me. You know that State of our Health, particularly that of My Wife Has Rendered it impossible for us to travel farther, Nuch more so to Embark at this Season of the Year - we are in a Safe place, and Waiting for the Spring. I am Now Well again - it is not Yet the case with my two friends. My Wife, altho She is a little Better, Has not Hitherto made great Progress towards Her Recovery. This Captivity Has Been More Hurtful to Her than to any body else.

"With great and Heartfelt Satisfaction I Hear that the Dreadful Distemper in Philadelphia and Baltimore Has Subsided. So Many friends I Have there, So Affectionate is My Attachement to the Mass of the Citizens, and so Diffieult is it to Hear Any thing from Your quarter that I Could not But Be Extremely Anxious, and So shall be until I Can Come at particulars about this Horrid Calamity. 
"There is another Subject of Unhappiness to me. These differences Between America and France. How they Damp every enjoyment of My Restoration to Liberty and Life, How I regret not to be able to do more than write a few Letters, How I wish it was in My Power to adjust them With Equal Convenience and Equal Dignity to Both Countries I Need Not talk to You, My Dear McHenry - a Quarrell Between the two Common Wealths is So Unnatural a thing that I Had Never feared I Should Live to See it.

"Inclosed is a letter to Gl. Washington Which I also trust to the Same very Uncertain Chance. That of Lieutenant Juimpi's not having sailed. I also enclose two quadrupli. cates to my two Heroic friends, Bolman and Huger. Present my Best and grateful Respect to the President, the Vice President, and all our friends, Particularly to Your Family. I Have not Yet Heard from My Brother Noailles. Let him know How we are. I Hope His answers will Soon Come to Hand. Remember me also to Gen'l Kosciusko. I Hope His Health is Better. My Great Regard for Him Makes me More affectionately Partake in every thing that Concerns Him. You know, Dear McHenry, How Heartily I am forever

$$
\text { "Your friend, }
$$

Other European letters came to McHenry from Lisbon, whither his friend, William Smith of South Carolina, had gone in the summer of 1797 as the minister and whence he wrote of the customs of the country and of the events of the European wars. Smith was a thorough Federalist and stood for a stern refusal to compromise with France. ${ }^{1}$

During the course of 1797, the forts in New York harbor were begun. New York ${ }^{2}$ appropriated $\$ 150,000$ for these fortifications, in expectation of being repaid, without reference to the balance found due from the state to the nation, by commissioners, and, as Adams ${ }^{3}$ thought, did not declare that the forts when built should belong to the United States, therefore, he thought the money should be expended by Hamilton, with reservation of rights of the national legislature. Pickering wrote that the jurisdiction of the forts was ceded, but doubted

\footnotetext{
1 These letters were printed in Sewanee Review, xiv, No. 1, January, 1906 .

2 J. Adams, viii, 556.

3 Some interesting letters from Murray to the President are printed in the appendix to volume 8 of John Adams's Works.
} 
whether the state intended to appropriate money to pay its debt to the United States and suggested, on November 6, that MeHenry write Jay to direct the work to proceed, stating that sums expended by New York should be credited on account of the balance, to avoid a claim from the state. Winter was near, nothing could be done until spring and, consequently, a little delay would not hurt matters.

On June 13, 1798, McHenry wrote the military committee of New York and sent the letter to Hamilton, asking whether the forts should be first undertaken on the islands in the harbor, or on Sandy Hook. A letter from Hamilton to McHenry, dated June 1, seems to be upon this matter as follows:

"My Dear Sir

"Our eitizens are extremely anxious that some further measures for their defence should take place. Do me the favour to inform me confidentially what means are actually in the disposition of your department for this purpose, when \& how they will be apllied.

\section{"Yrs truly \&c \\ "A Hamilton}

"A Capt Hacker formerly of our Navy is desirous of being employed. One or two good men have recommended him to me. It seems, however, - that he has been heretofore rather Democratic. I barely wish that his pretensions may be fairly but carefully considered \& that he may have such chance as he merits

"The sooner I hear from you the better."

On February 27, 1798, McHenry reported to the house of representatives ${ }^{1}$ that he had expended on forts, principally on Fort Mifflin, Pa., $\$ 39,400$, and that there remained a balance of the appropriation of $\$ 97,700$. The delay in building forts was largely eaused by the tardiness of the states in ceding sites. He suggested that, as the frontiers are likely for a long time to need all the existing army and forts cannot be garrisoned by militia, the army be augmented and that a regard to ultimate economy required that the forts be constructed of durable materials.

From Mount Vernon, Washington wrote 2 MeHenry on January 28 , asking many questions on public and private matters, especially as to the "meaning of the calm and apparent

1 State Papers, Milit. Affairs, i, 119.

2 Ford, xili, 4 ? 8. 
harmony" in congress and whether there are "no accounts yet from our envoys? If not, to what is their silence attributed, when the newspapers are filled with accounts of them as late as the middle of November from Paris, where they must have been at least six weeks." 1

1 Other unpublished letters from Washington on private matters, are dated from this period as follows:

“Dear Sir. "Mount Vernon 7 th. Feb. 1798

"Your two letters, both dated the 1st. instant, came to hand yesterday only. I thank you for giving me the perusal of their enclosures; and as I am upon the point of setting out to a meeting of the Stockholders of the Potomack Navigation, and may be from home two or three days, I return them without delay.

"I had, it is true, entirely forgot my old Coach until reminded thereof by Mr. Small; upon which, I wrote to Colo. Biddle (who transacts all matters of that sort for me in Philadelphia) to sell it for whatever it would fetch, and took it for granted that all expences (as he had money of mine in his hands) had been paid Let me entreat you, therefore, to direct Mr. Small to that source for payment.

"As the Gout \& Rheumatism are said to [be] Cousin Germans, it is no matter on which Acct. (I hope I may) congratulate you on a recovery

from - Complims. \&c. - and I am always

"James McHenry Esqr."

"Go. WAshington.

"Sir,

"Mount Vernon 4th. Mar. 1798.

"Your favour of the 9 th ult. came duly to hand \& would have received an earlier acknowledgment had not causes, of one kind or another intervened.

"Always desirous of promoting works which are calculated for the use and benefit of mankind; and believing that the one you have in contemplation if well compiled, will contribute to this end, I readily become a subscriber to it.

"For the flattering terms in which you have been pleased to introduce the subject to me, I pray you to accept the thanks of, Sir

$$
\text { "Your Most Obedt. - Hble. Servt. }
$$

"Go. WASHINGTON.

"Mr. John Parker

"Mount Vernon 4th. March 1798.

"Dear Sir,

"Knowing nothing of Mr. John Parker (whose letter I enclose you;) of his fitness for the work he contemplated;- or the utility of it when done; excent bringing All these Matters into a connected view ; - which indeed Might be useful- But knowing as I Well do, that many men when they want money, and do not readily know how else to come at it are too apt to set projects of this kind on foot, to obtain it; sometimes for the mere purpose of catching a penny, without meaning more than to get hold of the money; and oftentimes without abilities to execute their designs in Useful undertakings, by which attempts, more competent pens lye unimployed. I say, viewing things in this light, \& presuming you have a better knowledge of what is stated in his letter than I can pretend to, - of his views; and of the propriety of encouraging the proposed Undertaking; I have taken the liberty of putting along with his letter, My answer, to be forwarded to him, or not, as in your judgment, \& from existing circumstances, you shall deem best. -

"With truth \& sincerity - I am always

"Your affectionate friend

"Go. WASHINGTON.

"Are our Commrs. Guilotined? -

or what else is the Occasion

of their Silence?"

From Mount Vermon Washington wrote, on June 22, 1798, complain- 
As the year 1798 began and a rejection of our envoys seemed probable, Adams addressed a series of questions on January 24 to the heads of departments, asking them if war should follow such rejection. 1

'Two days later McHenry wrote, enclosing the president's queries: "My dear Hamilton, Will you assist me, or rather your country, with such suggestions and opinions as may occur to you on the subject of the within paper. Some of the questions it contains are very important and an immature step, or a wrong policy, pursued or recommended, respecting them may become extremely injurious, or beget disagreeable consequences. I am sure I cannot do such justice to the subject as you can. Let me, therefore, intreat you to favour me, as soon as possible, with your ideas. Take care of the paper. I received it only this morning. Yours most affectionately.", 2

\section{Hamilton's answer to this is as follows :}

"It may serve to prepare the way for a direct answer to the questions stated by the President to make some preliminary observations :

" 1 . It is an understood fact that there is a very general and strong aversion to War in the minds of the people of this Country - and a considerable part of the community (though even this part has been greatly alienated from France by the late violent conduct towards this country) is still peculiarly averse to a War with that Republic.

"2. A formal rupture between the two countries ipso facto carries matters to the greatest extremity, and takes all

ing of McHenry's fallure to answer his letters and asking, "what has been done with a letter of mine, put under cover to you (early In March last) to be forwarded, or suppressed, at your discretion, to a Mr. John Parker; who exhibited Proposals to the Publlc, for complling a complete Edition of all the Journals of Congress from the earliest period of them down to the present day?"-Lear's "Letters and Recollections of Washington," 255.

On June 26, McHenry wrote Washlngton apologizing for forgetting to answer owing to a press of business, and saying that he did not give Parker Washington's letter for Parker was working for a Democratic printer and McHenry thought it best not to give a person the "countenance of your name whose politics, according to my information, entitled him to none. If this objection is not valid," McHenry will yet deliver the letter. The objection must have been valid, for the letter to Parker remained among McHenry's papers to this day.

$1 \mathrm{~J}$. Adams, 1, 515.

2 C. F. Adams, in his life of his grandfather, insinuates that McHenry's plan was drawn by Hamliton with reference to Miranda and that this explains McHenry's reference to Spain. But Adams had asked McHenry to consider relations with spain. C. F. Adams also groundlessly insinuates that Pickering, Wolcott, and McHenry knew more of Miranda's project than they cared to disclose. 
the chances of evil which can accrue from the Vengeance of France stimulated by success.

“'3. A mitigated hostility leaves still a door open to negotiation and takes some chances, to avoid some of the extremities of a formal war.

"4. By a formal war with France there is nothing to be gained. Trade she has none - and as to territory, if we could make acquisitions they are not desireable.

" 5 . These premisses if just lead to this conclusion, that in the event of a failure of the present attempt to negotiate, a truly vigorous defensive plan, with the continuance of a readiness still to negotiate is the course advisable to be pursued.

"Then, if one or more of our Commissioners remain in Europe, it may be expedient to leave them there (say in Holland) to have the air of still being disposed to meet any opening to accommodation.

"If they all return, there is an end of that question, for they certainly are not to be sent back.

"The further measures presumed to be expedient for the Government in the event supposed are:

"1. To give permission to Merchant Vessels under proper guards to arm for defence.

"2. To prepare as fast as possible a number of Sloops of War, say Twenty, of from 16 to 20 guns each. Vessels already built may be procured fit for the purpose and perhaps in sufficient numbers.

"3. To complete as fast as possible the three remaining Frigates.

"4. To give authority to the President, in case of open rupture, to provide, equip \&c, by such means as he shall judge best, a number of ships of the line not exceeding ten in number. 'Tis not improbable these may be procured from G. B. - to be manned \& commanded by us. A provisional negotiation for this purpose may be opened. The authority ought to be broad enough, though correct in the terms, to permit the contracting with a foreign power to take such a number of its navy into the pay of our Government.

"In the first instance our Merchant \& other armed vesseis should be authorised to capture and bring or send in all vessels which may attack them and all French privateers, which they may find hovering within — leagues of our Coast. The vessels to be condemned \& the crews liberated. 
"To this end and for more important reasons, the Treaties of Alliance \& Commerce between the U. States \& France to be declared suspended.

"6. A substantial regular Foree of 20,000 men to be at once set on foot and raised as soon as may be. Of these not "5. A Regiment to| less than 2000 to be cavalry. An auxil. form two batalions iary provisional army to be likewise concommanded by a stituted of 30,000. Infantry on the plan Colonel.

"Each batalion to "7. To furnish the means, all the be commanded by a sources of revenue to be immediately Major \& to consist of seized and put in action with boldness 5 Companies to have \& a loan to the requisite extent on coma Captain two lieu-putation to be authorised.

tenants 4 sergeants "The more Revenue we have the more \& 100 rank \& file. vigour evidently we ean act with \& by taking a rank hold from the commencement we shall tke better avoid an aceumulation of debt. This object is all important nor do I fear any serious obstacles from popular opposition.

"The measures to be taken by Executive will therefore be. To Communicate to Congress with manly, but calm and sedate firmness \& without strut, the ill success of the attempt to negotiate \& the circumstances attending it. To deplore the failure of the measure.

"To inculeate that the crisis is a very "*I think the ov- serious one \&, looking forward to possierthrow of England ble events in Europe, may involve the \& the invasion of $/$ safety, liberty \& prosperity of this Connthis Country very try.*

possible so possible "That the situation points out two obthat any other cal-jeets: 1 . measures of immediate deculation for our Gov- fence to our Commerce and 2. of ulterior ernment will be a|security in the event of open Rupture. bad one.

Towards these the above mentioned measures to be recommended but without detail as to numbers of Ships, troops \&c.

"The idea to be thrown in that the hope of an accomodaand the provisional army at 20,000 . 
tion, without proceeding to an open Rupture, ought not to be abandoned or precluded, while measures of self preservation ought not to be omitted or delayed \& ought-to be prosecuted with a vigour commensurable with the present injury \& eventual greatness of the danger.

"The further idea ought to be thrown out that France, by formally violating, has in fact suspended the Treaties that they ought, consequently ad interim, to be suspended by us - since the observance on one side \& not on the other can only produce inconvenience \& embarrassment.

The necessity of ample provision of revenue \& force ought to be dwelt upon

"'There has been|with emphasis accompanied by strong latterly too much allusions to great future possible danEpigram in our Of- gers. In all this a stile cautious, solemn, ficial Stile.

grave, but free from asperity or insult
is all important.

"An Embargo seems now to be ont of place \& ineligible.

"With regard to Spain, nothing more seems advisable at present than to instruct our Minister at that Court to make respectful but energetic representations, pressing the fulfilment of the Treaty. The less is done with her Officers here the better.

"With regard to Holland or Portugal, it is not perceived that any thing is requested except to endeavour to continue \& eultivate good understanding.

"As to England, it is believed to be best, in any event, to avoid alliance. Mutual interest will command as much from her as Treaty. If she can maintain her own ground, she will not see us fall a prey - if she cannot, Treaty will be a public bond. Should we make a Treaty with her \& observe it, we take all the chances of her fall. Should France endeavour to detach us from a Treaty, if made, by offering advantageous terms of Peace, it would be a difficult \& dangerous task to our Government to resist the popular cry for acceptance of her terms. 'Twill be best not to entangle.

"Nothing more, therefore, seems proper to be done than, through Mr. King, to communicate the measures in Train to sound as to cooperation in case of open Rupture, the furnishing us with naval force - point'g the cooperation to the Floridas, Lonisiana, \& South American possessions of Spain, if rupture, as is probable, shall extend to her. To prevail on Britain to lodge in her Minister here ample authority for all 
these purposes; but all this without engagement or commitment in the first instance. All on this side the Mississippi must be ours, including both Floridas [McHenry added New Orleans]. Twill be best to charge with the instructions a confidential Messenger.

"In addition to these measures, Let the President recommend a day to be observed as a day of fasting, humiliation, \& prayer. On religious ground, this is very proper. On political, it is very expedient. The Government will be very unwise, if it does not make the most of the religious prepossessions of our people, opposing the honest enthusiasm of Religious Opinion to the phrenzy of Political fanaticism. The last step appears to me of the most precious importance \& I earnestly hope, it will, by no means, be neglected."

On February 15, McHenry ${ }^{1}$ submitted his answer to Adams, practically embodying Hamilton's paper. Later Adams submitted questions, when details of French news had come, whether the particulars should be disclosed to congress at once, and whether he should recommend a declaration of war. McHenry answered by appealing to his former paper. ${ }^{2}$

MeHenry thus spoke of alliances: "As to England. Notwithstanding her naval victories and undisputed control of the ocean, hel fate remains yet perhaps precarious and must continue, so as long as invasion remains practicable or possible. This consideration may render it best to avoid entangling ourselves with an alliance.", 3

On February 20, Hamilton wrote regretting he had not found time to read a report McHenry had sent. ${ }^{4}$ William

1 On February 13, Hamilton wrote McHenry (Hamilton, vi, 267) in reference to his private debts.

2 J. Adams, 1, 517. J. Adams, viii, 5.68. C. F. Adams says J. Adams had no suspicion as to the source of McHenry's policy.

3 Hamilton, vi, 278. March 27, 1798, Hamilton writing to Pickering, suggests no alliance with Great Britain, J. Adams had by form of queries opposed Engiish allance. See Hamilton, vi, 271, March 17. 4

My Dear Friend

I regret that my occupations have not permitted me to give your report more than a cursory reading, before my being obliged to leave the city for Albany. I have put it under a cover addressed to you. If it cannot conveniently wait my return, which will be in a fortnight, it will be sent you upon a line directed to $\mathbf{M r}$. "James Inglis at Col Hamilton's No. 26 Broadway N York." desiring him to forward you the Packet Jeft in his care for you which will be done.

Imterpret favourably \& forgive Yr Affect 
Pinkney wrote on February 26, from London, where he was commissioner to settle claims under the Jay Treaty.

"When I had the pleasure to see you last you requested me to write to you - and, if I have not availed myself of this Request, it is only because I have had nothing to communicate which wd. not come to you more promptly as well as more satisfactorily from other channels. Of the progress of our Commission you wd. naturally be apprized by our Dispatches to the Secy. of State - and of the great Events of which Europe has been the Theatre, my Letters could give you no Information equal to that wch you have better Means of acquiring. I think, however, that my Silence has been blameable - and that I shd. have written, if it were merely to remind you of my Claim to a place in your recollections, and to evidence the Value I do not cease to put upon your Friendship \& good opinion. I beg you to pardon me, if you believe me to have been faulty in this respect - and to allow my promise of Amendment, with this Specimen of it, to make my peace. I am aware that, in saying this much, I appear to make myself of more Importance than I am entitled to dobut you will be good enough to ascribe this seeming Vanity to the Proofs I have heretofore received of your regard.

"You have doubtless been much gratified by observing that, notwithstanding serious tho temporary Obstacles, the Execution of the 7th. art. of the Treaty has equaled our best Expectations, and you will be more gratified by learning that the prospect of an honorable Close to our Commission becomes every day mere certain. We have supposed it probable that we shd. differ from the B. Comn. on a point of more Consequence than has hitherto oceurred \& upon the Decision of which wd. depend whether the article shd. be idle and illusory or a substantial efficacious Provision. The Treaty prescribes 18 Months for the Exhibition of Claims in the first Instance, \& gives us a Discretion to receive them within 6 months after the Expiration of the 18. It is now perfectly certain that the judicial Remedy will not have been exhausted, in the great mass of the Cases within, either of those periods as the Lords of Appeal decide nothing, or at least very little. The Treaty makes it an essential Ingredient in every Complaint that it shd. be shown that the Compt. ed. not procure Redress, in the ordinary Course of judicial proceeding, and no Complainant can come to us, until he is in a Situation to alledge \& substantiate that Fact. of Course it wd. become 
important to determine whether a Man, whose Cause is still subjudice, without fault on his part, at the End of the 18 Months, is not authorized to demand our Aid, upon the Ground that he has tried the judicial Remedy to the Extent required by the Treaty. For, if he cd. not then demand it \& his Cause shd. remain undecided by the Lords until the End of the 6 Months, it is obvious that he wd. be forever witho't the pale of this provision, and, consequently, the Treaty wd. be almost a dead Letter. Upon this point, on which we had anticipated difference of opinion, we shall probably be unanimous - and I do not foresee any other on weh we are likely to have any considerable Difficnlty. I have Hopes of being able to return to America in the Course of the next Year - and it will, I am sure, give you pleasure to learn that my Health is so much recruited as to enable me to go back to the Bar without Inconvenience. If it shall happen that our Labours here have not been in vain (and there is every reason to hope so), I shall be so far from having Cause to regret my absence from my Country that I may justly felieitate myself upon it.

"Our Envoys at Paris are still statu quo. Tho French Law of the last Month denouncing indiscriminate Hostility agt. Neutral Commerce - \& Talier's late motion for another, by which all Neutral Vessels are to be brought in for Adjudication \&, if armed, condemned without further Enquiry (a regulation obviously in Aid of the former) seem to be an unequivocal Answer to our Demands of Redress for past Injuries. My Information does not enable me to form any decisive Judgment, but I shd. think our Comm'rs cannot remain much longer in France. If a rupture with the proud Republic shd. be unavoidable without the Sacrifice of our national Honor and Interests (and of this there does not appear to be any room to doubt) I hope \& trust that the public Nind in America will be prepared for it \& that we shall meet the Necessity with all the Spirit \& resources of the Country. Europe presents every day fresh Instances of French Ambition and the baneful System by which it is to be gratified. Switzerland is upon the point of being revolutionized, \& probably annexed to France not by the Troops of that Nation, but by the operation of that detestable policy which plays off the lower \& unprincipled portion of Society agt the Government. Berne is supposed to be prepared for a considerable Stand; but the prospect of its being an efficacious one is not such as could be wished. The Eeelesiastical States are on the Eve of being 
democratized or sunk into a French province. Portugal is menaced with a powerful Invasion - \& Spain has consented to the March of the necessary Forces thro her Territories - the consequences of which will obviously be fatal to both. Thus for the want of a timely Coalition among the different Powers of the Continent, each will, in its Turn, become a Prey to the inordinate Views of a Nation which, with Union they are still able to resist. G. Britain alone preserves the firm attitude with which she commenced the contest. But her Efforts ean only be defensive \& can respect herself alone. The threatened Invasion of this Country is probably mere vapouring; but if attempted to be carried into Execution, has every possible chance agt. it. I ought to make an A pology for troubling you with polities. I did not intend to do so, because I can state nothing upon these Topics but what I collect from Newspapers \& common Conversation, \& because you liave infinitely surer Sources of Knowledge. Mr. King's Dispatches have, I presume, made you acquainted with the State of our Claim to the Bank Stock. His good offices have been constantly employed to secure to Maryland the Effect of its Right, \& it is to be hoped will be finally successful. Every Motive of Justice \& Policy points to an absolute Transfer of the Stock to the State's use \& must ultimately produce it. 'Harper's Book has gained uncommon Celebrity here $-\&$ is read with avidity by people of every Description. Monroe's is re-published in London, but I have not seen it. From what I have heard of it, it contains that which only the Govt. of the U. S. could give to the world - his Instructions \&c. Whence a diplomatic Agent derived his Authority for the publication of such Docnments is inconceivable - unless the Govt. has given it to him.

"I will not add more to this long \& hasty Letter than to tell you that we pass our time pleasantly enough in London \& that my Family enjoy better Health than formerly; but that I am anxious to return to Maryland. We do not precisely know the Value of our Country \& our Friends, till we are separated from them. I beg you to be assured, my Dr. Sir, that of the latter there is none whom I remember with warmer Sentiments of Regard than you. I do not ask you to write to me; but I cannot help remarking that, if you shall have Leisure to give me a Line, you will gratify me highly by doing so.

$$
\begin{aligned}
& \text { "Yours sincerely } \\
& \text { "Wm Pinkney." }
\end{aligned}
$$


On March 19, Adams announced to congress the failure of the negotiators, without publishing the correspondence showing the full details of the transactions. Not only the commissioner's had failed but also Talleyrand's minions had demanded bribes and had been refused, Pinckney and Marshall had retired from Paris, leaving Gerry there.

On April 12, Murray wrote from the Hague:

"My dear Friend,

"At length I have heard once more from you \& Mrs M from her friend Mrs MeHenry - yesterday I recd. your letter of Novr. It has been almost as long in coming, as our Envoys dispatches are in going. A year this day since we received the last of your lind offices at the boat in wh. we embarked! One Year - and I shall just bear myself clear of every expense - \& that only with about 400 guilders in Pocket - but I could not keep your commands - the living here is as dear as in Philada - the demands from company more - the necessity of attending to various people in this \& other governments, greater - \& more urgent, as times waver from critical to temperate \& back again. The style of entertaining here is heavy, ceremonious, \& costly. We are rigid economists - we go in a Treck Schnyte if we go out of town - in a hack, if we go in the rain, in town. I keep old Will \& a man who speaks dutch \& english - who is essential to housekeeping. I keep no horse - nor have I been on one since I came - though I want exercise. Yet my dear friend furnishes as many rooms as we want only $-\&$ the noviciate among the dealers for every thing of Life \& they are all SHARPERS : so it is your Min. Resident is pretty much as he started - though I see there is a stir in Congress about our Salaries. I know what you will say - retrench - but you know not the sort of scene we are in - a marryd. minister must, he must see certain people at their houses \& of course at his own! You observed once to Hollingsworth, when I mentioned that I intended to carry Mrs. M. with me to the Springs - 'That is bad' - but on this voyage you know I conld not help it - we are rigid ceconomists — \& I often feel very uneasy at the necessity of spending money - we live as snug as possible - but we could not live with decency as genteel people under $£ 800$ a year Sterl - war has raised the price of everything but house rent - we live in the house of the U. S. - in which we have, from its size, almost died this dreadful 
winter, in damp \& cold. The repairs of this house cost some money, the bankers undertook it - they said their original powers extended to repair. I shall pay for one room - the most expensive one.

"We trembled for you in the fever, though we heard, as I mentioned in mine of 24 . Jany - that you all were safe. In that letter, I mentioned the Revolution here - of which I have often written to the Secretary of State. The winds have been furiously West \& N. W. ever since the 7. Oct. That must account, with probable captures, for your not hearing from the Envoys at Paris up to 3. Feb. But my dear Sir! a stroke is struck at Paris at the Commission that will pose every body. The Directory have selected Gerry - \& will open the negociation with him. I understand from Genl. P. will order P. \& M. to quit paris. I can not understand what new property Gerry has discovered in the mill stone ever turning \& ever grinding every thing - what new property he has discovered, by means of algebra, in his own powers or in their plans but so it is. The whole 3 made one commission - one is selected 'whose supposed opinions they say promise most confidence in them'! ! thus my dear Sir the Directory have us 'on the hip' - Why Mr. G. stays after all that has past - after the very ground of negociation is changed by acts subsequent to their arrival, no mortal but himself I believe can divine. I fear he is deceived in the degree of his own address \& ability to tread in a labyrinth without a clue - if he had had a clue. his colleagues must have seen it - \&, without one, I think he will lose himself. I do fear that with all his goodness of part he has the trick of mistaking the forms of a new \& brilliant Society for deference to himself - the lamps of Paris for illumination - the kiss of the Fish women for public joy \& these dames for dignify'd matrons meeting to hail him as the great pacificator. I fear this - of his good intentions I have no doubt - of his knowledge of men - such men - \& of women - \& such women - \& of politics conducted without chart or compass as ours are, I do doubt \& he must obtain Justice, \& settle the dispute on principles warranted by the spirit of America. And do that soon, or I shall think he wanted common sense in separating from such men as Pinckney \& Marshall, under circumstances of calumny agt. the Govt. U. S. \& dishonour to them too - if any thing said against an honest man-by France, ean be dishonour. If he does not obtain his objects speedily, it is entirely improbable 
he can justify a step that places so much power, in a crisis, in the hands of France, wh. step stagnates every measure in America while it strengthens France \& yet binds not F. to anything but to treat with him - no principle established no hope of success held out that Genl. P. had heard of on the 6 th. or he would have told me in his letter - in his of 23 . March - they had resolved $A l l$ to reject the proposal.

"I have seen Mr. M's book - \& despise it too much to dread another, wh. I should not be surprised to see engendered soon on the same soil \& not very unlike it.

"Harper's work does me much good. It is in England the property of a benevolent Society, the profits arising from its prodigious Sale are devoted to a charity. Pray tell our friend this - it has past 7 . editions - \& large ones.

"I will write again soon. The Govt. here are very friendly towards U. S. I rejoice Spain has opened her eyes as to Limits. I have taken great pains here with her minister, an amiable \& sensible man, lately in the council of State, on this subject, ever since last summer-but do not know that he has communicated on it to his Court. Mr. Delacroix is very polite to us - \& all his family. Pray remember me most kindly \& respectfully to Mrs MeHenry - \& do also to our fair and amiable young friend now Mrs. Marcou - and do also to Sedgwick - Hindman - Harper - Mr. Dennis - Tracey Rep. - S. Smith \&c \&c \&c \& Mr. Wolcott.

"God bless, you my dear frienc? \& believe me always affectionately "Yrs. \&c \&c \&c"

On March 27, Washington wrote McHenry, 1 asking if it can be true that some members of congress have had treas. onable correspondence with the Directory. "On this, as upor all other occasions, I hope the best. It has always been my belief that Providence has not led us so far in the path of independence of one nation to throw us into the arms of another. And that the machinations of those who are attempting it will, sooner or later, recoil upon their own heads."

Some dissatisfaction had arisen as to McHenry's administration of his department and on April 27, 1798, Robert Goodloe Harper ${ }^{2}$ wrote to Hamilton: "Could anything prevail on you to take the war department, a war minister is

1 Ford, xiii, 493. Sparks, xi, 230.

2 Hamilton, vl, 282. 
more important than a general. If Adams understood your willingness to come forward, the arrangement would immediately take place, MeHenry would give way and there is no difference of opinion among the federal party on the absolute necessity of his doing so." No answer to this letter has been found.

The growth of the navy demanded that more attention should be given it. On March 8, McHenry recommended that the war department should be assisted by a commissioner of marine and from this suggestion came the navy department. ${ }^{1}$ The frigate United States had been launched July 10, 1797; the Constellation on September 7 and the Constitution was to leave the ways in April, 1798. ${ }^{2}$

On May 12, McHenry wrote Hamilton ${ }^{3}$ that one or two, of the frigates will shortly be ready for sea and that Capt. Dale will sail in the Ganges within six or seven days. $\mathrm{He}$ asks for help in preparing instructions to the captains. As there is no secretary of the navy as yet, McHenry must prepare instructions to guide the conduct of the men of war in employing force to protect convoys against French ships. Congress shows a profound reserve and makes no declaration of war.

On May 17, Hamilton answered that the president, by the constitution, probably has power only "to employ the ships as convoys, with authority to repel force by force (but not to capture) and to repress hostilities within our waters, including a marine league from our coasts.

"Anything beyond this must fall under the idea of reprisals and requires the sanction of that department which is to declare or make war." The president should exercise no "doubtful authority," but should send a message to congress, asking for authority to give more "extensive protection" to our shipping. This "course will remove all clouds as to what the President will do, will gain him eredit for frankness and an unwillingness to chicane the constitution and will return upon Congress the question in a shape which cannot be eluded." A French privateer had made captures at the mouth of New York harbor. "This is too much humiliation, after all that has passed. Our merchants are very indignant; our gov-

1 State Papers, i, Naval Affairs, 33, 34.

2 Ingersoll's War Department, 29.

3 Hamilton, vi, 282. 
ernment very prostrate in the view of every man of energy.', 1

The navy department was not long to remain vaeant. Benjamin Stoddert of Georgetown, a merehant of moderate ability, who had been a fellow member of the Maryland senate with McHenry, was appointed seeretary and assumed the duties in June. After accepting the office, he wrote MeHenry thus:

"Dear Sir, -

“Geo. Town, May 28, 1798.

"Unqualified, as I really think myself, I have after a thousand struggles, aceepted my honorable, and at this erisis, important appointment. Who that has the feelings of an American, could refuse to try, at least, to serve his eountry at such a time? I put in thus early my claim on your Friendship for all the assistanee I shall need, and it will be a great deal. I mean to set out for Philadelphia as early as possible. I hope a week's delay will not be thought long, and I hope I shall not find it necessary to bestow more than a week on my private affairs. I go at first without my family, who are to follow, or to wait till the Fall, as I shall determine, after getting to Philadelphia. You did not write me a word about your wishes as to my acceptanee or refusal - make up for the deficiency by writing me on the receipt of this, and, if possible, flatter me into a belief that I may be able to avoid merited reproach. One letter may reaeh me before I leave this.

"I am, Dear Sir, with great esteen, "y'r. Serv.,

"Ben Stoddert.",

We learn of Stoddert's arrival in Philadelphia from a letter written thenee by William Hindman on June 13:

"Our Friend Stoddart reach'd here Yester Afternoon, $\&$ will wait upon the President this Morning, being anxious to be geered $\&$ enter upon the Duties of his Office; the applicants for Clerkship are numerous, \& some of the first Characters in the United States, He will not probably appoint his principal Clerk for some Days.

"You will see by the Paper, that there is to be a special Call of our House at after 11 Oelock to Day, as the Bills for the direct Tax And to authorize the Defence of the Merchant Ships of the United States against French Depredations;

1 Lodge's Hamilton, $x, 2 s 1$. 
will be read the third Time to Day. The last is a good Bill, tho' not so strong as some of our Friends wish'd it; I happened to be out on a Visit to Mr: Stoddert, when the Yeas \& Nays were ealled upon an Amendment moved by $\mathrm{Mr}$ : Harper. well.

"I have just seen your Nephew - Your Family are all

"I learn the joint Committee of both Houses to fix upon the Time of adjournment, will agree to rise the last of this Month or beginning of next, if They should thus report, I hope it will not be concurred with, tho' my Fears are it will. My best Respects to my much valued Friend Col Hamilton."

On April 3 the famons X Y Z dispatehes were made pub. lic and, amid the patriotic furor of enthusiasm they aroused, all were eager for action against France. ${ }^{1}$ McHenry's report to the house of representatives ${ }^{2}$ on April 9, 1798, contains a elear statement of his position in relation to France. That country "derives several important advantages from the system she is pursuing towards the United States. Besides the sweets of plunder obtained by her privateers, she keeps in them a nursery of seamen to be drawn upon in all conjunctures by her navy. She unfits, by the same means, the United States for energetic measures and, thereby, prepares us for the last degree of humiliation and subjection. To forbear, under such circumstances, from taking naval and military measures to secure our trade, defend our territory in case of invasion, and prevent, or suppress domestic insurrection, would be to offer up the United States a certain prey to Europe and exhibit to the world a sad spectacle of national degradation and imbecility. The United States possess an extensive trade. Heavy expenses must be submitted to for protection. The United States border upon the provinces of great and powerful kingdoms. Heavy expenses must be incurred, that we may be at all times in a situation to assert our rights over our own territory." Therefore, he recommends an increase of the navy, by building 20 smaller vessels, and, in case of a rupture with a foreign power, 6 ships of the line or frigates, and 6 galleys of one or two guns; the increase of the army by the addition of one regiment each of infantry, artillery, and cavalry, the first of these also to serve as marines; a law authorizing the President to eall out

1 Hamilton, vi, 285 .

2 State Papers, i, Military Affairs, 120. 
20,000 men as a provisional force if needed; more forts costing about $\$ 1,000,000$; more supplies, such as cannon, small arms, powder, saltpetre, copper, and military stores; and, to pay for all these, more revenue to be raised.

From Maryland, McHenry heard during the winter and spring. Uriah Forrest, on December 6, wrote from Annapolis urging Adams to agree to the request of the commissioners of the District of Columbia and ask Maryland at once for an advance of money, in addition to the $\$ 100,000$ loaned the year before. Two days later, he wrote again introducing a candidate for office and talking of the election as United States senator of James Lloyd, who introduced the Sedition Act in June, 1798. "I have had to make wonderful exertion to get Lloyd elected a senator. Better might have been found, but none would go down. He is as strictly governmental as it is possible, a man of nice honor and pretty good judgment, slow, and heavy.' Carroll of Carrollton wrote, on the same day, indorsing the same applicant, telling of Lloyd's election and asking for news from Europe of the embassy to France.

On April 18, James Winchester sent McHenry a long and important letter as to conditions in Baltimore. ${ }^{1}$

"My engagements in our County Court, which has been in session three weeks, \& a bad state of health has prevented my hitherto acknowledging the receipt of the Communications you was so kind as to enclose or to communicate the politics of this place.

"Yesterday, we had a numerous meeting at the Court House on the interesting situation of our affairs, and certain resolutions were adopted - approbatory of our Government, which you will see in the papers. Certain events, otherwise trivial than as they serve to teach us prudence and a cautious avoidance of the declaration of pretended reformed politicians, mark so strongly the views of a party here that I think it my duty to communicate them to you. It happened that I was selected to open the object of meeting, which I did by a brief statement of the outrages committed on this Country by France, and a recital of the fate of the Neutral Nations, who had reposed confidence in them, and, calling on each individual to declare, if any there was, his dissatisfaction at

1 Letters from McHenry's correspondence relating to Maryland politics in 1796 are found in So. Hist. Ass. Pubs., ix, 374 (November, $190^{\circ}$ ), and on the same subject in 1797 in So. Hist. Ass. Pubs., x, 31 (January, 1906). 
the resolution propounded, no opposition appeared. But not one of the name or immediate Connections of S. Smith attended. One of their party (I hear J. A. Buchanan) asked tauntingly, was there any complaint of British orders? The answer Was no. The immediate observation in reply was, It is an electioneering stroke \& has no other motive than to turn Genl. S. out of Congress. This I have learned this evening. They dare not face us. But they keep alive the spirit of the party in favor of France, tho' they are ashamed to avow it. They had rather sacrafice their Country, its honor, \& national character, than their individual popularity.

"This, connected with a cireumstance which occurred while I was at Annapolis during the last Session of Assembly attending the House as Council for the Landlords, satisfy me that there is a party here, however they may endeavour to conceal their real views by hypocritical professions, who ardently wish a connection with France of the nearest kind.

"You know I am considered rather democratic, and, under this impression, Govr. Henry unbosomed himself to me after dinner at Wharf's tavern. Thus, - 'Depend upon it, Sir, there is a British influence in this Country. I have seen it - yes, in this room. Mr. Jefferson is the only point to look up to resist it. $\mathrm{He}$ is the only mound to prevent its overwhelming us as a torrent - when I saw the British Treaty I did not think it could be possible I could have even been brought to vote for it - but the conduct of the late Executive left us no alternative but to adopt it or go to war, - necessity therefore compelled assent to it.' This conversation became public. The event was Mr. Winder's defeat \& Genl. Loyds election.

"I cannot help connecting the observation on our Town meeting. 'Was there any complaint of British orders,' with Mr. Henry's declaration That British influence was about to overwhelm us and tho' they will not openly show, at this time, their predilection for France, they will discover it in the first calamitous event which may happen to our Country. Depend on it they are not to be trusted. I speak of the party here.

"I have just had a meeting with Genl. Swan, Mr Carroll, Mr Dorsey, \& Mr. Hollingsworth on the subject of an address to the Government, which we have agreed onl, conformably to the Town Resolutions, Adding our willingness to submit to increased taxes, and praying that consideration of expences 
\&e may not be put in Competition with the important rights now at stake.

"The facts I have stated relative to Gov. Henry may be stated in any way in which they may be serviceable. Tis time to unmask hypocrites."

On May 6, Washington wrote 1 McHenry urging the establishment of an arsenal at Harper's Ferry and said: "The Demo's seem to be lifting up their heads again. They were a little crestfallen or one might say thunderstricken on the publication of the Dispatches from our Envoys, but the contents of these Dispatches are now resolved into harmless chitchat - mere trifles, less than was or ought to have been expected from the misconduct of the Administration of this Country and that it is better to submit to such chastisement, than to hazard greater evils by showing futile resentment. So much for a little consultation among themselves."

During the extra session of congress ${ }^{2}$ a bill was passed, on April 27, to add another artillery regiment and a second one, on May 28, to provide for a provisional army. ${ }^{3}$

Meanwhile Gerry remained at Paris, though his colleagues had left France. The news of Gerry's conduct aroused indignation on part of the administration and, on June 26, McHenry wrote Washington, "Gerry has been playing the double politician and besides a very foolish and hurtful game. $\mathrm{He}$ held conversations and correspondencies with Talleyrand, and, in other respects, has conducted himself in the most exceptionable manner. Lest he should have misconceived the dispatch of the 28th of March, he has been addressed to day in a manner which he will find it difficult to misconstrue and which, while it will mortify his pride, will prevent him from doing further mischief, or longer sporting with the honour, dignity, and integrity of his country. I think it probable that letters of marque and reprisal will be shortly declared. You see how the storm thickens and that our vessel will soon require its antient pilot. Will you, may we flatter ourselves, that in a crisis so awful and important you will accept the

1 Sparks, xi, 231. Ford, xili, 495. McHenry answered on June 26 , that it was very hard to have anything done for Shenandoah, but he wili do what he can.

2 State Papers, i, Military Affairs, p. 119. McHenry's report of March 8, and p. 123 report of Aprif 12 on cannon contract.

3 On June 5 , Hamilton sent to Wolcott to hint to the president to moderate his tone. Hamilton, vi, $29 \overline{5}$. 
command of all our armies? I hope you will, because you alone can unite all hearts and all hands, if it is possible that they can be united."

MeHenry still hoped for the best and, on July 1, wrote Washington: "Enjoy your happy situation or, if it is to be disturbed, let it be only by transient domestic cares and the pain of sympathizing with those whom you have stationed in places where there are more thorns than roses." 1 Only a few days later, however, McHenry was directed to call Washington into service again, that he might close his career at the head of the army.

$1 \mathrm{McHenry}$ complains of rheumatism in his wrist and tells Washington, "Your carriage still pays rent." 


\section{H A P T E R XIII}

THE PRONISIONAL ARMY AND THE STRIFE OVER THE GENERALS

$\mathrm{T}$

HE emergency which called George Washington into federal service, as head of the Provision Army, was a most urgent one. On July 3, McHenry wrote him: "The erisis and almost universal wish of the people to see you at the head of the armies of the United States has been too strong to be resisted. The President has rielded to causes so powerful and nominated you accordingly, which has been unanimously confirmed to-day by the Senate and thus you are again called upon by all voices to fill a station which all think you alone qualified for at this moment. I know what must be your feelings and how many motives you must have for preferring the privacy you are in the enjoyment of, to the troubles and perplexities of a commander of an army. This, however, is the crowning sacrifice which I pray to God, you may agree to make for the sake of your country and to give the last finish to a fame that nothing short of such a call as the present occasion could have been capable of increasing.

"I think it probable that the President will require me to be the bearer of his letter to you. I shall, in that case, have an opportunity to converse with you at large on several subjects relative to the army and agree with you upon such arrangements as may leave you as long as possible at Mount Vernon. Perhaps I shall set out on Friday or, at farthest, Monday next."

Before he received this letter, Washington, in a letter written on July $4,{ }^{1}$ answered MeHenry's query of June 26 as to whether he would assume command of the Provisional Army. In this frank communication he stated that he would not let his love of retirement cause him to withhold any services required by his country, especially when "its dearest rights are assailed by lawless ambition and intoxicated power." He must have three questions answered affirma-

1 Ford, xiv, 19. Sparks, xi, 246. 
tively, however, before he will accept the office: 1 . He does not believe there is a danger of invasion and inquires whether he will be free from criticism for "appearing again on a Public Theatre, after declaring the sentiments" of his valedictory address. 2. He wishes to be sure that the Americans do not prefer juvenile generals, as the French do, but that "it is the wish of my country, that the military force of it should be committed to my charge." 3. He must be certain that the army "to be formed should be so appointed, as to afford a well grounded hope of its doing honor to the country and credit to him who commands it in the field." A general staff he feels to be all important and he gives his views as to the inspector general, quartermaster general, adjutant general, and commandants of artillery and engineers.

Washington enclosed this letter in another personal one to McHenry, written ${ }^{1}$ on the next day, in which he asked him to show the enclosure as from himself to Adams, to whom Washington has "expressed tantamount sentiments, in more concise terms," and to write him the responses, "if you are at liberty and deem it expedient." Adams had already written Washington a letter, which "is strongly indicative of a wish that I should take charge of the military force of the country and, if I take his meaning right, to aid also in the selection of the General Officers." "The appointment of these are important," Washington wrote McHenry, "but those of the General Staff are all important, insomuch, if I am looked to as the Commander in chief, I must be allowed to choose such as will be agreeable to me." One great difficulty concerned the time when Washington should take command. Adams may wish this to occur at once. Washington, however, will not "come forward, before the emergency becomes evident," but is willing to have it known that he "will step forward, when it does appear so unequivocally," if the "matters, for which I have stipulated as previously necessary, are ascertained and accommodated." In the meantime, either the appointment of the general staff may be postponed, or the President may "advise with me on the appointment of them." Washington refers to this matter now, as he feels sure he can secure the services of some "very fit men," who will not serve, ex-

1 Ford, xiv, 29. Sparks, xi, 254. He thanks McHenry for information in the letter of June 26 , and says that he has already been applied to by candidates for the position of director of the hospital and has refused both on general grounds and because he wishes Dr. Craik appointed, if he ever needs a surgeon. 
cept as his "coadjutors." As to the officers to command the divisions and brigades, on whom much depends, Washington suggests that they be not chosen exclusively from the "Old Generals," several of whom are unsuitable.

On the 6th, Adams sent instructions ${ }^{1}$ to McHenry, who had been unwell, to set out at once for Mt. Vernon. The reasons for appointing Washington can not be detailed in writing. "As it is a movement of great delicacy, 2 it will require all your address to communicate the subject in a manner that shall be inoffensive to his feelings and consistent with all the respect that is due from me to him."

"If the General should decline the appointment, all the world will be silent and respectfully acquiesce. If he should accept, all the world, except the enemies of this country, will rejoice. If he should come to no decisive determination, but take the subject into consideration, I shall not appoint any other Lientenant General, until his conclusion is known."

Adams desired Washington's advice, especially as to the inspector, adjutant, and quartermaster generals, and suggested certain names for military positions to be mentioned to him. "His opinion on all subjects would have great weight and $I$ wish you to obtain from him, as much of his reflections upon the times and service as you can." McHenry wrote Washington at once, asking that he be met at Alexandria. On the next day, Adams wrote Washington: ${ }^{3}$ "'McHenry, the Secretary of War, will have the honor to wait on you, in my behalf, to impart to you a step I have ventured to take and which I should have been happy to have communicated in person, if such a journey had been, at this time, in my power. Mr. McHenry will have the honor to consult you upon the organization of the army and upon everything relating to it." Pickering had already written Washington, ${ }^{4}$ urging him to insist on Hamilton as his second in command, and on the

1 Schouler, 1, 407, states that Hamilton sent his letter to Washington, written on June 2, to Mt. Vernon in care of McHenry. If this be true, Hamilton kept the letter over a month before forwarding it (Hamilton, vi, 293). This shows how baseless is one of the charges against McHenry. Schouler probably means the letter of July 8 (Hamilton, vi, 389).

2 J. Adams, vili, 573 . Sparks, $x 1,531$.

3 J. Adams, vill, 575 . Sparks, $x i, 532$.

4 Pickering's Examination of Adams and Cunningham's letters, 1-161. On July 28, Pickering wrote Jay (Hamilton, vi, 330) that Washington was sometime balancing Hamilton and Pinckney as to priority and perhaps my letter of the 6 th, which Washington did not show McHenry, turned the scale. 
11th, Washington answred, ${ }^{1}$ stating that he had not yet seen McHenry, but preferred Charles Cotesworth Pinckney to Hamilton for second place. The same morning, Washington sent to Alexandria for McHenry and in the evening he arrived. ${ }^{2}$

On the next day, McHenry wrote Adams, ${ }^{3}$ that Washington will probably accept, provided he be not called into active service, until his presence be absolutely needed. He showed McHenry his letters of the 4th and 5th, which had not arrived in Philadelphia before the secretary left that place, and McHenry notified Adams that the letter of the 4th shall be given him, as it treats "on several points that will require your attention." McHenry will obtain from Washington the names of the persons he considers the best qualified for his "confidential officers." After completing his letter, McHenry showed it to the general, who asked him to add to the last sentence: ${ }^{4}$ " and without whom, I think, he would not serve."

Washington let McHenry return on the 13th with a "full communication" upon the several points he had in eharge." 6

On the 14th, Washington wrote Hamilton 7 that he desired to put him next himself and feared that by this step will lose Pinckney. Knox, "whom I love and esteem," has been placed last of the three. But "after all, it rests with the President to use his pleasure." Hamilton answered this letter, stating that he had a great regard for Knox, but must stand up for his own rights. Yet rather than see Washington

1 Sparks, xi, 257.

Dear Sir

Mount Vernon 11th. July 1798

My carriage is sent to Alexandria to bring you, and any companion you may have to this place

James McHenry Esqr.

Affectionately

$$
\text { I am always Yours, - and }
$$

Secretary of War

expected to be in Alexandria

3 Adams, viii, 574 . Sparks, xi, 533.

4 see Washington's letter of September 16 .

5 Sparks, xi, 261.

6 C. F. Adams charges, without any foundation that $I$ can discover (Adams, i, 528, 529), that Pickering and McHenry, with other friends of Hamilton, set in motion the most extraordinary influences to bring about Hamilton's being named as second in command and that Washington was made to fear that Adams wished to appoint Burr as a major general. C. F. Adams's statement is also incorrect that priority had not been settled at the time of the nomination, though McHenry and Pickering had invoked Washington to decide it at once.

7 Sparks, xi, 264. 
compromitted, 1 "I shall cheerfully place myself in your disposal and facilitate any arrangement you may think for the general good." On the 17th, Hamilton wrote Pickering that he was willing to go below Knox, but does not like to be the third in the list of major generals. ${ }^{2}$ Meantime Washington had written Knox, ${ }^{3}$ on the 16th, that Hamilton, Pinckney, and Knox, in the order named, were seleeted as major generals. "The first of these, in the public estimation as deelared to me, is designated to be second in command, with some fears, I confess, of the consequenees, although I must acknowledge at the same time, that I know not where a more competent choice could be made."

Knox answered, ${ }^{4}$ deelining the position, on the 29 th, before he had heard from MeHenry.

From Philadelphia, MeHenry wrote on the 18th that he had returned on Tuesday, and found the session of congress over, but the senate still sitting to aet on nominations. Before he saw his family, he presented Washington's letter to Adams, while the president and Mrs. Adams breakfasted. Botl of them were pleased.

Adams wrote a message, ${ }^{5}$ naming the three major generals, in the order which Washington gave them, though he said Colonel Hamilton, former rank being considered, was not entitled to stand so high and asked why Pinckney was preferred to Knox. MeHenry told him Washington's opinions and showed a eopy of the general's letter to Hamilton dated July 14. While they talked, Pickering eame in and said the senate had adjourned for the day. On the morrow, Adams said his mind had ehanged and he could not think of placing Hamilton before Knox; but, finally, he agreed to send in the names in that order, on MeHenry's statement that the parties, if aggrieved, might appeal to a board of officers or to the commander in ehief. Pickering then came in and placed Drayton as a brigadier general above W. S. Smith, Adams's son-in-law. Adams grew warm and said Smith should be adjutant general and Drayton a brigadier. Piekering was silent as to this, but suggested Sevier as a brigadier.

MeHenry considered him unprineipled but waived objeetions, as the appointment was one which might remain

1 Sparks, $x i, 537$.

2 Hamilton, vi, 326 .

3 Sparks, xi, 266.

4 Sparks, xi, 534.

5 Sparks, xi, 542 . 
nominal and might have a good effect in Tennessee. As the provisional officers might be wanted before fall, it was thought best to appoint them at once. After Pickering left, he sent MeHenry word that Smith was a swindler, which piece of information McHenry felt should have been given sooner. Before MeHenry went to Mount Vernon, Pickering had said in MeHenry's presence, that Smith would be a good officer. Hamilton had concurred in the propriety of appointing Smith and neither Wolcott nor McHenry had heard of the charges against Smith. Pickering now aided in the rejection by the senate of Smith's nomination as adjutant general and this exceedingly irritated Adams, who said there was an intrigue against Smith, who was no more in debt than Lee or Knox, who was no disorganizer and could procure proof from his creditors of their satisfaction with his conduct.

Edward Carrington was asked by Washington if he would accept a brigadier generalship and answered at once favorably from Richmond on July 18, 1798. "By this evenings maii I had the honor to receive your letter of the 15th. instant, and am impelled, by the very great sensibility with which it fills my mind, to reply to it immediately.

"It is impossible for me, Sir, to disobey your call to any Station which, in the threatened crisis, you may suppose me capable of taking: were I ever insensible to the honor resulting from the circumstance, the example under which your summons is made, could not but be irresistable in a mind impressed as that of every true American must be at this time. I freely give my assent to be disposed of agreeably to your judgment, with a view to the good of our beloved and injured Country, without annexing any conditions whatever. Having said this much, It may not be improper for me to observe, that the late increased duties of the office I hold, have brought into operation measures which, with the old business, render it of importance that my attention to the appointment you have assigned, be deferred as long as possible; and it would be my wish if the public interest admit of it, not to be called to it until indispensably necessary."

The bill increasing the army to twelve regiments of infantry and a regiment of dragoons, comprising 6 troops, had passed ${ }^{1}$ on the 16 th, and on the 20th, MeHenry wrote Hamilton, asking him to attend at once to providing a system for the forces. This letter-Hamilton answered on the 22nd, thus :

1 On the 16 th, congress adjourned and the senate followed on the 19 th. 
"Your letter of the 20th. instant, inclosing one from General Washington came to hand this day.

"The object you suggest in it is one, which no doubt deserves a primary attention; and it will be paid to it. But it will be useful that I should shortly confer with you fully on a variety of subjects, and after receiving an official communication of my appointment, I shall, without delay, repair to Philadelphia.

"I count always upon your confidence, as well in my personal friendship for you as in my zeal for the public service; and having no inclination to spare myself, it only remains for us to trace together the plan in which I can best second your operations and promote the service.

"Yrs with true attachment

"P S "A HamitoN

"In some instances we have missed it in our Brigadiers. It is very essential there should be no mistake about the field office - Festina lente in your choice of officers."

On the same day, McHenry wrote a letter to Pickering, in which are contained germs of the ideas which resulted in the Louisiana Purchase and in the Monroe doctrine. $\mathrm{He}$ enclosed a memorandum, with reference to the instructions to be given Rufus King, our minister to Great Britain, and asked that Pickering talk with Adams as soon as may be on these points: "It presses very strongly on my mind that we ought not to lose a moment in forming our resolutions relative to the 2 nd and $3 d$ especially, as the determinations had thereon must sensibly influence my arrangements respecting the public force. Will it not be proper that King be instructed at once concerning the French West Indies and New Orleans? Is it right that the measures taken by our government which may eventuate in putting Great Britain in possession of the French West India Islands should be productive of no equivalent to the United States? 2. Is it not expedient that the United States should, in the event of the French West Indies declaring themselves independent, be in a situation to give them aid and that provisional arrangements be made with England to prevent her from taking exceptions thereto or defeating the same? 3. Ought not Mr. King to inform the British cabinet, without loss of time, that the United States can in no event permit New Orleans to pass from the hands of Spain, 
unless to become a possession and part of the United States."

On July 22, Washington answers McHenry's letter of the 18th. He agrees to the nominations, ${ }^{1}$ though he thinks Smith would do better in the line, than as adjutant general, and asks why no quartermaster general ${ }^{2}$ is named. As to the man to be named for that office, he has a decided preference. Washington transmits an application for a commission and states that he will not take strong ground, in general, for any applicant. He suggests, however, that "when the President has fixed upon officers of established character to command companies, Gentlemen who prize their own honors and the reputation of their company, that it would be good policy to let them choose, or at least to recommend, their own substitutes." This would "facilitate recruiting and contribute much to the harmony of the company.'

For commander of cavalry, Washington is inclined to recommend Major Talmadge of New York (formerly of Sheldon's horse) and suggests a number of other names for commissions of various kinds.

On the 25th, McHenry informs ${ }^{3}$ Washington that Adams has gone to Massachusetts for the summer and that it is planned to have Hamilton, the inspector general, revise the army regulations. Adams's long and frequent absences from the capital, while business was left in the hands of the secretaries, who bore the responsibility without full power, was a great cause of the administration's troubles.

On July 29, Washington answered ${ }^{4}$ McHenry's letter

47.

1 He criticises the nomination of Sevier. Sparks, xi, 269; Ford, xiv,

2 No such general was provided in the law, is McHenry's reply. Washington wrote again upon the subject on August 2 :

"Private)

"Dear Sir,-

"Finding that I was not altogether correct, in giving the uniform of the Company of Greyheads in the Town of Alexandria, I amend, as soon as possible, the mistake, by transmitting the letter of the Capt'n thereof Col. Simms - to Mrs. Washington.

"Have you received my letter of the $22 \mathrm{~d}$ of July? The enquiry then made respecting the Quarter-Master-General is of serious, and interesting moment to me. If the business, which my own appointment has involved me in, increases - or even continues - I shall soon be under the necessity of calling upon that officer, or you, for a supply of stationery:- on you particularly for copying Paper; who, better than he, will know, or can direct the proper sort. I thought I came home well provided with these articles, but shall soon run short.

"Yours affectionately,

"Go. WASHINGTON."

3 Sparks, xi, 540. He did not apprise Pickering or McHenry of the day of his intended departure.

4 Ford, xiv, 55 ; Sparks, xi, 276. 
of the 25th, thanking him for the copy of the rules and regulations, asking that full information on all points be given him, and requesting that a secretary be allowed him at once, as he is overwhelmed with applications for commissions in the army. One of these early applications ${ }^{1}$ for a captaincy for Wm. Champe Carter of Albemarle assigns as a reason for his appointment not only that it is "praiseworthy in young men of fortune \& character, at this juncture to step forward in defence of the rights of their country,' 'but also that a few commissions might well be distributed in his part of Virginia as a "certain character [i. e. Jefferson], in his route from Philadelphia to Monticello, used every indirect means of damping the patriot spirit of the people." 2

The demands for commissions to be given to friends were many. We have already noticed that Washington, Hamilton, and Murray asked that certain men be appointed and the extant letters are sufficient to show how the secretary of war was showered with requests, as he has been at each renewed enlargement of the army.

Washington's caution is shown in his letters of August 10, and December 14:

\section{"Dear Sir}

"Mount Vernon 10th. Aug. 1798.

"The letter from Mr. Ames to Mr. Best, containing further evidence to his good character, I send.

1 The application is filed by his brother Chas. Canter, Jr., of Culpepper, July 25 .

Another of Washington's letters on the same subject was sent from Mount Vernon, on July 30, 1798.

"Dear Sir, -

"The writer of the enclosed letter, in name and character, is an entire stranger to me, - nor do I know whether, by the Law establishing the Cavalry, any provision is made under which such a person could be employed, tho' certain it is, if Mr. Macharg understands what he professes to be master of, he might be employed very advantageously in training that part of our force.

"I have wrote him to this effect: - adding, that as he is a stranger. his application to the war office must be accompanied by ample testimonies, not only of his skill in the business he professes, but to his character in all other respects, with which, and my letter to him, he would come properly before you, and without which I conceived it would be useless to apply.

\section{"I am, Dear Sir, your ob't.,}

A number of letters with reference to appointments to army positions from the McHenry papers are published in So. Hist. Ass. Pubs., ix, 99 (March, 1905), and X, 289 (September, 1906), also in Granite Monthly, xxxvili, 123 (April, 1906).

2 Letters from the MeHenry papers concerning politics in Virginia during this period will be found in William and Mary College Quarterly, xili, 102 (October, 1904), Virginia Magazine, xil, 257 (January, 1905 ), xil, 407 (April, 1905). 
"The other letter from Mr. Carter (who married a niece of mine) though I send also, but request it may be returned; what he says of a certain character may be treasured up, but not reported as coming from him.

"His brother is an utter stranger to me, and therefore I can add nothing to what he has said of him. The family you know, are among the most wealthy \& respectable in this State.

"My nephew Lewis might (but as he has never applied to me, I cannot say that he would) be glad of some appointment, He was an aid to Genl. Morgan in the Western Expedition.

"I am Dear Sir. Your Obedt. Servt. "Go. Washington."

"Chester 14th. Decr. 1798.

"Private

"Dear Sir,

"Having requested that the nomination of Mr. Custis might be with held (even if it should meet the Presidents approbation under any circumstances) until I could consult his Grandmother (Mrs. Washington -) and Mother, Mrs. Stuart; I further pray that no mention of his name for such an Office may be made until the result is known; - because, if their consent, being an only son, indeed the only male of his family, cannot be had, it would be better that the arrangement of him should pass entirely unnoticed, to prevent the uneasy sensations which might arrise from disappointment, if the knowledge of it should get to him.

"He now stands as Cornet, in the Troop proposed to be Commanded by Lawrence Lewis - who was an Aid de Camp to Genl. Morgan - on the Insurgent Expedition in 1794.

"Just as I was leaving the City to day, I had an opportunity for the first time of seeing Captn. Saml. Henley - who is a Man of a handsome \& gentlemanly appearance. Having no evidence respecting him, except from his own letter, while we were arrangeing the Massachusetts line, he was not included in it. Afterwards, a letter from Genl. Shepherd recommended him;-but at that time we did not conceive it of sufficient weight to travel the ground over again. I must acknowledge however, that his external appearance (for I had no conversation with him) made so favourable an impression on me, that (being an old officer too, and brother to a very 
worthy man) I should be very glad if his conduct will stand the test of investigation - to see him put as a Captain, in place of some Captain in that line, who has not served in the Revolutionary War. The particular one I cannot now name, but it will not be difficult to aseertain. With very great esteem \& regard

$$
\begin{aligned}
& \text { "I am - Dear Sir } \\
& \text { "Your Most obedt. Hble. Servt. } \\
& \text { "Go. WaSHINGToN. }
\end{aligned}
$$

"P. S. I know no character in the New England States (since the declination of Genl. Knox and Brooks) that have fairer pretensions to be appointed a Brigadier or even Majr. General, than Genl. Cobb. And if Genl. Dayton does not accept his appointment - pray press Colo. Howard strongly to come forward."

MeHenry wrote to Hamilton, ${ }^{1}$ stating that he had been appointed inspector general, with the rank of major general and that the nominations for generals had been sent to the senate on the same day and in the order of the annexed list. in which order they would be registered in the department. Adams considered that pay and emoluments of office should not begin until the officers were called into service. Hamilton accepted at once, recommended his nephew for a captaincy, 2 and came to Philadelphia. Doubtless, from his previous relations with McHenry, he expected that he would be given complete control of matters, and when he found that MeHenry proposed to keep affairs in his own hands, he returned home and wrote the following most ungenerous letter ${ }^{3}$ to Washington on July 29. He feels that he must do violence to friendship by stating that "my friend MeHenry is wholly" insufficient for his place, with the additional misfortune of not having the least suspicion of the faet. This generally will not surprise you, when you take in view the large seale upon which he is now to act. But you, perhaps, may not be aware of the whole extent of the insufficiency. It is so great, as to leave no probability that the business of the War Department can make any tolerable progress in his hands. This

1 July 25 Hamilton, v, 137.

2 Hamilton, $v, 138$. On September 9, 1798, Hamilton wrote a second letter recommending this nephew. Phllip Church, September 30, 1798. McHenry sald he would take good care of Philip Church as of his own son. Hamilton's acceptance dated July 28 is printed in Lodge, vi, 493. 3 Hamilton, vi, 331 . 
has been long observed and has been more than mentioned to the President by members of Congress. He is not insensible, I believe, that the execution of the department does not produce the expected results but the case is of course delicate and embarrassing."

"My real friendship for McHenry, concurring with my zeal for the service, predisposed me to aid in all that he could properly throw upon me and I thought that he would have been glad, in the organization of the army and in the conduct of the recruiting service, to make me useful to him. With this view," Hamilton came to Philadelphia. "But the idea has thus far been very partially embraced" and Hamilton, returning to New York with little fruit of his journey, feels that the censure due McHenry will fall on the principal military officers also. He asks Washington to write McHenry for a statement of supplies. This will give necessary information and prompt the secretary to exertion.

On July 30th, Hamilton, ${ }^{1}$ who had returned to New York, wrote MeHenry, asking that he and Knox be called into service. In addition to preparing the system of tacties and discipline, the inspector general may superintend recruiting and be useful in other ways, while Knox would be of "extensive service," especially in matters relating to artillery. Hamilton tells McHenry that "scruples of delicacy" cannot withhold him from stating what ought to be said, through "friendship to you or regard to the service." "I observe you plunged in a mass of details. I know, from experience, that it is impossible for any man, whatever be his talents or diligence, to wade through such a mass, without neglecting the most material things and attaching to his operations a feebleness and sloth of execution. It is essential to the success of the minister of a great department that he subdivide the objects of his care, distribute them among competent assistants, and content himself with a general but vigilant superintendence. This course is particularly necessary, when an unforseen emergency has suddenly accumulated a number of new objects to be provided for and executed."

On the same day, McHenry sent Hamilton a list of applicants for commissions from New York and the adjoining states and asked him to report on them and to suggest other names.

1 Hamilton, v, 138 ; Lodge, vi, 483. On August 8, Pickering and Wolcott wrote Adams on this matter. C. F. Adams mistakenly says they anticipated McHenry. 
MeHenry's answer to Hamilton's letter of July 30 is not preserved, but we find him writing on the 5th of August, asking for a list of officers from the southern states and stating that Wolcott holds back the order for elothing. On the 6th, McHenry wrote again, stating that he is indisposed and feverish, and told of the rejection of the nomination of W. S. Smith as adjutant general, and of the need that the appointments should be hastened. Two days later, he informed Washington that he has a bilious complaint and that yellow fever has broken out again in Philadelphia. He has written Adams to allow Washington a secretary and asked that he may call Hamilton and Knox into active service, ${ }^{1}$ as otherwise he will be swamped with business. ${ }^{2}$ On the 14th, Adams answered saying that Washington is in the public service from the date of his appointment and should have a secretary at once. Adams answered the other request thus: ${ }^{3}$ "Calling any other general officers into service at present will be attended with difficulty, unless the rank were settled. In my opinion, as the matter now stands, General Knox is legally entitled to rank next to General Washington; and no other arrangement will give satisfaction. If General Washington is of this opinion and will consent to it, you may eall him into active service as soon as you please. The consequence of this will be that Pinckney must rank before Hamilton. If it shall be consented, that the rank shall be Knox, Pinckney, and Hamilton, you may call the latter two into immediate service when you please. Any other plan will occasion long delay and much confusion. You may depend upon it, the five New England States will not patiently submit to the humiliation that has been meditated for them."

On August 6, Hamilton wrote Wolcott, urging that the generals be called into service, and adding: "It is impossible for MeHenry to get through all that is now upon his hands in a manner honorable to himself, satisfactory to the public, or proportioned to the energy of the conjuncture."

MeHenry had written Knox on the 25th of July, virtually repeating his letter of the same date to Hamilton. Knox answered ${ }^{4}$ from Boston on August 5, asking whether his

1 On August 20, Hamilton wrote to Washington on this matter. Hamilton, vi, 342 .

2 Hamilton, vi, 334.

$3 \mathrm{~J}$. Adams, viii, 580 .

$4 \mathrm{~J}$. Adams, vili, 579. On August 11, McHenry sends Hamilton this letter and asks his opinion thereon. 
revolutionary rank should entitle him to rank before the others or not and, if not, he intimated he should not accept the position. To Knox's letter of the 29th of July, Washington answered ${ }^{1}$ on August 9, repelling insinuations that his friendship was insincere and stating that he does not think the relative rank of much importance. Adams had nominated Washington without consulting him, induced, according to McHenry, by the urgency of his friends. As congress expected to adjourn on the Monday following Washington's notification of his appointment and as he wished that body to vest power in the president to make the necessary appointments, he "hastened, precipitately, Mr. McHenry's return, in hopes he might be back in time to accomplish this object," and, therefore, Knox ${ }^{2}$ could not be consulted, before his name was sent to the senate. Washington apologized for his advocacy of Hamilton, as he had been "inundated with letters which said that Col. Hamilton was designated second in command (and first if I should decline an appointment) by the federal characters of Congress, whence alone anything like a public sentiment relative thereto could be deduced."

To Hamilton, on the same day, Washington wrote, complaining that McHenry does not keep him informed and answering Hamilton's eomplaint of July 28. He added ${ }^{3}$ that Hamilton's opinion "respecting the unfitness of a certain gentleman for the office he holds, aceords with mine and it is to be regretted sorely, at this time, that these opinions are so well founded. I early discovered, after he entered upon the duties of his office, that his talents were unequal to great exertions, or deep resources. In truth, they were not expected, for the fact is, it was a Hobson's choice." But such is the case and what is to be done? Hamilton must have charge of recruiting and Washington will try to impress McHenry with the propriety of requiring Hamilton's assistance. "Delicacy, if matters become serious, must yield to expediency."

Not hearing from McHenry for a while and inspired by Hamilton's ungenerous letter, Washington wrote ${ }^{4}$ McHenry the day after he had written to Hamilton. The letter is "private and confidential, dictated by friendship, and flowing from

1 Sparks, xi, 280.

2 On August 8, Knox wrote Pickering that he cannot serve under Hamilton.

3 Hamilton, vi, 337.

4 Ford, xiv, 67 ; Sparks, xi, 286. 
the best intentions." If it has "too much the appearance of plain dealing," MicHenry should "look to the motives and manner of the communication." Washington took the place of general witl the understanding that he was to be kept apprised of what occurred, and offered to go to Philadelphia, if necessary, though it was midsummer, but McHenry has not written, and, fearing there may be delay, the general entreats McHenry, who has the more responsibility, because Adams is not a military man, to call Hamilton into service and place him in charge of the recruiting and also to call on Knox and to give Washington full information of what has been done. Much of the censure bestowed on McHenry was undeserved. He felt the danger of delay and asked ${ }^{1}$ Adams on August 4, that he, with the assistance of Knox and Brigadier General Brooks, take under his immediate direction the Eastern States, that McHenry himself should look to the Middle States, and Washington care for Virginia and the South, all subject to Adams's final determination. Four of the twelve regiments should be raised in each quarter, and, in the hopes that Adams would agree to his plans, McHenry wrote Hamilton on August 10, asking him to hold himself ready to come to Trenton, where the govermment will remove on account of the epidemic in Philadelphia. McHenry himself was unable to go to his office for several days before the 13th, on account of his bilious complaint and, on the 14 th, he and his family removed to Trenton.

On the 13th, Washington wrote $\mathrm{McHenry}$ from Mount Vernon as follows, showing how his feelings toward McHenry had changed on news of his activity:

"The Messenger that carried my letters of the 10th. to the Post Office brought me your favour of the 6th. - and yesterday I received that of the Stll.

"It gave me sincere pleasure to find by the letter, that you had suggested to the President, prompt \& decisive measurres for Organizing and recruiting the twelve Regiments of Infantry, \&c: - and the propriety also of requiring the Services of the Inspector General and Major Genl. Knox, to aid you in arranging the details, and superintending the Execution of different parts of your Multiplied duties - occasioned by the business coming upon you en Masse.

1 Sparks, $x i, 542$, McHenry wrote Washington that the absence of Adams made it impossible to organize the twelve regiments, unless McHenry "concentred information, digested it," and submitted a plan such as ho did in this letter. 
"Without such aid, \& subdivision, it would be impossible, in my opinion (in such an emergency) to carry the Act for Augmenting the Army, into effect with the precision and promptitude it seems to have contemplated.

"Any assistance I can give, consistently, to carry your Plans into effect, you may command with freedom.

"It is extremely painful to hear that the Yellow fever has again made its appearance in the unfortunate City of Philadelphia, and is spreading its malignancy;- and it is with much concern I am further informed, that you have return of your Billious complaint. I hope effectual measures will be pursued to check the first; and that you are, or soon will be, perfectly recovered of the latter. With very great esteem and regard - I am-Dear Sir

"Your Most Obedt \& Hble Servant. "Go. Washington."

A second letter of the same date ${ }^{1}$ from Washington almost apologizes for his letter of the 10th: "Finding that my ideas accorded so much with the measures you had suggested for the consideration of the President, filled my mind with exquisite pleasure and it would be uncandid not to confess that your silence and my entire ignorance of what was doing with respect to the organization of the army and recruiting the men, produced very disagreeable sensations." He wishes he could obtain an adjutant general from Maryland, which is "a respectable state well affected," but without a general officer, and hopes for McHenry a restoration to health.

On August 19, Hamilton wrote ${ }^{2}$ MeHenry that he will enter public service at once, if needed, but hopes he may not have to make "immediate change of residence," though he will "not object to a frequent attendance at the seat of gov.

1 Sparks, $x 1,290$, a paragraph is omitted fnom the printed letter as follows:

"(Private)

"My Dear Sir

Mount Vernon 13th. Augt. 1798.

"** The enclosed letter from the Collector of New York to me, will show what he has done with the tin box addressed to me. Some anxiety is felt concerning it; for as much as it is supposed to contain a present (probably a valuable one) from an East India acquaintance of Mr. Laws to Mrs. Law, and directed to me in hopes of Insuring its safety.

"Always Your Affectionate

"Geo: WAs hington."

Lodge, $x, 317$, prints a letter from Hamilton to McHenry advising the latter to communicate frequently and fully with Washington and on p. 318 one from Hamilton to Sedgwick stating that McHenry is "loaded beyond his strength."

2 Hamilton, vi, 338, 340 ; Lodge, x, 307, 309. 
ernment." Knox's letter, which McHenry showed Hamilton, "occasions me no small regret and embarrassment, my esteem and friendship for that gentleman would lead me far, but there is a very great difficulty in waiving a station to which, I am well convinced, I have been called, no less by the public voice of the country, 1 than by the acts of the Commander in Chief and of the President and Senate. The intention as to the relative grades of the officers appointed is presumed to be unequivocal. It is believed that the rule to which General Knox refers can have no application to the case of the formation of a new army at a new epoch, embracing officers not previously in actual service." He suggests that Knox may accept, with a reservation of his claim "ad referendum," encloses a draft of a suggested letter for Knox and states that, though he concedes a high value to Knox's merit, he cannot abandon his own pretensions. Pickering, meanwhile, was intriguing : against McHenry and, on the 21st, suggested to Hamilton that Knox be put in charge of the department of war, to solve the difficulty as to the generals, as Adams "has been informed of a very general dissatisfaction in its present direction."

Two days later, Pickering wrote Hamilton again, ${ }^{3}$ stating that McHenry had just handed him and Wolcott his letter to Adams, on the subject of calling the major generals into service, and Knox's letter to him: "I am glad to see you are renacious." McHenry told the other secretaries that Washington made Hamilton's appointment the sine qua non of his acceptance and that he showed Adams the letter Washington wrote to Hamilton, notwithstanding which Adams placed Knox first. McHenry thought that the old rule as to seniority is not in force, nor onght to be, but suggested writing to Knox and asking him to accept, with reservation of his claim. Why should we urge Knox's acceptance? Pickering asks. McHenry is " utterly uninformed" of Pickering's correspondence with Washington and Hamilton.

On August 22, McHenry answered Adams's letter of the 14th. stating that the choice of the major generals and their reiative military rank proceeded, "originally and exclusively," from Washington and that MeHenry "had no agency, direct or indirect, before or while at Mt. Vernon, in deciding

\footnotetext{
I Against this paragraph, McFenry wrote: "Certainly true."

2 Hamilton, vl, 343.

3 Hamilton, vi, 351 .
} 
his mind, either as to the choice or the arrangement of the rank of those he had selected," but that he said to Washington, when he "showed me his choice, that I concurred, but that the nominations and relative rank of those nominated must finally rest with the President." Meanwhile, McHenry was not to be blamed so much as Adams, whose desire to put Knox above Hamilton and whose absence in Quincy caused embarrassment and delay. On the 25 th, McHenry wrote ${ }^{1}$ Washington asking him to select cavalry officers and to find out all he can concerning candidates for commissions from the South, and telling him that he is authorized to employ secretaries and draw pay for his own services. ${ }^{2}$ A detailed statement of ordnance, powder, \&c., is promised. Tents and field equipage will be ready for next year's eampaign and MeHenry "can give almost instant life and activity to the recruiting service," as soon as Adams will act, if clothes are in readiness.

On the 26th, Knox wrote Washington ${ }^{3}$ that he will not serve as a major general, but, if there be an invasion, he will gladly act as aide de camp. Three days later, Hamilton wrote ${ }^{4}$ Sedgwick that the generals should be called into service. The decision on this point rests with Adams. "McHenry, as you know, is loaded beyond his strength." On the same day, Adams wrote MeHenry, showing no signs of yielding: ${ }^{5}$ " $\mathrm{My}$ opinion is and always has been clear that, as the law now stands, the order of nomination, or of recording, has no weight or effect, but that officers appointed on the same day, in whatever order, have a right to rank according to antecedent services. I am willing to settle all decisively at present (and have no fear of the consequences) by dating the commissions, Knox on the 1st day, Pinckney on the second, and Hamilton on the third." Gen. Washington ${ }^{6}$ has acted with perfect honor and eonsistency. "The power and authority is in the President. I am willing to exert the authority at this moment and to be responsible for the

1 Sparks, xi, 542. McHenry to Washington, August 18, 1798. J. Adams, viii, 582, Adams wrote McHenry, asking if the cession of Castle Island had been accepted. Lodge, vii, 44, prints letter from Hamllton to McHenry concerning the drafts of surveys of New York Harbor.

2 On the 25 th, Hamilton wrote McHenry suggesting that it would be well to write oftener to Washington. Hamilton, vi, 354 .

3 . Sparks, xi, 538 .

4 Hamilton, vi, 534.

5 J. Adams, vili, 587 .

6 The sentence: "Nor has he ever intimated a desire of the kind," printed in Adams's Works, is not in the original letter. 
exercise of it. All difficulties will, in this way, be avoided. But if it is to be referred to Gen. Washington, or to mutual and amicable accommodation among the gentlemen themselves, I foresee it will come to me at last, after much altercation and exasperation of passions and $I$ shall then determine it exactly as I do now. Knox, Pinckney and Hamilton." Adams wrote, "I will not send either of McHenry's lettel's to Hamilton, as neither contains sentiments that I can approve." "There has been too much intrigue in this business with General Washington and me, ${ }^{1}$ if I shall ultimately be the dupe of it, I am much mistaken in myself.' Adams closed by expressing sympathy for McHenry's ill health and that of his family and stating that Mrs. Adams "has been at the point of death, but is now a little revived."

On August 30, we find the first of many letters which passed between Hamilton and McHenry as to details of management of the army. It shows, as nearly all the correspondence does, how much friction there was between the various branches of the service:

"Col. Stevens tells me he has exhausted the money you sent him in preliminary purchase of Timber \&c \& is in debt with embarrassment to pay \& likely to be compelled to dismiss workmen \&c

"Such a state of things is hurtful to the public service, discredits the Administration \& increases expense. It ought to be avoided if possible.

"Stevens says pains have been taken to excite doubts about him - \& he fears they may have some effect. In justice to him I think it proper to say that I have the most entire confidence in his political fidelity to the Government $\&$ that, as far as my opportunity of being acquainted with his character as a man of business goes, there is good ground of confidence in his pecuniary fidelity also.

"But the plain alternative is to displace or to trust. The necessary operations must not stagnate on account of uncertainty about the Agent."

Adams felt that he had settled the question of precedence and did not refer to it, while writing ${ }^{2}$ on September 3,

$1 \mathrm{C} . \mathrm{F}$. Adams, in a long note to this letter, says McHenry was concerned in the intrigue. The only proof he gives is that Hamilton was in Philadelphia on July 7 and sent a letter to Washington on the 8 th, which. C. F. Adams alleges to have been carried by McHenry. Sparks, xi, 533.

2 Adams, viil, 591 . 
of certain nominations and calling attention to the exposed condition of Georgia. But the cabinet were not satisfied. On the $3 d$, McHenry wrote his friend, Uriah Tracy, that he has been much occupied and distressed by the humor (not a very pleasant one) which the president has discovered since leaving Philadelphia. If Knox be appointed second in command, a "serious rupture, or at least a misunderstanding, with Washington would follow." "All hands have been at work to prevent so many evils befalling us, at a time when we stand in need of the union of our best talents, men, and means. I hope and think we shall be able to subdue this storm, although it has blown almost a hurricane." He asked Tracy whether he thinks W. S. Smith, Adams's son-in-law, should have a regiment, as he sends a certificate that he did not interfere in the election for governor of New York and thanks Tracy for a suggested list of officers for the Connecticut regiment.

Writing ${ }^{1}$ to Hamilton on the 10th, MeHenry states he does not blame his friend's determination, expressed in a letter written two days before, not to serve as third major general and that all the cabinet but the attorney general will make respectful representation to Adams on the matter. ${ }^{2}$

Of matters not military we learn but little from McHenry's correspondence this summer. There is extant a letter from Lafayette:

\section{"Witmold - Holstein August the 30th 1798 "My dear McHenry \\ "When I Had last the pleasure to write to you, I was} far from thinking I should, at this period of the Year Be still detained in Europe. The Health of my wife, the primary cause of those delays, Has Been continually so Bad, it $\mathrm{Had}$ in the Spring taken a so dangerous turn, that untill now, there Has not Been for me a Moral possibility to embark even now that she is so far Recovered as to Have just Been able to Undertake an indispensable journey, for a few months, to France, I find that Besides tender motives not to hasten to put Between us the Atlantic, she shall soon Be ready to look with me. My presence on this Continent is essential to forward Arrangements respecting Her property which she is about to make. I need not telling you, my dear friend,

1 Hamilton, vi, 355; Lodge, x, 320.

2 Hamilton, vi, 356 . 
that Had I the smallest Hope to be useful in public Concerns, no personal Considerations, nor even the Dearer ones to my Heart eould one instant detain me - may I, in my inactive But not uneoncerned retirement, Be soon Blessed with the intelligence, now earnestly expeeted, of a mutual disposition to Reestablish Harmony Between two Nations, in the fate of whom my whole Soul is so deeply interested.

"My prineiples and sentiments IIave long Been known to you - the Appeal to liberty in the old world Has Reminded you of our Conversations in the New one - in my doetrine of opposition to long despotism, of obedienee in a free Constitution to National laws, you could Antieipate the pain which in the sereral eireumstances I Have Had to Act - from your knowledge of My Republiean Heart you are sensible that my objections to the present state of France are not owing to Her form of Government But to Her want of freedom - while that Government who resened me out of prison, and with whose Agents Abroad I Have every personal reason to be satisfied are nevertheless far from wishing to faeilitate my return or discouraging the nonsense now and then published against me, I am not myself in Hurry to witness measures which I disaprouve, nor am I uncertain of the National opinion in my Behalf. But such as I am situated, I eannot Be prejudiced $\mathrm{By}$ any other influenee than my attachement to the two Countries, When I now am persuaded that on the part of the directory there are actual and sincere dispositions to make up this unhappy Quarell. IIitherto I Have not, in my expressed Hopes, ventured so far. But now, I repeat it, I Have reasons to think that they are in earnest, and to flatter myself that either direetly, or through the Batavian Mediation which I know is to Be offered to you, matters may Be properly and Amieably adjusted.

"Thus far, altho' the Amerieans Have Been Materially injured, the Moral Advantages remain theirs - it appears to me the Freneh Government Had eaught the example not long Ago Given By that of Britain - this system of oppression on the part of the late plunderers and ineendiaries of the Country, the late prison-ship-managers, the eonstant ennemies to American independance, unjustifiable as it was, Had some thing less shocking than an imitation of such an unfair poliey $\mathrm{By}$ the early defenders, the first and essential friends of the United States - no doubt their Rulers were led into it on a supposition that it Had Been the means to Bring about your 
English treaty - thank God, instead of submission they Have met with Noble, Spirited Resistance - the dignity of America Has Been asserted and a Reconciliation on proper terms cannot But leave Her with an increase of national Respectability and political consequence - that situation of Hers, in which no man can more Heartily exult than I do, would, in my opinion, Be lost, if by a Rejection of Honourable Means to restore Harmony Between two Republics, By a precipitation of measures unnecessary for self defence, or an eagerness to $\mathrm{Be}$ too far entangled with other European powers You did Countenance the Accusation of Having seised on the faults of the Directory to engage elsewhere that independance which you are now so justly Applauded to defend.

"The British Court I Dislike and Mistrust - not for their intrigues against me, nor for their Vindictive share in $m y$ captivity - it is a matter of course, nor shall they ever forgive American names formerly doomed to proseription. But I Have Heard the boasts and Hopes of those men with respect to America, I Have known their Machiavelism in Holland, I Have witnessed their wicked exertions to vitiate the Revolution of France, and while I think England Has many of the more enlightened and virtuous friends of true liberty to Boast of, while I glory in my obligations to Her fine characters, I am convinced that in Her present Government no confidence is to Be Had - on the other Hand, altho' my love to My Native Country is unalterable, the arbitrary measures of Her Government at Home cannot agree with me, and notwithstanding I ever expected the doctrine of the rights of men to Be extended from France throughout the ancient world as from the United States to the rest of America I now Have a due respect for the mutual independance of enfranchised nations - nay, there Have Been in certain Revolutionary circumstances compliments from the United States which I would not Have paid to the then Governors of France - and while I don't deny that the idea of a war Between those two dear countries cuts me to the Heart, you, my confidential friend, Have known that in every transaction Great, or trifling, no man Has Been more than me tenacious of the interest and Honour of the American Republics, nor more attached to the Happy System of Federal Union. May I not, therefore, However Averse I am to the Actual Government of Britain, However Bound to My Native Country By everlasting ties of duty and Affection, However anxious to See the true American principles of liberty, Equality, and Re- 
publicanism fairly and Honestly spred throughout the world, may I not, says I, have my own opinion of the Dangers arising from your Connection with England against France, of the Advantages to be found in an Honourable Reconciliation, and of the dispositions of the French directory to make for it a sincere and proper trial.

"Measures, I Hear, Have Been taken with Respect to the piracies which, I really Believe, Have far exceeded the intentions of Government. Letters from Paris tell me that the Nentral Navigation shall soon Be on Better footing, was I not fearful to lose the opportunity to write to you, I would Have waited for answers I daily expect. I just now Have Hinted that Besides direct Commmications the Batavian Common Wealth is ready to interfere. Mr. Murray Has acquainted you with the changes operated in that Country - to judge the sentiments of Her actual Governors, one private circumstance may help you - on my emersion from the Olmuce Bastille the Batavians intended to invite me to their Country - the january Revolution. Long foreseen put an end to their plan now that the jacobines are out, the new Government Has taken up the same idea - my going there, as in their kindness for me, I understand it will be Agreeable to them, Appears to $\mathrm{Be}$ Adrantageous in many respects, particularly as it is much nearer to my family. Yet I am not Hitherto determined.

"Notwithstanding the efforts and threats of England and Russia, the Kings of Danemark and Sweden Have refused to part from their system of neutrality - so Has the king of Prussia who is satisfied with protecting the North of Germany - at Vienna the two Hostile Courts are aided by female Neapolitan influence, and it is probable an Austrian War may Be Renewed, the result of which will be the Ruin of the Royal father in law and Heavy losses to the imperial young man. Bonaparte, after the taking of Malcha, Has arrived safely and even uninterrupted at Alexandria - that expedition is Big with Consequences.

"'The Name and Merits of Vaublanc are not unknown to you. He was in 92 a member of the legislative assembly, where His virtues, eloquence, and Courage Commanded universal admiration, and exposed Him to great dangers. His life, Highly valuable to His Country and His friends, Has Been Happily preserved to make Him Again shine in the Council of the Cinq-Cent, and Among the most undeserving victims of the fructidorian proscription, there is not a more illustrions 
and upright statesman - this excellent patriot is now wandering out of France to which He shall soon or late Be gloriously Restored. His wife and daughter, lately married to Gnl Pinkney's Nephew, are gone to America and intend to land some where in Virginia. I beg you, my dear McHenry, I who require all other friends to pay them the Attentions that are due to their personal merits, and to the Husband and father with whom they are Blest - to Him I am under great obligations. He Has in 92 stood my defender. He Has Risked His life in my Cause. Gratitude and Affection Bind me forever to Him. I depend on you to let the two ladies experience that my American friends feel with me on the interesting occasion.

"Here is an offer of a quite different Nature - a French emigrant of the Aristocratic party Having in a letter to me, on my Release from the Coalitionary prisons, exposed, the state of misery to which $\mathrm{He}$ is Reduced, and Reminded me of His Services in the American Army, I Regreted not to Have it in my power to present Him with pecuniary assistance - to the expression of that sentiment it was Natural to add an offer to Carry His petition to America - the inclosed one He sent to me. But for fear of differing too much, I forward it to you who Best know what can be done - the part incombent on me, I felt the readier to Act as I Spurn the idea that His Having in Europe Belonged to a party opposed to us Could make me forgetful of His services to our Canse Under American Colours.

"There goes with this letter one to Gnl. Washington. I Beg you to present My Respects to the president, to the Vice president, and to Remember me to all other friends about you. I Can't know whether or not the expressions of $\mathrm{My}$ dutiful patriotic Attachement, of My profound and lively Gratitude Have Ever Reached the United States - if not, I Hope it will not Be imputed to Any deficiency on My part. But I beg you to let me know what Has Been received from me. I Have written to You UnAnswered letters. My Son George requests me to Remember Him to You. I join with Him in affectionate Respects to Your Lady and family - adieu, My dear McHenry, You know How friendly I am

$$
\text { "Yours }
$$

"Pay my Best Compliments to my Generous friends Bolman and Huger - no answer from this excellent and Heroic 
Huger Has yet Reached me. How Happy I would Be to Hear from Him!;

From Baltimore James Ash wrote on August 24, urging that the Federalists be not too extreme in proscribing members of the opposition:

“The judicious determination by Government, to put ourselves in a defensive posture, preparatory for any violence which France may offer, has been unanimously obeyed by the people. There are however, some characters here, I am assured intend well towards Government, who have acted very indiscreet and unwisely. They seemed to imagine, that nothing was left to be done, but to exterminate every one who had been of the Democratic side. It is true many are to be found in the Senate and House of Representatives, who no longer deserve to possess the confidence of the people; and even this ought to be taken restrictively. For if any persons of this description, from weakness of understanding, have been only tools to artful and designing men, and a hope remains of political reformation, I can see no reason why they should be condemned with the guilty. But leaving alone, those who served in political capacities; how must the mind and heart revolt, at the thought of the public wickedness, of these characters, being visited on all their dupes and followers; uninformed and misguided men amongst the people. The doctrine of extermination would be a delightful way to introduce a civil war, while, on the other hand, changing the deluded people by degrees from past error, as different dispositions can bear it, will nerve our union, Country, and Government stronger than at any former period. A remarkable instance of this kind happened lately. In a publication written by Mr. Martin, signed a 'Native American' one Mr. Pechin, a printer, here was Completely denounced, not only as a citizen but a printer. Now if Mr. Pechin had imprudently done wrong, would it not have been the Wiser way to produce gradual reform in preference to extermination? It appeared to me a miniature of the barbarous cruelties practised by the French. It excited much warmth amongst about a thousand who were Pechin's Subscribers. The publication of the inclosed observation, addressed to Mr. Martin, I have reason to believe had a good effect. This made Pechin my friend, and if he were ever hostile to Government, he is now as warmly a friend. If extermination 
be Mr. Martins policy, I shall never agree with him, because it is much better to reform, than to destroy. The one is a leading feature in genuine christianity, and good Government, the other the demon of anarchy and confusion. Before this newspaper acquaintance I never exchanged Six words with Pechin. He now Consults me on every movement of any importance. Yesterday he gave me a Manuscript pamplet to read, and requested my opinion; at this time he had not read it himself. It had a disorganizing tendency, tranquilizing the public temper as it respects us with France, and irritable in every other respect. I gave him an opinion in writing that no one but a Frenchman ought to publish such a Book, or some one regardless of his Country's good. He went away well satisfied with the impression and advice.

"I cannot either entirely agree, with some Gentlemen, in their views of our next election. Mr. Winchester has offered under their support; he comes forward and declares his intention is to support the administration. Let us eompare his professions with his actions, and trace the corresponding analogy. In the Day of Democratic Societies, Mr. Winchester was not only a member, but a violent one; and I have been lately informed from good authority, that he offered some resolutions at a meeting, which went to the subversion of all government. And when Electors were last chosen to elect a President, he roted and declared himself for Mr. Jefferson, and now he is to be the Supporter of the administration. 'Let no such man be trusted.' The people want a man of judgment to form opinion, and with firmness to give that opinion uniform Support. The whimsical and capricious character, is little to be relied on. For these reasons I think him an improper choice.

"I hope Gallatin may be turned out. I have written to several of my Correspondents, in that part of the Country, on the Subject. His Seat as it respects virtue, will be well supplied by Nevill, who is a man of honor, and worth.

"From an opinion, that every one should be ready in some Capacity, or other to serve his Country, at a period so critical, I made a tender of my services to Gen: Washington, with a condition that I should have it in my power to attend the General Court twice a year, unless called into service."

A fierce congressional campaign was made during the summer of 1798 on the Eastern Shore against Hindman, who wrote from Bellfield in Talbot eounty, on August 29 : 
"I was very sorry to see by the Papers Some Tine ago, tlat You were !:d up with a Fever, I hope You are now in perfect Health. Have You appointed the Officers to the Army? Col. IIindman perseveres in his military Zeal, \& would accept of a Regiment in the provisional Army, but Nothing inferior. I wrote to You Some Time ago in Favor of Doct: Wm. Nicholson, who wish'd a Captaincy in the P. Army, \& if not to be had would accept a Lieutenancy : He is a Sensible Man \& of great Intrepidity, \& what exalts Him in my Estimation is his differing from his Relations in Politics, $\mathrm{He}$ has always advocated my Elections, \& is now among my most active Friends \& can do much; He \& his Brother Jo: are So warmly opposed, that I wish it may not produce disagreeable Consequence. his obtaining Captain's Commission would aid the Federal Cause here very much, \& I must confess I have his Success much at Heart.

"The cunning Jacobins discovered, that the People are generally incensed against the French, are now the Foremost in abusing Them, \& affect much Wrath at being thought attach'd to that Nation, I hope this Deception will not avail Them. I have been laid up for some Time with a sore Leg. it is now nearly well. My friends are getting very warm \& active, which was highly necessary to counteract the furious Exertions \& infamous Lies on the other Side, Report says Seney is losing Ground in Consequence of correct Information respecting many Misrepresentations against $\mathrm{Me}$; \& a Cut given by a Mr: Clark in which He says that Mr: Seney avowed the Sentiment that Mr: Jefferson \& Mr: Madison would have done better at the Helm of Affairs than Washington \& Adams, I hear Seney denies it \& wants to Strike out Washington, conscious that any Thing said against Washington would damn Him with the People, it has just transpired, \& Puzzles Them much. I flatter Myself it will do great Good. I hear Seney has got a Cut from an Associate Justice, a poor Creature of his, endeavouring to prove a Negative; what Cheats \& Impostors these Jacobins are, From Them, good Lord, For ever deliver us. Many Betts are laid on the Issue of the Election, a curious One of 3000 Dollars to 130 , that I have not a Majority in every County ; Some of my Friends are Sanguine enough to think I Shall. I will not venture to predict the Issue, Things look more favourably than They did, \& probably will increase.

"I have just received a Letter from $\mathrm{Mr}$ : Campbell \&

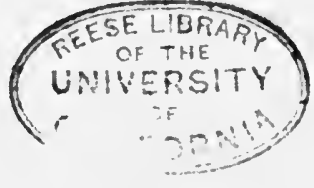


Doet: Harris, They both Speak doubtfully of Mr: Winchester's Election, \& I colleet 'They are of Opinion that Genl: Smith will be rechosen; if this Should be the Case I shall ascribe it to the Want of Exertion on the Federalists, whose purses ought to be open on the Occasion. mueh."

"The Yellow Fever must have deranged You all very

So bitter was the eampaign against Hindman that, on September 16, 1798, J. Sitgreaves ${ }^{1}$ writes McHenry from Easton, Pa., that Edward Tilghman has written him that great efforts are made to defeat Hindman. Consequently Sitgreaves has written Richard Tilghman, of Queen Anne's and suggests that MeHenry also write as to Hindman's "Estimation with our best public men, in and out Congress, You ean bear honorable Testimony; and you ean assert with equal Confidence that $\mathrm{He}$ has been Confidentially eonsulted on all the Operations of the federal Interest in the House of Representatives.'

When election eame, Hindman ${ }^{2}$ and three other Federalists were chosen from Maryland with four Jeffersonian Republicans.

MeHenry was now in constant correspondenee with Washington. On September 3, the latter wrote, ${ }^{3}$ aeknowledging lists of applieants, complaining of illness, and asking for a list of eaptains and subalterns in the revolutionary army to help in seleeting offieers from the "wide expanee" of the southern district. He wished for Pinekney's presence, suggested that it may be well to raise all of the cavalry in the southern states, and urged that our magazines be "well furnished with all necessary artieles of foreign dependence: the proeuring of which, if the country should be invaded, will not only be rendered precarious, but they must eome mueh higher." The keepers of powder magazines should be directed to be attentive to turning and proving powder, that there may not "appear to be a store," when there is none "fit for use." He urged rigid reeruiting rules. "It is much better to have a few good soldiers, than a multitude of vagrant and

\footnotetext{
1798 .

1 A prominent lawyer who was member of congress from 1794 to

2 Letters from the McHenry papers on Marvland politics in $179 \mathrm{~s}$ are found in So. Hist. Ass. Pubs., x, 101 (March, 1906), and on Maryland politics in 1799 in So. Hist. Ass. Pubs., x, 150 (May, 1906).

3 Ford, xiv, 79 ; Sparks, xi, 292.
} 
indifferent ones, who, besides other imperfections, may desert their colors in critical moments." At the end, he writes: ${ }^{1}$ "If any change should take place in settling the relative rank of the Major Generals, I shall hope and expect to be informed of it." On the 7th, MeHenry told him of Adams's determination to put Knox first and, as Washington had been ill, he added, "It will be proper you should intermit, for some time, your attention to business and avoid the early morning air, as well as much exposure to the hot sun."' 2 On the same day, Washington wrote Pickering that possibly he might have put Knox before Pinckney, if he could have gotten to Philadelphia in July. The president ought to ponder well before he consents to a change in the arrangement Washington suggested. Washington answered ${ }^{3}$ McHenry's letter on the 14th, regretting the delay in recruiting and appointing officers. For this delay, he blamed the executive, especially as that "spirit and enthusiasm which were inspired by the Dispatches from our Envoys, that resentment which was roused by the treatment of our Commissioners by the Directory," are "evaporating fast" and it is now much harder to secure suitable men. Two months have already been wasted. Washington asked for longer letters from McHenry and fuller information on certain points. His sacrifices entitle him to this and "from McHenry, as a friend and coadjutor, I certainly, shall look for it." Needed foreign articles should be imported at once. If war ensues, they will cost mole and "the obtaining them at all will be attended with hazard and delay." He objects to certain appointments, discusses the question of small arms and so ends this "free and friendly letter." On the 10th and 12th, MeHenry wrote him of the proposed address to the president and, on the receipt of the former letter, Washington said" that the news "filled his mind with much disquietude and embarrassment," but he cannot make any move at this time, "without betraying your confidential communication." He perceived "pretty clearly, however, that the matter is or very soon will be brought to the alternative of submitting to the President's forgetfulness of what $I$ considered a compact or condition of acceptance of the appointment, with which he was pleased to honor me, or to return him my commission." He, therefore, asks to be furnished with a copy

1 Ford, xiv, $\$ 7$.

3 Ford, xiv, \&7; Sparks, xi, 300 .

4 Ford, xiv, 91 ; Sparks, $x i, 302$ 
of McHenry's letter to Adams written from Mount Vernon and of the instructions from Adams, under which McHenry then acted.

On the 19th, McHenry conveyed to Washington an account of the change of plan and the decision of the cabinet to have Wolcott, who, having been absent in July, would not be charged with intrigue, answer Adams's letters of August 14 and 29, which Wolcott did on September 17, urging ${ }^{1}$ that Hamilton be placed first. McHenry continued: ${ }^{2}$ " Conceiving the whole of this business of a very serious nature and intimately connected with the public interest, I communicated the letters from the President to me as they were received to Mr. Wolcott, Mr. Pickering and Mr. Stoddert, as also my answers to him. The services of Gen. Hamilton being considered too important and consequential to be easily parted with, it was proposed that they should join in a respectful letter to the President. After, however, a good deal of deliberation, the idea of a joint address was relinquished for a representation from Mr. Wolcott alone, who did not appear to be implicated in his suspicions of intrigue. This has been accordingly drawn up and forwarded. It contains the grounds upon which you were induced to expect your arrangement would be adopted and reasons resulting from the relative talents of the generals and public opinion." On the same day, McHenry gave Washington a detailed account of Adams's conduct. ${ }^{3}$

Of Adams's letter of August 29, McHenry wrote ${ }^{4}$ that part of the letter, "being personal and unmerited, not a little wounded my feelings." On September 6 , he wrote Adains, asking why he was accused of intrigue and said: ${ }^{5}$ "It will sir, be a relief to me to be assured of your opinion in this particular, because I flatter myself I can convince you that, abhorring indirect practices, I never even contemplated any, or shall you not be convinced, I can immediately retire from a situation which demands perfect and mutual confidence between the President and the person filling it."

Answer to this letter was sent by Adams on the 13th. Adams still directed McHenry to issue the commissions on successive days and to call Hamilton and Knox into service. ${ }^{6}$

1 Gibbs, ii, 93.

2 Gibbs, ii, 93 ; Sparks, xi, 547.

3 Sparks, $x i, 542$.

4 Sparks, xi, 542.

5 Gibbs, ii, 92. Brown's McHenry, 22-34, defends him from the charge of intrigue.

6 J. Adams, viii, 593. 
"Your conduct throughout the whole has been candid. I have suspected, however, that extraordinary pains were taken with you to impress upon your mind that the public opinion and the unanimous wish of the Federalists was that General Hamilton might be first and even Commander-in-chief, that you might express this opinion to General Washington more forcibly than I should have done and that this determined him to make the arrangement as he did. If this suspicion was well founded I doubt not you made the representation with integrity.

"The question being now settled, the responsibility for which I take upon myself, I have no hard thoughts concerning your conduct in this business and I hope you will make your mind easy concerning it."

In his letter of September 19 to Washington, McHenry defended himself against the accusation of delay. Adams had as yet answered only two of the proposals McHenry made on August 4. Arms have already been ordered. Wolcott thinks we should fill our magazines first and raise the army last and so objects to the purchase of elothes. MeHenry thinks both should be done at once. "I should have no confidence in troops suddenly assembled and cannot think it good policy to depend upon a militia to meet the first operations of an enemy inured to war and having no better support than such raw troops." If an invasion come from the south, no eastern militia could be used, as eastern regulars could and so, if we wait, we may be left, as to the south, to its own militia and half the country may be overrun and piundered, before anything like a regular force can be collected. Wolcott is alarmed about finances and prefers to trust to chances, rather than to raise and pay an army, which may never be needed. ' "These things, my dear and revered sir, are mentioned to satisfy your solemn and affecting inquiries. You will now see (although I may not have apprised you of all $\mathrm{my}$ proceedings) the reasons, in the very nature of the transactions just detailed, which have prevented me from making to you certain communications, until they became unavoidable and necessary, as well for your information as my justification. You will also be sensible that I have not been idle, nor inattentive to the importance of the objects which interest our country and have drawn you into your present situation."

On the 21st, McHenry wrote again that he had made new

1 Washington in his reply agreed with McHenry's views. 
representations to Adams about Hamilton and Knox, on receiving Washington's letter of the 16th. Adams had shown great obstinacy, but McHenry still counted on his acting wisely and yielding. He cannot resist the display of facts which have been laid before him. Four days later, Washington wrote ${ }^{1}$ Adams, that he "explicitly declared in July," he accepted, provided "That the general officers and general staff of the army should not be appointed without my concurrence." Neither McHenry nor Washington had any doubt that this was the object of the former's mission and lest there should be doubt, Washington asked McHenry to declare this in his official letter to Adams, as Washington's letter might be made public; and, therefore, should not be encumbered with stipulations. Washington asked McHenry to take back the commission till Adams's reply. McHenry said that would not be necessary, for silence would be acquiescence and, if Adams did not agree, he would say so. Believing this and not wishing to imply distrust of Adams's intentions, Washington assented. Now Adams changes the order of the major generals and appoints brigadiers without Washington's knowledge. Washington's arrangement of major generals was designed. He had heard that the Federalists wished Hamilton second and this impression had been confirmed, in most unequivocal manner, by some respectable members of congress. If Adams did not like the order, why did he not alter it before submission to congress? Hamilton's place would be hard to fill. Why does not Adams begin recruiting? The rough draft of the letter, covering the foregoing points, Washington sent ${ }^{2}$ McHenry, on the next day, in strict confidence, as even the rumor of a breach between him and the president would be attended with unpleasant consequences. If Adams will not yield, the people must decide between him and Washington. On the 30 th, Washington wrote ${ }^{3}$ again, warning McHenry against giving commissions to the brawlers against government, "who would endeavor to divide and contaminate the army by artful and seditious discourses and, perhaps, at a critical moment, bring on confusion." There are enough Federalists to fill the places and "you could as soon scrub the blackamoor white, as to change the principles of a profest Democrat," who "will leave nothing unattempted to over-

\footnotetext{
1 Sparks, xi, 304 ; Foŕd, xiv, 92.

2 Sparks $x i, 315$.

3 Ford, xiv, 104 ; Sparks, xi, 317.
} 
throw the government of this country." On the same day, Adams sent this curt note from Quincy :

"Sir

“Quincy September 30th. 1798

"Inclosed are the Commissions for the three Generals Signed and all dated on the Same Day. I am Sir

"your most obedient \&ce "John ADaMs."

Before this letter eame, MeHenry wrote ${ }^{1}$ Washington that, though he has received no word from Adams, he expects the affair to terminate happily. He asked for a list of officers for the southern regiments, and stated that he had advertised for clothes, but that Wolcott still opposed paying for subsistence. There is news of a new coalition in Europe against France. Our conduct seems to have inspired the peoples with fresh hopes and courage.

About this time there must have arrived in Philadelphia the letters Murray wrote from the Hague on August 20 and 30, stating that his secretary, Dandridge, wished to return to America and enter the army and asking that MeHenry's nephew, John, might be sent in his place. In a later letter, he repeats the request thus: "I ain at a great loss for a rapid French reader and a writer of that insolent language, that I fear is to clothe every right (public) in Europe in its own idiom, genius, and dress - curse it, I wish no body spoke French. It is not half so vulgar not to speak Dutch - but I do come on." The request was granted and, on April 28, 1799, Murray wrote MeHenry that John MeHenry arrived at Hamburg on 13th instant, after a passage of seventy-three days. " "We expect him with impatience. He has left Hamburgh and is well.",

In his letter of August 30, Murray said: "This letter is on a subject doubly interesting to me, as it relates to the determination of $\mathrm{Mr}$ Dandridge to leave me, \& to the acquisition of another Secretary.

"Ever since we heard of the martial movements at home, Dandridge has been desirous of going to America. He has

1 On October 1, Washington wrote McHenry complaining of Adams's delay. Sparks, xi, 318.

2 January 7, 1799, Pickering wrote the United States at Hamburg to pay John McHenry $\$ 200$ travelling expenses. 
at last asked my consent. I have given it on his repeated solicitations - for from the manner in which we have lived, he would do nothing to disoblige me in this way. He is a most excellent \& estimable man \& has most fully equalled the short but good character which our illustrious Washington gave me of him. I have an affectionate esteem for him \& a brotherly solicitude for his happiness, prosperity \& advancement. He looks to the military eareer; \& though without the vanity of ambition, he has its better features - a wish to be useful \& an ardent desire to support the Independence \& glory of his country. Dandridge has no pretence \& no affec. tation of brilliance - but he has, I undertake to say, a sound \& strong understanding eultivated beyond what his simplicity \& modesty of manners would lead a stranger at first to attribute to him - of this accuracy of judgement I have often availed my self. He is completely a man for high \& delicate confidence, in fact I set a great value indeed upon him. You know him, but not as well as I have had it in my power to do. I do not mention him thus particularly to reconmend him, as in a mere letter of introduction, but to do him justice - \& to prove, as far as I can, his claim to a handsome \& honourable appointment in the army.

"I then present him to you as a candidate for a commission. I hope \& believe that you will give one suitable to him as a man of uncommon worth - as a true American, well enlightened on the subject matter of our dispute with France and as the late Secretary of the late President of the United States. I know that you are acquainted with my friend Dandridge - but I could not let him apply himself, as I feel interested in his career \& future lot \& wish to give him the proof of my esteem. He has been our inmate constantly \& Mrs. M. \& myself part from him with sincere regret. He has also been very happy with us. So much for my friend, whom I part with \& whom I commit to your kind protection.

"Now for the acquisition of another to fill his place. I have long thought, that should anything deprive me of Dandridge, that I would ask you to give me Mr John McHenry, your very promising nephew \& my correspondent! as I mentioned this to you before I left America, I hope that you have thought over my proposal. I sincerely wish that nothing may oppose itself to this object. I believe he esteems me - \& you know that he has always stood high in my regard. He shall live with us entirely as one of my family \& I undertake to say 
that, if he can be happy out of your paternal family, he will be so with us. Both Mrs. M. \& I like our young friend; and his relation to you and Mrs. MeHenry would endear us all to each other \& insure harmony \& friendship. He will have to find his own washing \& mending and that is all. That is arranged here with ease \& perfect snugness - \& the salary is 301. 10 Stirlg a year. He can also pursue any course of read. ing that your judgement may dictate. He may learn Italian,. Spanish, or German. Stay either as long as I do, or follow your directions \& entirely your views, without being pledged to any time. The business is not laborious to so young \& hearty a man viz. Copying, as to the article of Dress and clothes - it is not serious. His Philad. clothes are in a better style than is common here. Linnen cheaper \& the making of it cheaper. At his time of life, a tour of this sort will be both pleasant \&, I should hope, advantageous - \& may be so shaped, by your advice, as not to disturb any future plans wh. you may have in view for him. In fact, I wish to have him with me \& see no objections strong enough to oppose my plan. He had best come direct to Hamburg, or Bremen, or Holland, \& on his landing speak to the American consul, giving his name \& I will take care to write to those at these points to. receive him \& put him on the way to the Hague, where he will be kindly welcomed as your nephew \& my friend.

"Should no ship offer to these places - He had best come through England. He can easily get a passage across to the Tees or the Maas to Rotterdam \& then he is with me. I once, in 1784, left London at 4 o'clock in the morning, dined at Harich, and next day dined at the Hague. A winter passage, say in Nov. or December is not much to-England. I came in those months in 1783-4. He can be with me by Xmas or in January easily. However, I shall wait for him.

"Dandridge wishes a commission in the Infantry and, if he had experience, I would say that he has character enough to be at the head of a Regiment. I forgot to mention this in the first part of $\mathrm{my}$ application for him.

"Mrs. Murray sends her love to Mrs. McHenry, pray make my kindest compliments to her \& give the enclosed (if you please) to $\mathrm{Mr}$ John McHenry.

"The Three ministers viz Prince Repnin for Russia,. Count Cobenzl for Vienna, \& Lord Elgin for London, who. went not long since to Berlin to produce a new coalition have. left Berlin in utter disappointment - Ld. E. gone home - Ct. 
C. gone to petersburg \& P. Repnin gone to Vienna. No coalition, general. If the war begins again, there will be one between Austria \& Russia.

"The energy \& great respectability of the United States have produced a State of things in the Directory at Paris from which we may see the rights of Neutral nations, in general, respected. It would dilate every artery in you to see the glory which is spreading over the United States at this moment in the eyes of Europe. She comes on the stage at an instant highly propitious to eclat. When the heart of the continent had sunk - She plants her foot with firmness France recoils - and every body is revived - \& in triumph - for France does recoil - \& I believe reflection will but confirm - what astonishment first produced, \& that she will recoil further, if we will preserve a steady aspect \& a vigorous preparation. God bless my country, she indeed acts to a charm. I will again write, in June I wrote. I am dear friend affectionly

"\& truly always yrs"

Murray wrote thus two days later: "Be firm and persevering, my dear minister, and France will recoil, we shall triumph and once more establish the law of nations."

On October 5, the letter from Adams, of September 30, reached Philadelphia and McHenry copied and sent it to Hamilton, saying, "the sun begins to shine ${ }^{* * *}$ "This is a regal letter and, at the same time, a loyal proceeding. Hasten the military regulations. I shall, I expect, soon call upon you." To this letter Hamilton thus replied:

"New York October 9. 1798

"I thank you, My Dear Sir, for the prompt communication of the intelligence contained in your letter by yesterday's Post.

"As to the regulations (if as I suppose you mean) those for the tacties \& discipline of the army - I must answer that hitherto I have done nothing more towards it than some preliminary reading \& reflection. The undetermined situation \& the necessity of a close attention to my law business (which is in such a state I could neither abandon nor diminish) has prevented my doing more in respect to the matter in question. It will, henceforth, engage my particular attention; but it ought not to be precipitated. My plan will suppose a differ- 
ent organization of the troops \& some previous legislative measures to precede its execution. Besides the present sistem must be cssentially the base of another \& there is no urgency for a change. The course of the Winter will fulfill every useful idea — \& allow time to digest well additions or innovations. To organize \& to raise the army are the immediate desiderata.

"I shall be ready to attend your call

"Yrs affectly

"A Hamilton

"P S Young Rutledge, late Secy of General Pinckney, is himself desirons of going into the army but he cannot, in propriety, decide upon an application without the previous consent of his father whose permission he has asked. In the mean time, I would suggest for your consideration the expediency of keeping open for him a Captaincy of Infantry. His connections \& qualifications give him pretension to look to this. Yon will understand that he cannot now ask \& may not perhaps be allowed to accept: so that whatever is done, must be provisory

Ade A H',

On October 10, Wolcott wrote ${ }^{1}$ Hamilton, "You are first Major General." "I supposed MeHenry had transmitted the commissions but find, he still hesitates. I will, however, prevail on him to do his duty, if I can."

Adams wrote to Washington ${ }^{2}$ on October 9. informing him what he had done and stating that the difficulties between the major generals will be submitted to the general, as commander-in-chief, and Adams will ratify his action, though he has no doubt that the president has authority to determine the rank of officers. Adams thus yielded his contention. Before the vielding was known, Washington wrote MeHenry, ${ }^{3}$ on October 10, asking what would be the effect of his resignation, if Adams disregarded the order of rank of the generals and the conditions upon which Washington accepted his post. Conld Washington "with propriety and a due respect for my own character" help from resigning. Washington wished on this point to know Pickering's opinion and those of "the gentlemen who act with you." Does Pickering like Hamilton, Washington inquired, because of the "utility of the measure,"

1 Hamilton, vi, 365.

2 Sparks, xi, 548. J. Adams, vil, 600. If North refuses the adjutant generalship, Adams will nominate Dayton, unless Washington prefer another.

3 Ford, xiv, 105. 
or because he dislikes Knox? Would the New England states be disgusted, if Hamilton precede Knox in rank?

On October 15, Washington wrote ${ }^{1}$ again, with reference to the appointment of officers in the engineers and in the southern regiments, and stated that, in his view, officers should be appointed: First, from officers in the revolutionary army, who are in the prime of life; and then from "young gentlemen of good families, liberal educations, and high sense of honor," but, that care should be taken not to appoint "any, who are known enemies to their own government, for they will, as certainly attempt to create disturbances in the military, as they have done in the civil administration of their country." MeHenry submitted his correspondence with Knox to the cabinet $^{2}$ on October 13 and asked whether they considered that Adams be held to acquiesce in the settlement of relative rank, on the prineiple of and agreeably to the order of nomination and confirmation; whether he should consult Adams further, or send the generals their commissions directly; and whether he should send Adams a copy of their reply to his questions.

Pickering, Wolcott, and Stoddert, on the same day, ${ }^{3}$ signed a reply stating that the only inference they can draw is that Adams eonsents to the arrangement proposed by Washington and followed in nomination and confirmation, and therefore McHenry should send the commissions, directly, and it would not be "respectful to the President to address him again on a subject, which appears to have been attended with difficulties in his mind and the discussion of which can pro-

1 Sparks, xi, 322. Sparks, $x i, 549$, is a postscript to this letter. The beginning of the letter and another unprinted postscript follow:

"Dear Sir, "Mount Vernon 15th Oct. 1798.

"Your letter of the $2 \mathrm{~d}$. and those of the $5 \mathrm{th}$. instant came duly to hand.

"'Those of the latter date were received late in the evening preceding my visit to the Federal City, when I was detained several days on business; and is the cause of their remaining unacknowledged so long. "P. S.

"In treating on the subjects of Regimental officers for the augmentations, Colo. William Smith of New York again occurs. I know not on what precise ground the nomination of him was rejected by the Senate, and therefore to advise bringing him forward again might be improper, nor should I incline to do it, if there was just cause to impeach elther his integrity or his attachment to the measures of Government. But I have always viewed Colo. Smith in the light of an Officer possessing military talents, and conceive, if he would accept of it that the Command of our Regiments about to be raised in the Middle District of the United States could not be better bestowed.

On Col. W. S. Smith see an article by M. D. Raymond in Mag. Am. Hist., xxil, 74 .

2 Gibbs, ii, 101.

3 Gibbs, ii, 102 
duce no public advantage. We also think that no communication of our sentiments will be necessary, unless the Secretary of War shall discover, hereafter, that we have mistaken the President's intentions, in which case it will be proper that we should share in the censure." Guided by this opinion, McHenry sent the commissions and wrote this information on the 16th to Washington, 1 telling him of the course of events and that he had written Hamilton and Knox, calling them into service. Washington is requested to come to Philadelphia, as soon as possible and at any rate, before November 10, at which time McHenry hoped both Adams and Washington mav be together at Trenton, where the government is still carried on. This official letter was enclosed in a personal one, which is as follows:

"You will see by the enclosed the step I have taken, and the information and aid which I expect to derive from the Major Generals, in case it is approved, and also the desire $I$ have to draw you for a short time to Philadelphia. I know not how all this is to end, and feel perfectly tired of the uncertainty in which so many important measures are kept fettered and involved.

"I hope you will approve of the exposition I have given of my views, and the propriety of my fortifying or correcting my own opinions by those of the Generals. I have informed Hamilton of the points upon which I shall look for his assistance that he may come prepared.

"I am extremely anxious to know the result of your letter to the President.

\section{"Yours ever \& affectionately"}

Hamilton answered McHenry in two letters written from New York on the 19th. In one he expressed his satisfaction at the relative rank given him and promised to come, ${ }^{2}$ but did not expect to arrive at Trenton before November $10,{ }^{3}$ as

1 Ford, xiv, 115.

2 Hamilton, v, 141 ; Lodge, vi, 485.

3 Lodge's Hamilton, vi, 486. "It is my intention," wrote Hamilton to Washington from New York on October 29, 1798, "to proceed on the first of November to Trenton. My aid to the Secretary, to the full extent of what he shall permit me to afford, will not be withheld. But every day brings fresh room to apprehend that, whatever may be the props, the administration of the War Department cannot prosper in the present very well disposed but very unqualified hands." 
Knox cannot arrive before that date. In the other letter, he said:

"My Dear Sir

"I received yesterday your private letter of the 1.6 th with its inclosures, now returned.

"It was essential for you to take a decisive course \& to leave the blame of further delay at some other door. There can be no doubt of the propriety of combining the aid of General Officers. But Pinckney being now arrived, it seems to me very proper \& necessary that he also should be called upon. You will learn with pleasure that he sent me a message by young Rutledge purporting his entire satisfaction with the military arrangement \& readiness to serve under my command. Communicate this to our friends Pickering \& Wol. cott, as I am not well enough to write them by this post.

"Yrs Affecty

"A Hamilton"

Though Washington wrote ${ }^{1}$ Knox on October 21, urging him to accept the commission, the latter wrote Adams, on October 23 , before he could have received this letter, ${ }^{2}$ that it would be impossible for him to serve under officers so much his juniors. "No officer can consent to his own degradation." Pinckney accepted at once and, on October 26, thanked ${ }^{3}$ McHenry for the commission and hoped to see him in Trenton on Monday. On the 31st, he wrote again, promising to be at Trenton on November 10, regretting Knox's declination, and expressing a willingness to rank below Knox, if that will induce him to reconsider. $\mathrm{He}$ is glad to serve under Hamilton, though he outranked him in the last war. On October 21, Washington wrote McHenry, ${ }^{4}$ enclosing a copy of Adams's letter of the 9th and asking him to burn the note, that its existence might not be discovered and confirm Adams in his ideas of intrigue. $\mathrm{He}$ also asked for information, as to the captains and subalterns from the south, who served in the revolution, which information he had already requested sometime before.

In another letter, ${ }^{5}$ dated the same day, Washington ac-

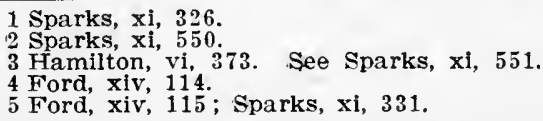


knowledges MeHenry's letter of the 16th and approves of all he has done, except the plan to officer the new corps in the southern and western states, which relies too much on the opinions of members of congress, who press applications oftentimes to get rid of them or "for local and electioneering purposes." Washington fears Knox's declination and asks for information as to Pinckney, who, he hopes, will accept and be of service in picking out southern officers. Washington had been ill, but wrote that he would try to be at Trenton on November 10 , or about that time. On the $23 \mathrm{~d}$, he wrote again from Mount Vernon:

"Dear Sir,

"It gave me very sincere pleasure to find by your letter of the 17 th recd. last night - that Genl. Pinckney accepts his appointment in the Army of the United States.

"If it would not be too inconvenient for him to remain at the Seat of Government until the 10th. of next month (the ulterior day, allotted for the Assembling of the Majors General at Trenton or Philadelphia) and you would advise me thereof, immediately, I would make every exertion in my power to meet them at that time.

"For a variety of reasons, which will readily occur, the sooner such a meeting could take place the better; - and perhaps no time, - season - or circumstances, would be more convenient than the one proposed:- nor more eligable for the purpose of concerting a Plan, upon general hypothesis; - and rectifying, as far as possible, the evils, which have preceded from delay in Recruitg.

"With great esteem and regard

"I am Dr. Sir. Your Most Obedt Serv.

"Go. WASHINGTON.",

Adams wrote McHenry, on the 22nd, that he will confirm any appointments which the generals and McHenry recommend. He cannot come on soon, on account of Mrs. Adams's illness. He had dated the commissions on the same day and agreed to confirm Washington's decision in the matter. 1 He rather sneers at the recruiting service and savs regiments are costly and no national plan has been formed for the maintenance of an army, so far as he has seen. Adams was already

- 1 J. Adams, viii, 612. On October 26, McHenry wrote Washington that Adams had not answered Wolcott and is extremely guarded in his expressions, but will not refuse your request. 
preparing for congress, as is shown by his letter to McHenry written on October 10 from Quincy:

"Dear Sir.

"The Meeting of Congress approaches, and it is necessary to consider whether Philadelphia is a safe Residence for Congress : and also the Particulars that will be proper to communieate and recommend to both Houses at the opening of the Session. I ask the favour of you to revolve these sujects in your Mind and write me the Result as soon as you can. I have the Honor

$$
\text { "to be, Sir your most obedient }
$$

On Oetober 30, MeHenry wrote to Washington that Knox declines, Pinckney will assist, Adams can not come, but "we wish you about Nov. 10."

Amid the unpleasant affairs of the season, there were pleasant ones and McHenry had loyal friends like Tracy, who wrote from Litehfield on the 8th of October, 1798:

\section{"My Dear Sir -}

"Your favour of the 3d inst. is duly recd. I thank you for it - and will endeavor to lay before you, names for another Corps. I conclude we shall in Connecticut be allowed as many Officers as will organize one more Regt. - including the provisional Army. If I am mistaken in this, please to let me know by an early opportunity. In the mean time, Govr. Turnbull, Col. Wadsworth, \& I will be seleeting the proper characters who shall be forwarded to you, as soon as may be. I thank you for the foreign news - \& should be more thankful for the Domestic, if it were more grateful in its Nature. Storms we must have, \& each must have his share - but it is a consummation devoutly to be wished, that they may cease from within our own household, as they increase from without.

"I am aware that we must undergo some difficulty, by a hint I had from Knox in a letter, but I said nothing, hoping it would blow over without much mischief. As to Wm. S. Smith commandg. a Regt., you know the appointment is in the hands of the Executive, by law; and it must take its course; but if all I hear of him is true, he ought, by no means, to have a Regt. Let it be remarked, that I may be misinformed. I only give my opinion under present impressions. 
Altho I am of opinion almost any compromise must be made, rather than have on our hands so much Executive blocking to our movements. The Officers of the 12 Regt. \& of the provisional Army, it seems to me should now be appointed as soon as convenience will possibly permit. The ardor of our Country will I fear cool - and recruiting will drag heavily. For God's sake let nothing retard this matter much longer - we must have our Army in forwardness.

"As soon as possible, we will forward you another Regt. of Officers, you can use them as Provisional or not, as you please. Could the Conmmissns. soon be sent to me, the success of recruiting is infallible. Every thing moves at present perfectly right in Connectieut, but too long delay will at any rate do no good. "There is a tide in the aftairs of men."

"I am unwilling to tax a busy useful man to write me, but must ask you to give me a line, if any thing particular, either foreign or Domestic, should oceur. I am Sir

"with esteem \& affection yrs.

"URIAH TrACY."

McHenry wrote Washington on November 9, that he had lodgings for him and that he proposed to bring out a few volunteers to give him a military reception. Pinckney was delayed, for a short time, owing to an aceident to his carriage, but, on the 10th, MeHenry submitted to Washington, Pinckney, and Hamilton lists of officers and proposals as to the number of officers and men to be taken from each State, according to the census. ${ }^{1}$ Discussion was also had, concerning allowances to officers detached on such services as to incur expenses on the road and at places, where there are no military posts.

Washington answered McHenry's proposals 2 in letter's written at Philadelphia on November 13 and 14. The earlier of these letters reads thus:

1 Hamilton, $v, 152$; Sparks, $x i, 552$.

2 Certain other questions were submitted by McHenry to the other secretaries about this time.

\section{"(Private)}

"Dr. Sir

"I have signed the paper upon which you requested the opinion of the Heads of Departments. - I take the liberty to suggest however, that writ ten official Opinions ought not in my judgement to be called for, without

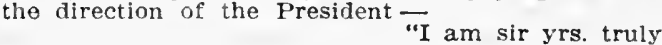

"Dec. 7, 1798 "OLIV WOLCOTT

James McHenry Esq." 
"Sir

"I observe by the concluding paragraph of your letter of the 10th. instant, that you contemplate conferences between the Secretaries of State and of the Treasury, and myself, for the purpose of obtaining auxiliary information from their departments. Several of the questions which you state, seem indeed, to require such information. But, on reflection, it has occurred to me, as most regular, that you should settle with these Officers what it may be reciprocally deemed necessary and proper for them to communicate; - to the end, that they may themselves, bring forward, either through you, or directly to me, as may be agreed upon, but without any previous application from me, such communications as the case shall be supposed to require. Whenever, too, I am to report a formal opinion, you will, I dare say, think with me, that the data upon which it shall be given ought, substantially, to be deposited with me in writing. Personal conferences besides, for more full explanation, may be useful, and will be very agreeable to me. Allow me to request your speedy attention to this Matter.

"I find also, that the Documents refered to in your letter of the 10th. instant, did not accompany it. As these will be necessary in forming an Opinion on several points submitted to me in your aforesaid letter, and which I have communicated to Major Generals Hamilton and Pinckney, I must beg you to furnish me with them without delay. The documents referred to are as follows - viz.

" 'List of persons who have been recommended for Commissions in the Army, with their letters of pretensions.'

"(N. B. A list of applicants South of the Potomac, and their letters, are in my hands. The lists and letters from the other parts will be wanting.)

" "Returns and Letters from Brigadr. Genl. Wilkinson, showing the Stations and number of the Troops on the North Western and Southern Frontiers.'

" "Return showing the description, places of Rendezvous, Stations and number of Troops now on our Sea-board frontier.

" "Return from the Superintendant of Military Stores, showing the quantity and kinds of Cannon, Field Artillery, Military Stores, and other Articles now on hand, belonging to the United States.'

"(N. B. This return should also exhibit the places at which these are deposited, and the quantity at each place). 
"To these must be added the estimate which you had made out of the monies which you conceived would be required for Military service, and the times at which the same might be wanted.

"I have in my hands a list of the General and Field Officers who served in the Revolutionary war, and of the Cap. tains and Subalterns from the States South of the Potomac. You will, therefore, be pleased to add to the documents, a list of the Captains and Subalterns from the other States, that the whole may be before me.

$$
\begin{aligned}
& \text { "I am, Sir } \\
& \text { "With very great esteem \& regard, } \\
& \text { "Your most Obedt. Servt. } \\
& \text { "Go. WASHINGTON." }
\end{aligned}
$$
follows :

The second letter, written on the following day, is as "Sir,

"In order to form an opinion on the query contained in your letter of the 10th. instant, whether it will be best to furnish Rations for the Troops by Contracts, or by purchasing and issuing Commissaries, it will be necessary that I should know the prices of Rations, now by Contract, at the several places where Troops are Stationed.

"Yon will therefore be pleased to add this to the doeuments which I Yesterday requested you to furnish.

"With great esteem \& regard.

"I am, Sir

"Your most Obedt Servt.

"Geo. Washington."

These letters he followed, after a month's stay in Philadelphia, with three long official ones dated ${ }^{1}$ December 13 and 16, and drafted for him by Hamilton. Washington forwarded with the letters of the 13 th a brief personal note:

"Private

"Dear Sir,

"I am really ashamed to offer the letters \&c herewith sent, with so many erazures \&e, but it was not to be avoided, unless I had remained so much longer here, as to have allowed my Secretary time to copy the whole over again;- and my 
impatience to be on my return homewards, on Account of the Season - the Roads - and more espeeially the passage of the Susquehanna - would not admit of this. With consideration \& respect I am Dear Sir

"Your most obedt. Servt. "Geo. Washington.

"P. S. Mr. Lear, you are sensible, was engaged with myself \& the Genl. Offieers; - of eourse eould not be employed in Transeribing what you will now receive, as the result of our deliberation at the mom't. we were engaged in other matters."

The difficulties connected with the appointment of William S. Smith continued to exist and are the subject of a letter Washington wrote ${ }^{1}$ on Deeember 13.

"Sir,

"You will observe that in the Arrangement of the Officers allotted to New York, there is an alternative of William S. Smith, or Abijah Hammond for Lieut. Colonel Commandant.

"Various considerations demand that the motive of this hesitation should be explained.

"Had military qualifications alone been consulted, the name of Colo. Smith would have stood singly, and he would have been deemed a valuable acquisition to the service. Had there been no other source of objection, than the erroneous political opinions lately attributed to him, his honor and attachment to his Country would have been relied upon. But as well myself as the two Generals, whose aid I have had in the nominations, have been afflieted with the information, well or ill founded, that he stands charged in the opinion of his fellow Citizens with very serious instanees of private mis. conduet; - instances whieh affect direetly his integrity as a Man. The instanees alleged are various; but there is one whieh has come forward in a shape which did not permit us to refuse it our attention. It respects an attempt knowingly to pledge property to Major Burrows, by way of seeurity, which was before conveved or mortgaged, for its full value, to Mr. William Constable, without giving notice of the eircumstanee, and with the aggrevation that Major Burrows had beeome the Creditor of Colo. Smith through friendship, to an amount which has proved entirely ruinous to him. While

1 A letter of Hamilton dated December 17, treats of the matters included in Washington's letters. 
the impossibility of disregarding this information forbade the selection of Colo. Smith absolutely; Yet the possibility that it might admit of some fair explanation, dissuaded from a conclusion against him.

"As it will be in your power to obtain further lights on the subject; it has appeared adviseable to leave the matter in the undeternined form in which it is presented, and to assign the reason for it.

"You are at perfect liberty to communicate this letter to the President. Candour is particularly due to him in such a case. It is my wish to give him every proof of frankness, respect and esteem.

"Lest it should be supposed that Major Burrows has officiously interfered to the prejudice of Colo. Smith. it is but justice to him to declare that such a suspicion would be en. tirely without foundation.

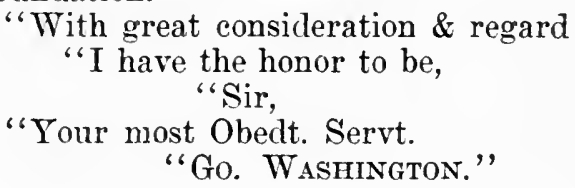

A week later, McHenry received Smith's defense. ${ }^{1}$ He had been speculating in western lands and his detailed account of his conduct proved satisfactory, so that he was placed in command of a regiment.

The great questions of the army were not the only ones to occupy McHenry's time during the summer and autumn. On July 27, Washington wrote him to procure colors for the "Gray-heads of Alexandria," 2 who had formed a company for the defence of the town and its vicinity, and about the

1 See Pickering's Examination of the Adams and Cunningham letters p. 144. Adams in his letters to Cunningham, 123, said that Pickering, "at the instigation of Hamilton, I suppose, who was jealous of Smith as a favorite of Washington and a better officer than himself, excited a faction in the Senate against him and, to my knowledge, propagated many scandalous falsehoods concerning him and got him negatived, though Washington had recommended him to me. But no personal or family considerations would have induced me to dismiss Pickering. My motives were pubiic altogether." Plckering (in "Interesting Correspondence between his Excellency Gov. Sullivan and Col. Pickering," in which the latter vindicates himself against the groundless charges and insinuations made by the Governour and others, 180s, p. 32) says Adams never told him cause of removal. Smith's defense is published in So. Hist. Assoc. Pubs. for $190 \%$.

2 Ford, xiv, 55. On August 13, McHenry wrote Washington that Miss Custis's colors advance. See also note 19. 
same time he received a charming letter from the fascinating Eleanor Parke Custis :

\section{"Mount Vernon July 26th 1798.}

"Sir

"You will perhaps be a little surprised when you see from whom this letter comes, as it is not very common for Ladies to begin a correspondence. however, as I have had the pleasure of your acquaintance some years, and I consider you as one of my old Friends; I wave all general rules, \& will proceed accordingly in this my Epistle to the Secretary of the War Department. I hope you arrived in Philadelphia without accident, \& found your family well; I assure you we regretted your departure but indulge the hope you will again favor us with a visit, \& bring with you, Mrs. McHenry and your young family. I shall now take the liberty of troubling you in regard to the Commission for a Standard, which you were kind enough to undertake for me. One of the Volunteer Dragoons dined with us today, he mentioned that the Company had a colour Staff which from its antiquity \& being used by the first Company in which Grandpapa was, in either the late War, or the French War (I forget which) they prized highly, and intended to honour my gift, by placing it on that Staff. If they send you the Staff for that purpose, will you be so obliging as to have placed on the tops of it - The American Eagle, hansomely carved, and gilt in the best manner in one talon an Olive Branch, in the other, implements of War. And also to have my favorite Motto - Conquer or Die - in letters of Gold on the Standard, which America is represented as presenting to the Dragoon. The uniform, I suppose you have been informed of My Company will, I think, be very respectable, therefore, I wish $M y$ Standard to be the hansomest ever seen in America. If the Antique Staff is not sent, will you have one, very hansomely made, with the ornament above mentioned.

"I hope you will excuse me for adding to your weight of business, which must already be allmost too much to bear.

"I must trust your good nature, which is I believe, allways gratified by an opportunity of confering favors.

"I amuse myself sometimes with the recollection of your walks up Chesnut Street to your Office. \& think you must find them disagreeably warm, particularly, with your regimental Coat and Large Hat. 
"Be pleased to present my affectionate regards to Mrs. McHenry, \& your Children; \& to divide with them

"The best wishes for your Health \& Happiness

"from

"ElenNor Parke Custis.

"P. S. My regards to all the Ladies, with whom I have the pleasure to be acquainted."

Miss Custis's desire for the standard led her to write a second interesting letter on September 6:

"My good friend's entertaining letter, and wise admonitions I received in due time, why I have not answered and acknowledged them before this time, perhaps I might find some difficulty in accounting for, but no doubt (as Ladies, allways you know are guided by good reasons) I had some very cogent and sufficient reason for not doing that which I now acknowledge ought to have been performed long sinee; however I hope you will excuse me. I know that you have so much good nature, and kind consideration, that I make no ceremony of imposing upon it, allways anticipating forgiveness. - I beg you will accept my sincere thanks for your very polite and friendly expressions, I assure you, your letter gave me infinite pleasure, and I often entertain myself with reading it over.

"I was very sorry sometime since to learn that you were very ill, but the clouds of regret have been chased away by the bright sunshine of pleasure on your recovery; I sincerely hope you will have no return of your indisposition, and that yourself and family may enjoy uninterrupted Health \& happiness. That cruel Malady, the Yellow Fever, has driven you from Philadelphia I hear, it is a most unfortunate circumstance for the poor Philadelphians, many who are now obliged to fly from that distressed City, will probably be prevented from returning, by the fear of the Yellow Fever becoming a constant Summer visitor.

"I am afraid the poor Painter who was executing the Standard for me has gone to The land of his Fathers - and left America, the Dragoon, and the Motto, to the mercy of the Yellow Fever; I assure you, I begin to be a littlo anxious for their fate, as I fear they will come to an untimely end. 
How lamentable would such a dire event be, $M y$ Troop are all uniformed and waiting for the Standard, which they are determined to defend with a bravery never excelled; even in the annals of Chivalry, and in the earliest ages of romance. I am afraid their patience (which is already threadbare) will be entirely worn out, if it is much longer delayed, and not having 'Conquer or Die' before their eyes, their patriotic and Heroic ardor may be exchanged for calculations of Loss and Gain and a resolution, - that it is better to stay at Home, and make money in Peace, which depends upon the caprice of a Foreign Nation, than to fight for their insulted Country, and a continuation of Our Independence, gain Honor and Glory, but spend their cash and love - their Heads. I will here take the liberty of informing you, that the Motto by you called sanguinary, has no enigmatical meaning whatever affixed to it, it is simply this in the literal translation, 'Never give up, whilst life remains, or Die rather than be conquered.' I never intend, be assured, to die of mortification on any account, and more particularly, for the cause you apprehend $I$ mean. The Ten thousand Knights whom I carry along so triumphantly in chains, exist only in your Brain, I am persuaded. I beg you to believe, that my intentions are peaceful \& charitable and not murderous and monopolizing; if any Chrysostom's wear chains, as they are forged by themselves, and worn voluntarily, so the peril be upon their own Heads, and the consequences, however disagreeable they may prove to them.

"The beautiful and inexorable Marcella was unjustly accused, I think her answer to the charges brought against her on Chrysostom's account, is excellent. Heaven, you say, has given me beauty, nay such a share of it, as compels you to love me, in spite of your resolutions to the contrary; from whence you draw this inference, and insist upon it, that it is my duty to return your passion. By the help of the small capacity whieh Nature has bestowed upon me, I know that which is beautiful is lovely; but I ean by no means conceive, why the object which is beloved for being beautiful, is bound to be enamoured of its admirer. Besides, you are to consider, that I did not chuse the beauty I possess; such as it is, God was pleased, of his own free will and favour, to bestow it upon me, without any solicitation on my part. The serip of paper I received in due time, I am indebted to you for your polite attention to my commission, and for employing a 
Deputy, when business prevented you from attending to it vourself; I have no doubt I shall be pleased with the execution of the Standard, which I am very anxious to see unfurled by $M y$ 'Troops, and I flatter myself, that should invasion impend, this company will be one of the first who march to repel the daring invaders; that they will be endued with real spirit, and do justice to the favorite Motto. I acknowledge, my mortification would be very great indeed, was I to hear that the Troops had suffered this Banner to fall into the hands of an enemy. If you can spare a few moments from the multiplicity of disagreeable business with which yon are encompassed, you will oblige me infinitely by a hint on the subject, with information relative to its progression, and when I may expect to recieve it.

"My Beloved Grandparents unite in kindest regards to Mrs. McHenry, yourself and Children, My Brother and self unite in respects and affectionate wishes to the same.

"Be assured my respected Friend

"of the esteem and Friendship of

"Eleanor Parke Custis."

A rather amusing letter sent from Mount Vernon on February 16, 1799, shows that Miss Custis's martial ardor did not canse her to send those she loved into the field:

"Dear Sir,

"The enclosed letter from Major Lawrence Lewis requires explanation, and it is the purpose of this letter to give it.

"He had, it scems, been making overtures of Marriage to Miss Custis some time previous to the formation of the Augmented Corps in November last, at Philadelphia; withont any apparent impression, until she found he was arranged as a Captain in the Regiment of Light Dragoons, and was about to try his fortune in the Camp of Mars. This brought into activity those affections for him, which before she conceived were the result of friendship only. And I believe the condition of the Marriage is, that he is to relinquish the field of Mars for the sports of Venus. His own letter must speak the result. This explanation, after what has happened, I thought was due from

"Dear Sir - Yr. Most Obedt \& Hble

"Go. Washington."

Delays still continued, so that Hamilton grew impatient. 
and wrote on December $16,1798,{ }^{1}$ If he is to have recruiting service, please let him know at once and send him instructions, that he may gain for McHenry's "final decision, new lights from officers, who have had experience in this branch of the service." His own experience is very limited "in this and, to form a right plan", is of "great importance."

He has been investigating tactics and will put more time thereon but must be paid and have travelling expenses, for his practice is falling off and he has a large family.

McHenry answered at once ${ }^{2}$ and said that recruiting will be wholly confided to him, but he must await supplies of clothing. "It is certain you must have been a loser in the way you mention, by accepting the office you now hold, and as certain that justice requires that none of the pay or emoluments annexed to it should be refused." 3

Indefatigable in work, Hamilton wrote almost daily to McHenry on all sorts of military matters and forwarded letters he had written to others on these subjects, as for example his letter of December 22 to General Gunn, a senator from Georgia :

"As to further military arrangement my ideas are these - Considering how little has been done towards raising the force already voted; that an important tax is yet in the first stage of an Essay - that a prospect of peace is again pre. sented by the temporizing conduct of France - that serious discontents exist in parts of the country with regard to particular laws - it appears to me advisable to postpone any actual augmentation of the army beyond the provisions of the existing laws, except as to the Regiment of Cavalry, which I should be glad to see increased, by the addition of two troops, and by allowing it to be recruited to the complement which has been proposed by the commander in Chief as that of the war-establishment. What this is will probably be communicated by the Secretary at War

"But a considerable addition ought certainly to be made to our military supplies. The communications of the Commander in Chief will also afford a standard for the increase in this respect, as far as concerns the force to be employed

1 Hamilton, v, 180 ; Lodge, vii, 42 vide p. 3.

2 Hamilton, vi, 374.

3 On the 19 th, Hamilton wrote that he is preparing a plan for the fortification of New York harbor and wishes certain plans to be bough: by the United States and loaned to him. Hamilton, v, 182. 
in the field. There are, however, some other objects of supply equally essential, which were not within the view of those communications. Heavy Cannon for our fortifications and mortars for the case of a siege. Of the former, including those already procured and procuring, there ought not to be fewer than one thousand from eighteen to thirty two pounders, chiefly of twenty four - of the latter including those on hand, there ought to be fifty of ten inch Calibers. This you perceive looks to offensive operations. If we are to engage in war. onr game will be to attack where we can. France is to he considered as separate from her ally. Tempting objects will be within our Grasp.

"Will it not likewise be proper to renew and extend the idea of a Provisional Army? The force which has been contemplated as sufficient in every event is 40,000 Infantry of the line, 2,000 Riflemen, 4,000 Cavalry, and 4,000 Artillery, making in the whole an army of fifty thousand. Why should not the provisional army go to the extent of the difference between that number and the actual army? I think this ought to be the case, and that the President ought to be authorised immediately to nominate the officers - to remain without pay till called into service. The arrangement can then be made with sufficient leisure for the best possible selection : and the persons designated will be employed in acquiring instructions.

"It will likewise well deserve consideration whether provision ought to be made for classing all persons from eighteen to forty five inclusively, and for drafting out of them, by lot in case of Invasion, the number necessary to complete the entire army of fifty thousand. In the case of Invasion, the expedient of drafting must be resorted to, and it will greatly expedite it, if there be a previous classing with a view to such an event. The measure too will place the Country in a very imposing attitude and will add to the motives of caution on the part of our enemies.

"'These measures are all that appear to be adviseable with regard to our military establishment under present appearances. A loan as an auxiliary will of course be annexed." wrote:

On the copy of this letter sent to MeHenry, Hamilton

"This is communicated in confidence. I send as well becanse I think it proper to do so, as because I wish you to see the train of my ideas." 
Two days later MeHenry's report on the reorganization of the army was sent to Adams and was transmitted by the president to eongress on the 31st. MeHenry's report is quite elaborate and states that "A very obvious poliey ${ }^{1}$ dictates to us a strenuous endeavor, as far as may be practieable, to place our safety out of the reaeh of easualties which may befall the contending parties and the powers more immediately within their vortiees." He proposes to have eaeh infantry regiment to consist of ten companies, formed into two battalions; each cavalry regiment to consist of ten troops formed into five squadrons; each artillery regiment to eonsist of four battalions, each battalion divided into four companies. The title ensign should be given up and that of lieutenant substituted therefor. There should be fewer officers. Aides should have their place filled by others in the regiment. There should be a quartermaster general and an hospital establishment. ${ }^{2}$ We should bring in from the Austrian or Prussian armies one or two engineers and artillerists as colonels and have an inspeetor of fortifications and of artillerists. Fit clothing for the soldiers can be made by tailors in the ranks. Regulations as to rations shonld be revised. "With regard to liquor, it may be best to exclude it from being a eomponent part of the ration," while allowing a diseretion to eommanding officers to cause it to be issued. Congress should make allowanee for disbanded soldiers to return home. The provisional army act and the militia law should be revised. An especial allowanee should be made to the inspeetor general. There should be a purveyor of publie supplies, exclusively for the war department, that the secretary need not be oecupied with details of lesser eoneerns. Hamilton, when seeretary of the treasury, thought that the purchase of military stores and supplies should be made through that department and so congress deereed by the statute of 1792 . The law was a mistaken one and partly responsible for St. Clair's defeat. Yet Hamilton advocated the policy thereafter, suggesting that a special pur-

\footnotetext{
1 State Papers, Military Affairs, 1, 124. Other minor reports of McHenry about this time are the following:

Letter from Sec'y of War, inclosing Statement of the Number of Cannon purchased for the use of the Frigates, Revenue Cutters and Fortifications, since January, 1794 ; etc. pp. 7 . Phila. [1798].

Letter from Sec'y of War, accompanying his Rep. relative to Running of a Line of Experiment from Clinch River to Chilhowee Mountain, by Order of Gov'r of the Terr'y of the U. S. South of the Ohlo. pp. 18. Phila. [1798].

2 Ingersoll's War Department, 212, quotes H. E. Brown's Med. Dept. of U. S. Army, 73, that the Medical Department was organized in 1798 , Stat. at Large, 1, 721, and enlarged in 1799, but disbanded in 1800 .
} 
veyor of supplies be appointed under the secretary of the treasury. This was done in 1794 and the conditions so continued until July 16, 1798, when the new law provided that the supplies should be purchased under the direction of the secretary of war. After MeHenry's report, referred to above, the act of March 3, 1799, authorized the secretary of war directly to make such purchases. As a result of the report the establishment of the staff departments may also be placed to McHenry's eredit.

From New York on December 26, 1798, Hamilton wrote to inform MeHenry that General Huntington has been displeased at not having received official notice of his appointment with his commission. "I hear nothing of nominations, what malignant influence hangs upon our military affairs 1 * * I left with General Pinckney a project of a Military School which he was to have sent me? Has he quitted Philadelphia? If so have you heard any thing of this paper? I want it."

Two days later MeHenry answered that the nominations "will probably be made to-day and Smith's will stand." Pinckney has gone without leaving a project of a military school. A foreigner cannot be put at the head of the second regiment of artillery. MeHenry asked Hamilton to throw the conclusions of the report into a bill and hoped to begin recruiting soon. At the same time he wrote Washington concerning his report ${ }^{2}$ and the nominations, stating that he advised Smith's appointment.

Washington had written to McHenry ${ }^{3}$ from the east bank of the Susquehanna on December 16, where he was detained by wind and tide, proposing that military affairs in the Carolinas and Georgia be placed under Pinckney, or that Virginia be added to the department, and General William Washington be given South Carolina and Georgia, subject to Pinckney. All the other troops, including Wilkinson's army in the West, should be placed under Hamilton. The new recruits from Tennessee and Kentucky should be under Pinckney. The present force there should be under Hamilton, as part of Wilkinson's command. Washington himself will not act until the army is in the field. Meantime it will be well

1 Lodge, vii, 47.

2 The report was sent Washington on January 5 .

3 Sparks, $x i, 374$. 
to concentrate responsibility and have all orders reach $\mathrm{Mc}$ Henry through the two heads.

Vernon :

On January 6, 1799, Washington wrote again from Mount

"Dear Sir,

"Your favour of the 28th Ulto. I have duly received.

"I have no wish that any sentiments of mine, handed to you officially, should be with held from Congress, or the Public. All I should have desired, would have been, that such parts of my Report of the proceedings which occupied the attention of the two Major Generals and myself in Philadelphia, and fit for Legislative consideration, might have been communicated entire; - with the reasons in support of the measures

"Extracts, without these, does not always convey the sense, or the intention of the Reporter.

"It is unnecessary I presume, to add, that such other parts of the Report as depend upon Executive decision, ought not to be delayed. Many valuable Officers \& Men have already been lost by it; - and if the arrangement is not announced soon, more will be so. The regulations with respect to the Uniforms, and Army distinctions, should be announced at the same time (if approved) in clear and peremptory terms; to guard, in the first place, Officers against unnecessary expence - and in the second place to prevent fantastic decorations at the whim of Corps. I do not recollect whether it is so expressed, but it was the meaning, that all Officers who are not directed to be distinguished by feathers, are not to wear any; but if it is not forbidden at the time of the annunciation, to those who shall, the practice will still prevail in the lower grades; - such is the propensity in favor of it.

"That those who applied for higher grades than they have been appointed to Shd. decline accepting them, was in many instances, apprehended - but to find among others, who were appointed, unworthy characters, is more surprising; although it is an evidence of the truth of the doctrine I advanced, that there was no dependence (except in a few instances) on the mode of obtaining information - for reasons wch. I detailed at the time.

"The Papers you have asked for went off before your letter was received - and safe with you, I hope ere this.

"I ought to have taken your advice with respect to draw- 
ing three, in place of two months pay; - Not keeping the acc. of my expenditures to, from, and at Philadelphia myself - Mr Lear paying them out of the money he received there, on his own account. - and not coming to the knowledge of their amount until I got home, I presumed two months Pay \&C. would have covered all my expences - but with the purchase of a few articles incidental to my journey, I find that the aggregate, amounts to $\$ 1115.55-100$ and the pay drawn, to 1039. 50-100 withont including in the first sum the preparatory expence of equipment, for the jour-

* One item alone of which a horse, cost I had rather sustain the loss, and the fatigues me $\$ 300$ of the journey, than it should be thought I was aiming to draw an Iota more from the Public, than my declaration at the acceptance of $m y$ Commission would authorise

"With very great esteem \& regard

"I am - Dear Sir

"Your Most Obedt. and

"Affectionate Servt.

"Go. Washington."

MeHenry answered on January 10th, writing concerning Washington's salary and stated that Hite's name was left out of the nominations because he and his connections, "who live in a very federal part of the country, are stated to be anti governmented and Jacobins" so that his appointment would excite disgust.

Hamilton was naturally worried and complained ${ }^{1}$ on January 7, 1799, of the unascertained situation he held. He has lost half his emoluments and he is uncertain as to whether he is "to derive from the scanty compensation of the office even a partial retribution for so serious a loss."

McHenry answered ${ }^{2}$ at once on January 9: "Dear Ham. ilton, An official letter of this date fixes the commencement of your pay and emoluments. I shall, soon as possible, define your duties and command. In the meanwhile, I should be glad to have your own ideas on the subject. You will proceed in your report for a system of tactics and discipline. You

1 Hamilton, v, 186 ; Lodge, vii, 50 .

2 Hamilton, v, 188 . 
will also endeavor to ascertain the best positions for your recruiting parties and general rendezvous \&c."

On the next day McHenry wrote that General Gunn of the senate committee has asked ${ }^{1}$ for a draft of two bills; one based on McHenry's report as to a regular peace and war establishinent, and one on all new matters pertaining to the provisional army. Gunn also asked that existing provisions might be incorporated in these bills. This seemed a judicious idea and Hamilton was requested by McHenry to incorporate in the two bills all that ought to be retained of existing laws. The matter was urgent and on the 11th, McHenry wrote? once more, asking Hamilton to lay aside other business and occupy himself on the two military bills only, as the session is short. ${ }^{3}$ McHenry cannot tell what will be done as to appropriations. Hamilton knows the "causes and obstructions which have prevented me doing anything" to carry the law for raising the army into effect during the past year. "If you want money let me know, that I may send you your pay." Hamilton answered MeHenry's letters on the 14th from. New York :

"Dr Sir

"I received on Saturday two letters from you, desiring that your different propositions might be thrown into two Bills \& suggesting the idea of an Incorporation of the several existing laws into one system. This idea is a good one, but to accomplish it with sufficient correctness would require several days to examine carefully and prepare with accuracy. Besides this, I incline to the opinion that it will be best in the first instance to present the alterations and additions proposed independently - that the progress of them may not be embarrassed by the consideration of an entire System; and I had even thought of a distribution into more than two divisions to secure at all events the passage of some things. The organisation on my plan would form one bill comprehending the Sections in the inclosed draft No. 1 to - inclusively - The Hospital department would form another Bill. The provisional army \& volunteers a third. The miscellaneous points a fourth. The plan however of two Bills is now pursued, except that I shall preserve the sections for the Hos-

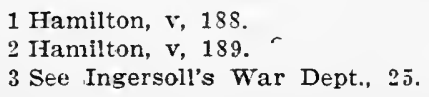


pital establishment separately; which with the provisional army Bill will go by tomorrow's Post.

"I do not exactly seize your idea about the Inspector of Fortifieations and, therefore, have prepared nothing on that point. Is it essential to have a distinct officer of this character? Or may not the objeets of it be fulfilled by some one of the Engineers of the establishment? I will endeavour to embrace your plan on this head and, if I do, I will throw it into the form of a Section of a Bill.

"I do not lose sight of the idea of an Incorporation of the whole Military system into one law; but I believe you will, on more reflection, judge it advisable to make this a subsequent operation of greater leisure and care.

"I remain with great esteem \&

$$
\begin{aligned}
\text { regard "Dr. Sir } \\
\text { "Yrs. Obed } \\
\text { "A HАмитом" }
\end{aligned}
$$

On the 15th, he forwarded ${ }^{1}$ a provision to be incorporated in the bill sent the day before and regretted that he could not yet send the provisional army bill. He sent the medical establishment bill 2 on the 21st.

MreHenry asked ${ }^{3}$ Hamilton on the 22nd for a proper arrangement of the forces, since Washington declines to take an active part. Hamilton replied on the 24th that this is a delicate subject for him and suggests that he and Pinckney be given authority, as Washington outlined, and that all communications from the West be sent open under cover of the secretary of war, who, in urgent cases and in the absence of Hamilton, will himself give orders and, otherwise, will leave Hanilton to control matters under the department's instructions. "You will take and reject as shall appear to you proper, assured always that, personally, I shall be content with any arrangement you may think advisable."

On February 4, McHenry answered, ${ }^{4}$ giving Hamilton instructions according to the ideas of Washington, and adding : "Finally I cannot conclude these instructions, without express-

\footnotetext{
1 Hamilton, v, 190, McHenry wrote Tousard on the 16th to inspect the fortifications of Newport, Boston, Marblehead, and Portiand.

2 Hamilton, v, 195 ; Lodge, vil, 3, 54, 29, Gunn, who knew nothing of Hamilton's hand in the matter sends Hamilton on the $23 \mathrm{~d}$ a bill McHenry had given him and asks him to prepare one for the provisional establishment.

3 Hamilton, $v, 197$; Lodge, vii, 59

4 Hamiton, v, 199 ; Sparks, xi, 563 .
} 
ing my most unlimited confidence in your talents to execute the high trusts which the President reposes in you and my own most perfect reliance upon your cooperation and assistance, in everything that concerns the army establishment, and the means to remedy whatever defects may be found to exist therein; and that I shall at all times recognize, in the execution of the orders which you may receive, the most perfect evidences of your candor and friendship."

Hamilton answered on the 6 th, discussing the recruiting districts and regretting that the objection that several "characters proposed" were anti-federalists prevented their appointment. 1 "We were very attentive to the importance of appointing friends of the government to military stations, but we thought it well to relax the rule in favor of particular merit, in a few instances, and, especially, in reference to the inferior grades. It does not seem advisable to exclude all hope and to give to appointments too absolute a party feature. Military situations, on young minds particularly, are of all others best calculated to inspire a zeal for the service and the cause in which the incumbents are employed."

On the 7 th, Sedgwick wrote ${ }^{2}$ Hamilton that he had been to see MeHenry about hastening supply of clothing and enlistments and found that Adams was opposed to an army and objected to the title of general. The next day McHenry wrote ${ }^{3}$ Hamilton that Adams has the recruiting instructions and seems in no hurry. They will be sent, as soon as he decides on them. Washington had been frequently writing to MeHenry: on January 27, on the details of uniforms, ${ }^{4}$ on January 28, on the arrangement of the relative rank of certain regimental officers $;^{5}$ on February 10, again on his own uniform. The last letter is as follows:

"My dear Sir,

"Your letter of the 1st. instant is received. Whatever appearance or shape, the Uniform intended for me, may take, by your direction, will be entirely agreeable to my taste. It being the commencement of a distinguishing dress for the Commander in Chief of the Armies of the United States

1 Hamilton, v, 209; Lodge, vii, 62. 2 , prints a letter from Hamilton to McHenry dated January 16, 1799, and accompanying a draft of a bill for a provisional army.

3 Hamilton, v, 211. On February 16, Hamilton (Hamilton, v, 215) asks to have the additional regiments distributed among the states without delay.

4 Ford, xiv, 148 ; Sparks, xi, 394.

5 Sparks, $x \mathfrak{j}, 396$. 
(whom so ever he may be) and probably will be a permanent one My wish (although as it respects myself personally I have no choice) is, that it may be correctly executed; - for which reason I thought it more eligable, in the first instance, that the direction concerning it should preceed from the Department of War, than from myself.

" I hope it will be made \& sent to me by the time mentioned in my last; - accompanied with the Cockades, and Stars for the Epanlets; without the whole of which the Dress will not comport with the order; of course must be incomplete.

"If my Nephew, Mr. Bushrod Washington, should not have left Philadelphia before the above articles are ready, and is certain of being here by the $22 \mathrm{~d}$. instant, it would afford a good and safe opportunity for the conveyance of them to me; - but if he has doubts on this head, I would not hazard the receipt of them by him, by that time; as you will perceive by the enclosed letter to Mr. McAlpin left open for your perusal and with an excuse for troubling you with these small matters, at a time when I presume you are pressed by important ones. I am with esteem \& regard, and much truth

$$
\begin{aligned}
& \text { "My dear Sir } \\
& \text { "Your Affect Hble Servant. } \\
& \text { "Go. WASHington.", }
\end{aligned}
$$

While matters were thus progressing slowly, Adams, who had never thoroughly favored war, startled the United States on February 18 by sending the senate the nomination of Murray as envoy to France. 


\section{H A P T E R XIV}

\section{EVENTS AFTER THE NOMINATION OF THE FRENCH ENVOYS}

DAMS, on June 21, 1798, had stood with the extreme
Anti-Gallican federalists 1 and had announced that
"I will never send another minister to France, without assurance that he will be received, respected and honored as the representative of a great, free, powerful and independent nation." He had signed the naturalization, alien, and sedition bills. But he was not anxious for war. Twelve years later, McHenry wrote: "I shall not pretend to penetrate into all the motives that weighed with Mr. Adams to retire from the ground of this declaration and send a third mission to France." 2 In his letters to the Boston Patriot defending his administration, Adams acknowledged that he concealed this intention from the heads of departments and stated that he was equally careful not to inform any member of either branch of congress. "I knew," 3 he wrote, "if I called the heads of departments together and asked their advice, three of them ${ }^{4}$ would very laconically protest against the measure and the other two ${ }^{5}$ would more modestly and mildly concur with them." 'The consequence would be that the thing would be instantly communicated to members of the congress and a clamor raised against it in the newspapers, all of which would probably excite the senate to put their negative on the measure. It may be briefly said, in answer to this,

1 In July, 179s, Col. John E. Howard wrote a letter to Dr. Thomas of Frederick, who printed it, stating that Gen. Samuel Smith said, at the president's table, that he would have given the douceur demanded by Taileyrand as the price of hearing our commissioners, that it would have been cheaper than war, that he was severely reprimanded by the president for his sentiments, that no person except Mr. Bayard present supposed him not. to be in earnest, that at another time he said he would give double the sum, or $£ 100,000$ sterling. Adams said he would not give the duty on a pound of tea, was surprised to hear such sentiments and had hoped that no virtuous American entertained them. (Broadside issued by Federalists).

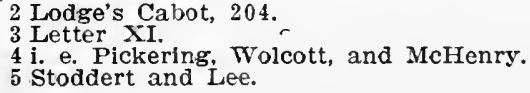


that the obvious course of obtaining new advisers whom he believed trustworthy should have been followed, if Adams distrusted his secretaries.

The sending to the senate of Murray's name ${ }^{1}$ as envoy to France aroused surprise and many objections. ${ }^{2}$ To the objectors to Murray's appointment to the French mission, Adams said that he thought Mr. Murray "a gentleman of talents, address, and literature, as well as of great worth and honor, everyway well qualified for the service and fully adequate to all that I shonld require of him, which would be a strict compliance with his instructions, which I should take care to provide for him, on all points, in terms that he could not misunderstand. That $\mathrm{my}$ motives for nominating him, in preference to others, were simply because the invitation from the French government had been transmitted through him and because he was so near to Paris that he might be there in three or four days, and because his appointment would canse a very trifling additional expense." He nominated an envoy because a letter written by Talleyrand to Pichon on September 28, and sent from the Hagne by Murray to Adams, approved the preliminary overtures Pichon had made and gave continned assurances that an American minister would be treated with proper respect. Murray was rejected by the senate, and Adams then nominated ${ }^{3}$ on February 25, Murray, Oliver Ellsworth of Connecticut, and Patrick Henry of Virginia. When Henry declined, he was succeeded by William R. Davie of North Carolina. Murray's nomination was not altogether a surprise to him, as is evident from his letter to MeHenry of January 30.

"You say nothing of my letters in Augt. respecting my friend John whom I begged of you as my Secretary, Dandridge having gone by my consent in Sept. to Mr King - \& I having taken a temporary Secretary for Three months unless Mr. J McHenry arrived sooner. This temporary Secretary I took (Mosr. Montflorence) from Genl. Pinckney's introduction $\&$ becanse he had been very faithful to Govt at Paris in the worst of times. I continned hin till the 20. Deer. Mr. MIcH not coming. I continued him the 20. Jany. - \& then till the

1 February 18. J. Adams, ix, 249. On Murray see Clement Sullivane's article in Southern Historical Society Publications, v, 151 , and Carey's Am. Museum, i1, 220 .

2 J. Adams, Ix, 249. In his letter to the Boston Patriot.

3 McMaster, 11, 429. 
20 next month - always under the terms express \& 'unless Mr. McH. should arrive sooner.' After the 20th Feb. I will not have any Secretary, unless John come, as I sincerely hope he will. I wish he had written five lines, by five ships, some one would have got to me - but I every day expect to see him enter \& announced by old Will. He will be quite at home with us - \& I recall more identically our pleasant evenings at your house - at Philada. - that charming city so dear to my memory what dreadful affliction it has suffered! $\mathrm{Mr}$ Hill I hear is dead - Miss Breck - Miss Westeot - good old Mr Anthony and poor Fenno - Bache too has still kept him company vis a vis! But doubtless many others have gone whom I knew - here I know nothing of what passes except by your letters \& one I had at the same time from Mr Bingham-I reed. a letter yesterday from My brother of 20 . May 1798 ! \& I hear from a Dutch gentleman not long from St Thomas's that the Delaware \& a 44 gun frigate were there as envoys. He seemed almost as much delighted as I was - \& from Mr Smith at Lisbon I hear to day that a new 28 was launched \& coppered at Newbury Port in 74 days! - from Hamburg I learn also to day that on the 7th. Dec the President was too much indisposed to meet the Houses \& of course no speech then. I sincerely hope that he has recovered \& been strong enough to look them full in the eye \& give them a firm determination.

"My dear Sir one half of the miseries which is brought upon the Sevl. nations whom french power has swallow'd up has been owing to the timidity of the Executive power. It is true that generally that was the centre of all power on this continent - this however only serves to illustrate more strongly the folly of timidity at all, in govt. The treasons wh. have latterly disgraced the very species of Man were in a great degree the consequences of this timidity in the Head of the Govt. That timidity, temporising, shuffling \& rank cowardise could but be seen by those in places of high trust \& in the army - when discovered a new principle of calculation was gradually formed in minds long weakened by a philosophy that refines away the coarse but more valuable properties of our nature, and each man becoming a politician, in the low \& selfish sense, balanced, doubled, feared the success of french enterprise, \& gradually was prepared so to act before hand as to be in a sort of character, by wh. he might avail himself of unlucky contingencies, if they came on. Thus Treason is 
really more a moral than a political disease in many of the public functionaries all over this continent! The People, on the contrary, true to nature, are willing \& anxious for that energy in the protecting Govt. wh. would save them from foreign domination. The gentry, call them nobles, in general, destitute of energy, seem to me incapable of high spirited action - of course when a moment comes, like that the other day at Turin \& all over Piedmont, in the Roman \& Neapolitan Territory all was policy without energy — \& submission wt. out salvation!

"We have nothing official of the Neapolitan army since 3 Jany inst. Then Mack well fortify'd in Capua had offered an armistice to Championnet wh. was haughtily refused. It is believed that there has been immense Treason in the $\mathrm{N}$. army! That the French shd. have retired from the Tuscan Territories, wh. it is believed they have done, is a singular thing if true - \& leads some to believe that the Emperor \& France will yet agree- a thing wh. seems to me almost impossible! We have as yet nothing official on these things.

"The insurrection in Belgium still rages - sometimes in battles of 3 - \& 4000 well fought - often in skirmishes from woods, \& harrassing better managed. The dear silky gentry are out of the struggle - but they will not escape, many rich men have been taken up \& sent to Paris on suspicion of secretly aiding with money the insurgents, who are literally poor \& hardy peasants, fighting with the cross marked on their clothes. The french suffer exceedingly in this kind of desultory war \& the soldiers prefer any sort of battle to that with which they are regaled if they show themselves in smaller parties - of this sort we could give them a plenty.

"I had written thus far when Colonel Hitchborn ${ }^{1}$ (431. 1512. 1238. 1246. 1451. 710.) was announced. He is just from Paris. He seems much altered in his opinions as he now most heartily curses them. My particular reason for mentioning him here is this - a circumstance that has made me think with rapidity \& pain! He says that after he \& those with whom he associates of our country knew what the proposals were wh. Woodward \& Mr Gerry carry'd out last summer, he \& they recommended me $(1050)$ as the person to whom government shd. send a commission if any minister were named!

1 The numerals are written in the text of the letter and the meaning of the cipher was written over them after the letter was received by MeHenry. 
I regret this whole affair \& so told him. I know the state of parties. I know their ways of thinking on hearing of such an unsought unthought of thing. I feel that it is due to you \& myself (920. 1463) to declare solemnly that I (1308) never hinted even such a thing - never expected it \& NEVER WISHED IT! and that it is teetotally without a hint from or to (me) 1050 ! In fact I have but one character on this great question particularly. Those of both parties who know me, know what it is - to make proselites to the great cause of our Govt. \& our country's Independence, I do certainly vary my small means occasionally \& adapt them, as far as I can penetrate, to the characters of those whom I would save if possible \& bring over - but not a moment do I disguise my opinions. This gentleman passed a week here in Sept. on his way. I had heard of his violence agt. our Govt. \&c \&c \&c - he paid me a visit. I treated him with politeness - \& after that often canvassed things with him. I found we differed - but whether his politeness shortened the difference or whether a knowledge of what he saw here had worked, he spoke rationally \& apparently with sound views. I there pointed out what $I$ believed to be the intention of France as to general Dominion, at least in Europe. He did not think with me. Since, to day - He has declared to me that he is now convinced of that truth. That plunder \& repine \& Dominion are their objects. That they shd. so treat us had they the power \&c \&c \&c.

"His son in law (612.489.948. 1457. 1005.) has been lately put in the Temple at Paris, \& he (954) ordered to quit Paris - he stay'd at Passy a few days. As those letters from that party at Paris may reach your ears I thought it due to you my dear Sir \& to myself \& the Govt. to make this explanation-\& Col. Pickering, who will have the goodness to decypher for you, will also do me justice in reading this letter Happy here - dreading storms \& quicksands, my ambition goes not higher. You wd. never hear such remarks from me, indelicate but in such circumstances, had I not got at the intelligence wh. I have troubled you with. I am always

"My dear Sir most truly \& affecty yrs."

Written on cover of letter by Murray was:

"Observe my seal. Tis the old one. The cock for a crest. The Goose - that vigilant guardian of the Capitol, I see with pleasure, 
is yours. But why a wild one-for I see

it is chained! It is however a good device. "on reflection - I wish that nothing may be said to Col. P. or anyone on the particular intelligence which I have mentioned. Unless circumstance render it proper - because protestations, even agt. such an idea are indelicate to be first mentioned. If you copy the cypher on a bit of paper it can be decyphered without showg the whole.

"Since writing the inclosed, there is reason to suspect that french affairs in the Neapolitan Domn. are not so flourishing - and it is said \& believed that the French retired from Tuscany in consequence of a threat from the imperial Genl. doubtful I think. A report circulates this evening that Ehrenbritstein has surrendered. Peace appears to me impossible, while power remains in such hands as wield it at Paris. Personal safety \& views impel them to exterior war. They would tear out the very vitals of $\mathrm{F}$. had they exterior peace! Feb. 1799.",

Congress meanwhile considered ${ }^{1}$ and passed the medical establishment act on February 25 and the act for better organizing the troops on March 2. By the latter act the army was directed to consist of four regiments of dragoons, one regiment and a battalion of riflemen and forty regiments of infantry. This act, of course, caused a great increase in efforts to recruit troops, of which subject the following letters of Hamilton treat.

"private

"Dr Sir

New York March 10. 1799

"Ought it not to be a rule to forward from your department to the Major Generals, as they are passed, copies of all laws respecting the military establishment? At any rate you will oblige me by sending those of the session just finished.

"I believe in the $5 \S$ of the Recruiting Instructions, filled up in Manuscript, the term of enlistment is five years. The Jaw for augmenting the army $\S 2$ directs the enlistment to be 'for and during the continuance of the existing differences between the U States \& the French Republic.' If there be any thing varying this, it has escaped mo. Will you inform me? This inquiry is suggested by a new revision of the recruiting instructions.

As it may yet take time to prepare for me a complete list

1 Hamilton, v, 218-233. 
of the officers of the army, I should be glad to have one of the field officers only, with a note of the stations or destinations to which they have been assigned. I want much to place them over the detached posts \& to concenter the direction.

"I observe the XIII $\S$ of the Recruiting Instructions authorises the appointment of certain Courts Martial. Where is the power for this Regulation?

"Sometime since I requested you to send me the organization of the officers, as reported by the Commander in Chief. You replied that no such document had come to you. I imagine that I must not have expressed myself clearly, for I well remember that the document, which I mean, was made out in Mr Lear's hand writing for the purpose of being sent by you. It was an arrangement or distribution of the Officers who were nominated into Regiments, batalions, and Companies, assigning to each company, by their names, its proper complement of Officers.

"It appears to me very important that the Regimental Pay Masters \& Quarter Masters should be designated without delay. They are the proper organs through which all issues of monies \& supplies ought to pass. If I remember rightly, in the late war, the Q. Master \& Adjutant were appointed by the commander of the Regiment. The Paymaster was designated by the Officers of each Regiment. What has been the practice lately? Whatever be the mode, I wish very much to be instructed to have the thing done.

"Will it not be advisable speedily to direct the field Officers of each Regiment to report for the consideration of the President an arrangement of the relative rank of their officers in the Regiment. This will not work any inconvenience as to the corps, of which the Officers have not yet been appointed. And it being done will facilitate future operations.

"Yrs very truly

"A Hamilton"

"Private

New York March 14. 1799

"Dear Sir

"It is a construction of the law warranted by usage that the President shall appoint the requisite number of Lieutenants \& leave three of them to be designated for Quarter Master \& Pay Master in the manner practiced in the late army. But if this is supposed not to be a good construction, the end 
may be produced by making it a rule that recommendations shall eome through the described Channels to the President \& that, unless for some extraordinary reason, he will, as of course, nominate or appoint.

"But whatever be the mode, pray let it be adopted at once \& put in a train of execution that these essential officers may be appointed.

Yrs. truly

"A H

"P. S.

"Since writing the above, it has occurred to me as worthy of consideration whether it will not be expedient to enlist indiscriminately for all the corps and to insert an alternative in the eall as to the term of service thus - "for and during the continuance \&e or for the term of five years, at the option of the U States.' As there are soldiers of both descriptions to be enlisted, I incline to think the laws will bear out the alternative in point of exeentive propriety - \& the option would be evidently valuable. The principal question is whether soldiers would not more readily enlist for the casual duration of existing differences than for the known time of five years."

The indefatigable Hamilton wrote daily, sometimes even twice a day. He sent acceptable amendments ${ }^{1}$ to the recruiting regulations, and submitted arrangements of districts ${ }^{2}$ for $^{\circ}$ reeruiting from Conneeticut and the Middle States, offering to do so also for all New England, Maryland, and Virginia. ${ }^{3}$ He did not understand that he might begin reeruiting at onee ${ }^{4}$

1 McHenry on the 18 th accepted Hamilton's work. Hamilton, v, 235.

2 March 15. Hamliton, v, 234.

3 Pinckney may do it for the Carolinas and Georgla, and residents of Kentucky and Tennessee for those states. March 16, Hamllton, v, 234 . Dr Sir

I send you the draft of a third Biil. I shall quickly send you that of a fourth which will comprise whatever more remain.

Yrs truiy

A. $\mathrm{H}$.

Private

Dr Sir

New York March 18, 1799

If my memoranda be right I sent Wilkinson's letter, by duplicates through you. If so I presume it is not necessary for the certainty of conveyance to send a triplicate. If I am mistaken in the first Idea, or if any thIng more is requisite, be good enough to say. If otherwise, no reply. It is very extraordinary that I recelve no acknowledgement of $\mathrm{my}$ letters from the commandant at Fort Miffin (Elliot I believe) Diplicates went through you. Can you inform me? Has not this officer too strong a love of independence?

Mr. Tracy seems to have understood you that it was left to my discretion to begin the business of recruiting whenever I thought proper. I have so understood the matter. If this be your idea be so good as to express It

Yrs Affecly A HaMiltoN 
and urged that there be an agent for the commissariat at Philadelphia. ${ }^{1}$

McHenry's position was a hard one and he had not enough sternness to surmount all the difficulties of a procrastinating president and a cautious secretary of the treasury. Washington again admonished him, ${ }^{2}$ in a long letter, which was not only private but "a friendly one from George Washington to James McHenry." The general added, most generously: "If the sentiments which you will find in it, are delivered with more freedom and candour than are agreeable, say so, not by implication only but by explieit language; and I will promise to offend no more by such conduct, but confine myself, if occasion should require it, to an official correspondence." He complains that commissions are kept back, the recruiting service arrested, and himself left uninformed. Washington is not a "mercenary officer," but, came forth through a "high sense of the Amor Patriae" and should be told all that occurs, "though detached from the army" at present. The "golden opportunity" for recruiting and the idle winter months have nearly passed. In the busy summer, recruiting will be extremely difficult and the "rif raf of the populous cities, convicts and foreigners" must be taken. Sueh regiments are no better than militia. Washington first intended to stop with these remonstrances; but, reflecting that he may not again write with such freedom, continues with the further complaint that the five weeks' work of the two major generals and himself at Trenton and Philadelphia has been set at nought, for "any member of Congress who had a friend to serve, or a prejudice to indulge." Special instances are referred to and the better course is emphasized of following absolutely the arrangement made by the board of general officers. The president had power to make any promotion he pleased, but must observe rules and attend to the feelings of the officers, if "he wishes to preserve the peace and harmony" of the army.

"There is one matter more, which I was in doubt, whether to mention to you or not, because it is of a more delicate nature than any I have touched upon; but finally friendship has got the better of my scruples. It respects yourself personally. ${ }^{3}$

“**** Whilst I was in Philadelphia, and after the Mem-

1 Hamilton, v, 236. -March 19. "Please send list of Connecticut officers. Is not the Adjutant General exofficio the deputy inspector general?" 2 Ford, xiv, 158; Sparks, xi, 406. March 25.

3 This paragraph has never before been printed. 
bers of Congress had begun to assemble it was hinted to me in pretty strong terms by more than one of them, that the Department of War would not, nay could not, be conducted to advantage (if War should ensue) under your auspıces; for instead of attending to the great outlines, and principles of your office, and keeping the Subordinate officers of the Departments rigidly to their respective duties, they were inattentive, while you were bewildered with Trifles."

Washington calls to McHenry's attention the fact that he had already advised McHenry to leave details to others and "bestow your thonghts and attention to the more important duties." These "were alone sufficient to occupy the time and all the consideration of the Secretary." The delay in issuing commissions and beginning recruiting, which "exciterl general reprobation and blame," canses Washington to recur to the subject and to say that most people aitributed the delay to "the want of system and exertion in the Department of War." Washington writes this, "as a private man to his friend," and knows such a letter would be improper from the commander in chief to the secretary of war. If McHenry does not receive it in good part, the purity of his intentions is the best apology Washington can offer. In any case, he is McHenry's "most obedient and affectionate humble servant."' 1 MeHenry soon answered, defending himself from the blame of the delay. $\mathrm{He}$ was not offended at the rebuke, but wrote: "Accept my sincere thanks for your letter and let me intreat you to continne to give me such proofs of your friendship, as often as you think they will be useful to apprise me of the public expectations, or any omissions or faults into which I may fall." The delay in issuing commissions is due to the fact that ninety-five men, to whom they have been offered, have not answered McHenry's letters and the relative rank can not be settled, until all are heard from. To issue a partial list of commissions would be a questionable proceeding. The delay in recruiting was due, first, to the pestilence in Philadelphia; next, to the troubles concerning Hamilton and Knox; thirdly, to the condition of the federal treasury. The United States cannot furnish sufficient white cloth for vests and overalls. The purveyor has as many men as he can get making clothes. Lastly, the president's procrastination and opposition to the expense of the army have delayed recruiting. Adams has said, "Why

1 Ford, xiv, 166 ; Sparks, xi, 413, 420. March 31. 
should any one enlist for $\$ 5$ per month, when he ean get $\$ 15$ at common work" and that "there was no more prospect of seeing a French army here than in heaven." "The situation into which I have been thrown, during the past year, by others, who prevented all those measures from being carried into effect, which the public expected would necessarily take place in conformity to the laws, could not fail to attach to me much censure and excite in the minds of persons, who could not be informed of the facts, that I wanted capacity for the proper conducting of my department."

Washington was satisfied by McHenry's defense of his official conduct and answered, "While I was at Philadelphia and since, when I heard your conduct arraigned, for not having the angmented force organized sooner, and for the consequent delay in recruiting; I did then, and on all other proper oceasions, declare that circumstances over which you had no control were the causes thereof and that no blame ought to be attached to you." About the delay of the commissions, however, Washington felt something must be done. If the department of war waits to receive answers to its letters, "months, nay even a year," may be consumed.

"Those who live in Post Towns - near Post Offices - or who are in the habit of enquiring at these places for letters, would have been enabled to answer your address to them in time; but a number of others may be uninformed of your letter to them at this hour - especially as many of them have been sent to wrong offices, \& will only be heard of by the advertisement of them."

To avoid this delay, he suggests the insertion in the newspapers, which nearly every one sees, the names and grades of the men from whom no answers come, with the request that such persons reply without further delay.

On April 23, Washington sent MeHenry word that he approved of his plans, but regretted greatly that the favorable moments for recruiting had passed. He spoke of certain officers and assured McHenry that his own purpose was merely to have the general good advanced. ${ }^{1}$ Adams left Philadelphia early in the season. On Mareh 29, he wrote ${ }^{2}$ McHenry asking that a record of vacancies and recommendations be sent him, before any army appointments be made, and, on April

1 Ford, xiv, 174 ; Sparks, xi, 420.

2 Adams, viii, 629 . 
1, Wolcott ${ }^{1}$ wrote Hamilton, "We have no President here and the appearances of languor and indecision are discouraging to the friends of the government." He complained of McHenry who "does the best in his power, yet his operations are such as to confirm more and more a belief of utter unfitness for the situation."

The tireless Hamilton transmitted, on April 8, a plan ${ }^{2}$ for improving methods of procuring and issuing military stores, which plan McHenry approved, thinking it like that of the Revolutionary army and thus supported by experience. ${ }^{3}$ Courts martial caused some concern, as the United States were not now in a state of general hostility, nor at war; Hamilton transmitted ${ }^{4}$ a sentence against a deserter without acting upon it, though he thought an example should be made, and asked $^{5}$ that sentences be not referred to him, where the courts were instituted by the department and not by him. Adams was inclined to show clemency towards deserters sentenced to death and the proceedings of courts martial, at times, showed "culpable ignorance of the rules of war." On May 27, Hamilton wrote McHenry ${ }^{6}$ that desertion prevailed to a ruinous extent. The remedies for it are a greater attention to discipline, ${ }^{7}$ to which Hamilton will look; better care in furnishing supplies, to which McHenry will doubtless see; forbearance to enlist foreigners, and energy in punishment of offenders. As to the last, Adams should be urged that severity is indispensable to uphold discipline. ${ }^{8}$ McHenry answered at once ${ }^{9}$ agreeing to Hamilton's arguments, stating that one of the deserters should be executed and that apprentices should not be enlisted. To this last point, Hamilton agreed. ${ }^{10}$ On the question of executing the deserter, considerable correspondence passed. Adams wrote ${ }^{11} \mathrm{McHenry}$, that he did not object to sentencing such persons to death, but wished to be sure that the officers of the court martial were regularly commissioned and objected to the fact that it accepted a plea of guilty.

1 Hamilton, vi, 406.

2 Hamilton, v, 247 ; Lodge, vil, 69.

3 Hamilton, v, 252 ; Hamllton, v, 248 . On the 17 th, Hamilton notified McHenry that he was coming to Phlladelphia for a personal conference.

4 Hamilton, v, 249. April 20. Lodge, vil, 76 .

5 Hamilton, v, 250. April 23. Lodge, vii, 77.

6 Hamilton, v, 263 ; Lodge, vii, 88 .

7 IIcHenry had suggested this step on May 9 and Hamilton adopted it in his letter of the 25 th. Hamilton, v, 261 ; Lodge, vil, 87.

8 Hamilton, $\mathrm{v}, 264$.

9 May 28. Richard Hunt.

10 May 29 .

11 June 5 . Adams, viit, 654 . 
MeHenry was doubtful as to the regularity of the commissions and Adams replied that he will approve the death sentence, if the court be considered regular by the unanimous vote of the heads of departments. ${ }^{1}$ A month later, Adams wrote that another deserter should be hung and, probably, also the one first spoken of, but that the question should be submitted to McHenry's colleagues. ${ }^{2}$

The cabinet thought the judgment of the court martial probably legal and Adams finally left the question of clemency in McHenry's and Hamilton's hands. ${ }^{3}$ Unless they advised mercy, the man should be hung. McHenry consulted Hamilton as to this and found the latter to incline towards leniency. ${ }^{4}$ "The temper of our country is not a little opposed to the frequency of capital punishment. Public opinion in this respect, thongh it must not have too much influence, is not wholly to be disregarded. There must be some caution, not to render our military system odious, by giving it the appearance of being sanguinary. Considering the extreme lenity in time past, there may be danger of shocking even the opinion of the army by too violent a change. The idea of eruelty inspires disgust and, ultimately, is not much more favorable to authority than the excess of lenity." So Hamilton proposed merely to degrade the deserter, unless McHenry sent word to the contrary. In the early autumn, Adams authorized. 5 MeHenry, if he desire to do so, to pardon, at the foot of the gallows, a soldier who was not only a deserter, but aided two prisoners to escape from confinement, when he was sentinel in eharge of them, and lost his own arms anù accountrements. A noteworthy question as to duelling led to a letter from Lee to McHenry.

"Sir

"Office of the Attorney General "Philadelphia 26 april 1799

"I had the honor to receive your letter of the 9 th. instant which, enclosing a statement of the case of Captain Vance, propounded several questions to which my answer is requested.

"The challenge contained in Capt Vance's letter of the $2 \mathrm{~d}$.

1 Adams, vi, 659. In another irregular court martlal case, which occurred about this time, Adams instructed McHenry to approve of the dismlssal from the service of the men court martialled. Adams, vili, 656 .

2 July 13. Adams, vili, 665.

3 Adams, viii, 667 .

4 July 29. Hamilton, v, 289; Lodge, vii, 100.

5 Adams, ix, 30 . 
of april to Mr. Simmons is expressly predieated by Capt. Vanee on the expressions of Mr. Simmons threatning to punish him personally as soon as the trial before a court martial should be concluded. If these expressions were used by Mr. Simmons, I do not know how it is possible they can have been either necessary or proper in the exercise of his official duties as aceountant in the war department, and especially if uttered in the absence of Capt Vanee. Though the latter part of the letter alludes to the motives which he ascribes to MIr. Simmons for the part he took in prosecuting him before a court martial on another charge, yet the ehallenge appears to me to have proceeded from the threats of personal punishment declared by Mr. Simmons in the presence of Capt Butler. If these threats had not been expressed, there is no probable cause to believe the challenge would have taken place. The affair is therefore to be eonsidered as a private one, to which the principle of protecting eivil officer's in the discharge of their official duties, from the resentment or violence of military officers ought not to be extended. Consequently the president, in my humble opinion, onght not to be advised to dismiss Capt. Vance from the service of the United States before a trial, nor ought a trial before a court martial to be ordered of his transaction.

"The letter undoubtedly amounts to a challenge, which is by the laws of Pennsylvania deemed an offence, that is cognizable and punishable in the ordinary courts of eommon law jurisdiction.

"There certainly are cases where an officer of the army should be made to answer before a court martial, for his misconduct or crime in relation to other eitizens; as for instance if he should, with the aid of the soldiery seize, and punish with stripes of his own motion a eitizen of the United States, or if he should steal the property of a eitizen, or eommit any other enormity manifestly degrading to the station of a Military officer : the present ease is not in my opinion to be considered of this kind.

"The sentence of a military eourt in the ease of Capt. Vance and Mr. Simmons, would not be a legal bar, to a proseeution in a eourt of eivil jurisdietion.

"I have the honor to be sir your most

"obedient servant

"Charles Lee" 
Adams felt ${ }^{1}$ that MeHenry's doubts as to whether the president could appoint to newly created offices in the recess of the senate were ill-founded and said such appointments were his right and duty. Hamilton differed from this and wrote ${ }^{2}$ McHenry that the president had no power to appoint the new officers in the recess, as no vacancy existed. A vacancy is a power to fill a place, after a casualty, not to make an original appointment. Lee, the attorney general, agreed with Hamilton, although the title of the act anthorized the president to "fill certain vacancies in the army and navy," and Adams decided ${ }^{3}$ that, as there was a difference of opinion and no need of haste, he would defer appointments until the senate should meet.

McHenry, therefore, asked ${ }^{4}$ Hamilton's opinion as to the best rule to be adopted, with reference to promotion of officers in the twelve additional regiments, and received the following replies:

"Philadelphia April 26th. "1799

\section{"Dr. Sir}

"I have reflected, as you have desired, on the most proper principles for regulating the relative rank of the field officers of the Twelve additional Regiments.

"It is always prudent, when no special reasons dictate a deviation, to adopt for cases of this kind a rule which steers clear of comparison of personal merit and avoids the danger of wounding the pride of any of the parties concerned. With this view (since I am not aware of any special reasons that recommend a different course) I am of opinion that as to all such of the Field officers, who have served in the army of the U. States, it will be advisable, among those now of equal grade, to let their relative rank at the close of the war govern. This, according with military prepossessions, will be most likely to be satisfactory to all.

"As to those who may not have served in the army, considerations of personal merit and weight of character can alone decide, except that where they may have served in the service or Militia, other things being equal, their relative rank there may guide.

\footnotetext{
1 Adams, viii, 632. April 16.

2 Hamilton, v, 255. May 3. Lodge, vii, 80 .

3 Adams, viii, 647 . Letter of May 16 .

4 Hamilton, v, 250 . Letter of April 23.
} 
"As between those who have served in the army and those who have not, it appears to me expedient to prefer the men who have served in the army, except where very superior qualifications may manifestly claim a superiority

"With great esteem \& regard

"Yrs Obedly

"A HaMitTon"

\section{"Dr Sir}

"Philadelphia April

$$
\text { 26. } 1799
$$

"I have a second time matmrely reflected on the proper rule for promotions in the army, and I continue to adhere to that which was adopted by the General Officers last winter, \& which is recapitulated in your letter. I am persuaded that, in the general course of things, it will work well and satisfactorily

"A moment's hesitation as to its universal application arose from the situation of the four Regiments of the old establishment. The understood rights of

The promotions to field officers should be complete before the rule is applied the older Captains, as resulting from past usage may appear to be enfringedBut this inconvenience must be encountered - perhaps mitigated by a distribution of the oldest Captains among the four Regiments. 'There cannot with propriety or order be two Rules - That which is proposed will after a little time operate favourably every where \& give equal chances.

"With great esteem \& regard

"I am Dr Sir

"Yr obed servt.

"A Hamilton",

Hamilton was urgent, 1 before he left Philadelphia, that the artillery regiments be organized into companies and disposed of and submitted MeHenry a plan for this, asking that MeHenry settle the arrangement and communicate it to the major generals. MeHenry wrote Washington, on April 29. of the promotion plans and that he will now push the 
recruiting and the supply of clothes. As to the speed of the preparation of clothing, Hamilton was very sceptical and wrote on his return to New York:

\section{"My Dear friend -}

"New York April 30. 1799

"I hear of no cloathing arrived. The recruiting service is now actually begun here and elsewhere. I trust that the cloathing and other articles will certainly reach the Regimental rendezvouses before any of the men are there. It will be a discouraging omen, if it proves otherwise. I beg you to appreciate the importance of having the articles forwarded as soon as they can be, even to those places where the business is not yet completely organised, in the reliance that what remains to be done must be quickly completed.

"P. S.

$$
\text { "Yrs. truly, }
$$

"I find by a return of Cloathing just received from. Mr. Hodgsdon that the process in preparing the Cloathing continues to be very slow - proving more \& more the expediency of ehanging the button No. 1 on the six hundred and odd suits - I pray you to let such articles as are ready be forwarded to the several destinations, for it will damp extremely the recruiting service which is now begun, if the supplies for the recruits are not ready to be delivered to them - fast as they may be raised."

McHenry suggested, on April 29, that Hamilton correspond with Washington. He did not know that his friend was so doing and that the correspondence was not always friendly to him. Thus, on May 3, Hamilton wrote: "It is understood that the President has resolved to appoint the officers to the provisional army and that the Secretary has thought fit to charge the Senators ${ }^{1}$ of each State with the designation of characters." The clothes are still delayed and report states that Adams and Wolcott do not wish to accelerate the raising of the army. Yet, if McHenry's "energies for execution were equal to his good Dispositions, the public service under his care would prosper as much as could be desired. It is only to be regretted that good dispositions will

1 This reference to senators produced trouble in New Hampshire. Lodge's Hamilton, vil, 79 ; Granite Monthly, xxxviii, 123. 
not alone suffice and that, in the nature of things, there can be no reliance that the future progress will be more satisfactory than the past."

On May 5, Washington wrote ${ }^{1}$ McHenry that, while the officers who lived near the capital should draw pay from the time of their acceptance, they should not hold relative rank from that date, for such a course would be most unjust to officers appointed from a distance.

Two days later, Adams wrote concerning appointments. "Merit I consider, however, as the only true scale of gradation in the army. Services and rank, in the last war or in any other war, are only to be taken into consideration, as presumptive evidence of merit, and may at any time be set aside by contrary proofs." 2

Hamilton wrote constantly. What shall be the disposition of troops for the summer, why does not the accountant pay money more promptly, why should not the colonels recommend officers for promotion, why not annex Maryland to Pinckney's command and give Hamilton command of all the forces in the West? ${ }^{3}$ Such are some of the queries which are sent during the early days of May. MeHenry answers and gives various directions that Maryland had better not be taken away from Hamilton's command at present, that enlistments are for five years, that the colonels are to recommend, but that even they are not exempt from partialities, that no foreigners are to be enlisted, if it can be avoided. 4 $\mathrm{He}$ is also busy making contracts for the supply of rations to the forces. About this time, 5 Washington wrote, concerning the officers to be appointed from Virginia, whom he had been asked to select. He feels not sufficiently acquainted

1 Sparks, xi, 426; Ford, xiv, 174. He approves of McHenry's plans for promotion. May 2, McHenry wrote, asking who should suggest officers from North Carolina, where the governor was not sufficiently impressed with the need of real federal men.

2 Adams, vill, 640 .

3 May 30, McHenry informed Hamilton that Tennessee would be under Pinckney. York.

4 May 23, McHenry asks Hamilton to recommend officers from New "Sir,

Tay 13, Sparks, xl, 429. Sparks leaves these sentences unprinted:

"Sir,"Your favour of the 2d. inst. concerning dispatches of the 10 th ulto. was brought to me by the messenger who carried my letters to you (of the 5 th \& 6th.) to the Post Office in Alexandrla. * * * There are many matters necessary for me to settle before I could leave home with any tolerable conveniences, and many things, the providing of which would run me to an unnecessary expence, if I am not called to the Field. * * "

Sparks, $x 1,447$. August 12, Washington wrote that there was no $\mathrm{im}$ mediate prospect of officering the Virginla quota unless some other method of finding officers be provided. 
with the people to do this alone, but has summoned the aid of Generals Morgan, Lee and Marshall, and Colonels Heath and Carrington. The task is delicate, for he must find whether men will accept positions, which may not be offered them. He suggests, therefore, that the war office give public notice that it may have to raise the twenty-four additional regiments and that it requests that "all those, who are desirous of serving their country on the terms specifier in that act, would signify the same" to Washington, or to whomever the department should appoint in any state to receive the applications. These applications should be in writing and accompanied by testimonials and would be of great use in selecting persons to receive appointments. Washington thinks, from Adams's acts, that "stronger indications of hostility have been received" and asks to be told at once, if this be so, that he may prepare for active service. He also urges that the "most prompt and pointed attention be given to the procuring and instructing" men in artillery and engineering; in which the "great advantage of the armies of France" lies. MeHenry answered, six days later, that he feared to advertise for officers, lest people should say the service was unpopnlar. To this subject, Washington recurred in a letter of June 6, enclosing letters from Marshall and Lee, which show they can be of little assistance. He promises to pursue the search for officers from Virginia to the best of his ability. Washington transmits ${ }^{1}$ a number of applications for appointment as officers and discusses them, reverting especially to the position of chief of engineers, for which he thinks no Frenchman ought to be employed at this time.

We also learn of Virginia matters from a letter sent from Charlottesville on May 3 by John Nicholas.

"Your inclosures of the Commissions to the Officers of Capt. Hay's company of volunteer rifleman, together with a letter to myself, \& another to Cap Hays, have been duly received; the delay of which I can readily believe imputable to no other cause than those you have assigned. The propriety of the govt's giving incouragement to federalism in this quarter of the Union, where its' sparks, I am sorry to say, are too rare, can not be unknown to those in the President's and your situation. It was my great zeal for those principles \& that conduct which I have ever approved of in the administra-

I Sparks, $x i, 432$. 
tion of our govt., I undertook to recommend the volunteer corps of riflemen of Albemarle; \& an not a little gratified, I can assure you, to find that recommendation has met the approbation of the President \& yourself, altho' all " the requisites of the law have not been complyed with." Those requests shall be attended to, \& the necessity of a complyance with them fully impressed on that little band, which I will also endeavom to have encreased. But I have to inform you, which is the principal object of troubling you at present, that the 'printers copy of general regulations,' mentioned in you: letter to me, was not inclosed: owing, no doubt, to the variety $\&$ multiplicity of other and more important business of your department. You will, therefore, oblige me by inclosing a copy of those regmlations as soon as the business of your office will admit.

"You will, before you receive this, have learnt the stats of our elections. As far as they are yet known, there is great reason to hope we shall obtain a federal majority from this state. At any rate we have secured Marshall (\& Goode in the room of $\mathrm{T}$. Claiborne) two important changes. I have lost my own election by a very great majority, owing to the powerful influence, the well known opinions and great exertions of my good friends \& much admired patriotic Countrymen T. Jefferson \& James Monroe: but if I mistake not, the first of those gentlemen will feel the influence of a majority of the citizens of his own state against him at the next election for a vice president. I flatter myself the northern states will join us in the election of Marshall or Pinckney to that office; \& in case of our present good old president's declining (which God forbid) either those two, or Hamilton \& one of them to the two offices.

"With due consideration, I am Dr. Sir

"Your most obedient huble servant"

Washington wrote again about his uniform ${ }^{1}$ on June 7 .

Mount Vernon 7th. June 1799. Private)

When I began the enclosed letter (left open for your perusal) I intended to addres it to Colo. Biddle; who transacts all matters of that sort for me in Philadelphia; but as I wrote on, it occurred that, possibly, the Quarter Master might be a more appropriate character to accomplish my order:- for this reason, I have left the letter without a Superscription, in order that you might direct it to the one, or the other as you shall deom best. - and I give you this trouble for the reason which is assigned on it: and for which, \& troubling you with such trifles. I pray your excuse.

I had thoughts once, of asking Genl. McPherson to execute this Commission for me: (believing, thereby, that it would be well done) but never having been in the habit of corresponding with him, I declined it, 
The question of uniform was an engrossing one. Hamilton had written MeHenry ${ }^{1}$ that he did not like the hats provided for the soldiers. "Nothing is more necessary than to stimulate the vanity of soldiers. To this end a smart dress is essential. The Federal government ean afford to provide this and should do so." He urged also that arms be speedily provided and no time be lost in teaching the recruits their use, in performing guard and other duties. The provision of supplies was still tardy and Hamilton wrote concerning this:

"private \& confidential

New York June 14. 1799

"I use, my Dear Sir, the privilege of an old friend to write to you in language as explicit as the occasion requires. The fact is that the management of your Agents, as to the affair of supplies, is ridiculonsly bad. Besides the extreme delay, which attends every operation, articles go forward in the most incomplete manner. Coats withont a corresponding number of vests. Cartouche boxes without belts \&c \&c nothing intire - nothing systematic. Tis the scene of the worst periods of our revolution war acted over again even with earicature.

"Col Stevens tells me that lately materials for tents were purchased here and sent to Philadelphia. This is of a piece with what was done in regard to eloathing and it is truly farcical - proving that the microscopic eye of the purveyor can see nothing beyond Philadelphia. It is idle to pretend that the materials in such cases cannot be made as well elsewhere as at Philadelphia and that double transportation and the accumulation of employment in a particular place beyond its means can tend to economy or any other good end - and the delay is so enormous as to overballance any minute advantage, if any there be, that attends the plan.

"It is a truth, My Dear Sir, and a truth which you ought to weigh well that, unless you immediately employ more competent Agents to procure and to forward supplies, the Service will deeply suffer and the head of the War Department will be completely discredited.

on reflection; - and of course the Stars for my Epaulets have stood suspended, \& I would thank you for sending them to me; - and if it is not heaping too many trifles upon you, also for requesting Mr. McAlpin (if he has been able to obtain the gold thread) for letting me have my Uniform Cloaths by the Anniversary of our Independence - forwarded in the manner he has heretofore been directed. I am always and very Affectionately Yours

Go. WASHINGTON.

1 Letter of May 18. Hamilton, v, 256; Lodge, vii, 80. 
“The object will very soon be much enlarged to an extent to which such men and such measures can never suffice.

"You must immediately get a more efficient Purveyor \& I believe a more efficient Superintendant - or nothing can prosper.

"My frankness \& plain dealing are a new proof of the cordial friendship which I must always cherish for you Adieu

"Affect yrs

"A Hamilton"

McHenry replied, on the next day, that Hamilton's attacks on the purveyor ${ }^{1}$ and superintendent ${ }^{2}$ are but too well founded. He expects to appoint an assistant to the former but the latter "has so strong a supporter, that I dont see how to get rid of him."

McHenry was much interested in the development of a permanent laboratory, or arsenal, in Philadelphia and wrote to have Captain Elliott sent there. He also enquired why Major Toussard should be sent to the Potomac, instead of completing the duty which McHenry had assigned him.

Hamilton answered McHenry's letter thus:

"Dr. Sir -

“New York June 17. 1799

"Your favour of the 15th. is received. I am very glad you have determined on changing the Purveyor. I think it likely that Mr. Williams will be a good substitute.

"As the subject of the Q. M. G' - removal to the seat of Government began with you. I think it best that you should write the definitive order.

"My instruction to Major Toussard only communicated his eventual destination. It was my idea that he should first execute the duty to which you had assigned him. I shall take care that there is no misapprehension.

"I have not time to recur to my letter ordering Capt Elliot to Philadelphia. But I believe the idea was included of his calling upon you for orders. The inclosed will settle the matter

Yrs. Affecly

"A HaMilton",

In his frequent letters to McHenry, Hamilton urged the sending of supplies and bounty money $;^{3}$ suggested that there:

1 Tench Francis.

2 Colonel Stevens.

3 Hamilton, v, 272. Letter of June 18. 
be fast sailing vessels and signals before the principal ports, that we be not entirely surprised by the enemy; and, continually pressed for steps to be taken to increase the supply of clothing and tents. If blue eloth cannot be found ${ }^{1}$ in sufficient quantity to avert the terrible delays, he proposes to take some other color for whole regiments. The delay in raising cavalry seemed to Hamilton especially grievous and he suggested raising one troop and enlisting the non-commissioned officers of the other and then enlisting all the officers for instruction and exercise. ${ }^{2}$ Cavalry tactics must be established. That arm of the service is not brought to perfection even in England. This plan McHenry thought well of, but seems to have done nothing at the time, from a desire to husband his means and guard against interrupting the infantry recruiting. ${ }^{3}$ Hamilton thought the engineers and artillery should be separated and complained ${ }^{4}$ that the artillerists were not uniformly drilled. About this time, McHenry proposed to offer Count Rumford the positions of lieutenant colonel and inspector of artillery or of engineer and superintendent of the proposed military school, a project McHenry had at heart. Adams approved of the plan and McHenry made proposals to Rumford, through Rufus King, but without success. Rumford had written King suggesting that he would be happy to present to the proposed military academy of which King had told him, his collection of military books. King thereupon wrote McHenry suggesting that Rumford wished to revisit America and that his experience might be useful for the academy. McHenry at once conferred with Adams and on his consenting to the offer, asked Rumford, through King, to take charge of the academy, but Rumford, after considering the matter, declined to accept the position and King on September 28 transmitted MeHenry this declination. ${ }^{5}$

From Litchfield, Connecticut, Uriah Tracy sent cheerful news of the recruiting on June 10:

“*** The recruiting Officer in this Town has nearly his number, \& can have the whole in an hour, but I have advised him to wait a little \& pick the best. He has a fine set of stout

1 Hamilton, v, 271. Letter of June 16. Lodge, vil, 94.

2 June 21 and 25. Hamilon, v, 275, 276 and 278; Lodge, vii, 95. July 2, Hamilton wrote again. Hamilton, v, 284.

3 July 27. Adams, ix, 4.

4 Hamilton, $v, 278$. Iftter of June 28. Adams, vili, 660 . Letter of June 24.

5 Ellis's Life of Rumford, pp. 352 to 359 . 
orderly Yanky's as you would wish to see - and the recruiting is very successful all over the State - as I am informed.'

"N B. Are we to have a minister from France? If so, ought not the Senate to be eollected?"'

He wrote again from Litchfield on June 24:

“*** In the county where I live, there is one eompleat company raised, \& three more ean be raised here in a month, altho' the busiest season of the year - \& in next autumn, I can raise a Regt. here in this single eounty in a month - \& they shall all be natives, \& the best of men for activity, size, \& character. This looks like bragging, but it is not so. I declare it is a sober statement of faets, as I really believe. Capt. Ramsey, the recruiting officer here, informs me he is troubled to get rid of men, who wish to inlist - \& that he could have inlisted 200 by this time, had he had money \& clothing. I will write to Mr. Sedgwiek, but not diselose my knowledge of his letter.

"If the Devil should send a French Minister to the U. States - altho' I dread a journey to, or stay at Philada. in the hot season, yet by all means let the Senate be eonvened. I had rather risk it, than not to have it in my power to say at once, as I will most certainly, that he ought, be he who he may, to be sent directly back again. I will not consent to say a word to a French Minister on the subject of negociations. I sineerely wish it were so, that the Executive could \& would dismiss him instanter. If he offered an indemnity for past injuries I would aceept, but go no further, we want no contract, league, or covt. with that set of wretches.

"I trouble you often, \& now with a long letter, your goodness will excuse me."

Even there, however, there was complaint concerning supplies, as we learn from a letter written at Litchfield on June 17, by John Allen :

"Your favour of the 12th. relative the proposed Contract for officers shoes is duly reed. It furnishes me, too, with the knowledge of the Cause of the very miserable manner in which the soldiers are supplied with that artiele. Capt. Ramsey, who is stationed at this place, unites his protestation with those of his men against the scandalous frauds practiced on them. The shoes which have been dealt out to the men here, \& I understand the same to be the faet at all the other stations, are of the very worst leather and, worst manufacture. A march of 20 miles would totally ruin the greater part of them 
- and the heels of many of them drop off immediately on handling them. The hats of the Soldiers are of the same quality, a rain or two has rendered several of them utterly useless - and the Cloaths are but little better, particularly in the making.

"By these things the public service is discouraged, \& the Government itself disereditted. Very many respectable people impute these defects to circumstances that should not be often named - they surely deserve, \& I trust will undergo a rigid scrutiny - they must be traced to their source.

"Permit me also to inform you that the recruiting service has met with very handsome success. Capt. Ramsey, here, already has 56 fine fellows. But Sir, why are they not furnished with Arms? The appearance of so many soldiers scattered thro' the Country, part of them only properly elad, $\&$ none of them with Arms, makes the whole business assume too much of the air of a farce. The people call out for more promptness \& energy in their business - and really, sir, if the Administration is to be saved from contempt \& ridicule of the Country it must be by a more vigilant \& irresistable pressing forward of the proper measures.

"I am induced to write thus plainly by the Murmurs of both Citizens and Soldiers, and which the Interest and honour of the Government demand there should no more causes for."

There were obstacles at Philadelphia, whence McHenry wrote Hamilton ${ }^{1}$ that Wolcott had prejudices against augmentation and said the revenues were inadequate, that either the army or navy must be suspended or dropped, and contemplated a statement on these points to Adams. MeHenry felt that "peace, honour, and respect, at home and abroad, depends upon the permanency of our litle army" and intended to press forward, as he could. Pickering seemed favorable to vigorous measures and MeHenry thought of writing paragraphs for Fenno's newspaper, showing "the necessity of our army." He exhorted Hamilton to "keep up, among your Eastward friends, a due sense of the propriety" of action.

At this time, Hamilton wrote ${ }^{2}$ "It is a pity, my dear sir, and a reproach that our administration have no general plan. Certainly, there ought to be one formed without delay." Among other things it should be agreed what precise forces should be created, land and naval, and this should be

1 Hamilton, vi, 408 . Letter of June 26.

2 Hamilton, v, 283; Lodge, vii, 99. 
proportioned to the state of our finances. We should have 6 ships of line and 20 frigates and sloops of war. He offered to come to Philadelphia, if advisable, and try to form a general plan, in consultation with the cabinet, feeling that, if the chief is too desultory, the ministry ought to be united and steady. " "Besides eventual security against invasion, we ought certainly to look to the possession of the Floridas and Louisiana and we ought to squint at South America.' The United States has money enough to do what is needful. McHenry felt the truth of this last statement and wrote Adams : ${ }^{2}$ "Being a nation and, not of the lowest order, there are 3 things essential for the maintenance of our proper grade among the powers of the earth: (1) An army and means adequate to its support, (2) A system calculated to keep its wants regularly supplied, (3) Genius in the general who commands it. If we can combine these things with a navy, and I believe we can, we shall have nothing to fear from without or within."

A sportive side of the war is found in MeHenry's sending Washington and Hamilton small boxes ealled the game of Tactics containing military figures, as a substitute for chessmen. In acknowledgment, Hamilton wrote:

$$
\text { "June 21, } 1799 .
$$

"I thank you, My Dear Sir, for the military figures you have sent me. Tactics, you know, are literally or figuratively of very comprehensive signification. As people grow old, they decline in some arts, though they may improve in others. I will try to get Mrs. Hamilton to accompany in games of Tactics new to me. Perhaps she may get a taste for them \& become better reconciled to my connection with the Trade. Militant.

"I will endeavour to get the Book you mention. "Adieu Yrs.

$$
\text { "A. H. }
$$

"In answer to a private letter long since received from you, I ought to tell you that I am in the habit of writing to General Washington."

The postscript shows a slight shame that he had concealed this correspondence so long.

1 McHenry wrote Hamilton "The army and the expenses attending it are not to all equally desirable. The Secretary of the Navy has no objection to a few regiments, but thinks the rest of the revenue would be better applied to the marine. I go on."

2 Adams, vili, 662 . 
Another point urged by Hamilton was the promotion of Wilkinson to the grade of major general. MeHenry did not trust Wilkinson, and even Hamilton urged the promotion, chiefly, because it would be good policy to avoid all just grounds of discontent and to make it the interest of the indi. vidual to pursue his duty. ${ }^{1}$

"Half ${ }^{2}$ confidence is always bad." Hamilton wrote: "This officer has adopted military life as a profession. What can his ambition do better than be faithful to the government if it gives him fair play?" McHenry answered ${ }^{3}$ that he would not oppose the promotion, if Washington desired it, but wished nothing to be said of the matter to Wilkinson and added, "until the commercial pursuits of this gentleman, with his expectations from Spain, are annihilated, he will not deserve the confidence of government." Washington asked MeHenry how the promotion would be made and was ${ }^{4}$ told that he should recommend it, in an official form, to be laid before the president. Washington declined to do this, saying that other officers had been appointed to important places, without consulting him, and there should be consistency in the course of the administration. He especially objected to shouldering the responsibility, in doubtful cases such as this. ${ }^{5} \mathrm{He}$ also regretted that Howard and Lloyd declined to recommend offcers from Maryland and said he did not know the people of that state well enough to do it himself. Even in his own state, as the secretary would not advertise for applicants, Washington finds a difficulty in obtaining suitable men, which could be avoided only by dividing the state into districts and committing the recommendation from each district to some one man. ${ }^{6}$

1 Letter of June 15. Lodge, vii, 92. On promotions see Hamilton's letter to McHenry of June 15, printed in Lodge, vii, 98.

2 Hamilton, $v, 278$.

3 Letter of June 27 . See Washington's letter to McHenry of June 25. 4 Letter of June 29.

6 A little later Washington wrote : "Private)

"My dear Sir,

"After reading, and putting a wafer into the enclosed letter, be so kind as to send it as directed. -

"The young Cornet (in my family) is anxious to receive his Milltary equipments. Daily fruitless enquiries are made of me to know when they may be expected. -

"Perhaps if you were to jog Mr. Francis, the Purveyor, the sooner they might be purveyed and the young gentleman gratified.

"I wish them to be handsome and proper for an Officer, but not expensive. In my last on this subject I requested that the Sword might be silver mounted. Yet any 6ther mount, such as the Officers of Cavalry use, would answer just as well. With esteem and regard - I am always "Your Affect Humble Servant

"Go. WASHINGToN." 
The plan which IIcHenry sent Adams on ${ }^{1}$ June 29, for providing and issuing military supplies, seemed to Adams one which the presidential authority alone was not adequate to establish and he wrote McHenry, asking whether he wished the project adopted by congress, and that he look into it carefully with Wolcott and Pickering, before recommending it for enactment as law. Adams refers to McHenry's zeal for his department thus, "As it is an excellent principle for every man in public life to magnify his office and make it honorable, I admire the dexterity with which you magnify yours, by representing an army and means adequate to its support, as the first thing necessary to make the nation respected."

MeHenry 2 wrote to Samuel Sewall, chairman of the committee of defence, on June 28, 1799, stating that, as the ordnance is in bad condition, and the secretary of war cannot visit foundries, ete., there should be an inspector of artillery, to see that contracts are properly carried out. He took up the subject of a military academy and stated that instructors in arithmetic, geometry, mechanies, hydraulies, and designing are needed to teach artillerists and engineers the art of fortification.

Natters went far too slow for the assiduous Hamilton, ${ }^{3}$ who wrote on July 10:

"Why, My Dear friend, do you suffer the business of providing to go on as it does. Every moment proves the insufficiency of the existing plan \& the necessity of auxiliaries. I have no doubt that at Baltimore, N York, Providence, \& Boston additional supplies of Cloathing may promptly be procured \& prepared by your Agents \& it ought to be done,

1 Hamilton, v, 285; Adams, vili, 662.

2 State Papers, Military Affairs, i, 128.

3

$M y$ dear $M a c$

New York July 15. 1799

If Meade was here he would tell you there never was an Irishman but would now \& then discover the potatoe on his head-

I did not mention the particulars you cite in the case of the Hollander. because the very necessity of troubling you on the subject implied that he was not naturalised \& was without the letter of the Regulation

Agreeably to your permission, I shall give a special authority to Col Ogden to enlist the man in question.

Yrs. truly A $\mathrm{H}$

My dear Ham. If you will read your case you will perceive it was impossible that I should find the Hollander within the spirit of the regulations $\mathrm{w}$ here you seemed to have placed him. If it had been so I should have tho't a special permission unnecessary. 
though it should enhance the expense. 'Tis terrible at this juncture that there should be wants any where.

"So of Tents. Calls for them are repeated from Massachusetts, where better and cheaper than any where else they can certainly be provided.

"Pray take a resolution adequate to the exigency \& rescue the eredit of your Department.

$$
\text { "Yrs Affecly }
$$

MeHenry answered at once, ${ }^{1}$ that recruiting must stop; unless elothes can be provided. Last year, the eontract for clothing failed, because not enough white kersey for vests and overalls could be found in the United States and, this year, no person could be found to make a contract, because of a well founded belief that not enough white and blue cloth could be procured in the United States, in season to complete the needed number of suits before late autumn or early winter. Most of the eloth was imported, after the arrival of the spring vessels, which explains the delay. Now 400 suits per week ean be furnished. Will this number suffice? On the 22nd, Hamilton replied that two-thirds of the quantity of clothes promised would suffice.

Rations and winter quarters for troops also commanded Hamilton's attention ${ }^{2}$ and he wrote concerning them: "My Dear Sir

"I perceive by your letter of the 16th that mine of the 12th has not been rightly understood.

1 Hamilton, v, 288. July 8, letter from Hamilton to McHenry, answering one on questions of rank and promotion. Lodge, vii, 98, see p. 111 for a similar letter of August 25.

2 July 17 , he wrote McHenry about stationing troops where rations were cheapest and July 30 (Hamilton, $v, 292$ ) he sent regulations for delivery of fuel, stationery, and horses, and wrote concerning the barracks. Hamilton, v, 289; Lodge, vil, 107, prints a letter of August 19 about organizing supply departments, etc.

Private

"New York July 1799.

"Dear Sir

"I return you enclosed your draft of a letter dated the 25 th instant to the several contractors \&c - with a paragraph at foot which is submitted to be added for reasons that itself will announce.

"The doubts you mentlon are natural. They had occurred to my mind. But considering that the Public is entirely free as to the stationing of the troops, I think that with candour and good policy the measure may be pursued. "I hesitate whether the invitation ought to extend to the contractors for Massachusetts. Their price is as low as it can well be. The position heretofore intended for three Regiments is in Massachusetts, and it seems just that the moderation of the contractors there should be rewarded by the enjoyment of the advantage. The competition of Connecticut New York \& New Jersey may be excited with a view to the three regiments, which were intended to be placed in the vicinlty of Brunswick.

$$
\begin{aligned}
& \text { "W1th great regard } \\
& \text { "Yrs. truly }
\end{aligned}
$$


"Its principal object was the supply of the present year. This it aimed at cheapening by exciting a competition among the actual contractors, on the ground that the troops, while not required for actual service, might be stationed collectively where the supply was cheapest, as at Brunswick or Trenton in New Jersey, or East Chester in New York or Bristol in Pennsylvania, it being immaterial whether three Regiments are at one or the other of those places and the Government having its option to station them at either. Thus the contractors in Pennsylvania, New Jersey, \& New York might be induced to bid against each other. So the contractors in Maryland \& Virginia, it being indifferent whether the three Regiments shall be on one or the other side of the Potowmack.

"In Massachusetts, the ration is Eleven cents \& five Mills. This is reasonable \& shews how it may be afforded. In the State of Rhode Island it is fourteen Cents. No reason for this difference. In Connecticut it is still higher with still less reason. The three Regiments for the Northern Quarter will of course be stationed in Massachusetts in the vicinity of Uxbridge.

"The Price in New York where issues exceed 400 is 10 eents \& 5 Mills. This is much too high though predicated on the old ration. At Brunswick in Jersey it is 16 cents \& 21/2 Mills predicated on the New Ration. This is higher still. At Trenton it is 16. This is still too high. But the difference ought in my opinion to give a preference to Trenton over Brunswick. I think, however, upon my plan a reduction may be obtained at both places. And 'tis by care in operations of this kind that economy on a large scale will be attained.

"I hope I have now explained myself sufficiently. If your views vary in consequence of the explanation, you will inform me officially - if not privately. And I shall govern myself accordingly. It was my intention to have written myself to the Contractor respecting Winter Quarters, after having settled with you the General Principles. But if you think proper to do so yourself, it will be equally agreeable to me. But I shall be glad previously to know your intention $\&$ submit to you some ideas.

$$
\begin{aligned}
& \text { "Yrs. Affectly } \\
& \text { "A Hamilton }
\end{aligned}
$$

"P S

"My suggestions as to the Contract for next year were 
merely incidental. I had not seen your advertisement as I recollect."

McHenry had written Adams, on July 12, that an army and navy establishment is essential to the present and future interests and greatness of the United States and that "we must run the risks which other nations have run" and Adams agreed to this, but still thought congress must approve the plan for supplying the army. ${ }^{1} \mathrm{He}$ is satisfied, however, to agree with the heads of departments, if they think the powers already given are sufficient. ${ }^{2}$ When dissatisfied with McHenry's department, Hamilton did not hesitate to say so, as is shown by a letter written July 22, on which MeHenry endorsed, "This is not so, this error arises from the articles being forwarded at different times." Hamilton's letter reads :

"The return lately sent me shows strongly the want of system of your Agents. Instead of an equal apportionment, while some Regiments are altogether without certain articles, others have a full, a very ample supply of them. This appears particularly as to Muskets, Cartouche boxes, Knapsacks, \& canteens - with regard to some of these articles, indeed, I know that orders have been given for supplies which do not appear in the return. But as to others, I am not informed of any similar circumstance. I call your attention to these particulars that the inaccuracy may not, in the pressure of your business, escape your observation.

"An apportionment, where all cannot be fully supplied tends to distribute accommodation \& to prevent discontent."

Still Hamilton wrote, ${ }^{3}$ on the same day: "I count always upon your confidence, as well in my personal friendship for you as in my zeal for the public service, and having no inclination to spare myself, it only remains for us to trace together the plan, in which I can best second your operations and promote the service." To this letter, he signed himself, "Yours with true attachment."

Towards the end of July, ${ }^{4}$ Adams wrote to McHenry that he has no objection to raising a troop of cavalry but adds, "I never think of our means without shuddering. The system of debts and taxes is levelling all government in Europe. We

1 July 18. W. S. Smith sent McHenry his revolutionary record On August 10, McHenry wrote him that no allowance was made for fuel to officers.

2 McHenry submitted the question to Pickering on the $21 \mathrm{st}$

3 July 36 , Hamliton wrote McHenry asking that the routire of promotion be followed and the rules which govern it be promulgated.

4 July $2 \pi$. Hamilton, $v, 288$. 
have a career to run, to be sure, and some time to pass, before we arrive at the European crisis, but we must ultimately go the same way. 'There is no practicable or imaginable expedient to escape it, that I can conceive." At this time, McHenry referred the question of establishing another arsenal to the other heads of departments. The answers of Lee and Stoddert are preserved.

"Sir

Philadelphia 1 August 1799

"1st. I am not satisfied that there is a necessity for establishing a fourth arsenal with magazines at the present time, when the three which have been established, are not carried to the extent of usefulness of which they are obviously eapable. It appears to me to be an unnecessary expenditure of public money, because such an establishment will not for sometime to come be requisite, the three others answering all the present purposes.

" 2 d. The buildings and alterations at Springfield should be immediately commenced.

"3 The buildings at Harpers ferry should be prosecuted.

"4 The buildings at Rocky mount should be commenced.

"I have the honor to be very respectfully your most obedient servant.

$$
\begin{aligned}
& \text { “Charles Lee", } \\
& \text { “Navy Department } \\
& \text { "1 August } 1799 .
\end{aligned}
$$

"Dear Sil"

"I am unwell \& cannot attend the meeting without pain. I will however give you my opinion on the subject of a fourth Arsenal - for I presume it is a fourth - \& that neither of the others are to be declined.

"If the three Arsenals already Fixed on, were completed $\&$ filled with Arms, I should suppose - it might be proper to establish a fourth a fifth \& a sixth - provided there was money - but under present circumstances, I really think it will be most wise, to go on with great spirit, with the three already. determined on, and which, in my opinion are properly placed - One being to the East - One to the South - \& one in the middle of the States - and to let a fourth alone, until these three are filled with arms.

"I think your submission contained a query, whether Work begun at Harpers Ferry should be finished - or whether addl. works should be made there. 
"Judging as an officer of the United States, with a view to the Interest of the whole - \& on this principle only, will I judge while I remain in office - it is most clearly my opinion, that the Arsenal at Harpers Ferry, should there be an difference in point of magnitude in the three, should be the more important - the Mother Arsenal. It is without comparison the most convenient of the three to the Western Country. It is more convenient than either of the other places to all parts of the States. It is nearly in the centre.

"Your submission also, If I recollect right, contained a quere - whether additional Works should be made at Springfield. There is no question with me, that all the works necessary to the object, should be made there, without hesitation or delay.

"To sum up in few words - my opinion is - that the three arsenals, in the places designated by the Genl. officers, viewing with a military Eye, the land, should be pushed with all possible vigor - and that, when money can be spared after filling these, it will be time enough to think of other Arsenals. Exeuse my abruptness. I write in pain. I have the honor to be with great respect Dr Sir Yr ms Obedt Servt.

"Ben Stoddert."

Another diffieulty with Hamilton oeeurred concerning one Captain Frey whom McHenry had ordered to discharge certain men and to report to Major Hoops, commandant at New York. Of this Hamilton wrote: ${ }^{1}$

$$
\text { "N. Y. July } 311799 .
$$

"You will see, my Dear friend, in the case of Capt. Frey, the evil tendency of correspondence, by the head of the War

1 Hamilton had previously complained of McHenry's directly dealing with officers.

"My Dear Sir

"New York May 2d. 1799

"Your letter having informed me, that you some time since encouraged Capt Willing to expect a furlough, and having learnt from him that in consequence of this encouragement he had made arrangements and entered into engagements for the voyage, I thought it would compromit you to refuse the request. I have therefore very much against my own judgment complied. The precedent in my opinion is a bad one. Let me intreat you on future occasions to avoid the occasion of similar embarrassment

"Yrs. Affectly A H"

On October 24, McHenry wrote Hamilton that Elliott wishes his own men at the Philadelphia Laboratory and asked McHenry for them directly. Hamilton was hurt, wished Elliott to go to the field and wrote that, if the "representations of a particular officer, founded upon a detached view of the subject and addressed to the Secretary of War, are to decide in the 1st instance the propriety of the employment of any given force, there will remain very little continuity in our military establishment." McHenry did not yield, but said, "Send any 25 men." 
Department with inferior officers, when there is a superior. For a thousand good reasons, it cannot be too carefully avoided. Perhaps a sudden emergency, when the superior officer is in a situation that recourse to him might defeat the object is the only exception.

$$
\text { "Yrs truly, }
$$

He also issued a general order, stating that Frey exceeded his powers, "Nor can the seeming countenance which was subsequently given to his acts by the department of war vary their real nature. The circumstances which had intervened were probably unknown and a disposition to give facility to the service must be presumed to have caused the Secretary to have overlooked the incompatibility of the proceedings with his instructions." 'This stricture, wrote MeHenry, was not necessary and "should have been avoided. The head of the department of war ought not to be held up in a general order as having been ignorant of or having been inattentive to his duties." "I perceive you entertain an opinion that I have wantonly or ignorantly given orders to inferior officers within the command of their superior. This is not the case, whatever may have been insinuated to you to the contrary.' McHenry "always received from his friend his intimations with, at least a disposition to benefit by them:" but this accusation was unjust. Hamilton's idea of the relations of the secretary and the various officers was as follows: "In my conception, the true rule is this, The Secretary of war and his subordinate agents may correspond immediately on the business of expenditure and supply in its various branches, with all those officers who are charged with it, such as Quartermasters, commissaries, paymasters, and other descriptions of persons, forming what is commonly called the eivil staff, but they ought to hold no communication with any merely military officer, i. e. any officer not attached to the business of expenditure or supply, other than the principal officer of an army or within a military district or command. This rule would confine the communications of the Secretary of war to Gen. Washington and the 2 Major Generals. It is true that there are special cases, in which it may be proper to depart from the rule, such as sudden and unforeseen emergencies, where the public interest or service might suffer by a delay incidental to a communication with the chief and there may be geographical circumstances which may require exceptions, but these ought to be 
previously settled with the chief, defining the extent and the objects - complaints by inferiors of injuries received or supposed to have been received from the chief, but the cases are and must always be supported by some important reason of a special nature."

He had not intended to offend MeHenry and wrote:

$$
\text { “New York Aug. 5th. } 1799 .
$$

"If there be any thing in my general order lately sent you which imputes to the Secretary of War ignorance or inattention, I agree with you, my Dear friend, that it ought not to have been there. I add that, if done with design, it would be a very culpable indecorum. But if it does bear this construction, I have very clumsily executed my own intention. And I give you my honor that so far from being sensible of it, my aim was quite the reverse.

"I have already told you my opinion, that the letter from you to Capt Frye was, in the view of Military Etiquette, irregular. It ought to have been addressed to Major Hoops. If my memory serves me right, it refers to the matter by Capt. Freye \& thus gives him the pretext of your sanction. It was necessary to do away this reference - and at the same time to obviate, on the mind of the army, the idea of irregularity on your part. My object was to reconcile these two things.

" The means, I employed, were these two suggestions - 1 That the incermediate circumstances were unknown to you. In this, you see nothing amiss. 2 That from a disposition to give facility to the service, you overlooked the inconsistency of what was done with your instructions. Does this imply ig. norance or inattention? I think not. Every superior sometimes overlooks, that is forbears to take notice of, the incompatibility of the conduct of an inferior with his instructions, though he clearly perceives (and, consequently, acts neither from ignorance nor inattention) that incompatibility - but willing to give facility to the service in the particular instance he thinks it best to wave any objection to what has been done $\&$ even to give effect to it. In civil \& military life this has happened to myself; and yet to have it stated would not in my opinion charge me either with ignorance or inattention. There may often be geod reason for overlooking a fault which we perceive. To overlook is very different from not to see or not to attend to. It is in one sense to excuse, to forbear to 
punish or animadvert upon And it seems to me that it is plainly in this sense that it is used in the general order. Most certainly it was intended so to be.

"Now let me rebuke you in turn. How would you imagine that I entertain an opinion that you have wantonly or ignor. antly given orders to inferior officers within the command of their superior? It is to injure my friendship for you to suppose that I could think you had wantonly done so. That you may have done so, through want of a strict habit on the subject, or perliaps from some incorrectness of ideas with regard to military Etiquette, I have indeed believed but nothing worse. And I cannot think that this belief ought to give you pain. It only implies that you have not been long enough called by situation to contemplate or practice upon that etiquette to have formed exact notions of it and a habit of conforming to it. I do not myself pretend to be an adept in this species of knowledge; though I have endeavored to systematize my ideas on the subject. They are these, in brief, that the Department of War mav regularly correspond with the Civil Staff or a officer charged with the business of expenditure \& supply in its various branches without passing through the medium of the Chief Military Officer. But that, in all other matters, the correspondence ought to be with them exclusively - saving the case of sudden emergency, in which the object would suffer by using him as the medium.

"Yrs Affecty.

"A. H."

To the latter letter McHenry thus replied on August 10, "I am fully satisfied my dear Hamilton, from what you say, that you had no intention to insinuate in the general order anything that could affect my character in the eye of the public or army and I am no longer uneasy. Upon the other point, let me assure you that the military rule or correspondence, which I have departed from in some instances, as relative to General Wilkinson, did not take place without substantial cause. I am in possession of my justification, were it necessary to stir the subject. There may be, however, particnlar cases, independent of these where I have erred through inattention and, who is it will not, with so much business to attend to as I have." He sends a military text book and adds, "The book has merit. But as Aristotle's rules never produced a good tragedy; neither, in my opinion, will the best military 
books produce a great general. Both characters are the result of the energies of genius."

Meanwhile matters had gone on slowly at Paris. ${ }^{1}$ Lafayette had written MeHenry on April 18, in his joy over the news that the war had been averted for the time, ${ }^{2}$ "I must express the happiness I have felt in hearing that plenipotentiary ministers are going from the United States to bring about a reconciliation with France. I am persuaded, as I have formerly written, that the French Government are in earnest."

MeHenry's own town of Baltimore, where a fort had been established, called by his name, ${ }^{3}$ and destined to become famous in connection with Key's poem, was much concerned about the fortification and Samuel Smith wrote Adams from Baltimore on July 24:

"I Do myself the honor to Inclose you a publication of the Committee of this City, whether it will have the desired effect contemplated I cannot yet determine. The following Expression Induced me to address you. We are informed by the Sect. of War that the Finances of the U. S. did not admit of a larger appropriation than twenty thousand Dollars towards the fortifications to be erected near our City.

"This information is Certainly not Calculated to make a very favorable impression on the public Mind. What will foreign powers think when they are told from the Sect of War that our finances are Such that more than twenty thousand dollars Conla not be Spared to fortify A City known to be of the Commercial Consequence of Baltimore. But is the Secretary correct - on recurring to the Appropriation Laws, I find that, in May 1798, the Sum of two hundred \& fifty thousand dollars were appropriated for fortifying the Ports \& harbours \&, in June following, a further sum of twenty five thousand, making together, with the Amount unexpended of former appropriations, a sum between $\$ 420 \& \$ 440$ thousarid dollars, of which there remained unexpended on the 30 September last, agreeably to the report of the Secty. of the Treasury 326 thousand dolls. And of this last Sum, I am inclined to believe, a. Considerable proportion remain still unexpended. From this Statement, I eannot but hope \& believe that you will be of Opinion that a larger Amount than twenty thousand dollrs.

1 April 20, Adams wrote Pickering approving the statements of the heads of departmens concerning our relations to St. Domingo.

2 J. Adams, viii, 628.

3 There was also a Fort McHenry on the Mississippi. 
ought to be granted. I am informed that the last Estimate States 60 thousand Dollars as the sum required - however, I presume that twenty five thousand, in Addition to that already cxpended, would be as much as Could be expended this summer. With the greatest Respect

"I have the Honor to be "your Obedt Servt"

Adams transmitted Smith's request from Quiney on August 5:

$\because \mathrm{Sir}$

"I return you Col. Hawkins of 23 of May inclosed in yours of 29. July and am happy to find that all accounts agree in holding out expectations of a continuance of Peace with the Indians.

"Inclosed is a letter to me from Gen. S. Smith of Baltimore, dated 24 July with an address to the Citizens of Baltimore from the Marine Committee, in a slip of a Newspaper. I wish that Justice may be done to that City, and that it may have its proportion of Aid in the fortification of it. I wish also to know, What Sum is destined for the fortifications of Castle Island \& Governors Island in Boston Harbour. I wish also to know the plan for appointing Surgeons \& Mates for Garrisons \& Regiments \&c.

$$
\text { "J. Ad.uns.", }
$$

Many of the Federalists were displeased with the French mission and Robert Goodloe Harper wrote MeHenry from Baltimore on August 2 :

“**** I always thought the mission an ill-judged \& unlucky measure, but having been adopted I think that the policy and dignity of the government, equally demand that it should be persued in a spirit of fairness and liberal good faith. The question, then, is, whether the engagement of Mr. Talleyrand such as it appears in Mr. Murray's communication, does not fully imply an audience of the Directory? I think it does; and, therefore, that a formal answer in the affirmative, to that condition, was not necessary. He says 'they shall be received according to their functions, and respected according to the Law of Nations.' Can this be done without an audience? I should suppose not, since, as far as I am informed, an audience is one of the marks of respect invariably allowed, to foreign ministers, by the Law of Nations. "The French, it is true, might refute it, and shelter them-. 
selves under the evasive silence of Mr. Talleyrand, but it would be a manifest and paltry quibble, which must disgrace them still further, and add new strength to our cause: whereas should we avail ourselves of this silence to break off the affair, we should give them, and their party, an opportunity of throwing the blame upon us, and charging us with insincerity from the beginning and I confess that I should fear the effect of this charge among our people.

"Besides, the President, in his communication to the senate, which will, probably \& perhaps with reason, be considered as the measure of the assurances, makes no express mention of this audience: from whence it seems to have been considered, by him, as included within the general expressions. To insert a particular measure of it afterwards, and make their silence upon it a ground for breaking off, would, in my opinion, be a very hazzardous, if not a very improper conduct; to which, I think, it would be very difficult to reconcile the American mind.

"In fine, my dear sir, I see in this silence, and in the intimation of Mr. Talleyrand which you have noticed, the marks of that paltry spirit, combined with insolence, whereby the Directorial counsels have, at all times, been distinguished. If they mean to lay a snare for us, the best way of avoiding it, as it appears to me, will be to accept the assurances, and send the ministers; with instructions, at the same time, to insist on an audience as part of the promised reception. Thus we may save our own dignity and disappoint their acts. But I am already of opinion that it will never do, to retain ministers on account of this silence, whether accidental or designed, of Mr. Talleyrand.

"Who is to supply Henry's place? It would afford one a pleasant opportunity of seeing France, and Europe, of judging by the eyes as well as the ears.

$$
\text { sir, "God be with you \& your's is the sincere wish of, my dear }
$$

Washington felt ${ }^{1}$ that the conditions were critical and wrote McHenry: "I think you Wisemen of the East have got yourselves into a hobble relatively to France, Great Britain, Russia, and the Porte, to which allow me the privilege of adding our worthy Demos. All cannot be pleased! whom will you offend? Here then is a severe trial for your diplomatic

1 August 11. Ford, xiv, 193. 
skill. But to be serious, I think the nomination and appointment of Ambassadors to treat with France would in any event, have been liable to unpleasant reflections (after the Declarations which have been made) and, in the present state of matters in Europe, must be exceedingly embarrassing. The President has a choice of difficulties before him in this business; if he pursues the line he marked ont, all the consequenees cannot be foreseen. If he relinquishes it, it will be said to be of a piece with all the other acts of the administration - unmeaning, if not wicked, deceptious, \&e, \&e, \&c, and will arm the opposition with fresh weapons, to eommence new attacks upon the Government, be the turn given to it, and the reasons assigned, what they may." $\mathrm{He}$ asks the truth concerning certain eharges of bribery brought against public otficers in the Republiean newspapers and is most earnest in urging the prosecution of the makers of false charges of this sort. Adams's tarrying in Massachusetts disturbs him and he inquires, "Is the President returned to the seat of Government? When will he return? His absence (I mention from the best motives) gives much diseontent to the friends of gorernment, while its enemies chuckle at it and think it a favorable omen for them."'

Hamilton, still impatient over delays, ${ }^{1}$ wrote thus: "Believe me the service is every where suffering for the want of proper organization. It is one thing for business to drag off another for it to go on well. The business of supply in all its branches (except as to provisions) proceeds heavily and without order or punctuality - in a manner equally ill adapted to economy on a large seale, as to effieiency and the contentment of the army. It is painful to observe how disjointed and piece meal a business it is : - among other evils is this that the head of the War Department and the chiefs of the several divisions of the army exhaust their time in details, which. beyond a general superintendenee, are foreign to them and plans for giving perfection to our military system are unavoidably neglected. Let me repeat, my dear friend, my earnest adviee, that you proceed to organize without delay the several branches of the departments of supply; that is to fix the places and appoint the agents."

McHenry, answering on the 29 th, defines what he regards the scope of his duties; "I consider it the duty of a com-

1 Hamilton, v, 300. August 13, 1799, Hamilton to McHenry concerning his own position. Lodge, vii, 103. 
manding general not only to make returns of all articles, among these elothing, wanted for his troops, but to make them in such season as to allow of making up and transporting them to their destinations. That I consider it to be my duty to direct as far as practicable and as promptly as may be, a compliance with the requisitions made, by eausing the delivery of the articles called for to the Quartermaster General for transportation. I suppose my duty is completed by such delivery to the Quartermaster General and that all ulterior orders respecting the destination and distribution of the articles proportionately at different posts should exclusively emanate from the commanding general." Any ease of neglect should be reported to the Secretary of War. McHenry explained the law as to pay and said he issued warrants on the treasurer who applied moneys according to the warrants and orders of the commanding general. Hamilton was already considering the question of winter quarters for which he proposed huts to be built by the soldiers with the assistance of a few carpenters. ${ }^{1}$ He suggested that three regiments may be quartered in the barracks at Carlisle. ${ }^{2}$ At first MeHenry thought that place too remote, but afterwards favored placing troops there and at New Brunswick. Hamilton also asked for an allowance for quarters and fuel for himself. ${ }^{3}$ He was not rapacious, but he needed the money. The fortifications on Governor's Island in New York harbor and the regulations eoncerning promotions also occupied the joint attention of the general and the secretary. ${ }^{4}$ The latter wrote that the established practice was to fill vacancies in newly created regiments with new men and, when the regiment marched nearly complete to headquarters, relative rank was settled according to the officers' succession. MeHenry expected to appoint two eadets in each regiment and to promote according to merit. Hamilton was not satisfied with the secretary's principles of promotions to new regiments and wrote 5 that commissions ought to be held as rejected, if not accepted in three months. ${ }^{6}$ MeHenry ${ }^{7}$ answered that the commanding general had the declaration definitively of relative rank of majors and 1 Hamilton, v, 299, 308, 341. September.

2 Hamilton later changed his mind and preferred Greenbrook. Lodge, vii, 105 .

3 Hamilton, v, 297.

4 August 25. Hamilton, v, 303.

5 September 19 . Hamilton, v, 331.

6 Hamilton, v, 326 . September i1, Hamilton wrote for an allowance for officers' servants and that there should be a corps of invalids. 7 September 23. 
company officers in each regiment and that "military etiquette on the subject of succession is the production of rank once settled," after which settlement it "has been tenaciously adhered to, most probably with beneficial results.',

Hamilton replied 1 that the introduction of new characters into a corps once organized should be confined within narrow limits. The right of succession he "considered as the primary reward of service." It "has its foundation in natural justice and in very strong passions of the human heart." As soon as a corps is organized, the expectation of promotion arises spontaneously and the time of the definitive arrangement is too uncertain to make it a fit criterion of the right of succession and would make regiments, completed at different times, have a different relative rank, which would be prejudicial to the service. Washington felt 2 that lieutenant colonels and majors, who have been in service, should come first, but wrote that his information as to others is not sufficient to arrange them nor indeed to arrange among themselves those who have seen service. His own position was that he was serving the country without pay, ${ }^{3}$ other than "reimbursements of actual expenditures, unless, by being called into the field, I shall be entitled to full pay and the emoluments of office." To do otherwise, is to run into danger of misconstruction and, though put to considerable inconvenience, through the necessity of entertaining visitors, he declined to take the two months' pay which McHenry offered him. Washington recommended very few persons for commissions, and at least once, in the case of Joln Tayloe, wrote from Mount Vernon on the 5th of May to request that a resignation be accepted :

\footnotetext{
1 September $2 \pi$

2 Ford, xiv, 202. September 15. An interesting unpublished letter of Washington's follows:

"Private Mount Vernon Sept. 1st. 1799.

"Dear Sir -

"I find by looking over my files that your favour of the 14 th \& 24 th. of August have never been acknowledged, - I now do - the receipt of them.

"I thank you and through you Governor Davle for his "Instructions to be observed for the formations and movements of Cavalry' and would ask you to mention this to him when you shall see him which must be soon

"I pray you to direct Mr. Francis the purveyor to furnish me with the cost of the equipment of Washington Custis as a Cavalry Officer. I have had a small sum in the Bank of Pennsylvanla locked up being afraid to touch it lest there might not be enough left for that event \& should find difficulty in remitting the Bal'e. I regret exceedingly the cause of your removal to Trenton and am My dear Sir - With great esteem

"Your Affet. Hble Servt

"Go. WAshington."
}

3 Ford, xiv, 201 . September 14 
"Sir,

"This letter will be presented to you by John Tayloe Esqr. - whom the President of the United States was pleased to nominate and appoint to a Majority in the Regiment of Light Dragoons.

"Mr. Tayloe waits upon you to explain his motives for declining that honor, at present, the propriety of which, I persuade myself you will not only acquiesce in, but applaud, as the result of laudable and Patriotic principles.

"This Gentleman is a Senator in the Legislature of this State - The Politics of which you are not to be informed of. A part, however, of which, is to suffer no person to remain in either house thereof - nor to enjoy any office under Its government, who holds any Commission, or Appointment of whatsoever Nature or kind, under that of the General Government. The consequences then of his accepting the Military Appointment would be, the vacating of his Senatorial Office; and as he informs me, the probable introduction of an opposition Member in his place.

"Mr. Tayloe's patriotism leads him to serve his Country in any capacity wherein he can be most useful; - either in the Civil or Military line; and having been pleased to ask my advice on this occasion, I have frankly given it as my opinion, that under his statement, and in the present aspect of our public affairs, I thought his services in the first - that is in the Senate - were more immediately necessary and important than they would be in the latter - because they are now actively employed in the one case, and may lye dormant in the other, unless hostilities on Land Should be the result of French politics.

"To this opinion he has yielded, or seems inclined to yield; - with a hope however (as there may be an impropriety in keeping the vacancy open) that, if the exigency of the times should render it expedient to raise more Cavalry, the service to which he is most attached - that his motives for declining his present appointment may be not forgotten but aid his pretentions to, and solicitude to obtain a new one. Having requested me to relate these circumstances, it was but just I should do so; - and to add, that with great respect -

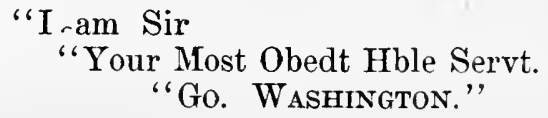


From Adams and Hamilton came letters as to individual appointments, one of which affords additional proof of the purpose of the administration to nominate for commissions in the army only "Federal characters."

"NewYork Jan. 19. 1800.

"Dear Sir

"The inclosed letter speaks for itself.

"I think upon the whole unless there are objections, of which I am not aware it will be expedient to place Mr Wilson in the new Batalion, so as to reinstate him fully in the situation in which he would have been if he had not left the Service. He appears to me a genteel sensible young man - and as to his morals has been well spoken of. You best know if there are any faults in his character which render the matter ineligible - If there are not I shall learn with pleasure that he has been appointed.

"It seems to me a very obvious policy will lead to the gratification of the wish expressed in the close of the letter. This may be a means of bringing new interest to the support of the army. And I am not afraid of introducing a proportion of very young men whose connections are not of very sound polities. The Military State has a very assimilating influence. Let me add that it may be useful to make me the instrument of affecting this appointment. You will easily understand my meaning.

$$
\begin{aligned}
& \text { "Yrs Affecty } \\
& \text { "A Hamilton." }
\end{aligned}
$$

Hamilton was still unsatisfied and, though he admitted 1 that some of the officers' complaints are baseless, yet others have foundation and the defects in the public plan, causing these complaints, should be remedied. "It is an opinion of some standing with me that the supply of the army except in the article of provisions has been most commonly so defective, as to render a considerable degree of discontent a natural consequence. In a revolution, lack of supplies may be acquiesced in, but not in a mature state." Hamilton does not wholly blame McHenry for this, as "I well know your disposition to ameliorate our plan."'

In another letter, Hamilton returned to the same question

1 Hamilton, v, 306. September 3, Pickering recommended that a cargo of saltpetre at Boston be not purchased for the government. 
and stated that "The want of a proper organization of agents in the various branches, of the publie service of a correct and systematic delineation of their relative duties has been a material canse of the imperfect results, which have been experienced, that it continues to embarrass every operation and that, while it lasts, it can not fail to enfeeble and disorder every part of the service." The amount of supplies purchased depends on the establishment and not on the opinion of the commanding officer and so the Secretary of War must gauge the amount.

Hamilton wished the forming of permanent arsenals, 1 the separation of the business of procuring and issuing supplies from the duty of a particular commander, and an arrangement of deputy paymasters.

McHenry laid this plan before Adams and he asked that it be submitted to the heads of departments for an opinion, as it involved much expense and possibly needed legislative action. The old system is "defective in particulars, too weakly manned in some of its branches and susceptible of amelioration," but we can not change it at once. For the present, it must be kept. McHenry gave Hamilton a detailed statement of his understanding of the actual conditions as to supplies: 1. Clothing. Until recently it was the duty of the secretary of the treasury and now it is the duty of the secretary of war to provide annually by contract for full complement. This implies a surplus, as the army is always below the establishment and the additional quantity is ordered for exigencies, deposited in the public stores and drawn through requisition by the commanding general on the secretary of war and by the latter on the superintendent of military stores, who packs, sends, and charges it to the various officers. The quartermaster general then takes and delivers the clothing to the officers, who give to the soldiers, taking receipt from them. 2. Ordnance and other military stores and camp equipage. The secretary of war has the duty to supply these in accordance with the appropriations. These sometimes are particular and specific and sometimes aggregate, with much discretion. In the latter case, he should ask information from the commanding general. These supplies are distributed in the same manner as clothes. 3. Medicines, surgical instruments, and hospital stores. There is no medical purveyor or apothe-

1 Hamilton, v, 320 . 
cary, but the seuior surgeon of each hospital or garrison, ete., makes a return to the commanding general and he sends these returns to the secretary of war, who directs the ordinary purveyor (sometimes after advice of experienced physicians) to purehase and turn the supplies into the public store, whence they are distributed, as are the clothes. 4. Quartermaster's stores and means of transportation. Sometimes the quartermaster must buy directly and again he may get better prices, ete., from the purveyor of the war department. Requisitions are sent from the commanding general or the quartermaster general and the quartermaster at a post, or a confidential sergeant, if the post be small, keeps the supplies. 5. Pay of the army. Rolls properly made out go to the paymaster general and the secretary of war must put sufficient sums in his hands to pay. There are agents in distant places, but the rolls are never dispensed with. "The existing system of supplies, executed as I have delineated, will bring the wants of the service, in a great degree, if not completely, before the eommanding general, eonsequently, will enable him to exercise the superintendance expected from him with much effect. It would seem too that the general superintendance of all military concerns peculiarly belongs to him, as he can exercise it to most advantage. The observation applies to every commander of a separate army or great military districts." Estimates must be made in good season.

Pay to the soldiers fell behind. MeHenry wrote ${ }^{1}$ that the treasury would not advance the money. Hamilton said, if the muster rolls are not in good form, 2 accept them provisionally. 'The pay department needs reforms. He admitted he drafted the form of muster rolls, when seeretary of the treasury, but thinks it may be departed from. The troops are uneasy. MeHenry ${ }^{3}$ repeats that the treasury will not pay without proper muster rolls.

In contrast with Hamilton's ceaseless activity, we hear but little of Pinckney. In September, he wrote McHenry that he was at Newport for his wife's health and wished quarters found at Harper's Ferry for the regiments ${ }^{4}$ he should command. During October, Hamilton is continually

1 September 16. Lodge, vii, 125.

2 Hamilton, v, 334 . September 21, Lodge, vii, 141.

3 September 28 , October 25, November 16 .

4 Sparks, $x i, 466$. On November 5 , Washington wrote McHenry about the winter quarters. 
writing on the brigading of the regiments, ${ }^{1}$ on the disposition of the permanent regiments, ${ }^{2}$ on courts martial, and judge advocates. ${ }^{3}$ He is often accused of British sympathies, but his letter of October 12, on the arrangement of troops shows he leaned to no foreign power. He therein states that the existing "good understanding" between the United States and Great Britain justifies an arrangement, not of the highest efficiency, "but the permaneney of friendship between nations is too little to be relied upon, not to render it prudent to look forward to more substantial precautions, than are immediately meditated."

On Angust 5, Murray wrote that Talleyrand would receive an embassy and some held that, as the president had directed the commission to proceed, whatever opinions may have been entertained respecting its original propriety, the nation's honor and dignity demanded that it should be pursued in a spirit of fairness and liberal good faith. Other Federalists dreaded sending it, as did Tracy, who wrote from Litchfield on September 2:

"My Dear Sir-

"Is it true that Govr. Davie is appointed a French Envoy in room of Patrick Henry?

"Is it true that Mr. Ellsworth and he are going to Europe? I am mortified \& discouraged for fear this is all true - and I shall be much obliged to you to let me know : - I do not say, $I$ will do nothing more, if they all should turn out fact - but I am really in pain for fear they will turn out so. Do pray, my Dear friend, let me know, if it be not a State secret.

"I have sacrificed as much as most men or at least as much as any individual to support this Govt. and root out Demoeracy, \& French principles, but, really, Sir, I feel it to be lost and worse. What will it signify to send you on a list of Officers? - my time \& property have been devoted to my Country \& still should be, if any good can accrue; I will make no rash promises now; - but you may rely upon it, I will know what is about to be done before I stir another step in

1 Hamilton, v, $345,347,355,356$. Other letters of this period are in Lodge, vii, viz. p. 113, September 2, 134, September 17, 141, September 19 149 ; October 12 (on brigading the army). 151.

2 McHenry disapproved this on November i5, but approved of another arrangement on February 27, 1800.

3 See Am. State Papers, Military Affairs, i, 145. November 12, 1799. 
public business. I can \& will resign, if all must be given up to France \& our Democrats.

"With much esteem I am

"Sir yr. friend \& humble. servt .

"URIAH Tracy"

Fever in Philadelphia in the summer again drove the departments away. Trenton was again their temporary abode, whither Adams came on October 10.

He found Hamilton and Davie there 1 and determined, apparently with some suddenness, to dispatch the embassy at once. Sometime previously he had sent instructions to the envoys to Pickering for revision and had received in response a letter of which Adams wrote, some years afterwards ${ }^{2}$ that it was signed by all five secretaries, earnestly entreating him to suspend the mission. It was really signed only by Pickering and probably not approved of by Lee. Adams had also received two letters from Stoddert, urging him to come to Trenton at once and revise the instructions in person. ${ }^{3} \mathrm{He}$ stated, in his later defence, that he "determined to go to Trenton, meet the gentlemen face to face, confer with them coolly on the subject and convince them, or be convinced by them." Three days after Adams's arrival, Ellsworth came rather unexpectedly and, on the 15th, Adams called the cabinet together and carefully went over the instructions. His later impressions were that he found all the people in a surprising pitch of enthusiasm and expecting immediate news of Louis XVIII's restoration and that he in vain argued against the possession of such views by the heads of departments. Both Stoddert and McHenry denied that there was any such discussion or that the subject of suspension of the embassy came into their meetings, which were merely devoted to revising the instructions. Having "respectfully offered their opinion, their duty terminated."

Hamilton had come to Trenton to consult with McHenry abont Wilkinson and McHenry wrote, in after-years, that he had no reason to suppose that he knew Adams was coming, nor did Hamilton ever mention to McHenry what passed between him and Adams at that time, nor whether anything was said respecting the mission. Adams wrote that he found Ellsworth

\footnotetext{
1 Lodge's Cabot, 206. See Adams's letter to Ellsworth of September 22. Adams, ix, 34 .

2 In letters to Boston Patriot. Adams, ix, 253.

3 Adams, ix, 19 and 25 .
} 
and Davic ready to embark and that Hamilton urgently dissuaded him from sending the mission.

On the morning of the sixteenth, 1 Adams sent Pickering orders to have the envoys depart for Europe immediately. The cabinet had not been consulted in regard to the matter of the immediate sending of the envoys, though Adams had previously left them in virtual charge of all the affairs of government for six months.

After years had passed, McHenry wrote of this act of Adams's and of his defence of it with a bitterness which time had not softened:

"Throughont these letters ${ }^{2} \mathrm{Mr}$. Adams affects to consider a President of the United States as every thing in government and the heads of departments little more than mere clerks. I cannot subscribe to this hypothesis. Do not the heads of departments like him hold a high and responsible station in government? In offering advice to a President, do they not perform an incumbent duty. What more did we do? Less we ought not to have done. Not, therefore, to our recommendations or advice, but to his own wayward disposition, his own wavering and changeable policy are to be charged the humiliations our country has since experienced."

On October 18, Adams wrote McHenry thus from Trenton :

"Sir"

"As a few Weeks only intervene between Us and the Meeting of Congress I request the favour of you to turn your Thoughts to the Subject of Communications both of Information and Advice necessary to be made to that Body at the opening of the Session: and in particular I propose a Summary of the Rise, Progress, declension, and Suppression of the Rebellion in Pennsylvania. Every thing in the Indian Department and on the Mississippi as well as all other things relative to military Service necessary to be laid before the Legislature and, in general, your Sentiments on the State of the Nation at large \& abroad will be very acceptable from Mr MeHenry to his faithful humble Servant

\section{"John Adams"}

Three days later, ${ }^{3}$ Hamilton, who had just returned

1 Adams, ix, 39.

2 Lodge's Cabot, 206.

3 Hamilton, vi, 414 . 
from Trenton, wrote Washington that Adams had determined to send commissioners to France, in which step Wolcott and McHenry were not consulted. He regrets it and hopes it may not lead to an alliance with France against her enemies.

Pinckner, on his return from Rhode Island, wrote ${ }^{1}$ Hamilton: "The envoys are then to sail. I presume this must be a very deep measure - much too profound for my penetration." On November 10, still smarting from the slight Adams had put upon his cabinet by not consulting them upon this important matter, ${ }^{2}$ McHenry wrote Washington, having been too busy to do so before this date. The prevailing rumor of disagreement in the cabinet and the difference of opinion between Adams and the heads of departments concerning the French mission is true. Adams had nominated Murray, early in the year "without any consultation, or giving the least indication of his intention" to any of the secretaries. Even if such a course were necessary, it was "such a departure from established practice as could not fail to excite considerable sensibility." During the summer, because of conditions abroad, the heads of departments presented to Adams "the propriety of a suspension of the mission." He took no notice of the subject of this letter, but a few days after arriving at Trenton, "convened the Secretaries to agree on instructions and ordered the commissioners to sail."' $3 \mathrm{He}$ knew that "three of the heads of departments have viewed the mission as impolitic and unwise." Stoddert had joined in the summer's letter, but Adams does not class him with the other three secretaries and both Stoddert and Lee appear to enjoy his confidence. The president seemed especially displeased with Pickering and Wolcott, "thinking they have encouraged opposition to his plans to the eastward," but appeared to McHenry less displeased with him and "rceeived and treated", all the secretaries with "apparent cordiality."

It is uncertain, McHenry continued, whether he will think it expedient to dismiss any of the cabinet. Lee and Stoddert are believed to think "he ought, and would, perhaps, if asked, advise the dismission at least of one. There are, however, powerful personal reasons, especially: at this juncture, which forbid it: and it is more than possible, as these chiefly respect the eastern quarter of the Union, they will prevail." Mc-

\footnotetext{
1 October 25.

2 Sparks, xi, 573 .

3 See McMaster, ii, 449, 190.
} 
Henry thinks, however, that "the evil does not lie in a change of Secretaries, as these may be replaced with good and able men, but in the mission, which, as far as my information extends, is become an apple of discord to the Federalists, that may so operate upon the ensuing election of the Federalists, as to put in jeopardy the fruits of all their past labors, by consigning to men, devoted to French innovations and demoralizing principles, the reins of government."

The election in Pennsylvania of October 10, in which McKean, the Republican, defeated James Ross for governor, showed that the anti-Federalists were most vigilant. They have given a "false coloring to the intentions of government" and have made much of certain recent negotiations with Toussaint in St. Domingo, whereby certain merchants were enabled to sell him various needed goods, these supplies being sent in the same vessel which carried our agent. They also dwelt on the charge of "British influence" and Adams's letter to Tench Coxe, stating that the appointment of Pinckney as minister to England was due to British influence, is shortly to be made public by the opposition. ${ }^{1}$ All these causes made MeHenry "confess I see more danger to the eause of order and good government, at this moment, than has, at any time heretofore, threatened the country." He appealed.to Washington to say what ought to be done. For his own part, he thought the dismission of Pickering and Wolcott would be unwise and considered the "wisest expedient" would be for Adams "to conciliate his ministers by a conduct, which does not reduce them, on great occasions, to ciphers in the government and, by this means, endeavor, at least, to restore mutual confidence and harmony of action." It is uncertain whether Adams will see this, or whether he will yield to "the irritation which his mind suffers from those who flatter him, or badly advise him." "I see rocks and quicksands on all sides and the administration in the attitude of a sinking ship. It will, I imagine, depend very much on the President, whether she is to weather the storm or go down."

On November 17, Washington replied, ${ }^{2}$ in the last letter he ever wrote McHenry. He has "been stricken dumb" by McHenry's epistle and believes it better to "remain mute, than to express any sentiment" on these important matters.

1 See C. C. Pinckney's Life of T. Pinckney, p. 170.

2 Ford, xiv, 215. 


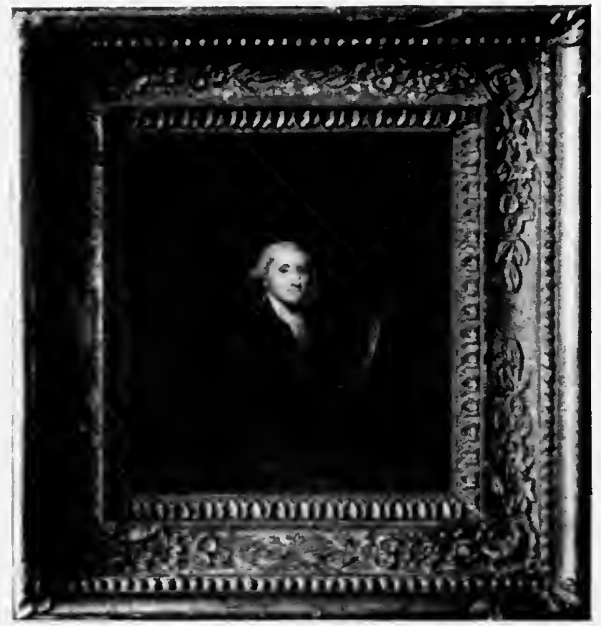

GEORGE WASHINGTON

Reduced in size from miniature owned by the heirs of Dr. James McHenry

(Copyright, 1907, The Burrows Brothers Compony) 

He has for some time ${ }^{1}$ viewed national polities with an "anxious and painful eye. They appear to me to be moving by hasty strides to some awful crisis; but in what they will result, that Being, who sces, foresees and directs all things, alone can tell. The ressel is afloat, or very nearly so, and considering mrself as a passenger only, I shall trust to the mariners, whose duty it is to watch - to steer it into a safe port."

On December 14, 1799, Washington died. On the 1Stl, McHenry wote Hamilton, " "You and I, on this solemn occasion, experiencing, in common with our fellow citizens, deep regret for our country's loss, have our sorrows lightened by a recollection of his friendship towards us both and the many days we have spent as members of his family and sharers of his confidence." The country should "show the most reverential testimonials of that profound grief with which every good heart must be penetrated at the loss of a citizen, statesman and commander, so eminently distinguished for virtues. talents, and services."

The following order was issued to the army: "The President with deep regret announces to the army the death of its beloved chief, General George Washington, sharing in the grief which every heart must feel for so heavy and afflicting a public loss and desirous to express his high sense of the vast debt of gratitude which is due to the virtues, talents, and ever memorable services of the illustrious deceased, he directs that funeral honors be paid to him at all the military stations and that the officers of the army and of the several corps of volunteers wear crape on the left arm by way of mourning for 6 months.',

Washington's death put no conclusion to the strained relations between Adams and his secretaries. On December 29, Wolcott wrote Fisher Ames, "The President's ${ }^{3}$ mind is in a state which renders it difficult to determine what prudence and duty require from those about him. He considers Col. Pickering, Mr. MeHenry, and myself as his enemies; his resentments against $\mathrm{Maj}$. Gen. Hamilton are excessive;

$1 \mathrm{He}$ asks for further information as to the British influence charge against Pinckney, which is a "perfect enigma" to him.

2 Hamilton, $v, 388$.

3 Gibbs, ii, 313, Hildreth, v, 371. The attack on MeHenry on p. 373 seems unfair. There is no evidence that he took the same position as Pickering. 
he declares his belief of the existence of a British faction in the United States.

"Among the officers of government there is a sensation of unhappiness. I do not know whether you are acquainted with Mr. McHenry; he is a man of honour and entirely trustworthy; he is also a man of sense, and delivers correct opinions when required, but he is not skilled in the details of Executive business and he is at the head of a difficult and unpopular department. The diffidence which he feels, exposes his business to delays and he sometimes commits mistakes, which his enemies employ to impair his influence."

In November and December, Hamilton and McHenry were engaged in preparation of tactics, uniforms, and the needed revision of the articles of war, especially as to court martials and the punishment for desertions. ${ }^{1}$

Early in January, a number of reports were made to congress on military affairs. ${ }^{2}$ Adams formally recommended a military school on the lines of Hamilton's letter to MeHenry. There should he a fundamental school for all officers, with a two years' course, and a subsequent course of one year each for the navy, for cavalry, and for infantry, and of two years for engineers and artillerists. He also recommended a modification of the two regiments of artillerists and engineers and the establishments of three regiments in their places, onc of horse artillerists, one of foot artillerists, and one of engineers. The report recommended revision of the militia laws and discussed the artillery in French and Austrian armies, ${ }^{3}$ showing close reasoning on the subject. Recommendation of fortification of harbors and dock yards was also made. The enlistments in the twelve regiments were reported, as well as

1 Hamiliton, v, $384,385,386,392$. Hamilton suggests that officers ought to be required to provide their own servants and not be allowed to use the soldiers.

2 State Papers, Military Affairs, 1, 130. January 6, on expenses of the Springfield armory since its establishment in 1795. Military Affairs, 1, 132. January 13, refers to Military Academy report. Military Affairs, i, 133, January 14. Military Affairs, i, 142, January 31. Annals of Congress, 1800, Appendix, 1397, 1800-01 Appendix, 1415. An important letter from Hamilton to McHenry about the Military Academy is found in Lodge, vil, 179 , one an tactics on p. 187 , one on uniform on p. 188, one on servants for officers on p. 189, one on the articles of war on p. 194 and two on accounting on pp. 197 and 203 .

3 The President requests the Secretary at War to have an Extract made from the Precis des evenemens militaires, translated into our language and printed of all those Parts which relate to the Horse Artillery, and to consider whether this system cannot be introduced into our military system and especially into a Militia Law or Volunteer Corps. When printed in Sufficient Numbers, the public attention will be turned to the subject and our officers will be furnished with copies.

January 9, 1800. [Note from Adams to McHenry]. 
the proposed revision of the articles of war and of the tactics, and increased pay was asked for the paymaster general. The supplemental report on the proposed military school shows ${ }^{1}$ wide reading. An extract from it is of interest. "Whether our country is to be plunged into a war, or enjoy, for a length of time, the blessings of peace and interior tranquillity; whether the portentous events which have afflicted Europe, and, in their progress, threatened the United States, are to subside into a settled state of things; whether the blessings of peace and the customary relations among the transatlantic powers are to take place, or hostilities shall be continued, protracted, and extended beyond their present limits; in either view, it is equally a suggestion of policy and wisdom, to improve our means of defence, and give as much perfection as possible to such establishments as may be conceived essential to the maintenance of our rights, and security from insults. The unavoidable collisions growing out of trade and the reciprocal restrictions of great commercial states; the apprehensions and jealousies natural to powers possessing contiguous territory; the inefficacy of religion and morality to control the passions of men or the interest and ambition of nations: the impossibility at times for governments to adjust their differences, or preserve their rights, withont making sacrifices more to be dreaded than the hazards and calamities of war - all these considerations, illustrated by volumes of examples, teach the soundness of the axiom - si vis pacem para bellum. And what time more proper to prepare the materials for war, than a time of peace, or more urgent, than that in which a nation is threatened with war."

On receipt of McHenry's reports, William Pinkney wrote from London on the 20th of March, 1800:

"I am much obliged by your enclosing me your excellent Report to the President on the subject of our military System. Of any thing contained in it, except its general principles, I am a very poor judge; but, so far as an attentive reading of it can authorize me to have any opinion, I should think the arrangements you propose will, if adopted, be beneficial to a very important Extent. The Manner in. which your Details are given must have the Merit of perspicuity, for even I, who am as little of a military Man as it is well possible to be, believe that I perfectly understand them.

1 Military Affairs, i, 142. January 31, 1800. 
Your introductory Remarks, and those of a similar Nature to be found in different parts of the Report, are capable of being properly estimated by every Man of understanding and of their Foree \& Solidity there can be no Doubt. I wish most cordially that they may produce their just Effect, and that the country may be indebted to your labors for the security you aim at giving to it.

"I w'd ask you to drop me a line now \& then, when you shall have Leisure. It has been stated to me that you devote yourself to the Duties of your office beyond a due Regard to your Health - and I will not desire to put upon you the additional Burthen of writing to me. And yet, if at any Time a vacant moment sh'd occur in which it might be Relaxation rather than Fatigue to tell a sincere Friend that you continue to think of him, I eannot avoid saying that you will gratify me much by so employing it."

During January, the suspension of recruiting ${ }^{1}$ was discussed in congress and McHenry feared it would be ordered by the house, as occurred late in the month. ${ }^{2}$ On February 18, McHenry wrote Hamilton, enclosing the draft of the naval academy bill and telling him that the senate has "yielded to the supposed momentum of public opinion and stopped enlistments. The navy is to ingulph everything and it is certain, should we give to it all our money, it cannot give us in return adequate protection. Both establishments are indispensible, I mean the military and naval. Some, however, think one of them sufficient and that, to undo the one, is to secure funds for the other. You find, by my report, that I have pursued a different course and presumed both necessary." 3 Hamilton wrote MeHenry as to the question what is

1 January 17 and 25 , Hamilton, v, 400 .

2 Pickering writes concerning the salary of the chief clerk in the war department on January 22 . January 13 , McHenry joined all the cabinet but Lee in slgning a paper stating that John Randolph's contemptuous language towards the President requires censure. Adams, ix, 46; Hamilton, $v, 396,397$.

3 Hamilton, v, 401. On February 10, C. C. Pinckney wrote from Shepherdstown that soldiers should not dig a canal but study tactics. Hamilton wrote McHenry on February 19.

"Dear Sir

"I have read with great pleasure your letter to the Committee of Defence. It presents the subject in a very correct and interesting manner, such as I should expect much good from; if I did not begin to think with Chlef Justice Elsworth, that there is in a government like ours a natural antipathy to system of every kind.

"Yrs. Affecty.

"A. H." 
a separate military district and on the undue care, as it seemed to him, shown by the accountant in payment of money appropriated to be used according to the discretion of the commanding officer and directed by him to be disbursed by a subordinate agent. In such case, the "charges ought to be admitted, without difficulty, and the superior officer made responsible for improper directions, in his office or in his pocket, both according to eircumstances." A month later, in a similar vein, Hamilton asks for sanction of a certain account, which neither paymaster nor accountant ean adjust, 1 and called it a "fresh instance of the want of some interior regulation of your department, by which cases out of the general rules may be decided with due dispatch. Every day shows me, more and more, the embarrassments which, from the same cause, perplex and distress every military agent who has anything to do with directing or making expenditures."

On March 21, Hamilton wrote 2 again that the accountant was wrong in saying that no authority, short of congress, can make allowances to an officer, beyond the emoluments fixed to his office by law. On May 5, we find Hamilton still objecting ${ }^{3}$ to the accounting system of the war department and proposing to extend the functions of paymasters to paying traveling expenses, postage, and stationery of officers of the line, expenses for apprehending deserters, etc.

On March 1, McHenry, who felt himself too busy to do justice to the subjects, wrote Hamilton asking him to prepare bills (1) for the modification of the two artillery regiments, (2) for the fundamental school and the school of artillerists 4 and engineers, (3) for other matters referred to in McHenry's report which require legislation, (4) for a definition of tho officers who are entitled to double rations.

Hamilton wrote on that same day to Henry Lee: "Believe me I feel no despondency of any sort as to the country. It is too young and vigorous to be quacked out of its political

1 Hamilton, v, 402. February 28, 1801.

2 Hamilton, v, 409. On March 19, MeHenry told Hamilton he thought the accountant was wrong.

3 Hamilton, v, 423.

4 Ingersoll's History of the War Department, 35 , states that the reports establishing the corps of engineers and the military were more clear and convincing than those of any other head of the War Department from the beginning. (See Stat. at Large, i, 552) Boynton's West Point, 18, says McHenry's mllitary academy plans were "equally illustrative of the comprehensive and discrlminating talent of their author and of the beneficial consequences to be anticipated from the establishment of a milltary academy." The bill failed in the house (Journal of 5 th and 6 th Congress, 634 ). 
health and, as to myself, I feel that I stand on ground which, sooner or later, will ensure me a triumph over all my enemies." He was not sure how far enlistment had been suspended and wrote from New York on March 3, 1800 :

"Private

"Dr Sir,

"I am told, though I really have not seen the law, that one has passed suspending the Recruiting Service for the Twelve Additional Regiments. You are aware that an instruction from your Department ought to precede my agency upon that law.

$$
\begin{aligned}
& \text { "Yrs. Truly } \\
& \text { "A Haminton." }
\end{aligned}
$$

MeHenry replied, telling of the establishment of the quartermaster general's office in Philadelphia and of the suspension of enlistment. In the twelve regiments 8,418 noncommissioned officers and men were authorized; but, by the last returns, only 3,399 had enlisted and there was, probably, enough elothing on hand to last through the year. As to the bills, Hamilton wrote twice, as follows:

"Dr. Sir

"March 8. 1800.

"Herewith you have the draft of a Bill respecting the Corps \& Engineers \& Artillerists. I vary in mode but not in substance from your report by defining the Regiment of Artillerists at its Complement (say four batalions \&e.) and I suspend the organising \& raising of one batalion. This comes to the same result \& appears to me most correct \& systematic. I leave a blank for the privates, suppose there may be a mistake in printing as $I$ cannot make out the principle of 700 privates to three batalions 65 - (an odd number) to a company. Perhaps the actual establishment is a preferable standard say 48 per Company excluding Artificers, which for a full Regiment will amount to 768

"I cannot endure your two Colonels to a Regiment of Engineers. Tis Monstrum horrendum informe \&c.

"Yrs. truly

"I am preparing a third Bill.," 
"Dr Sir

"March 9, 1800.

"Some ill health joined to much occupation has delayed longer than I wished The preparation of the Bills you desired. Herewith I send you one of them.

"I regret extremely the dismembrement of the School of the Navy from the rest. Clear I am that all ought to be united under the Director General, who might himself be subject to the orders of the Secretary at War in relation to the three first Schools, of the Navy in relation to the last. There is a manifest incongruity in the idea of a Fundamental School embracing the Navy and that of the Separation of the School of the Navy. This elementary institution may without impropriety \& with much advantage be united.

"To be at the same place will facilitate instruction \& conduce to economy. To be at the same place without union will lead to collision \& disorder.

"I have not filled up the particulars to be taught in each School Your report seems to contemplate something different from my plan \& yet does not present the detail. That which was in my plan was maturely thought of. The most difference seems to be that you regard the business of the other Schools (except the fundamental) to be the application of what is learnt in the fundamental School to the practical purpose of the others. My plan supposes that it is not necessary or proper in the fundamental School to do more than give that elementary instruction which is equally necessary for all the corps - leaving the higher branches necessary for particular corps to be prepared in the appropriate Schools. The one idea or the other requires a very different distribution of the branches to be taught. You can easily fill the blanks, as you finally take the one or the other course. If you prefer the scheme in my letter, you will only have to insert from it verbatim, or nearly so, the objects to be taught in each School.

"You will observe some auxiliary ideas incorporated, but they have an eye to the results in your report. The principal alteration is the latitude in the first instance as to the appointment of Director General. I think it very probable that a. more fit character for this important trust may now be found out of the army than in it.

"Another difference is that small additional compensations are proposed for Directors who may be Officers. It will be, I fear, impracticable to find fit men willing to undertake 
the constant drudgery of these stations without some additional rewards.

$$
\begin{gathered}
\text { "Yrs truly } \\
\text { "A. H. }
\end{gathered}
$$

"I have put between Brackets what may be omitted to accommodate the Bill entirely to your Report"

On March 19, McHenry wrote Hamilton that he was trying to push the naval academy plan, but feared failure. Ten days later, he sent a copy of the bill, as it came from the committee, adding the words "you forgot, when you thought to combine all into one plan," that "the little passions are great inter-meddlers in the most important affairs."

Of Pinckney and his forces, we have two glimpses; in a letter from Hamilton to McHenry and in one from Pinckney himself to the secretary concerning the dismission of an officer, Hamilton writes:

"Dear Sir

$$
\text { “New York March 17, } 1800 .
$$

"General Pinckney has transmitted me confidentially the copy of a letter which he has written to you respecting the employment of the troops during the Ensuing Summer. I agree with him in the inexpediency of employing new troops in operations not military, as the digging of Canals \&e and in the propriety of some extra compensations to any troops, who may be so employed, as a donceur and a guard against discontent. This will certainly disorganise the troops, before they are yet formed by a course of instruction and discipline, and it will prevent the introduction of a just military pride among them.

"If our troops are to be continued, it were most eligible for them that they could be left without any other occupation than that incident to a course of instruction. But I am well aware that there are considerations which may oblige to a different conduct. And I have reconciled my mind to the idea of drawing them in Brigades towards the principal points to be fortified on our Sea Coast, there to be engaged in working upon the fortifications, by detachment. This will not violate prejudices and the matter may be so managed as to leare a good deal of time for exercise.

"General Pinckney has also mentioned a suggestion of yours on the point of allowances for travelling Expences to General Officers and their suites. The substance is that General Officers should be allowed all reasonable extra expences \& 
that the general regulations respecting extra compensations shall apply to the aides. He remarks on the difficulty of separation - as one table must serve all \&c.

"I think the remark well founded \& do not perceive how the discrimination can be reduced conveniently to practice. If adhered to - it must come to this that the Expenditures of the General and his suite, which are inavoidably blended will be included in an account - and credit given for the allowances to the aids - the ballance, if otherwise reasonable, to be paid to the General. This would be a complication without an object.

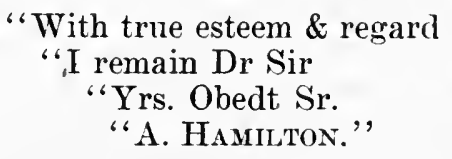

On March 7, Lafayette wrote from La Grange, commending Madame de Fleury to McHenry and referring to Washington's death as depriving the world of "His Greatest Ornament.",

Murray, who had been so regular a correspondent, now writes rarely and we find only one of his letters dating from this winter.

"My dear Sir"

"The Hague 2d. Dec. 1799.

"I have received your favour of the $22 \mathrm{~d}$ Octr. John, who is an excellent young man, has yours. We live happily.

"With yours, I received some others!! ! I have reason to believe that my letters to Talleyrand of $5 \& 18$ May last make a noise against me.

"Why in the name of Diplomacy \& of all regularity were they given, as well as the assurances to the public, if at all given? Why were they not more maturely considered in their character, properly speaking they were not - at least the first official, but private letters. I said I wrote by order of Government; but I was, in relation to the Govt. which I addressed, an Individual, a traveller, Unknown to it officially Mr. T. knew Mr. M. but I speak as a Diplomat, I say I was unknown as a man having authority to communicate the intentions of my Govt. to a foreign Govt. for the purpose of their doing a high Governmental act in consequence of such a communication! At most it is impossible to make my letter more than semi-official. 
"As to the air of pleasure with which it was written, I was to presume that success would be agreeable. It was to a Government. No matter good or bad, hated or not. The career once opened, the incidents followed from the principle adopted.

"The air of empressement which I gave then to a thing to be received from a man whom they did not officially know whose authority, nor they nor any but myself had seen - that air upon an occasion presumed to be agreeable - was, I aver in the true spirit of an inofficial letter of that sort \& not repugnant to that of an official one!

"If this affair have made a noise as I rather think it has, I beg you as a candid man - even if you too have thought these letters improper, to show this letter or rather to mention my grounds at least to the President \& to Genl. Washington.

"As to Pichon you will hear more of him. I have written to Harper yesterday.

"Let what will come, I am ready. I have been greatly worry'd here \& injured in health \& exhausted in Spirits, I have acted with Zeal \& honour. I have not been inactive. I was ordered to be active, So I have as little to reproach me with as most men, who act in such times \& with very little guiding.

"It is impossible to say what Bonaparte means, ultimately, he \& Seyes. This is certain, that there are symptoms of a pacific principle at work. These may be the winter curtain to cover the preparations for another campaign! There are other symptoms too-more moderation, more liberality in France - better Diplomats though Revolution men, yet moderates \& some of the old aristocracy are sent abroad, Bourgoing goes to Copenhagen. The Jacobins displaced. Many Emigrants of the Royal constitution of 1791 expressly rased from the list \& permitted to return as the Maubergs (son of La Fayette) Leancourt - Genl. Valence (of Doumourier's family) \&c \&c \& I believe soon La Fayette himself. No power in Europe will be disarmed by professions, \& I pray that we may not be! however, there may actually be more decency \& more moderation of manner towards us or them.

"I am always affectionately yours "My dear Sir"

Relations with the president continued outwardly pleasant although grown more formal. McHenry still attended the drawing rooms and, at one of them in April, Mrs. Adams 
told him that, if any regiment went to Rhode Island, she hoped it would be the one W. S. Smith commanded. ${ }^{1}$

The president requested McHenry to send him a list of officers appointed in the recess of the senate ${ }^{2}$ and asked him with the other heads of departments, if there should not be a public printer. MeHenry took counsel with Chase ${ }^{3}$ on the matter and answered, favoring the project, but doubting the power of the president to establish an office with a fixed eompensation and suggested the passage of a law authorizing such an officer. The list of officers in the 12 new regiments was transmitted to the senate ${ }^{4}$ on April 15, with the recommendation that vaeancies in the old regiments be filled from the most deserving of the disbanded officers and that all vaeancies, henceforth, be filled by promotion, as a failiure to do this, has a bad effect. ${ }^{5}$

1 See Lodge, vil, 206.

2 March 31, Adams, ix, 48. Aprii 23, Adams, ix, 50.

3 Samuel Chase's opinion reads as follows:

"By the Constitution Act 2. Sec. 2. The president is authorised to nominate and with consent of the Senate to appoint certain enumerated officers, 'And all other officers of the United States whose Appointments are not herein otherwise provlded for and which shall be established by Law.' But Congress may by law vest the appointment of such inferior officers, as they think proper, in the president alone, in the Courts of law, or in the Heads of Departments.

"Is a printer to the President an Officer of the United States? if he can be so considered his office must be established by law and he must be nominated by the President to the Senate.

"It is evident that there ought to be a public Printer, not only to publish the Laws, and Papers which either Branch of the Federal Legislature should direct, but also State Papers, as Treaties, proclamations and official Papers of the different Departments, but forelgn and Domestic Intelligence which the people might consider as authentic.

"It seems to me that the President can exercise no Power as President not granted to him by the express Words of the Constitution, or necessarlly implied by some expressions in that Instrument. he may appoint a Printer, to be calied the Printer to the president but he can be considered only as a private Person, and entitled to no Compensation, without a law ascertaining the Sum. If the Departments employ such Printer he will be paid for his Services and Compensation as they desire

"I would suggest - as there is no Printer at Washington whether the Senate could not be induced to propose a bill to request \& authorise the Senate to appolnt from time to time some fit trusty or faithful discreet Person of unquestionable attachment to the Government to be Printer to the United States whose duty it should be to publish or to superintend the publishing of the laws of the United States, \& all Papers which either Branch of the Legislature, or the President, or any of the Departments of Government should direct, and that he shall receive Compensation for all such servlces, and that the presldent be authorised to remove such printer, and to appoint another in hls place. It wlll be said that the President wishes to create offices. If there is no appropriation of Money by law which can be properly and clearly applied to pay a printer appointed by the President, a Clamor will be ralsed, that he misapplies public Money"

July 8, 1799, Chase wrote McHenry and Charles Carroll of Carrollton asking them to withdraw their objection to bringing water to Baltimore from a Branch running through thelr lands.

4 State Papers, Military Affalrs, 1, 146.

5 State Papers, Military Affairs, i, 15.2. On May 1, the war department asked the house for $\$ 100,000$ for fortifications for the next year. 


\section{H A P T E R XV}

FRIES'S REBELIION AND THE WEST IN 1798 TO 1800

$\mathrm{I}^{\mathrm{N}}$

the counties of Northampton, Bucks and Montgomery, Pa., the Germans resisted the officers, who came to measure windows, preparatory to levying the new tax which congress had put on houses. Some of the rioters were arrested but were rescued from the marshal in Bethlehem by a party headed by one Fries. Adams issued a proclamation, ordering that this resistance be put down. Great alarm was felt in many quarters as to what the troubles might portend. When McHenry notified Hamilton of the insurrection, he acted at once and wrote:

"Sir

“New York March 16th. 1799

"In compliance with the object of your letter of the 15 . instant, I have put in motion two companies of Artillerists from Fort Jay (Henry's and Cochran's) who are to embark at ten this morning for Amboy and to proceed from thence by way of Brunswick to New Town in Bucks County. There (at Brunswick) Lt. Boote with his party is instructed to join them. The two companies, as they march, will exceed together seventy men, and will go provided with all necessaries except that the number of tents will be incomplete. If we had known the wants of It. Bootes party, they could not have been supplied from this place. Inclosed are the directions to him. Tomorrow you will be advised of the exact number of men and tents.

"I trust you will excuse the deviation from your order as best calculated to fulfil its object. 'The march from West Point would have been attended with great difficulties and much delay. The River will speedily open and if necessary, the substitute can then be brought from West Point to Fort Jay. In the mean time, no inconvenience is likely to ensue.

"A person will go' by concert between Col Stevens and the Contractor, in the double capacity of Quarter Master and 
Commissary. He can easily do both duties. Perhaps indeed, the expense of such a person might have been saved, had there been a sufficient number of officers with the companies. But it has been impracticable to send more than one Captain and two Lieutenants.

"I defer till tomorrow to give any order to Major Ford. Were it not that the presence of Major Hoops was requisite at a Court Martial which is to trye Captain Frye and Doctor Osborne, it would perhaps be more in order to send him with the major part of his Command, But this point is reserved.

"With great respect \& esteem "I am

"Sir

"Your obed Servt.

"A Hamilton",

A second letter from Hamilton written on March 18, 1 said: "Beware, my dear Sir, of magnifying a riot into an insurrection, by employing, in the first instance, an inadequate force. 'Tis better far to err on the other side. Whenever' the government appears in arms, it ought to appear like a Hercules and inspire respect by the display of strength. The consideration of expense is of no moment compared with the advantages of energy. 'Tis true this is always a relative question, but it is always important to make no mistake. I only offer a principle and a caution." Auxiliary cavalry can be gotten from middle states without interfering with farming.

Harper wrote McHenry on the 26th:

$$
\text { "So. 3d. Street. Nar: 26th. } 1799
$$

"My dear sir

"I am afraid that I shall appear importunate, but as you have done me the honour to communicate with me on the subject of the insurrection, I trust you will excuse me for troubling you again with one or two remarks on the means of suppressing it.

"I confess I shudder at the consequences which may result from attempting this business with too small a force. The people to be dealt with, are ignorant, biggotted, numerous, $\&$ united. Their leaders, who possess an intire influence over their minds, are committed to the full length of treason. They are impressed with an opinion that insurrection prevails everywhere, and that the government, threatened on every side,

1 Hamilton, v, 235 ; Lodge, $\mathrm{x}, 349$; Lodge, vii, 69. 
cannot collect a force sufficient to punish them. The counties implicated in the business contain, at least, three thousand effective men. From recent accounts, the spirit of revolt, and the boldness of the revolters, encrease with rapidity. Under these circumstances, ean it be well to depend, even in the first instance, upon 240 horse, \& a few companies of regular infantry, many of them new units, and the whole amounting, in all probability, to not more than 250 or perhaps 200 men? Would it not be safer \& better, in every point of view, to put in motion, immediately, the whole of the Volunteers, and the requisite cavalry? This would be a force sufficient to overawe the rebels, and, probably, prevent resistance. Should no more march than have been mentioned, it seems very probable to me that resistance will take place, many valuable lives may be lost, and the worst consequences ensue.

"The General, I know, is empowered to call out a greater force, if after he advances towards the scene of insurrection, circumstances should seem to require it. But what effect must this have on the rebels? When they see a small force sent against them, and that done, halt through a sense of its own weakness, and wait for reinforcements, will they not be encouraged to prepare, and be allowed time for preparation? Will it not appear to them as a proof of weakness on the part of the government, which must encrease their audacity?

"Besides ought the descretion, in a case of this kind, to be transferred from the department to the Genl? ought he to be required to judge about the question of force?

"It is with you to decide, and I am persuaded that you will decide wisely, on these various questions: but I cannot help expressing, in the strongest \& most decided manner, my conviction that every principle of sound policy requires the whole of the volunteers \& regulation cavalry to be put immediately in motion. Perhaps, instead of marching the whole force to the neighborhood of Bethlehem, it might be sufficient to advance about twenty miles, to some convenient point, and then send forward into the county a Detachment of Horse \& infantry. But I should advise marching the whole to Bethlehem in the first instance.

"I am my dear sir, with great affection \& esteem

"Yours most sincerely

"Roв: G: HaRPER."

Hamilton wrote ${ }^{1}$ MeHenry on March 29, that all the

1 Hamilton, $v, 240$. 
regulars but one company had reached the first points of destination against the insurrection. "However slightly the present governor of Pennsylvania comes into contact with insurrection, there is delay in quelling it." 1

On March 30, McHenry wrote Washington of the proceedings of the troops against the "ignorant and mulish" insurgents.

Adams had gone to Massachusetts, whither McHenry sent him news of the insurrection and whence McHenry received cordial approval of his measures. ${ }^{2}$ Fearing that the two companies of horse, which could muster only about 60 men, would not suffice, MeHenry had submitted to the heads of the departments and the attorney general the experliency of calling on the governors of Pennsylvania and New Jersey to hold a respectable body of militia in readiness to march against the insurgents. The insurgents were soon dispersed, so that shortly thereafter Adams could congratulate MeHenry on Gen. McPherson's success.

"Sil"

"Quincy April 191799

"I recd last night your favour of the 11 and thank you for the Copy, of General Macpherson's Letter and the list of the Prisoners. The Generals Conduct has been prudent and Successfull, and will terminate in the permanent tranquility of the People.

"I return you Reeder's Letter and Jackson's address. Have these Democrats, a morality of their own? or have they none? Do they really believe that lying is lawfull for the public good and that political Lyars have no part in the Lake of Sulphur and fire? I think that a Representative in this part of the Country convicted of setting his hand to such a Lye, would Suffer Something very like a roasting in the Lake, from his own constituents.

"I inclose you Letters from Daniel Flint, John Cooper, and H. G. Otis, which I pray yon to give the regular attention to.

"Inclosed also is a Letter from Caleb Gibbs with Documents Numbered 1-2-3-4-5-6. which you will also consider in their turn.

"I have the honor to be, Sir your most obedient

$$
\text { "JoHN ADAMs", }
$$

1 Mckean, a Jeffersonian.

2 Adams, viii, 632 . 
McPherson reported to McHenry on May 3 that he arrived at Reading on April 20 and found the opposition broken. He dismissed the Lancaster troops on the 21st, but left the regulars in Reading and thinks other troops should be stationed in Allentown and Easton.

Great feeling had been aroused against Fries, as is shown in Tracy's letters.

He wrote from Litchfield on the 6 th of May:

"The insurrection in Pennsylvania must be treated with severity, I suppose military execution was impracticable, but if some executions are not had of the most notorious offenders — I shall regret the events of lenity in ' $94 \&$ ' 99 — as giving a fatal stroke to Government. . . . and much time cannot elapse before we shall all understand, that undue mercy to villains, is cruelty to all the good \& virtuous. Our people in this State, are perfectly astonished, that cost must continually be incurred for insurrections in Pennsylvania for which they say they are taxed \& yet no punishment is inflicted on the offenders. I am fatigued \& mortified, that our Govt., which is weak at best, should withhold any of its strength at a time when all its energies should be doubled.

"Have you any influence with the Prest of the United States? Why in God's name is not the Alien Law inforced? Why is old Letomb permitted to exercise, the functions of his defunct Consulship - in open defiance to all the shadow of Govt. we have? Do, my dear friend let ' we, the people,' know that you, the Executive, are willing to put Laws in force, at least when they are made to last but for a season, a little season. Pardon me, I cannot intend to offend you; but I will make you \& all other Secretaries accountable for all the unaccountables of the Executive."

He wrote again from Litchfield on the 20th of May, 1799:

“*** Our Legislature is in session, Kentucky \& Virginia Resolutions will meet their just answer - and all things proper for sound federalism will be done. I spent 8 or ten Days with them - in which time I did not, as I believe, weaken their faith or measures.

"I thank you for the information respecting Fries \&c but I am in fear that something will occur to release that fellow from merited Death." 
On May 16, Adams congratulated ${ }^{1}$ McHenry on the end of the rebellion and, on the 29th, the latter conferred on Hamilton power to continue or to remove troops from Pennsylvania, advising that a regular force be continual there for some time. Hamilton answered on June 6:

"I return MIr. Patterson's letter. It is not my intention inmediately to withdraw more than Cochran's \& Henry's Companies. The other troops may remain in the insurgent scene. I should prefer their remaining together. Perhaps the vicinity of Easton may be the best single station. But I am not without apprehension that the Troops may be corrupted by remaining long in a disaffected scene. Is there no well aftected spot in the reighbourhood of Easton where they may answer the end?

$$
\text { "Yrs. affectly }
$$

In May, Hamilton had recommended ${ }^{2}$ that soldiers be not stationed in the scene of the late insurrection and McHenry committed the matter to his judgment, though inclining to maintain a regular force there. In July, Capt. Adlum reported from Reading, recommending that the troops be continued there and at Easton. The disaffected persons pass the soldiers in sullen silence and do not associate with them. $\mathrm{He}$ thinks. Bucks and Northampton Counties a strong country, with many passes, of which it would be well to have a military survey, for numbers wonld join the French, if they invaded the country. The treason cases dragged along. Fries was convicted, awarded a new trial and convicted again. On Sept. 7, MeHenry joined the other secretaries ${ }^{3}$ in a letter recommending to the president that none of those condemned for complicity in this insurrection should now be pardoned. Adams, however, issued a pardon, being wiser than his councilors in this matter.

During 1798 , no matters of much moment occurred in the west. In the early summer, McHenry received an interesting letter from James Ross, the Pennsylvanian federalist.

"Dear Sir

"Pittsburg. 15 June 1798.

"I take the liberty of enclosing to you a pamphlet which,

1 Adams, viii, 648 .

2 Hamilton, v, 261, 264.

3 Adams, ix, 23. 
in my Judgment, is extremely well written, and the very important subject handled in Manner not to be Answered.

"The Spirit of our young men would be very easily brought into the Measure of association in Volunteer companies under the Provisional Army law : this would have an effect upon political opinions \& perhaps upon some of our Elections; as this subject is now occupying your Attention, will you think of forwarding a sketch of what you would think the necessary arrangements and bond of association, in order to enable the President to appoint officers. It would of course be understood that the men would not be called to serve out of this Country except in case of extreme necessity.

"Genl Wilkinson sailed with his Galley a week Since and we have heard that she passed Grave Creek on the third day after leaving this place. The Genl. has been decided and Zealous in his politicks here, and his examplary decision has produced some good effects here and has made proselytes among his friends of Kentucky who are frequently passing thro this place. I like his present opinions respecting the policy of strengthening the Mississippi \& opposing by all means in our power the Introduction of the French into Florida. Our people who have returned from thence lately say that the Spaniards are much alarmed at the report of the cession to France.

"It might be easily learned whether the Spaniards would not thank us for a cooperation in that quarter, as there is now a prospect of their quarrelling with France again.

"We hear nothing from Tennessee-nor do I learn that any arrangements have been made by the Indians for removing over the River Mississippi, as was suggested - on the other hand, there is reason to believe that the Spaniards are not at present in the humour of this migration. But this is on the Report of our traders. The fact may be otherwise.

"Be so kind as to present my most respectful compliments to Mrs. MeHenry \& believe me to remain very faithfully "Dear Sir

"Your most obedient

"Humble Servant

"JAMEs Ross."

Early in August, Lee answered certain questions McHenry asked, concerning operations in the west. 
"Sir

"I have given Mature consideration to the questions proposed in your letter of yesterday.

"It is well established, as a general rule by the laws of nations, that one encmy may not attack another in a neutral territory : but to this rule there are exceptions. One exception is, if there be imminent danger of a great mischief, which may not certainly be prevented, unless by entering into the neutral country and here meeting the enemy. In such a case upon the principle of necessity, this violation of neutral rights is excusable or justifiable. It must be left to the discretion and judgment of General Wilkinson to decide upon the circumstances which may require an application of this exception to the general rule before stated and for a right Decision and conduct in this particular, he must consequently be responsible. At the distance of his army from the President, it is not proper to give any instructions more precise on this head.

"You perceive, Sir, that I understand your questions as predicated on the idea that the french army is intended to invade the United States and to act against General Wilkinson's army : and my observations have been designed to answer both. The same necessity that will warrant our General to enter the spanish territory and there oppose the french army, will certainly warrant him in opposing its passage up the Missisipi: or rather the opposition in the latter case will be less objectionable than in the former, for the fourth article of our treaty with spain makes that river a high way open and free to both nations.

$$
\begin{gathered}
\text { "I have the honor to remain } \\
\text { "very respectfully sir your } \\
\text { "obedient servant } \\
\text { "CHARLEs LEE", }
\end{gathered}
$$

McHenry wrote Wilkinson at once, to stop any French troops ascending the Mississippi under the Spanish flag and to advance into Spanish territory, to defeat an advancing foe, if the danger of mischief be so imminent that it cannot utherwise be certainly prevented. He may not call out the militia. This must be left to the governor, but he may search craft probably carrying prohibited articles to New Orleans 
and must report as to whether there should be a new post on the boundary, near the 31st parallel. ${ }^{1}$

Nothing more is heard from the west until November 6, when McHenry writes Washington that Gayoso probably was in connivance with $Z$. Cox and made a population project with him. There is discontent in Natchez according to Wilkinson and the people are moving to Spanish territory. The presence of judges, the settlement of the right to the soil and jurisdiction, the establishment of some principle by which to ascertain and fix individual rights to the land within the territory are essential matters.

On November 29, McHenry urged ${ }^{2}$ Adams to send congress a message, which may lead it to declare war with France, suggested mention of the surrender of the posts on the east bank of the Mississippi by Spain, and recommended that the president be invested with power to seize Louisiana and Florida on behalf of Spain, in case of danger that France seize them.

On January 31, 1799, McHenry writes Wilkinson that he is forwarding supplies and a galley is kept ready for service. He regrets that Wilkinson called on the governor of Louisiana to surrender Cox, as this demand, which might become a congressional question, should have come from Washington. Wilkinson must be careful not to make Gayoso unduly jealous. "We must consider the influence France exercises over the councils of Spain, be at all times on our guard against hostilities and, as far as possible, prepared to meet them, should the weakness of the latter oblige her to give to France possession of Louisiana or the Floridas." Henceforth, Hamilton will give Wilkinson orders. The latter must let governor Sergeant have any buildings delivered up by Spain for a courthouse, ete., if the post be not thereby deprived of necessary accommodations.

In the west, matters were fairly quiet in the last year of McHenry's secretaryship. The galley, Senator Ross, eaused some correspondence.

McHenry felt Fort Massac was the better rendezvous than Pittsburg as the want of water at the latter place at certain seasons would prevent a descent of the river thence. $\mathrm{He}$

1 J. Adams, viii, 594. C. F. Adams says McHenry's letter to Hamilton against Wllkinson shows remarkable knowledge of projects against Spain.

2 J. Adams, viii, 604. 
thought Hamtranek, ${ }^{1}$ commanding at Fort Wayne, was too far from Ohio and that there should be a new distribution of anthority there.

Hamilton did not fear an invasion by the Mississippi and thought that one galley would not be of much use against invaders. He wrote to Hamtranek and sent a copy of this letter to MeHenry from New York on May 2d, 1799:

"Dr Sir

"Very mueh attached to the idea of leaving the commanding offieer of a distinet \& distant army to regulate himself his particular dispositions, I have referred the employment of the Galley to Col Hamtranek, on the supposition that, by the departure of General Wilkinson, the eommand has devolved upon him; with the intimation only of my opinion that probably the lower posts on the Mississippi offer the most natural position.

"It seemed to me that this Galley would render more service as a kind of sentinel and an auxiliary defence to those posts than any other way - the invasion of the western eountry, by a water expedition up the Mississippi, exeept the part immediately in the neighbourhood of the Spanish Territories, has never struek me as much to be apprehended - and if it shall happen, it will doubtless be with means against which a single Galley will be of little eonsequenee. Henee the keeping her unemployed at Massae to wait the possibility of such an event appears to me not likely to eounterraet in utility the expense of building and equipping her. As a protection to an offensive movement on our part, the position below will be as eligible as higher up.

"But not being aware of the views which may have influenced the building of the Galley, I sent a copy of my letter to you to enable you to do what you have done. And sinee you think it best that the Galley shall eontinue at Massae, till after a eonference with General Wilkinson, and as it is not important, in $\mathrm{my}$ opinion, that her destination be immediately fixed, I now send you another letter for Col Hamtranek, direeting him to permit her to remain at Massae till further order.

"If General Wilkinson, as direeted, shall have left the Western army for the Seat of Government, it is presumable that Col Hamtranek will have changed his own position, so as

1 September 28, Hamtranck wrote concerning the drunkenness of the Indians at Detroit. 
to be in one more convenient for communication with this Quarter \& with the different posts under his command. I have acted on this presumption, though my letter is addressed to him where he was known last to be. But, at any rate, especially in matters not urgent, I prefer delay to the breaking in upon the regular Military order.

"With great esteem \& regard

"Dr Sir

"Yrs Obedly

"A Hamiton"

In the above letter the following was enclosed:

"General Hamilton respectfully transmits the Secry of War the copy of a letter to Col Hamtranck on the subject of the Galley. It will shew what has been deemed by him the most eligible step"

"Sir,

“New York April 29th. 1799

"The secretary of War has informed me that a Galley lately built at Pittsburg, called the Senator Ross, has been by him ordered to Massac, there to receive further orders; The commander of the Western Army being from Situation most competent to judge what will be the most useful employment of this Galley, I leave it with you to dispose of her, as you shall think best; observing only that the lower posts on the Mississippi would seem to me the most fit destination. The Secretary of War having instructed the commandant of Massac to pursue the orders I should give, I send you a letter to.him directing him to obey your commands.

"I think it most expedient for the present that the Galley should be officered and manned by officers and men to be detached from the line. I presume it will not be diffieult to find those who have sufficient marine knowledge to answer the purpose.

$$
\begin{aligned}
& \text { "With great consideration } \\
& \text { "I am Sir } \\
& \text { "Yr. Obedient Servt. } \\
& \text { "A HamiLton" }
\end{aligned}
$$

MeHenry gave no encouragement to white men who made illegal purchases of land from Indians. "The persons who 
have speculated illegally in Indian lands and who have excited them to complain to government, will, no doubt, continue to practice upon them and even to stimulate them to acts of hostility, should they consider such a proceeding calculated eventually to procure to them from the United States a title to their purchases." Such answer he made to the Chippewa, Ottawa, and Pottawatomie chiefs who came to Philadelphia. 1

It was felt that the officer's at the posts held too many talks with the Indians and spent too much money: Hamilton urged ${ }^{2}$ purchase of lands from Indians to prevent collision with pioneers. "Temporising measures, on a distant frontier, are often proper for a government which does not choose to keep on foot a considerable force, effectually to awe sedition and hostility." He wrote ${ }^{3}$ to Hamtranck, by McHenry's orders, that the military must not intermeddle in Indian affairs. The governors of the Northwest and Mississippi Territories are ex-officio superintendents of Indian affairs under MeHen'y and the military are only auxiliary, that is, "they cietermine when and where supplies are to be furnished to those people and what other accommodations they are to have.".

On the same day Hamilton wrote Wilkinson, who was at Natchez:

"sir

“New York May 23d 1799.

"I begin now to be anxious to learn that you had received my letter desiring you to repair to the seat of Government, in conformity with an intimation from the Secretary of War, to the end that, with the aid of your lights and experience, a general plan for the arrangement of the affairs of the Western army, with an eye to the existing posture of our political concerns, might be digested and adopted. If by any accident that letter should not have gotten to hand, I must urge you

1 May 18, May 22 Adams wrote W. S. Smith (Adams, viii, 652), concerning an Indian agent who complained against McHenry, directing Smith to send the papers to the Secretary. See IState Papers, Indian Affairs, 1, 64.5. St. Clair on Indian Affairs. He was then superintendent of them.

2 Hamilton, v, 259. See also Lodge, vil, 151 on situation of Western garrisons and p. 85 on purchase of Indian lands.

3 May 23. Hamilton, $v, 257$. On the same day, in a third letter, Hamilton told McHenry he had directed Colonel Strong, if necessary, to withdraw the garrison from Mackinac. He wrote Strong on the $22 \mathrm{nd}$, that he preferred to have Detroit made safe, rather than to fortify Mackinac and told him not to use martial law in Detroit. 
to iose no time in complying with its object. It left to your option to come by way of New Orleans, if you could obtain the needful consent there, and if you should think it the most convenient, and a perfectly safe route.

"You will, of course, previous to your departure, leave the requisite instructions with the officer who is to succeed in the command, making the proper reserves as to those discretionary powers which a confidence personal to you may have dictated.

"On the presumption that you would have left the Western army, ${ }^{1}$ as is shown by Hamilton's letter of May 29, to $\mathrm{Col}$ : Hamtranck as the senior officer of the army.

"With great consideration

"\& esteem I have the honor to be

"Sir -

"Yr. obedient servt.

"Alexinder Hamilton"

There was some question as to what constituted the Western army, ${ }^{1}$ as is shown by Hamilton's letter of May 29, to McHenry:

"The enclosed, my Dear Sir, was written on this idea that, though the Troops in Tennessee are annexed to the eommand of General Pinckney, as far as a distinct supervision on the sea-board is concerned, yet they remain a part of the western army and are subject to the general superintendance and direction of the commander of that Army. This connection seems necessary to the due course of service on the Western Quarter. There appears to be an intimate relation of objects between the troops in Tennessee and the other troops in the Western Quarter - as to the Indians and as to military operations - and a necessity of mutual support, perhaps occasionally of detaching from the one to the other. If so the Troops in Tennessee can hardly be detached from the Western Commander and, in matters of common concern, he must extend his attention to all. If your idea be not radically different, if it

1 Rivardi, the commander at Niagara, wrote Hamilton on August 8, 1799. It was very hot, the thermometer standing at $96^{\circ} \mathrm{F}$. "The surgeons of the British continue to attend our sick with the greatest attention and appear to receive an obligation, while they lay me under one. I sincerely wish, however, tor be soon able to decline their further good offices." McHenry on August 30, wrote Hamilton that he always adds temporary surgeons' mates when apprised that a garrison in the West or on the frontier wants them. 
extend not to a total separation of the Troops in Tennessee, this letter is proper. If it does extend to a total separation, then I will request you to exchange the words 'in Tennessee' and to add after dependencies 'except the troops in Tennessee' and then to forward the letter. As to the troops on St Mary's, I understand that they were never considered as forming a part of the Western army \& so not included in the letter as it stands. Favour me with a line expressing what you shall have done

$$
\begin{gathered}
\text { "Yrs. Affectly } \\
\text { "A H" }
\end{gathered}
$$

On the Indian trade Wolcott wrote ${ }^{1}$ McHenry on August 17, "My opinion has, you know, been somewhat different from yours on the subject of Indian trade. I consider the public establishments as in every respect nuisances, the capital must from the nature of things be lost. Abuses will be committed by the public agents, sooner or later; and it is impossible that the Indians should be well supplied. The interest and policy of the government, in my opinion, requires that the Indian trade should rest principally in the hands of a few men of capital." These would be interested in preserving peace, which interest pedlars do not feel. "My plan would be to keep the trade in few but good hands, and to give up the public stores as soon as possible." During 1799, the boundary was being run between the United States and Spain and between the Cherokees and the whites in Tennessee and these matters caused McHenry much thought. The questions he had to consider may be seen from the following letter:

"Sir

" Hillsboro 30th of June 1799

"The two letters you did me the honor to write me last month, I did not receive till the 20th Inst. Not knowing when the mail departed, I have lost a week in making you this acknowledgment.

"The opinion I ventured to give you in my letter of the 30 th of July, \& which you think worthy of some attention, was not without reasons, on which I thought I could rely.

"Your inquiry points to persons; to this purpose what I am about to trouble you with, appears to me quite insignificant, in your hands it may assume some value.

1 Gibbs, i1, 247. 
"To you who know the rise and progress of the Tennessee settlements, so much better than myself, it would be superfluous to mention it, however concisely. The happiness to be attained by the orderly and peaceful establishments \& pursuits of society are not the objects those settlers were in search of - this you have seen and felt, \& against their turbulent temper have been constrained to afford protection to the Indians this corrective to their conduct has worked no reformation on their minds - they burn with indignation at the restraints put upon their avidity for the Indian lands.

"The Indians on their part, have nothing so much at heart as to retain their lands, \& keep as far from the Tennessee people as possible. When it is considered that, hunting is the chief object with the Indians, whether for sustinence or recreation, \& that, as the game decreases, its value is enhanced, it cannot be believed they will willingly contract their sphere \& diminish the chief source of all their joys and comforts. The bloody fellow said 'We will not sell a foot of land for that boat' (pointing to a large barge) full of dollars 'Weighty as these reasons are on the side of the Indians, there is yet another not less operative; the lands they part with furnish an increase of numbers $\&$ power to those who, for many reasons, they regard as their principle of decay' \& the probable means of their final extinction. Ideas like these, I know, some of the most sensible of the Cherokees do really entertain; Doublehead once said to me 'I know I must die by the hands of these men, but it will be in contending for my right.' They know and acknowledge that the people of Tennessee are able to destroy them, and with it are well convinced they are willing to do it.

" On the federal Government alone they build their hopes; they seemed confident in its justice \& humanity \& no way diffident of its power. The last talk we gave the Indians, was of a more serious nature than any which preceded; the effect was apparent. It was intimated that their friendship for the United States was doubtful and we feared they intended to withdraw their affections from our Father the Presidentthe bloody fellow was greatly affected, \& with a countenance denoting excessive anxiety \& in a manner that imposed confidence said, ' $I$ have taken the President fast by the hand as my Father \& I never will quit it.' After the conference was over the chiefs severally \& ât different times, said they hoped we were yet friends, \& we begged them not to doubt of it. 
"I had taken my leave of those with whom I was best acquainted \& never expected to see one of them again: In the evening Bloody Fellow \& Doublehead came together to our house, saying they did not like the way in which we parted and that they eame to spend the evening with us in friendship. They began with some advice to Mr. Steel, respecting his rout to Natehes, by putting him on his guard against a danger to which he was exposed, in passing thro' the Indian country as he had intended, \& offered to conduct him a safe way by water.

"Doublehead asked if I should return to the treaty, I said I should not, at which he seemed sorry (for he had declared himself my friend) I expressed my sorrow at leaving them in such ill temper towards our people \& desired him to think well on what I had several times mentioned to him, in our private conversations; he said he had been doing it, \& that he \& Bloody fellow, had eome on purpose to let us know it; that they had been deceived; Irad they known at first what they then did, they believed things would liave been otherwise; that they had wished to meet again (which before they seemed not inclined to do) \& they hoped the treaty would be happily coneluded. We talked over the subject of tho boundary, \& I understood the treaty made is, in this respect, exactIy what those two Indians seemed willing to agree to.

"I am perplexed with the Bloody fellow's story to you, because by that, it seems, they believed the United States were desirous to purchase their land \& water too. Yet he did repeatedly express his doubts of our Mission - required the Commissions to be shown and read. After they were read some of them said the white people eould write anything \& impose on the Indians, who could not read; they then examined the seals - \& Dinsmore and Col. Butler were called on to vouch for the authentieity of the Commissions - an argument too was drawn, from Col Butler's attending us with the federal troops - all this did not entirely dispel their doubts, for after this, Bloody fellow said, we did not speak the language of the President, but of 'those men' (pointing to the Tennessee Commissioners) some notice being taken of this, he said, $h$ ? lid not mean those men, but others, pointing towards Knoxville.

"Doublehead, in a conversation, which I did not ehows" to trust t' any other interpreter than his own Nephew, intimated his suspicions that, the Commissioners were but lab- 
ouring for their own particular interest; that some of them had larger claims on the Indian lands. I answered for myself that, I neither had, nor intended to have, a foot of land in that country \& I believed my colleagues were equally clear; he shook his head \& pointed to Mr. Walton and said he came from Georgia: I told him he was wrong, but he retained his opinion \& said the President did not want to buy the land. I asked who informed him of these things - he said my ear could not receive anything from his mouth \& this secret he would not intrust even to his Nephew.

"I have not a paper with me relative to the Treaty of Jellico \& may have forgot some other facts, but these convinced me, that the Indians had been misled, respecting our Mission. How and by whom, this has been done, you earnestly inquire. I am unable to answer: at least in the way that might assist your researches \& satisfy my inclinations. I will do the best I can.

"On my way to the treaty I heard repeatedly that Govr. Sevier ought to have been a Commissioner \& that he was improperly neglected by the federal Government: some added that Mr Blount should have been appointed, on account of his great experience in Indian affairs \& his personal influence over the Cherokees. At Knoxville I conversed with both these gentlemen \& Mr. Blount told me the Indians would sell the land which has since been purchased. I believe the Gov. said nearly the same thing \& believe both told me they had seen \& talked with some of the chiefs.

"It was said a Col. or Major somebody (I forget his name) was seen at times, among the Indians \& that he was sent by the Govr. \& Mr. Blount, it was said that Watts had been with $\mathrm{Mr}$. Blount \& had reed. from him a good deal of money, but this was mere report.

"Commissioners were sent to the Treaty, to watch over the particular interest of the State of Tennessee. I understood it was done by the Govr. They furnished us with several lengthy memorials, which we supposed were intended to embarrass us. They often and at improper times, as we were told, had the Indians with them. One of their Commissioners was a gentleman from Georgia very recently removed to Tennessee. The secretary to that Commission, was also a Georgian adventurer with Mr. Coxe, \& left intrusted very confidentially with the managment of his affairs.

"As the schemes of Mr. Coxe \& his companions were 
altogether desperate, while peace remained \& as something might be hoped for from war \& disturbance, their all seemed, therefore, to depend on things being brought to this condition to answer good purposes in the treaty a more improper person could not have been selected, to fill the place of Secretary.

"I am at a loss to point my suspicions. Coxe's people may have proved conspirers for their own interests. The Govr. may, at least, have been pleased to see the treaty fail in our hands; so it may have been with Mr. Blount-many others in Tennessee had views no way suited to peaceful compacts with the Indians - be assured they want all the land and not a part. A militia Captain, his name I believe is Cox, being asked what would satisfy the people, said that, for the present they wanted all the land to the Tennessee River: but said he, to be candid, I dont believe that will do long; we shall force the Indians over the Mississippi \& perhaps may follow them there. Captain Cox is not singular in these sentiments - they are not inspired by influential men; no man will have inflnence there, who does not entertain them, or something like them - in this they see their exaltation and a means of gratifying ambition \& avarice; hence springs the under current which crosses your purposes.

" The Federal Government overshadows their firm prospects with a dark \& deadly gloom; while peace remains, scarce a ray of hope appears to comfort them : their policy is to alienate the United States from the Indians \& they will not be too scrupulous in the means.

"Whoever shall have the address to effect this, will rise high in the estimation of his countrymen - the very desire to do this attacks their confidence and affection. War is desirable; add only the money of the United States to carry it on and nothing more remains to be asked for, at least for the present.

"You will not understand me to speak thus without any exception; doubtless, there are many who differ widely from those I have described; but these are the active, enterprising men, they possess the energies of the state and will govern it - among such numbers and with such motives to thwart our negotiation, I know not where to look for such an accumulation of circumstances as will mark ont \& distinguish particular offenders.

"You have commanded me, Sir, to write confidentially to you \& I have done so; this letter has insensibly grown beyond 
my expectations: I have to regret that other duties call me off without leaving me time to correet or make it more intelligible, if further explanation should be required, you have only to speak \& shall be obeyed.

"Should it be thought that, for a Commissioner, I have failed in aequiring necessary information, my apology will be found in the peculiarity of my situation. Ignorant of the Indian language, the Indians ignorant of mine, not an inter. preter to be trusted on either side \& abstracted from every white man who might be able \& willing to give me intelligence - such was my situation, from the first moment I heard of any attempt to counteract us until the treaty adjourned.

"What you injoin respeeting military appointments for the eventual army, shall be obeyed: for that army you can have whom you please. I shall soon see Govr. Davie \& will talk with him on the subject.

"With very great respect I am Sir

"Your most obt. sevt.

"AlFred MOORE"

Hamilton ${ }^{1}$ felt that a passion for building permanent forts existed and should be restrained. Wilkinson had already spent $\$ 80,000$ on Loftus Heights, which was started improperly and without submission to the president before Hamilton beeame major-general. MeHenry would have advoeated a smaller fort there and did not believe in large forts. Hamilton thought, however, that MeHenry was too exacting, in wishing all plans submitted before they are earried out, and wrote, " "I cannot adopt the opinion that every measure, in all circumstances, which may involve considerable expenditure, should be submitted through the Secretary of the appropriate department to the President for his approval and that, withont sueh approval formally and explicitly announeed, no act leading to its exeeution should take plaee. A precise rule for distinguishing the different cases is impractieable; it must be a matter of sound diseretion and of fair eonfidence on all sides."

MeHenry stood his ground ${ }^{3}$ and felt that too mueh had

1 November 10 W. S. Smith wrote Hamilton on religious services among the troops. He had the minister of the parish in which his regiment is encamped preach last Sunday and wishes to employ him regularly. He will preach cheaply and render the employment of any other chaplains unnecessary.

2 Hamilton, v, 360,371 ; Lodge, vii, 170 .

3 See Hamilton, v, 401 . February 21, 1800 . Letter to McHenry on the Western army. 
been spent on Loftus Heights and that every act involving considerable expenditure should be transmitted to the president for approval and without this approval no act should take place. To Hamilton's claim that exceptions were necessary, McHenry answered, "True, in the active scenes of a campaign amidst the hurried operations of war, in which success often depends upon promptitude and when the general quoad hoc is the centre of information, the rule must be often dispensed with and so, in a degree, upon a sudden or imminent well grounded expectation of attack, using a sonnd discretion and upon the responsibility of the officer or commissioner."

In October, Hamilton suggested that the number of western posts be reduced. McHenry agreed to this, provided, (1) we keep possession of those which, in the hands of foreign power might be disputed as our right; (2) we keep up our influence with Indians and in case of war check them and cover the settlements; (3) we keep enough to observe operations of and in war be barrier and annoyance to white neighbors; (4) we secure the allegiance and obedience of citizens remote and exposed to the insinuations of foreign emissaries and misguided or treacherous citizens; (5) we protect the passage at the confluence of great rivers, both with military view and to afford facilities to and excite trading enterprise.

Just before leaving office, McHenry made a report to the house of representatives, in which he discussed the subject of Indian rations which are given from the army stores, ${ }^{1}$ recommending a separate arrangement and treating the questions of the visits of Indians to the seat of government, which MeHenry had tried to render less frequent. He also tried to establish more resident agents and discussed the cost of transporting the Indian annuities.

1 May 20, 1799, he wrote Winthrop Sargent, governor of Mississippi Territory, that the federal government would reimburse hlm for his expenses for an interpreter and for provisions for the Indians, but McHenry wishes him to keep a careful account and not be wasteful. 


\section{CHAPTER XVI}

THE FEDERALISTS IN THE PRESIDENTIAL CAMPAIGN OF 1800

$\mathrm{S}$ Adams's presidential term drew towards its close, the
Federalists in congress held a secret caucus in the
senate chamber, at which it was agreed that they would support the president for reelection and would vote also for General Charles Cotesworth Pinckney of South Carolina. It was intended that Pinckney should be the vice president, but the federal constitution at that time provided that each elector should vote for two persons for president. The person receiving the highest number of votes became president and the one receiving the second number vice president. Thus it was possible for either nominee to succed to the presidency, if the party's representatives in the electoral college did not vote, unanimously, for both nominees.

The Federal enthusiasm produced by the X. Y. Z. letters had cooled, the alien and sedition acts were unpopular, the lack of sympathy between the president and Hamilton became more marked, especially after the death of Washington. In the cabinet, Pickering and Wolcott were unfriendly to Adams and leant towards Hamilton. McHenry was so upright that, though he was Hamilton's dearest friend, Adams could make no charge of underhand dealing against him. But the fact that he was Hamilton's friend, tended to make him more and more distasteful to Adams. In the early days of May, ${ }^{1}$ came news that the election in New York had been lost to the Federalists. This still more aroused Adams's hostility to Hamilton, whom he thought to have contributed to the defeat, because of enmity towards him. It was also suggested that Adams thought that a breach with Hamilton and his friends, from whom he could now gain nothing, would help him in the South and rumors spread that Adams would try to secure his own reelection with Jefferson as vice presi-

1 See Hildreth, v, 370 ; J. Adams Works, 1, 566 ; Hamilton's works, 1, edited by J. C. Hamilton, 714 ; Lodge's Hamilton, vii, 349. 
dent. ${ }^{1}$ Then too Adams must have felt that he wished ad. visers who would sympathize more closely with his views as to the reduction of the military system.

Adams had "learned to cherish some regard" for McHenry "in his personal intercourse," but felt that it was to Hamilton that the secretary of war "habitually deferred as the arbitrator of his official administration. 'To him, he looked and not to Mr. Adams as the guide of his political system." "

Yet on the morning of May 5, when Adams sent this note to McHenry, "The $\mathrm{P}$. requests Mr. McHenry's company for one minute," there was no new cause for a breach with him and, but for Adams's failure to control his temper, that interview might have passed as many previous ones.

In a letter written, on May 20, to his nephew, John McHenry, at 'The Hague, ${ }^{3}$ McHenry stated that he had, "with the privity of the President, taken a house in Georgetown a few weeks previous to the event \& made arrangements for the removal of my family thither." The cabinet had been "'disjointed" ever since Pickering, Wolcott, and McHenry had opposed the president, thinking that "the mission to France might have been happily dispensed with,' while Stordert and Lee agreed with Adams. McHenry thought he had perceived a "new set of principles" introduced and that the "acts of administration were, as far as practicable, to be made subservient to electioneering purposes. Every day increased Adams's alarm on this subject and his distrust of those gentlemen near him who did not constantly feed him with news or hopes, flattering to his election. At times he would speak in such a manner of certain men and things, as to persuade one that he was actually insane. For my own part, I had never taken a single step to depreciate his character, or prevent his election, or expressed any public disapprobation of the mission." The arrangement that botl Adams and Pinckney should be supported equally for the presidency, increased

1 On July 17 , C. C. Pinckney wrote to Hamilton asking if these rumors were true. See Plckering's Examination of Adams and Cunningham's letters, 93.

2 Adams, 1, 566. I have found no proof of C. F. Adams's statements that McHenry's conduct was "subject to vaclllation and change, under the disturbing force applied from time to time by the wiil of the President himself. The effect was to present to the world an appearance of irregularity and uncertainty, which materially contributed. to shake confidence in the system of the administration. These symptoms became more perceptible, as the difference between the President and Mr. Hamilton became more wide," or that McHenry's "Deference to the wishes of Adams became cold, reluctant and dilatory."

3 Glbbs. Administration of Washington and Adams, ii, 346. 
Adams's apprehensions, as he feared it was "an abandonment of his interest."

When McHenry came, Adams spoke first of business, in connection with the purveyor of supplies, and when that was disposed of, the president, smarting under the fresh news of the New York defeat, "was led on to say many unguarded and some harsh things, that might have been omitted." It was a long and stormy conversation, in which Adams seemed to McHenry "indecorous \& at times outrageous." Adams charged MeHenry with influencing Washington to place Hamilton before Knox on the list of generals, with eulogizing Washington at Adams's expense, with failing to appoint to a captaincy in the army a North Carolina elector who had voted for Adams, and with attempting, in a report to the house of representatives, to eulogize Hamilton, who contributed to the loss of the election in New York out of ill will to Adams. Further, McHenry had joined with the other secretaries in signing a letter to Adams, concerning the suspension of the mission to France. How should he or they, presumptuously, intermeddle or pretend to know anything of diplomatic affairs. McHenry had best resign. It was a pitiful exhibition of rage and spleen and Adams afterwards regretted that he had "wounded the feelings" of McHenry. The latter promptly resigned, ${ }^{1}$ sending his letter of resignation on the sixth, and asking that he might remain in office for a few days to complete unfinished business. This resignation Adams accepted in the iollowing. note of the 7th of May:

“Sir"

"I have received the Letter you did me the honor to write on the sixth day of this month, and consider the requests contained in it as very reasonable.

"They are readily agreed. I am Sir

"with much esteem, your most

"obedient and humble Servant "JoHN ADAMS"

Brown well sums up MeHenry's official carcer in the war office ${ }^{2}$ in these words: "His management of it was marked more by fidelity \& industry, than by aný conspicuous

1 May 7 , Sedgwick wrote Hamilton that Marshall had been nominated as secretary of war but would not accept. "He was never consulted \& had no intimation that McHenry was to retire." Hamilton, vi, 438.

2 Life of McHenry, p. 35 . 
talent for conducting the complicated affairs of a great department.', McHenry's letter of resignation to the president concluded thus: "Having discharged the duties of Secretary of War for upwards of four years with fidelity, unremitting assiduity, \& to the best of my abilities, I leave behind me all the records of the department, exhibiting the principles \& manner of my official conduct, together with not a few difficulties I had to encounter. To these written doeuments, I cheerfully refer my reputation as an officer \& a man." 1

In his tract, entitled the "Public Character of John Adams Esq., President of the U. S.," printed six months later, Hamilton wrote the "ill treatment of Mr. MeHenry cannot fail to awaken the sympathy of every person well acquainted with him. Sensible, judicious, well informed, of an integrity never questioned, of a temper, which, though firm in the support of principles, has too much moderation \& amenity to offend by the manner of doing it - I dare pronounce that he never gave Mr. Adams cause to treat him, as he did, with unkindness. If $\mathrm{Mr}$. Adams thought that his execution of his office indicated a want of the peculiar qualifications required for it, he might have said so with gentleness \& he would have only exercised a prerogative, entrusted to him by the Constitution, to which no blame could have attached, but it was unjustifiable to aggravate the deprivation of office, by humiliating censures \& bitter reproaches." 2

Between MeHenry's resignation and his retirement, ${ }^{3}$ Adams and Wolcott were together and the former introduced McHenry's name into the conversation, stating that he considered him a "gentleman of agreeable manners, of extensive information, \& of great industry; that he verily believed" McHenry's "hands were pure:" that he was "happy in understanding" that McHenry's "circumstances were afflnent" and that the loss of his office would not distress his family; "if any suitable office should become vacant," Adams said "he would with pleasure confer it upon" the late secretary of war.

Adams's attack on Hamilton was unwise, for the latter ${ }^{4}$ recently had written Sedgwick "To support Adams \& Pinckney equally is the only thing that can possibly save us from the fangs of Jefferson. It is, therefore, essential that the 476.

1 Unfortunately they were burned within the year, see note on page

2 Hamilton, vii, 717.

3 Gibbs, ij, $395,409,410$

4 Hamilton, vi, 436. 
federalists ${ }^{1}$ should not separate without coming to a distinct \& solemn concert to pursue this course bona fide."

On May 7, Hamilton urged on Governor Jay ${ }^{2}$ that the New York federal state legislature be called, before it was succeeded by the anti-federal one just elected so as to pass a law for "the choosing of the electors by the people in districts, a measure which he believed would secure a majority of electors in the country" for a Federal candidate. He feared that Pinckney would not be supported by the Adams men and wrote that, if both are "upheld in the East with entire good faith, on the ground of uniformity, I will, wherever my influence may extend, pursue the same plan. If not, I will pursue Mr. Pinckney as my sole object." 3

Just at this time, on May 7, Pickering wrote to William Smith at Lisbon telling him of the Jeffersonian victory in New York, whose twelve electoral votes will probably be cast for the Republican candidate. "This will, doubtless, turn the scale of the Union in favor of Mr. Jefferson. The only chance for a Federal president will be by the election" of General Pinckney. He will be "voted for in the Carolinas with Jefferson and will be elected, if the New England states keep him on their votes. There is some danger that part of the Massachusetts votes may onit General Pinckney, unless the train of information between this time and the election of president should convince them of the impropriety of continuing Mr. Adams. Here we see the beginning of a plot, which was eonsidered all through the eampaign and might have succeeded, if Pinckney would have lent himself to it.

Adams, having begun his attack on Hamilton's friends, continued it by asking Pickering for his resignation and, when he refused to give it, promptly dismissed him. The news of McHenry's resignation eame as a surprise to all. On hearing of it, Chase wrote him on May 12 from Annapolis:

\section{"Dear" Sir,}

"I was surprised to see in the Papers your Resignation. I imagine this Resolution was suddenly taken, at least it was to Me very unexpected. I am really sorry for it, and feel a Wish to know the Cause. I also see in Fenno that the Antifederal Ticket has prevailed in N. York, \& his opinion that

1 i. e. those in congress.

2 Hamilton, vi, 438 .

3 Hamilton, vi, 44i. Letter to Sedgwick, May 10. 
this event ascertains that Mr. Jefferson will be elected. I wish you would give Me your Idea, and the State of the Votes as You expect it will be in each State - I expect to close the Session of this Court on Saturday next - direct to $\mathrm{Me}$ - Baltimore, \& if I am gone, I shall direct it to follow Me to Richmond - I hope you can justify your Resignation, at this Time.',

The nobility of MeHenry's character is clearly shown in the letter he sent to Hamilton ${ }^{1}$ on May 13, conveying the news of his resignation: "I have the honour to communicate to yon that, on the 6 th. instant, I requested of the President of the United States permission to resign my office of Secretary for the Department of War. To the above request, I added a proposition that $m y$ resignation be considered as to take place on the first of June next, in order that I might be for a short time, in a convenient situation to explain to him, or to my successor, any of the measures taken by me as Secretary of War that might require elucidation \& also the inducing motives to some of them, which were known to myself. The President answered that my requests were reasonable \& readily agreed. I am making my arrangements for the removal of myself \& family to Baltimore \& shall not continue in an official station longer (if so long) than the 1st. of June." Such a letter naturally mystified Hamilton, who answered ? it from New York on the 15th:

"If, My Dear MeHenry, your retreat is from any eircumstances painful to yourself, I regret it with all the Sincerity of a real friend; otherwise, I congratulate you. It is impossible that our public affairs can proceed under the present chief or his Anti federal rival without loss of reputation to all the Agents - Happy those who are released from the fetter.

"But my friend we are not to be discouraged. Zeal and fortitude are more than ever necessary. A new and a more dangerous Era has commenced. Revolution and a new order of things are avowed in this quarter. Property, Liberty, and even life are at stake. The friends of good principles must

1 He wrote him on May 10th saying nothing of his resignation, but stating that he still hoped for the establishment of a military acadeny. If not at present, at any rate, at the next session of congress.

Hamilton, vi, 442 . A letter from Hamilton to McHenry dated May 5, 1800 , and treating of Col. Taylor's case is printed in Lodge's Hamilton. vil, 208 . 
be more closely linked, more watchful and more decided than they have been. Of this enough for the present.

"More hereafter - Cannot we see each other, without my coming to Philadelphia, before you go to Maryland.

"Yrs. Affecty.

"A. Hamilton.",

On the 19th, Hamilton wrote again, urging payment of the troops before they are finally discharged and stating that he will defer disbanding them until they are paid, unless positively ordered to the contrary. ${ }^{1}$ By the $23 \mathrm{~d}$, however, he must have known the cause of McHenry's resignation, ${ }^{2}$ from the brief note he dispatched from the camp at Scotch Plains.

"Dr. Sir

"The letter with the enclosed came to hand preceding my leaving the City for this place. The hurry of the first moments here prevented my sending it sooner.

"Oh mad, ! mad, ! mad, !

"Yrs. Affecty.

"A. H."

On June 1, Stoddert took charge of the war department temporarily, soon to be succeeded by Samuel Dexter, and McHenry returned to Baltimore, resolved to retire to private life, from which, indeed, he never again emerged.

There were still some hopes that the New York electoral vote might be saved for the Federalists and Robert Goodloe Harper wrote to Hamilton, on June 5, inquiring of the prospects. In Maryland, ${ }^{3}$ he thinks, the Federal party have the entire management of affairs and warmly support Pinckney and Adams. Most would be well satisfied to see Pinckney president and even desire it, but feel that no direct attempt can be made to supersede Adams. "It wonld create uncertainity, division, \& defeat." 'Therefore, let both men be up-

1 Hamilton, v, 429. The letters on pp. 435 and 437 are wrongly stated to have been written to McHenry; they were addressed to his successor. Lodge's Hamilton, vii, 215. Lodge in the letters on pages 221 and 224 makes the same mistake as J. C. Hamilton.

2 sedgwick had written him on the 15 th telling him Pickering and McHenry were sacrificed as a peace offering. Plckering wrote W. Smith at Lisbon on May 28 telling him of McHenry's resignation and in a letter to Goodhue on the 26 th he said, McHenry had been put out of office because thought "too subservient to the views of Pickering and Wolcott." 3 July 17 , C. C. Pinckney wrote to Hamilton that Maryland might. change her manner of voting. 
held, till the electors come to vote, and then let those who think Mr. Adams unfit to be president drop him silently. Harper suspects not a few will pursue this conduct and would do so himself, if an elector, "for I am so thoroughly impressed with Mr. Adams's incapacity \& with the mischief that must result from an administration systematically \& ably opposed \& too weak \& versatile to be supported by men of sense \& principle, that I could never, under any circumstances, give him my rote." Pinckney's own position, however, was decidedly against this intrigue, as was shown by two letters sent McHenry from the camp at Shepherdstown, Va.

The first of these was headed private and dated June 10 th, 1800.

"Dear Sr.

"Your private letters of the 19 th ultimo $\&$ 1st instant came safely to hand, for both of which I am very much obliged to you.

"Mrs. Pinckney was last week attacked with the Ague \& Fever owing to some very unreasonable cold weather we have lately had. I, therefore, cannot carry her to Carolina during the Summer I shall set ont with her in September, be part of October in North Carolina, in Georgia the beginning of November, \& in South Carolina from the middle of November during the whole winter. I shall, in the mean while, know as well, as if I was present, what is going on in those States. I shall be at Mount Vernon about the 20th. of next Month for a few days, but shall return to this place $\&$ be principally here or in this Valley during the summer. From what I have heard of the character of Mr: A, I am not surprised at the very unworthy \& indecorous treatment Mr. Pickering \& you have received at his hands. If the Federalists will act with decision, energy, \& union I have no doubt but they will gain a complete victory at the ensuing Election over the Jacobinical party, notwithstanding the untoward result of the Election at New York and the tergiversation of Mr: A - Can the accounts I have heard be possibly true that he is endeavouring to coalesce with Jefferson, and that he stigmatizes the Federalists with the odious appellation of a British Party, and that he declares that he and Jefferson will convince the federal junto of their joint power?

"With regard to the conduct of the Southern States at the ensuing Election, I think they are bound fairly \& candidly 
to act up to their agreement entered into by the federal party at Philadelphia, with out the Eastern States should be convinced of Mr: A's abandonment of federal principles, his attempt to form a party with Jefferson, and his unfitness to be President, and on these accounts or some of them, should consent to substitute another Candidate in his stead. This Event I do not think impossible, \& his conduct \& the critical situation of our Country may require it. But to preserve the Union, this must originate to the Eastward - The Middle States can then take it up, \& the Southern ones with propriety follow.

"Marshall with reluctance accepts, but you may rely on his federalism, \& be certain that he will not unite with Jefferson \& the Jacobins. I expected more firmness \& decision from Stoddart. I had no idea of his wavering. As you have now leisure time on your hands, Do sometime favour me with a line - You are in the centre of politics, I am out of them here. Have you heard lately from our friend Murray. Do remember me to him, when you write.

"Mrs Pinckney unites with me in respectful Compliments to Mrs. McHenry, \& I am with great regard \& esteem "Yrs. truly" "Charles Cotesworth Pinckney.",

The second letter was sent on June 19th, 1800 .

"Dear Sr.

"I am very much obliged to you for the perusal of your exquisite Dialogue, which, agreeably to your desire, I return in this enclosure. I had not an opportunity of availing myself of your permission to communicate it to your friend Brigr. Genl. Washington, as he had left the place before I received it. He proceeded to the City of Washington, \& I gave him a letter for you, in case he should meet you, if he did not, it was to be put in the post for Baltimore. It was dated the same day as vours the 10th instant. I refer you to that for my opinion of what I think the conduct of the Federalists should be respecting the ensuing election. If any alteration should take place in the agreement entered into by the Federalists at Philadelphia, it should originate and be sanctioned in the Eastern States; otherwise we shall be inevitably divided, and the Anti-federalists obtain that success which I am sure they will not, if the Federalists are united, active and ener- 
getic. I am told Mr. A denies the coalition with Mr. J stated in an article under the Trenton head. I should be glad to know, if there is any ground for such a supposed Union. He certainly used to speak very slightingly of ' $J$ 's political talents and in the Dialogue, (and I have heard on many other occasions) now speaks handsomely of him, as the Man in the United States fittest for President, excepting always I presume himself. I shall certainly inform you of my movements, but at present have no thoughts of quitting this place till the middle or 20th of next Month, when I shall visit Mrs. Washington at Mount Vernon.

"Mrs. Pinckney unites with me in best respects to Mrs. McHenry \& I always am with great regard \& esteem

"Yrs very sincerely

"Charles Cotesworth Pinckney."

In spite of this, the intrigue went on. On June 18, Jonathan R. Wilmer wrote Hamilton from Baltimore, stating that the district system in Maryland will give Jefferson several votes and that, if New York goes Republican, the governor of Maryland thinks of ealling the general assembly together to afford an opportunity of changing the system.

By July 1, Hamilton's opposition to Adams had increased, he still doubted the support of Pinckney in New England, wrote Carroll ${ }^{1}$ that "it is not advisable that Maryland should be too deeply pledged to the support of Mr. Adams," for "if he is supported by the federal party, his party must in the issue fall with him.".2 He had already conceived the idea of publishing a pamphlet showing Adams's unfitness for reelection.

A month later, on July 18, Wolcott, who still held the secretaryship of the treasury, though busily intriguing against the president, wrote ${ }^{3}$ McHenry of the campaign. "The

\footnotetext{
1 Hamilton, vi, 444.
}

2 Gibbs, ii, 390, ff. contains a correspondence about a "sportive effusion," which Liston, the British minister to the United States, wrote on July 19, 1798, to James Buchanan of Baltimore stating that he "must now endeavour to lead Mr. Adams by the nose" and has no need to exert himself in holding "conferences with my bosom friend the Secretary of State, or keeping Oliver Wolcott \& McHenry right," for "they are all so staunch that I have now no occasion to look after them," etc. Buchanan showed the letter in London, where Rufus King, the minister from the United States, secured a copy and, thinking the letter a serious one. sent it to Pickering. He showed it to McHenry who pronounced it a "mere piece of sportive irony" using terms copied from the Aurora, the opposition paper. However, to make the matter sure he showed the letter to Liston, who pronounced it "mere badinage."

3 Gibbs, ii, 381 . 
Adamites" think they will carry all New England but Connecticut, whose loss they attribute to Wolcott. "If you will but do your part, we shall probably secure Gen. Pinckney's election. At any rate, the prospect is almost certain that the country will be freed from the greatest possible curse, a Presidential administration, which no party can trust, which is incapable of adhering to any system, in connection with which no character is safe."

The high-minded, honorable MeHenry revolted from such reasoning and answered Wolcott on July 22, four days later. "Have our ${ }^{1}$ party shown that they possess the necessary skill and courage to deserve to be continued to govern? What have they done? They did not (with a few exceptions), knowing the disease, the man \& his nature, meet it, when it first appeared, like wise \& resolute politicians; they tampered with it $\&$ thought of palliations down to the last day of the late session of Congress. Nay, their conduct, even now, notwithstanding the consequences full in view, shall the present chief be reelected, in most if not all of the States, is tremulous, timid, feeble, deceptive, \& cowardly. They write private letters. To whom? To each other. But they do nothing to give a proper direction to the public mind. They observe, even in their conversation, a discreet circumspection ill calculated to diffuse information or to prepare the mass of the people for the result. They meditate in private. Can good come out of such a system? If the party recover its pristine energy \& splendor, shall I aseribe it to such eunning, paltry, indecisive, back door conduct? Certainly I shall not, but to a kind \& watehful Providence alone, who will not punish the many for the faults of the few, who bears with our mistakes, who winks at our weak schemes, who overlooks our feebleness \& follies, \& who guides unerringly, \& according to the end he has ordained, all the government of the world. I carry, you see, my religious principles into my politics."

MeHenry doubts of the possibility of electing Pinckney president, since the caucus decision that both Adams and he be equally supported has been promulgated to the people and it is doubtful if all the Eastern electors will support Pinckney. McHenry refers to the proposition to summon the next legislature of Maryland, if it be Federalist, and have it choose electors. These would, doubtless, vote for both Adams and

1 Gibbs, ii, 384. 
Pinckney; but, if the people elect by districts, there will be three or four Republicans chosen. In his bitterness against Adams, McHenry charges him with bringing the "peace \& prosperity of the country" into jeopardy "for eleetioneering purposes ;" with trying, "in the government, to be everything \& do everything himself ;" with lacking "the prudence \& discretion indispensable to enable him to conduct with propriety $\&$ safety, even the colloquial intercourse permitted between a President \& foreign ministers;" with being "incapable of adhering to any system" and, consequently, "forever bringing disgrace upon his agents \& administration;' with possessing "foibles, passions, \& prejudices," which "must expose him incessantly to the intrigues of foreigners \& the unprineipled \& wickedly ambitious men of either party." Therefore, "the high \& dearest interests of the United States cannot possibly be safe under his direction." 1

Woleott replied: "I think that the elements are fermenting \& that you will see sport presently." ?

In August, the plotting continued in the federalist ranks. Cabot believed that we are pledged to give Adams the "full chance of the United vote concerted at Ihiladelphia," that "we are not strong enough to break up a new form, in the face of our enemy," and acknowledged that the party at large

1 An unpublished letter of John Rutledge, Jr., written from Newport July 17,1800 , to Hamilton, is of considerable interest. He states that Adams is very strong in Rhode Island, where it is charged that Hamilton is trying to produce a plurality of suffrages for Pinckney; that the New York election was lost through Hamilton, whose private pique at not succeeding to Washington's rank in the army is the cause of his opposition; and that he supported Pinckney, because the latter will administer the government to please him. Rutledge is trying to induce all Federalists to support both candidates and thinks this will be done in South Carolina, where the affection felt for Pinckney by all classes is such that he may be voted for, even in the event of an antifederal legislature. It is doubtful whether all of Rhode Island votes will be cast for Pinckney. Champlin said, if anything would justify Adams's friends passing by Pinckney, it would be the plot Hamilton had contrived for excluding Adams. To this Rutledge answered that the electors should support principles rather than men. In Massachusetts, the "Middlesex lukewarm federalists Adams's private frlends," such as Dexter, Otls, Cushing, and Gerry try to get Pinckney omitted, but "the Essexmen, who proceed upon true federal principles, such as Ames, Sedgwick, Cabot, \& Goodhue will outwit them \& see that both are supported. Adams has begun a hot canvass \& by civility \& condescension is trying to have the Jacoblns' support him with Jefferson, but his countrymen are too cunning to be duped by him. Hamilton's plan for prevalling on the Maryland electors to discard Adams will not be practicable, in spite of Charles Carroll's influence, for Stoddert. Cralk, \& Chase, are attached personally to Adams, while General Samuel Smith, \& Dent, though Democrats, will support him to exclude Pinckney. But the plan can be carrted out in Pennsylvania, where Ross dislikes Adams \& likes Pinckney, or in Delaware where Bayard would follow this course, ", he knew what Hamilton told Rutledge about McHenry's dis-
missal."

2 August 2, Gibbs, ii, 395. 
preferred Adams to Pinckney. ${ }^{1}$ Fisher Ames supported Cabot's view and said ${ }^{2}$ to Hamilton with admirable wisdom: "Sincerity will do much to extricate us. Where is the inconsistency of saying Pres. Adams has not our approbation of some of his measures, nor do we desire his reelection, but many federalists do, \& the only chance to prevent the triumph of the jacobins is to unite \& vote, according to the compromise made at Philadelphia for the two candidates? I am, therefore, clear that you ought not with your name, nor, if practicable in any way that will be traced to you, to execute your purpose of exposing the reasons for a change of the Executive."

Harper wrote from Baltimore that Pinckney may count on the unanimous vote of Maryland and the Carolinians will support both candidates. ${ }^{3}$ Stockton hoped that New Jersey wonld be federal and was sure that the electors would vote for Pinckney and another federalist at any rate and, probably, for Adams. Bayard wrote Hamilton that Delaware was safe. 4

Meanwhile McHenry remained in quiet in Baltimore, whither Dr. Benjamin Rush wrote him on August 12 from Philadelphia :

\section{"Dear Sir}

"The bearer has been unfortunate in business in our City, owing chiefly to his Connection with a Man from whom he expected better things. He wishes to try his fortune in Baltimore, and has therefore applied to me for a letter to you to advise him what to do. A subordinate place in your Customs - or the Oversight of a farm would suit him. He has physical energy and mind eno' for either of the above situations.

"Permit me to congratulate you upon your recovering your freedom \& independance by retiring to private life. Public measures, \& public men appear very differently to persons who see them at a distance, from what they appear to persons who are Actors in, or under them. If your feelings are like mine in this relation to politics, you would not give your present abstraction from them to be the President of the United States. While children dispute, and fight about

1 Hamilton, vi, 459, 462 ; Gibbs, ii, 408 .

2 Hamilton, vi, 464 .

3 Letter to Hamilton, August 9, 1800.

4 Hamilton, vi, 456. 
gingerbread, and nuts, and Party men about posts of honor, the pleasure of one evening's successful investigation of a moral \& physical truth - or an hour spent in literary or philosophical Society, will more than outweigh all that ambition even conferred upon her Votaries.

"You carry into retirement the love and esteem of all good Men. To me you have ever been very dear, and never more so than at the moment I subscribe myself your ever affectionate friend

"BenJa. Rush",

MeHenry asked ' Wolcott on August 2, to write down what Adams had said of him after his resignation, to provide himself "with such means of defence against possible future attacks upon my character." On the 24th, he wrote again, regretting Wolcott's illness, so inopportune, when the enemy are marshaling their forces, and complaining that his successor Dexter had opened a letter Murray sent him from Holland. Samuel Chase thinks the game is doubtful. His cousin, Judge J. T. Chase of Annapolis, may have an eye on the federal bench, so they have said much of one and little of the other candidate in their speeches, but the former will vote for both candidates if chosen elector. ${ }^{2}$

On Alugust 26, Wolcott answered the letter, sending an account of his conversation with Adams, but stating that McHenry could never appeal to Adams's declarations in support of his character. He thinks no improper use was made of Murray's letter. Adams's personal friends are trying, rather unsuccessfully, to form a new party - the constitutionalists. Probably Jefterson will be elected and, certainly, the Chases will be disappointed in any expectation from the administration. Wolcott will "do all in my power, consistent with truth \& integrity, to promote the election of General Pinckney. The consequence must be that I must resign next winter, unless I shall be previously removed. Perhaps all our exertions will not secure General Pinckney's election; you can, however, when you please, secure us against the caprice of Mr. Adams, by making known the circumstance which attended your resignation.", 3

1 Gibbs, ii, $395,408,409,410$.

2 On September 3, in a letter to Philemon Dickinson, McHenry says Samuel Chase will vote for Pinckney.

3 He slurs Stoddert's conduct. "Cunning like murder will out." McHenry never made public any statement as to his resignation. 
Late in August Hamilton wrote as follows, in answer to a lost letter of MeHenry's : ${ }^{1}$

"New York. Aug. 27. 1800.

"Indeed, My Dear Mac - I have not enough the gift of second sight to forsee what N. England will do - The mass of the people there are attached to Adams and the leaders of the second class pretty generally. The leaders of the first class pretty generally promote the joint support of Adams \& Pinckney either because they dislike Adams or hate \& fear Jefferson. Upon the whole I believe, though not with perfect assurance, that Pinckney will have almost all the votes of N. E. - Adams will have all.

"The state of New Jersey is more uncertain than I could wish. Parties will be too nicely balanced there. But our friends continue confident of a favourable result. If the Electors in this State are Federal they will certainly vote for Pinckney and I rather think will do with respect to Mr. Adams what may be thought right. date.

"In New York there is no chance for any Federal Candi-

"I think, at all events, Maryland had better choose by the Legislature If we have a majority of Federal votes throughout, we can certainly exclude Jefferson \&, if we please, bring the question between Adams \& Pinckney to the House of Representatives.

"We fight Adams on very unequal ground - becanse we do not declare the motives of our dislike - The exposition of these is very important but how? I would make it \& put my name to it but I cannot do it without its being conclusively inferred that, as to my material facts, I must have derived my information from members of the Administration. Yet without this, we have the air of mere eaballers \& shall be completely run down in the public opinion.

"I have written a letter of which I shall send a copy to you another to Woleott. If I am not forbidden, Col Ogden will commit it to the News Papers

$$
\text { "Yrs truly \& Affecy. }
$$

"P. S. I have concluded to send the enclosed to you instead of Major Jackson"

1 Lodge's Hamilton, $\mathrm{x}, 388$. 
Three days after Hamilton's letter was written, McHenry wrote Wolcott as follows: ${ }^{1}$

\section{"Dear Sir,}

"I have recieved your letter of the 26 th inst., in answer to the request contained in mine of the $2 \mathrm{~d}$, and thank you for communicating to me the favourable things which the President, Mr. Adams, was pleased to say of, and his kind intentions towards me, so immediately after insulting me in the grossest manner, by the mean and despicable mode he adopted to effect my resignation. I beg you will not conclude from the desire I have expressed to ascertain a cireumstance so marked, as it is, with candour or abject duplicity upon his part, that $I$ ever can consider my official character in any respect dependent upon his, then opinion of it or of me. I merely presumed that, in the infinite vicissitudes of affairs, it might not be improper for me, or my family, to possess the fact anthenticated by a person whose veracity no man can question.

"It was as you well know, my constant endeavour to conduct the business of the War Department with economy, and to render its important expenditures of permanent utility to the United States. I dislike the system of expediency, or providing for every public want and necessity, as they originated. I laboured therefore, incessantly, to introduce every where a different system, and to lay at a small expense, certain military foundations, eapable of producing, in seasons which must occur to all nations, the most decisive effects. It has so happened, however, that some necessary allowances and expense authorized by me, were misunderstood, or distorted; that very few of the gentlemen in Congress were disposed to an examination requisite to enable them to form just opinions on these expenditures; and that still fewer of them were qualified, from military experience, or knowledge of the subject, to appreciate the merit or utility of my arrangements, and propositions ; or if qualified were either prejudiced against me, or too much occupied with their own systems, or speculations, to attend to, or support mine.

"When, I look back on the past, I lament only, that I did not leave the office when Gen. Washington retired from the Presidency. I should at least have saved myself from a

1 Gibbs, il, 413. 
most mortifying scene, and insults which I shall never forget. I console myself, however, with the idea, that most of what I have either done, or proposed, during my administration of the department of war, will bear the strictest scrutiny; and one day or other (perhaps a day of trial or misfortune to the United States,) be duly estimated and considered, and that no successor can administer it well, and, at the same time, more economically. ${ }^{1}$ I am dear sir, with real friendship and attachment, your ob't serv't.,

\section{"JAMES MCHENRY."}

A second letter from McHenry to Wolcott followed two days later, ${ }^{2}$ attacking Adams for his inaccurate statement that Adams's term of ambassador to England was limited to three years, because the Pinckneys wanted the place. McHenry had been in the confederation congress when the limitation was made and had voted for it. ${ }^{3} \mathrm{He}$ speaks of Adams's "Low ambition, envy, \& ridiculous vanity" and cries out, "Will any friends remain to him, after so plain \& clear an exposure by himself of his character!" Wolcott had asked whether Carroll of Carrollton supported Adams. "No," answered McHenry, for he "considered him totally unfit for the office of President \& would support, as much as he could, the election of General Pinckney." This was proved, by a

1 In this connection, the testimony of Gibbs (vol. 2 , p. 358 ), may be cited, "Mr. McHenry's abilities \& merits have, it is fully believed, been greatly underrated. No man, without transcending the limits of lawful authority, could, during the time, have more successfully managed his office, under the disadvantages with which he labored. His personal character was not only without reproach, but was worthy of all admiration. No public man of his day possessed, more implicitly, the confidence \& affection of his friends than he did."

2 Gibbs, 1i, 414 . See p. 424.

3 Adams had written a letter to Tench Coxe concerning this matter in May, 1792, and the Aurora, the opposition newspaper, now obtained a copy and published it. In a letter to Philemon Dickinson on September 3, McHenry wrote that the letter showed a small mind and was a proof not of British infiuence but of "the eternal vanity of its writer, his inextinguishable thirst for office \& deadly enmity to every man likely to become his rival or competitor." While McHenry was in congress, he knew that there existed an opinion that Adams was not "quallfied from certain foibles \& defects in character to manage, unaided \& alone, prudently \& successfully the interests of the United States. Than in the letter is it possible for low ambition, envy, and ridiculous vanity to go further in associating and combining malignant suspicions to wound the character of a fellow citizen?" It is only fair to say that Adams apologized handsomely to Pinckney for writing the letter (Gibbs, ii, 425). Hildreth, v, 378 , states that Adams, during Washington's first administration, was inveigled into confidential correspondence with Tench Coxe, "a mousing politician and temporizing busy body though a man of considerable financial knowledge and ability, who held, at that moment, the place of Assistant Secretary of the Treasury." 
letter Carroll 1 wrote to Hamilton about this time, though Carroll there strongly expressed himself as favoring the reelection of Adams with Pinckney, as the only means to defeat the Republicans. Carroll hoped the Maryland legislature would be Federal and choose the electors, but feared continuance of the district system, in which at least three of the state's elector's would be Republican.

McHenry wrote to Philemon Dickinson on September 3, that the Maryland electors would vote probably for both federal candidates, but that the "growing lukewarmness" towards Adams might continue the district system and lose the Federalists four votes. He has hopes that Pinckney will get a number of Carolina votes. Just before this, on August 30, Edward Carrington wrote to Hamilton not to calculate upon the issue of a congressional election of president. "The Federalists have one plain \& easy thing to do, unite on Adams \& Pinckner, leaving the issue between them to fate." It would be lamentable should opposition win through our divisions. Maryland is more agitated, than ever before over an election. Every federal elector in the South will vote for Adams and no anti-Federal one will vote for Pinckney, save possibly in South Carolina, so well organized are the Republicans. It will require a unanimous vote in the East for the election of either Adams or Pinckney.2

The divisions of the Federalists were their destruction. Wolcott still remained in office, though he wrote ${ }^{3}$ Hamilton: "The most flagrant outrage on decency attended the demand of Mr. MeHenry's resignation." Hamilton's rage against Adams was still increased by the latter's discourteous failure for two months to answer his letter, asking if Adams had charged him with being a member of a British faction. ${ }^{4}$ Wolcott was now in communication with Hamilton over the wording of his ill-advised attack on the president. ${ }^{5}$ McHenry had an attack of intermittent fever in September and, on his recovery, wrote Wolcott that he feared the East would not rote for Pinckney. It rests on Connecticut "to give us Adams or Pinckney for our next President." 6 The Chases support Adams. because they think he will win.

1 Hamilton, vi, 467.

2 If Connecticut rote against Adams will not New Hampshire against Pinckney?

3 Gibbs, ii, 415.

4 Hamilton, vi, 449, 470.

5 Hamliton, vi, $470,471$.

6 Gibbs, ii, 419. September 23. 
Politics did not entirely occupy McHenry's letters to Wolcott and he asked him to have the manufacturers of Connecticut cider send some properly bottled to Maryland, to see whether it could not be used as a substitute for imported wines. ${ }^{1}$ In the same letter, McHenry asks when trade will be opened with Haiti and blames the South for the ratification of the treaty which Barlow made with Tripoli. That treaty declared that "the government of the United States is not in any sense, founded on the Christian religion." McHenry's strong faith led him to exclaim: "What else is it founded on? This act always appeared to me like trampling upon the cross. I do not recollect that Barlow was ever reprimanded for this ontrage upon the government \& religion." The Haitian matters were touched on by McHenry's letter 2 of October 4. Fearing an attack on the conventions made with Great Britain and with Toussaint, he asks Wolcott to take copy of all such papers, before he leaves the department.

The discord of the Federalists increased. Cabot wrote ${ }^{3}$ Wolcott on October 5, that the engagement to support "both candidates should be" sacredly respected, "but is strongly inclined to believe **** we should do as well with Jefferson for President \& Mr. Pinckney for Vice President, as with anything that we can now expect," and he felt that "such an issue to the election, if fairly produced, is the only one that will keep the federal party together." On October 12, McHenry sent word ${ }^{4}$ to Wolcott that Maryland had probably an anti-Federalist majority in her house of delegates, so that the plan of choosing electors by the legislature must be given up. McHenry had hoped for six or seven votes from the state for the Federal candidates. Now he expects four or five only. "There is every symptom of languror \& inactivity, with some exceptions, among the well informed federalists, which every new recurrence to the conduct \& character of the chief seems rather to increase than diminish. Mr Charles Carroll of Carrollton did not go down to Annapolis from his country residence to aid in the election of members for our legislature. I also know many others who did not vote on the cecasion."

In October, McHenry received two interesting letters

1 Gibbs, ii, 420. September 26 .

2 Gibbs, ii, 423 .

3 Gibbs, ii, 433.

4 Gibbs, i1, 433. 
from Philemon Dickinson, who was then living in retirement near Trenton, New Jersey.

The first letter was dated Hermitage, October 7, 1800.

\section{"Dear Sir}

"Not withstanding the unremitted exertions of the opposite party, which greatly exceed all their former endeavours, we have a well formed hope that we shall have a very handsome majority - In which case, Genr. Pinckney will get every vote in this State.

"The Quakers in general, are in strong motion - altho. we have some luke-warm Federalists, as we stile them, we have a great number of active decided ones, to whom much merit is due. Our Election eommences this day Tonight. the moment, the returns are recd. you shall hear from me-You must have your Electors chosen by your Legislature, to ensure a complete rote-Our Friends here, are anxious to know your expectations generally thro. the Union - on all great oceasions, despondency should be banished, as we ought, so I trust we shall, suceeed in the election of the Man we wish - You must at all events, secure to the Genr. a majority in Cong. it may there be done with safety, his success, depends on the accomplishment of this measure. You know a friend of ours who ean arrange this necessary business with the most perfect suavity - I am well informed that, tho the Legislature of Pennsl. will be summoned, as soon as elected, it will probably end in a district law, this will give us a few votes - but it would be more favourable to our wishes, that no law should pass Col. Burr is their object for Vice President - who, tis said, is \& has been very active - Give me your calculation in your next. I think, you put down Jersey.

$$
\begin{aligned}
& \text { "I am } \\
& \text { "Dear Sir } \\
& \text { "With Sentiments of Esteem \& } \\
& \text { real regard } \\
& \text { "Yours Sincerely } \\
& \text { "P. Dickinson.", }
\end{aligned}
$$

The second letter was sent from the same place on October 31. 
"Dear Sir

"We have chosen seven Federal Electors. No doubt is now entertained of Vermont, \& strong hopes of success in Rhode Island. The other Eastern States are too strongly impressed with the necessity of united measures, at this important period, to hesitate a moment. taking this for granted, \& judging from Southern representations, I look forward with full confidence, to the accomplishment of our wishes It is expected, the Federalists in your State, will make the most vigorous exertions, to aid the common cause - Once more let me request that you will strongly impress on the minds of certain Eastern Friends, the absolute necessity of obtaining a majority (if it should only be a single vote) in Cong. to favor the man who interests us most - there it may be done with safety even to a greater extent.

"Hamilton's publication, no doubt you have seen. hope it will produce the desired effect - When our friend W. returns, I will give you particulars - If I do not in time, pray inform me- $\mathrm{I}$ feel myself deeply interested, in the issue of this business.

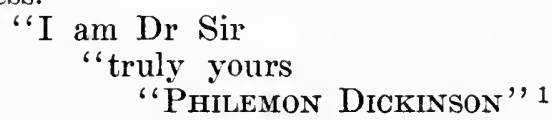

A part of Hamilton's letter attacking Adams had appeared, being published from a copy secured by Burr. Hamilton then published it in full, and, though he urged the support of both candidates, the arraignment of Adams could not fail to injure the party's cause. Shortly thereafter Carroll of Carrollton wrote the following very interesting letter to McHenry :

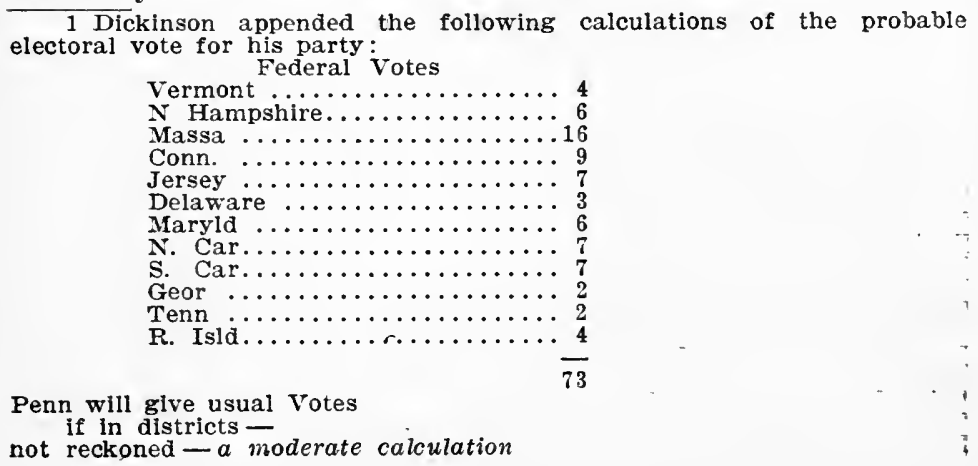




\section{"Dear Sir}

"Annapolis 4th Nov. 1800

"I regret my absence from this city when Mr. Caldwell brought your letter of the 21st inst, as it deprived me of showing those attentions \& that eivility, to which his character \& his near connection with you justly entitled him.

"I hoped to have had the pleasure of a visit from you at the Manor; I wished much to see you to discourse on a variety of subjects \& particularly on the present eritical situation of this country. The President remarks that we are fallen upon evil times; I fear a great part of the evil may be attributed to his shifting conduct, his passions, his indiscretion, vanity \& jealousy - I had a high opinion of Mr. Adams, and I still believe him to be an honest man, but his integrity can not compensate for his weaknesses, which unfit him for his present station. Were a competition for places and power between the friends and opposers of the administration the only object of the contest, it would be a matter of indifference to me by what party the governt. should be administered: If Mr. Adams should be reelected, I fear our constitution would be more injured by his unruly passions, antipathies, \& jealousy, than by the whimsies of Jefferson: I am not acquainted with ye characters of the leaders of the opposition, but it is to be apprehended, that to obtain \& retain power, they might sacrifice the true interest \& real independance of this country to France. Judge Duvall says that no well informed man can doubt of there being a british faction among us, wishing to establish a monarchy in lieu of a Republican govent; if he writes the truth, I own I am not of the number of the well informed. I know of no such faction; if it exists \& is endeavouring to effect such a change, its attempt should be crushed. If our rountry should continue to be the sport of parties, if the mass of the People should be exasperated \& roused to pillage the more wealthy, social order will be subverted, anarchy will follow, succeeded by Despotism; these changes have, in that order of succession, taken place in France: yet the men, so far as I am informed, who stile themselves republicans very generally wish success to France; in other words the friends of freedom here are the friends of Buonaparte, who has established by a military force the most despotic governt. in Europe: how are we to reconcile this contradiction of their avowed principles? is their aversion to the English constitution the cause of this inconsistency, do 
they consider the naval power of that nation as the strongest barrier to $\mathrm{yr}$ revolutionary arts, by $w h$ all the rulers of France, each in their turn, have endeavoured \& are endeavouring to weaken \& subvert all other governments, that France may establish an influence over all, \& thus become all-powerful? They dare not avow the sentiments, yet their wishes \& their conduct point to it - I wish the british to retain the empire of the seas, while the rulers of France are actuated by such motives: the decided naval superiority of Britain is ye only effectual check to ye ambition of that soi-disant Republick: the true interests, \& independance of this country re. quire, that those rival nations should be balanced.

"If the people of this country were united, it would have nothing to fear from foreign powers; but unhappily this is not the ease; many of the opposers of ye present administration, I suspect want change of the federal constitution; if that should be altered, or weakened so as to be rendered a dead 'letter, it will not answer the purposes of its formation and will expire from meer inanity: other confederacies will start up \& ye scene of ye Greeian States, after an interval of more than two thousand years, will be renewed on, this continent, \& some British or Buonaparte will melt the whole of them into one mass of despotism.

"These events will be hastened by the pretended Philosophy of France: divine revelation has been seoffed at by the Philosophers of the present day, the immortality of the soul treated as the dreams of fools, or the invention of knaves, \& death has been declared by public authority an eternal sleep: these opinions are gaining ground among us, \& silently sapping the foundations of a religion the encouragement of ye good, the terror of evil doers, and the consolation of the poor, the miserable, and the distressed. Remove the hope and dread of future rewards \& punishments, the most powerful restraint on wicked actions, \& ye strongest inducement to virtuous ones is done away. Virtue may be said is its own reward; I believe it to be so and even in this life the only souree of happiness; and this intimate \& necessary connection between virtue \& happiness here and between vice and misery is to my mind one of the surest pledges of happiness or misery in a future state of existence - But how few practice virtue for its own reward! some of happy disposition \& temperament, calm reflecting men, exempt in a great degree from the turbulenee of passions may be virtuous for virtue's sake: small, however, is 
the number who are guided by reason alone, \& who can always subject their passions to its dictates? he, who can thus act, may be said to be virtuous; but reason is often inlisted on the side of the passions, or at best, when most wanted, is weakest - Hence the necessity of a superior motive for acting virtuously; now, what motive can be stronger than ye belief, founded on revelation, that a virtuous life will be rewarded by a happy immortality? without morals a republic cannot subsist any length of time; they therefore who are decrying the Christian religion, whose morality is so sublime $\&$ pure, $w h$ denounces against the wicked eternal misery, \& insures to the good eternal happiness are undermining the solid foundation of morals, the best security for the duration of free governments.

"If there be force in this reasoning, what judgt. ought we to form of our pretended republicans, who admire \& appland the proceedings of revolutionary France!

"These declaimers in favor of freedom \& equality act in such a questionable shape that I cannot help suspecting their sincerety.

"This is a long preaching letter : \& I fear tedious \& dull one; but you wished to know my sentiments about the present parties \& impending fate of our country, and I could not give them, without developing the reasoning of my opinion you see that I almost despair of the commonwealth - The end of every legitimate Government is the security of life, liberty \& property : if this country is to be revolutionised, none of these will be secured. Perhaps the leaders of the opposition, when they get into office, may be content to let the constitution remain as it is, \& may pursue the policy \& measures of Washington's administration: but what will become in that case of their consistency? Patriots, you will say, are not always consistent; granted; yet other patriots $\&$ opposers will arise to arraign this inconsistency, \& the storm once raised who will stop its fury?

"Celui qui met un pein à la fureur des flots,

"Soit aussi des méchans arrêter les complots.

"My only hope is in that Being, who educes good out of evil : may he, in his abundant mercy, incline the hearts of our countrymen to peace, justice, \& concord.

"I have read Mr. Hamilton's pamphlet; the drift of its publication at this time I conjecture was not so much with a view of vindicating his character, as to prevent the electors 
in Massachusetts from scattering their votes in order to secure the election of Mr. Adams in preference to Mr. Pinkney. All, with whom I have conversed, blame, however, Mr. Hamilton \& consider his publication as ill-timed; altho' I pay a deference to the opinions of others, whose motives I know to be good, yet I can not help differing from them in this instance. The assertions of ye pamphlet, I take it for granted, are true; and if true, surely it must be admitted that Mr. Adams is not fit to be President, and his unfitness should be made known to the Electors \& ye Publick; I conceive it a species of treason to conceal from the Publick his incapacity.

"Altho' your remaining rather a spectator of than an actor in the passing scenes, is founded on a proper motive, yet you will find it impossible to retain a neutral character, nor do I think it fit you should: we ought all, each in our several spheres, to endeavour to set the public mind right, \& to administer antidotes to the poison that is widely spreading through the country.

"Excuse the interlineations, \& the incoherence of this letter. I write currente calamo, I have not time to arrange \& methodise my thoughts, or to copy. I am in the sentiments of real regard and esteem

$$
\begin{aligned}
& \text { "Dr. Sir } \\
& \text { "Yr. most hum. Servt } \\
& \text { "CH. Carroll of Carrollton", }
\end{aligned}
$$

On the evening of November 8, the war office building in Washington ${ }^{1}$ burned, the fire destroying "every paper \&

\footnotetext{
$1 \mathrm{Gibbs}$, ii, 446. In the General (Aurora) Advertiser, for November 12, 1800 , appeared the following item:

WAR OFFICE BURNT

The following note was received yesterday mornlng by Colonel Patton, esq., Postmaster at Baltimore:

"Baltimore, Nov. 9.

"The War-Office at Washington City, was destroyed by fire last evening, and all the papers belonging to it, except the accountant's."

We have seen a letter dated Washington, Nov. 8, 12 o'clock at nlght, confirming the above. It states, "That two small englnes and about fifty buckets of various kinds, with a bad supply of water was all the means they possessed here to quench it - that the accountant saved the greater part of his papers, but all the rest were burnt- One house and the only one adjoining it was burnt; It was owned by Jonathan Jackson, who died but six hours previous to the fire- his body was let out of the window - his children and furnlture were saved." The writer says, "the fire exhlbited a dreadful scene, as it raged wlthout control; all their efforts belng ineffectual.
}

Extract of a letter from Washington City, dated November 8.

About 7 o'clock this evenlng, I was alarmed by fire in this city. We all ran as usual, and behold it proved to be the War-Office. Before I 
record of the Secretary's office," so that we can not go to the department files for a record of MeHenry's administration. The next day, MeHenry wrote ${ }^{1}$ to Wolcott, telling him that "Tomorrow, the electors of this State are to be chosen by the people in their respective districts here. We shall make little or no exertions for the federal candidate; not from any indifference to the good old cause, but from a kind of conviction that our labour would be lost \& an opinion generally imbibed by the utter unfitness of one of the federal candidates to fill the office of President. Indeed, almost every well informed man, whose sentiments I have been able to ascertain, has but one way of thinking respecting the present chief. Whether he is sportful, playful, witty, kind, cold, drunk, sober, angry, easy, stiff, jealous, cautious, confident, close, open, it is almost always in the wrong place or to the wrong person. For such a chief who has not the wisdom 'stultitia caruisse,' who can contend or encourage others to contend? In truth I cannot."

Dickinson still wrote hopefully on November 10 :

\section{"Dear" Sir"}

"From the best information recd. the Legislature of Pennsylvania will have a concurrent vote in the choice of their Electors, for President \& Vice President. This you will deem favorable to the Federal interests - if you can secure six votes in your State, \& we should not be disappointed in our Southern expectations, we may, with a little management, succeed in the election of the man we wish.

"I did not see our Friend W. on his return, he can give you more accurate information respecting Eastern politics, than I possess; from what I hear Massachusetts will give to Mr. Adams, a majority of 2 or 3 Votes. Connecticut must at all events, give to Genr. Pinckney a majority, without which,

got there all was involved in uncontrolable flames. It fortunately happened that the office had been kept in a house not adjoining any others; for had there been an hundred they must all have gone. The accountant's department was in the same building; but he had the good fortune to save the greatest part of his papers:- the books and papers in the war-office were entirely consumed. How it originated nobody knows but it is presumed, that the experience which we have had in this case of the want of engines, buckets, \&c. wlll induce those whom it concerns to provide against the recurrence of such distressing calamities. We had but too small engines, illy provided with water, and about 30 housebuckets.

See also Am. State Papers, Claims, p. 249; Misc., i, 232. Ann. of Cong., Sixth Cong., Second Session, vi, 1357 to 1376 .

(This note is due to the courtesy of J. W. Cheney, librarian of the war department.)

1 Gibbs, il, 445 . 
he stands no chance for the presidency - let me hear from you within the next ten days - as I am going a journey.

$$
\begin{aligned}
& \text { "I am Dr Sir, } \\
& \text { "Truly "Yours } \\
& \text { "PhiLeMon Dickinson }
\end{aligned}
$$

"P. S. Our Electors tis believed will vote

for Adams \& Pinckney."

Hamilton, for some strange reason, seems to have written nothing to MeHenry until November 13 , when he sent him the following ${ }^{1}$ letter :

"Dr. Sir

"To prevent a mortal scism among the Federalists, he must be voted for by them every where.
"You have seen my letter. You would think the elose of it temporising. But the Federal Stomach would not bear a stronger dose. I regret that my early opinion was not pursued. All would then have stood better

"The press teems with answers to my pamphlet. I may have to reply. If so, I shall reinforce my position by new facts. Assist me with such as you may possess.

"Did you yourself see the letter, in which he declared that a single visit to the opposition would hurl the british Ministry from their thrones. Give me a precise account of it?

"Is not your letter to the President recapitulating your last conversation on the files of the War Office?

"Yrs truly,

To Hamilton's letter, McHenry answered that he has read Hamilton's attack upon Adams. "Although I am not pleased with the facts attached to my name *** having been

$1 \mathrm{He}$ wrote a similar letter to Pickering on the same day. Hamilton, vi, 477. See Goodhue's letter of November .15, Hamilton, vi, 478.

The statement made by Cunningham in his letter to Adams (p. 147) is false and too foolish to need refutation, that the latter's expressions censuring General Hamilton, which occasioned him to write his most famous letter, were uttered confidentially to Pickering and McHenry and "by the latter, as you supposed, dishonorably betrayed to Hamilton. 
brought into public view," without consulting me, "I can coneeive, nevertheless, what might have prevented you from not acquainting me with your purpose.

"The chief will ${ }^{1}$ destroy himself fast enough without such exposures. Can it happen otherwise to a man (as I wrote the other day to Mr. Woleott) who, whether sportful, playful, witty, kind, cold, drunk, sober, angry, easy, stiff, jealous, eareless, cautious, confident, close or open, is almost always in the wrong place to the wrong persons.

"Mr great fear is that while he is destroying himself, he will destroy the government also.

"Those among the federalists in this State, I mean those within my observation, the most anxious for the eleetion of Mr. Adams, pretend to consider the publieation of your letter rather calculated to distract than to do good. Carroll of Carrollton. however, approves of it. Let this console you from one of the wisest, most prudent, \& best men in the United States.

"The statement of my last conversation with the President was made official and entered in the letter book appropriated to record communications with him. I plesume the book eontaining it has been burned with the other reeords of the department. I wish the remembrance of it, which harasses my feelings, could have been destroyed also. The folly, madness, \& insatiable vanity of this man is exeited by, and descends to, things the most trifling.

"A few days after my dialogue with the President. Tousard came \& told me. "Well, I have at last seen the President - a very extrordinary conversation with which he has favored me. You must not tell, however, that I have seen him.' I replied I would not, as it belonged to valets de chambre only to see great men, Among other things the President eomplained in a violent passion that he was negleeted by every officer, for that forts had been named Pickering, IIamilton \& IIII $\mathrm{cry}$, and that not one of them had been named Adams, except perhaps a diminutive work at Rhode Island. The supple Frenchman no doubt satisfied the angry chief, for Tousard informs me, that before his leaving him, he put his hand on his shoulder, \& mildly assured him he should be appointed colonel of the seeond regiment of Artillery \& engineers in a few days.

"When I employed Tousard on the fortifications to the

1 Hamilton, vi, 479 . 
Eastward, the President wrote me a surly letter upon the subject, ${ }^{1}$ which made it necessary for me to reply that Tousard was employed, because I could find no other person qualified to send on the business. This pacified the madman, \& Tousard was permited to remain."

McHenry's letter received instant reply from Hamilton.

"My Dear Mac

“New York Nov. 22, 1800.

"I am sorry that you were not pleased with my not having consulted you before I used your name in my publication. It was my intention to have done it - but finding myself pressed in point of time I concluded to wave it and on this resoning.

"The nature of the transaction is such as dispensed $\mathrm{Mr}$ MeHenry from any obligation of delicacy to conceal any part of it. No blame ean therefore, attach upon him for the disclosure. By putting it on the files of the War Office, he has made the whole conversation a public document liable to public discussion by any body that ean get at the contents. Extracts from it of the most exceptionable parts have been in free circulation and have been seen by many. My knowledge of it comes from a variety of persons who have seen the document itself and the extracts. The subject has been matter of conversation at various tables. Thus circumstanced, the thing is in possession of the public \& in no wise to be regarded as a confidential communication to me. I am, therefore, at liberty to use it. And upon the whole - it is perhaps best for Mr. McHenry in point of delicacy, if there be any such point, that I should publish without than with his special permission.

"The information as to facts which involve some official delicacy came to me from another not from you. Here I thought it indispensable to consult \& did so.

"Moreover in some of your letters to me, you had declared the opinion that Mr. Adams was to be openly attacked? How was this to be done with success, but by the disclosure of similar facts. About the expediency of certain measures, there would be an endless diversity of opinion, but all candid sensible men will agree in the conclusion to arise from the particular anecdotes showing the character of the man.

1 Probably Adams's letter of September 4, 1798. 
"You do not tell me how your election is going nor what your electors will do.

$$
\begin{aligned}
& \text { "Yrs. truly \& Affecty } \\
& \text { "A. H.", }
\end{aligned}
$$

On November 8, Wolcott resigned from the post which he ought to have left months before. On the 19th, McHenry wrote him ${ }^{1}$ lamenting the burning of the war office, not only from the national but also from the individual standpoint, fearing that it will enable "calumniators" to say and insinmate "words which can not longer be refuted." He also says that Hamilton thinks of answering some of the replies to his letters and asks Wolcott to get Griswold or Dana to obtain information from the state department, as to one of Adams's letters while minister to England. Wolcott at once answered, stating that members of congress can no longer consult the state department files and hoping that Hamilton will not answer at present.

On December 2, McHenry wrote 2 Wolcott that he had "pointedly advised Hamilton against an answer \& thinks he will postpone" writing one. MeHenry knows that members of congress consult the state department files in spite of Wolcott's letter, \& wrote, as to the latter's resignation: "Let us rejoice that your conduct \& administration bids defiance to the strictest scrutiny \& that your retiring from the office you have so long filled will not lose you one of your real friends. As for the rest, take leave of them all kindly. I insist.on your eating dinner with me in Baltimore on your way home $\&$ wish you so to arrange the time \& company that 2 or 3 of our Connecticut friends in Congress may accompany you. You must not deny me this favor."

There seems never to have been ground for the rumors which Hugh Williamson heard that MeHenry and "Pickering proposed a publication versus the President, as soon as the Election is over." MeHenry's letter of December 1, to Hamilton shows his position in regard to Hamilton's use of his name, "What is past \& cannot be amended between friends had better be forgotten. Let it be so, if you please, I am content." He urged Hamilton that nothing further be written by him on the subject, till all answers are in. "You cannot now make more forcible impression nor prevent the elec- 
tion," in which opinion Wolcott agreed. Maryland had already chosen electors, five for each party, but it was not certain until the last moment that all of the federal five would vote for Pinckney.

By December 12, it was evident that the Federalists had failed and Woleott wrote bitterly, "So much for the consequences of diplomatic skill." 1 Ten days later, Dickinson wrote McHenry as follows:

\section{"Dear Sir}

"The event of the Election, has proved very different from our expectations, the consequences that may follow, time must discover. The new President will commence his career with an overflowing treasury, having in it at present, at least, two million o a half of dollars. Is it supposed that the most distant attempts will be made, to impair the contracts already entered into by the Government? great changes are expected \& probably will take place, from various causes - but I am strongly inclined to believe, there will be no deviation, from the strict \& honorable line of Conduct heretofore pursued, respecting all Government engagements. Has the change made any impression on the Friends with you? I am informed some British agents in Phila. have taken the alarm - but,

$1 \mathrm{Gibbs}$, ii, 457. About this time Stoddert wrote:

Dr. Sir

Geo Town - 8. Decr. 1800.

I have requested $\mathrm{Mr}$ Campbell to sell to you Town lots in Baltimore they are the same about which I sometimes spoke to you in Philadelphia They were taken many vears ago by $F \& S$ in payment of a bill - \& have been Idle on their hands ever since - That they may be no longer so I have desired Mr. Campbell, to take for them what you will give. I know you like a good bargain - but I know too there is a monitor with you, which will prevent your making too good a bargain, \& therefore scruple not to let you know the price of the lots will be in your own power.

There is no ascertaining absolutely whether Jefferson - or Burr will be President - I think however the chances are in favor of the former - as to my own particular, I cannot be affected except as a mere citizen - for I have long determined to quit office I should have done it before March. had Mr. A - been re-elected, so that he might have appointed a successor for me - My affairs - but still now $\mathrm{my}$ health requires a different mode of life from that which I have persued for the last 30 years -

The Senate I imagine will, after a great deal of consideration, take the Treaty with France, Just as it is - they talk of conditional ratification but I am inclined to think it ought to be taken as it is, or totally rejected. carrying a condition would be to give out of our hands, to France, to determine 6 Mo's lience whether there should be peace or War- Mrs. S joins in respect \& good wishes to Mrs McHenry - Ann Danlel - John, \& little Margaretta, Dr Sir Yr Friend \&C

We know not who is to be Sec. of War - Mr Dexter has taken the Treasury Dept. 
should suppose without any real cause. No Country on earth, ever had it more in its power to discharge its debts, than America. I hope the rulers will not want inclination, possessing such abundant means. Our Election begins tomorrow, \& will continue two days, I entertain no doubt of the issue we shall unquestionably, be decidedly Federal. When at leisure give me your sentiments on the present situation of our affairs."

It was soon found that Jefferson and Burr were tied in the electoral vote and the situation is well described in a letter Uriah Tracy wrote MeHenry from the city of Washington on December 30 :

"My Dear Sir. -

"This day the Honble. Saml. Dexter has been nominated Secy of the Treasy in room of Olivr. Wolcott Esq: resigned. Who is to be Secy. at War in room of Mr. Dexter I know not. Arthur St. Clair is nominated Govr. of the North Western Territory - and it is now officially ascertained that Jefferson \& Burr have each 73 votes for Prest. \& vice Prest. and that the Democrats are in a sweat - is also ascertained, but not officially, unless you consider my assertion as official. They are in the most violent state of apprehension, for fear Bur will be chosen, or at any rate that Jefferson will not. The calculation now is - N. Hampshire, Massachusetts, Rhode Island, Connecticut, Delaware, \& Carolina, in favor of Burr, Vermont, \& Maryland divided. This leaves but 8 States, to rote for Jefferson, \& the probability is that $\mathrm{N}$. Jersey will be for Burr - if so; it makes 7 for Burr \& 7 for Jefferson, \& two divided. This you know, is as yet, conjecture only. But the conjecture is founded on a probable state of things, which will be on the 2d. Wednesday of Feb. next. Burr has written to Genl. Smith, I see by a publication in the Baltimore paper - \& made him a proxy, to say that Burr, will not stand in the way of Jefferson \&c. You, who know Burr, ean perfectly understand this. Burr is a cunning man. If he cannot outwit all the Jeftersonians, I do not know the man.

"It is really pleasant to see the Democrats in such a rage for having acted with good faith, they swear they will never do it again, \& mutually eriminate each other for having done so now. Each declaring, if they had not had full confidence in the treachery of the others, they would have been treacher- 
ous themselves; and not acted, as they promised, to act - at Philada. last winter, (viz) all vote for Jefferson \& Burr.

"The Federalists say, they like not either of the Candidates, but as the anti's have brought them forward, they will take the least of two evils. to time.

"How this momentous aftair will terminate, must be left

"present me respectfully to Mrs. McHenry "\& believe me yr. Friend \& obedt. Servt. "URIah Tracy",

Hamilton had written, as early as December 16, urging the Federalists in congress to support Jefferson, rather than Burr, and to MeHenry he gave strong reasons for such conduct and a scathing denunciation of Burr in two letters, one dated New York, January 4, 1801, and the other, without date, but from internal evidence written shortly afterwards. ${ }^{1}$

The first of these reads thus:

"My Dear Mack,

"By yesterday's post I received your letter of the 31 of December. I was just about to write to you on the principal subject of it.

"Nothing has given me so much chagrin as the Intelligence that the Federal party were thinking seriously of supporting Mr. Burr for President. I should consider the execution of the plan as devoting the country and signing their own death warrant. Mr. Burr will probably make stipulations, but he will laugh in his sleeve while he makes them and he will break them the first moment it may serve his purpose. But will not his interest govern him? It doubtless will, as he understands it. But stable power and great wealth being his object and these being unattainable by means that the sober part of the Federalists will countenance, he will certainly deceive and disappoint them. A $H-$ Lee \&c \&c may find their account in it but good men or the Country never will. At least such ought to be the calculation; from a profligate, a bankrupt, a man who laughing at democracy has played the

$1 \mathrm{As}$ early as February 1,1792 , relations had beoome strained between Hamilton and Burr. John Ledyard then wrote Hamilton that he saw Burr, found him friendly to Hamilton and recommends him to be supported for governor, and two days before this, Gen. Philip Schuyler wrote Hamilton that there is no use to hold resentment against Burr for the part he took last winter. 
whole game of Jacobinism nothing better ought to be expected. Nor should a mere chapter of accidents be hazarded; it ought to be enough for us to know that he is certainly one of the most unprincipled men in the U. States.

"Very different ought to be our game. Under the uneertainty of the event we ought to seek to obtain these assuranees from Mr. Jefferson as the motive of our cooperation in him. 1. The support of the present federal system. 2. An adherence to the present neutral plan. 3. The preservation and gradual inerease of the Navy. 4. The keeping in office all our Federal Friends except in the Great Departments. There and in other matters he ought to be free.

"Be assured, Fou eannot better serve your Country than by exerting your influence with your friends to detach them effectually from the idea of supporting Mr. Burr.

$$
\text { "Adien Yrs truly }
$$

"A. HaMiton.

"Private \& Confidential",

On the eover of the letter is written in MeHenry's handwriting :

"As well might be expected to measure a strait line with a crooked rule as to find public virtue in the private profligate. Prostrate the beauteous ruin lies and all

That shared its shelter, perish in its fall.-Burk.

"He trembled at the apprehension of his losing the Presideney, and he sacrificed every thing to seeure it."

The second letter is more extended:

"My Dr. Sir

"I was at Albany when your letter got here. I hav snatched the first hour from my avocations to sketch to you my thoughts in a rude shape.

$$
\begin{aligned}
& \text { "Yrs. Affecty. } \\
& \text { "Very Confidential. }
\end{aligned}
$$

"He is in very sense a profligate; a voluptuary in the extreme, with uncummon habits of expence; in his profession extortionate to a proverb; suspected on strong grounds of having eorruptly served the views of the Holland Company, in the Capaeity of a Member of our Legislature (He cooperated in obtaining a law to permit Aliens to hold and Convey lands) \& 
now is supposed to have been largely remunerated, and he is understood to have been guilty of several breaches of probity in his pecuniary transactions. His very friends do not insist upon his integrity.

"2. $\mathrm{He}$ is without, doubt insolvent for a large deficit. All his visible property is deeply mortgaged, and he is known to owe other large debts for which there is no specific Security. Of the number of these is a judgment in favour of Mr. Angersteen for a sum which with interest amounts to about 80,000 Dollars.

"3. The fair emoluments of any station under our government will not equal his expences in that station; still less will they suffice to extricate him from his embarrassments and he must, therefore from the necessity of his situation, have recourse to unworthy expedients. There may be a bargain and sale with some foreign power, or combination with public agents in projects of gain by means of the public monies; perhaps and probably, to enlarge the sphere - a War.

"4. He has no pretentions to the station from services. He acted in different capacities in the last war, finally with the rank of Lt. Col. in a Regiment, and gave indications of being a good officer; but without having had the opportunity of performing any distinguished action. At a critical period of the war, he resigned his commission, assigning for cause ill health, and went to reside at Paramus in the state of New Jersey. If his health was bad, he might without difficulty have obtained a furlough and was not obliged to resign. $\mathrm{He}$ was afterwards seen in his usual health. The circumstances excited much jealousy of his motives. In civil life, he has never projected nor aided in producing a single measure of important public ntility.

"5. He has constantly resided with the party hostile to federal measures before and since the present constitution of the United States. In opposing the adoption of this Constitution he was engaged covertly and insidiously; because, as he said at the time 'it was too strong and too weak,' and he has been uniformly the opposer of the Federal Administration.

"6. No Mortal can tell what his political principles are. He has talked all around the compass. At times, he has dealt in all the Jargon of Jacobinism; at other times, he has proclaimed decidedly the total insufficiency of the Federal Government \& the necessity of changes to one far more energetic. The truth seems to be that he has no plan but that of Getting 
power by any. means and keeping it by all means. It is probable that, if he has any theory, 'tis that of a simple despotism. He has intimated that he thinks the present French Constitution not a bad one.

"7. He is of a temper bold enough to think no enterprize too hazardous and sanguine enough to think none too difficult. He has censured the leaders of the federal party as wanting in vigour and enterprize, for not having established a strong Government, when they were in possession of the power and influence.

“8. Descerning men of all parties agree in ascribing to him an irregular and inordinate ambition. Like Cataline he is indefatigable in courting young men and profligates, he knows well the weak sides of human nature and takes care to play in with the passions of all with whom he has intercourse. By natural disposition, the haughtiest of men, he is at the same time the most creeping to answer his purposes. Cold and collected by nature or habit, he never loses sight of his object and scruples no means of accomplishing it. He is artful and intrigning to an inconceivable degree. In short, all his conduct indicates that he has in view nothing less than the establishment of supreme Power in his own person. Of this nothing can be a surer index than that having in fact high-toned notions of Government, he has nevertheless constantly opposed the federal \& courted the popular party. As he never can effect his wishes by the aid of good men, he will court and employ able and daring scoundrels of every party and, by availing himself of their assistance and of all the bad passions of Society, he will, in all likelyhood, attempt an usurpation.

"9. Within the last three weeks at his own table, he drank three toasts successively. 1. The French Republic. 2. The Commissioners on both sides who negotiated the Convention. 3. Buonaparte. 4. La Fayette and he countenanced and seconded the positions openly, advanced by one of his guests, that it was the interest of this country to leave it free to the Belligerent Powers to sell their prizes in our ports: and to build and equip ships for their respective uses, a doctrine which evidently aims at turning all the naval resources: of the United States into the channel of France; and by making these states the most pernicious enemy of G. Britain, to oblige her to go to war with us.

"10. Though possessing infinite art, cunning and ad- 
dress, he is yet to give proofs of great or solid abilities. At the bar he is more remarkable for dexterity than sound judgment or logic. From the character of his understanding and heart, it is likely that any innovations, which he may effect will be such as to serve the turn of his own power rather than such as will issue in establishments favourable to the permanent seeurity and prosperity of the Nation, founded upon the principles of a strong, free and regular Government."

Pickering doubted the advisability of eleeting Burr ${ }^{1} \&$ Gouverneur Morris wrote Hamilton several times, stating that he would not support Burr, though some Federalists favored him as a vigorous, practical man. ${ }^{2}$ 'The Republicans want Jefferson and they are the majority of the people. Among the suggestions made by the Federalists, was the wild one that they "should prevent any election \& thereby throw the government into the hands of a President of the Senate," going even "so far as to cast about for the person." The Federalists felt that they must choose "among rotten apples," ${ }^{3}$ but Hamilton had no hesitation in his choice. $\mathrm{He}$ wrote again and again to Sedgwick, Rutledge, Marshall, and Bayard, urging support of Jefferson. ${ }^{4}$ In this, there was no selfishness. He felt: "If there be a man in the world I ought to hate, it was Jefferson. With Burr I have always been personally well. But the public good must be paramount to every private consideration." This noble stand caused the election of Jefferson. The majority of the Federalists favored an attempt to make a bargain with Burr, but some wavered. McHenry, at first, was inclined to remain neutral, as is shown by Uriah Tracy's letter to him on January 15:

"My Dear Sir.

"Your favor of the 5th. inst. - puts me in mind of the man, who being a lodger only, in a house on fire, refused to get out of his bed, when informed of it, beeause being a lodger, it was nothing to him. I would not, certainly, were I in your place, fatigue myself much about politics; but as one of the community, can you be so indifferent about public affairs? You say 'you ean neither prevent nor amend existing evils.' What if all men should say the same? Are there not duties,

1 Gibbs, if, 461 .

2 Hamilton, vi, $494,503,516$.

3 Hamilton, vi, 492, Green to Hamilton.

4 Hamilton, vi, 499. 
incumbent upon all, \& each; when all have the power of government in their hands? I think I know too much of your goodness of heart, to believe you a perfect Stoic. The high Destinies, as they are called, of this United and enlightened people, are up; not at auction, but for speculation. Jefferson or Burr, is the question, and a question of speculation; the 11th of February decides it, or rather begins the decision, how soon it will end I know not, and as to this event, I am quiet about it, for go which way it may, it is a diabolical Jacobin trick to force either of them upon us. Either will be bad, and it is difficult to find causes of preference. I am, upon a comprehendsive view of the subject, in favor of Burr: principally, because, I think a paralytic eomplaint is most to be shunned, by a popular Government.

"Govr Jay has refused the office of Chief Justice, who will have it now is uncertain - and yet uncertain who will be Secy at War.

"Remember me respectfully to Mrs. McHenry, \& believe me respectfully

$$
\begin{aligned}
& \text { "yr. obedt. servt. } \\
& \text { "URIAH Tracy }
\end{aligned}
$$

After Hamilton's scathing denunciations of Burr reached MeHenry, he seconded Hamilton's efforts and it is probable that it was partly due to him that the Marlyland Federalists finally abstained from voting and permitted the Republican members from that state to cast the ballot for Jefferson. The interest McHenry took in the matter is shown by a letter written him on January 17, from Washington, by William Hindman, one of Maryland's Federal representatives:

\section{"My dear Friend}

"Your Favor of the 10th came to Hand, when I was too unwell to pay any Attention to Business, I am now barely able to go to the Senate Room.

"I Find that You \& our Friend Genl: Hamilton are bitterly opposed to Burr's Elevation to the Presidental Chair, \& I must acknowledge that your Reasons are very cogent, \& merit serious Consideration; there is one Point on which You are unquestionably mistaken, which is, that the general Opinion is in Favor of Mr: Jefferson; the Federalists, almost with one Mind from every Quarter of the Union, say elect Burr, with a few Exceptions in New York \& some other Places. I 
observe You have considered only one side of the Question, You are silent with Respect to Mr : Jefferson, the Federalists will tell You that They must be disgraeed in the Estimation of the People, if 'They rote for Jefferson, having told Them that He was a Man without Religion, the Writer of the Letter to Mazzei, a Coward \&c \&c. Burr is but little known to the People, the Antis can say Nothing against Him, as their votes have placed Him where He is. I shall be silent as to his Virtues $01^{\circ}$ His Vices. He is a Soldier \& a Man of Energy \& Deeision, $\&$ as Europe is now plunged into a dreadful War, of which We may perhaps partieipate, I will ask You whether it would not be wise to have such a Character at the Head of our Affairs. I believe, moreover, that He would support the Federal Cause, as the Jeffersonians would become his bitter implacable Enemies.

"I lament that there should be any Diversity of Sentiment among the Federalists of this Subjeet.

"The Treaty is not gone thro", it is now in the Hands of a Committee for Report."

While the country waited the action of the house of representatives, Adams nominated to the vacant office of chief justice, John Jay, and, on his deelination, John Marshall, the secretary of state, with whose eonfirmation by the senate began the most brilliant judicial career in the nation's history. .Just after Jay's nomination, MeHenry wrote Wolcott ${ }^{1}$ on January 22:

"My Dear Sir,

"I think your last letter to me, is dated the 29th ultimo, and you are still at Washington.

"I have presumed that one of two eanses, or" perhaps both of them eombined, may detain you. 1st. The tardiness of the committee which was appointed to report, respecting transactions in the Treasury Department. 2d. That your co-operation, or rather assistanee for a time, was indispensable to your suecessor. I am anxious to hear from you the true case. Although I have made up my mind, upon the propriety of remaining as much as it is possible, a quiet and indifferent spectator to passing events; and have determined never to appear in a public charaeter, either under the anthority of a State, or the United States, I reserve, notwithstanding, to my-

1 Gibbs, ii, 468 . 
self the entire privilege of feeling a proper concern for those of my friends who may be engaged in public scenes as actors or sufferers, and of making, and communicating to my friends, my own comments upon public occurences. Thus far, it appears to me, I may indulge in public affairs, without disturbing the tenor of my life, or that tranquility of mind which I aim at, and which I consider an essential ingredient in human happiness. I know not what you think of the late nomination of Mr. Jay, to be Chief Justice, so immediately after he had publicly declared it to be his intention to spend the remainder of his life as a private citizen. The nomination excited the idea, that Mr. Adams considered such declarations were always made without sincerity, and meant to be disregarded. It pleased me, of course, to see Mr. Jay act as a consistent and I think a sincere part, in refusing an appointment thus unseasonably if not under the existing cireumstance, indecorously offered.

"Mr. Adams, it strikes me, has committed another blunder, but it is true one not altogether so rare; I mean in rewarding dear friends, and neglecting old ones. Here it was expected by every body, that he would have named Mr. Patterson to the vacant seat on the bench, except by MIr. - who thought he should have been appointed, and by me, who thought the President should have appointed himself.

"I am told that some of our statesmen have conceived a project to convert a Jacobin of the first water, into a sound federalist; and to convince this Jacobin, who is known to be well skilled in the powers of numbers, that his weight alone, will make the lighter scale the heavier, and like a charm recover for them the public opinion which has been lost by the half measures of Congress, and false measures of the President. I certainly do not breakfast upon such chimeras. I cannot persuade myself that public opinion is to be regained by such means, much less that it is to be forced. A different course must be pursued to recover what has been alienated, and to gain upon the quiet good sense of the well-disposed part of the community. For this purpose, time is required - a new series of events; and to these, the slow process of wisdom, patience, and prudence operating upon the errors and mistakes of those who may govern. If a shorter shall be attempted by our statesmen, I wish them a good journey, but I do not expect they will arrive at the goal. 
"Let me hear from you, and the news that may be afloat. Yours, aff'ly.

$$
\text { "JaMes McHenry." }
$$

When the balloting for president began on February 11, Stoddert wrote: "It is now three o'elock \& the doors of the Capitol shut, which seems to show that the first ballot eould not determine the great question." MeIlenry seems to have made speeial arrangements with his friend Tracy of Connectieut to have daily bulletins of the balloting sent him and these show elearly the progress of events.

"My Dear Sir

"Washington 11th. Feby 1801

"The votes for Prest. have this day been opened \& eounted, 73 for Jefferson \& Burr, \& 65 \& 64 for Adams \& Pinekney, with one for Jay. The House of Reps. are now at the business of electing from these two; they have 8 or 9 trials, alike in result, \& States for Jefterson, 6 for Burr \& 2 divided.

"They have passed a vote not to separate till a President is ehosen - both parties are apparently unyielding - this is 1/2 past 5 P. M. what will be done, time must diseover.

$$
\text { "Yrs respeetfully, }
$$

"My Dear Sir

$$
\text { "City of Washington 12th. Feby. } 1801 .
$$

"This is one o'elock P. M. The House of Reps. have this moment voted, I believe the 30 th. or 31 th. time, \& at every time come out alike, 8 states for Jefr's. 6 for Burr, \& 2 divided. Maryland \& Vermt. divided - 4 New England States, Delaware \& So Carolina for Burr, \& the residue for Jefferson. They (the House) have been at it all night, \& have now postponed the next ballot to tomorrow noon - (13th.)

"The Feds, to a man vote for Burr, \& the opposition to a man for Jefferson.

$$
\begin{gathered}
\text { "Yrs respeetfully, } \\
\text { "URIAH TracY }
\end{gathered}
$$

\section{"1801}

"Feby. 13th. Friday 15 minutes past one - P. II "House of Reps - have this moment elosed 
the 2d. ballot for to-day, \& come out ut supra \& have postponed the next ballot to noon of to-morrow saturday.

"yrs. respectfully

"U. TracY"

"My Dear Sir

"City of Washington 16th. Feby. 1801.

"This is $1 \%$ past 12 o'clock - on Monday, the House of Reps have this moment, taken another ballot and remain as before, 8, 6, 2. They have postponed their next-ballot to tomorrow noon. (Tuesday $17 \mathrm{th}$ ).

"yrs respectfully

"URIAH Tracy",

"My Dear Sir

"City of Washington 17th. Feby. 1801.

"This moment $1 / 2$ past one - we are informed the House on a second ballot this day, have elected Thomas Jefferson Esqr. Prest. 10 States voting for him. They had one ballot at noon, and were as before, but on this ballot - 4 Maryland members, one Vermont member, \& the one member from Delaware did not vote. Of course Lyon carried Vermt. and Maryland was carried by its four Democrats for Jefferson \& gave him 10 states.

$$
\begin{aligned}
& \text { "yrs respectfully } \\
& \text { "URIAH TRACY }
\end{aligned}
$$

"N B. James A Bayard the member from Maryland " is this moment nominated by the Prest. to the Senate, Minister Plenipo. to France!"

The long struggle was over, the Federalist party had fallen from power forever, but they had so established the character of the government that Jefferson was to begin a period which has well been styled a "Republican administration of Federalist principles."

During the whole summer of 1800 , the negotiations of the American commissioners continued at Paris and two letters from Murray to McHenry are preserved.

The earlier one was sent from Paris on the 18th of May, 1800 :

"My dear Friend,

"An opportunity arises wh. enables me to thank you for

1 A mistake for Delaware. 
a few lines wh. have escaped from you to me by way of introduction of some of our countrymen - young G. Mr R's friend I have reed. with the cordiality due to one honoured by your recommendation.

"For mature information respecting the state of things between U. S. \& F. \& a tableau of things generally as' having a bearing on the great questions now before the European world, I refer you to our correspondence with the Secty. of State you will be charmed with it. Condense - Condense - you told me some time since. The almanaeh's \& court-records style ever were to me matters of decided aversion; - \& I have great consolation, while my plumage is plucked - to hear even Mr A[dams]'s letters (from Berlin) aeknowledged to be at least Long letters! ! ! believe me I do not compare mine to his, wh. to me are masterly diplomatic pieces - but it eases me respecting criticism.

"A scrap of a news paper now \& then falls in our way from Philad. McK[ean] governor — \& fed's divided on the eve of an election of P. - ! ! in truth, I know nothing equal to this but what is before us here not a single speck of wisdom in a crumbling but victorious coalition - disputes on collateral points - Russia absolutely withdrawn - \& those who remain agt. F. uneertain of each others plans \& objects even! My dear Sir, the Fedl. men must unite in supporting the P. the honour of the country requires it - as far as exterior reputation is concerned, - as to the interior motives, you know better than I do. There could not be a more triumphant event for $\mathrm{F}$. than an abandonment of the P. by the Fedl. party. The sting which wounds him must rejoice the enemies of the U. S., at least those who have been mortify'd by the only blow which has been given to them in the U. S. during the present war.

"I send you a news paper. Their accounts from the Rhine are to be read with due reserve - they are, however, lucky in one or two affairs. In Italy, Massena's fate must be decided by the 15 inst. - the day in wh. B. declared he wd. relieve him - B. with his usual preeision \& velocity lately set off for Geneva with the army of reserve - he will try to turn Milan - if he do, Italy will be in Jeopardy. Garrisons in Piedmont wd. greatly, weaken the austrian army. B's exertions have been immense \& his conduct wise since he came into power. He negociated, till he quelled at least 60,000 chouans - \& pacify'd them — thus liberating 50,000 seasoned troops 
for the frontier - while G. B. neglected those intrepid \& organised bands \& he has raised in two months 4 milln. Sterling every shilling of which has been devoted to the armies \& to equipments. It is believed that so exaetly has the new raised money been directed to those objeets that a great part of the functionaries in the Govt. have but pay from one quarter of a month to another at a time. It is true, bowever, that this severity ill agrees with such a people \& the real spirit of the times.

"I take the liberty of inclosing some letters - some were given to me by Mr. D. from Mr. E. Mr. E believing I had some opportunity.

"John is well \& we all prefer Holland to France-my health is almost a wreek - though the air here is better than that of $\mathrm{H}$. - but I was acclimated there, \& the sudden change has shaken me terribly.

"N. B. I rather suspect that a certain gentleman is more satisfy'd with the poliey of the measure now, than when it was made in Feb., 99."

The later letter is dated Paris, October 3, 1800, and reads thus :

"My dear Sir,

"At the same time that the appearance of Mr John MeHenry surprises you, it will be explained by himself. Ever since your letter to him of May, he has expressed a wish to return - he says en bonne foi to study law. I have recommended him to study merehandising, as the surest road to wealth. We part with mutual regret - his eandour, good sense, \& good manners have made him a greater favorite at the hague than any youth of our country has had the good fortune to be. He quits Mrs. M. \& myself with our highest esteen \& I do hope will remember us with pleasure. He has, throughout in all situations, acted with absolute propriety $\&$ is a most estimable young man. I think you will do me the justice to say that he is improved - \& I know \& he knows that you love him paternally.

"We have signed a convention. They apply the principle of free bottoms free goods from the signature for the purpose of extricating a great number of our ships, uneondemned. The Sca Letter alone \& certifieates of eargo (as relatively to contraband) any reglement au contraire Free ship \& cargo.

"I am so tired with being engaged day \& night for twelve 
days past I can scarcely write. I have less inclination, too because your nephew will tell you all he ought about every thing.

"I set off the 10th. for the Hague. I the less opposed John's wish to return, because in the Spring I shall probably be recalled - \& he gets his passage in the Portsmouth free. I shall be lazy then also. Your hint having much abridged what was really a fault - length of letters! !

"Do not fear Jacobin principles by contact with the present Goxt. of France. I wish we had a little more of the non resistance principle wh our folks may learn here, \& as to Jacobinism it is detested. I give you my word, I wish we were as quiet as they are here!

"Pray my dear Sir drop me a line at the Hague now and then - \& believe me affectionately

$$
\begin{aligned}
& \text { "Y "\& respectly always } \\
& \text { WM. V. Murray },
\end{aligned}
$$

The long perseverance of the American commissioners was on the point of being rewarded. On October 11, Ellsworth wrote Wolcott from Havre, "You will see our proceedings' and their result. Be assured, more could not be done withoul too great a sacrifice, \&, as the reign of Jacobinism is over ir. France \& appearances are strong in favor of a general peace I hope you will think it was better to sign a convention than to do nothing." He sent a similar letter to Hamilton and, in truth, the envoys had agreed to a treaty which removed all present danger of a war with France. 


\section{H A P T E R XVII}

RETIREMENT AND DEFENSE OF HIS ADMINISTRATION OF THE WAR OFFICE

\section{1-1803}

$M$ CHENRY was now a man of about fifty years of age and had retired from business and politics. John McHenry, his nephew, wrote of 1 him: "Although he was fond of leisure, there was nothing slothful in his temperament. While in office, he was indefatigable in his official duties and, after his retirement from office, he spent most of his time in reading and keeping pace with the train of political events in this country and Europe." He possessed an ample competency and had built himself a country seat which he called Fayetteville, after his French friend. The house was situated on a tract of 95 acres, bought in 1792 from the Ridgeleys, part of a tract known as Ridgeley's Delight, about a mile west of Baltimore as it then was, in the neighborhood of the present Baltimore and Fremont Streets. A part of the tract is now comprised in Alexandroffsky, the residence of Mr. Gaun M. Hutton. There he spent the remaining fifteen years of his life in dignified repose, broken only by summer visits to the Virginia Springs, ${ }^{2}$ or by longer stays in Youghiogheny Glades in Allegany County, where his eldest son, Daniel William MeHenry, settled. He had few enemies and his relations to his friends were close, as may be seen from a letter to his brother-in-law, John Caldwell:

"Dear Jack

\section{“Baltimore 2 May 1801}

"I recd yesterday evening a letter from you upon which you will permit me to remark.

"I observe that between us, there can be no motive for

1 Brown's McHenry, 41.

2 March 15, 1801. T. Lewis wrote him about accommodation at Sweet Springs for the summer. 
corresponding by letters, so long as there remains to us the opportunity of talking freely with each other every day and, if we please, every hour of every day, and especially too, as we ought to be sensible what we may say to each other of each other will and should always be taken by us respectively in good part. Now to your letter, you seem to say: 1. That under circumstances it was improper for me to be seen in the play house in the same box with Mr. \& Mrs. McCurdy as sucl a public appearance with $\mathrm{Mr}$ McCurdy must injure you in the estimation of the people of Baltimore, 2 that your councels are disregarded by me. 3 . that you cannot be an underling. 4 . that $I$ can afford to play with the sentiments I have expressed in writing, meaning I suppose that I can be seen with a man for whom I should have no regard. 5. that being seen with this man in a box in the play house must injure you in the eyes of the people of Baltimore. 6. that I may treat Mr. MeCurdy with attention and politeness in private life, but not in public.

"As to the first. I do not ask Mr. McCurdy to the play, nor did he sit in the box with me. The compliment was paid to Grace \& Jane, who were asked to partake of our ticket. But I must observe that I should, in my humble opinion, have done nothing to injure your interest had I ever asked Mr. McCurdy. I consider it, connected as I am with the man, to do nothing that may tend to widen the breach between you and him, on the contrary, to leave a door open for a renewal of a good undestanding between you \& him, or at least to the common intercourse usual between persons so connected. I judge of Mr. McCurdy's conduct as I do of every other man's, and as I wish to have my own considered - with grains of allowance for few of the weaknesses incident to human nature generally and the particular prejudices, foibles, or infirmities of the individual concerned. Right or wrong, he has conceived that you have treated him rudely and in his own house. He acts under this impression, which time only and information gradually acquired can remove. I do not think I should serve you or any body else by aggravating this misunderstanding, or by coming myself to an open rupture with him on that account. Take an example. There is scarcely an injury, within their power, which Gen. Smith and his brother Robert Smith, and this is well known to the whole eity, have not attempted to do me. Besides the latter in particular has, in print with his name to it, called Mr. Oliver, for whom I have a sincere friendship \& to whom I am under great obligation, a 
thief, and it is believed, by their misrepresentations incited Cap. Graybil to, beat and abuse Mr. Oliver in a most shameful manner. Has all this prevented your accepting an invitation to dine with Mr. Robert Smith? Have I ever desired that it should prevent your being on speaking, and if you pleased, visiting terms with him or his connections? To return, I yet hope, that you will find the intercourse with Mr. McCurdy may be reestablished without any improper or disgraceful condescensions on your part. To forget and forgive is not only a christian duty - but calculated to promote individual interests and general happiness. Independent, however, of all such considerations how could my having Mr McCurdy in the same box with me by invitation injure you? Be assured, you and I are not of such consequence as to attract public conversation from so trifling an incident. But if it did, would not my going to his house, and talking with him at his door produce the same effect. And if known that you and he had disagreed upon any point, so as to prevent your sitting in the same box together in a play house, would not a knowledge of that circumstance alone account for my being seen with you, at one time, and with him, at another. without any prejudice resulting from it to you or I hope to me.

"As to the second, that your counsels are disregarded by me, I do not know what instances you allude to. It is, however, to speak generally, to require too much to expect, that our respective counsels should always be embraced, we ought indeed he willing to give and receive advice or counsel. I believe it best that we should be left reciprocally to exercise in all cases our own judgement and to follow or not the advice or counsel, without giving offence.

"As to the 3. that you cannot be an underling. Indeed, my friend and brother, you will never be placed by me in so degraded a character. We must neither of us be underlings. We are equals and I trust we shall continue equal.

"As to the 4th. If it is to be understood as I have expressed it - I do not consider my present intercourse with Mr McCurdy, if it can be called intereourse, at variance with any sentiments or opinions I have expressed respecting him or with propriety.

"As to the 5th. I can see no difference, when it is known that you and he are not on terms, between appearing with Mr. McCurdy in a play house or in public, as in his own house. If the one condemns, the other cannot justify you. The fact 
is my behaviour to the man, has and can have no influence upon the opinion the public or individuals may form of you. This must principally depend not upon my conduct as it respects Mr McCurdy or any other person but upon your own.

"And now let me close this letter by assuring you, that I shall continue to love, respect, and aid you as far as in my power, in the full expectation that you will endeavour to think on common subjects and occurrences in life like the generality of men; that you will make allowances for human frailties, $\&$ cease to torment yourself by inspecting too minutely, or refering too metaphisically to the acts of those who may be dis. posed and who are in a situation to befriend you in your profession and above all that you will labour to aid yourself, without which the services of your best friends must prove unavailing.

"Your sincere friend and brother "JAMES MCHENRY"

A letter written by McHenry from Baltimore on the 8th of April, 1801, to Charles Carroll of Carrollton, gives an interesting estimate of Albert Gallatin, Jefferson's secretary of the treasury:

"Dear Sir.

"I now send you, in conformity with my promise, Mr. Gallatin's 'sketch of the finances of the U. S.' published in 1796. This gentleman has lately favoured the public with another production, calculated, as I understand, to support some of his estimates in Congress, or controvert some estimates made to Congress by the Secretary of the Treasury, but not having seen, I can say nothing respecting it.

"As to this sketch, you will find in it many facts, an appearance of candour relative to some, and unmerited censure and insinuations of other leading measures of finance. In the last section particularly, you will observe, a mixture of truth and hypothesis, of just remark and fallacious reasoning respecting the funding system.

"I have long considered the author of these sketches, in no other light, than that of a political adventurer; a man, whether thrown upon our shores, by design, or who sought them by choice, determined to make use of his talents, in the way best adapted to the end all such adventurers have in view, importance and office. 
"Mr. Gallatin, from his first entrance into Congress, down to the present time, seems to have fixed upon the Treasury Department, as the ladder, by which he could with the greatest probability of success, aseend to popularity and power. He studied it, of course, through all its details, and mastered it so far, as to be able, on fit oceasions, to give such colourings to its measures, and the estimates and views of our finances, presented from time to time, to Congress, as best comported with his ultimate object. Taxes and Treasury operations, come into contact with so large a proportion of the community, and with almost every measure of government, that the knowledge he possessed of such subjects, and the watchful attention he seemed to diseover, to draw from the people, as little money as possible, as well as to the direetion of its expenditure, conld seareely fail, with his talents, to produce in time its intended effect. Mr. Madison was for a season eonsidered, by his adherents, the opposition Lord of the Treasury domain, he conld not, however, keep possession of this territorv, and yielded it up, with all its rights, privileges, and franehises, to Mr. Gallatin, who has reigned over it, ever since without a rival among his party.

"How will Mr. Gallatin conduct himself as Seeretary of the Treasury? Will he not carry into practice, generally, the maxims and principles by which he has acquired the office? Will he not weigh against the national honour and security, the number of dollars and cents, it may call for to maintain them? Will he not, in other words, endeavour to confirm his powers by much the same process employed to obtain it? Neckar, another political adventurer, raised himself to the head of the finances of a great kingdom, by popular and theoretic principles; and was highly instrumental, by the application of these principles, at a most eritical moment to the destruction of its government. I do not extend my apprehensions to so disastrous and dreadful a point as it respects our government under the administration of Mr. Gallatin. Are we to enjoy a long peace, which I trust we shall, his maxims and principles, generally speaking, may operate to lessen the public debt, and the public expenditures, without, perhaps, any breach of public faith, consequently may augment the disposable revenue of the U. S. But, under this system, no efforts, or but feeble ones, can be made, to strengthen the seaboard and frontiers with proper fortifications, to lay up warlike stores, and form military and naval 
institutions, calculated to perpetuate military knowledge, and extend it whenever it shall be wanted for the purposes of war. I would however hope, inasmuch as to secure the attachment of a majority of the people, seems to be the basis of his system of conduct, that the good sense and present composition of the people of the U. S., of which he cannot be ignorant, is such that he will not find it his interest to exclude from the majority he may rely upon for support in office, virtuous men of property and talents, and that he will occasionally at least yield something to their opinions and wishes.

"Nearly the same system and set of principles, I think likely to infinence the public conduct of $\mathrm{Mr}$. Madison and Mr. Jefferson; for they too, in one sense of the appellation, are like Gallatin, political adventurers on the tempestuous sea of democracy.

"Should my conjectures be well founded respecting these three political characters, who will be the real arbiters of the fate of the U. S. I flatter myself, that altho' our affairs will not be managed by men of our choice, or always perhaps as we might wish, and that many things will be left undone, under colour of a regard to economy, which ought to be done, yet that they will be generally, so conducted, as to afford no glaring causes for extraordinary alarm or complaint. This anticipation I find consolatory, and most sincerely pray, that it may be realised; for what is it to me, or the orderly and reflecting men of property, who value a quiet life and are averse from taking any active part upon the public stage, who governs, provided they are honest men, or govern honestly.

"Having been imperceptibly led into a longer letter than I had intended to accompany Mr. Gallatin's book, and to express my hopes from the new administration, I cannot think of closing it, without also mentioning some of my greatest fears.

"During the whole of the administration of General Washington, appointments to office, were invariably made, not with a view to the extension of executive influence or future elections, but upon the ground of the fitness and qualifications of the persons for the offices to be filled, and a regard to an equitable distribution of them among the several states.

"This rule was not followed with the same punctilious. 
observance by Mr. Adams. He thought it an essential part of the art of governing to apply the influence of rewards, through the medium of appointments to offices, to future elections.

"This new principle in our government (if I may so express myself) is calculated to excite serious apprehensions. And I feal that the present President, in practicing upon it, will go further than did his predecessor. But this is not the worst of it. I fear above all things, the operation of this principle upon the conduct of the needy man of talents, who believes in no religion, the ambitious rich man without virtue or honesty, and your political adventurers and office hunters of every description. All of these (and they are a numerous and encreasing brood belonging to both parties) either see, or will see, that the direct road to public employment, to the Presidency itself, is in and through elections, and that whoever can influence elections (no matter by what means) gains everything.

$\therefore$ It is in the very nature of this principle to make good men bad, to compel them to resort to improper practices by like practice, and to call up, and keep in perpetual activity, all the evil spirits of the nation. And as no President can gratify more than a small portion of these perturbed beings under our government, in its present form, may it not, in a little time, render everything that ought to be stable, fluctuating and insecure, and fill all offices, even to the first and highest, with the most profligate, needy, desperate and unprincipled men in the community?

"This is certainly a woful state of things which the exercise of the right of election, so beautiful in theory, may bring upon a well meaning and generally virtuous republican people. And to what does such a state of things evidently lead? I see, said my hair dresser to me (a French Royalist) one day, during the late contest, relative to the choice of a President, that it is much easier for a people, to have a king. born to them, once or so in a century, than to be obliged to make a President themselves every four years. Does it not lead to a change of government, and to justify the opinion expressed by this barber? And what means have we to counteract or obviate such a state of things? We have as yet a majority of men of property in the U. S. who have no desire. for or longing after office, and who really wish to see our affairs both at home and abroad well administered, and by 
honest men, under our present form of government. But we must acknowledge, that this same majority is by no means united, is much disposed, generally, to political lethargies, and even when perfectly free from this disease, very deficient in foresight and energy.

"I am dear Sir with sinccre regard and affectionate attachment.

$$
\text { "Your most afft. }
$$

The chief interest of McHenry's life, in this latter period, lies in the correspondence he kept up with such Federalist leaders in congress as Pickering, Tracy, and Tallmadge, which throws considerable light on the course of events and of which considerable portions are given. Baltimore was on the way to Washington and McHenry was often visited by these northern leaders. On November 10, 1801, he writes Pickering, congratulating him on his expected return to Boston, reproaching him for not visiting him on his homeward way and inviting him to do so, when he shall have opportunity. To this letter, Pickering replied as follows:

\section{"Dear Sir,}

"Easton Nov. 10. 1801.

"I have had the pleasure to receive your letter of the 5th. - Altho' I have not written, I have often thought of you - latterly, with a determination to write you, as soon as I could have the pleasure of doing it from my "native ground."

"The summer past I have spent at the Great Bend of the Susquehannah (where it approaches nearest to the Delaware) labouring to make a comfortable establishment for my son, who was in the Navy, and is now there a farmer: while a surveyor was resurveying and subdividing (for convenience of expected settlers) the parcels of land I have in that quarter, and which my son takes under his care.

"At the receipt of your letter, I was at Philadelphia, with my wife only: we returned immediately to Easton, and this week shall proceed directly from hence to New York and Boston. The season is too far advanced to admit of the visit you so kindly request.

"I am gratified that my former friends retain their confidence: my ealuminators themselves do not believe their own slanderous tales; but these serve to mislead their followers. 
However, 'none of these things move me.' I shall quietly pursue my object, to cultivate a small farm in the vicinity of my numerous relations and friends; and be contented to get my bread with the sweat of my brow. Old as I am, the more I labour, the better I endure it and the more vigorous my health.

"You took some interest in my eldest son, who went with Mr. Smith to Lisbon. He has spent near two years, chiefly with Mr. King, in London, whence he has lately returned. $\mathrm{He}$ resumes the study of the law, in Boston or Salem; and I trust with peculiar advantage; from his stock of general knowledge, acquired, by diligent reading \& observation, during near four years residence in Europe.

"I presume you will spend much of your time in the country, enjoying the pleasures of rural affairs. The books you read, and the experiments you attend to, may present some new things congenial with my pursuit: the communication of them will be highly aeceptable to me. Useful plants and sceds likely to thrive near Boston, may be conveniently sent by vessels bound to Boston or Salem.

"Mrs. Pickering desires to be affectionately remembered to Mrs. MeHenry to whom I pray you to tender my respects; and to accept vourself the assurances of my attachment and esteem."

Of the letters from Hamilton, after Jefferson's election, but one brief note is preserved.

"My Dear friend,

"New York Nov. 21, 1801.

"The Prince Bailli Ruspoli of the order of Malta, who will deliver you this letter was strongly recommended to me by Mr. King. He appears to me a very Gentlemanlike respeettable man. As such I ask for him your civilities. Amony these you can do nothing more grateful to him than to give him a letter of Introduction to some friend of yours at Washington.

"Adieu my Dr. Mac.

"Yrs. ever

" "A. Hamilton."

Hamilton's son, Philip, died in the latter part of 1801, 
and on December 4, McHenry wrote condoling with him and saying, "I lost my eldest ehild, a daughter, after she had discovered whatever can promise to flatter parental expectations. Is there ought in this world ean console for such losses and who shall dare to hope that he is to pass through it without tasting a portion of its afflictions?"

Charles Lee, who had been attorney general in Adams's eabinet, wrote McHenry from Alexandria on November 28, 1801, after the news of the peace between Great Britain and France:

"The peace will give a shock to merchants of enterprise every where in this country: The invisible effects of universal peace after such a war can be mere conjecture. I augur good. On the part of Britain, the treaty is liberal and magnanimous: On the part of Bonaparte fortunate and wise

"Should Bonaparte live, which I hope, even here we shall feel the benefit by restraining the sallies of wild irrational experiments upon fundamental laws \& constitutions. If your private affairs have received as much advantage by the leisure of private life to attend to them, as mine have, you may be blessed as I am with the change. To each of ns, the manner has been unpleasant, but for that it is our consolation that neither is to be blamed.

"Should you pass through this town ever I hope again to see your.

"I am well"

With Lafayette there was an exchange of letters from time to time, and a long one dates from the end of 1801 .

"Lagrange 1st. Frimaire November. the 22d. 1801. "My dear McHenry

"The arrival of a frigat with the American Ambassador makes me hope for a Letter from you - in the mean while, I will not Loose two opportunities that offer to let you hear from me - polities I shall not this time dwell upon-You will know, before this reaches you, that a general peace has taken place - France has been powerful at war, happy in her treaties - From the first prineiples of her revolution, however poisoned, disfigured and sullied they have been, She has derived great means of prosperity - how soon liberty, her primary object, may become the fruit of her Triumphs and 
a consolation for her sufferings, Depends much upon the temper of one man, and its appreciation of true glory — but I am among the few who persist to profess that the Liberal seeds which among so much weed have been sown upon European and particularly upon French ground cannot and shall not be ultimately lost - I live for my part in a rural, happy State of retirement. The affairs of my friends or some particular object, Such as the other day the pleasure to dine with Lord Cornwallis, call me now and then to paris. I sometimes visit Bonaparte my deliverer from Ollmutz whose conduct by me is constantly obliging. I see my other acquaintances in and out of place, but my journeys to the Capital being rare, and my Stay very short, I spend the almost totality of my time in my rural habitation of Lagrange forty miles from paris, where, surrounded by my family and visited by some friends, I an devoted to a new pursuit of mine, that of agriculture. hitherto I have only got the ground work with a large farm arround my Dwelling - but, if ever I can manage the trifling remains of $\mathrm{my}$ fortune So as to have a sum sufficient to stock and improve it, I shall consider it as a very happy circumstance - but before I launch into those luxurious rural enjoyments, I must have got rid of my debts, and insured to myself and family, an independent, tho' modest subsistance. You will hear that M. Otto is to go over as an Ambassador I think he will be a very good one - I hope my answers to American friends respecting their idea of my going in that Capacity have appeared to you satisfactory - the health of my wife, family arrangements, some unsettled concerns of my friends and companions might have proved sufficient motives had not the first of all been very obvious viz. my old habit of an American Citizen and Soldier, which I feel would make me awkward in any foreign emploiement, even from my native, which in political interest and national affection I consider for the United States as a Sister country Let me keep myself to be, as soon as I can, a private Visitor to that dear, Second home of mine, the freedom and prosperity of which is to me a Source of the purest satisfaction, and I may add, a not undeserved reward.

"I apply to yon, my dear friend, for an object which I have very much at heart - Bushrod Washington is writing the memoirs of our venerated, my paternal friend-it is a history of the American revolution - Great use will be made of my correspondence with the General - his character will 
receive a new lustre from those confidential communications which, particularly during the intrigue of 1777 and 1778. he had with me. Therefrom also the Transactions with France may be illustrated. there will be found the details of that decisive Campaign in Virginia which began with the general's desire to me that Virginia might be lost as late as possible and ended with the Capture of Lord Cornwallis. You remember that on the exertions and manoenvres of the small army which I commanded, the fate of the Southern States and the grand stroke of the War of 1781 did entirely depend - and, as you have been, in these very important periods, my confidential aid and friend, none can give a better account of every transaction, Indeed of every transaction during the revolution, particularly those which in the Cabinet and the field have concerned me - upon you, therefore, my dear McHenry, I rely for your critical review, friendly assistance, interesting illustrations for that work. I have mentioned you to Mr Bushrod Washington as the friend and companion whom he ought to consult. Present my affectionate respectfull compliments to Mrs McHenry and family - We are very often, in my family rural circle speaking of you and wishing you were among us. With everlasting and most affectionate friendship I am yours.

$$
\text { "Lafayette." }
$$

In the beginning of 1802, Tracy, now in the United States senate from Connecticut, wrote of the Jeffersonians' successful attempt to repeal the act ereating circuit courts, of the reduction of taxes, and of the negotiations with Great Britain. ${ }^{1}$

"My Dear Sir

"Washington 30th. Jany. 1802.

"You have all the particulars of our Senatorial struggle upon the repeal of Judiciary Law.

"It is now resting before the Select Committee, but for my own part, I have no expectation of saving it at last. The party are determined to be revenged, \& if they break thro' any barriers, Constitution or not; this poor little Law must be immolated on the altar of malice \& revenge.

"Respecting Mr.-King, I am now told from anthority

1 MeHenry's own political positon, after Jefferson's inauguration may best be seen from his letter to Charles Carroll of Carrollton on April 8, 1801 . 
which eannot be disputed that all the negociations are probably at an end with [out] effecting any thing. What the prospect is of beginning again, or success, if that should happen, I cannot say, but I believe at present, the thing is at an end, probably Mr. King will be recalled, under pretence that some fool or knave, or both characters blended in one, of the right "sect" may replace him.

"From 3 to 5,000,000 Dollars I understand was contemplated as a round sum for settlemt. of British Debts, out of this was to be deducted spoliations \&c. But of this information I wish you not to feel much confidence, as I am not certain the sources from which I derive are correct. This last observation only applies to sum; the first part of it, that the negociation is broken off; is I think correct.

"Apropos of this adm'n Will this enlightened people not discover the opacity of such fools. They must repeal taxes on rum, Carriages - loaf sugar \&c-\& because this must be done, they must not regulate, lower, \& accommodate to the actual wants of the poorer class, the taxes on Salt, broken Tea, Coffee \& brown sugar \& Molasses. The people deserve all which ean be put upon them if they do not see that their interest is disgraced. 1

"Yours affectionately

Later in the year Lafayette wrote:

"Ma Grange 18h Vendem, October the 10h 1802
"I am requested to forward the inclosed to Baltimore and Beg you to Recommend it in your name and mine - An Opportunity I eagerly seize to let you Hear from me, and to tell you, my dear friend, that not one line from you Has since a long while Reached my Hands - I Hope you will not Receive a foolish Newspaper Report Respecting my supposed death which Has Been Contradicted the Next day - I enjoy a very Good Health, and Quietly Live in the midst of my family, further than ever from wishing to abandon that life of Retirement - two of my ehildren are married - not yet Virginia - they all are under my Roof - my daughter in

1 McHenry trusted that a sufficient number of Federalists is still to be found to guard the Constitution "from the danger of innovation" and to restore it to that state in which it came out of the hands of the convention. 
law (whose father, formerly my colleague of Assembly and a General officer in the Army I commanded, is now a senator by the name of Tracy), Has every amiable qualities which can contribute to our Happiness - the country place I in Habit is Between thirty and forty english miles, 13 leagues, from Paris where I go very seldom - my friends come to see me and among them I Had lately the pleasure to Receive Mr Fox and genl Fitzpatrick - I am very fond of farming and would long ago Have Begun a Business in which $I$ am sure to find Both profit and delight - But it Requires Advances and Hitherto I Have Had to think more of my debts than my pleasures - altho I Had in the two Revolutions made pecuniary Sacrifices, there Remained enough of my fortune to answer my wishes - But it Has Been, during my proseription, dilapidated and sold - I found on my Return a load of ereditors - my actual abode, which I prefer to all others, Has Been in Herited By my wife - I Have made the Best arrangements I could - yet I am still embarrassed in an Heavy debt, the Greatest part of which Belongs to American citizens or merchants - supposing it was paid, there would Remain for each of my children, which I Have already given to two of them, a property of Hundred and twenty Guineas a year - for my wife and nyself, including the usual military pension, about five Hundred Guineas annual, which might Be a little enereased $\mathrm{By}$ good farming, Had I declared the first expenses under those circumstances you will approve my making some inquiries about grants of land, state and continental, which Have Been often mentioned to me - I Have writen about it to my friends, Victor Dupont and Co, who offered their kind services, and should they apply to you for information or assistance, I am sure they shall find it - you Remember that the amount of my pay Has Been during my captivity sent by Congress and employed in preservative measures - it Has Been confidentially said to me, Between us, it was the intention of certain friends to take into consideration my former expenses and to move Congress for some Resolution respecting me - I shall make no application, But will consider it a duty to my creditors and an Honourable circumstance for me to accept whatever they would please to do under the proportion which might Be derived from my old expenses - a small fortune, after it Has Been cleared, will suffice for us - I do not choose to encrease it by any of the plans to $\mathrm{Be}$ found in the present institutions of France - and I think a plain life suits 
Better my situation than any other - But I confess I would much wish the little I Have to $\mathrm{Be}$ unencombered, and I have thought I might find some resource in the grants which, I am told, Have Been formerly set a part for me.

"My old confidence in you, my dear MeHenry, Has made me enter those details - I Hope you Have Received letters I wrote By duplicate Respecting the History of General Washington undertaken By His nephew - you will no doubt Have, and you may seek opportunities to see the work and make your observations.

"Adieu, my dear friend, present my Best Respects to Mrs McHenry - my compliments wait ou the family - Accept those of my wife and children, and Believe me most affectionately

\section{"Yours LAFAYETTE"}

Few other letters of ${ }^{1}$ note date from 1802. One of these is from Stoddert, who was in continual financial difficulties and was interested in the investigations into the management of the executive departments which the Republicans instituted.

\section{"Dr Sir}

$$
\text { "Geo 'Town } 20 \text { July } 1802 .
$$

"I have ascertained the faets respecting the Secretaries of State in regard to their aeets. all monies were charged to Pickering and to Marshall, who intended an arrangement at the Treasury to take off the responsibility from him by charging at once to the person sent the money - but this was never done in his time - It was done since Mr Madison came to Office, but not till after $42000 \mathrm{D}$. were charged to him, sent by Dale to the Barbary Powers - Mr Madison took Dale's rect. \& the amt. against Mr. Madison was balanced by transferring the cliarge to Dale - \& this before Dale left this Country, Since his return, his acet is also settled by the rec'ts produced by him for the delivery of the stores \& money or money alone.

"This is the only instance of charge against Mr. Madison. In other transactions, the money in his dept. has been at once charged to the persons sent it - or in some way to free him

1 An indication of the kind of courtesies expected from city friends may be seen in W. V. Murray's letter from Cambridge on August 3, 1802. "Mrs. Murray took the liberty of sending her Piano Forte to Mrs. McHenry with a letter requesting to have it strung and tuned. My brother will bring it home if it be ready." 
from responsibility. This is different from my impressions I was sure this prudent arrangement had been adopted by Genl. Marshall - \& that Mr. Madison had succeeded to it.

"The President has become a great Friend to the Navy I believe. He has a proposal for securing Ships from decay; $\&$ if Congress will adopt it, as I hope they will, he should not, he says, object to building a 74 every year. It is intended to make a dry dock for the reception of 12 ships at the Navy yard or the Eastern Branch - on the principle of locks the water is to be taken from the little Falls of Pato'c. carried through Geo Town \& the City, \& is to fill the locks, so as to bring the Ships into the lock, which afterwards may be made dry - \& is to be covred - the whole expense will not exceed he thinks 200,000 Drs. If it does not exceed half a million, the money will be well laid out, \& the work will be worthy a great nation. You know my partiallity for the Navy - My interest in the City - both will be benefitted. and ships once built will require little expense \& be subject to no Decay in Peace."

The investigating committee, appointed by the house of representatives on December 14, 1801, reported April 29, and congress adjourned on May 3. The Federalist minority of the committee, Bayard, Griswold, and Cutter, opposed the report, especially as it was made very late in the session and they were not consulted in the preparation of it. The majority's report charged a "wanton waste of the public treasure" and the Republican newspapers said this document "exhibits a scene of past iniquity, much more frightful and of a nature much more dangerous and alarming than anything yet delineated, or conceived, of the late administration." 1

On May 1, Griswold, as a member of the committee, attacked the report and moved a recommitment. The charges against McHenry ${ }^{2}$ were that he had unsettled accounts for $\$ 3,877,792.50$; that $\$ 152,608$ were improperly spent for a laboratory on the Schuylkill ; that money had been improperly ex-

1 Annals of Congress, 7th Cong., 1st Sess., 313, 319, 1251. The investigation was originally started to find irregularities in Pickering's accounts, but the motion was extended so as to cover an investigation to all moneys drawn from the treasury. The motion was carried without a division.

2 Annals of Congress, 7 th Cong., 1st Sess., 1255. The report is printed in State Papers, Finance, ii, 752 . 
pended for secret service ${ }^{1}$ and in the Indian relations; that Uriah Tracy, United States senator from Connecticut, had been improperly paid for a trip to the West, at a rate of $\$ 8$ a day and his expenses; and that the federal government had wrongfully paid McHenry's house rent. Griswold defended MeHenry against all the charges, especially the first two. $\mathrm{He}$ explained that the "mode in which business is transacted in the offices of the accountants of the war and navy"' is this: "Whenever a sum of money is advanced to an individual, he is immediately charged with it and, although it may have been advanced for services actually rendered or supplies furnished, yet nothing passed takes credit, till a voucher is produced for every item in the account, and the account, although nothing is due upon it, remains unsettled and, in the sense of the committee, a balance unaccounted for." 'Therefore, the quartermaster's department has $\$ 900,000$ charged against it, on account of a dispute as to a small part of that sum.

As to the laboratory, MeHenry was a "man of liberal mind, and of large extensive views, and disposed to found every permanent establishment upon a scale which should, in some measure, comport with the future prospect of this country and prove them to be the establishments of a nation and not of a petty corporation." He established an arsenal at Philadelphia, because that city, as a great mercantile port, was a fine place to collect military stores and because he found these stores kept in private buildings and exposed to fires and accident.

Nicholson defended the report, but his defense of the charge of unsettled accounts was weak. As to the arsenal, he asserted that no authority had been given to build it and that its expense was wrongly charged against the quartermaster's fund. ${ }^{2}$

Bayard, a Federalist member of the committee, protested against the report, ${ }^{3}$ stating that the evidence was not sufficient to prove that McHenry owes the United States a dollar, that a laboratory was necessary for the preservation of arms and stores and, by analogy to the Washington navy yard just

1 Sate Papers, Finance, i, 816, 817. Letter of McHenry to Simmons, accountant of war department, directing him to pay accounts certified by the president for secret service to James Ross and Samuel Lewis to the amount of $\$ 1320$ and saying Simmons is not comptroller of the department's disbursements, but merely a sub-auditor and countersigns checks to preserve reguiarity in the finances, not to restrain advances.

2 Annals of Congress, 7th Cong., $126 \pi$.

3 Annals of Congress, th Cong., $12 \pi 2$. 
built, it was right for McHenry to take the cost, $\$ 152,608$, from the quartermaster's fund. He also defended Tracy's mission, which John Randolph especially attacked. ${ }^{1}$ Randolph also attacked the secretary for building the laboratory on land leased, but not owned, by the government. After the last speech, Griswold's motion was lost by a vote of 22 to 46 .

McHenry prepared a defense of himself against the charges made against him, which he embodied in a letter to the speaker which was read in the house of representatives on December 28, and was later printed for McHenry in pamphlet form in Baltimore. ${ }^{2}$ Some Republicans objected to its being read and Randolph of Roanoke called it indecent, but the house supported Macon, the speaker, and ordered it read, ${ }^{3}$ by a vote of 62 to 16 . After reading the letter, it was laid on the table and, on the next day, ${ }^{4}$ Randolph offered an amendment to the rules that, if any paper be offered which, in the opinion of any member, contained matter insulting to the dignity of the house, the question of reading it shall be determined by vote of the house. The amendment was referred to a committee and never reported, while no action was taken on McHenry's letter. In his defense, the late secretary of war said that his disbursements were less than the appropriations. Of the $\$ 4,000,000$ unaccounted for, $\$ 1,756,391$ were disbursed before 1797 and $\$ 1,800,000$ of the remainder were advanced bofore MeHenry took office. The present administration disbursed $\$ 700,000 ; \$ 908,092$ has been accounted for and is improperly included and $\$ 341,854.49$ was duly applied though not accounted for, so that McHenry owes no balance. The whole trouble came from a bad system of bookkeeping. The accountant of the war department and the auditor and comptroller of the treasury see that a proper account is made and, unless the secretary of war interferes with them, he is not liable in any event. "Advances made by the secretary of war were always charged to the receivers of the money and not to the secretary of war and some of these agents have not settled." The laboratory was properly charged to the quartermaster's fund and there had been the previous custom to

1 Annals of Congress, 7th Cong., 1283.

${ }_{2}$ "A letter to the honorable, the Speaker of the House of Representatives of the Unlted States with the accompanying documents read in that Honorable House on the 28 th of Dec, 1802, by James McHenry, late Secretary of the Department of War, Baltimore, Printed by John Butler, cor. Gay and Water Sts., 1803."

3 Annals of Congress, 7 th Cong., 2nd Sess., 293.

4 Annals of Congress, 7th Cong., 2nd Sess., 297. 
spend from that fund the sum needed to supply a place for supplies whose purchase was authorized. While in office, McHenry reported that the building was in process of construction and would be paid for from the quartermaster's fund and there was no complaint. Indian affairs and the Indian trade were in the hands of the war department. 'This gave the department a foreign side, and furthermore the laws of the United States provide for secret expenditures in connection with the Indians and arrangements had to be made with governors of Canada and Louisiana about the surrender of the western posts. MeHenry tried to render less frequent the visits of the Indians to the seat of government and to have more resident Indian agents, thus bettering the moral and physical conditions, bringing the Indians into narrower compass on reservations, and placing them more perfectly under the control of the United States. On May 23, 1800, just before leaving office, he recommended that a proper person examine the Indian trading houses and garrisons and that the military leaders give the Indians as few rations as possible. As a result of this recommendation, Tracy was sent, quite properly. As to house rent, ${ }^{1}$ in April, 1800 , anticipating the speedy removal of the capital from Philadelphia to Washington, IIcHenry sent his chief clerk to the latter place to rent, for a year, a house for the war office and a dwelling for the secretary. This was done before Adams asked McHenry's resignation and after this MeHenry considered "the public bound to save me harmless from the effects of my engagement." The other secretaries agreed with him and so the needed sum was paid by the federal government. McHenry's defense may fairly be called a successful one and we may well agree with his summing up. "It was my lot to be entrusted with the direction of the Department for a course of time, during a great part of which, the affairs of this country were considerably agitated. Whether the Department was administered well or ill, whether such of the plans projected by me, as were carried into execution, and others offered by me to the consideration of the councils of the United States, have, or would probably have, in their results, conduced to the public benefit. must be committed to time and the dispassionate judgment of others to decide. I have not vanity sufficient to flatter myself that, while in office, I was always right and

1 See Contract with Mrs. French for house rent. State Papers, Finance, i, 820. 
never surprised into error; too well do I know that it is impossible to conduct a great and complicated department, so as always to avoid mistakes. My own mind does, however, derive satisfaction from a review of my endeavors for the public good, and I confidently trust I have shown that any errors justly attributed to me are not those imputed in the report of the committee of investigation."

McHenry's defense led to several letters from his Federalist friends. Tracy wrote twice.

"My Dear Sir

"City of Washington 3d. Jany. 1803.

"Your favor of the 22d. Decr. has been reed. a sufficient length of time ago, to have had an answr. before now ; but my health is still low, \& I have had an ague \& fever, \& have not written since I reed. your letter, excepting once to my family. I am somewhat better now; but the weather is so disagreeable that I cannot exercise sufficiently, \& this incapacitates me from writing or indeed from any enjoyment.

"No apology was requisite for not communicating your intention of addressing Congress, on the matter or manner of it. It seems to me perfectly correct, that it should be your own exclusively, \& delicacy dictates that you should not have consulted your Congressional Friends.

"I have not seen your memorial, but am told by members of the House who did hear it, that it was well done, \& adapted well to its purposes. The House has taken no measures with it, after struggling violently to prevent its being read; but it was all read however disagreeable to them. You have probably heard the Speaker's Opinion was in favor of reading \& that the hot ones appealed, but the House supported Macon \& it was all read.

"Our Majority with pusillanimity at their head, are appalled at the aspect of New Orleans, they fear war, because it costs money \& blood, neither of which ought, in their Opinion to be expended in this reign of Parsimoney \& Economy. The Kentuckians, \& Tennesseeites, \& Mississippi Territorianists are alive, \& pushing on one side, for prompt and energetic measures, The Federalists are for prompt measures; \& the Jacobins talk faint \& look wild.

"In this state of irresolution, the proper time to act will pass by, \& can never be recalled. The French will take possession of Louisiana \&e. 
"The Jacobins seem to wait for next session to communicate their attacks on the Constitution, \& even for any further attacks on the old ordr. of things. What may come forward I do not know ; from present appearances they seem too irresolute to do any thing.

"They exult in Gallatin's Statement of a full 'Treasy. an event highly honble to the old admin's'n; but these fools claim the credit of it themselves. It is really difficult to decide which they merit most the appellation of fool or knave, Fools they are, God knows; but I am, lately, more than formerly convinced that Fool is their predominant characteristic. I know there is no fool, but what is a knave, especially if you trust him in public business, his very folly operates knavery in a high degree and our Country will rue the day, in which they drest fools with authority, it was a sorrowful act!

"Present me respectfully to Mrs. McHenry \& family, in which George (my little Son) joins me, \& believe

$$
\text { "me yours sincerely, }
$$

"My Dear Sir

"Washington 11th. Jany. 1803.

"I expected to have found the Report you mention in your last favor of the 4th. Jany. among my old papers, but not being able to lay my hand upon it, I have directed a Copy to be made out, \& will forward it the moment it is finished.

"James Munroe Esqr. of Virginia. is Nominated Plenipo. Extra to France \& Spain both jointly \& severally with R. R. Livingston in the one place \& with the immortal Charles Pinckney in the other to settle all the New Orleans, \& Louis iana scrapes with these European reprobates. This our intrepid Executive has laid before the Senate this day. "Hail Columbia happy Land."

"Your friends all say, that your defence, which was real before the Reps. of the Majesty of the People, much against their will, was an able \& ample defence, \& the treatmt. of it attempted by the Jacobins, proves their opinions better, than any declaration they would make directly, as they would not own the truth without much reluctance. It lies on the Table, \& nothing I conclude, will be done with it.

"I am confident I wrote to you upon this subject, before I recd. your letter, \& if you have not recd. it, I wish you would let me know; as I am not confident that our Post-Offices are 
perfectly free from mistakes with some of my Letters; - there are a number of unaccountable delays, \& losses of my letters, which have induced me to suspect and tho I wish not be jealous \& much less to accuse improperly, I mean to know, or at least attempt to know, what is the difficulty.

"I cannot think myself of sufficient importance' to call forth the talents of this Departmt. in searching for my little treasons against the present virtuous Admin'n, but, if the Infernal scoundrels open my letters, \& put them aside, or destroy them, I will try to chastise them for it and sooner or later I shall certainly effect it. The babyish conduct of our great men, I can despise \& forgive; but if villainy must be added to a childish folly, it ought to [be] brought to condign punishment.

"Please to say how d'do in the most friendly manner to Mrs. McHenry for me, \& believe me your friend.

"URIhH Tracr"

Later in the year McHenry sent Wolcott some copies of the pamphlet, which the Connecticut man acknowledged thus:

“My Dear Sir.

“New York May 30th 1803.

"I reed. your favour of the 11th instant a few days since, accompanying a number of copies of your letter to the Speaker of the House of Representatives; those addressed to your friends in this city, have been delivered, those intended for Massachusetts \& Connecticut, shall be forwarded without delay.

"The perusal of your address has given me much pleasure. I thought I understood the Report of the Committee of Investigation well, before, but I now understand it much better. - you have placed several matters in a new and striking point of view, \& have brought to light several documents, which escaped former researches:- the investigators have been well investigated: the attempt to disgrace honest men, has covered the authors with confusion:- poor rognes - they have only displayed an impotent malice.

"I thank you sincerely for your kind wishes fo: my welfare. I hope some part of your prediction will be verified:for though I do not expect nor wish to be rich, yet I hope so 
far to suceed in my new vocation - as to secure a competency for my family.

"I hope you will not so far forget your friends of the old school, as not to drop me a line oceasionally \& as you have the felicity, to be a man of independence \& leisure, I pray you to assist, in guiding us out of the turbid waves of Jeffersonian liberty -. If we were on a 'tempestuous sea' of clean salt water, I should feel more indifferent than I now do, about being drowned, in good company : - but to be suffoeated in a dirty goose pond, is too offensive \& degrading Excite Maryland, if possible, to do something - almost any movement will afford relief.

"Mrs. W - will not eome here till the Autumn - I shall communieate Mrs. MeItenry's message to her, with the eertain knowledge that it will be very aceeptable. Please to present my best respects to her \& to my young friends of your household \& remain assured of the sincerity, with which I continue "Dr. Sir your friend

"\& obed. Sert.

"Oliv WolcotT" 


\title{
CHA P T E R XVIII
}

\author{
THE FEDERALISTS IN OPPOSITION, 1803-1812
}

$\mathrm{D}$

URING 1803, McHenry became interested in a project to establish a college in Baltimore to bear the name of the city and to have as its basis an academy conducted by Dr. James Priestley. A charter for this college was passed by the legislature and McHenry wrote an appeal to the citizens to support it. ${ }^{1}$ This appeal was unsuccessful and when his own son John, whom he had sent to Princeton, became ill and discouraged there, he was forced to send him to St. Mary's College on the outskirts of Baltimore, conducted by the Sulpicians. MeHenry's tender fatherliness may be seen in a letter sent his son on December 31, 1805 .

"My dear John.

"I expect to see you, George, and Edward to-morrow. You may, if you think proper, invite to spend the day with you, two of your college acquaintances.

"On the eve of a new year, accept, my beloved son, of my anxious and fervent wishes for your daily happiness. May every new year add to your mental improvements, give strength to your good habits, and when you shall come forth into the world the accomplished scholar, render you dearer and dearer to your fellow citizens. Above all things, I pray to God, that while we remain here below, your and our lives may be so spent as to ensure to us, through the merits of our redeemer, a blessed hereafter.

"Your affectionate father

$$
\text { "JAMES MCHenry" }
$$

News of the Louisiana treaty came during the summer of 1803 and McHenry rather disapproved it. He wrote Picker-

1 A letter written by James McHenry to his son at Princeton, and the address to the citizens of Baltimore are printed in the Johns Hopkins Newsletter for 1904. 
ing on October 27 , asking the truth of rumors about it and said: let the Republicans amend the constitution without help from the Federalists. Before this, he had heard from Wolcott and Tracy on the subject as follows:

"Dear" Sir,

"New York Aug. 4th 1803.

"By our friends: Mr. Harper \& Mr. Thompson \& Mr. Cooke I have recd. the agreable information of your health \& prosperity, in which my feelings are deeply interested. That nothing may happen to disturb your felicity is $\mathrm{my}$ ardent wish.

"I take the liberty to ask as a favour that you would ascertain the expence of the agency for adjusting the accounts of the State of Maryland, before the Board of Commissioners of the United States. If I am not mistaken, Mr. John Wright - was the Agent - perhaps, however, he was only the Principal Clerk - What I wish to know is, the Salary \& Duration of the Agent - \& the expence of Clerk hire, Office rent, Contingencies \&c \&c. They can, I presume, be ascertained from the person who was Agent or from the Audts. in the State Treasury. The information will be useful to me personally \& is wanted for that purpose only.

"Is there any secret article in the Lonisiana Treaty, which will create difficulties, or has G. B. Manifested discontent in relation to this affair? It appertains to you to discover \& reveal the mystery, if one exists - In my capacity of cidevant Secy. of the Treasury - I promise to pass your accounts, the Committee of Investigation notwithstanding.

"Please to present my respects to Mrs. and Miss McHenry \& the young Gentlemen \& remain assured of the Esteem of

$$
\begin{aligned}
& \text { "Dr Sir, yrs. } \\
& \text { "Oliv. Wolcotr.", }
\end{aligned}
$$
1803.

Tracy's letter was sent from Washington, October 19th,

"We are, in the Senate hard at work upon the three French Treaties, or rather one Treaty \& two Conventions; which are yet secret but will, it is presumed, soon transpire. You have read the Message, \& contemplated its contents.

"All things conspire to obtain popularity, \& all exertions are aimed at that object. How long luck will attend such 
fellows is uncertain; but it is a long road which never turns.

"I have thought in looking over the history of my fellow men, both written \& experimental, that the everlasting \& unceasing tendency has been $\&$ still is to place rule, command, or governint. in the hands of unworthy men. Such are the imperfections \& I may add depravity of human nature, that the chance is a bad one, to get a good King, Govr. Prest. or any other character to govern men. And any good man, actiner in such conspicious capacity, has always been a light shining in a dark place. When shall we see a Washington - Not till we get to Heaven:- But we may see many, very many, of a different character, who will make great pretentions to patriotism \& virtue; \& even involie Washington's name, \& profess to emulate his virtues. Poor human nature; this world is thy trial, here, self denial \& restraint, mortification \& disappointment, are thy lot; Addison says in one of his pieces in the Spectator; "in this world our happiness' must consist in restraint, in the next in enjoyment."

"The bustle, intrigue, \& vice, almost absolutely requisite to obtain wealth \& power, the darling objects of the human heart, are so incompatible to a Christian \& all his feelings, that they must generally remain with those, whose want of principle will permit them to adopt any means however wicked, to obtain their objects:- The few exceptions, seem only to confirm the general rule.

"New .Jersey you know has come out in the last Election Democratic, the Feds say that it is owing to bad votes, foul play \&c-but you will discern that bad votes, foul play, \&c. must be expected in such a state of things, as are in existence in this Country. What with bad votes, foul play \&cwe shall probably take the same course, that our predecessors have marked ont for us, their tracks lead to the grave \& that with hasty step. In contemplating our situation, I am convinced, that the accession of Louisiana, will accelerate a division, of these States: whose whenabouts, is uncertain, but somewhen is inevitable.

"North \& South, with the difference of climate, produce, population \& manners, are now but just held together, with a sense of interest \& force of habit; but only add a large accession to the Southern tendency to disorganization; \& the Northern section will fall off, by force of its own weight. This event, I deprecate, but not so much, that I would submit to any thing, \& every thing to avoid it. 
"I believe, Sir, you are fatigued with this preachment. permit me therefore to subscribe myself yr. friend.

\section{"Uriah Tracy."}

Lafayette wrote him twice in the year 1803 and MeHenry replied to these letters in a long and interesting one.

"Paris Germinal the 10th 11th year "( 30 Mareh) 1803

"My Dear McHenry

"I take the opportunity of General Bernadotte's Departure to let you hear from me. You have no doubt been alarmed with the aecount of my having broken my thigh in the worst place I could chosen viz the Col du fémur My eure is complete and I am certain that I shall not have the least lameness, but the new machine to which $\mathrm{I}^{-}$am indebted for it has so severely wounded me, and my lying on the baek has been so long that I must still undergo much pain and trouble before I am quite well. Now permit me to introduce to you and Mrs MeHenry General Bernadotte and his lady. both perfectly Calculated to be weleome and well pleased in America, the glorious share that General Bernadotte had in the triumphs of the French armies, you know perfeetly well, his private character and civic virtues are not less deserving attachment and regard, his personal disposition towards America is such as we can wish. to you it is not superfluous to add that General Bernadotte is my friend. adieu dear McHenry

$$
\text { "I am Most affectionately yours }
$$

The seeond letter was sent from near Paris, June 1, 1803.

\section{"My Dear McHenry}

"I have not this very long time received a Line from you - I dont Know whether you have got my Letters - The Last one was an introductory one for Gel. Bernadotte - You will have heard that I had the misfortune to break my 'Thigh, at the col du Femur The fraeture has been more perfeetly mended than in any ease perhaps of the kind - But the $e x$ tensive machine invented for that purpose having been severely applied, and by me Supported as long as I could, there have resulted from it Very Deep Wounds which will Still 
Keep me two or three Weeks before they are healed - I now am at a Village where my Daughter in Law's family have their house - her Father has left the huzzards to become Aide de Camp to an Inspector of Cavalry. We shall all, viz my wife, Son, Daughter in Law, two Daughters, their husbands, and three Grand Daughters, meet again by the middle of July at Lagrange - my beloved rural place of retirement Where the Whole Family Live with us.

"I am heartily Sorry for the War Between France and England Whatever may justly be Said of the Politics of our Goverment, it appears evident to me that, on this Side, peace has been Sincerely wished for and that in the British Cabinet it has been quite the reverse - They Disliked the Treaty made by Themselves at Amiens, and they Determined to Break it - That is the English of the Business. - We are not without Some hopes of a Speedy reconciliation.

"I Seldom felt so great a Joy as I did on the accession of Louisiana and the anticipated one of the Floridas to the free and happy territory of the United States - The scheme of a French Colony in that quarter I did on every Account reprobate - It was big with Evils - The present Arrangement is on the line of the gradual enfranchisement of the American Continent and Secures eternal good Understanding Between France and the United States.

"I have with heartfelt gratitude, pride, and pleasure heard of the Gifts in Lands which Congress have been pleased to grant to me - Indeed, my Dear Friend, Circumstanced as I am, unwilling to meddle with public affairs, having found on my return large Debts and very little property, I consider the Kindness of my American Fellow Citizens, either in general Congress, or in particular States, as the most honourable Way to rid myself of my embarassments, and to Secure the modest Situation, Which I prefer to an expensive State - The only luxury I should like to indulge is the improvement of my Farm as I am Fondly Devoted to Agricultural pleasures - Was you to ask me why I would not as well like be under the Same obligations to this other Country of mine, for which also, in my pecuniary times, I spent a good part of my fortune, I would Frankly Answer that here I dont Find a true national representation, and that too many people, friends and adversaries, have suffered, to make an exception of the Kind in my Behalf agreeable to my feelings - Amer- 
ican Bounty on the contrary is freely granted, and accepted without Scruple or inconvenience

"You have, I am Sure, presumed a friendly remembrance of Gel. Chattelux : his Widow and her Son, a Very promising Youth, both ruined by the revolution find themselves in a particular Situation which the inclosed note, made by Madame de Chattelux Does sufficiently explain - I assured her you would by your Enquiries, and, if there is a chance of Success, by your Exertions, Do for the Father's memory, and the advantages of his Family whatever may be in your power.

"Adieu, my dear McHenry, present my respects to your" Lady - My attachments to all the Family, and think often of your constant affectionate friend

\section{"Lafayette"}

The inclosure was a curious one and gave an inaccurate legend :

"Lord Baltimore, in consequence of a Grant issued under the Reign of Charles the 1st. which gave to him and his heirs the propriety of the lands Situated to the north of the River Potowmack, as also divers privilege of Great importance laid down the foundation of the province of Maryland in the Year 1632.

"Upon the death of King Charles, the inhabitants of Maryland having Submitted to the Authority of Cromwell, Lord Baltimore was obliged to fly to Virginia; but at the time of Charles the Second's restoration, he returned and was reinstated in his rights and privileges. The Constitution he had established in the Year 1638. had been revised in 1650 . and altered in Some respects: Such as it was modeled at this last period, it remained in activity untill the Year 1776. When the present laws, forms, and independance were proclaimed.

"Lord Baltimore left no male issue, and his two Daughters married two brothers, of the name and Family of Plunkett's of Castle Plunkett in Ireland: His property and privileges of every sort of nature had been entailed upon the Eldest: but from circumstances unknown (it is supposed owing to the Absence of the right owner \& the presence of those who had a sort of Claim) upon the death of Lord Baltimore, his illegitimate Children usurped the property \&c. which belonged to the Legitimate Descendant and notwithstanding every Sort of application made by these, continued 
to remain in possession of their Lands, original Titles, honor's \&c. untill the revolution having taken place, their attachment to the English Cause was the occassion of the property they held illegaly being confiscated, but it Seems they received from Great Britain a large Sum as an indemnification

"The Branch of Plunkett's derived from 'Lord Baltimore's Eldest Daughter is extinct

"Alfred Chastellux Son to General Chastellux, and his only Child, in right of his Mother Mary Plunkett, great Grandaughter to Miss Talbot Lord Baltimore's Second Daughter is the Direct and Legitimate Descendant of Lord Baltimore: is he not entitled in justice to claim an indemnification, as the Legal heir of $\mathrm{him}$ Who laid down the foundation of the State of Maryland? \& to a grant of favor, as being the Son of General Chastellux who contributed to establish the Independance of the United States, and whose unbounded Attachment to the prosperity of America is Sufficiently Known."

McHenry answered Lafayette's letters from Baltimore on October 25, 1803.

"Since my last I have been honoured with two letters from you, 1 - Dated June 1st the other the $30 \mathrm{March}$. The 1st of June I received about six weeks ago, and the 30th March which eame [to] hand during the last month. The letter of June relieved me from much uncertainty respecting your situation. As I could not entirely discredit public prints, which stated the accident that had befallen you, I had become extremely anxious to learn from yourself the extent \& nature of the disaster. I thank god that you are recovered or nearly so, and without the affliction of perment lameness. You must indeed have suffered a great deal from the machine. constant extension, in such a case, being equivalent to constant pain.

"It was the wish of your friends that Congress should have made their grant of land to you more worthy of your acceptance. I believe we are to ascribe the limitation entirely to the reigning policy, which calls for the strictest economy in every expenditure that might attract public attention. Were you to come among us, you would find yourself in many points of view, as it were, in a new world. Most of your old friends in private life, friends tremblingly alive 
to whatever is likely to affect their popularity. The people too changed, that is because more democratical. Great and lesser Demagogues in every State and districts and the prejudices and violence of party, leaving little or no room for moderation or social intercourse between men of opposite polities. In such a state of things with economy the cry of. every Demagogue or seeker of popularity, I need not observe that any application to the legislature of Maryland at this time in favour of the son of Genl. Chastellux would be unsuccessful.

"These are no doubt evils in themselves, and what is worse, may lead to still greater. We cannot tell what further changes such democratical opinions may produce in the public mind [in] the government itself, when a people are made to believe, that they themselves are every thing, and have a right to have every thing fashioned to their way of thinking, they are in the sure road of alternately ruling their Demagogues and being ruled by them, and the fundamental laws and institutions of the State disregarded or trampled upon as they stand opposed to the passions or interests of their leaders. Such has generally been the consequences of flattering the multitude in Republies, for in republies any leviations in the people from their preseribed rights, and in the government from the free exercise of its authorities lead rapidly to Democracy, in other words confusion and licentiousness.

"As yet, however, such consequences are more feared than felt: and feared only by the most reflecting part of the community those in power excepted, who act as if they thought they conld be able to manage the multitude according to their views of the public interest. The people, generally speaking, still preserve a degree of respect for the forms of election and the constitution, and those in power, for the general welfare, with this qualification, that it must be carried and essentially connected with their popularity.

"In the mean while, the general prosperity of the country is on the increase, and the laws, except perhaps where certain political questions are concerned, executed with the usual fidelity and integrity.

"With respect to my self I would not say that I am an unconcerned spectator, or indifferent to all that passes. Having an interest at stake, loving real liberty and wishing for its maintennance, I cannot, without regret, look upon any 
conduct in rulers or the people which tends to endanger and finally destroy it. In my eyes despotism of the muititude is the most terrible of tyrannies.

"You tell me you are in love with retirement and rural concerns. I do not pay much attention to the latter, but I am so great a stickler for ease and quiet, it must be a tornado [or] earthquake in politics indeed which would throw me into public Life. I wish you were equally decided in your choice of a retired life, but my dear general, you will, if I am not mistaken, for the sake of your family your friends, or some other good and powerful motive forego La Grange, its fields - its fences, its shades and herds and flocks, for public life.

"It will, however, always be a solace to me, that you are happy \& that your children connect themselves in a manner worthy of their parents; and to receive you in the arms of friendship should any occasion lead you to revisit the United States.

"Mrs. McHenry prays to be respectfully presented to Madam La Fayette, and that she will accept her constant wishes for her happiness."

McHenry was soon to lose two of his warmest friends. Murray died on December 11, 1803, and Hamilton's death occurred in the next year. On January 2, Tracy wrote, inclosing a speech he had recently made in opposition, to the Twelfth Amendment to the Constitution.

\section{"My Dear Sir}

"I have again been guilty of almost an act of suicide, in making a foolish speech, \& more foolish publication of it. But since it has cost me so much to bring it to light, I am determined to tax my friends with a sight of it, whether they will read it is left with each one, in a free Country, to decide for him self. I have inclosed one to you, as a New Years gift, \& wish from my soul it was worthy of the person to whom presented, \& of the affectionate friendship I feel for him.

"We have no News Yet from New Orleans; but expect it soon. I mean Official news. There are reports, \& newspaper paragraphs; \& it is probable that peaceable possession will be given, by the Spaniards, \& French Prefect L'Aussat. If peaceable possession is obtained, there will be a triumph to Democracy. 
"Had I any thing worthy of yr. attention to write, I would make up a letter with it; but our political sense presents nothing but a sameness of sterility; one barren waste of hypocritical pretensions to foster the liberties of the people, while popularity is the real object.

"But I had rather be buried under the ruins of my Country, exerting my feeble strength to support it; than to ride in the foremost \& most exalted Chariot, of him who is laying it waste. Let Democracy tremble, for the Day of account is at hand. If they destroy us, it will serve to accumulate vengeance for themselves; and the short lived triumph will but aggravate their woes.

"But I am rambling into the regions of the horrible, it is enough to tax you with a long book, \& not add a long letter to it.

"Please to present me respectfully to Mrs. MeHenry \& family, \& believe me yrs. sincerely

$$
\text { "URIAH Tracy }
$$

"N. B. I am afflicted at the death of our friend Vans Murray; but it is the will of God. Man ought not to complain, when infinite Wisdom \& goodness, are accompanying infinite power!"

In New York state the acrimonious campaign carried on by Burr for the governorship was to result in Hamilton's death. I have found no letter from McHenry on this sad event, but three letters from Wolcott to him are preserved among MeIIenry's papers upon that election and its melancholy sequel.

The first letter is dated New York, April 9, 1804 :

\section{"My Dear Sir,}

"I have recd. your favour of Mar. 31. \& have spoken to Genl. Hamilton who has promised to reimburse the fee you paid to Mr. Martin.

"The good wishes and affectionate concern of my friends, among whom, I rank you in the first elass, are more than an equivalent for all the evils which I have experienced, from the vindictive spirit of my political adversaries. It affords me a high consolation to reflect, that I have not deserved this treatment and I firmly believe that it will not be in the power of the Philosopher \& all his Minions to break my spirit or starve 
my family: they shall certainly find that I am no Quaker in politicks, and that I mean stedfastly to resist Oppression.

"The Opposition to the Merchants Bank, which at first originated in the private views of a few stockholders of other Banks at length assumed a different aspect and finally degenerated into a party question: The Merchants Bank, really was not a political Association: being opposed however by a number of wealthy Men, (chiefly Federalists), the Clintonians hoped by crushing the Bank, to divide the Federal Party: in conducting their opposition, they have, however, divided their own Party, and have reluctantly been compelled to pass a Bill which, on the whole, will be favourable to our Interests:

"This State is agitated to its center, with intrigues and schemes, calculated to produce an influence on the approaching Election: I can give no opinion what the result will be, but it is said to be most probable that Colo. Burr will succeed: It is certain that he commands a numerous \& intrepid party who are not to be intimidated, or subdued: In our present distracted situation, few men look forward to ultimate consequences: it is sufficient to decide most men; that all confidence in the prevailing faction is lost, and that Colo. Burr is from situation and necessity the Enemy of the Enemies of good Men.

$$
\begin{gathered}
\text { "I remain Dear Sir, with sincerity } \\
\text { "Your faithful Friend } \\
\text { "OLIv. WoLcoTT." }
\end{gathered}
$$

The second letter is written from New York, July 16, 1804:

"My Dear Sir,

"I have recd. your favour of the 14th: The afflicting event you anticipated has occurred: Hamilton is no more: I will not attempt to describe my feelings: you will learn all the circumstances \& the last acts of his life will elevate the character of our late Friend, though they must produce conflict of emotions, to which your bosom has been a stranger.

"Genl. Hamilton left a will by which all his property real \& personal is vested in Trustees for the payment of his Debts: This property consists almost entirely of real estates, chiefly new Lands and a valuable County Establishment nine Miles from this City: This property cost about 80,000 Dollars \& he owed about 55,000 Dollars - the Lands are rising 
in value but wholly unproductive of Revenue: he was apprehensive \& I believe justly, that a forced Sale, would leave nothing for his family \& perhaps not even produce enough to pay his debts: A number of Gentlemen here have resolved to raise a Fund among the Friends of the decd. for the payment of these debts \& to provide for the Children. The design is, that a select number of Gentlemen of easy Fortunes, shall, without much eclat \& publicity, subscribe what may be sufficient. I have been desired to make this intention known, to a select number of Friends \& before I reed. your Letter had determined to address you \& Mr. Gilmore, leaving it to your judgement, to whom the communication ought to be made in Baltimore \& not doubting your disposition to cooperate.

"I am Dr Sir, with high Esteem

"\& sincere affection, yr. friend

"Oliv. Wolcott."

From New York on August 2, 1804, Wolcott wrote for a third time :

"My Dear Sir",

"I addressed you a hasty Letter the 16th. ultimo, at the request of several Gentlemen of this City, who have proposed to raise by contribution, a pecuniary Aid for the family of our departed Friend Genl. Hamilton. Understanding that doubts have existed in Philadelphia, whether this proposal did not originate without the knowledge of the Connections of the Family and might, therefore, offend the sensibility of those it was intended to benefit, I have found it necessary to make certain explanations known there, which I presume will be fully satisfactory. It being possible that similar impressions have been entertained at Baltimore I must take the liberty to address you again on this Subject.

"The property left by Genl. Hamilton, consists almost entirely of new Lands and a Country Seat Nine Miles from this City. The whole valued by himself at about 80,000 Dollars. The debts are chiefly Notes discounted at the Banks \& Monies borrowed on Mortgage amounting to about 55,000 Dollars. The difference is $£ 10,000$ New York Currency.

"This brief Statement will enable you fully to inderstand, the enclosed Paper, which is a copy of one left by Genl. Hamilton \& which is now entrusted to you, on the condition expressed in. Mr. Pendletons Letter to me. There is no doubt, that the anticipations of our Friend, respecting the 
consequences of forced Sales to raise Money to discharge $\$ 55,000$ in debts, would be verified. All the property would be sacrificed \& his Children deprived of every Memorial of the labour of their illustrious Parent, except his reputation.

"Mr. Govr. Morris, Genl. Clarkson, Mr. Gracie, Mr. Bayard \&c \&c have consulted on this Subject \& their joint opinion is, that it is in every Respect, fit, proper \& necessary, that a number of Gentlemen of Fortune, should come forward \& pay these debts \& provide handsomely for the family. A sum of 100,000 Dollars is the amount proposed.

"It would be an Error to consider Genl. Hamilton's Family as objects of public Charity, but though this is not their Situation, it is certain that they might reasonably expect advancement in Life, from the exertions of our departed Friend. These hopes must, however, be totally disappointed, unless the proposed aid is obtained. It is true that the provision ought in justice to be made by Congress, or by the State of New York, but no person acquainted with the present State of public affairs, will place the least reliance on this resource. Instances of similar benefactions in antient \& modern times must be familiar to your mind \& it is certain that they have always been considered equally honourable to the Receivers \& Givers. The suggestion that the Family would be offended by such a proof of the Gratitude \& Attachment of the respectable part of the Community, is here well understood to be unfounded.

"The mode of giving Effect to the proposed design has been considered \& it is supposed that a medium course between the ostentation of a public indiscriminate subscription, \& the secresy of private donation would render the provision most munificent \& of course most honourable for all Parties concerned. All that is proposed may be easily affected without any sensible burthen \& when the enclosed document is perused $\&$ it is considered how greatly the men of Property are indebted to the labours of General Hamilton, they must doubtless be affected by his declaration, that those "labours have amounted to absolute sacrifice of the Interests of his Family.'

"Not doubting your disposition to exert your influence in giving effect to the benevolent object of this Letter, I remain

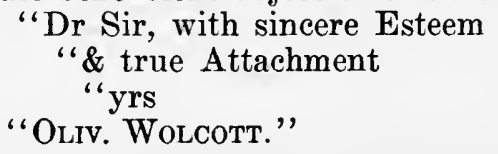


Of McHenry's life in 1805 and 1806, we know almost nothing. McHenry wrote Pickering on February 19, 1806, thanking him for his portrait which he had sent, and referring both to the agitated condition of public affairs, and to the disagreeable and contemptible position of the president. "We are threatening Europe with all possible harm and not daring to take a single step that might materially affect the existing revenue or render a resort to taxation necessary. The President is enraged with Spain, even to bloodshed and prevented by his friends from breaking the peace. Though suspected of not being perfectly ignorant of the expedition prepared by Miranda against the Caracas, he is obliged to deny any knowledge of it. Called upon to pursue that expedition with a naval force, he takes refuge in Congress. Contradieted and insulted by the little Spaniard and frightened almost to death by the more formidable Frenchman, Jefferson is pale and trembling in his capital, filled with anxiety and looking to Europe for events to justify his policy and extricate him from his difficulties."

On March 31, McHenry wrote again, telling Pickering that the Federalists cannot forget the system instituted by opposers of government, such as Jefferson, who set up a press to vilify the authorities and paid for it from the public money.

In 1807, his letters to Federalist leaders begin again to be more frequent. On January 29. he writes Pickering, asking him to explain Jefferson's message about Burr's conspiracy. Can Jefferson think the supreme court will try Burr? He regrets that he has not seen nor heard from Pickering and expects him, with Hillhouse and other friends on their return from the session, to "spend at least one sociable day with me."

On February 6, he writes again, as the Aurora insinuated that James Ross, of Pittsburg, and the Western Federalists were concerned in Burr's expedition. Ross wrote McHenry that he had no connection with Burr. Of other western Pennsylvania Federalists, O'Hara threatened to disinherit his son, if he entered the expedition. Wilkins sent his son in the boat to get his property, if possible, from Natehez and openly and decidedly interfered to dissuade men from entering the expedition. The only one of the Federalists in the expedition was Col. Newell's son and he promised his father to return, if anything like hostility to the Union proved the object of the expedition. Ross never saw nor knew of Burr's plans. 
Stirring in such matters does not mend them and, therefore, MeHenry does not intend to answer the Aurora. MeHenry approved of Pickering's vote to suspend the habeas corpus act, as there were symptoms suspiciously like rebellion, and asked whether Randolph of Roanoke will not be apt to run Monroe against Jefferson for the presidency, should the last named permit himself to be nominated again.

Pickering answered three days later from Washington:

"Dear Sir,

$$
\text { "City of Washington Feby. 9. } 1807 .
$$

"I have your letter of the 6th before me. I thank yon for the communication of what you received from Mr. Ross, in relation to Colo. Burr's project: tho' as far as concerned him and other respectable federalists, the declarations of the Aurora and of all the democratic papers in the United States, would scarcely authorise a doubt, much less fix any reproach.

"Really I had not at this place heard one word of the adjustment of all our differences with Great Britain: our intelligence came from Baltimore, in its news-papers. Your letter, however, induced me this morning to ask Mr. Giles, if the Government had ree'd. such information? They had not (he answered) last Saturday. He added, nevertheless, that Mr. Magruder of Georgetown, who had written to Mr. Gilmore (of your eity) to get some insurance made - had recd. an answer, that, in consequence of the adjustment of our differences with Great Britain, he had been enabled to procure the insurance at 3 PCent. when prior to their intelligence, it could not have been obtained under $41 / 2$ PCent.

"It has been said here, that the intelligence was sent to Baltimore on the authority of General Smith. He is (or has for several days been) with you.

"The session is drawing towards a close, and I rejoice at it; sick at heart with the feeble administration of our affairs, and the impending prospect of our becoming a province (or rather provinces, as it is his policy to divide) of the $\mathrm{Em}$ peror and King. This danger must be apparent to the men of understanding among them: but they will not hazard their popularity by proposing adequate measures of security \& defence; for this would require money - and money taxes. These men know that the people are fond of peace - that they are willing to be deceived: and seeing it is possible that G. Britain may weather the tempest, \& that we may find safety 
under her wings - they are inclined to rest their hopes, as to futurity, on that contingency; for the sake, in the meantime, of maintaining their power, \& keeping all the offices in the Union. Perhaps before the session ends, we shall see the pliant temper of the legislature, in relation to the interposition of the French Government, in support of Beaumarchais' claim. Glaring as is our right of rejection, I am far from confident that the claim will not be admitted. I shall rejoice to find myself under a mistake.

"The French Government have also made a demand, on the Executive, for indemnity, in the value of the French ship of the line run ashore on our coast, and there burnt by the British. If $\mathrm{Mr}$. J. should shift the decision of this claim also, from his own shoulders to those of the Legislature, it would not surprise me. It will be cheaper, more economical, to admit and pay these claims, than hazard a uar-especially a war with France! Thus is the dignity of our Nation maintained abroad! Such is the spirit of the supporters and pillars of our Government! adien.

"I dismiss the ungrateful subject, and cordially bid you

\section{"T. Pickering"}

During this year, McHenry employed his leisure by compiling and publishing the "Baltimore Directory and Citizens Register for 1807. Containing the names, occupations and places of abode, of the inhabitants, arranged in alphabetical order, to which are added a list of the names of all the principal officers employed in the service of the United States, a calendar for the year, several useful tables, duties, \&c. By James McHenry." The introduction states, "The Public are respectfully informed, that no effort has been spared to render this work useful and worthy of public patronage. The advantage which citizens, as well as strangers, gain from a Directory, leaves no doubt on the mind of the Compiler, but that he will be recompensed for his trouble, in thus presenting them with a volume of such useful matter as cannot fail to produce general satisfaction." 'The book is a dnodecimo bound in boards, containing 204 pages.

In the latter part of the year, McHenry wrote several times to Pickering, in one letter ${ }^{1}$ giving the latter a detailed account, in answer to an enquiry, of an act of piracy on the

1 See letter also of December 22. 
Chesapeake, ${ }^{1}$ by some Frenchmen, who eseaped punishment, because the federal court could take no cognizance of an act committed within the territorial waters of a state and the county courts could not, as their jurisdiction did not extend into the middle of the bay.

McHenry was suspicious lest Moreau's visit to New Orleans should lead to a possible seizure by the French of the Mississippi mouth and, when the embargo is proclaimed, is perplexed, finding no one who can explain the circumstances, on which it is predicated and passed. If France threatens and England shows every disposition to peace, why does congress pass an act which bears injuriously on both, as it operates a complete suspension of foreign trade. McHenry wished Pickering and the other friends would visit him on New Year's Day and. wrote that he had been little in Baltimore for the past four months, as he had been much indisposed of late.

Pickering answered this letter two days later:

"Dear Sir,

"City of Washington Decr. 26. 1807.

"Till last evening, when I received your letter of the 24th I had not known that you had been out of health: I am happy to find that you are getting better, and hope for your perfect recovery \& long enjoyment of the first of earthly blessings.

"To explain the conduct of an administration, in which wisdom has little agency, \& principle still less, would puzzle a more sagacious head than mine. Yet I have thought, for many months past, that the whole train of their proceedings, since the attack on the Chesapeake, admitted of a solution; \& till within a month I was satisfied my reasoning was correct. I have since entertained some doubt.

"I took it for granted that Mr. Jefferson would endure almost any thing, rather than engage in war: for he had placed his greatest merit in having preserved the U. States in peace. Peace was ever in his mouth; \& it seemed to be the leading principle in his administration. War would greatly diminish, if not destroy the revenue; - a war with England would annihilate it. The national debt, of the gradual extinction of which he makes his annual ostentatious parade, would rap-

1 Printed in Green Bag, xvi, 172. See also Md. Hist. Mag. for Dec., 
idly be increased: and commercial revenue failing, internal taxes must be resorted to: and all these evils combined, he would think sufficient to destroy his popularity. And, therefore, I had uniformly said, that he would as soon hang himself as go to war.

"Such was my reasoning - and I felt vexed with my mercantile friends in Massachusetts, for suspending their business, upon Mr. Jefferson's artificial alarm of war, merely because the Leopard had attacked the Chesapeake \& taken out four deserters. But I must make this apology for them they supposed his proclamation to be true, in all its parts: whereas I was morally certain, that in its most essential parts, it was false: \& so I did not hesitate to pronounce it. I knew the British did not and would not claim it as a right, to search our national armed ships. I was sure that they would not voluntarily increase the number of their enemies, especially by a wanton attack on the U. States, their best eustomers. In the nature of things, it was impossible the attack could be 'unprovoked.' Capt. Humphrey's taking out only the deserters, previously and repeatedly demanded \& refused, while he left untouched other known British subjeets, demonstrated that the conduct of our government \& its officers, had been marked with aggravated insults and injuries. The President said this attack was made, after it had been 'ascertained' that the men taken were native citizens of the U. States. This also I pronounced to be false; and insidions as well as false: Of its falsehood, the proofs are before the public. It was insidious, because it was intended to be understood by the people, that these men were poor impressed Americans. It is in proof that they had all voluntarily entered on board the British ships \& two of them only Ameriean citizens.

"It was insidious, because he meant the people should believe that the native citizenship of the deserters had beeu 'ascertained' to the British commander: otherwise the taking them by force was not 'marked' with peculiar 'character' of atrocity, or of blame.

"Well - the alarm of war was raised \& industriously propagated, by all the presidential partisans. Indignation was kindled into a flame, throughout the Union. To confirm the belief of an impending war, 100,000 militia were ordered to be detached, to be ready to march and fight the British Navy! This was a measure so perfectly ridiculous, that we should have thought no man of common sense would have 
hazarded his reputation upon it. But, Visionary as he is, Mr. Jefferson knows, incomparably better than his opponents, how to address himself to the nonsense of the multitude. And they are now so completely the dupes of his hypocrisy that 'tho' he laugh on them, they believe it not.'

"The attack was on the 22d. of June. Early in July he issued his proclamation. In that he announced his intention to demand reparation of the British Government. The Revenge was ordered to be got in readiness to carry his demands to London: and, doubtless, she might have been dispatched in eight-\&-forty hours. Yet she was detained till the 28th of July. For what reason? To give time for the leaven he had conveyed into the public mind to ferment. It operated to his utmost wish. And when at the highest point of effervescence - he ordered the Revenge to sail : carrying with her declarations and demonstrations of universal wrath against Britain, and of the disposition of the people to go to war with her, unless she yielded all the points on which Mr. Jefferson had insisted. The Attack on the Chesapeake, in the actual state of the public mind, was to be used as a political engine, to extort from Great Britain, not merely the most ample reparation for that wrong, but the favourite point of exempting from impress all persons sailing in merchant vessels, under the American flag. What other advantages he aimed at and insisted on, I do not sanguinely conjecture; tho' probably, it was that freedom of commerce which would admit us, under the title of neutrals, to become the auxiliaries of France, in carrying on her commerce \& that of her vassal states, with one another, with their colonies, and with the whole world. And he and his partizans were weak enough to imagine, that with such peremptory demands - with his hundred thousand militia with the people's bullying rage - and terrible denunciations of war - the British Ministry would be frightened into compliance! But, alas! they were not frightened. They manifested the steadiness of men of sense \& firmness, and that regard to justice and respect for our neutral rights, which ensured a fit reparation. All this was manifested before the Revenge arrived, before any demand of reparation was presented. What followed in London, all America knows. The instructions to Mr. Munroe, to link together inseparably the Chesapeake affair-with other claims, prove Mr. Jefferson's design to extort what in fair negotiation he had found Britain would not yield. 
"As soon as I saw the President's proclamation for a premature session of Congress - I saw and declared it to be part of the same contemptible farce. It was designed to hold out to $\mathrm{G}$. Britain, this language. 'You must make reparation promptly, and you must concede the other points I have insisted on: otherwise, Congress, whom I have summoned to meet six wecks earlier than their ordinary period, will declare war against you.' Now you will recollect that in his message, on our assembling, he showed that he had not expected by that time, an answer from London. But a special Envoy was coming, to make, in the most respectful way, honorable amends. With a knowledge of this, what ought to have been the conduct of our Government? When peace and amity and friendly intercourse \& commerce were evidently desired by Britain : - if we felt a corresponding disposition, should we seize every occasion - and even without occasion, go out of our way, for topies of abuse, for insulting language, for irritating measures? However, I construed all this silly bluster, all this billingsgate, (as derogatory to the dignity of a legislative body, as it was indecorous towards G. Britain) by the same rule as I had done in regard to the previous proceedings of the dominant party. Unquestionably, while they gave vent to their imbecile rage, they expected to inspire Britain with dread of our wrath \& our arms. Hence these ebullitions of words, were accompanied with Appearances of preparation for war. Gun-boats and fortifications are talked of \& talked of - and at length voted: propositions for an army of thirty thousand men are hinted at - then made and the Secretary of War is called on for his estimate of the expense of raising \& maintaining them for one year: and here this mighty army still rests. In the mean time, a bill is brought into the Senate, to add to our peace establishment, one regiment of infantry, one battalion of Cavalry, and one battalion of rifle-men! Such a bill was last year brought in by Samuel Smith, \& passed in the Senate, but wastejected at once in the house. Now the measure is renewed, evidently in the expectation, that in the midst of this military bluster, it may be smuggled thro' the house. It has passed the Senate, as before.

"Next comes the Embargo. For the motives - I mean the ostensible motives of the President, I must refer you to the article 'Embargo' in the National Intelligencer of Wednesday \& Friday, the $23 \mathrm{~d} \& 25$ th instant. The first is an elaborate, long-studied justification of the measure; and is 
undoubtedly the work of Jefferson or Madison, or the fruit of their joint efforts. The second is a continuation of the same - some after-thoughts. In this, one truth has escaped from their pen: the embargo is designed as a weapon of negociation. But I have got into a third sheet, without answering your plain question. Upon what circumstances is the embargo predicated? Really not upon anything communicated to Congress, which had not been previously known, \& literally or substantially published, in all the news-papers from Boston to Washington! Why then so much secrecy? By a solemn confidential message \& closed doors, within two or three days after the arrival of Dr. Bullers from France, with dispatches from our minister there, to raise high the public expectation; to keep up the apprehensions of impending danger \& war; and so cause the mischievous measure to go down more smoothly; and excite a belief of its indispensable necessity, for the public safety ; without which, the great \& good \& wise Mr. Jefferson, the father of his country, - would not have recommended it.

"The answer of Regnier, the Grand Judge, to the French Atty. General, \& the British proclamation of Octr. 16, calling for a return of British subjects to their own colours \& country, were all the documents the President would trust the Senate with, and all which on this oceasion he laid before Congress; excepting the letter (a short one) from Armstrong to Champagny, \& the answer of Champagny, which you will see by his message, the President ordered to be returned, unpublished. These two letters also were solely on the subject of the imperial decree of Bonaparte, of Novr. 21. 1806. and their contents ought to have been made public. But Champagny's contained a constriction of the decree which French impudence only would have formally declared: and this probably was the principal reason why Mr. J. did not think proper to have the contents of the two letters published. Suppose I should tell you that this letter, which I am now scribbling to you, was written with red ink: would you believe me? I wish I was at liberty to particularize these letters.

"I just learn that Smith; the President's printer, is striking off in hand-bills, immense quantities of the embargolaw, with the two justificatory pieces (before mentioned) annexed, to be circulated thro'out the U. States; to preoccupy the public mind, and convince the people of the wisdom \& necessity of the measure. But nature will rebel against rea- 
son: the actual sufferings \& losses, even of good democrats, will produce a clamour that will reach the palace: and the act must be repealed.

"I have time to say but a word more. Mr. Jefferson is unquestionably terribly afraid of Bonaparte - While he hates England. The power of the latter (I have reason to believe) he thinks cannot much longer be upheld: some of his creatures say - not many months. He will not declare war against G. Britain - while he provokes it - provokes her to strike first, to make her appear to be the aggressor. He then may mount his war-horse; and, Britain hunted down, \& gasping, he may come in at the death; and have some merit with the world's master.

"I commit this letter to your prudence. Very sincerely yours

\section{"T. Pickering"}

MeHenry wrote Pickering again, before going to church, on Sunday morning, January 3, 1808, stating that he believes the federal administration, "whose wisdom is mystery and whose weapons are deception," tried to force Great Britain to declare war on us and asking if the British ministry are sufficiently informed and enlightened to adopt a pacific policy. Tracy has died and we have no longer his aid. All the friends of peace in congress must declare themselves.

McHenry's younger son, John, sailed for Enrope in 1807 and spent several months on the continental tour. When he arrived at Paris, he found that Lafayette's wife had just died, of which event Lafayette wrote McHenry:

\section{"My Dear MeHenry}

\section{"Autenil January 11th 1808}

"Your letter of an Old Date and a Card from Your Son Were Left for me in the Most Cruel Moments that Can tear the Heart of Man - Overwhelmed With the Loss of an Adorable Wife Who During thirty four Years Had been the Blessing of My Life, I was Carried to this place, Where for Some Days I Attended Nothing But My family and our Common Grief. the first thing that Struck me Was Your Son's presence in paris, the first thing I did Was to propose a Meeting the More Confidently, as I expected He Wonld Stay Some time in town - it is only Last Night I Heard He Was going the Day after this - I Went this Morning to paris, and So 
did My Son - there We were told He Was at Versailles, and intended to Set out to Morrow Very early - I still Am in Hopes to See him, But Hasten to Send this Line to You, Expressing $\mathrm{My}$ Heartfelt Regret not to Have Better improved the whole time of his passage through paris - I Know, My Dear McHenry You will sympathize With me - Most Affectionately Your Constant friend

$$
\text { "Lafayette", }
$$

On March 20, Stoddert writes to McHenry from Georgetown to tell him of the breaking of the negotiations with the British minister.

"Dear" Sir"

"I rec'd your favor by Mr Boyd - but too late to say any thing by him. I should say nothing now, but that it may be interesting to you or your Friends, to know, that the neg'n with Mr Rose is certainly ended. He departs about Wednesday, as Mr Foster, who goes with him, just informed me. From a quarter I can rely on, I have it from Mr. Madison, that this important thing, has gone off in this triffing way. Mr. Rose declared his ability \& inclination to make complete satisfaction for the Chesapeake ontrage - but before he could advance further, he required that the Prests proclamation should be withdrawn - After sometime, our Gov. yielded so far as to say it should be withdrawn after satisfaction *** do not agree to withdraw it before and so the ** ended.

"Neither party expect it will lead to war - the King of England is now to determine whether he will yield the point of honor - if there is a point of honor in it.

"Do you not clearly see in this the fears of our Gov to accomodate with England, lest France should be upon us. I do not believe there is any love for France left. But there is great fear. Mr Jefferson thinks the Embargo will coves' everything - on that he is willing to rely. I suspect the People will be outrageous when they hear that Rose is gone, $\&$ this great evil is to continue. If you want to understand the British Doctrine in this case, look at the affair of Nootka Sound. I have not a doubt they are right \& that our Gor knew it - but was deterrmined to find some obstacle. Yet I do not believe they wish the quarrel to go further with England. 
"God knows what I am myself to do in these times, when money, plenty as it is, is all locked up from any employment. I hoped, being so very low in price, I should have sold my little farn 'ere this — \& got to Blads - but I seem further off than ever. Yet here I cannot live - nor can I move from hence. But I must have patience — \& fortitude.

$$
\begin{gathered}
\text { "Dr sir very sincerely yrs. } \\
\text { "BEN STODdeRT.", }
\end{gathered}
$$

Stoddert wrote again from Georgetown on March 31, 1808:

\section{"Dr Sir}

"It may be interesting to you \& your friends to know the account of the communication from the President resterday, with closed doors. Mr. Pinkney had had a conference with Mr Canning on the subject of the proclamation, with which the latter expressed himself well satisfied \& reiterated assurances of the friendIy disposition of that court towards us - the despatches from France were of a nature to excite both indignation \& alarm - In reply to several notes from Genl Armstrong on the subject, generally as I understood of American vessels in the power of France - Mr Champagne had written, after communicating with the Emperor, in substance to this effect - that the U. S., considering the high provocation rec'd, should have declared war against Britain - and associated herself with the Powers of the continent to restore Freedom to the seas - that, in fact. the Emperor cousidered the U. S. at war with England ever since the date of certain decrees - (whether his own, or those of Britain I know not.) - and that as to the American vessels, they were put in a state of sequestration \& their ultimate fate would probably be governed by the conduct of the $\mathrm{U}$. S. in regard to Britain.

"This information I collected in a way to be pretty certain of its correctness exeept perhaps in not representing the letter of Champagne to Armstrong, in a view quite so bad as the truth. Yet if it goes into the papers as a letter from this quarter, \& a member should be aceused of betraying a secret, I could not give up my informant - \& therefore, I wish you not to send it to the press, nor communicate the con- 
tents as from me, except to Mrr. Oliver, \& your particular Friends.

"There was a letter from Armstrong of 22 Jany - accompanied by extracts of conversations held with the minister - either the letter, or the extracts, held up the expectation that the vessels were expected to be given up - Champagne's letter just mentioned was dated 15 Jany - this subsequent communication from Armstrong, seemed to convey a ehange of disposition on the part of France - but the extracts were without dates - \& the members not understanding whether the conversations were before or after the 15th, tho' certainly it was meant by the press to convey the Idea, they were after - they passed a resolution appointing a committee to wait on him for dates - this passed by a majority not inconsiderable \& is some symptom of approaching distrust in Executive infallibility.

"All idea of war with Britain seems now at an end - \& the talk is - war with France - But if to be avoided by cunning without much aid from wisdom, we shall have war with neither.

"Strong efforts will be made to have these communications made public.

"You see in the whole correspondence between our Gov. \& Britain a predetermination on our part to make no aceomodation - yet we do not want to go to war - but to have just so much quarrel with Britain as to prevent war with France - but Bonaparte seems to be penetrating the views of Mr. Jefferson, \& will no longer be deluded by appearanees, however specious.

"I hope somebody will take up Mr. Madison's letter to Rose \& do Pub Justice - to me it appears destitute of truth - \& sound argument. His premises are generally false but it is cunning and he knew the mass were ready to swallow any thing. Before the printing was finished, many who have not yet read it, pronounced it to be a complete triumph over Rose - who, by the bye, scarcely knew what to do with good matter.

"I am still here - \& God knows when I shall get away to Blad'g - for in the present state of things, even men's faculties seem to be locked up - as well as their money, \& the products of the country. The latter would be unlocked, if the executive could really be convinced the Embargo began to be unpopular. I have it from good anthority, that no man has 
yet said to Mr Jefferson, that it did not greatly please the country.

"I am D sir very truly yrs \&c

"BEN STOdDERT. 1

"I know not whether I spell the French minister's nam? right - Champagne - you know the fellow I mean."

Tallmadge also writes about this time of congression I and New England matters:

\section{"Dear Sir}

"Washington March 25th. 1808.

"I now learn that the Monument designed to commemorate the Name of our friend Tracy, is to be raised next week. As Mr Blodget intends to record the names of those who contribute their mite to this laudable Undertaking, you will be pleased to furnish the names of those persons in your Vicinity who wish to promote it. I understand that his plan admits of but one Dollar to each Subscriber.

"We have now compleated four Davs in reading Documents communicated to Congress by the President, on the $22 \mathrm{~d}$ instant. Both Houses have been in conclave during the reading, but the principle part of the papers will be printed for the benefit of the Sovereign people. It will be a voluminous publication, but the Senate have ordered 500 copies \& the House of Reps. 5000 do to be printed. Thus the great Dearth, is to be succeeded by a redundance of Information, such as it is.

"We have gone through with the papers which relate to G. Britain, \& tomorrow expect to take a peep across the Chan-

\footnotetext{
1 An undated note of Stoddert's from about this time is as follows: "Dr $\stackrel{1}{\text { Sir }}$

"Simmons who was formeriy so subservient to Wiikinson, has become his Enemy, which one would think was an evidence of some favorable change in the conduct of the Geni. - and opposes all he can, the settl of his Public accots. The Genl. however, is likely to out general him. He sent me this letter sometime since, I wished your repiy might reach him at Washington about the 15 Inst.

"We shall certainly have no war with Spain Pinkney I understand, has not raised his reputation even with the men in power. We shall keep the country - \& wait for an attack from Spain. France will not let Spain attack while she has occasion for all the money of Spain. In process of time when Engiand is off her hands, it may be convenient to set Spain upon us. At any rate, it is good, always to have a pretence for Quarrel, to be made use of or not, as she may see occasion. These men rely on France in this dispute-and attribute to the friendship of France for us, what we owe oniy to her desire to engross all the money of Spain.

$$
\text { "D sir yrs. very truily, }
$$
}


nel. I fear this information will be limited. The Letter from Mr Munroe, of a late Date, is not much relished by the Jeffersonian \& Maddisonian party. They would be glad to dispense both with the reading \& the printing of that Letter, which I presume will be called up tomorrow - From present appearances, I think some noise will grow out of all this parade of publicity \&e \&c.

"The Spirit of 76 seems to be again breaking out in New England. In Northhampton the people have assembled \& voted on public measures like freemen, \& have recommended similar meetings through the county. In the State of New Hampshire, the dominant party begins to take back Ground, $\&$ hopes are entertained that the Embargo may prove an useful medicine. If these primary Assemblies should begin to act with vigor, my word for it, the higher eonstituted Authorities will feel their Influence.

$$
\begin{aligned}
& \text { "I am D Sir, very affectionately } \\
& \text { "\& Sincerely yours, } \\
& \text { "BENJ. TALLMADGE. } \\
& \text { "Saturday morning 26th March }
\end{aligned}
$$

"P. S. Since I wrote the foregoing, I have procured a No. Hampton paper which I will enclose for your perusal. A letter from a Gentleman at N. Hampton, just reed., remarks that, in consequence of the Notification expressed in the 4th vote, Meetings had been legally warned \& held through Hampshire County (of which No. Hampton is the County Town) \& that between $50 \& 60$ Towns had united to petition Congress \&c \&c. These petitions may soon be expected at the seat of Government. As soon as these Events are made known, I presume the Majority will begin to talk about an Adjournment of Congress \&e"

On March 29, McHenry introduced to Pickering Mr. Wil. liam Cook, a retired lawyer of Baltimore, a wealthy and much esteemed man of sense, formerly a Tory, who is now president of the Maryland bank and whose son is in Paris, prosecuting a claim against the French government. McHenry had read gladly Pickering's letter to Sullivan, and had added his mite of approbation in a letter sent to Wagner's paper.

Pickering replied on April 8, after the appearance of MeHenry's article: 
"Dear Sir,

"I have made inquiry for Callender's Prospect Before. $U s$; but have not yet obtained it. Have you the book? If not, can you procure and send it to me immediately? If you cannot get the book, can you send me any extracts (some were formerly given in News-Papers) which pointedly reproach General Washington as well as Mr. Adams? If you find neither book nor extracts, will you be so good as to write me, from your recollection, the principal expressions against one or both those Presidents? Have you copies of Jefferson's two letters to Callender? I have heretofore seen the originals. My object respecting these letters is, to prove that Jefferson encouraged Callender to write the book, and actually caused 50 dollars to be paid him by Geo. Jefferson at Richmond. Perhaps Judge Chase has the Prospect before us.

"I see, my dear friend, that the 'story' which I told for your individual amusement, you have worked up into a public vindication of the character of the writer: and $\mathrm{Mr}$. Dana thinks you have given a Rowland for the Oliver of $m y$ unprincipled enenies. But When in a Second letter I referred to the "Story" it was simply to point to the applicability of a very local to a national subject, lest, reading it slightly, you should think it a trifling \& impertinent tale: but I did not even dream of its ever meeting the public eye. I do not conjecture what notice may be taken of it: but tho' it be exactly true, perhaps Rowland may be again required to appear on the stage to vindicate its publication.

$$
\begin{aligned}
& \text { "With great truth } \\
& \text { "I am yours } \\
& \text { "Timothy Pickering", }
\end{aligned}
$$

On April 11, McHenry answered that he cannot get the book, but that the worst parts are reprinted in the reports of Chase's trial. Two days later, McHenry wrote again, send. ing the desired extracts from a copy of the book which he has procured and asking whether the rumor is true that Armstrong's last dispatches are worst of all. Pickering answered these letters on April 15:

\section{"Dear Sir,}

"Last evening I recd. your favour of the 13th. with extracts from the Prospect before us, which will answer my purpose fully. I am very much obliged by the pains you have 
taken to procure me information. I am doubtful, however, whether I shall find time before the close of the session to take up the Hero of Carter's Mountain. I have Sullivan at the Post with my cat o' nine tails ready. But the first whipping must be at Boston: Perhaps he may be carted thro' other States; notwithstanding the personality of the thing.

"The seourging is for a long and impudent and false letter which he sent in answer to my second to him; in which his offences are so numerous \& aggravated as to demand long \& strong animadversions, my difficulty is to bring them within a reading compass. Would you believe that this rascal insinuates that I was concerned in Burr's conspiracy? He got ashamed and afraid of his own letter, and, therefore, published only some pretended extracts, to serve his then pending election: But the extracts are in fact forgeries; not one corresponding with the original. I shall publish his whole letter \& expose his baseness and Deliberate Lying.

"This slander, joined with torrents of abuse kept up in one continued stream since my first letter obtained so great a run, has determined me, at length, to come forth with a defence of my character. And this, my dear friend will consist of a simple narrative of my public life during the last 39 years. You will see (for I will take care to send it to you) that the facts require no comments. Such a review I never before took; and but for this occasion, my children \& friends would have not known my strong grounds of vindication. The throng of business at the close of a session will probably prevent my meditated attack on higher game than Sullivan. My very long letter to him in answer to his of March 18th, I commenced a few days since, at leisure hours; and now I only want leisure to copy it. John Smith's trial cost a whole week, six hours a day.

"Have you Jefferson's letter to Mazzei? If you have, will you pardon me for asking the additional trouble of making out a copy for me?

"Mr. Hillhouse has proposed some radical amendments to the Constitution. John Wescote junr., who will be found at the Globe tavern, Baltimore, has this morning taken the amendments with Mr. Hillhouse's explanatory observations. They merit your attention. Highly republican, his propositions are supported by reasons which eannot be overthrown. Nothing will save our Republic but their adoption. The 
Printers here were so occupied with public documents \&e that it was necessary to send the amendments \& explanations to your eity. 500 copies are ordered for Congressmen. If you and your friends wish for any, the printer can strike off any additional number you \& they may wish. This public paper ought to have a general circulation.

"Truly \& affectionately yours “T. Pickering.

"P. S. Mrr. Hillhouse's amendments and observations are all founded on experience, and digested, as you will see them, with long attention \& labour. You can see the manuscript in Westcott's hands. I think he would find his acet. (or the printer he employs) in printing a few hundred copies for your city \& adjacent country. You can advise him whether in your opinion they would have a ready sale to indemnify him."

As congress reopened in 1808, MeHenry wrote Pickering. on December 3, that he was sorry not to see him when he passed through Baltimore, and wished to know if Pickering can tell him, without violation of confidence, whether Armstrong has advised war with France, or an arrangement with England. MeHenry suspects that those who ery for war with both countries desire it with England alone. On the 27 th he writes again, regretting the abuse of Pickering by the government writers, thanking him for copies of speeches sent and commenting on the disgust the administration's adherents show at the British victories in Spain.

On the 29th Pickering answers him as follows from Washington :

"Dear Sir,

"Last evening I received your favour of the 27th. You will believe me (for you know me) when I say, that in no public act of mine have I calculated on 'future fame.' I have only anticipated the approbation of a certain portion of society for my well-intended endeavours to do public good; and in general, not even that. For the most part (and always at the outset) I have thought of nothing but the means of doing that good, or of counteracting an impending evil. To an intimate friend only would I express these sentiments.

"I am gratified to receive yours with many other testimonies of approbation. The reproaches of my enemies produce no other effect than regret that my labours are less ex- 
tensively useful than my wishes would make them; and that their perverseness and malice prompt them to sacrifice the public interest to their resentments, and to their selfish and ambitious views.

"Mr. Jefferson having recommended the embargo from motives which will not bear the light, it must be continued, in order to support his sinking reputation. His partisans having linked their popularity with his, will go all lengths to preserve it. Such of them as are convinced of their error, are too proud to admit, by abandoning him, that they have been his dupes. The evils of his administration must continue a while longer, to open the eyes of the general body of the people who can think, to see the evidence which has been and probably will be exhibited of the greatest political imposture that ever cursed a country possessed of the means, like ours, of correct information.

$$
\begin{aligned}
& \text { "I am dear sir } \\
& \text { "very truly yours } \\
& \text { "Timothy PICkering.", }
\end{aligned}
$$

Pickering at this time strongly entertained the idea of publishing a Federalist history of the past fifteen years and on January 19, 1809, wrote Jacob Wagner, now publisher of the Federalist newspaper in Baltimore, the following letter: 1

1 On January 29, McHenry wrote Pickering and followed with other letters on February 4, 8, and 9, attacking the administration for its foreign policy, etc.

An unpublished letter of this period from Pickering deals with Gen. Wilkinson :

"My dear Sir,

“Washington Feby. 5. 1809.

"Last evening I received the two parts of the Pretensions of Thomas Jefferson for the Presidency, which I will take care to return to you as I go homeward.

"The inquiry to which you refer respects the application of money profusely, and in other cases in direct opposition to law, by the Secy. of War, in the case of Genl. Wilkinson - and for advancing his pay up to the 1 st day of December, 1809 , when he stands charged on the accountants books with upwards of ten thousand dollars (to Dearborne's knowledge) \& has been repeatedly pressed to come to a settlement. In addition to all this, the President about three weeks ago gave him a warrant for secret service money to the amount of $1196 \$$

"Turn to the law of March 16. 1802. and in the 4th section you will see that Wilkinson is to receive $\$ 225$. a month for pay, rations, forage \&c excluding every other perquisite or emolument. Notwithstanding which, Dearborn admitted bis acct. of $\$ 2033$. for 36 rations a day at Natchitoches \& New Orleans, including quarters and stabling \&c. for 6 months at $\$ 100$. a month; the rations under a palpably false construction of the 5th section of the same act. The accountant refused to pass the acct. So the President \& Atty. Genl. were resorted to ; and on their order $\&$ opinion, the comptroller has admitted the claim of $\$ 2033$. The Atty. Genl. seems now to be a very convenient executive instrument to furnish 
"Dear Sir,

"Washington Jany. 19, 1809.

"I want to collect materials for an investigation of the source of the calamities which distress our country. This will embrace men \& measures; but above all Mr. Jefferson, whom I consider as responsible, primarily, for all. It appears to me indispensably necessary to place the insidious policy \& conduct, \& the unexampled outrages of the French in a conspicuous point of view - looking back to the negotiation of 1782 at Paris, where but for the penetration \& firmness of Mr. Jay, we should have lost the fisheries, the western territory \& the navigation of the Mississippi.

"I have a number of documents in Masstts which would be useful; but they will [be] unattainable during the present session. Have you the instruction of the Comtee. of public Safety to Genet, in which were confessed the views of the Court of Louis XVI to keep us back and check our growth. If you have these instructions, I wish you to send them to me by a safe conveyance - I will return them as I go home, with any other documents you have which can enter into the investigation, in which I am about to engage. If you have not the instructions, perhaps you may find them at Mr. McHenry's. Perhaps too you can give me much useful information on the subject of my inquiry, consistently with the honourable confidence reposed in you while in the department of State.

"I shall first publish a short answer to the charge of keeping back dispatches from Mr Eppes, made in the House of Representatives; and I had thought of sending it for insertion in the North American - if agreeable to you. This will be the introductory address to the people of the U. States. But mention this only to Mr. MeHenry and it will behoof me to be rather reserved \& promise little: for it would mortify me

the form of a legal apology for illegal acts. His opinion in the cases of Beaumarchais' claim and Judge Johnson's Mandamus, I consider as of like character.

"Dearborn was nominated to be collector for the port" of Boston. Accidentally I had heard of some of these facilities in expending the purblic money, \& on that ground objected to the appointment.\& a comtee was appointed to inquire - Giles chairman. He, however, appears to see nothing improper. It is wonderful that Hillhouse \& I should be on the comtee. We are investigating; and now I see that Randolph has taken up the business in the House.

"I am, my dear sir, "with esteem \& affection

"Another item. Of 36 agents for fortifications, old major Wescott, a valuable revolutionary officer, and Dearborn's young son, a lawyer without business, were alone allowed pay as Engineers! Young Dearborn at $\$ 3$. per day, in addition to $2 \mathrm{P}$ Ct. commission on expenditures." 
to the last degree to begin with a flash \& end in smoke. I am disposed to think, from what I occasionally hear, that plain \& forcible statements under my signature will, at this time, make impressions alike useful \& extensive. I deprecate the toil it will compel me to go thro'. but if accomplished in some degree adequate to my conceptions of the subject, all the other labours of my public life will be comparatively trifling. At no other time, since $\mathbf{1 7 7 6}$, has the public mind been in a state so impressible.

"I wish you to see Mr. McHenry, \& show him this letter, $\&$ pray him to excuse me for not writing to him - for I could only have made known the same things; \& my time is limited. I think he can furnish much useful information \& some important documents. All his \& yours it will be best to send by some person who is to come here \& go no farther. I will carefully return all when I go home. It is likely Judge Chase, who was long in the Old Congress, can furnish materials for the contemplated work.

$$
\begin{aligned}
& \text { "I am dear sir } \\
& \text { "with sincere esteem } \\
& \text { "yr. obedt. servt. } \\
& \text { "'T. PICKERING }
\end{aligned}
$$

"I dare say Mr. McHenry has W. L. Smith's two pamphlets entitled Thomas Jefferson's pretensions to the Presidency, which I wish to see."

In 1809, John Adams began to publish in the Boston Patriot a series of letters defending his public career. Of these letters Pickering wrote McHenry on June 4:

"Dear Sir,

"You see that Mr. Adams is giving a history of his administration, in his own way. Doubtless it may become proper that this history be reviewed. Perhaps you have read all he has published; I very little. You possess probably some documents which would be important in such a review; besides a recollection of many interesting facts. These I wish you would put on paper - and collect the others. It is my intention, at the close of this session (which I hope will happen before this month expires) to pass a day or two at Baltimore - on my way home.

"Mr. Malbone, a Senator from Rhode Island, as well as usual this morning, was going with other members from Rhode 
Island to the Hall to attend public worship. Arriving at some rails at the foot of Capitol Hill, he stopped \& leaned upon them - saying, 'here is my usual resting-place.' The words were but uttered, when he fell, and instantly expired. He was a pleasant and amiable man.

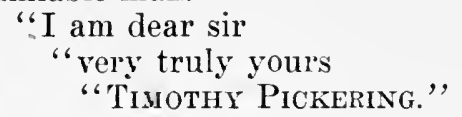

MeHenry answered the letter on June 16. He proposed to leave home shortly with the greater part of his family for Colonel John Lynn's in Allegany county, where they will probably remain until the end of September. He asks whether Adams's writings are "likely to become history? Who pronounces the name of this calumniator of the dead witl veneration? Who celebrates his acts? Who is emulous to tread his footsteps? In a few years his name and his fame, if not borne up by other pinions than his own, will sink in that gulph destined to swallow up all memorials of merit and demerit like his." It is not worth while to answer his letters. ${ }^{1}$ These letters of Adams and those to William Cunningham which appeared in 1823 were answered by Pickering in a volume printed in 1824 .

On June 23, McHenry wrote Pickering from Hancock, where his youngest daughter, Margaretta, who died young, was ill with fever, commending to his friend her physician, Dr. J. G. Scott, who intended to remove to North Carolina. During his journey to Allegany county, MeHenry stopped at Bedford Springs and wrote an account of that watering place to his daughter Anna whom he had left in Baltimore.

"My dear Ann.

"Bedford Springs 4 July 1809.

"The accommodations here are pretty good. The prineipal building is 70 feet by 20 . There are besides it several lesser houses appropriated for visitors. It stands in a valley between two hills or rather mountains, (with which this county abounds) that seem to keep a northeast course. From the house to the medicinal spring is about 150 yards. The water seems to possess, if not the same properties, at least the same powers, as the waters of the Sweet Springs of Virginia, or

1 Printed in J. Adams, ix, 236, and following.

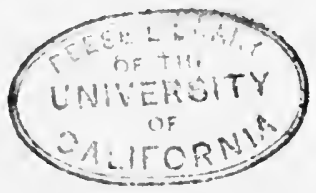


those of Balstown in the State of New York. It flows from the base of the mountain on the south side, and supplies two shower and plunging baths, situated within 15 or 20 feet of where it rises. There is also about half a mile distant an artificial warm bath, and above it a billiard table. This place affords shady walks, for lovers; shrubs and wild flowers, for botanists; petrifactions for virtuosi; streams, and trout, for fishermen; and pheasants, woodeocks and partridges, for gunners. The town of Bedford is also within two miles of the Spring, where there are some very agreeable females and families.

"If inclined to see us on the mountains, instead of visiting York Spring, three days in the public stage would bring you to Bedford, and this place; from whence, after a short stay, you could easily obtain horses to carry you to Cumberland, which is only about 30 miles distant, or Augustus could meet you at the springs with horses from Mr. Lynn's, could we be ascertained of the time they would be wanted. It appears to me however, that a project of this duration, could not be made to quadrate with Mr. Boyd's engagements. It would perhaps suit John better, provided he had finished his farming and other business. Give him to understand this that he may take it into consideration.

\section{"JAMEs MeHenRy"}

After a summer spent near Cumberland "amidst woods, green glades, mountains, and solitudes, 'MeHenry wrote Pickering on October 16, shortly after his return to Baltimore. The Federalists have lost in the elections for the Maryland legislature, but not by a large margin, considering the mass of influence against them and the fact that honorable men rarely take as much trouble as less scrupulous ones in politics. He hints at some crooked commercial dealings of Smith and Buchanan and adds that some Republicans in Maryland prefer Nicholson to Samuel Smith and Gallatin likes him, but McHenry does not think he will win.

The old difficulties of closing MeHenry's accounts with the government came up again in the early part of 1810 and Pickering interested himself in the matter, apparently with success.

On March 15, McHenry wrote Pickering of Pinkney's dispatches, of Macon's bill and of Secretary Smith's attempt to prove that Jackson, the English minister, was disapproved 
by his government. Pickering's reply to McHenry dealt with current politics, especially with the negotiations which William Pinkney, our minister to England, was carrying on in London.

"Dear Sir,

"Washington March 17. 1810.

"Last evening I received your letter of the 15th. The supposition you put, to account for the reported declaration of Ld Wellesley to Mr. Pinkney, of his disapprobation of Jackson's conduct, is natural, and (if he made any declaration of the kind) undoubtedly just. But for my own part, I needed no solution whatever except this - That Ld. Wellesley is not a fool. I would not say so much of some other statesmen. It is not difficult to discover that some men are defective in understanding: and that others, tho' celebrated for learning and extensive diplomatic research, may yet want common sense and political integrity.

"In his message at the opening of the present scssion of Congress, Mr. Madison plainly insinuates - and insinuates for the purpose of popular deception - that 'a minister' plenipotentiary' - without any special authority, could enter ints an 'arrangement' - that is, make a treaty, which should bind his government. This he would be ashamed to avow in explicit terms : it would make him a subject of ridicule among all men of information. But for temporary purposes - or rather in expectation that a people, whom Jefferson had found it easy to deceive for eight years, might continue the dupes of similar artifices in his successor - he was willing to hazard not only the above insinuation but the contempt which could not fail of being felt towards him by all the respectable portion of the Community at home, and of the English \& other foreign nations, as far as the correspondence, subscribed by his secretary, with Mr. Jackson, should extend.

"The talked of letter from Pinkney to Smith is dated so early as the 4th of January, and declared to be only a private one - consequently not the subject of a call from any member of Congress. I have not seen it: altho I learn that Smith has made himself extremely busy in reading scraps of it, here and there, to many members, federal as well as democratic. A temporary purpose is to be answered by giving out that Ld. Wellesley disapproved of Jackson's conduct: for that implies that our administration was in the right; and there- 
fore that in the pending election in Massachusetts, the people ought to support the candidates who are ready to support the administration. With the same view, in respect to New Hampshire, Madison's shameful correspondence with old Genl. Stark was had. Genl. Stark was never capable of writing the letters now \& for a year or two past bearing his signature : and at this time is a mere child.

"There is another answer to your question - "Which shall we believe?' Jackson or Smith. One we know is capable of deceit: against the other we can bring no such charge. From the view I have had of Jefferson's conduct during six years of his administration, I feel myself warranted in pronouncing, That Deception has been its leading principle. Madison was his 'zealous \& enlightened cooperator' as J. himself has testified: and by his inangural speech, explicitly declaring his approbation \& admiration for Jefferson, is identified with him. He appears to have entered into all his views, and assisted in his plans of deception, as the printed documents furnished by themselves will prove.

"It is but two or three days since, for the first time, I was told by a member of the Senate (I think it was Anderson) that Macon's Bill was an 'Executive measure.' It is hung up for the present - and perhaps will die, as well as the nonintercourse with the session.

"I recd. your packets of St. Hilaire's letters. The material one, with my remarks, is with the Comptroller. It is the one in wh. he acknowledges the rect. from you of $\$ 2500$. and asks pressingly for $\$ 90$. more. Your receipt to me is for $\$ 2560$. Do you recollect how you paid him the $\$ 60$ ?

"I am glad to find you can write, as it proves you are recovered from sickness.

"Believe me ever yours

"T. PICKERING.

"Our old friend W. [olcott] at New-York has avowed political sentiments for a couple of years past, which astonish all his friends : and some of them say they can resolve it only by a supposed insanity quo ad hoc. He carries a some half dozen men with him."

On the 27th, McHenry, who sorrowed because of the death of his daughter Margaretta, "who was very dear," wrote Pickering again, deploring the fact that some Federalists had been converted to Madisonianism. 
Stoddert became uneasy at Adams's attacks on his secretaries and wrote as follows from Bladensburg, 14th of April, 1810:

“*** I will not add to the length of my letter, except to ask you are Mr. Adam's misrepresentations to remain unnoticed by those on whom it is most incumbent to contradict them? He gives countenance to the most unjust opinion, that there was British influence in his Cabinet, - leads the world to suppose that the dissatisfaction arising from the measure of Murray's nomination, was at the measure \& not at the manner of it - to believe that the letter from the heads of Departments was intended to produce a relinquishment of the negt. with France, instead of merely a short suspension of it, in consequence of the then experiences in France - and that there had been many meetings at Trenton between the Departments, in which he laboured to no purpose to convince their minds the mission ought to go on when in truth I believe, a word was not said between him \& any of the Departs on the subject, their only meetings were for the purpose of agreeing on the instructions to be given. He came to Trenton determined, as was known to the Departments - and I then thought his determination right but had no occasion to say so to him. I am truly

"Dr Sir Yr obliged Friend \&c \&c "Ben Stoddert."

Shortly afterwards Pickering wrote MeHenry thus:

"Dear Sir, “Philadelphia May 7. 1810.

"I trust you have received your packet of papers relative to St. Hilaire. I left them with Gadsby's bar-keeper, sealed up, together with two Newspapers, the Whig \& Aurora, which Mr. Wagner borrowed for me at a Coffee House \& promised to return, of which, therefore I reqnest your particular care, to hand Mr. Wagner.

"You will recollect that the partisans of Jefferson (and particularly his son-in-law Eppes, in the House of Representatives) have charged me with keeping back from President Adams some dispatches in 1798, the doing of which, he, Eppes, said, had well nigh involved us in a war with France. I intended to have asked you whether you were acquainted with 
any circumstances which could have given rise to this falsehood. Until within about two years, I never heard of such dispatches, \& now know nothing beyond the report. Adams you know spent much of his time at Quincy; and if the delivery or communication of any dispatches to him was delayed, of which I have no recollection, it might have been occasioned by such absence of Mr. Adams. I can only conjecture what they can have been - letters from Mr. Murray containing the dishonourable \& insidious overtures of 'Talleyrand thro' Pichon, whom he sent to the Hague to carry on the intrigue. Do you recollect the expression in Talleyrand's or Pichon's letter to Murray - 'And if the American Govt. (or President) send such a man as you, there will be no difficulty in settling all our difficulties:' or words to that import? I wish to iscertain this. Perhaps you or your nephew may recollect the words or the sentiment. Mr. Adams then, after his big speech that he would never send another minister to France, until \&e. had the meanness to let the French Govt. nominate his minister! within a year or two, when thinking on his corrupt bargain with the Democrats to secure his second election to the Presidency. I have not been able to repress a suspicion that the negotiation with France originated in the same influence $\&$ with the same ultimate views, tho' antecedent to the bargain for my removal \&c..

"You will much oblige me by giving your own recollections \& what other information you can obtain on this subject. Please to direct to me at Wenham, Massachusetts.

"I remain my dear sir

"very sincerely yours.

"T. Pickering"

McHenry answered on July 25, giving his recollection of the matter. There is a family tradition ${ }^{1}$ that, about 1810 , MeHenry was "a good deal oceupied in writing a book after the plan of the Travels of Anacharsis, a book which he admired." The manuscript of the work was placed in a trunk to be sent to his son's country home and as the trunk was lost, MeHenry was discouraged and did not resume the work. ${ }^{2}$

1 Brown's McHenry, 42.

2 On January 13, 1810 , Doctor Mason of New York who planned writing a life of Hamilton came to McHenry with a letter of introduction from Mrs. Hamilton and was lent by McHenry a large number of the letters sent by Hamilton. The life was never written and Charles Scribner recovered for James Howard McHenry in 1844 a large number of the letters, but some seemed to be lost, among them one of August 26, 
When congress met again, McHenry wrote, on December 15, of Madison's relations with England and France and asked why Pickering fails to visit him? The answer came two days later.

\section{"City of Washington Decr. 17. 1810.}

\section{"Dear Sir,}

"I have received your letter" of the 15th. It would give me great pleasure to spend some time with my good friend between Boston \& Washington : but I always find so many things to occupy my attention when about to leave home, that $m$. wishes \& even intentions of proceeding leisurely along have hitherto been disappointed. If practicable, I will hurry less on my return; especially as it may be my last.

"I send herewith the requested copy of the documents which accompanied the President's message. His taking possession of West Florida may seem to be a bold step. It was certainly a rash one; because unwarrantable on any ground which can be assumed. I am satisfied that we have no title: and if we had, Spain was in possession; we had acquiesced in her keeping possession, and made it subject of negotiation, and even to negotiation an end was put, five vears ago. by a word from France. This furnishes irrefragable proof that the order to disposses the Spaniards now, is by the permission, if not by the advice, or even direction of France: and hence a strong presumption arises, that the revolutionary proceedings in Florida have been secretly instigated by our own administration.

"Altho' I lave never felt uneasiness about my aecounts as secretary of State - because I liad not charged even a cent which had not been expended in the public service: and altho' the Comptroller's letter to me last spring admitted that I was not responsible for a single item which had been suspended: yet I was pleased with the promptitude \& politeness with which Mr. Duval gave me notice, at the commencement of the present session, that those accounts were finally closed. I inclose a copy of his letter of the 5 th inst. which, if the enemies

$1800,$. "containing account of blrth, \&c," which we would greatly like to have. The Collection of Facts and Documents relative to the death of Maj. Gen. A. Hamilton, printed in 1804 , contains (p. 95) an article from the Fredericktown (Mid.) Herald. 
of truth renew the oft repeated and refuted lie, may be published to their confusion.

"With sincere respect \& esteem

"I remain as ever yours.

"'T. Pickering."

Tallmadge did not fail to keep MeHenry informed of the congressional proceedings and wrote him on December 21, from Washington:

"My Dr Sir

"I duly reed. your Letter of the 18th inst. \& it happening to be on an Evening when a number of our federal republican friends were convened at Col. Pinckney's room, I took the liberty to communicate the same to them. I believe we all view the State of our public affairs very much in the same light as you have stated them. How we shall alter or arrest the course of our public measures, is a Question not easy of solution. It can not have escaped your notice that the Exposure which was made, at the last session of Congress, of our Executive Conduct relative to $\mathrm{Mr}$ Jackson, operated manifestly to the Injury of the federal cause. The ery of British Attachments, in opposition to the Interests of our own country, was rung from one End of the continent to the other; \& what is one of the most prominent Evils attending every Effort to throw light on any national Question, is that those who really need Information never read a federal paper, \& the other papers are filled with attempts to mislead the Ignorant, \& to traduce the characters of those who are able to enlighten.

"A Resolution requesting the President to open new negociations with G. Britain, would be deemed \& declared an improper Interference with Executive Duties, \& a mean submission to British Influence \& power. I am not sure but our cause would suffer by it, nor am I by any means certain but we shall find it absolutely necessary to make the appeal in the manner you have suggested, before the session shall close.

"On the subject of West Florida, Mr. Giles has probably foreclosed any measure of the sort you have suggested. We have a Bill just laid on our Tables, originating with Mr Giles, declaratory of the boundary of the Orleans Territory. By this Bill the River Perdido is fixed as the Eastern boundary. If I can get a spare copy, I will enclose one - the fact is the 
President's Proclamation on this subject must be borne out, \& in this way the high Responsibility of the Executive, even if his conduct should lead to a Declaration of war, must be assumed by Congress. In the same way, I presume, we shall be called on to legislate respecting the Proclamation applying the non Intercourse to England.

"I thank you for your Intimations respecting the State of our country. They will not be overlooked nor forgotten. If I can possibly get a spare copy of the Documents, as well as of Mr Gallatin's Report, they shall be enclosed. I am truly \&

"very affectionately yours "Benjn. Tallmadge."

Early in 1811, McHenry wrote Pickering, asking when Short was sent to Russia and regretting the excessive patience and resignation of Federalists, when courage and energy are most needed. "In our government the multitude are everything." Pickering answered at once.

\section{"Dear Sir,}

“Washington Jany. 5. 1811.

"I reed. your letter of the 3d. yesterday, as I was on my way to the palace, to dine with 'Little Jimmy,' as the stage driver called him, on my last journey from Baltimore to this place. That I might not forget, and so 'neglect' the object of your request, I give you here the words of 'Long 'Tom' (Wilkinson's appellation of 'the moon-shine philosopher of Monticello,' as a gentleman of distinguished science and literature called him in a letter to me) - 'I accordingly commissioned, in the month of August last, William Short'- \&c. His message bore date Feby. 24. 1809.

"From my childhood I was used to hear my father (a plain farmer but a man of sense) repeat to different people, (\& particularly to clergymen who called at his house, and few if any of whom, he thought sufficiently explicit in showing the people their sins - ) these words of the Wise Man - "The fear of man bringeth a snare.' This fear is the source of the evil you lament: the dread of slander from the vile; or of loving popularity, power, place, or interest.

\section{"Sincerely adieu.}

$$
\text { "T. Pickering." }
$$


A fortnight later, Tallmadge wrote:

\section{"Dear Sir}

"Washington Jany. 16th. 1811.

"I have reed. \& perused your Letter of the 14th instant with pleasure. The Man who could devise a remedy, practicable in its operation, for the political Evils which now hang over us, \& threaten to ingulph Us in ruin, would merit much from this degraded Country. Notwithstanding all the Information from Genl. Armstrong, \& the Declaration of our Secy. of State that the repeal of the French Decrees is merely nominal, \& of Course never have justified the President in issuing his proclamation, yet the non Intercourse is to be enforced towards G. B. with peculiar vigor. If our Democrats in Congress as well as in the Country will not believe their own senses, \& when such indubitable proofs are before them, will not be convinced that the measures of the Administration are not correct, how ean you approach their understanding with any hope of Success?

"On the subject of admiting the Terry. of New Orleaus into the Union as one of the States, the unconstitutionality of the measure was urged with such force that it seemed as if a Barber's block could not have misapprehended it \& yet the party to the tune of 77 in the House remained unmoved. Mr. Quincy exhibited the Consequences of this measure in strong Colours, for which they were angry enough to have turned him out of the House. Will this do any good, here or elsewhere?

"This day on a call for Information from the Secy of the Treasury, your quondam Govr. Wright was very noisy \& very abusive towards the Directors. In my reply to his Excellency, among other things I remarked that I had hopes. this great Question renewing the Charter of the Bank of the $\mathrm{U}$. $\mathrm{S}$. would have been discussed with Calmness, \& free of all party Distinction $\& c \& \&$. Mr. Eppes replied, \& remarked that this Bank originated in party, that it had been supported by a party, \& that it would undoubtedly be a party Question on its present Discussion. Now this being the Case, what hope is there of a renewal of this Charter ; \& in fact what Question can come forward in which the power of party will not be brought to bear upon it: I am almost induced to believe that it would be well for the Country, if the federal Gentlemen would let the 
majority pursue their own Course, \& only vote on the final passage of a bill.

"We have no news from Florida of a late Date.

"In the papers of this Day you will see the new non Intercourse Bill. One blessing to result from it will be an Increase of our Duties on Imports. A bill to this Effect will be imported shortly.

$$
\begin{aligned}
& \text { "With Sentiments of respect } \\
& \text { "\& Esteem, I am affectionately yours } \\
& \text { "BENJN. TALLMADGE." }
\end{aligned}
$$

About this time, Pickering received the censure of the federal senate 1 for reading in public session a letter of Talleyrand written in 1804 , confidentially communicated to the senate and from which the seal of secrecy was not removed. McHenry wrote Pickering, on January 26, commending his conduct, as there was no obligation to further concealment and each senator is the judge, when the obligation ceases. "I dislike confidential communications. They are great evils in a government such as ours and may be made instruments to its ruin. If affairs are wisely administered, there will be no need for such communications.",

Pickering answered this letter as follows:

"Dear Sir,

$$
\text { "City of Washington Jany. 28. } 1811 .
$$

"I have been favoured with your letter of the 26th: and altho' Mens conscia recti is impenetrable to the shafts of malice, and heeds not the reproaches of slanderers; yet it must be always sensible to the approbation of estimable and upright friends. I thank you sincerely for the strong expression of your opinion condemning the proceedings of the Senate in their vote of censurc, in my case; seeing no offence had really been committed: for the object of the rule, its very essence, is to prevent the disclosure of State Secrets, and it was acknowledged that I had divulged none. But the letter of the rule was violated: and half the Senate, every day violated another rule - which forbids the reading of any printed paper or doing some other things incompatible with the proper attention of members, while the journal is reading and business transacting. And this inattention retards business, \&

1 Pickering, iv, 194. 
occasions errors which might otherwise be prevented. If one day had intervened, I have some reason to think that Clay would not have offered his resolution, or that, finally, he would have withdrawn it, but for the opposition of some of his party, especially of Saml. Smith; who from the first to this last session of my having a seat in the Senate, has manifested an asperity \& ill-will towards me for which, tho' perfectly indifferent, it did not occur to me how to account; nor indeed did I ever waste a single thought upon it. But I presume you know that he was principal in the intrigue with President Adams to effect my removal from office. Now I have more than once met with the remark of some profound observers, 'That One man had injured another too much to forgive him.' This seems a little paradoxical; yet is probably correct. Indeed it seems to have obtained the authority of a maxim. And why should the Aggressor be implacable? Because a voluntary aggression originates in a bad heart: and Pride joins with malice and other base passions to urge the wrong-doer to persist in the error or injury once committed.

"I have two pamphlets of yours - the 1st \& $2 \mathrm{~d}$ part of Thomas Jefferson's pretensions to the Presidency, printed in 1796. I wanted to derive some information from them, \& find what I expected: but the $2 \mathrm{~d}$ part is imperfect, by the omission of a half sheet, in place of which a duplicate half sheet is inserted. Perhaps Judge Chase or other friend may have it entire: if you can get it, have the goodness to send it to me (taking care to have no more than 2 ounces in weight in one packet) \& I will be eareful to return it, together with your own, after the close of the session. Pray can you tell me who wrote those pamphlets? The Author held a good pen. ${ }^{1}$

"I am dear Sir

"very affectionately yours. "T. PiCkering"

Later in the session, on February 28, Tallmadge wrote McHenry of the progress of events.

"My Dr Sir

"Washington Thursday morning

"Feby. 28th. 1811.

"I am set down to acknowledge the Rect. of your Letter

1 On January 29, McHenry told Pickering that W. L. Smith of South Carolina wrote the pamphlet for whose author he asked. 
of the 26th. inst., but I own to you the fatigue of the two last Days \& nights has almost unfited me for mental or bodily Exercise.

"After working at the non Intercourse Bill for several Days, \& drawing out all the force of the friends to the Bill, we began to attack them at close Quarters, \& to press the Action very elose indeed. The objects of the Bill were distinetly marked out, showing that hostility to G. B., \& Union with France, were the prominent features of the Bill. Every Attempt to amend the Bill failed, \& even on some very plain \& neeessary points, the Majority voted not to amend. The speaking was now confined almost exclusively to the federal side of the House, \& we kept the side warm with our Artillery, I assule you. This was on Tuesday last, \& we were told that they had determined to take the Question before they rose. By midnight it appeared, on several collateral Questions, that they had not a Quorum present, \& by 2 o'Clock in the morning we found that without our aid, they could not make a House for business. We began oceasionally to draw off into Committee rooms \&c, when a Vote was taken to send for the absent Members. Not one obeyed the eall (for having no Quorum, they could not form a Warrant to compel the Attention of absent Members) \& a little after three in the morning, the House adjourned to the great mortification of the Majority. Yesterday we resumed the same subject, \& continued the Debate much in the same manner, until nearly 3 oclock this morning, when they determined to bring the business to a close, \& put an End to further Debate. The previous Question was moved on every proposition, \& at about Day dawn this morning the final Question was taken \& earried, \& that obnoxious Bill will go to the Senate this Day, precisely as it came to our House, with Eppes's printed amendments. It will undoubtedly pass in the Senate.

"Early last Evening, it was discovered that the Bill had been engrossed for its final passage even while we were preparing numerous Amendments. Mr. Randolph made a question of it in the House. The Speaker plead Ignorance of the fact, \& to save the Clerk, Mr Eppes confessed that he had requested the Clerk to have it done. This drew from $R$. some severe remarks, to which $\mathrm{E}$. replied, \& $\mathrm{R}$. rejoined in such a manner as to wound E. severely. Our Duelists say they cannot avoid fighting. Indeed it is said that an exchangc of Cards took place promptly. 
"I will forward such Documents as were preserved for me during my absence.

"In this day of increasing trouble, let us not preserve each others Letters. I am yours truly

"Benjn. Tallmadge,"

Pickering still retained his plan of answering Adams's letters and wrote McHenry as follows on February 8:

"Dear Sir,

"Do you remember the tenor of the conversations at 'Trenton, in the autumn of 1799, when President Adams came thither from Quincy, relative to the mission to France? You will recollect that Judge Ellsworth came also, \& Govr. Davie - \& that Genl. Hamilton was there. Mr. Ellsworth, I recollect, was invited by us (heads of departmts.) in the hope that his opinion might have some weight with Mr. Adams to suspend the mission. But was not Hamilton's coming merely military? Mr. Adams (in his lucubration published in the Boston Patriot, letter VI.) expresses his astonishment at our 'obstinacy' on this subject, \& mentions Who has a copy of this letter? the letter we all signed earnestly entreating him to suspend the mission. He says the reason we gave was - the operations of the Austrian \& Russian armies under Prince Charles \& Suwarrow, wonld speedily place Louis XVIII on the throne. He mentions Ellsworth \& Hamilton as expressing the same opinion. He also intimates that two of the Heads of Depts. (meaning Stoddert, no doubt, \& Mr. Lee) had always appeared moderate \& candid. If you have not this (\& the other letters which Mr. Adams has been publishing for near two years past) I believe Mr. Wagner can furnish you with them. Have the goodness to recollect and communicate to me what you can on this subject. All particulars of our conversations with Mr. Adams at Trenton have escaped me.

"You will recollect that, in Mr. Adams' message to Congress June 21. 1798, He said he would never send another minister to France, until he reed. assurances that he wd. be reed., respected \& honoured as the representative of a great, free, powerful \& independent nation. Genl. Hamilton in his letter of 1800 , on the conduct and character of John Adams, President says that all his ministers were opposed to this declaration that he wd. send a minister to France: though Mr. 
Adams was advised to say he wd. receive one from France: Do you remember this? I do not.

"Some time or other, if God spares my life, I purpose animadverting on Mr. Adams' publications; and wish to obtain authentic information on every important point. If you can find all his letters published in the Boston Patriot \& will send them, you would be enabled to give me useful information. Some time ago, I recollect to have heard that Mr. Stoddert asked with indignation - Whether all Mr. Adams' misrepresentations (I do not know but he said lies) were to pass unnoticed? In Boston, long ago, I heard it said, 'It wd. be best to let him go through' \& then answer. But he has been at it near two years - with the vain details of his diplomacy and has only come down to the year 1781 .

"Very affectionately yours

" T. Pickering

“P. S. I once saw your details of Mr. Adams' insults to you prior to yr. going ont of office. I shall wish to read again your statement on my way home.

"You doubtless have Hamilton's letter of 1800, before mentioned: Will you read it \& make remarks which may be nseful to me - especially of facts stated by Mr Hamilton."

On the 10th, McHenry answered that he had written an article on Serrurier's mission which would appear tomorrow in Wagner's Journal. The next day Pickering replied.

\section{"Dear Sir}

"Senate Chamber Feby. 11. 1811.

"I have before me yours of yesterday. I saw Mr. Stoddert last week. A question I asked him, led him to say, that he had long since read Mr. Adams first eighteen letters published in the Boston Patriot - and in consequence had written to Mr. Adams a long letter, stating his errors or misrepresentations - that he had recd. a short, but polite answer - and that he would furnish me with copies of both. He said explicitly that he had no knowledge of the cause of my dismission. I informed him of the corrupt motive. He then mentioned a fact, that at some time before, Genl. Smith \& his brother-in-law Wilson Cary Nicholas spoke to him, by way of inquiry - Whether some means could not be adopted for a reconciliation, or union (or some such word which I do not precisely remember) of parties : but heard no more of it. 
"I have not seen the answer of either House of Masstts. Legislature to Gov. Gerry's speech. Otis is president of the Senate - but that body is equally divided - 20-20.

"I have no information relative to Serrurier's mission. I cannot imagine that Mr. Dana can have taken offence because I believe you incapable of intending one - and that he is too sensible \& too candid to admit an interpretation of an ill aspect where he must believe that a candid \& friendly face alone was intended to be presented.

"If you have not read Mr. Adams' first 18 letters (I believe about 95 octavo pages) I pray you to read them. His virulence against Hamilton is unexampled: but the integrity $\&$ talents of Hamilton are above the reach of his veteran slander. Yet he ought to be scourged with scorpions

$$
\begin{gathered}
\text { "Most truly yours } \\
\text { "T. Pickering", }
\end{gathered}
$$

Two days later Pickering wrote again:

"Dear Sir,

"Washington Feby. 13. 1811.

"Yesterday I received from Mr. Stoddert the copies of the letters mentioned in my last - which have the goodness to return to me, when you have perused them. Perhaps they may remind you of some things which may be useful to me to know. I do not subseribe to all Mr. Stoddert's opinions on the duty of Heads of Departments. Particularly that of implicit obedience, or resignation. On the contrary, I should think it their duty to prevent, as far as practicable, the mischievous measures of a wrong-headed president. The morning on which Mr. Adams nominated Mr. Murray, you know that every body was astonished: and one of Mr. Adams's very special friends, a member of the House of Reps., stepped over to my office, and with an air of alarm asked me 'How this nomination had happened?' I answered, that I knew no more of it than he. 'Is the man mad?' Was his reply.

"You will notice Mr. Stoddert's remark in his letter to me, That while I am at liberty to make any use I please of his letter, Mr. Adams' might require more delicacy.

"I am very sincerely yours "'T. Pickering.'

On February 23, McHenry wrote a long answer to Pick- 
ering ${ }^{1}$ with reference to Adams's letters in the Boston Patriot, "From the cursory reading, I perceive he has fallen into many errors, some important forgetfulness and not a few striking misrepresentations, to say nothing of his coarse and unmanly abuse of a deceased statesman."

"How many recollections have these puerile letters awakened. Still in his own opinion the greatest man of the age, I see he will carry with him to the grave, his vanity, his weaknesses and follies, specimens of which we have so often witnessed, and always endeavored to veil from the public." ?

Adams depreeiated Hamilton. While not palliating his pleasures, MeIIenry hesitated not to compare his public life with Adams's and concluded: "As to their minds, abstraetly" considered, Hamilton's was profound, penetrating, and invariably sound and his genius of that rare kind, which enlightens the judgment without misleading it; the mind of Mr. Adams like the last glimmering of a lamp, feeble, wavering, and unsteady, with oceasionally a strong flash of light, his genius little and that too insufficient to irradiate his judgment."

Adams's and the secretaries' foreign system for some years was the same. "Ours was General Washington's. We held with him that we ought never to quit our own to stand upon foreign ground; under no pretext to weave our destiny with that of any European power; that our true policy was to avoid permanent alliances with any portion of the foreign world; to trust to temporary ones for extraordinary emergeneies, and to suitable military establishments to enable us to aet up to and avail ourselves of our maxims. Three of the gentlemen who were heads of departments with Mr. Adams were also heads of departments with General Washington. These gentlemen could never for a moment depart from his maxims, they were the soul of their system; they could not tear them from their hearts and retain their honor and integrity; they held them to be the only sound ones for their country, the only ones proper for the guidance of our foreign affairs and, in no instance, did they ever advise or countenance departure from them."

Letters now passed frequently between the two friends.

Pickering wrote from Washington on the 26th of February, 1811 :

1 Printed in Lodge's Cabot, 204

2 Correspondence between Adams and Cunningham, 47. 
"Dear Sir,

"To-day I recd. your letters of the $22 d \& 23 d$. with the mentioned inclosures.

"I had never contemplated the publishing of Mr. Stoddert's letter, or Mr. Adams' answer: I was glad to be possessed of them - the former for the recital of what Mr. Stoddert knew, and the latter for the sentiments of the writer. Mr. Stoddert told me that $I$ wrote the joint letter advising a suspension of the mission to France: if so, I doubtless have it at home. I have not looked over my papers (of which I have no inconsiderable quantity) since I packed them up a dozen years ago.

"As to Gerry's nomination, I do not recollect what you said; but I see the correctness of it, as you recite it. I well remember Wolcott spoke against him, tho' with moderation, While I was absolutely silent. For I had heard nothing scarcely of Gerry's weakness \& perverseness in the House of Representatives; and I had, during the war, when he was in Congress, entertained a favourable opinion of him - not as a great. but a decent man, \& perfectly honest. I remember Mr. Adams (in answer to some objections by Wolcott or you, or both) said that Mr. Gerry was an honest, firm man, on whom French arts would be tried in vain: or words to that effect. I am sure of the idea.

"I must suspend other observations until we meet. I will speak to Colo. Tallmadge for the documents.

"Your affectionate friend

"T. Pickering.

"The President this day nominated Joel Barlow minister plenipotentiary to France!",

A second letter from Pickering is dated Washington, February 27, 1811:

"Dear Sir,

"I have before me your note of yesterday. Whatever you recollect to have been omitted in your letters of $22 \mathrm{~d} \&$ $23 \mathrm{~d}$, be pleased to write down, \& retain until I call upon you; when, if more convenient, you can incorporate the same in your letters already written. I troubled you for information, to refresh my memory, which is not tenacious; and it had that effect; enabling me to note to you in my answer several things which otherwise I should not have recollected. I wish to pro- 
vide myself with every weapon for the combat which may ensue between the man at Quiney \& myself : for his atrocious conduct calls for a severe scourging which he shall receive. He little imagines that I know \& have long been possessed of the secret of my dismission; but which I should have permitted to have sunk into oblivion had he not become an open apostate, and a malignant slanderer of Hamilton.

"If I get a passage from here to Baltimore next Monday, I shall pass Tuesday with you: if for want of a conveyance, I do not reach your eity till tuesday evening, I must stay there on Wednesday - perhaps also on Wednesday - perhaps also on Thursday; in order to take the stage to Lancaster.

$$
\text { "Very truly yours, }
$$

Pickering wrote again from Philadelphia, March 12, 1811:

\section{"Dear Sir,}

"I am again reading your long letter; and it leads me to ask if you have recently read General Hamilton's printed letter on" "the public conduct \& character of John Adams Esq. president of the United States.' If not, I wish you to do it, I think it probable that it may bring to your recollection some facts which may be useful in the laborious work in which I am engaged; and which, of course, you will have the goodness to communicate.

"In relation to Genl. Hamilton's being at Trenton, Mr. Adams says he ought not to have been there without his permission; but should have remained with the troops, teaching them military tactics; which, however, he chose to leave with one who understood them better or could teach them better: Was not this the President's son-in-law, Colo. Smith? Pray let me know.

"When Genl. Marshall was at Washington, I laid before him Mr. Adams' first 18 letters, which he had not sfen. He earried them with him to Richmond, \& returned them with a remark - That he had read them with avidity, \& equal regret.

"I am dear sir

"very sincerely yours

$$
\text { "T. PICKERING. }
$$

"P. S. I have just written to Mr. Wagner a paragraph to add to my last number - VI. Do inquire if he receives it." 
On March 14, McHenry wrote, referring to Adams's ignorance of military matters, and said of Hamilton that he "had studied military service, practically under General Washington and his advice in many instances (a fact known to myself) had aided our chief in giving to the machine that perfection to which it had arrived, previously to the close of the revolutionary war." During that year, McHenry joined with Robert G. Harper, Charles Ridgely of Hampton, John Eager Howard, James Howard, Walter Dorsey, and Samuel Sterrett in the call of a "conference" with reference to the approaching senatorial election in Maryland for the state legislature.

In that year also was published in Baltimore a work entitled "The Three Patriots, or the Cause and Cure of Present Evils, Addressed to the Voters of Maryland." This work has been attributed to MeHenry, though the identification of him as the author is not quite clear. The work is very pessimistic and labors to show the causes by which the United States have been depressed in ten years to a worse condition than that from which they had been raised and to show by what simple means they may be restored to their once enviable situation. The United States are called by the author "a federative republic" and said to correspond to no one of Aristotle's forms of government. Native Americans are then properly all Federalists and all Republicans. The author discusses Freneau, Duane, Callender and Bache, Genet and Fauchet. "He prays that the angel, which presides over the destinies of Maryland, may permit the voters to choose suitable electors for the State's Senate" and urges all to vote. Even thus early the sale of votes and repeating were practised at elections. Many "for a little self indulgence, to avoid a slight exertion, a walk or ride of a few miles, will put at risk the benefit of civil liberty and all the untold blessings that result from equal laws."

As McHenry passed into the evening of his life, he still heard from Lafayette, who wrote him from La Grange on December 22, 1811:

"It is an Age, My Dear McHenry, Since I Had the pleasure to Hear from You, But Altho I Complain of Your Silence, I Am Sure of Your friendship. Vessels, public and private, Have Come from the Bay, Nay from Baltimore Without a Line to me, Which Has Been a great Disappointment. there Will $\mathrm{Be}$, no Doubt, Dispatches Sent to france in the Spring - I Beg You to improve the opportunity and to write me the par- 
ticulars Concerning Yourself and family which my Heart So eagerly wishes to know. My situation is about the Same. I Live in Rural Retirement with fourteen Children and Grand Children around me. Mourning the Loss in Comparison to which all other present misfortunes are Nothing to me, and every Day more attached to My Solitary plan of Life. We Have Reasons to Hope from the Reception given to the Minister and the expectations He Has Been Authorized to form, that the Answer to his Note Will Be Better than Any that Has Been obtained for a long time - that You will more Certainly Know, when this Letter Reaches You - perhaps Shall I write another Before the frigate Sails - in the Mean while Receive, My Dear MeHenry, the Most Affectionate Wishes and Sentiments of Your old and Best friend

$$
\text { "Lafayette" }
$$

War was now imminent and throughout the winter, in which the question of declaring it was debated in congress, Tallmadge kept McHenry informed as to the course of events.

Writing from Washington, January 16,1812 , he said:

\section{"My Dear Sir}

"I have reed your letter of the 12 th. instant, \& thank you for the Extract of a Letter inclosed therein.

"The Great Question now before us is the War with $G$. Britain. If we could draw any safe conclusions from the noisv, blustering Speeches of our Kentucky \& T'ennessee Bretheren, who are all alive to the Distress \& sufferings of our Seamen, \& the violation of our commercial rights, we might well say that war must be the result. But the more sober, reflecting sort of folks, think that the war par'y must fail for want of two much essential Ingredients, (viz) Men \& Money. A Gentleman was in our Galleries yesterday who had come quite from N. Hampshire \& heard some of our war Gentry Declaim, \& he was perfectly astonished - He said he heard nothing of war until he reached N. York; at Philada. but little more \& at Baltimore not much more, but when he heard such war Speeches, he knew not how to Credit his senses. The moral of it is this, that the Country does not partake of our warfire Yesterday your Representative $\mathbf{M r}$. Little, laid a resolution on the Table calling on the President for a List of all Vessels captured or detained by B. Cruisers since the year 
1794 - It being objected to, as unnecessary, the reason he offered in favor of the measure was "to rouse up the dormant spirit of the People against that Nation.'

"This Day the Prest. has sent us a message containing a late Correspondence between Messrs Foster \& Munroe - It originated with Mr. Foster, explaining his Late Còrrespondence which he said had been misrepresented as it related to his Demand of a Repeal of our non Importation Law, \& of his views of the repeal of the Berlin \& Milan Decrees \&c. The Pt. takes occasion to eall on us for renewed Exertions \&c \&c - You will soon see the Letter published."

He wrote again from Washington on February 29, 1812 :

"My Dear Sir

"I have reed in due Course, your obliging Letter of the $22 d$. instant, \& thank you very sincerely for your kind invitation to halt at your hospitable Mansion on my return home. Mrs. Tallmadge unites with me in cordial respects to Mrs McHenry, \& beg you both to be assured that we shall feel very happy in calling on you when we pass on thro' Baltimore, if we can -possibly spare the time. After our absence of six months (\& I fear we shall continue our sessions for that period) we are all of us very glad to use all reasonable Dispatch in returning home.

"You have undonbtedly noticed the System of revenue which has been reported by the Commtee of ways \& means. We have taken up the items in Commtee of the whole House, where they passed with but little opposition. When the Question came before the House, they fared very differently. All that part of the Report which related to Import, Tonnage \& Drawbacks was carried by heavy majorities - As soon as we came to the internal Taxes, Excise \&c, it was manifest that the Patriotism which they (the Democrats) had boasted of so much, was increased very much by self Interest, popularity \& Such sort of principles. The Debate being confined solely to the exclusive Republicans, they began to criminate one another with want of true patriotism, \& strong Intimations were given that, so long as the burden could be laid on Commerce, they were willing to support the war with great Zeal; but as soon as Salt was offered as a fit subject for Taxation, \& other matters of domestic manufacture for Excise 
\&e \&e, the war fever subsided. Such remarks from their own friends were very grievous to be borne.

"On the Salt Tax the Phalanx broke, \& if we had not adjourned, I fully believe the Exeise Duties would have shared the same fate - If you see the N. Intelligeneer, you will find in this Days paper, the mournings, \& Lamentations of the Editor. It is said motion will be made on Monday to reconsider the Vote on the Salt Tax, but even should they carry that Tax, I think they cannot go through with the remainder.

"As for their making war, I have never believed they were sineere in their professions, altho there was Danger that they should so manage the business as to get our Country into a war. Their Chance now seems to rest upon some favorable arrangment to be made with France by Mr. Barlow, or by some favorable Change in the B. Couneil - The latter does not look very probable \& the former Event would be greatly to be deprecated - I presume your London Correspondent has long before this Seen Causes of Irritation in abundanee in the Presidents Message, \& the proceedings of Congress to apprehend that the orders in Conneil will not be speedily removed.

"It would seem as if the madness of modern Democracy" eould not wish to push this Country in a war with a Treasury so exhausted, \& a Commeree so defenseless \& so nearly ruined.

"I have found it very difficult of late to get a Duplicate of almost any Report or Doeument laid on our Tables - When extra Numbers are printed I shall not forget You - At present I have none on hand - Please to aceept of the enclosed Speech, \& believe me Sincerely

$$
\begin{gathered}
\text { "\& affeetionately Yours } \\
\text { "Benjn. TAllmadge." }
\end{gathered}
$$

On Mareh 9, Madison sent congress a message transmitting congress the papers which he had bought for $\$ 50,000$ from John Henry, showing that a short time previously he had been sent as an emissary of Great Britain to report on the possibility of detaching Massachusetts from the Union. Tallmadge wrote MeHenry on the 13th, coneerning "this most extraordinary eommunieation" and MeHenry at onee replied in a letter which has not been found, giving Tallmadge some valuable information on the matter. When he received this letter, Tallmadge sent McHenry a copy of the draft on the 
treasury to pay for the papers which Madison bought, enclosing it in a letter dated March 16 :

\section{"Dear Sir}

"I thank you most sincerely for your Letter of the 14th. instant, with the Record Evidence which accompanied the same - It was seasonable \& useful. The pitiful \& mean attempt of the Pt. to accomplish the desirable Object of injuring the Characters of honorable Men; of endeavouring to excite a spirit of Indignation against G. B., \& of promoting his own \& Gerry's Elections, I hope \& trust is seen thro', \& will in a great measure fail - The monstrous Sum of money paid to this vile Swindler, Staggers \& confounds many, \& some who profess to have been the friends of the Administration - Since the Rect of your proof relative to the negociation.

"Of the D'ft on the Mechanick's Bank three Members of our House from the three Great States (viz) Massachusetts, N. York, \& Pennsylvania, Messrs Quincy, Emmot, \& Milnor went over to the Treasury Office, determined to examine the Books, as to the origin of this business, I mean the payment - The result shall be annexed.

"Perhaps it may be tho't best to give a summary of this business, as soon as the Materials are prepared.

$$
\begin{gathered}
\text { "I am my Dr. Sir } \\
\text { "Affectionately Yours } \\
\text { "BenJN. TalLMadGe" }
\end{gathered}
$$
1812.

Tallmadge wrote again from Washington on April 11,

\section{"Dear Sir}

"I have recd. your Letter of the 5th inst. to which I reply, that if any thing could be relied on from the Speeches \& solemn Declaration of those who advocated the Embargo, while we were in Conclave, it was to be viewed as the preeursor of War. I have been so long worried, \& wounded with such gasconade \& nonsense, that dreadful as I view the Scourge of War, I feel sometimes almost willing that it should take place. If a new order of things could be produced by this dernier resort, Dear as the purchase would be, the Country might perhaps venture to pay it; but I am not so sanguine as many who fully believe that such an Event would change the whole political face of our Country. Altho' 
we are wholly unprepared to enter upon a war with G. Britain, \& altho' I have never believed that the Administration were seriously resolved upon war, yet I do believe if such a proposition was laid upon the Speaker's Table, it would be carried in the House of Rept. by a considerable Majority Such seems to be the madness \& folly of many of our Rulers.

"Govn. Wright seems to be in a perfect phrensy because the Commissions are not yet given out to the Officers of the new Army, nor any recruiting orders furnished-As the King can do no wrong, The Sect. at War takes all the weight of the Governor's Artillery.

"A proposition to repeal the non Importation Law has been before the House, but has been postponed to monday after next - It met with violent opposition from the war hawks, as base \& contemptible, \& calculated to abate the Zeal for war in the Country, as well as in the House - For my own part, I am not fully convinced that the measure is not very deceptive. If a temporary suspension of the non Importation law should be intended with a Clause preparing an Increase of Duties 100 pet., the people would thank them for the boon, while this would only serve as a temporary relief to the 'Treasury, \& thereby the direct Tax, Excise \&c \&c, would be suspended. The fact is, we have so long \& so often been deceived by these French politicians, that it is not amiss to suspect \& watch them.

"We have also before us a proposition for an adjournment. A Commtee. of Conference has been appointed, but the issue is quite doubtful.

"One precaution I think we shall do well to attend to, \& which I request you will observe (viz) to burn each others Letters.

"We have no positive Intelligence from the Hornet, altho' it is rumoured that She has passed up the Chesapeake.

"I am affectionately

" \& sincerely yours

"Benjn. 'TALluadge."

A week later Tallmadge wrote:

"Dear Sir

"Washington Apl. 18th. 1812.

"I thank you for your Letter of the 15th. instant, the 
Sentiments contained in which very fully accord with $\mathrm{my}$ own. I confess to You that altho' I have been repeatedly disappointed in my hopes \& Expectations, I have neverless cherished the hope that when the measures of the Jeffersonians policy become pretty fully exposed, \& their deliterious Effects were felt \& understood by our Countrymen, they would be induced to detect \& change the advocates \& Abettors of them. The pertinacious adherence of the party to that System of measures which the past \& present Administration have been pursuing with undeviating Steps, brings all $\mathrm{my}$ hopes to a stand, \& I have only to look about me with an astonishment that I am unable to describe. I have this morning been conversing with some of our Eastern Democrats, particularly from Massachusetts, on the Question of war, \& my Soul Sickens at the prospect that these men should persist in the Declaration that they will vote for a Declaration of War, altho' they are well convinced that it must bring ruin upon themselves \& their Constituents. The truth is, in addition to the Evils which must necessarily result from the prevalence of party Spirit, the Demos appear to me now to be under the Influence of passion - The Defeat which their Cause has lately reed. in Massachusetts in the Election of Govr. Strong, \& the failure of the Henry plot so far from disheartening them seems to whet their Appetites for revenge - You must not therefore be surprised, if a Declaration of War should actually be proposed in a few days. For the present, I shall omit to remark on the political Consequences which may possibly \& not improbably result from such a measure. I hope as one of the worst that may be feared, You \& I may not witness the awful Calamity of seeing our own Citizens engaged in destroying one another.

"May we always rejoice that the Lord reigns \& that altho' Clouds \& darkness, as to Us, may seem to be round about him, yet Justice \& Judgment will be the habitation of his throne forever.

$$
\begin{aligned}
& \text { "I am affectionately } \\
& \text { "\& sincerely Yours } \\
& \text { "BenJN. TALLMADGE." }
\end{aligned}
$$

At the end of the session, this letter came from Washington, June 17, 1812 : 


\title{
"Dear Sir
}

"Haring tided through a long session to very little purpose, in behalf of our half ruined Country, I have now determined to leave this place the ensuing week; believing that before this week shall close, the important stand will be taken by this Govt. - Heaven only knows what our Destiny is to be; but my fears forbode every Evil - As the Cap to this Climax, I dread that above all, which shall link us to the fortunes \& chain us to the Carr of the French Emperor.

"My stay in Baltimore will probably be too short to allow me the pleasure of calling at your House - I shall do it if I ean.

"I shall enclose, by this days Mail, Copies of sundry Documents \& am

\author{
"Sincerely \& \\ "Affectionately yours \\ "Benjn. Talluradge."
}




\title{
C H A P T E R X I X
}

\author{
MCHENRY'S LAST DAYS
}

$1812-1816$

N 1812 a mob destroyed the printing office of the Federal Republican, a bitter anti-administration paper edited in

Baltimore by Alexander Contee Hanson, killed General Lingan, and severely injured several other men. The city was in a turmoil for some time and just after the excitement McHenry wrote thus to his friend, Robert Oliver, on the eve of leaving the city for a sojourn in Allegany county:

\section{"Dear Oliver}

\section{"Near Baltimore 24 June 1812.}

"You acted nobly at the meeting at the Mayor's office, and all day yesterday. Instruct our friends; inforce it upon them, that all they hold valuable on earth depends upon a union of force, to discountenance and put down every attempt against the laws and the public peace. Let them do as you have done, face the evil, as soon as it appears. If they shrink from it, they will quickly be made sensible, that they walk the streets at the mercy of the secret instigaters of misrule; that the air of Baltimore is the air of a prison; that houses are no places of safety; that there is a mine under them ready to explode, the moment, they shall either by word or by look, give offence to their masters. I lament that I am obliged to leave the City. I rejoice, however, that the train in which things now appear, leaves me little or no room to fear for those friends I leave behind me."

The presidential election was at hand and the Federalists combined with the dissatisfied Republicans in the support of DeWitt Clinton against Madison, who was a candidate for reelection. Of the Federalist position and of the nomination of Clinton, we learn much from a letter sent McHenry by Stoddert: 


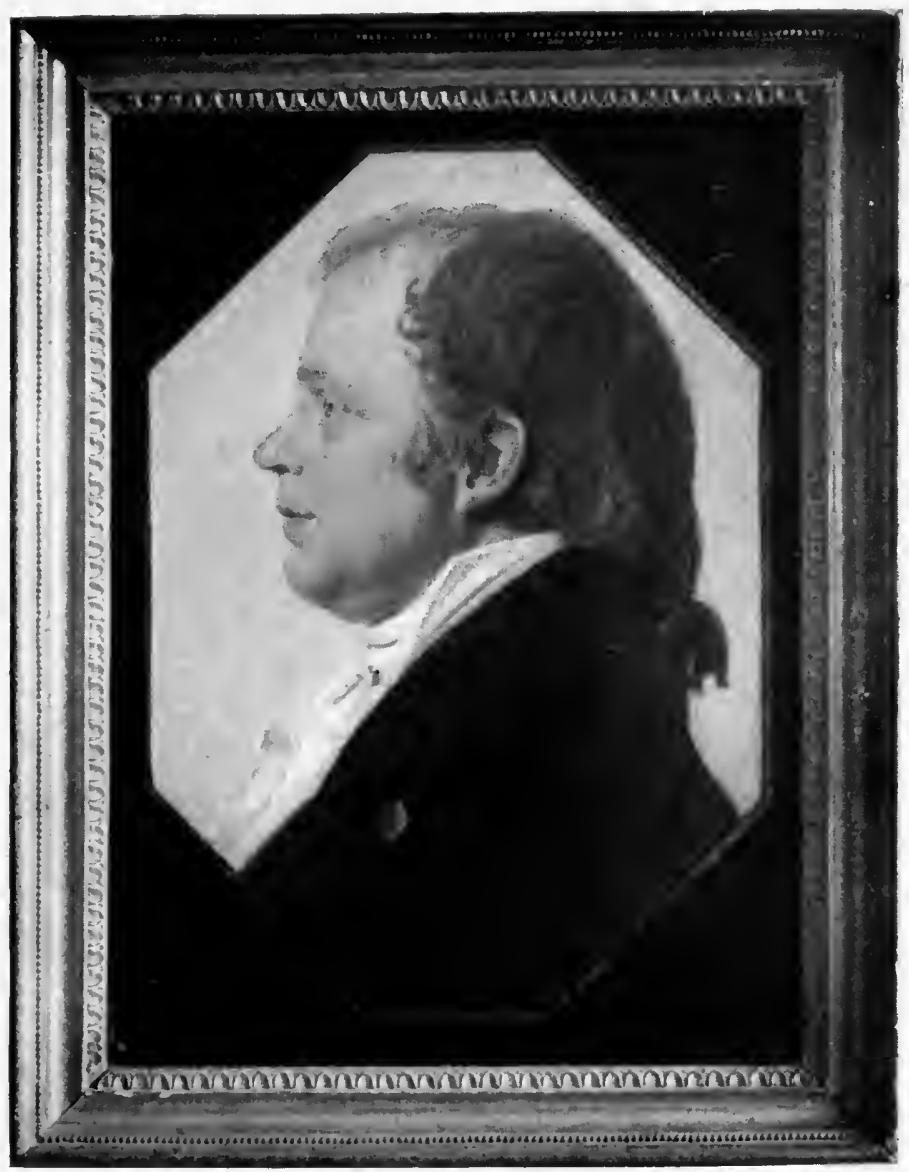

DR. JAMES McHENRY

Much reduced from painting owned by the heirs of Dr. James McHenry (Copyright, 1907, The Burrows Brothers Company) 

"My Dear Sir

“Blad[ensburg] 15 July 1812.

"You will probably think, \& justly that my own embar. rassed affairs were sufficient to oceupy my whole mind. But I cannot help thinking also for my Country.

"Success in this War, would most probably be the worst kind of ruin - But we are, I believe, in no danger" of being ruined by success - For where can we hope for suceess? not surely on the Ocean. As to Canada, the taking of it would be injury to ourselves, and would be of trifling importance to our Enemy - it would bring us no nearer to Peace.

"Two years duration of this war, will produce one or two events - Division or Alliance with France - which is but another name for French Rule over us - another name would be destruction to civil liberty in this hitherto Free \& happy land.

"There is but one way to save our Country. I am thoroughly convinced and that is to change the administration and $I$ am not less convinced that this can be affected by bringing forward another Virgn. as the competitor of Madison.

"D. Clinton can have no chance-The Democrats in every State where they are the ruling party, will support Madison in preference. In New York, where they have nominated him, they ean not secure to him a vote. He has no chance of a vote South or West of Maryland, \& no chance of general support in the East. It would be easier for the Fedts. to elect an Eastern or Northern Fedt., but this they can not aceomplish.

"Under this impression, I have sent to the Spirit of 1776 , under the signature of a Maryland Farmer, an address to the people of the U. S. but meant more particularly for Virga. - recommending John Marshall for Presdt. D. Clinton or R. King as New York should decide, for Vice Presdt. no doubt King would be the choice - and this I have done, because - every body else - seems to be seized with apathy, the most unpardonable in the dangerous crisis of our affairs, and because I felt it sacred duty \& not because - I think my talents fit me for a writer to the Public.

"There is a real change in Virga. - and it will be greater in the Farming Country, as the Wheat is preparing for Market - and in the Farming Country there are most votes - 
They vote for electors in Virga. by a general ticket. and I am thoronghly persuaded that if the men in that State, who prefer Marshall to Madison, can be animated into Exertion, he will get the votes of that State.

"What little I can do by private letters to affect this will be done I have already recd. a letter from Jo Davies to whom, being here 10 days, I mentioned the subject, \& who then thought success impossible - but who now writes me, he has entirely changed his opinion - and that if the Virgns. have nerve to believe it will be agreeable to the Northern \& E. States, he is sure Marshall will get the Virga. votes.

"Should he fail there, the effort in Virga. will secure him votes in North Carolina, \& perhaps further South \& in the West - and but a few will be wanting in these quarters, if the Fedts. every where else unite for him.

"Pinkney nor no other man out of Virga. conld have a chance of a vote in Virga. where there is more State pride than in all the Union besides.

"It is not because I prefer Marshall to several other men, that I speak of him - but because I am well convinced it is vain to talk of any other man. and Marshall is a Man in whom Fedts. may confide - Perhaps indeed he is the man for the erisis, which demands great good sense, a great firmness under the garb of great moderation

"I suppose the Spirit of 1776 is taken at your Coffee honse. Pray read (perhaps it will be in Friday's paper, I know not that it is in the paper of yesterday) the Maryland Farmer - and if you approve it - and Hewes is not under too much control of the Mob. let him insert it. but you must not stop here - but by your pen support a cause, on which all that is dear to you depends, Yon can not believe that the men who have plunged us, so headlong into this War, will make peace. War is what every act of Madison, every word, \& every thought, has long pointed at - but on what American ground, God alone can tell Jefferson too has been most busy in urging the members with whom he could correspond this one of his correspondts. told me who voted for war directly in the teeth of his own conviction of right. Our Union is worth saving, so is civil liberty - so is the prosperity of those who possess it. All will be swept away, if the course of Madison \& the Arch Juggler behind the curtain is not immediately arrested. this is not the time to object to a man, 
because he is a Virgn., in ordinary times a sufficient objection - the only consideration now should be, who of good men can turn out Madison?

"Why, for the honor of Balto, is there not an association of all men of property, \& all men of principle, whether they have property or not - of the respectable Democrats $\&$ the Fedts. to support the laws in Balto - in proportion as this War is unpopular with thinking men, will be the efforts of those who rule, to stifle free inquiry - the mob is the most powerful auxiliary of the Executive, \& this is known at headquarters But the Union I speak of would overeome the mob of Balto. - and essentially preserve the Peace, \& retrieve the Character of the City. Do not flatter yourselves you have not lost reputation by suffering the last disgraceful transaction. Shall the House of such a man as R. Oliver be pulled down - \& the press be muzzled \& the character of Balto sustain no injury? I do not think so poorly of the feelings \& intellect of other places.

"An association (it ought to be written \& signed) by the Fedt. alone, might lead to civil war-every good would result from one begun by .Jas Buchanan \& such men - and including the Fedts. - and I would make even all the poorer classes sign it, then would surely $\mathrm{J} B$ with the least encouragement, wonld take an active lead in this. I am half determined to go to Balto to endeavour to effect it - and should have done it, had the expense been a very easy thing with me.

"I am Dear Sir truly yrs "BEN Stondert."

Harper wrote Colonel Lynn, of Allegany county, from Baltimore, September 25, 1812, on the same subject:

"My Dear Sir

"at the request of some of our friends in this State, I lately attended a meeting of federal Gentlemen at New York assembled from all the States north and East of Virginia, to deliberate on the conduct which may be proper for the fed. eral party to pursue, in the approaching election of President. The meeting was very full and respectable. It was attended by Delegates from all the States north of the Potomac, and from South Carolina.

"After a very full and free communication of Sentiment and information, we found no hope nor chance of electing a 
federal President. Vermont is lost to us. It is quite certain that we could not get the votes of Maryland. Those of New York are very doubtful, and Pennsylvania desperate. We might hope for five or Six votes in Maryland, but eannot rely on more than those. As to North Carolina, though we learn that very considerable changes have taken place, yet there does not appear, from any facts known to me, any reason to expect, that the votes of that State could be obtained for a federal Candidate.

"The choice of a president of our own, being thus desperate, nothing remains for us but to acquiesce in the reelection of Mr. Madison, or take the chance of getting rid of him and his political System; the worst part of it at least, by giving our aid to Clinton.

"In favour of this policy the meeting was almost unanimous. It consisted of more than Sixty persons, of whom Mr. King and Mr. Radcliffe of New York, and Mr. Sitgreaves of Pennsylvania were the only dissentients. Mrr. Sitgreaves rather disapproved the policy than opposed it. His opinion was, that it would be better to take all the hazards of Mr. Madison's reelection, including that of separation and french alliance, than to endanger, as he thought, our own honour, union and existence as a party, by giving our aid to Mr. Clinton. This opinion he expressed in conversation, but took no part in the debate. Mr. King warmly and very eloquently supported it in debate. With these three exceptions, the meeting was, I believe, unanimously of opinion that we ought to support Clinton in preference and opposition to Madison, as the only means now in our power of averting the evils which have assailed and still threaten us.

"The expectation that Mr. Clinton, if elected, will change the present course of measures, in all essential points, rests much more on his position, Geographical and political, than on his professions and assurances. But they have been ample and positive. They were made without reserve. And repeated while I was in New York. In Substance, they amount to this; that Mr Clinton looks with abhorrence on a french alliance, in any form or under any circumstances; that he holds Buonaparte and his views and System in Such detestation as to be willing to bear a great deal from England, rather than throw the least weight, into the french scale; that he thinks a peace with England, upon honourable terms, is 
easily attainable, and ought to be made as Soon as possible, that he is opposed to the whole restrictive System, and thinks that commerce ought to be fostered and protected, to which end a navy, fully commensurable with the resources of the nation, ought to be immediately provided and constantly maintained; and that, while the present war continues, the honour of the nation ought to be supported, by a vigourous and manly exertion of its force.

"If Mr Clinton relied on federalists alone for success, these sentiments ought to be and no doubt would be, published. But he eannot be elected without the aid of a large portion of the Democratic party which the avowal of such opinions, or the Knowledge that any explanation had been made by him to the federal party, would certainly, in a great measure, and perhaps entirely, alienate from his cause. WV must, therefore, consider the communications as strictly confidential, and take every precaution to prevent them from beeoming public. His sentiments are no doubt known to his confidential friends. But we have seen the grounds on which they have thought it best to rest his pretentions. The general probability, arising from his character Situation and connections that he will pursue a more correct course than Mr. Madison, is a sufficient justification to us in giving him the preference.

"The hope of electing Mr. Clinton rests on this. We can certainly give him New York, New Hampshire, Rhode Island, Connecticut, Delaware and part of Maryland. There is a great probability that we may, in conjunetion with his Supporters among the Democrats, give him Massachusetts Jersey, Pennsylvania, and the greater part if not the whole of Maryland. We entertain the same expectation of North Carolina; and his friends expect to carry Vermont and part of Ohio.

"The meeting did not resolve to recommend the support of Mr. Clinton. It was thought best to take a course somewhat different. they resolved that it appeared impracticable to elect and was, therefore, inexpedient to propose, a federal Candidate; and that it should be reeommended to the federalists throughout the United States, to exert themselves in the approaching Eleetion of Electors, to procure the choice of such persons, as will be most likely to effect by their votes a change in the present course of public Measures, They then 
appointed a Committee, to collect and disseminate information on the Subjeet. The Committee sits in Philadelphia. Three of its members, Mr. Hopkinson Mr. Binney and Mr. Meredith, reside there. The other two are Mr. Sitgreaves and Mr. Duncan of Pennsylvania.

"The plan of operations which appeared best to the meeting, and which they resolved to reeommend to their friends generally is to let the Clintonian Democrats take the lead, in all the Demoeratie States and Districts, and to Support them Silently with our votes; while we every where exert ourselves to the utmost, to place federalists in the House of Representatives and the State Legislatures. That seemed to be the best mode of keeping Clinton right, if he should be eleeted, and of restraining Madison in his mischievous course, should we be forced to bear him four years longer.

"The plan adopted at New York leaves us at large, to profit by favourable events. With as many Clintonian Electors as we ean carry where there are no hopes, or but very faint ones, of carrying federalists, and with all the Federal Electors that we ean get, we may hold the fate of the Candidates in our own hands, and at the decisive moment, take the course whieh we may deem best for the public safety. We do not stand committed to Mr. Clinton. He and his friends must, therefore, do all in their power to eonvince us, that he deserves the preference, in other words, that we may expect from him a different eourse of measures, or else we may drop them and try the effeet of submitting four years longer to Madison, in hopes of a complete cure in that time. We may even bring forward a federal Candidate, should any thing oceur to warrant the attempt.

"I an my Dear Sir, with very great regard yours most truly

"RoB : G. HARPER.

"P. S.

"If you and our friend Thomas approve the policy it is not yet too late to make a change in your arrangements, I submit it to your consideration whether it would not be best for you both to decline, in favour of such Clintonian demoeratic Candidates as may be offered in your united district. The mere cireumstance of being eleeted is, of course, no objeet with either of you. Should your election as federalists be doubtful, of which you are the best judges, the eourse 
which I suggest would give some additional chance for success. Let me know whether you approve it, and I will endeavour to get Clintonian Candidates brought forward by the chiefs of that party here, whom I know, though I have had no sort of communication with them. Perhaps you and Thomas can manage that point better. Tell me what you think on that head.

$$
\begin{aligned}
& \text { "Your's most truly } \\
& \text { "RoB: G. HARPER.", }
\end{aligned}
$$

An unsigned letter written from Baltimore on Scptember 24, 1812, gives additional information:

\section{"My dear friend}

"I returned a few days ago and found the town very yuiet, but no dependance can be placed on the civil authorities. The privateers \& army, have carried off a large gang of Ruffians, but we have still a sufficient number left to do mischief, in case any exciting cause should occur.

"You acted wisely in leaving the town, and I advise you to remain where you are until our elections are over.

"The meeting at N. York consisting of 64 members, decided almost unanimously to support C. - but for obvious Jeasons their arrangement is to be kept out of view as long as possible. He has given the necessary assurances and I look forward with confidence to a happy change, in case $\mathrm{C}$. is elected I think Mr. Thomas, \& Col. Linn, should give way to C.'s friends, unless they are certain of success.

"It is impossible to form any correct opinion of the issue of the Presidential election.

"If Madison is elected, \& we have not a sufficient majority in the state Govt. to secure the Gov. \& Council, our situation will be deplorable. You will see by the Newspapers that every thing goes on well in Europe. I hope Bonaparte will meet the fate of Charles the 12 of Sweden."

McHenry accompanied his son Daniel, after the latter's marriage, to his home in Allegany county at Cherry Tree Meadows, expecting to return in the autumn. Mrs. MeHenry wrote several years later that "while there, my dear husband was taken with an infirmity in his legs, which, notwithstanding every means was used for his relief, gradually encreased till he was entirely deprived of the use of them, the winter 
then coming on, we were obliged to remain there till the following summer, when with great difficulty he was got home. From the commencement of the disease he did not expect to recover \& tried to prepare his family to part with him - he was so patient \& cheerful during his illness that many who saw him could not realize the idea that he could expect to die with such composure; but Blessed be God his long \& painful confinement was made a time of great profit to him, he was enabled to support \& improve it \& to say at all times, even in his most painful moments, when praying for relief, or patience to endure to the end, not my will, Lord, but thine be done." Tallmadge continued to keep him informed of the course of events and the letters which passed between them and which follow are important as showing the Federalists' position.

"Dear Sir

"Washington Novr. 29th. 1812.

"I have before me your Letter of the $22 \mathrm{~d}$. instant. Really you have retired pretty much from the bustle of the world, \& I think vour retreat very judicious at this ominous period of the police of your quondam City. Indeed it has seemed as if Baltimore was almost ruined, as a place suitable for Gentlemen who loved Washington \& imbibed his Sentiments.

"Our Sessions hitherto, have been rather barren of incident than otherwise. Govr. Wright has had another retal. liating Bill before the House which went thro' the Comtee. of the whole, \& was engrossed for its third reading - The Govr. felt very confident of Success, \& in fact his Bill had reed. no opposition, until it was on its very last Stage, when a few of us gave it Battle \& it was negatived by a Majority of ten.

"The House passed a Bill raising the wages of Privates in the Army to Eight Dollars, \& the non commissioned Officers accordingly. It also authorises the Enlistment of Minors above 18 Years old, \& secures from Arrest Debtors of any magnitude or Amot. who will fly to the American Standard, as anciently Criminals were protected by the horns of the altar. The Senate have made some material Alterations, in this Bill, where we could effect nothing.

"I intended to forward the Presidents Message \& Documents accompanying the same - Also J. Russell's Correspon- 
dence, \& last Statement, which is supposed to have been written in the Latitude \& Longitude of Washington, for important State purposes.

"Our Northern \& Western Armies seem to be doomed to misfortune and Disgrace - One large Item in the iatter account is the wonderful propensity which some of our Commanders have to write proclamations - Alexr. Smyth has lately issued one more replete with absurdity than any that have preceeded it.

"Perhaps I may occasionally enclose an Eastern Newspaper.

"I am affectionately Yours

"Benjn. Tallmadge.

"(Forget not to burn)",

"Washington Decr. 5th. 1812.

"Dr Sir

"The Secy. at War (Dr Eustis) has resigned \& it is whispered that Genl. Armstrong is to succeed him - Other changes are said to be in Contemplation for our Cabinet.

"Yours in Haste.

"Benjn. TAllmadge."

"Dear Sir

"Washington Decr. 28th. 1812.

"Your Letter of the 19th. instant is before me - I take it for granted that you have not given up your habitation at Baltimore, but for a short time. Perhaps your Residence on the Allegany hills, may serve to endear B. to you the more; provided nevertheless, the Mob of that City should not take the police of it into their own hands. In such Event, the frozen Coasts of Greenland would be prefered to it.

"We have passed the Bill from the Senate authorising the Pt. to build 4 Ships of 74 Guns, \& 4 Frigates of 44 Guns Each. Ays 70 - Noes 56 .

"Also the Bill to relieve the Merchants from the payment of their penal bonds- Ays 64 Noes 61 .

"Our Military Commtee. yesterday reported a Bill to augment the Army 20 Regiments, making an addition of as many thousand Men - The Mortality in the northern Army is wonderful, \& almost incredible - I should suppose, the uar party would have quite as much as they could do, to fill up the old Establishments of 35,000 men. One thing, I be- 
lieve I may assure you, those who were the most ardent for war, at the last Session, have become greatly cooled in their zeal.

\section{"I am affectionately Yours \\ "Benjn. Tallmadge.}

"P. S. As I pick up \& enclose almost any papers that remain, after the Gentlemen of our Mess house selected such as they need, you may very probably have some in Duplicate, $\&$ others of very little consequence. If you need the President's Message at the Commencment of the Session, with the Documents accompanying the same, together with Russel's last Communication, they can be forwarded

"I do not remember whether I have sent them or not."

"Dear Sir

"Washington Decr. 31st. 1812.

"I have just returned from the funeral of John Smilie Esq; long a Representative from Pennsylvania. He died yesterday at 2 oclock P. M.

"Mr. Hamilton, the Secy of the Navy, has resigned the Seals of his Office; so that the War \& Navy Departments are now without official heads as they are said, by some, to have been without brains.

"We are progressing with an Increase of the Army, by adding 1 Major to each Regt. 1 third Lieut. \& 1 Sergeant to each Company, \& 20 new Regts - 20,000 Men for one Year - We have also a Bill before us for creating a long List of General Officers - We do intend to contest the Ground on these Bills but they will all pass.

"Was there ever such a Disgraceful Scene transacted by any body of military men, as our Armies of the North have exhibited - It affords serious Contemplation to our war $h a w k s, \&$ they are excessively tender on that Subject.

"I am sincerely yours

"Benjn. Tallmadge"

Very few of McHenry's replies to Tallmadge have been found. A long and interesting epistle was written by McHenry from Cherry Tree Meadows, January 15, 1813:

"Dear Sir,

"According to geometricians, called surveyors, this place

I now inhabit is elevated above Washington, at least three 
thousand feet, and, yet, notwithstanding the advantage of commanding ground, it is very certain I can see nothing of what is going forward in this City. Thus situated, and having been for a fortnight past shut out from all intereourse with friends (the severity of the weather preventing me from sending to the post office) it entered into my mind to try whether or not, some news could be obtained, through the channel of dreams, to which you know wise men in all ages of the world, as well christian as heathen, have resorted, without scruples and often with success. Encouraged by such I have had a dream which, with your good leave, I shall now relate - I fancied myself in the palace at Washington, where my attendance had been requested by $\mathrm{Mr}$. Madison. Information, it seems, was wanted, which it was supposed I could give, respecting certain military officers of the revolution, for whom stations were contemplated in the army. This business being disposed of, Mr. Madison asked me, what I thought of the times? Perceiving that his table was covered with federal news-papers from all parts of the union, here, Sir, said I are intelligeneers, better able to satisfy you than I am - I acknowledged the nierit of the information, he replied, but I cannot always rely on their reasoning or trust to their facts. They announce that, as President, I have lost the confidence of a vast portion of the people, of the Eastern and middle States, and in other seetions of the union, that doubts and surmises are eating my popularity, and undermining its very foundation. Believe them, also and the war must soon die a natural death, from this diminution in public confidence, the impossibility of raising men and an absolute want of money to carry it on. In all this, I can see the wishes of federalists, but not the truth. You are of opinion then, said I, that the public confidence has undergone no change, and the result of late elections, in various districts of Country is no evidence of the fact? If I thought otherwise, he replied, I should think very erroniously. What experienced mariner is alarmed by the variations of the needle? It would be strange, indeed, was the art that has fixed for so many years the character of the times, all at once to loose its virtue. But I find, you, as well as some of my weaker friends have mistaken the mere semblance of a change, for a real change; not considering that this semblance being produced by transient causes, like those false suns sometimes seen 
in the heavens, must soon disappear. As to the war, England is too seriously occupied in Europe, to occasion us much trouble in America. I fear nothing from want of men or money. All this case requires, is to give to the war sufficient duration, which without victories, many men, or much money must secure its object. It was the voice of Mr Madison I heard, but on looking at him he had the very form of Mr. Jefferson. Suddenly loosing sight of the spectre, the palace, and Washington, I imagined my self seated on the banks of the Duero. The English army appeared at some distance, its tryumphant ensigns waving in the wind. Alas, said I, your victories, though splendid, have not been conclusive, and the means of your nation for continuing this war, tho' great, are opposed by means, perhaps greater. A train of painful reffections now took possession of my mind, from which I was roused by a noise on my left, that seemed to partake of flight and dismay. On turning round, I saw Bonaparte pursued by a Russian bear, his guards scattered, and, the animal gaining fast upon him. He cannot escape, I exclaimed, when, the next instant, I saw him in Paris, with Barlow on his knees, in the act of presenting a letter from the President of the United States, which read one way, congratulated him on his successes in the North, and near approach of the freedom of the sea, read another seemed to call for justice and the fulfilment of a promise. Blockheads, said Bonaparte, crushing the paper in his hand and turned from the prostrate minister, without inviting him to rise.

"I again fancied myself in Washington, that the 13 Congress had met, and that I saw the new and old federal members convened and deliberating together on the properest course for them to pursue. It was under discussion, whether or not, as a means to bring about peace (to effect which it was observed most of them were elected) they ought to oppose all grants of money for military purposes. The speaker seemed to think, that appropriations for maintaining the war should be resisted, excepting such as were required for the protection of the frontiers and extension of the navy. This procedure, it was argued, if it did not force the President into a peace, would at least change the war from offensive to defensive, and thereby, in all probability, abridge its evils. The debate intermitted. Mr. Randolph now rose. I could perceive, that several members seemed surprised how this 
gentleman got amongst them. Without, however, noticing their surprise, he said, he would take the liberty, in addition to the proposition under debate, to offer a few reflections for consideration to be cast, if they should be approved of, into a proper form, and submitted to the President of the United States.

"I lay it down, he said, as a great political, nay moral maxim, that if it be in our power, it becomes our duty, to put an end to this war. To affect this, let us, in the first place, bring together into one account the vast sums of money already expended on a war yet hardly commenced. Let us next show, that this war, if prosecuted according to the system avowed by the late President, in one of his messages to Congress, and practiced upon by the present President, viz, of fighting with militia, till such time as a regular army can be raised and disciplined for actual service, it must occasion a most dreadful and umprofitable sacrifice of useful lives, render, from the expensive nature of the system, the public expenditures unsupportable, and induce, from mere deficiency of means, a resort to foreign subsidies, and foreign troops. Let us then state that the view of our unsettled differences with great Britain, derived from public documents, happily presents no obstacle to their adjustment, so obstinate, as cannot be removed; that, on the contrary, it encourages a reasonable expectation, that a fair trial to adjust them cannot fail of success. Here let a mission be recommended, to consist of men perfectly cognizant with the commercial and other great interests of the union, to proceed immediately to London, with authority to conclude a treaty of peace, comprising an arrangement of all our differences with the United Kingdom of Great Britain and Ireland. And if it so pleases you, but this proposition perhaps you may not choose, considering the crafty character of our Cabinet, let the representatives, ever true to the interest and dignity of the nation, pledge their honour that should a negociation thus begun, fail in attaining a settlement of differences on fair and equitable terms, to call into action all their capacities and energies, in the prosecntion of a vigorous war by land and sea.

"I may gentlemen be mistaken, for who is he who may not; but I cannot help entertaining belief, if this measure shall be adopted without delay, and these ideas expressed, in plain and respectful language, it eannot fail to make a strong 
and salutary impression, as well on the public as on the President. Yes, I say adopted without delay. Moments in the present situation of things are precious. Depend upon it, if there be a manouvre in the tactics of the palace, by which the President can prolong the war, and yet appear to the public most anxions to bring it to a close, it will be practiced. Would not a proposition for an armistice be of this nature, accompanied with an offer, if accorded to, of sending a Minister forthwith to London, to arrange and settle terms of a treaty. The people would not see, that the proposition was deceptious; they could not be made to comprehend why, in this stage of the business, the preliminaries or basis of a treaty must be adjusted, between the two nations previous to a suspension of hostilities. May not also the same purpose be affected by a law, rendering it penal to employ on board our ships of war or merchantmen British subjects, to take affect whenever Great Britain should do certain things inadmissible in fact or in form.

"There is another consideration not less cogent for our doing whatever is proper for us to do without loss of time. The present is, perhaps, the only one that is allowed us, in which to rescue our Country from the calamities of war, nay from calamities still greater. Should the effort to obtain the proposed mission be delayed, till after Great Britain shall have settled her plan for the war, and entered upon its execution, who can expect from it success? For myself, I do not. A new obstacle will have then interposed, too obstinate I fear, to be removed. While fiddling about Canada, and playing the rogue, at Angustine, New Orleans will pass into the hands of Great Britain, and be rendered impregnable against our arms. What think you, Gentlemen! Will not this event stamp a new character on the war? Will not ten thousand considerations, political and commercial, make the English nation sce in the permanent possession of this place, complete remuneration for years of war and millions of money. Who among us will undertake to say, when, or how, a war is likely to terminate, between people, one of which, will feel the strongest interest to retain, that which the other has the most powerful motives to recover? This is no fancy, no child of fairy-land. I see the reality before me. It affects my senses, as forcibly as did the fatal writing on the wall, the mind of Belshazzar. Do not deceive yourselves. 
New Orleans once occupied by Great Britain, the war becomes interminable, or the United States, are no more. No matter then who reigns as President, or what party preponderates, that circumstance will work no change in our destiny. The thought sickens me almost to fainting. But, he continued, lifting up his eyes to heaven and looking beyond means and instruments, I know there is a power which baffles devices the most eunningly formed, against whom, no wisdom or understanding can prevail!

"Randolph sat down, a deep \& solemn pause of some minutes ensued. Mr. Pitkin now rose. At this instant, I was summoned to my lodgings, and before I got back, the meeting had adjourned.

"Perceiving Mr. Dana coming out of the house, well, said I, taking him by the arm. What is done? Great things. he replied, We have eaught the fox, and only wait for the arrival of your friend, Mr. Pickering, to kill him.

"I now imagined myself advanced several centuries into futurity. 'The occupations and pursuits of men did not appear to have undergone any change, their dress only had altered. Curious to learn what was said by its writers of the transactions of the present period, I examined the most esteemed history, and found them compressed into a very few pages. I searched in vain for the names of the generals, popular orators and statesmen who had occupied so great a space in our newspapers and public dispatches, but their names were not recorded. I observe also, that even the characters of our Presidents were given in a few short sentences. The first it was remarked possesed no splendid talents, but shone the real 'patriot King.' The second had acted the sage and the fool, by fits. The third, excelled in hypocrisy, and governed by deception. The fourth had virtues, but sunk them in the vices of his predecessor. What! I exclaimed. not allow one genuine ray of candor and upright dealing in the Presidential lives of two such popular statesmeu! In saying this, the book fell from my hands, and I awoke.

"And now feeling myself no longer under the influence of fancy, I beg you to believe, that I am not dreaming, when I assure you, that I am very sincerely your frieud \& hble serv."

Tallmadge sent a brief note from Washington on January $16,1813$. 
"Dear Sir"

"The Senate have ratified the Nomination of Genl. Armstrong, Secy at War, \& Wm. Jones, Secy. of the Navy. The former rubed hard in the Senate, \& it finally passed 18 to 15.

"The Bill to raise 20.000 additional Troops will probably finally pass, altho' it had a hard time in our House. The Debate has embraced the whole range of our foreign Relations.

$$
\begin{aligned}
& \text { "I am affectionately yours } \\
& \text { "BenJN. TALLMAdGE." }
\end{aligned}
$$

A second letter from MeHenry dated Cherry Tree Meadows, Saturday, January 23, 1813, accompanied the longer one written earlier in the month.

"Dear Sir

"The snow, and distance of the post office, (16 miles) from this place, shut me out from all news for a fortnight. Last Saturday however, my messenger surmounted all difficulties, and brought me next day, the accumulation of weeks. What I did during this time you will be told by and by. 1stly. I have to acknowledge your letters under date of the $19,28,30, \& 31$ st ulto. and two of the 5th. and 9th. 2dly. To beg you to thank Mr. Davenport for the aid he has so kindly lent to furnish amusement to a man confined to his room, by gout, or something very like it, and unable to walk across it without assistance. 3dly. To request you to send me half a dozen copies of Mr. Quincy's speech on the army bill, should it appear in a pamphlet form. The short sketch I have seen of it in the.Baltimore Federal Gazette, and your account of its pungency \& brillianey, makes me anxious to see it entire, and to give it circulation. Mr. Quincy adds the graces of the elegant scholar to the talents of the statesman. 4thly. Yon have furnished me one copy of the President's message \&c. and Mr. Russel's Supplementary evidence, another will oblige me, that I may have one set to leave with my son, and a second to take home. I shall also be grateful, if you can spare me copies of the printed reports made by the heads of Departments in the course of the session. These furnish facts, the knowledge of which is necessary to a correct understanding of our public affairs and the manner in which they are conducted. And now you shall know how 
the interval I have spoken of has been employed. Vouchsafe to accept of the enclosed dream, not by way of a return for your many favours, for it is no equivalent, but because I have nothing better to send, and because I thonght it, the result of a few idle hours, was better to send than nothing at all at all \& having thus committed myself, let me entreat you, as the dream is intended to be perused by you and your friends only, who, occasionally, eonfer together how best to promote the publie good, that it may not pass this limit. There it will be understood, elsewhere it might not"

During the year 1813, a number of additional letters from Tallmadge have been preserved in which he speaks freely of events at the capital. Thus from Washington, on February 8, 1813, he wrote:

\section{"Dear" Sir}

"I thank you for your obliging Letter of the 23d. with its accompanying Documput. Although it comes nnder the figme of a Dream, I rould give more for it, as a state paper, than any or all the Documents, relative to onr foreign Relations, that have been laid before us during the present reign. In fact, it has one prominent superiority orer the latter, inasmuch as it exhibits the truth, altho' in a figure. I wish I could with propriety say as much of the others. Be assured that no improper use shall, on any decomnt. be made of it. It has passed under the eye of some of our friends among whom is Majr Davenport. In no case ( $I$ repeat it) shall it be used to the Injury of the Dreamer.

"The Documents communicated at the commenement of. the Session shall be inclosed: but there are many which are printed during the Session of which only a single Copy can be obtained.

"We have been almost over whelmed with News from Russia, \& the last Arrivals from Emrope bro't Intelligence of the Death of Bonnaparte, which gained great Credit. We have a Rumour this day, however, that he has reached Poland. Expectation is all alive for further Intelligence: \& while some look forward to the Death of that military Despot. as an Event most auspicions to the peace of Enrope: others view it with foreboding apprehension. For ny own part, I can say with great truth, that if, in the Course of divine Provi- 
dence, he should be taken away, I shall most heartily acquiesce in the Dispensation. At all Events, I believe it may be relied on, that the loss of the F. Army in the Horses, Artillery, Baggage, \& even Men, must be immense.

"We have, for some time, been discussing the Bill, accompanied by a Report of our Commtee on foreign Relations, relative to Seamen - It is well understood that both of those papers eame from the Cabinet, thro the aforesaid Committee, to Congress, without the alteration or addition of a single word. Whether the Object in view is to enable the Administration to open a Negociation for a peace, on liberal terms, with frankness \& sincerity; or whether this Bill is intended to deceive the people, by apparently removing the Cause in Dispute between the two Countries, \& then throwing all the blame of continuing the war on G. B. is not well settled. I confess I have never doubted for a moment that the Intention of the Admn. was to continue the war, if by any means they eould make it so popular as to engage the people on their side. Unless the Bill should be considerably amended in some of its propositions, it will get the support of the peace party in Congress. Without their aid, it seems as if it would not pass. The ardent warmen do not like it, lest it should produce peace. I am Dr Sir,

"Sincerely \& affectionately Yours

"B. Tallmadge."

"Dear Sir

“Washington May 30th. 1813.

"We have yet done nothing worthy of notice, nor shall we before the Committee shall report.

"Our Intelligence from Europe is highly important. We may now calenlate on Russia, Prussia, Sweden \& Austria having united to limit the power of Bounaparte-May Heaven grant that they may sueceed, \& that our own Country may not be found ultimately, a solitary friend of this great Robber of Nations.

"I am affectionately yours

"Benjn. Tallimade."

“My Dear Sir

“Washington June 10th. 1813.

"I have been made very happy by the Rect. of your Let- 
ter dated the 4 th. instant, \& hope you may continue to amend in health - Happy is that man, who from the furnace of affliction can look up to his merciful Protector \& say 'not my will but thine be done.' At this trying hour the peculiar Excelleney of Religion is made manifest, \& then the Believer is enabled to exhibit the peculiar worth of his faith, inasmuch as it serves to support him even in the near prospect of Dissolution, when to the Infidel every thing must be shrouded in Gloom \& darkness \& despair.

"The Mission to Russia has not vet recd. the advice \& Consent of the Senate; not so much as to its Object, as the means employed. In fact, it has become very questionable whether Mr. Gallatin ean execute the Office of Embassador \& still retain his hold, over the Treasury De Partment.

"The P. has also nominated Mr. Russel a Minister to Sweden. This will not probably pass the Senate, as the $E x$ pediency of such a Mission seems to be questioned, \& of Course, there being no vacancy, the Pt. had no Vacancy to fill in the recess of the Senate.

"This day the Commtee of Ways o Means reported their System for Taxes, consisting of twelve bills, all of which are made the order of the Day for monday next, By some, it seems to be doubted whether these bills can be carried; \&, by others, whether the friends to the War will not move a postponement of them to the next Session - at any rate, they will come up to the business with some reluctance.

"That the Admn. have no serious \& cordial wish to have a peace, I have long believed; \& hence the Mission to Russia has no very prominent features indicative of peace. Nevertheless, in the present State of the European world, Peace may come to us.

"The loss of the Frigate Chesapeake, is a most mortifying occurence. We have no particulars of the action, only from those who were at some Distance, \& beheld the short Conflict. I expect shortly to get the Intelligence from Hallifax.

"New London is at this time full of apprehension, oecasiond. by the arrival of three of our public Ships, having been pursued in by a superior B. Fleet. I understand there are 4 Ships of 74 Guns lying off New London Harbour, \& it would not be very wonderful if they should enter in, \& try which ean do the other the most harm. In such an Event, the; City of N. London must suffer greatly. 
"Your particular friends here are well. Col Pickering has written to You since I recd. your last. Wishing you all possible happiness.

\author{
"I am sineerely \\ "\& affectionately yours \\ "BenjN. Tallmadge"
}

"Dear" Sir

"Washington H. of Reps. June 16th. 1813

"In one of the enclosed papers, you will find an able report from a Comtee, made to the Genl. Assembly of Massachusetts. One of a similar Nature has been made to the Legislature of Maryland. A petition has this day been presented to Congress, by the Corporation of the City of N. York. praying for assistanee from the Genl. Govt. to defend that City. I think the Admn. will have as much as they ean attend to, if the Militia are harrassed \& ealled out by the Govt of the States, to repel Invasions \&c, from the multiplied Calls that will be made upon the Genl. Govt. for payment \& support. This war, my friend, is a very troublesome thing \& the sooner we ean be relieved from it the better.

"We have this morning reed. unpleasant Intelligence from our Northern Army. It is said that Genl. Chandler \& Winder, with about 170 Men, were surprised \& Captured.

"We seen to be doomed to suffer disgrace from that Qr.

"The Taxes remain untouched as reported.

"I am sincerely

"\& truly yours

"Benjn. Tallmadge"

\title{
"Dear Sir"
}

"Washington June 24th. 1813

"I thank You for your Letter of the 18th. instant, \& altho' I am always rejoieed to hear from You, \& especially to get a letter written by yourself : ret I must say to You that I will forego that pleasure at any time, rather than have you fatigue \& injure yourself

"We are now working on the Taxes, \& really they seem to drag heavily on. The Advocates for the war, who have indeed made it necessary for us to lay these burdens upon the people, cannot agree on the principles to govern in the direct Tax. If I could judge from what has already taken 
place, I should believe the Taxes would not be laid during this Session.

"The enelosed paper will give you the acet. of the Capture of the Chesapeake, with all the partieulars that have come to hand-relative to that important Affair. That single Confliet is enough to make a Christian mourn over this ealamitous War.

"Adieu. I am affeetionately

"Benje. Thelmadge

"P. S. The Pt. eontinues quite unwell - it is said the B. Heet below Menace even an approach to this place, if not by their Ships, by their Men from on board"

"My Dr. Sir

“Washington July 9th. 1313.

"With mueh pleasure I aeknowledge the Rect. of your" Letter dated the 22d ulto. \& hope this may find Yon in tolerable health, \& above all that you may grow in Grace, \& be ripening for a better world.

"We have now got through with the heaviest part of the Taxes. The Land Tax \& the whiskey Tax constitute more than half the labour of the whole Srstem. Great diffienlties have presented themselves as we progressed in the business, \& great Inequalities \& Injustice have been done in Apportioning the Land Tax. For Instanee, in the State of Ohio, the Sum apportioned to that State was laid solely on its - population to the amot. of $\$ 104.000$. Then to make the thing go down with the people, they laid only 42.000 on the Resident \& $\$ 62.000$ on the non Resident Population. This was so enormously oppressive, that it went down hard, even in our House.

"The Pt. has got so mueh better that he begins again to attend, to public business. He has replied to the Senate respeeting MIr. Gallatin's Nomination on the Mission to St. Petersburg, \& pleads both precedent \& the Constitution to justify him. Whether the Senate or the Pt. will recede camnot yet be determined. If the Senate regard their own Character for Consisteney, I think they will not easily be driven from their Ground.

"Our War seems to go with marvelous Effect. We loose Arny after Army, \& Detachment after Detachment, until I should suppose our force must be considerably redueed. One General passes away after another, until finally Genl. Wilkinson is ealled to the North. Genl. Williams, (of Artillery mem- 
ory) is now here. I have just been giving him a Caution not to venture too rashly across the Niagara frontier.

"So far as I can judge, there is no disposition to relax on the War Establishmt. They must have more money, \& their means of obtaining it are limited. But so long as they will borrow on unlimited premiums, or rates of Interest, they will probably get money.

"As I purpose to leave this place for Connecticut in a day or two, I can only wish you the best of Heavens blessings $\& a m$

\section{"sincerely \& \\ "Affectionately yours \\ "BENJN. Tallitadge.}

"P. S. It is intimated by those who peep behind the Curtains that Genl. Armstrong is to command the Army. Some difficulties have arisen as to Munroe's Claims, this being a Stepping Stone to the next Presidency."

Davenport who has been referred to by Tallmadge wrote from Washington July 28th, 1813:

\section{"Dear Sir}

"Your favor of the 23rd. of the present month was received yesterday. I can assure you it affords me great satisfaction that $I$ have contributed in any degree to your gratification and amusement - your confinement and seclusion from the busy world, calls loudly upon your friends to afford you such relief as in their power and they certainly cannot be averse to gratifying your wishes by producing to your view the passing eventful seenes with which the world now groans the wormwood and the gall seem to be our portion, and the vile passions of mankind are sublimating the dose to the ruin of all around them.

"I fear Bonaparte is again successful and that he has made the Russians \& Prussians drink abundantly of the bitter cup, of which he has no small share himself. That he consents to an armistice does not prove that his victory has been complete. Our French friends rejoice above measure and consider the day as theirs, and speak of a festival on the event. In my opinion, our disasters at home call for sorrow and mourning, rather than rejoicing at foreign success. I fear the day of peace is far off. It must be our consolation in the 
day of calamity and distress that the Lord reigns, that He will achieve good from evil, and that the rage of man shall praise Him, and that 'the remainder of wrath he will restrain.'

"My ardent wish and prayer is that you may speedily have restoration of your limbs to their former activity and that your health may be again established

"I remain dear Sir very affectionately

"your obedt. servt.

"JN. DAvenPort JR."

Pickering had neglected writing to McHenry for some time, but did so on June 9, as follows:

"Dear Sir,

"City of Washington June 9. 1813.

"Colo. Tallmadge yesterday showed me your letter to him in which you remember 'your old friend.' It was a remembrance which I take pleasure in acknowledging; and joined to the sentiments expressed in regard to your own situation, afflicted with bodily infirmities, could not fail to excite reflections of the most serious kind. I am some years older than you; but my constitution \& health are unimpaired : yet not one day passes in which I fail to think on the frailty of every human frame; and that, when I close my eyes to sleep, I may not see the light of another day. If I am not depressed, it is because my .best hopes \& expectations lie beyond the grave. Early instrueted in the duties of virtue \& religion, \& with pure examples, in my parents, daily before me, I have always endeavoured to 'keep myself unspotted from the world'; yet with a consciousness of deficiencies to humble me before the searcher of hearts, when repeating 'forgive me my trespasses, as I forgive those who trespass against me.'

"Such is the nature of my consolations amid the calamities of life \& in the prospect of a future existence: and such also must be yours. This I say, because in my whole intercourse with you, I have seen nothing but undeviating rectitude of conduct, exemplary manners, \& the serious deportment of a christian. I have not forgotten - I shall never forget - your parting words at our last interview. 'If we do not meet again in this world, I hope we shall in a better.' 'To which my heart \& mouth responded assent. In a volume of dissertations by Dr. Price, there is one on the happiness of those who were 
friends in this world, meeting together in another. It is a most pleasing, cheering \& animating discourse. In a note, he quotes a passage from Cicero's works, by which it appears that that celebrated orator \& moralist, in the most feeling manner, anticipated the same happiness. I wish I could recollect the whole sentence. 'O proclarum illum diem' (he-begins) when he should go to the assembly of departed worthies, 'et ad Catonem meum, quo nemo vir ullus melior natus est, nemo pietate praestantior.'

"The day before yesterday I met Bishop Carroll, with the fine, calm, composed, but cheerful countenance which distinguishes that good man. He mentioned with tender affection \& regret the situation of 'my friend McHenry.' There is a charm in the manners, \& especially in the face, of Bishop Carroll, of which I have rarely, if ever, seen the equal.

"Present my lind regards to Mrs. MreHenry and believe me ever most truly yours.

\section{"Timothy Pickering.}

"P. S. If yon favour me with an answer, note the year \& day of your birth. My own are July 17. 1745."

On June 13, McHenry answered, speaking of Bishop Carroll as a "truly good man, I can safely say, from a long and social intercourse with him, that the benignity which you describe as appearing so strikingly in his countenance is not greater than the real benignity of his heart." He speaks of his own health which is now better, and of Pickering's, and of reunion in a future state. The universality of the opinion that such remion will occur is not only an expression of a thing wished for, but also evidence of its reality.

On July 24, McHenry wrote Pickering again, "When we labored together in the same cabinet for the public welfare, I conceived for you a real esteem and sincere friendship. I could not mistake your character and valued it according to its worth. It wanted the courtly charm of pliancy but possessed, what is better, the roughness of inflexible integrity and a candor that defied concealment. The calumnies that have since assailed you (in which I have also partook), as I knew them to be unmerited and unfounded, could in no ways lessen this esteem." These calumnies were exposed by MeHenry's letter to the Speaker of the House of Representatives, which McHenry had printed, but "distributed only a few of them, with an injunction not to publish their contents. This is the 
only trouble these calumnies gave me, and the only notice I ever took of them, public or private, Religion, I thank God, enabled me to forgive their inventors, as for those, who, too ignorant to discern the motives in which they originated and the purposes for which they were propagated, and who yet entertain them, they never stood in need of my forgiveness. I pitied them as mistaken and deceived enthusiasts. With respect to a different description of men, who knew their falsity, but not, withstanding, will seize occasions, in cold blood, to keep them alive among the populace, I forgive them and I pray that they may be forgiven by God.",

He has gained a little strength and wishes to try by short stages to return to Baltimore, where his children anxiously await him. "The physicians, too, urge exercise, as essential to recovery. I have determined, therefore, to make the experiment and leave the issue to that Being whose providence is like extended to individuals and nations, without whose privity a sparrow does not fall to the ground."

This letter Pickering answered at once:

"My dear Sir,

"City of Washington July 27. 1813.

"To-day I received your favour of the 24 th. I hope it will not be the last to me: I hope you may recover strength 'to regain your old home,' and have the happiness to see the faces of your children : you now enjoy the greatest consolation on this side Heaven - pious resignation to the will of the anthor of our being.

"You refer to your vindicatory pamphlet: I may have it at home; yet I should wish to have another copy set apart for me, to be received if $I$ should live to return hither, next autumn, through Baltimore.

"I have had occasion, many times, to recite to different friends, the base attempt of president Adams to degrade Hamilton from the rank of first to that of third major general, in 1798 : that after you had made out the commissions for

"Hamilton

"Pinckney

"Knox

"you sent them to Quincy for the President's signature: that he did not sign them, but directed you to express his opinion 
to Genl. Washington, that these gentlemen ought to rank thus

"Knox

“Pinckney

"Hamilton :

"and if the General should be of the same opinion, then that their commissions should be arranged accordingly: but that before you had time to consult General Washington \& to receive his answer you received from Mr. Adams a peremptory order to make the commissions in that order: that you of course obeyed: but that General Washington demanded, in strong terms - terms which Mr. Adams could not disregard that the commissions should conform to his original arrangement: - and that Mr. Adams was constrained to yield, \& did yield; and I believe altered the commissions you had a second time sent him, with his own hand.

"If you find yourself strong enough to favour me with an answer - correcting errors, if there be any, and adding facts and circumstances which it may be useful for me to know (especially in unmasking baseness and hypocrisy) I shall be much gratified. If your prayer for the prolonging of my life should be answered, I mean to resume my original design of tracing the calamities of our country to their true source - Thomas Jefferson - exposing him \& his second, Madison, in all their frauds and baseness to the view of the world - as the necessary means of undeceiving the People deluded, by their deceitful practices, to pursue the paths which have led to their ruin. This I shall not attempt in a weekly newspaper - but in a book deliberately reviewed and methodized.

"I believe that no one who has read my letters of 1811 can doubt that the outrages practised by Mr. Adams, towards the close of his administration in respect to individuals among federalists and against the federal eause, $\&$ positively my own removal from office, were the fruit of his intrigues with the democrats, to secure his re-eleetion to the presidency. I have reason to believe that Samuel Smith and Wilson Cary Nicholas were prime agents in this intrigue, in which the old man was their dupe. But it did not occur to me, till a year after I wrote those letters, that the unlooked for nomination of Murray to negociate a treaty with France, might probably be ascribed to the same cause. I think it not unlikely that Jefferson, who knew the superlative vanity of Mr. Adams, touched that very sensitive chord; flattering the old man with 
visions of everlasting fame, added to the immediate plaudits of the people of the U. States, hailing him the Deliverer of his eountry from the ealamities of war; thus laying a sure foundation (as Mr. Adams would infer) for his reelection.

$$
\begin{aligned}
& \text { "I remain, my dear sir, } \\
& \text { "ever most truly yours. } \\
& \text { "'Timothy Pickering." }
\end{aligned}
$$

On MeHenry's return to Baltimore he was somewhat restored to health and took his last public position, that of president of the newly organized Bible Society of Baltimore, whose address to the public he prepared, showing a pure and elevated Christian faith. 1

Apparently Pickering did not receive the pamphlet he asked for until the next winter, when he wrote in acknowledgment :

"Dear Sir,

$$
\text { "City of Washington Feby. 12. } 1814 .
$$

"Mr. Boyd sent me the printed copy of your letter to the House of Representatives, and a pamphlet having the title of the 'Three Patriots,' committed by you to his eare, fo! which I pray you to accept my thanks. T'he pamphlet was printed 'for the author' I have read it with interest, and wish to know who wrote it.

"Colo. Tallmadge \& I came on together from New York, \& arriving at Baltimore to dine, intended to have called to see you at the edge of the evening : but company detained us until we were apprehensive it might be too late, in your particular situation. Tho' enfeebled in body by the malady which has so long afflieted you, I am happy to find you consoled by the mental enjoyments which are the companions of virtue \& piety. These consolations will never desert you. Accept the assurances of affection \& esteem.

\section{"'Timothy Pickering",}

Fron Pittsburg on the 30th of September 1813, McIIenry's old friend James Ross wrote him:

"Dear Sir

"During the summer I have been long absent from Pittsburg and did not receive your letter written on your departurs from the Glades Until a few days before your other of the 20th instant reached me by last mail.

1 This address was reprinted in the 70 th report of the Maryland Bible Society in 1903. 
"It gives me great pain to learn the infirm state of your health, and the more so as your journey into the Mountains, \& the exercise necessarily attending it, might have reasonably been expected to rouse and renovate the system: Still however, the good effects of moderate exertion may be hoped for, and may display themselves after you are settled at home: And still you possess the Undiminished faculties of a Mind stored with science, fortifyed by sound philosophy, and tranquillized by all the consolation of a well spent honourable life: A life that I ardently pray may be prolonged for the happiness of yourself your family \& friends:

"I have not been forgetful of the Kenhawa lands: The sale for U. S. direct Taxes was made to a company, that has not chosen to disclose the persons who eomposed it and from all that I have been able to learn; one of the Company (Mr. Jackson) now in Congress was the real purchaser who has since disposed of these among other lands: It is in my opinion very eertain that the sale is a Nullity, as the assessment, entries on the Books, sales, deeds, every thing, is in a wrong name viz. James Mitterny, instead of James McHenry:- of this opinion also are all the council with whom I have conversed; - and some of them speak of the whole transaction at the Sale as being defective, and clearly against the provision of the Acts of Congress:- on that head there is nothing to fear -

"As to the State taxes, I sent by a friend of Mine the Abstracts of your patents, and the Surveys to enable him to pay in Wood County where the lands lie. But no charge was found on the Books there against you; Altho, they had also a charge against a certain Mitterny: At the time my friend was making these enquiries, Mr. Caldwell Sent there also, to pay all arrearages and was satisfied that Nothing could be legally demanded, Until a new assessment, after which, if they be back-Taxes reported, I shall take eare that the taxes are paid for you, should Mr. Caldwell neglect it: In future, he will probably be More Attentive, as he has sold his Mills, \& returned to the practice of the law, which will carry him twice a year into that County:

"Should he fail however in Attention, My friend Mr. Robinson who lives in this place, goes once a year into Wood County where your lands lie, \& he will not forget to do all that is requisite, and it will give him no trouble, as he has a 
large estate there himself, and has, hertofore, very obligingly done for you all that $I$ requested.

"Mr. Caldwell is now in New Jersey, and I expect to ses him here on his return, when I will press upon him a division of the land, and a final Settlement of the whole business: Lest he should pass by another road to Wheeling, I will write to him again respecting these lands, and press him to visit them, and take from all the occupants Written lease: this he long since engaged to do, but I fear it is yet to do:

"Should any thing else occur to me which would be Useful, I will have it done without waiting for your directions, \& I cannot but think that all is yet Safe.

"You will have heard that Commodore Perry has achieved a most signal victory over the British on Lake Erie, and captured their whole fleet on the upper lake: This in its consequences to our frontier is little short of Genl Waynes Victory over the Indians in 1794 . The Indians must retire and Separate before Winter, \& will no more reassemble. Upper Canada will devolve to the U. S. without any effort by Genl. Harrison, who has always threatened Much but has done Nothing, Unless you call an expense of five Million, Nothing:

"It is singular, that the heroes who have excelled our National flag triumphantly over the Enemy on the Ocean \& on the Lake, should be all federalists: Perry is so decidedly a federalist, that his friends thought his politicks bordered upon intolerance of his opponents.

"I observe that you expect a peace, but to me it appears improbable that we can reckon upon a solid durable peace being made by those who have made war merely to please France; Unless there be general European peace: Should Mr. Madison break off from the Confederacy, he might expect denunciation, \& exposure of all that has ever been written or proposed between Bonaparte \& Mr. Jefferson on the present Administration, and I vehemently suspect, that rather than see such an exposure the war would be continued by our present Rulers.

"Present me very Respectfully to Mrs. McHenry, to Mr. $\&$ Mrs. Boyd and believe me to remain with most affectionate regard

\author{
"Dear Sir \\ "Your faithful friend \& \\ "Most obedt. Servt. \\ "JAMEs Ross."
}


McHenry wrote Pickering on March 10, stating that the history of the past 12 years should be written by the federalist minority and mentioning that he hears members of congress suggest Dexter for presidential nominee in 1816. Though he was but little over sixty years of age, McHenry's health, which had never been robust, was entirely shattered by his attack of paralysis and from the beginning of 1814 he was almost a helpless invalid. Mrs. McHenry later wrote:

"While he was thus suffering, our excellent son Daniel brought his wife to her mother's to be confined, after which owing to his reluctance to leave his Father, we cou'd not get him to fix a day for setting out for his home. At length, my beloved husband mentioned one, \& insisted on their starting but oh! my dear madam, how shall I tell you, that he left us in health in the morning, \& before night was brought home a corpse. I leave you to judge what our situation was, for I cannot describe it, but I recollect all consideration for myself was lost in apprehendsion of the effects of the shock, on the dear affectionate parent then laying on a bed in extreme pain from which he was never to rise; for my poor Anna who was advanced in pregnancy \& my widowed daughter-in-law surely we should have been overwhelmed had we not been upheld by an Almighty arm - our God and Saviour sustained us by the precious promises of the gospel \& enabled us to derive comfort from the recollection of the good and virtuous life he had led; which gave the sweet consolation of faith, that altho' he was suddenly \& awfully taken from us, he was not surprised \& that the Redeemer, whom he trusted, would mercifully supply whatever was wanting in his preparation for death - He rode, unknown to us, a vicious horse who had the habit of throwing his rider - he threw our beloved. We had scarcely got over our first poignant distress after this sad event, when we were thrown into great alarm by the British Fleet \& Army threatening an attack on Baltimore. Our terror was inexpressible. my husband could not be moved, my daughter would not seek safety by leaving us, my only son thought it his duty to leave his Father, tho' his attentions were so needful to him, to go out in our defence. he was foremost in battle at North Point. we thought we should never see him alive again, when we parted with him \& great indeed must have been our desolation \& suffering \& that of 
thousands had not an Almighty \& ever merciful God interposed in our behalf - may we ever gratefully remember this great deliverance - my son was restored to us alive, but being previously much weakened by his long confinement with \& watchful care over his Father, the fatignes of marching \& his laying on the ground one night in a heavy rain brought on a billious cholie, from which he suffered much by repeated attacks - for many months the same fall, my daughter was seized with billious fever during which, she gave birth to a very delicate infant $\&$, in two months, she was called upon to resign it. Her health was much injured by the many severe trials she had experienced in body \& mind. I thought I knew all, but part was concealed from me, Mr. Boyd in the fall was troubled with an intermittant which shook his frame a good deal, after he got rid of the chills, he became nervous \& took a religions turn, but owing to the scene of peculiar distress in which I was constantly engaged, I was not aware of his real situation, indeed we were all strangely blind to it for a long time, \& my dear husband \& myself often talked of, \& felt thankful for the change that had taken place in him, seeing him more attentive to his religious duties, and accounting for his depression by his participation in our affliction.",

It was soon found, however, that Mr. Boyd, the husband of McHenry's daughter Anna, was of disordered mind and this aftliction increased the family's sorrow.

On October 10, 1814, Hugh Williamson ${ }^{1}$ wrote, sending his regards and regrets on account of McHenry's paralysis.

We find but one more letter from Tallmadge, dated Washington, March 24, 1814:

"My Dear Sir

"I am happy in receiving a letter from You dated the 11th. instant. \& rejoice to find that your present State of Health permits you to use your pen.

"The Subject most inmediately in view in your Letter, I have submitted to some of our friends, as requested. No

1 A Presbyterian clergyman and physician, in 1772 , he visited Europe to collect funds for Newark Academy. He lived In North Carolina whose history he wrote, removed to New York in 1793 and was in congress from 1791 to 1793 . 
difference of opinion exists as to the importance of preserving \& condensing certain public Documents for the last 12 years, so that the world, \& particularly those who may succeed us, might examine the measures we have been pursuing, $\&$ if possible, profit by our Example. I fully believe many things, literally true, will by posterity be treated as fabulous Such a Collection of facts, or history of the times, will undoubtedly be furnished - It will be no easy matter to engage different Gentlemen to contribute their Exertions in such a Work. A person by the name of Palmer, has already commenced a work in the form of a history intending to embrace the great Events which have occurred for a few years past - My fear is that he does not commence his work far enough back; but as I have not seen his labours, I can only report from others - I learn that he has compleated two Vols. \& intends to progress.

"We have some reason to believe that the late friends of the Embargo begin to doubt its Efficacy in subduing or starving the Enemy. A proposition is before the Senate, to be called up on Friday next, to repeal the Embargo. If the Eastern Members should advocate the Continuance of this System (\& some begin to believe that it is doing good to our Country) or if they should withhold their opposition to the passage of such a law, most probably it would pass.

"We are debating the Yazoo Bill, \& rather believe it will finally pass. If this Bill could be disposed of, it seems very probable that we might adjourn by the 11th proxo. as proposed.

$$
\begin{gathered}
\text { "I am, Dr Sir, very affectionately } \\
\text { "\& sincerely your friend \&c } \\
\text { "BENJN. TALLMADGE" }
\end{gathered}
$$

From Georgetown, District of Columbia, Archibald Lee wrote on December 20,1814, and gave a gloomy view of the prospects for peace :

"My Dear Sir.

"I wish I could give you satisfactory intelligence upon our foreign \& Democratic relations - indeed I am sick at heart there. I found awaiting my return a long letter from Mr. Bayard 19th Au. He predicts a long war and assures me 'it will neither be the fault of the Administration nor the 
Commissioner's should the negotiation fail' - we have heard a great deal of stuff about the polite attentions of Alexander, He says. 'In Russia we had generally to wait twe months for an answer to a note - here we were all here more than a month before the B. Commrs. made their appearance, and this was nearly four months after Ghent was appointed or fixed, by the B. Govt. So that in fact we have had our ministers dancing attendance for 18 months on a fool's errand - a pretty Republican negotiation and a dignified procedure for the only free people on Earth such we would be though what course the Hartford convention mav deem justified by the state of the country I am unwilling to anticipate. The characters selected to deliberate are grave and valuable members of society, they are reflecting and prudent men, and such are unlikely to put to risk important objects - we are certain such men will not act upon a bare majority, and no rash measure can probably obtain the support of a large majority - there are certainly many weighty subjects deserving consideration and there are some changes in the present tattered constitution certainly called for - I believe nothing short of certain correctives will satisfy the Eastern people and, certainly, no measure out of God knows how many silly projects will bring home with more force the necessity of a change - than the power given to the President to call upon Inferior Officers of the militia to order out the Drafts in the event of the Governors of State refusing to obey his orders a pretext of law that never can be sanctioned by the States and certainly calling for decided notice - whatever power may be extracted from the ragged remnant of a once valuable Constitution to countenance conseription - I should have supposed this ereation in states of an imperium in imperio would have been shunned' - Mr. Bayard eloses his letter by observing that 'after being amused as long as their purposes may require, we shall be civilly dismissed' - no doubt this will be the issue."

J. Foncier, the builder of Fort MeHenry, wrote McHenry on September 13, 1814, when on the eve of returning to France, expressing his gratitude for favors and asking for a letter of recommendation, and another French friend, Paquiet, a former professor at St. Mary's College, wrote on September 1, 1815, from Annapolis, stating that he regrets "parting with 
you and your respectable family, whose kind regard to me has been, for a number of years, the only enjoyment which alleviated my labors. Accept, together with them, my hearty thanks for all that benevolence, with which you have honoured me; and believe that, to whatever distance I may be removed, I shall ever preserve the remembrance of it, as one of the most flattering, the most relished favours $I$ ever received in my life.",

During 1815, McHenry continued in about the same condition, às is shown by letters from him and his wife on Angust 7 to his son John, who was summering at York Springs, Adams county, Pennsylvania:

"My dear son

"Robinson will perhaps find a conveyance for these few lines tomorrow, intended to express our wishes that you should give the waters a fair chance to operate effectually on your system, by not leaving them just when they seem to be having the desired effect. Your Father is laid down for the night (after having been propt on his side to take tea \& for some time after) or he would have written himself; but he desires me to assure you that we are doing very well, he contimues easy, his wounds are almost healed, \& he entreats you to set your mind at rest about him, that you may receive full benefit from your present advantages.

$$
\begin{gathered}
\text { "Your ever affectionate } \\
\text { "MIother } \\
\text { "M. MIcHeNkY" }
\end{gathered}
$$

"My dear son

$$
\text { "Tuesday morning - }
$$

"By no means leave the springs before you have reaped the benefit now promised by the use of the waters. Breakfast is on the table, and I must send this to Mr. Robinson who goes early to town in search of a conveyance. I confirm all your mother has written respecting me.

\section{"Your affectionate father "JAMES MCHenry"}

The love for the old friends continued to the last, and on December 17, 1815, he invited Pickering to come over and dine with him on Christmas day.

On March 28, 1816, Pickering sent the following letter of introduction of two of his children to McHenry : 
"My Dear Sir,

"This will be presented to you by my youngest son, Octavius, who is on his return, with his sister, to Massachusetts. My daughter has seen Mrs. Boyd; and I have a desire that she and her brother may be made acquainted with the other members of your family.

"Having heard nothing to the contrary, I presume you are as eomfortable as when I had the pleasure of seeing you. You will believe that I sincerely wish you all the enjoyment compatible with your situation. The greatest possible happiness consists in the composure of mind \& pious resignation belonging to the character of a christian.

\section{"Adien!}

"T. Pickering."

The letter was never presented. John McHenry wrote Pickering on the next day that his father was ill with an "obstinate fever."

MeHenry lingered for a month longer and died on May 3. His wife wrote of the event:

"In May 1816, my dearest and best earthly friend was taken from me, \& altho' I had been long, in a great measure, prepared for this event, yet, when it came to the point of separation, the loss of such a husband could not be borne without much affliction; but, I thank God, I had not to mourn as one without hope. I believed he was going to the enjoyment of that felicity we had long so fondly anticipated; Oh! how soothing is such a hope to the mourner's heart. I sought to rejoice that he was not only relieved from great misery here, but received to that world of inconeeivable hliss to which he had long aspired."

Here we come to the end of the life of a courteous, highminded, keen-spirited, Christian gentleman. He was not a great man, but he participated in great events and great men loved him, while all men appreciated his goodness and the purity of his soul. His highest titles to remembrance are that he was faithful to every duty and that he was the intimate and trusted friend of Lafayette, of Hamilton, and of Washington. 

A P P E N D I C E S 



\section{A P P E N D I I}

McHenry's interests in trade and commerce and his official position as member of the congress of the confederation led him, in March, 1784, to write a series of three articles entitled, "Observations relative to a commercial treaty with Great Britain." 1 In these articles, McHenry forcefully argued that "Peace is the moment when past injuries ought to be forgotten *** America experiences by the peace a new situation; a momentous arrangement demands her attention; a commercial treaty with Great Britain that may ascertain the interests of the two nations so as to obviate future dissentions." His purpose in writing was "that our ardor for obtaining an honorable treaty of commerce may not be checked, or false resentments encouraged" and, after showing that there was no opportunity for the peace commissioners to make such a treaty, he stated that the British ministry "build their expectations of leading us to their own terms *** by a presumed want of unity in our councils, a factitious display of the superior credit of their manufactures and the perfect reliance of this country upon these; artfully concealing the absolute dependence of England upon the United States for the consumption of her manufactures and prosperity of her West India Islands." He then claimed "that America is in a situation to enforce a liberal treaty." The West Indies are so dependent upon the United States that Maryland, in 1773, exported thither 84,500 barrels of flour; 10,333 barrels of bread; 4,500 bushels of rye; 266,000 bushels of wheat; and 233,000 bushels of Indian corn. The United States "are alone able to supply" these islands with such products, "at a price necessary to their prosperity, regularly and efficaciously." "The supplies of the British West Indies were derived, during the war, from the United States, by capture and through neutral islands." If Great Britain cut us off from these mar-

1 Reprinted in Carey's American Museum, V, 317, 464, 550. 
kets, our surplus exports may easily be sent to the continent of Europe. There are also many articles which we can import cheaper from other countries than from Great Britain. "We ought to confine our imports from Great Britain to such articles only as she can sell cheaper than her neighbors or other nations, especially whilst our custom for other articles is to remain without an equivalent. We have obtained a range of markets as wide as our wishes and the cheapest must soon be universally known." The British "grasp at the exclusive trade of America, even without a treaty," and "do not perceive that their proceedings are operating as a stamp act and bringing the United States to act as a nation."

A long list is given of articles which can be imported from the several European nations cheaper than from England and of the usual exports to those nations. "Charged with these facts, our commissioners may hold a candid but decisive language with the British administration." The taste of America has been in favor of British manufactures in the past, but agents from the continental nations will soon learn how to meet this point. "But what is more than all to be heeded by Great Britain is the establishment of manufactures in America, for which she is so happily gifted; and which must gradually take place and succeed, till at length she will find little occasion for the manufactures of Europe. Nothing but a commercial treaty, on the most liberal principles, can check the progress of things in America, which is approximating to this independent, desirable, and respectable situation." The plausible argument that we import more from Great Britain than we export to her and, therefore, are forced to continue trade with her, McHenry answers by saying that, if the imports are greater, we pay the difference by bills of exchange drawn on countries to which our exports are greater and might well transfer trade to these lands. The future will encrease our ability, by giving greater payments for greater commerce from a greater country, which country will be richer by the establishment of manufactures and will receive imports at a lower price, because of the world's competition. The states should not "leave the accomplishment of a commercial treaty entirely" to commissioners, but should pass needed laws. "Maryland is proceeding in this great business with caution; she has laid some light duties upon goods imported in British bottoms, but I presume she expects the other states will follow her example; as remaining singular would 
not answer the intention of these duties. She has also, in the same act laying the duties, proposed a new article for the confederation; but this cannot be operative till every state agrees to one substantially the same. The power it contains is pointed at no kingdom, and, in its fullest extent, must increase our navigation; and we may reasonably expect that, under this power, Congress would devise a navigation act suited to the circumstances of this country." 


\section{A P P E N D IX II}

In addition to the letters published or referred to in this work, the following letters from Dr. James McHenry's correspondence have been printed:

1. In a pamphlet entitled "Autograph Letters, etc.," containing the text of a number of letters given by James Howard McHenry to be sold for the benefit of the Maryland School for the Blind in 1859 are found the following letters to McHenry from Washington, June 26, 1799; Pickering, January 28, 1800; Charles Lee, November 25, 1799; Lafayette, March 7, 1800; Wolcott, December 12, 1800; William Pinkney, March 20, 1800; Lafayette, August 6, 1805; Tallmadge, March 10, 1812; Rush, February 3, 1780; Jefferson, November 25, 1792; Washington, December 10, 1783; Chase, September 24, 1796; Wayne, February 24, 1796; Charles Carroll of Carrollton, December 2, 1796; Pickering, August 3, 1796; Hamilton, January 19, 1797; W. H. Harrison, 'May 12, 1797; Rufus King, August 4, 1797; C. C. Pinckney, September 19, 1797; T. Pinckney, December 11, 1797; Stoddert, 'May 28, 1798; Hamilton, September 9, 1798; Washington, July 30, 1798; John Adams, September 21, 1798, and July 27, 1799; Washington, August 2, 1798; R. G. Harper, August 16, 1799; and from Thomas Paine to Washington, June 5, 1778. These letters were all reprinted in 'Dawson's Historical Magazine, 2nd series, ii, 363 and $\mathrm{ff}$.

2. In Johns Hopkins Newsletter for March 10, 1904, vol. 8, no. 3, Address to Citizens of Baltimore City in behalf of Baltimore College (1804) by McHenry and his letter to his son John written about 1806 .

8. In Green Bag, xvi, (March, 1904), 172, "An Interesting Criminal Case" containing a letter from Pickering and McHenry's answer of December 3, 1807.

4. In 70th Annual Report of Maryland Bible Society, 1903, Address of the Bible Society of Baltimore to the Citizens of the State of Maryland written by McHenry, 1813.

5. In Army and Navy Journal, xlii, (October 22, 1904), 195, "The Case of Gen. Anthony Wayne," contains letters from Hamilton to McHenry, July 15, 1796; from Chase, July 22, 1796; from Charles Lee, November 20, 1796; and from William Vans Murray, August 8, 1796.

6. In William and Mary College Quarterly, xiil, (October, 1904), 102 , letters are printed from John Steele to McHenry, March 27, 1796; from Josiah Reddick to Zach. Copeland, January 25, 1799; and from J. Parker to McHenry, April 29, 1799. 
7. In Virginia Magazine, xii, (January, 1905), 257, are printed letters from Jefferson to John Wise, February 12, 1798; from Thomas Dillon to McHenry, 'May, 1796; from Charles Lee, February 2, 1797; from Pickering, April 23, 1796; from Joseph Anderson, 1797 (?); from Benjamin Hawkins, May 23, 1799.

8. In Virginla Magazine, xii, (April, 1905), 406, are found letters from Charles Carter, Jr., to Washington, July 25, 1798; from Wolcott to McHenry, May 28, - - ; from Hamilton, May 15, 1799; from,R. G. Harper, July 29, 1799; and from Harper to C. C. Pinckney, July 26,1799 ; from C. C. Pinckney to McHenry, March 20, 1800.

9. In Pennsylvania Magazine, xxix, (January, 1905), 53, are found letters from Rush, May 17, 1778; from John Beatty, October 15,1778 , and October 26, 1778; from Lord Stirling to General Phillips, January 3, 1779; from John Cochran to McHenry, January 29, 1779; from Rush, June 2, 1779; from a French officer, November 7 and 14,1779 ; from Robert Troup, November 10, 1779; from Rush, January 19, 1780.

10. In Pennsylvania Magazine, xxix, (July, 1905), 326, are found letters from Richard Howell, December 6, 1798; William Hindman, April 14 and December 17, 1794; and from John McHenry to his sister Anna M. Boyd, August 1, 1809.

11. In Southern History Association Publications, ix, (March, 1905), 99, are found letters from W. B. Grove, August 20, 1798; from Robert Adam to Grove, August 16, 1798; from Hugh Williamson, April 29, 1800, and November 29, 1800; from D. Harris, March 3, 1796; from Mrs. A. Boyd to John McHenry, July 14 and July 15, 1809; and from Mrs. James McHenry to John MicHenry, August 13, 1817.

12. In Southern History Association Publications, ix, (September, 1905), 311, are found letters from Charles Carroll of Carrollton, 'March 13, 1785; from A. Boyd to John McHenry, September 2, $18^{\circ} 09$; from R. H. Goldsborough, etc., June 1, 1811; from J. R. Plater, etc., June 3, 1811; from Nicholas M. Bosley, July 23, 1811; from Rev. Mr. Paquiet, September 1, 1815; and a broad. side attacking the supporters of McHenry and Coulter in the Baltimore town election of 1788 .

13. In Sewanee Review, xiv, (January, 1906), 76, the correspondence of William Smith, of South Carolina, with McHenry while the former was minister to Portugal.

14. In Southern History Association Publications, ix, (November, 1905), 374, are found letters from James Winchester, April 22, May 1, and November 16, 1796; William Vans Murray, June 24, September 24, October 9 and 28, November 2, 15, 20, and 23, 1796; Philip Key, 1796; Charles Carroll of Carrollton, November 28, 1796; and Samuel Chase, December 4, 1796.

15. In Southern History Association Publications, $x$, (January, $1906), 31$, letters from William Hemsley, November 13, 1797; Uriah Forrest, December 6 and 8, 1797; David McMechen, December 7, 1797; Samuel Chase, December 10, 1797; and Charles Carroll of Carrollton, December 8, 1797. 
16. In Southern History Association Publications, $x$, (March, 1906), p. 101, letters from George Salmon, July 31 , September 25 , and October 7, 1798; William Hindman, September 8, 1798; and David Stewart, September 15, 1798.

17. In Southern History Association Publications, x, (May, 1906), p. 150, letters from S. Chase, January 19, 1799; William Hindman, June 1 and 7, November 29, and December 9, 1799; John Dennis, June 24, 1799.

18. In Southern History Association Publications, (September, 1906) p. 289, letters from John Adams, September 4, 5, 14, 17, October 4, 5, 1798, April 14, 1799; Alexander Hamilton, December 17, 20, 1798, January 19, June 22, 1799, March 26, 1800; and William Vans Murray, August 20, 1798.

19. In Pennsylvania Magazine, xxx, (January, 1906), 110, letters of Timothy Pickering to James and John McHenry, September 12, 1797, December 13, 1804, February, 1807, January 6 and 19, 1816. In Pennsylvania Magazine, $x x x, 118$, Tench Coxe to the president of the United States, April 5, 1797.

20. In Southern History Association Publications will shortly appear letters from W. S. Smith, December 20, 1798; Lafayette, September 3 and December 3, 178-; Margaret C. McHenry, 180(2 letters); Anna M. Boyd, August 28, 1809; Uriah Tracy, 1800, (2 letters), and an anonymous letter from Cork, Ireland, in 1797.

21. In American Historical Review, xi, (April, 1906), 595, papers on the Federal Convention of 1787.

22. In Granite Monthly, xxxviii, 123, letter from John T. Gilman, May 22, 1799.

James McHenry's letters recorded in American Book Prices Current, 1902 , p. 613 , as sold at auction, 10069 , A. L. S., 1 page, 4to. Fayetteville near Baltimore, December 9, 1792, to Tench Coxe. Henkels', November 29, 1901 . $\$ 4.00$.

1905. A. L. unsigned, 3 pp., 4to. Ambler's Plantation (opposite James Island) July 8, 1781, to 'Major General Greene. Henkels', January 27, 1905. $\$ 5.50$ (printed in Magazine of American History, ii, (November, 1905).

A. L. S., 3 pp., 4to. Head Quarter's near Soan's Bridge July 10, 1781 , to Governor Lee. Henkels', January 27, 1905 . \$5.50.

A. L. S., 1 p., 4to. An address, Annapolis, October 16, 1786, to Daniel of 'St. Thomas Jenifer asking for rellef for members of Annapolis Convention. Carson, Henkels', October 26, 1904. \$3.50.

A. L. S., 2 pp., with franked address, Philadelphia, April 12, 1796, to Peter Hoffman. Treaty with Great Britain. Carson, Henkels', October 26, 1904 . $\$ 3.00$.

A. L. S., 2 pp., 4to. Holt's Forge, July 10, 1781, to Governor Lee. War letter of Greene's movements. Henkels', January 27, 1905. $\$ 5.50$. 


\section{N D E X}

ADAMs, Charles, 258.

Adams, Charles Francis 453.

Adams, John 53, 87, vice president $117,137,188$.

Adams, John, chosen president 191. $197,198,200,202,204,205,206$, administration 1797-1798 208, 209, 211,213 , French policy in 1797 223 to $225,234,242,258,259,266$, $268,270,271,272,283,286,288$, $291,295,299,302,305$, sends Murray to Holland 226,229 , appoints Washington General and strife over precedence 309 to 311,313 to $316,320,321,323,325$ to 328,335 , $337,338,340,341,344$ to 351,355 , $362,368,605,606,607$, events after sending embassy to France 370 to $372,378,380$ to $382,384,386$ to $389,394,395,397,399,400$, 406 to $409,413,414,417$ to 424 , 430,431 , conduct in Fries's Rebellion and Western affairs 432, 435, $437,438,440,443,446$, dismisses McHenry 453, 454, 515，547，558, 564, McHenry's opinion of him $453,463,468,477,479,553,569$, 595 , in presidential campaign of $1800452,453,455,456,458$ to 461 463 to $466,469,473,474,476,478$, 480 to 482,492 , his appointments to office $490,491,503$, defends career in Boston Patriot 552, 557. 566 to 570 .

Adams, Mrs. John 313, 327, 349 , 430.

Adams, John Quincy 226 to 228 , $230,239,241,494$.

Adet, Pierre A. $160,185,186,189$ to 193,201 to $206,248,276$.

Adlum, Capt. 437 .

Albany, N. Y. 29, 485.

Albemarle Co., Va. 317, 389.

Alexander I, Czar of Russia 613.

Alexandria, Va. 9.2, 94, 118, 311, $312,316,355,387,50.6$.

Alexandria, Egypt 331 .

Algiers, Dey of, Frigate for 180 $181,251$.

Allegany County, Md. 75, 125, 397, $553,580,583,587,589$.

Allen, John 393.

Allentown, Pa. 436.

Allison, Rev. Francis, incorporator of Newark Academy 2, preaches at Annapolis 81.

Allison, Mrs. Grace, 62, 73, 75.
Allison, Rev. Patrick, incorporator of Newark Academy 2.

Allison, Capt. William 1, 2, 5, 6, 64, 73,75 .

Ambler's Plantation 38 .

Amboy, N. J. 29.

American Museum 95, 127, 619.

American Philosophical Society 92.

Ames, Fisher 189, 421, 463, 464 .

Ames, - 317

Amiens, Treaty of 524

Amsterdam, Holland 128, 208, 211, $225,226,227,235,242,275,283$.

Anderson, Joseph (U. S. Senator) 556.

Angersteen, Mr. 486

Annapolis, Md, $36,41,54,55,59$, 61,64 to $68,71,72,78,83,85,89$, 108, $110,123,124,139,143,154$, $162,179,197,202,205$ to 207,305 , $306,456,465,470,473,613$.

Anne Arundel County, Md. 2, 109, 138.

Anthony, Mr. 372 .

Antil, Dr. 11, 13.

Appointments to office $178,288,345$, $346,384,386,411$ to $413,431,490$, 491, 502, 503

Archer, Mr. 204.

Arkansas 260.

Armstrong, Genl. John 53, 540, 543 ,

$544,547,549,562,589,596,602$.

Army organization in 1796182 .

Army organization in $1797288,293$.

Army organization in 1798303,307 .

Army organization Provisional 309

to $314,316,317$ to 327,336 to 341 . 344 to 369,438 .

Army organization in 1799375 to

406,409 to 418,422 to 431 .

Army organization in $1807 \mathbf{5 3 8}$.

Army organization in 1812588 to $590,596$.

Ash, Jas. 333 .

Atley, Col. 9 .

Augusta Co., Va. 121.

Aurora, The 185, 203,461, 468, 476

$533,534,557$.

Austria, 344, 374, 375, 598

Auteuil, France 541 .

BACHE 372, 572.

Bahamas 143 .

Baker, Capt. 235.

Ballymena, Ireland 1

Balston, N. $Y$. 554 . 
Baltimore, Md. $1, \sqrt{32}, 34,35,42$ to 44,64 to $66,71,75,76,78,79,82$ to 85,92 to $94,100,108,114,117$ to $119,129 / 133$ to $136,138,139$, 142 to $145,167,168,172,191,194$, $199,202,205,207,211,251,255$, $274,284,287,305,333,397,407$, $457,458,460,461,464,476,481$, $482,483,497,498,500,509,514$, $526,531,534,536,548,549,561$, 571 to $574,579,583,587,588,605$, 607.

Baltimore fortlfications 406,407 .

Baltimore College 520 .

Baltimore, Lord. See Calvert.

Baltimore Mob of $181.2580,583$, 589.

Baltimore aids continental army 35 to 37 .

Baltimore incorporated 144,153 , 154.

Baltimore Theatre 43

Baltimore in 1814610

Baltimore Co., Md. 109.

Banister, Mrs. 120 .

Bank in Baltimore 154, 162, 207.

Bank of U. S. 562.

Banneker, Benjamin, Negro mathematician 127.

Banning, Col., of Dorchester Co. Md. 142

Baraud, M. 93.

Barbary Powers 511.

Bard, Dr. 117.

Barlow, Joel 470, 570, 575, 592.

Barnard, Major Gen. John G. 76 .

Barros 279.

Barthelemy 279

Bayard, Jas. A. $195,370,464,488$, $493,512,513,612,613$

Bayly, Wm. 137.

Bear, Mr. 198.

Beaumarchals 535, 551.

Bedford Springs 553

Belgium 229, 232, 238, 373.

Bellfield, Md. 199, 209, 249, 334 .

Bergamo, Italy 229 .

Berkeley' 'Springs, Va. 159.

Berlin Germany 343, 494.

Berlin Decree 574.

Bernadotte, General 523.

Best, Mr. 317.

Bethlehem, Pa, 432, 434.

Bible Society of Baltimore 607 .

Biddle, Col. 290, 389.

Bielfeld, Baron de 241.

Bingham, Mr. 372.

Binney, Dr. '28.

Binney, Mr. 586

Bladensburg, Md. 543, 544, 557, 581 .

Blair, Will, witnesses McHenry's will 5.

Bland, Dr. 123.

Blodget, 545.

Blount, Gov. Wm. 175, 262, 268, $269,448,449$.

Boissy d'Anglois 275 .

Bolman 288, 332 .

Bonaparte, Napoleon 208, 232, 238 , $277,285,331,430,473,487,494$, $507,533,540,541,543,579,584$, $587,592,597,598,602,609$.
Bond, Mr., Britlsh chargé des affalres to U. S. 161 .

Books bought by McHenry 229, 242, $243,246,274$.

Boole Lt. 432

Boston 200, 236, 274, 367, 397, 407,

$413,504,505,540,551,559,567$.

Boston Patriot $55.2,566,567,569$.

Botetourt, Va. 1.47.

Boudinot, Elias 15, 16

Bourdeaux, France 235.

Bourgoing, M. 430 .

Bowie, Walter 137.

Boyd, James P. 76, 542, 554, 607, 611.

Boyd, Mary 76

Boyd, James McHenry 76 .

Boyd, Andrew 76 .

Boyd, John Pillar 76 .

Boyd, Anna, see McHenry.

Boylton, Capt. 235.

Bradford, Capt. 50

Brant, Joseph (Thayendanega) 169

Breck, Miss 372.

Bremen, Germany 283, 343.

Bristol, Penn. 399.

British hospitals at New York 10 to 14 .

British prisoners at Frederick 43 Brooks, Gen. 319, 322.

Brown, F. J., author of sketch of James McHenry 2

Brownjohn, Dr. 13.

Brownsville 270.

Bruff, Capt. 171, 174.

Buchanan, James 461, 583.

Buchanan, J. A. 306.

Bucks Co., Pa. $432,437$.

Bullers, Dr. 540 .

Burke, Rev. Edmund 173.

Burke, Edmund 209.

Burr, Aaron 200, 204, 471, 472, 482, 483,484 to 490,492 , campaign for Governor and duel with Hamilton 529,530 , conspiracy $533,534,548$. Burrows, Major $354,355$.

Burrows, - 257.

Bushtown, Md. 98

Butler, Col. 19, 268, 447.

Butler, Capt. 383.

CABARRUS 243 .

Cabot, George 212, 213, 226, 463, $464,470$.

Cadwalader, Mr. 41.

Caldwell, John 26, $75,117,260,473$, 497.

Caldwell, Margaret, see McHenry.

Caldwell, Mrs. Margaret 75, 120.

Caldwell, David 75 .

Caldwell, - 608, 609

Calhoun, James 211.

Callender's "Prospect before Us" 547,572 .

Calonne, M. de 87 .

Calvert, Frederick, Lord Baltimore 67.

Calvert, George, Lord Baltimore 525 .

Campbell, Mr. 335, 482.

Cambridge, Mass. 4, 6 . 
Cambridge, Md. 142, 189, 195, 198 , $208,511$.

Campion, M. 93, 94.

Canada 86, McHenry plans trip thither 8 , fears England will cede to France 250 , named 265,515 , $581,594,609$.

Canning, George 343.

Cape Francois 191, 192

Cape of Good Hope 247.

Capua, Italy 373 .

Caracas, Venezuela 533.

Carey, Jas. 261.

Carleton, Sir Guy, Lord Dorchester. $47,49,173$

Carlisle, Pa. 410

Carlyle, Mr. 38.

Carmichael, Mr. 108

Carnot, M, 276, 279

Caroline County, Md. 136, 199.

Carondelet, Baron de $260,261,269$

Carper, Mr. 147, 148.

Carrington, Col. E. declines Sec. of

War 163, accepts brig. gen. 314 . 388 , on election of 1800469 .

Carroll, Charles, of Carrollton, 97

108,115 , friendly to Jefferson 136 , 137 wrote Hamilton in 1792139 , resigns from U. S. Senate 139 , in Id. Senate 154 , writes of French affairs $202,204,250$, approves of Washington's address 206, writes 305 , named $306,431,461,463,468$ to $470, .472,476,479,500$.

Carroll, Bishop John, controls German Catholies 137,138 , writes on Indian missions 171,173 , Pickering's opinion of 604 .

Carroll, Daniel $59,62,87,97,100$ to 104,106 to 108 .

Carter, Mrs. Angelina (Schuyler) 44,45 .

Carter, Chas. Jr. 317, 318.

Carter, John 44, 45.

Carter, Wm. Champe 317.

Cary, Wilson Miles 2, 76 .

Cary, Sarah Nicholas 76 .

Casberry, Mr. 57.

Caughnawaga, (Cohnawaga) 169. 170.

Cecil Furnace, Md. 181.

Ceylon 247.

Chamberlain, Mr. 140.

Champagny, M. $539,540,543$ to

545.

Championnet, M. 373 .

Champlin, Mr. 463.

Chandier, Gen. 600

Chapin, Indian Superintendent, 169.

Charles I. King of England 525 .

Charles II. King of England 525 .

Charles, Prince of Austria 5.66.

Charles XII of Sweden 587 .

Charleston, S. C. 49, 56, 92, 93, 142 , 235.

Charlotte, N. C. 266.

Charlottesville, Va. 388.

Chase, Samuel $41,46,59,83,88,95$, $97,108,110,113,114,137,153$, $158,160,547,552,564$, asked by Washington through McHenry to accept seat in Sup. Ct. 163, ac- cepts 164, 168, opinion as to

Wayne 193, of France in 1796203 . 205 , invests in Western lands 273 , opinion as to printer 431 , regrets McHenry's resignation 456 , in Presidential election of 1800463 , 465,469 , impeached 547 .

Chase, Jeremiah T. $7,465,469$.

Chastellux, M. de $31,525,526$.

Chastellux, Mme. 525 .

Chastellux, Alfred 5.25 to 527 .

Cherokee Indians $174,175,260$ to $262,273,445$ to 449 .

Cherry Tree Meadows, Md. 587, $590,596$.

Chesapeake Bay 106,536,577.

Chesapeake, U. S. S. 537, 538, 542, 599,601 .

Chester, Pa. 54, 318

Chestertown, Md. $13 \mathrm{~s}$

Chippewa Indians 443

Chisholm, John D. 177.

Choptank River 142 .

Christie, Gabriel 198, 199.

Church, John Carter 44, 45.

Church, Philip 319.

Cincinnati, Ohlo 261 .

Cincinnati Society $\$ 7$.

Claiborne, T. 389 .

Clapham, Mr. 67.

Clark, Mr. 335.

Clarkson, Genl. 532

Clay, Henry 564

Clinton, Dewitt 580, 581, 584, 585 ,

587.

Clive, Lieut. 26 .

Cobb, Genl. 319.

Cobenzl, Count 343,344 .

Cochran, Capt. 432, 437.

Cochran, John 76.

Cocke, Wm. 268.

Cole, Mr. 256.

Commerce, Federal Regulation of 90,91 .

Conde, Prince de 237 .

Congress, Continental, passes resoJutions commending McHenry 8, commissions McHenry as Major 32 , Gov. Lee writes it of Md. 38 , McHenry dissuades Hamilton from membership in it 44 , peace negotiations 47, McHenry enters it 5.5. his service in it $56,57,59,62,67$, $78,82,83,87,88$, Md's. contributions of money to 89 , regulation of commerce by 90 .

Congressional election of $1792 \quad 136$ to 139

Congressional election of $1794 \quad 156$. Congressional election of $1796 \quad 196$ to 199.

Connecticut $106,328,351,377,378$, $392,393,398,399,436,462,469$, $477,481,483,508,518,585,602$.

Connecticut cider 470 .

Constable IVm 354

Constellation, Frigate $\mathbf{2 5 1}$ to $\mathbf{2 5 6}$. 302.

Constiturtion of U. S., Adoption of 94,96 to 113

Constitution, Amendments proposed to $132,139,144,154$ 
Consuls 89.

Contee, Mr. 108.

Cook, Wm. 546.

Cooke, Mr. 521.

Cooper, John 435.

Copenhagen, Denmark 430.

Cornwallis, Lord 38, 507, 508.

Coulter, John 108, 114, 115.

Coxe, Mr. 449.

Coxe, Daniel 269, 270.

Coxe, Tench $108,140,142,420,468$.

Coxe, Zachariah 266, 267, 269, 271,

$272,440,448,449$.

Crabb, Mr. 198

Craik, Dr. 118,310

Cralk, Mr. 132, 134, 223, 463.

Creek Indians 174, 175, 261.

Cromwell, Oliver 525 .

Crookshank's Tavern 118.

Cuipepper, Va. 317.

Cumberland, Tenn. 171.

Cumberland River 261, 272.

Cumberland, Mfd. 554.

Cunningham, Wm. 553.

Cushing, Mr. 463 .

Custis, Eleanor P. 182,355 to 359

Custis, Washington P. $318,359,396$, 411.

Cutter, Mr. 512.

Cutting, John B. 97, 113.

DALE, Commodore 302, 511 .

Dalias, Mr. 201.

Dalmatia 232.

Dana, Mr. 234, 235, 481, 547, 568, 595.

Dandridge, Mr. 183, 187, 227, 341 to 343,371 .

Davenport, Anthony \& Moses 236. Davenport, Major John, Jr. 596 , 597,602 .

Davie, Genl. Wm. R. 266, 371, 411, 416 to $418,450,566$.

Dayton, Gen. 319, 345 .

Deakins, Mr. 204.

Dearborn 550,551 .

Debt of U. S. 109,602

De Bute, Dr. Louls 11 to 13 .

De Costa, Capt. 191.

Delacroix, M. 301.

Delaware River \& State 142,195 $198,463,464,472,483,492,504$.

Del Campo, Marquis 243.

De Lesa, Manuel 263.

Delft, Holland 249.

Delozier, Daniel, suggested for office 138 .

Dember's Artillery 264

Denmark 331.

Dennis, John 199, $244,301$.

Dent, Mr. 463

D'Entrigue, Comte 279

Deserters 381,382 .

D'Estade, M. 229.

Detroit, Mich. 173, 265, 441, 443.

De Winter, Adml. 285.

Dexter, Samuel $169,458,463,465$, $482,483,610$.

Dickinson, Philemon $465,468,469$, $471,472,478,482$.

Digby, Adml. 47.

Dillon, Thomas 171 .
Dinsmoor, Silas $175,261,447$.

Diplomatic service 89 .

Done, Mr. 197.

Dorchester, Lord, see Carleton.

Dorchester Co., Md. 142, 198, 199. 201.

Dorsey's Ferry 2.

Dorsey, Mr. 306 .

Dorsey, W. 198.

Dorsey, Walter 572 .

Doughoregan Manor, Md. 250 .

Downingstown, Penn. 257.

Drayton, Gen. 313.

Drayton, Wm. 92.

Duane, 572.

Du Bourg. Wm. 143.

Duck River, 261.

Dulany, Mrs. Nancy 49 .

Dumas, M. 275 .

Dumfries 236 .

Dumfries, Va. $93,261$.

Du Mourlez, M. 430.

Dunbar, Mrs. 120.

Duncan, Adml. $238,285$.

Duncan, Mr. 586 .

Dunkinson, Mr. 195

Dunlap, Jas., named in McHenry's wili 5 .

Duniop (printer) 100

Dupont, Victor \& Co. 510

Duvall, Gabriel 204, 473.

Duvall, - 559 .

D'Yrujo, Spanish Minister 261, 266. 269.

EAst Chester, N. Y. 230, 258, 259, 399.

Eastern Shore 132, 134, 136, 142, 157.

Easton, Pa. 336, 436, 437, 504 .

Eccleston 140, 141, 197, 201.

Eden, Sir Robert 66.

Education in Md. supported by MCHenry 144, 154, 155.

Ehrenbreitstein, Germany 375 .

Elbe River 238 .

Elk River, Head of $35,54,78$.

Ellicott, Mr. $178,261,263,269,270$.

Elliot, Capt. 373, 391, 402.

Ellsworth, Oliver $371,416,417,424$, $495,496,566$.

Embargo of $1807539,542,544$ to

546,550

Embargo of 1812576.

Emmot, Mr. 576 .

English Privateers 144.

England, Bank of 89 .

Epes, Mr. 551, 557, 562, 565 .

Erle, Lake 609

Eustis, Dr., Sec. of War, 589.

Evans, Walter 271, 272.

Falling Springs, Va. 121.

Farris, Jas., Jr. 271, 272.

Fauchet 159, 160, 572 .

Federal Gazette 596 .

Federal Republican, The 580.

Federalist, The 110 .

Fenno's Gazette 230, 241, 246, 266, $372,394,456$.

Fishkill, N. Y. 25.

Fitzherbert, Mr. 50 . 
Fitzpatrick, Gen. 510 .

Fitzsimmons, Mr. 105 .

Fleury, Ime de 429 .

Flint, Daniel 435 .

Flint Parker \& Co. 110

Florida, Boundary of $178,261,295$.

Florida, 395, 438, 440, 5.24, 559, 560 562 .

Foncier, J. 613.

Ford, Major $\$ 33$.

Foreign trade, McHenry's views as to 142,619 .

Forrest, Uriah 77, 115, urges McHenry for U. S. Senate 145, 161, on Md. politics 198 , writes 305 .

Fort Jay 432 .

Fort McHenry 144, 406, 613

Fort Massac $264,272,440$ to 442 .

Fort Mifflin, Penn. 2s9, 377.

Fort Ontario 174.

Fort Washington 9, 261

Fort Wayne 265, 440 .

Fortifications $256,288,367,406$, 450 .

Foster. Mr. 542, 574.

Fox, itr. 510

Fox, Josiah 180, 181

France, Revolution i7s, 193, 224 , $237,238,247,275$ \& ff. 329,331 .

France, foreign policy in Europe $22 S$ to 234,236 to 238,245 to 247 . $277,341,343,372$ to $375,430,506$ $507,524,598,602,609$.

France, relations with Indians 260 .

France, intrigues in West 264 to

$266,272,438,439,516$.

France, privateers $142,143,191$ to $193,195,235,292,302$.

France, relations with, in 1796187 to 195,201 to 206 .

France rejects Pinckney 208 to 222

France, relations with, in 1797216 to 225,228 to $235,240,242$ to 252 $257,276,277,288$.

France, captures of our vessels 235 , $236,245,276$.

France, government, X. Y. Z. mission $274 \mathrm{ff}, 284,286,289$ to 301 , $304,307$.

France, relations with, in 1798302 to $305,315,329,331,343,370$, 440.

France in West Indies 42, 43, 191 , 315.

France, French Sallors recruited at Baltimore 143.

France, relations with, after nomination of envoys $370,393,406$ to 409,416 to $420,429,453,454,473$ to $475,482,487,490,493$ to 496 , $506,557,558,566,567,570,606$.

France, relations with, in Revolution $87,94,109,508$.

France, relations with, in 1806 and following years $535,536,538,540$, 542 to $545,549,551$.

France, relations with under Madison $559,562,565,570,573,575$, 581.

Francis, Tench $391,396,411$.

Franklin, Benjamin 52, 87, 89, 107.
Frederick, Md. 146, 152, British prisoners at 43 .

French, Mrs. 515.

Freneau, Philip 5ं72.

Frey, Capt. 402 to $404,433$.

Fries's Rebellion 418, 431 to 437 .

Fries, Mr. $436,437$.

Friuli, Italy 229,232

Furguson, Henderson \& Gitson, 236 .

Gale, Geo. $11 \overline{5}, 141,142$.

Gallatin, Albert 2:2, 334, McHenry's opinion of 500 to 502,517 ,

$554,561,599,601$.

Ganevain, John 143

Gardoqui (Spanish minister) $\$ 3$.

Gayoso, 261, 26y, 440 .

Genet $173,201,203,551,572$.

Genoa, Italy $229,246,276$.

Georgetown. D. C. $59,195,303,453$.

$492,511,512,534,542,543,612$.

Georgia $272,32 S, 360,363,37 i, 449$, 459.

Georgia relations with Indians 174 , 186.

German Empire 229, 232, 239, 279, 331.

Gerry, Elbridge, IIcHenry's experience with, 224, 225, on embassy $274,275,299,300,397,373,463$, named $67,104,569,570,576$.

Ghent, Belgium 613.

Gibbon, Edward $22 \dot{S}$.

Gibbs, Major 26 .

Gibbs, Caleb 435 .

Gibson. Gen. 259.

Giles, Wm. B. $534,551,560$.

Giles, Major Edward 41 .

Gilmor, 294, 531, 534 .

Gllpin 204

Godoy, Prince of the Peace 261 .

Goode, Mr. 389.

Goodhue, Benjamin 199, 200, 458, 463.

Gordon, Dr. William, historian 37.

Gorham, Mr. 105.

Gouvion, Col. 87 .

Gracie, Mr. 532.

Grant's Tavern 118, 126.

Grave Creek 438.

Graybil. Capt. 499.

Great Britain, relations with U. S. before $1901,166,195,220,231$, $232,235,250,294,295,329,408$, $416,470,508,521$.

Great Britain, relations with France 228, 229, 231, 238, 243. $247,277,280,293,298,315,330$, $343,495,506,524$

Great Britain, intrigues in West, $261,265,266,269,284$.

Great Britain, relations with $U$. S. after $1801508,521,534,536$ to $545,549,555$.

Great Britain, relations under Madison, $560,562,565$.

Great Britain. War of 1812 with 573 to $579,581,584,589,592,593$, 595,598 to 601,609 to 613 .

Great Britain, neace with, in 1783 $47,4 \mathrm{~S}, 50,51,55,71$. 
Great Britain, navigation laws 90 , 91.

Great Britain, trade with 129,131 , 619

Greenbrook 410 .

Greene, Gen. Nathaniel, gives Mc Henry oath of allegiance 17 , wishes MeHenry as aid 31, writes Lafayette of war at South 35 , writes McHenry from Guilford Court House 37 , from high Hills of Santee 38 , referred to 39 , writes McHenry 178356 , Lafayette suggests statue of 89 .

Greenleaf, Mr. 200.

Greville, Mr. 47, 49.

Griswold, Roger 481, 512 to 514 .

Guilford Court House 37.

Guion, Capt. 264, 265

Gunn, Gen $360,366,367$.

HabershaM, Mr. 174.

Hacker, Capt. 289.

Hague, The 125, 226, 228, 229, 248 , $281,255,299,341,343,371,429$ $453,496,558$.

Hague, The, Embassy at 238, 239 299 .

Haiti, 470

Halifax, Nova Scotia 599 .

Hall, Col. J. C. 137.

Hall, Annie Eliza 76 .

Hall, Martha 125 .

Hamburg, Germany 1ss, 210, 283 . 341,372,

Hamden, Lord 228.

Hamilton, Alexander, writes McHenry $17781 \overline{5}$, is prescribed for by MicHenry 17, in Washington's military family 19 , McHenry defends his bravery 20 , writes McHenry $2 \mathrm{~S}, 31$, marries 29,30 , writes McHenry of breach with Washington 34, MeHenry writes him 41, 43, Washington writes him of McHenry 51, in Constitutional Convention 100 , congratulated on Treasury Secretaryship by McHenry 123, McHenry approves his plan for U. S. Bank 129, corresponds with McHenry on appointments to office 129,130 , $138,141,142$, McHenry asks his advice as to accepting position in Md. Senate 131, correspondence on Congressional election of 1792 136,137 , slandered by Mercer 137 instructions as to privateers 143 , Monroe protests against sending him as minister to Great Britain 144, resigns Secretaryship 155 , $156,158,159$, suggests MeHenry to Washington for Secretaryship of State 161, friendship for McHenry 615, advises McHenry on various matters $166,167,180,183$ and advises sending McHenry to France 188, warns against French war 189 , on Pinckney's rejection 212,213 to 223 , influence on McHenry $225,291,295$, writes on Spanish relations 266 , on $\mathrm{N}$. $\mathrm{Y}$. forts 288,289 , on French relations Jan. 1798291,302 , Harper complains of McHenry to him 301 , named 304,307 , question of precedence as general 311 to 314,321 , 322,325 to 3218,338 to 341,344 to $346,454,605,606$, in provislonal army $315,316,319$ to 321,324 , $325,344,347,351$ to 353,360 to 363,365 to 367 , complains of McHenry to Washington 319,347 , general in army 1799375 to 378 , $381,382,384$ to 387,390 to 392 , 394 to 400,409 to 411,413 to 415 417 , 418, suggested for president 389 , writes on dispute with McHenry as to subordinate officers 402 to 405 , receives a game from McHenry 395 , on Washington's death 421 , commands in West 440 to $444,450,451$, in presidentlal campaign of 1800452 to 454,456 to $458,461,463,466,469,478$, 479 , attacks Adams $455,461,464$, $472,475,476,480,481,567$, opposes Burr for President 484 to $4 \mathrm{SS}$, named 496,505,506, attacked by Adams $56 \mathrm{~S}, 569,571$, his military knowledge 572, in Army 368 , 422,424 to $426,42 \mathrm{~S}, 429,566$, in Fries's Insurrection 432 to 434 , 437 , his death 529 to 532 .

Hamilton, Mrs. Alexander 29, 45, $129,55 \mathrm{~s}$.

Hamilton, Philip 505.

Hamilton, Major $263,264$.

Hamilton, Sec. of Navy, 590.

Hammersly, Mr. 140.

Hammond, Abijah 354

Hammond, British minister to U. S. 160,161 .

Hammond, Mr. 133 to 135.

Hampshire Co., Mass. 546.

Hamtranck, Col. 441 to 444 .

Hancock, Md. ј̄ 3 .

Hanover, 238.

Hanson, Alexander Contee 108, 124. 580 .

Harford Co., Md. 109, 125.

Harford, Henry 67.

Harned, David 118.

Harper, R. G. 285, 298, 301, 304, $407,430,434,45 S, 464,521,572$, 583.

Harper's Ferry arsenal 182, 183 , $307,391,401,402,415$.

Harris, Dr. 336

Harrison, Col. 195

Harrison, R. H. 124 .

Harrison, William Henry 261, 263, 609.

Hartford Convention 613.

Harwich, England 343 .

Haverstraw, N. Y. 21, 23, 31.

Havre, France 496.

Hawkins, Dr. 12.

Hawkins, Benjamin 175, 177, 407.

Hay, Col. 23.

Hays, Capt. 388 .

Heath, Col. 388 .

Helder, The $226,227$.

Hemsley, Mr. 197. 
Henly, Col., Indian agt. 171.

Henley, Capt. Samuel 318.

Henry, John 115, 139, 141, 156, 204 , $222,223,306,307,575$.

Henry, Patrick 371, 408, 416.

Henry, Capt. 432, 437.

Hewes, Mr. $5 \$ 2$.

Hierschell's Tavern 118 .

Hill, Mr. 372 .

Hillhouse, Mr. 533, 548, 54.9, 551.

Hillsboro, N. C. 445 .

Hindman, Wm. candidate for Congress 1792136 , in 1796197 to 199 on Pinckney's rejection 208 , writes McHenry $249,271,301,3.03,334$ to 336 , on Jefferson's election 489 . Hitchborn, Col, 373,374 .

Hite, Mr. 365 .

Hoche, Lazare 238.

Hodge, Dr. Hugh 13.

Hodgdon, Mr. 181.

Hodgsdon, Mr. 386

Holland 227 to $250,274,281,283$ $285,300,301,330,331,343,465$, 495 , debt to 109 .

Holland Co. 485 .

Hollingsworth, Mr. 133 to 136,299 , 306.

Holstein, Denmark 287, 328.

Holston River, 171, 267.

Holston Treaty 175 .

Hooper, Mr. 142.

Hoops, Major 402, 404, 433.

Hopkins, Major 138.

Hopkinson, 586.

Horner, Miss 60 .

Hornet, The 577 .

Horry 238.

Howard, John Eager 39, 76, 115, 143 , declines Sec. of war 163 , suggested for Congress 194, elected to U. S. Senate 202,205 , named 319 $370,396,572$.

Howard, James 572 .

Howard. Jullana Elizabeth 76 .

Howe, Sir Willam 9, 10, 13, 14.

Huger, Mr. 288, 332, 333.

Hugues, Victor 192

Humphreys, David 86, 180.

Humphreys, Capt. 537.

Huntington, Gen. 363 .

Hutchinson, Dr. James, writes McHenry 15.

Hutton, Gaun M. 497.

Hydestown, N. J. 13, 15.

ILLINOIS Indians 172.

Illinois country $265,273$.

Indian affairs in 1796168 to 178 .

Indian affairs in $1797259,261,262$ 266 to 269,271 to 273,438 .

Indian affiairs in $1799407,418,441$

to 443,445 to $451,513,515$.

Indian education $176,177,261$.

Indian missions 171 to 173,176 .

Indians 86,609 .

Indians killed near Pittsburg 129.

Intendant of Md. 41.

Ireland 525 .

Iroquois Indians $169,170$.

Istria 232.

Italy $229,232,494$.
Izard, Capt. 284.

JACkson, Andrew 177.

Jackson, - 435,466 .

Jackson, Jonathan 476 .

Jackson, British minister 554 to

556,560 .

Jamestown, Va. 38 .

James River 39.

James Island 38

Jannin, Rev. 271.

Jay, John $87,155,19 \&, 289,311$, 456,551 , refuses Chlef Justiceship 489 to 491 .

Jay Treaty $170,179,194,200,284$, 296.

Jefferson, Geo. 547.

Jefferson, Thos. 97, $10 \mathrm{~S}, 113,121$, 158 , corresponds with McHenry on business 12S, on politics 136 , relations to U. S. Constitution 137 , Chas. Carroll's opinion of 139 named 190,191 , defeated in 1796 198 to 200,203 to $205,212,213$, $229,2 S 8,306,317,334,335,3 \$ 9$, in presidential campaign of 1800 452,455 to 457,459 to 461,463 , $465,466,473,482$ to 485,488 to $490,492,493$, as president 500 , $502,508,512,533,534,536$ to 542,544 to $548,550,552,556,557$, 561,564 , on war of 1812582,592 , $593,595,606,609$.

Jellico 261,448 .

Jenifer, Daniel, of St. Thomas, 42, S9, 90, 97, 99 to $104,106,107,132$. Johnson, John 266, 267.

Johnson, Judge 551 .

Johnson, Louisa 241 .

Johnson, Thomas 55, 97, 108, 112 , $113,115,124,161$

Jones, David 264

Jones, Wm $59 \overline{\mathbf{6}}$.

Jonesborough, Tenn, 266 .

Jourdan, Camille 279.

Judiclary, Act of 1802508 .

Juimpi, Lt. $287,288$.

KANAWHA Lands $60 \mathrm{~S}$.

Kentucky 111, 118, 261, 264, 271, $272,363,377,438,516,573$.

Kentucky Resolutions 436 .

Key, Philip 202, 204 to 206 .

Kilty, Wm. 143.

King, Rufus, writes of Pinckney's rejection 208, named 294,298, 315. $371,392,505,508,509$. suggested as vice president $5 \$ 1,584$.

Knox, Henry $108,155,156.158$, $164,254,255,312$ to 314,319 to 323,325 to $328,337,338,340,346$ to $350,378,454,605,606$.

Knox, Col. 119.

Knox, Mr. 261.

Knoxville, Tenn. 171, 267, 447, 448. Kosciusko, Genl. 288 .

Kreyesteln, Adml. 285 .

LABIGar, Mr. 191.

Lafayette, G. M. de 19, 51, 97, .13T, McHenry on his staff 29, writes McHenry on French and English 
liberty 32, takes command of forces in $\mathrm{Va} .35,38$, stops at Baltimore 36, has McHenry with him in Virginia campaign 37 , wishes McHenry as secretary 53 , writes from Paris 87, 90, sends animais to Washington 92, mentioned 128 , project to buy house for in Washington 133, McHenry asks to be sent to secure his release 144, 145, writes McHenry $287,328,406,429,430,487,506$, $509,511,523,526,541,572,615$.

Lafayette, G. W. $184,185,332,542$.

Lafayette, Mme. $287,328,510,528$, 541.

Lafayette, Noailles 288.

La Grange, France 429,506, 509 , $5.24,572$.

Lancaster, Pa. 436, 571 .

Larned, Mr. 169.

Latour, Maubourg, 287.

Laurens, Henry 20.

Laurens, Col. John 20

L'Aussat, Prefect of New Orleans 528.

Lauzon, Gen. 49.

Law, Thomas อ2 4

Law, Mrs. 324

Lear. Tobias 1S3, 354, 365, 376.

Ine Couteulx, Messrs. 129.

Ledyard, John 484.

Lee, Archibald 612.

Lee, Charles, Atty. Gen. under Washington 166,183 , under Adams 208, 224, 258, 370,382 to $384,401,417,419,424,438,453$, 566 , letter from 505 .

Lee, Gen. Charles 19, 20.

Lee, Gen. Henry 165, 210, 314, 484

Lee, Gen. 388, 425.

Lee, J. 108.

Lee, Gov. Thos. Sim 37, 38, 108, 143.

Le Freire, Chev. 161, 185, 186.

Leopard, H. M. S. 537 .

Lepeaux, M. 279 .

Letomb, M. 436 .

Lewis, Capt. 185

Lewis, Major 173,174 .

Lewis, Lawrence $318,359$.

Lewis, S. 513 .

Lewis, T. $272,497$.

Leyden, Holland 242, 281.

Llancourt 430.

Liberty, French \& English, compared by Lafayette 32 .

Lindsay, Mr. 43.

Lingan, Gen. 580

Lisbon, Portugal 240, 282, 2\$8, 372 , $456,458,505$.

Lisle, Belgium 238, 243, 280.

Liston, British Minister 185, 186 , 461 .

Litchfield, Conn. 350, 392, 393, 416 , 436.

Little, Mr. 573.

Livingston, Mr. 234.

Livingston, $R, R=5$ to 53,517 .

Lloyd, Col. 134.

Lloyd, Edward 59 .

Lloyd, Jas. 55, 138, 305, 306, 396.
Lodge, H. C. 226 .

Loftus Heights $450,451$.

Lombardy, 246.

London, England 52, 53, 195, 208, $211,296,343,423,505,538,539$, 575,594

L'Orient, France 93, 235.

Ioring, Joseph, Commissary of Prisoners at N. Y. 10, 11, 14.

Louis, Col. 170.

Louis XVI of France 551 :

Louis XVIII of France 566

Louisiana $260,263,315,395,440$, 515 to 517,522 .

Loulsiana Treaty 520, 521, 524 .

Lynn, Mass, 204.

Lynn, Col. John 553, 554, 583, 587. Lyon, Matthew 493.

MaAs Sluys 241 .

Maas River 343 .

McA.lpin, Mr. $369,390$.

MeCurdy, Mr. 498 to 500 .

McGaw, Col. Robt. 9, 12.

Macharg, Mr. 317.

MeHenry, Agnes 1, 2.

McHenry, Anna 1.

McHenry, Anna [Mrs. Boyd] 75 $482,521,554,609$ to 611,61 .

McHenry, Charles Howard $\mathbf{7 6}$.

McHenry, Daniel, settles in Baitimore as merchant 1 , death 2 , James McHenry names him in will 4 , receives letters from son 16 , 23 , dies 50 .

MeHenry, Daniel William 75, 118, $119,123,482,497,521,587,610$. McHenry, Grace 75, 77, 505 .

McHenry, James, birth 1, 2, early education 1, emigration to America 1, at Newark Academy 2 writes verses 2 to $4,60,77,83$, portraits 2 , studies medicine 4 enters Continental army 4, will 4 , surgeon at Cambridge, Mass. 6, receives resolution of commendation from Congress 8, surgeon Fifth Pa. Bat. (McGaw's) at Fort Washington 9, prisoner at New York 9, writes of hospital life there 10 , paroled 14 , exchanged 15, summoned to Washington's camp 16, appointed military secretary 16, 17, prescribes for Hamilton 17, at Monmouth 19, defends Hamilton 20, marches with Washington to Haverstraw 22, 23, receives no pay $28,48,132$, plans European trip 28, on Lafayette's staff 29, at Hamilton's wedding 29,30 , seeks definite military rank 31, discovers Arnold's treason 31 , wishes to join Greene 31 . is commissioned as Major 32, returns to Baltimore $3,2,35$, entry into political life suggested by Lafayette 34 , induces Baltimore merchants to aid Continental army and gives money to it himself 35 , goes to Annapolis 36 , in Virginia campaign 37 to 39 , elected to Maryland Senate 41, writes 
Hamilton of prospects in Jife 43, illness $36,43,45,43,117,138,144$, his father dies 50 , tries to enter the diplomatic service $51,123,131$, elected to Congress 515 , speech on Pennsylvania mutineers 57, services in Maryland Senate 56, 58, $59,62,70,89,92$, services in Congress $56,57,59,62,78,82,83,87,89$, 92 , member constitutional convention of 178796 to 107 , absence through brother's illness 100 , member in Maryland ratifying convention 108 to 1.13 , loveletters 59,61 to 71 marriage $62,64,71$, 73,75 to 77 , children 75 , letters while at Annapolis 78 \& ff., letters to wife from Pliladelphia 98, 104, 106 , from Sweet Springs, Virginla 117,179 , arranges for Washington's resignation 67 , member 1 st Presbyterian Church 75, salary as Congressman 89 , as delegate to Constitutional Convention 98, corresponds with Washington on fed eral regulation of commerce 90 , opposes instruction of representatives $9 \overline{5}$, member House of Delegates $114,123,124,145$ to 153 , invites Washington to visit him $116,117,133,135$, retires from public life because of brother's death 126, 129, 130, 159, writes Jefferson on mercantile business in Paris 128, chosen again to State Senate 130 , corresponds with Washington and Hamilton on appointments to office 130,132 to 136,138 to 142 , second service in Senate 131 to $133,139,144,154$, 162 pushes project to buy Lafayette a house 133, supports Adams in 1792,137 , atacks Mercer 136 to 138 , suggested for U. S. Senate 139,145 , solicits subscriptions for French refugees 142, asks Washington to be sent to secure Lafayette's release 144 , suggested by Hamilton as Secretary of State Hamilon appointed Secretary of War 163 , accepts 164 , enters on office 168 , attends to Indlan affalrs 169 to 179 , naval affalrs 180 to 182 , military affalrs in $1796 \quad 182$ to 184,186 , regrets Washington's retirement 193 , continues in cabinet under Adams 208, writes Washington of illness in $1796 \quad 182$, com mends Banneker 127, Pinckney's rejection 209 , enfoys work 211 . consults with Hamilton as how to advise Adams on Pinckney's rejection 210 to 223 , his opinion of the triple embassy 224 to 226 . Murray buys him military books $229,242,243,246$, attends to naval affairs in 1797251 to 256 , recommends fortifications 256, recelves wine cooler from Washington 257, leaves Philadelphia on account of yellow fever 257 , is ill $258,290,311,321,324,327$, con- ducts Western and Indian affairs 260,268 to 274 , buys books from Pinckney 274 , directs forts at $N$. Y. 288,289 , asks Hamilton to help as to policy 291, dissatisfaction with 302 , naval affairs 302 , consults Hamilton May, 1798, 302, relinquishes navy May, 1798, 303, policy towards France 302 , writes Washington of Gerry 307 , hopes for Washington's repose 308 , calls Washington to lead army 309 , visits $\mathrm{Mt}$. Vernon 311,312 , precedence of generals 312 to 348 , consults Hamilton 313 , writes Washington 316,317 , on appointments 319 , consults with Hamilton 344 , 360 , procures colors for Mliss Custis 355 to 359 , his management of war affairs in 1799375 to 406,409 to 416, Adams asks information for message 418, Wolcott's opinion of 422 , ill 469,556 , supposed to write Three Patriots 572 , dismissed by Adams 453 to 458,465 , 467,469 , takes part in Maryland politics in 1811 5\%, in presidential campaign of 1500459 to 497 . complained of by Hamilton and Washington $319,320,322$ to 324 , corresponds with Washington 336 , 339,340 , cleared of intrigue $33 \mathrm{~S}$, 339 , takes house at Georgetown $453,513,515$, country place 397 . defends administration of department 467,511 to $519,556,604$, compiles Baltimore Directory in 1807535 , writes book which was lost 558 , president Baltimore Bible Society 607 , owns Kanawha lands 608 , is paralyzed $5 \$ 7,607,610$, 611,614 , spends time in Allegany County 586 to 607 , dies 615 , articles on British trade in 17946619 letters from, printed elsewhere 622 , autograph letters sold 624 .

McHenry, James, Jr. $i 6$.

MeHenry, Jas. Howard 76. 558.

McHenry, John (brother of James) settles in Baltimore as merchan: 1, his mercantile career 2, James McHenry names him in will 4,5 , James McHenry in Jan. 1776 dissuades hlm from enlistment or return to Europe 6, writes James McHenry 24, partner with him 50 , goes to his wedding 64,71 , illness $97,100,117,120,121,123$, dies 125, mentioned 132.

McHenry, John, Jr. on uncle's acceptance of secretaryship 163 , mentioned $229,284,285$, goes to Holland 341 to $343,371,453,495,496$. on uncle's character $29,125,497$.

McHenry, John (son of Jas.) 76 , $482,520,521$, goes to Europe 541 . farming \&c. $554,610,611,614,615$. MeHenry, John (son of Jas. Howard) 76 .

McHenry, Juliana 76 
McHenry, Margaret C. 1, 53, 163, 164, $166,183,185,227,229,241,258$, $284,299,301,343,357,359,438$, $460,461,482,484,489,505,508$, 511,517 to $519,521,523,1525,528$, $529,574,587,604,609$, birth 2 love of James McHenry 27, 59, 61 to 71 , marriage 72 to 75 , children 75,76 , letters from husband $78,98,104,106,117,146$ to 153 . writes of family afflictions, \&c. $610,611,614,615$.

McHenry, Margaretta, 76, 482, 553, 556.

McHenry, Ramsay, 75, opinion of James McHenry 29.

McHenry, Wilson Cary $\mathbf{7 6}$.

Mack, Gen. 373.

Mackay, Mr. 104.

McKean, Thomas 420, 435 .

MeKim, Isaac 191.

Mackinac, Mich. 265, 443.

MeLaughlin, Mr. 89

McLure, Jas. 20

Macon's bill. 554,556

MeMechen, David, 108, 114, 202.

MePherson, Gen. $389,435,436$.

Madagascar 275 .

Madison, Bishop Jas, 149.

Madison, James $51,104,108,112$ $161,212,213,273,335,502,511$, $512,540,542,544$, president of the U. S. $555,556,559$ to 562,573 to 579 , his second election 580 to 587 , 591 to 593,595 , second administration $601,606,609,613$.

Magruder, Mr. $\mathbf{5 3 4}$.

Malcolm, Mr. 259.

Malbone, death of 552 .

Mallet, Dr., British surgeon general at N. Y. 11 to 13 .

Malmesbury, Lord, $238,280$.

Malta, 94, 331

Malvern Hill, Va., 38

Marbois, M. 161,275

Marcou, Mrs. 301.

Markworth. Wm. 257

Marshall, John $224,274,299,300$, $454,460,488,490,511,512,571$, 581,582 .

Marshall, Gen. 388 .

Martin, Luther, 97, 100 to 102,104 106 to $108,113,134,160,333$.

Martin, Mr. 529

Maryland General Assembly 41, 44, 95.

Maryland Delegates to Constitutional Convention 94,100,108.

Maryland House of Delegates 114 $123,124$.

Maryland Patriotism in 1781 39, 42 .

Maryland finances $41,42,89$.

Maryland will not pay McHenry

for Revolutionary services 49.

Maryland Senate $41,44,55,56,58$, $62,70,89,92,130$ to $133,139,144$ $153,162,197,202$.

Maryland accounts with U. S. 521 .

Maryland Provincial history of 525 . Marvland Stock in Bank of England 89,298 .
Maryland appropriates money for D. C. 305 .

Maryland, Washington on 324 .

Maryland in army $377,387,396,399$

Maryland Polities 1789115

Maryland Polities 1796197 to 204 .

Maryland Polities 1798305,333 .

Maryland Polities in $1800,458,461$ to $464,466,469,470,472,479$ $482,489,492,493$.

Maryland Polities in Jefferson's administration 519 .

Maryland Politics in 1809554.

Maryland Politics in 1811572 .

Maryland Polities in 1812581,584 , $585,587$.

Maryland Polities in 1813.600 .

Maryland trade with Great Britaln, 619.

Mason, Dr. 558.

Mason, George 106 .

Massachusetts $398,399,409,435$, $456,472,476,477,483,518,537$, $551,556,567,575$ to $578,585,600$. Massena, Marshal 494.

Massie, Major 122,123

Matthews, Mr. 198, 199.

Mauberg, M. 430 .

Mazzeí, 490, 548 .

Meade, Mr. 397.

Mentzes, Dr. exchanged for McHenry 15

Mercer, John T. 97, 100 to 104,107 , 108, 113, MeHenry's oplnion of 134, candidate for Congress 136, 137.

Meredith. Mr. 586 .

Miami River 173

Middle States 377 .

Middlebrook, N. $\mathbf{Y}, 25$.

Milan, Italy 494.

Milan Decree 574.

Miles, Col. 9, 12, 14

Miles River 136.

Military academy $363,392,397$, $422,423,425,427,457$.

Militia of Maryland 144

Millerstown 118 .

Milnor, Mr. 576.

Miranda 533.

Mississippi River and Territory 89 , $263,269,295,418,438$ to 441,443 , $449,451,516,536,551$.

Mitchell, W. 272 .

Monmouth, Battle of 19 .

Monmouth, Md. 75 .

Monroe, Jas., recall from France $188,189,193,210,298,301,389$, named $517,533,538,546,574,602$.

Montflorence, M. 238, 371 .

Montgaillard, Comte 279 .

Montgomery County, Pa. 432.

Monticello, Va. 317 .

Moore, Alfred 450 .

Moreau, Gen. 536.

Morgan, Dr. 8.

Morgan, Genl. 39, 318, 388.

Morris, $121,122,169$.

Morris, Gouverneur 105, 488, 532.

Morris, Col. 37, 40.

Morris, Robert 48, 87 . 
Mt. Vernon $174,180,182,185$ to $187,209,210,224,289,290,309$, $311,314,316,317,325,338,346$, $349,356,359,364,389,396,410$, 459,461 .

Moylan, Col. 39.

Mulin, M. 276 .

Murdock, Mr. 204.

Murray, $W \mathrm{Wm}$. Vans, recommends to office 140,141 , writes on British prize 142, on politics in 1794155 , 158 , 174, on the Randolph dispatches 159,160 , on visits to foreign ministers 161 , congratulates McHenry on appointment 164,166 , 167 , named 176 , opinion as to Wayne 183, writes on French crisis 189 , will retire from Congress $195,196,199$, writes of home affairs 195 , writes on election of $1798,197,199,200,201$, on Pinckney's rejection 208 , minister to Holland 226, letters on European affairs 227 to 250,274 to $2 S S, 299$ to $301,317,331,341$ to 345,558 , commissioner to France 370,407 , $416,419,429,460,465,557,568$, 606, writes McHenry from Paris 493, writes on return 511, dies $528,529$.

Murray, ifrs. Wm. Vans 157, 195, $227,229,2 \$ 4,299,342,343,495$, 511.

Muscle Shoals 271, 272.

Mutineers, Pennsylvania 56, 57.

Nantes, France 245 .

Nashville, Tenn. 171 .

Natchez, Miss. 261, 264, 269, 274 , $440,443,446.533$.

Natchitoches, La. 550 .

Naturalization 157.

Navy, 180 to 182,251 to 256,302 ,

$303,372,427,512,589$.

Neapolitan Territory 373,375 .

Nevill, 334.

Newark, Del. 2, 3.

Newark, N. J. 104.

Newburgh, N. Y. 46, 51 to 53 .

New Brunswick, N. J. 398, 399 $410,432$.

Newburyport, Mass. 236, 372.

New England $90,377,456,460$ to $462,466,492,546$.

New Hampshire 111, 386, 469, 472. $483,546,556,573,585$.

New Haven, Conn. 86.

New Jersey 261, 3.9S, 435, 464, 466 , $471,472,483,522,585,609$.

New London, Conn. 599.

New Madrid, Mo. 260, 264, 271.

New Orleans, La. $260,263,270$ $295,315,316,439,444,516,517$. $528,536,550,594,595$.

Newport, R. I. 115,463 .

New Windsor, N. Y. 35.

New York 38, 47, 49, 69, 90, 108 , $109,111,137,236,256,263,288$, $289,302,320,326,328,347,360$, $363,374,386,387,397$ to 399,402 , $407,410,426,428,432,457,480$ $484,489,504,505,518,521,529$,
$531,556,573,576,581,584,587$, 600,607 , British hospitals at 9, 10 , election in $1800452,454,456,458$, $459,461,463,466$.

New York State politics in 1804 530 .

New York State politics in 1812 585.

Newell, Col. 533.

Niagara $186,444,602$.

Nicholas, John 388 .

Nicholas, Wilson Cary 567, 606.

Nicholson $200,513,554$.

Nicholson, TVm. 334.

Noel, French Minlster to Holland $245,248,249,281$.

Non Intercourse bili 563,565 .

Non Importation bill 574,577 .

Nootka Sound 542 .

Forfolk, Va. 39, $208,256$.

North, Gen. 345.

Northampton Co., Pa. 432, 437.

Northampton, Mass. 546 .

North Carolina 111, 256, 268, 387. $454,456,459,464,472,553,582$, $584,585$.

North Point, Md. 610.

North River 23.

OGDEN, Col. $397,466$.

O'Hara, Mr. 533.

Ohio Co. 109

Ohio River 262, 264, 441.

Ohio, State of 585,601 .

Oliver, Dr. (refugee from Boston) $11,13$.

Oliver, Robert 211, 498, 499, 544, 580,583

Olmutz, $331,507$.

Onefda Indians 176.

Orange, Prince of $\mathbf{2 4 9}$

Orangetown 29.

Orleans, Duke of 237 .

Orleans Territory 560,562 .

Osborne, Dr. 433

Ostend, 235 .

Oswego, N. Y. 186.

Otis, H. G. $435,463,568$.

Ottawa Indians $\mathbf{4 3}$.

Otto, M. 507 .

Oxford, Md. 142 .

PAcA, William 55, 61, 65, 66, 108 , $110,113,124,134,142$.

Palmer. Mr. 612.

Papal States 229, 297, 373.

Paquiet, Rev. M. 613.

Paramus, N. J. 21, 22, 486.

Paris, France 49, 52, 128, 193, 208,

$211,235,236,238,247,248,274$ $275,277,279,285,290,297,299$, $300,344,371,373,375,494,495$. $507,510,523,541,542,546,551$, 592 .

Parish, Mr. 188.

Parker, John 290, 291.

Passaic Falls described 21.

Pastoret, M. 275.

Patterson, Mr. 437, 491.

Patterson, Wm. 36 .

Patton, M. C. from Del. 195.

Patton, Col. 476. 
Paulus Hook 27

Pechin, Mr. 333, 334

Pendleton, Mr. 531

Pennsylvania $90,112,383,418,420$,

435 to $437,463,477,576,584,585,614$.

Pennsylvania Mutineers $56,57$.

Perdido River 560

Perry, Wm., suggested for offlce $121,132,136,139$ to 141,158 Perry, Mrs. 120.

Perry, Commodore O. H. 609.

Perth Amboy, N. J. 432.

Philadelphia 4, $5,24,25,42,48,50$, $52,53,56,58,61,65,71,72,75$, $78,82, S 3,96,98$ to $100,108,109$, $118,128,131,133,140,143,164$ to $168,175,183,185$ to $187,191,193$, $199,200,230,241,243,246,254$, 256 to $259,287,290,299,303,313$, 317,319 to $321,323,324,328,341$, 347,349 to $351,353,357,364,365$, $372,378,380,381,383,389$ to 391 , $394,395,401,402,417,426,439$, $458,460,463,464,492,494,504$, $513,515,557,571,573,586$, extravagance at 20 .

Plchegru, M. $275,279$.

Pichon. M. $371,430,558$

Pickering, Octavius 615 .

Pickering, Timothy, a member of Washington's cabinet 158, Sec. of State 163,165 to 167,169 to 171,175 $176,180,181,188,190,192,197$, 201,205 member of Adams's cabinet $208,209,224,227,229,230$, 239 to $241,250,255,257,260,266$, $269,270,272$ to $274,282,283,285$, $288,289,311$ to $316,320,322,325$, $338,341,345,346,348,352,370$, $374,375,394,397,400,406,413$, 417 to 421,424 , dismissed by Adams 456, in presidential campaign of $1800452,453,456,458$, $459,461,478,479,481,488$, in Congress $504,505,595$, censured by Senate 563 , sends portrait to McHenry 533, defends administration of department $511,512,604$ to 607 , corresponds with McHenry on federal politios 533 to 541,546 , to 561,566 to 571,600 , friendship in McHenry's last days 614,615 , views on future life 602 , on McHenry's health 607 .

Plckering, Mrs. Timothy 505 .

Pierce, Mr. 97.

Pledmont, Italy 373, 494.

Pike, Mr. 264, 272

Pinckney, C. C. declines sec. of War 1.63, sent to France 189 , refused acceptance 193,205, 208 to $213,216,217,223$, on new embassy $225,230,231,234,235,238$, $241,242,274,299,300,307,371$, precedence as General 311 to 313 , $321,326,327,341,605,606$, service as General 332,336 , named 345,348 to $352,363,377,387,389$, $415,420,421,424,428,444,517$, candidate for vice president 452 , $453,455,456,458$ to $465,466,468$ to 471,476 to $478,492,582$.
Pinckney, Mrs. C. C. 459 to 461

Pinckney, T., Vice Presidential candidate $1796202,204,206$, makes treaty with Spain 260 .

Pinckney, Col. 560 .

Pinkney, Ninian 153

Pinkney, Wm. 132, 153, 162, 178 ,

$179,296,423,543,545,554,555$.

Piracy on the Chesapeake 535.

Pitcairn $20 \mathrm{~s}$

Pitkin, Mr. (Congressman) $\mathbf{5 9 5}$

Pittsburg, Pa. 129, 211, 259, 269, $437,440,442,533,607$.

Plater 204.

Plater, Mrs. 67

Plunkett, Mary 525, 526.

Polanan, V. 241, 249 .

Poland. 597.

Polk, Ezekiel 267.

Polk, Wm. 266.

Portalis, M. 275

Portsmouth, N. H., Navy yard 190.

Portsmouth, Va. 39.

Portugal 228, 237, 247, 295, 298 , 294, 298.

Post Offlce $185,380,517,596$

Potomac River 207, 290, 352, 353 , 399,512 .

Potowmack Co. 162

Pottawatomie. Indians 443.

Potts, Richard 108, 133, 139, 145 , resigns from U. S. Senate 202.

Powell, Samuel 108.

Presidential election of 1796195 to 204,454 .

Presidentlal election of $1800 \quad 452$ to 496.

Presidential election of 1812580 to 587.

Price, Dr. 603

Prince, Mr. 274

Princeton College 520

Princeton, N. J. 56, 57, 59, 60, 82.

Principio, Md. 181.

Prize vessels 142

Providence, R. I. 397.

Provost, Mrs. 22, 23.

Prussla 238, 331, 598, 602.

Public Printer 431 .

"Publlus" 41.

Pursile, Mr. 270

Purviance, John, suggested for office 138 .

Purviance, Robert, on Commlttee to raise funds for Lafayette 36 .

QUAKER missionaries to Indians 176 .

Quebec 173.

Queen Anne's County, Md. 136, 197, $199,336$.

Quincy, Mass. 341, 350, 407, 435, $558,566,571,604$.

Quincy, Josiah 562, 576, 596 .

RADCLIFFE, Mr. 584

Ramsay, Nathaniel 55, 75, 76 .

Ramsay, Sophla Hall 75, 610 .

Ramsey, Capt. 393, 394.

Randolph, Edmund 100, 155, 158 to 161,166 . 
Randolph, John, of Roanoke 514, $533,551,565,592,595$

Rawllins, Col. 14.

Reading, $\mathrm{Pa} .436,437$.

Red Spring, Va. 150.

Reed \& Ford 210.

Reed, Major 50.

Reeder, Mr. 435.

Regnter, M. 540 .

Rensselaer, Mr. 213.

Repnin, Prince 343,344

Representatives, Instruction of 95 .

Revolutionary Army want of supplies $20,21,35,50$.

Revolutionary War, Events of 27, 34 to $40,42,508$.

Rhine River 280,494

Rhode Island 5.6, 89, 235, 399, 431, $463,471,479,483,532,1585$.

Richardson, Mr., appolnted to office 140 to 142

Richmond, Va. 314, 457, 547, 571.

Ridley, Matthew 36 .

Ridgely, Mr. 137, 138 .

Ridgely, Chas., of Hampton 572.

Rivardi, 265,444 .

Rivet, Rev. Mr. Indian missionary $171,172,271$.

Robertson, Mr. 161.

Robinson, Mr. 608, 614 .

Rochefontaine, Col. 184.

Rocky Mount 401.

Rocky Hill, N. J. 57.

Rodgers, Mrs. 179.

Rome, Ancient 236, 279.

Rose, British minister to U. S. 542 , 544.

Ross, James $138,211,259,269,420$, $437,463,513,533,534,607$.

Ross, - 185, 243.

Rotterdam, Holland 236, 249, 274 $281,283,286,343$.

Ruessess Creek, Tenn. 271.

Rumford, Count $\mathbf{3 9 2 .}$

Rush, Dr. Benjamin, preceptor of James McHenry 4, transmits vote of Congress 8, is written by McHenry while a prisoner 9, writes McHenry 16, 27, 464, 465 .

Ruspoli, Prince Bailli 505.

Russell, J. 588, 590, 596, 599.

Russia 243, 331, 343, 344, 408, 561 597 to $599,601,602,613$.

Rutledge, John 160.

Rutledge famlly 225 .

Rutledge, Major John, Jr. 238, 242, $345,348,463,488$.

St. Augugtine, Fla. 594.

St. Clalr, Gen. Arthur 362, 443, 483.

St. Genevieve 279.

St. Hilalre $272,556,557$.

St. John's College 155 .

St. Louls, Mo. 271

St. Mary's River 445

st. Mary's College, Baltimore 520, 613.

St. Petersburg, Russia 344, 601 .

St. Thomas 372 .

Salem, Mass. 505 .

Salmon, Geo., suggested for office 138.
Salomons, M. 235 .

Sands, Mr. 208

Sandy Hook, N. J. 289.

Santhonax, Commissary 191, 192.

Santo Domingo, refugees from 142

143 , trade with 191 , named 406 ,

420.

Sardinia 229 .

Sargent, Gov, 440, 451.

Savannah, Ga. 256 .

Schuyler, Angelina. See Carter 44.

Schuyler, Gen. Philip 29, on Mc-

Henry's application for a commis-

sion 31 , ili 213 , named 484 .

Schuyler, Peggy 44.

Schuylkill River 512 .

Scotch Plains 458 .

Scott, Mr. 206.

Scott, Gustavus 124.

Scott, Dr. J. G. $\mathbf{5 5 3}$

Scribner, Charles 558.

Seaman Rutgers \& Ogden 236.

Sectionalism 522 .

Sedgwick. Theodore $199,200,301$, $324,326,368,393,454,455,458$, 463,488 .

Senator Ross, Galley 440 to 442 .

Seneca Indians 129 .

Seney, Mr. 335 .

Serrurier, M. 568

Sevier, John 261, 262, 267, 313, $316,448$.

Sewall, Samuel 397.

Sheldon's horse 316 .

Shepherd, Gen. 318.

Shepherdstown, W. Va. 424, 459.

Shield, Mrs. 118.

Shippen, Dr. 27

Short, Mr. U. S. representative at Paris, 1791 128.

Short, Wm. 561 .

Sieyes, Abbe 430

Simmons $383,513,545$.

Sitgreaves, J. $234,23.5,336,584$, 586.

Sklpwith Mr. 120.

Small, Mr. 290.

Smille, John 590

Smith, President's printer 549

Smith \& Buchanan 554.

Smith, Mr. 67, 84.

Smith, Dr. 274.

Smith, John 59, 548

Smith, Robert 124,133 to 135,137 , $206,498,499,554$ to 556 .

Smith, Gen. Samuel, writes McHenry, 177820 , position in 1792137 , elected to Congress 138, writes Hamilton as to offices 138 , as to prizes 142, supports Washington as to Genet 143 , denies expedition against Bahamas is planned 143 , in Congress 167, 198, mentloned 192, 193, opposed Jay Treaty 194, on Pinckney's rejection 211 supports French 235,370 , named $301,306,336,406,407,483$, $498,564,567,606$, in Congress in $1807,534,539,554$.

Smith, Wm. L., 130, 202, 282, 288, $372,456,458,505,552,564$. 
Smith, Wm. S. $53,89,313,314,316$, $321,328,346,350,354,355,363$, $400,430,443,450$.

Smyth, Alexander 589.

Snake Run, Va. 150.

Somerset County, Md. 197.

South America 395.

South Carolina 111, 205, 256, 363, $452,456,459,464,469,472,483$, 492,583

Southern States 90,91.

Spaight, Col. 94.

Spain 109, 235, 237, 243, 247, 250, $260,291,294,298,301,315,396$, $533,545,549,559$.

Spain, western intrigues 262, 265 to 267,269 to $271,291,438$ to 440 , 445.

Sprigg, Richard 198, 205.

Springfield, Mass. 401.

Stark, Gen. 5 a 6.

Staunton, Va. 118, 119, 121, 147, 152

Steel, Mr. 447.

Sterrett, Samuel 108, 123, 572 .

Stevens, Col. 327, 390, 391, 432 .

Stewart, Charles Morton, Jr. 76 .

Stewart, Priscilla 76 .

Stilles, Capt. 287.

Stirling, Lord, invites MeHenry to Christmas dinner 26 .

Stockbridge Indlans 176.

Stockton, Mr. 464

Stodder, David 253, 256.

Stoddert, Benjamin $303,304,338$, $346,370,395,401,402,417,419$ $453,458,460,465,482,492,566$ to 568,50 , letters in retirement 511,542 to $545,557,580,583$.

Stoddert, Mrs. 482.

Stone, Gov. John H. 139, 162, 202.

Stone, Thomas $59,83,108$.

Stricker, Capt. 143.

Stringer, Dr. 8.

Strong, Col. 443.

Strong, Caleb, Gov. of Mass. 378.

Stuart, Mrs. 318.

Stull, Col. 130 .

Suffran, Adml. de 95.

Sullivan, $\mathrm{Mr}$. 57, 546, 548

Susquehanna Ferry $179,363$.

Susquehanna River 504.

Suwarrow, Marshal 566 .

Swan, Mr. $192,193,306$.

Swan, Major 56.

Swanwick, John 199. 200.

Sweden, 228, 331, 59.8, 599.

Sweet Springs, Va. 111, 118, 120, $121,145,159,497,553$.

Switzerland 297.

Swope, Col. 9.

Symmes, Mr. 110.

Talbot Co., Ma. 136, 198, 199, 334.

Talleyrand $299,307,371,407,408$, $416,429,558,563$.

Talmadge, Benjamin $19,316,504$,

$545,546,560,562$ to $566,570,573$

to 579,588 to 590,595 to 607,611 , 612.

Talmadge, Mrs. Benjamin 574.
Taxes 509, 574, 575, 599, 600,601. Taylor, John 411, 412.

Tees River 343.

Tennessee $174,177,261,262,266$ to $269,271,272,314,363,377$, $387,438,444$ to $449,472,516,573$. Texel, The $226,229,238,241,245$, $284,285$.

Thomas, Mr. 586, 587.

Thompson, Mrs. 26 .

Thompson 521 .

Thomson, Chas., Sec. of Congress, sends extract from its minutes 8 , writes $17 \mathrm{SS} 10 \mathrm{~S}$, escorts Washington to inauguration 117.

Thornton, British consul 143.

"Three Patriots" 572, 607.

Tilghman family 142 .

Tilghman, Edward 336 .

Tilghman, Richard 336 .

Tilghman, Tench, writes McHenry 25 , is with Washington but ill 35 , mentioned $133,134,136,140$.

Tousard, Major $367,391,479,480$.

Toussaint l'Ouverture $4: 0$.

Tracy, Gen. (French) $\mathbf{5 1 0}$

Tracy, George 517 .

Tracy, Uriah $301,328,350,377,392$,

$416,436,483,494,489,489,492$

$493,504,508,509,513$ to 517,521 ,

522 , death 523,529 , monument 545 .

Trenton, N. J. 82, 260, 269, 270,

323,347 to $349,378,399,411, \$ 17$

to $419,461,471,556,566,571$.

Trevor, Mr., British minister to Holland 228.

Tripoli 470

Truxton, Thomas 251 to 256 .

Turin, Italy 373 .

Turkey, 408 .

Turnbull, Gov. Jonathan, Jr. 350 .

Turnbull, Secy. 46 .

Tuscany 373,375 .

UPPER Marlborough, Md. 137.

Uxbridge, Mass. 399 .

VACHER, Mme. 88 .

Valence 4.30 .

Valley Forge, Pa. 15, 16.

Vance, Capt. 382,383 .

Van Staphorst 239.

Venice, Italy $229,232,233,242,276$.

Vergennes, Count de 87.

Vermont $472,492,493,584,585$.

Verplank's Point 49.

Versalles, France 51, 87, 542.

Vienna, Austria $331,343,344$.

Vincennes 261 .

Virginia 86,110 to $112,317,323$, $332,363,377,387,389,396,399$, $508,517,581,582,583$.

Virginia Resolutions 436

Virginla Campaign of 178137 to 39 .

Vose, Col. 51.

Voublanc $275,331$.

Wabash River 171, 273.

Wadsworth, Capt. Decius 184 .

Wadsworth, Col. 350 .

Wagner, Jácob 546, 5̄ 0, 557, 566, 567,571 . 
Wallace, Mr. 266.

Walton, Mr. 448 .

War Department, administration of 163 to $431,480$.

War Department, burning of 476 , 481.

War Department, McHenry's administration of, defended 511 to 519 .

Warm Springs, Va. 119.

War of $1812589,590,599$ to 601 . 609 to 613

Washington, The 88 .

Washington, Bushrod 369, 507, 508, 511.

Washington, George 4, 97, 157, gives McHenry leave of absence 8 , IcHenry writes him of British hospitals 10 , of parole 15 , summons McHenry as military secre. tary 16, at Monmouth 19, march to Haverstraw described 21, life in his military family described 23 , arrangements of winter quar. ters 26 , his plans of campaign 27 , places McHenry on Lafayette's staff 29, at West Point, Arnold's treason 31 , Hamilton writes McHenry of breach with him 35 , hears from Lafayette of McHenry's activity 35 , letter from McHenry about Virginia campaign 37 , writes McHenry 41 to 43,46 to 51 , at Princeton 56, resigns commission at Annapolis 59,67 to 69 , miniature of 85 , Lafayette recommends statue of 89 , corresponds with McHenry on national regulation of commerce 90,91 , on animals sent by Lafayette 92 , in Constitutional Convention 100 105,108 , watches Md. ratifying convention 110 , writes of importance of eleoting Federalists to Congress 113, invited to visit $\mathrm{Bal}$ timore $116,117,133$, McHenry corresponds with him on appointments $123,124,133$ to 136 , denies he wishes Mercer's election 138 , consents to reelection 139,162 , declines to send McHenry to secure Iafayette's release 145 , thanked by Maryland legislature 162, appoints IrcHenry Sec. of War and consults him as to Chase in Supreme Court 163,168 , cabinet 165 , 166,167 , discusses Indians 169 , 175,177 , Western forts 173, 174 , consulted as to frigate 180,181 , affairs at $\mathbf{M t}$. Vernon 182,210 , entertains McHenry 184, mail to Mt. Vernon 185 , visitors there 185 186 , false rumor of inquiry 186 , frames message 187,188 , recails Monroe 188, declines 3d term 193 197, address to Congress 206,207 esteem felt for him 210 , asks for news 210 , McHenry writes him of relation with France 223,224 , gives McHenry wine coalers 257 . writes on Blount 261, named 284, 287,288 , writes McHenry 288 . writes as to Parker's book 290 , on France 301 , writes McHenry against Democrats $30 i$, named 308 , called as head provisional army 309 , his conditions of acceptance 310 , visited by McHenry 311,312 , precedence of generais 311 to 314,321 to 322,325 to 341 , $345,347,349,454,606$, asks Carrington to be gen'l 314 , named $315,317,334,335,342$, writes on army 316,318 to $321,323,336$, $351,353,354,367,368$, censures McHenry 322 to 324,378 to 390 , Lafayette's message to him 332 , ill 337 , opinion of Democrats 340 , McHenry summons to Trenton 347 to 351 , named by Mifiss Custis 356 writes of her mariage 359 uniform 368 , communication with McHenry on military affairs 385 to $389,395,396,411,415,420,430$ 440 , on European affairs 408,419 , 420 , receives game from McHenry 395 , recommends Taylor 412 , appointments to office by 502 , named $467,468,475,547,569,572,58 \mathrm{~s}$ 615 , dies $421,429,453$, biography of 599,511 , his character 522,595 . Washington, Martha 116, 126, 18:, 318,461

Washington, Gen. 460 .

Washington, Wim. 363 .

Washington City 133, 162, 206, 207. $272,305,346,460,476,483,492$, $493,504,508,515$ to $517,521,534$ $536,540,545,549,551, \quad 555$, 559,561 to 563,568 to $571,573$. 574,575 to 578,588 to 592,595 $597,595,600$ to $604,607,611$.

Watkins, Mrs. 22

Wayne, Anthony, at Monmouth 19 in Virginia campaign 39,39 , suggested as Sec. of War 165 , in Western service 171,173 , enter Detroit 174 , charges laid against him 183, named 264, 609 .

Wellesley, Lord 555 .

Tenham, Mass. 558 .

Westcot, Miss. 37 ?

Westcote, John 548, 549.

Westcote, Major 551 .

TVest Indies $42,43,49,232,277$ $283,315,619$

Tiest Point, $\mathrm{N}$. Y. 31,432 .

Western Intrigues 262 to 274,439 to 451 .

Testern Lands 110

Western Posts transferred from Great Britain $86,170,171,173$, $174,515$.

Western Posts transferred from Spain 260, 261, 269, 270, 274, 440 , 515.

Theeling, W. Va. 609

Whiskey insurrection 15.5. 320 .

White Sulphur Springs, W. Fa. 160. Wilkins, Mr. 533 .

Wilkinson, Gen. James 174 , charges Wayne 183 , in Western army 259 . $269,352,363,377,396,405,417$, 438 to $441,443,450,545,550,601$. 
Williams \& Co. 137.

Williams, Gen. 601 .

Williams, Otho $\mathrm{H} 29,39$, asked to accept federal office 129 , characterized 130 , ill 138 .

Williams, Major 14.

Williamson, Hugh, congratulates McHenr ${ }^{\prime}$ on appoin'ment as Sec.

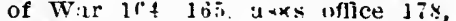
writes on French Crisis 190, election of 1796200 , on election of 1800481 , on McH ?nry's health 611 .

Willing, Capt. 402.

Willing Morris \& Swanwick 89.

Wilmer, Jonathan R. 461 .

Wilmington, Del. 54, 142 .

Wilson 413

Wiison, James 107.

Winchester, Va, 118, 147, 162 .

Winchester, James 194, 201, 305, 334,336 .

Witmold 328 .

Winder, Mr. 306.

Winder, Gen. 600

Wolcott, Oliver, in Washington's cabinet 166, 167, 177, 180, 185, $188,196,197,199$, in Adams's cabinet $208,224,241,257,258$, $268,301,307,314,320,321,325$, $338,339,341,345,346,348,349$, $351,352,370,381,386,394,397$ $406,419,420,421,445$, in presidential campaign of 1800452 , $453,455,461$ to 463,465 , to $470,477,479,481$ to $483,490,496$, letters from $518,519,521,529$ to $532,556,570$

Wolcott, Mrs. Oliver 519.

Wood County 608 .

Woodward, Mr, 373.

Worcester County Md. 197.

Wright, Gov. $198,199,562,577,588$.

Wright, Edward 199.

Wright, John 521.

Wright, Thomas 55 .

Yellow fever in Philadeiphia 257 $287,321,323,324,336,357,378$, 417.

Yazoo Bill 612.

Yonge, Mr. 241.

York 'Springs, Pa. 554, 614.

Yorktown, Va. 38,39

Youghiogheny Glades 497.

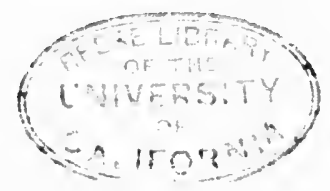





RETURN TO the circulation desk of any

University of California Library

or to the

NORTHERN REGIONAL LIBRARY FACILITY

Bldg. 400, Richmond Field Station

University of California

Richmond, CA 94804-4698

ALL BOOKS MAY BE RECALLED AFTER 7 DAYS

- 2-month loans may be renewed by calling (510) 642-6753

- 1-year loans may be recharged by bringing books to NRLF

- Renewals and recharges may be made 4 days prior to due date.

DUE AS STAMPED BELOW

\section{SENT ON ILL}

\section{JAN 281999}

\section{U. C. BEFIKELEY}

\section{NOV 292004}

\section{ELI LU TNACKS SEP 1 Y OO}


U.C. BERKELEY LIBRARIES<smiles>[GeH3]</smiles>

c007029768

THE UNIVERSITY OF CALIFORNIA LIBRARY 


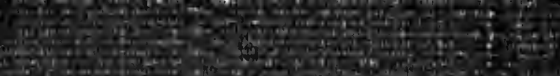

2.

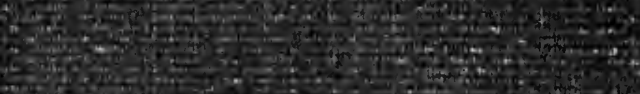

(2)

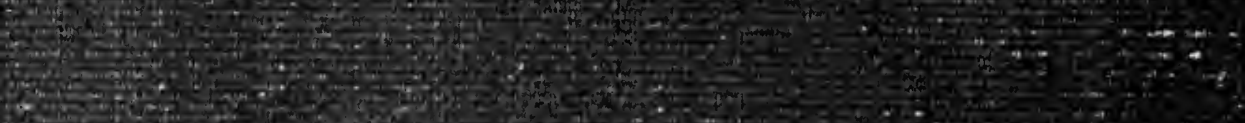

6.

(1)

6.

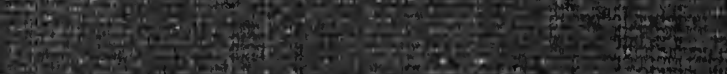

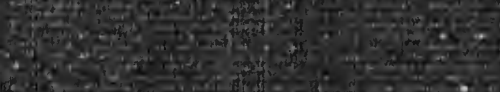

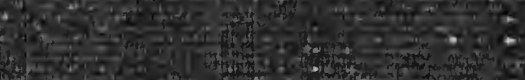

(1)

3.

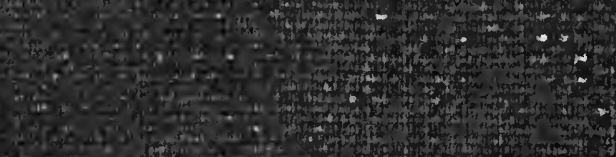

(10)

(15)

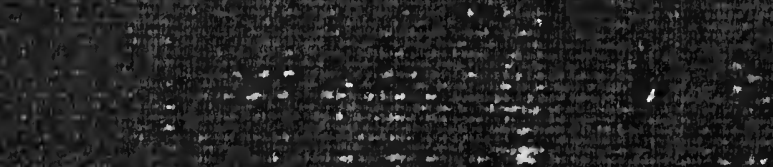

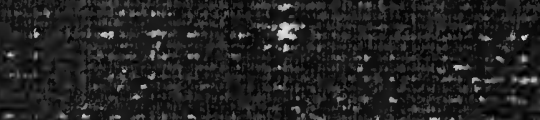

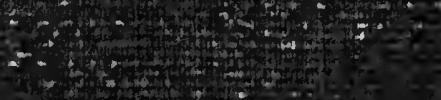

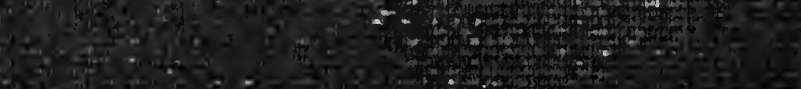

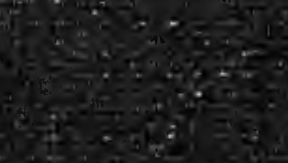

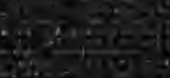

titis

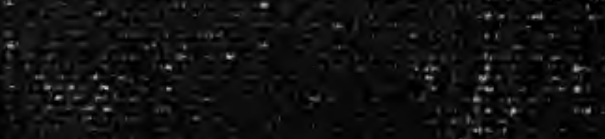

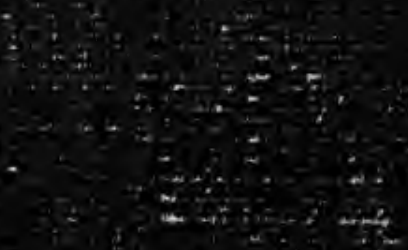

